B O N N E V I L L E Assessment of the Fishery Improvement Opportunities on the Pend Oreille River

Recommendations for Fisheries Enhancement

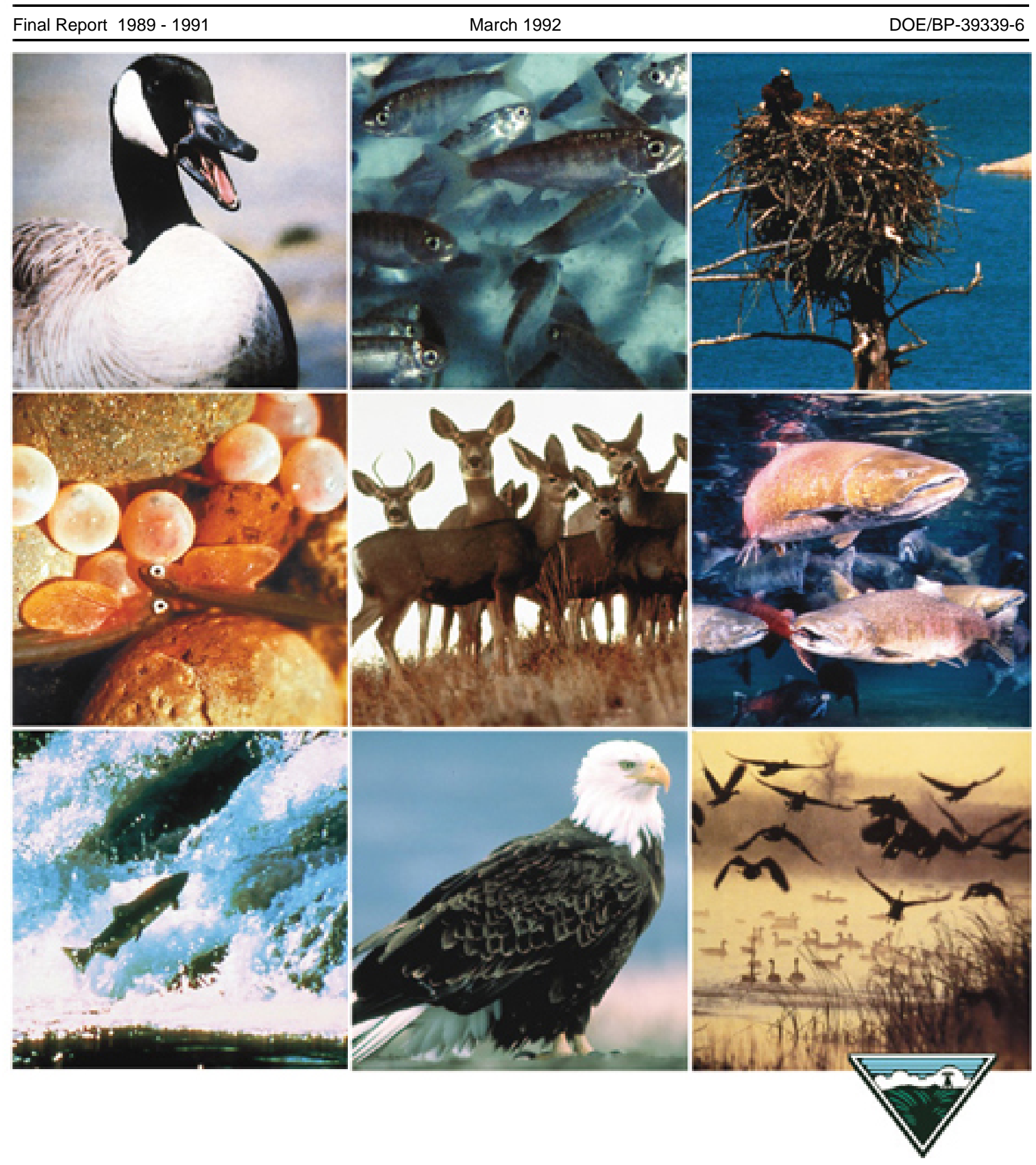


This Document should be cited as follows:

Ashe, Becky, Allan Scholz, "Assessment of the Fishery Improvement Opportunities on the Pend Oreille River; Recommendations for Fisheries Enhancement", 1989-1991 Final Report, Project No. 198806600, 323 electronic pages, (BPA Report DOE/BP-39339-6)

\author{
Bonneville Power Administration \\ P.O. Box 3621 \\ Portland, OR 97208
}

This report was funded by the Bonneville Power Administration (BPA), U.S. Department of Energy, as part of BPA's program to protect, mitigate, and enhance fish and wildlife affected by the development and operation of hydroelectric facilities on the Columbia River and its tributaries. The views in this report are the author's and do not necessarily represent the views of BPA. 


\title{
ASSESSMENT OF THE FISHERY IMPROVEMENT OPPORTUNITIES \\ ON THE PEND OREILLE RIVER: \\ RECOMMENDATIONS FOR FISHERIES \\ ENHANCEMENT
}

FINAL REPORT

\author{
By: \\ Becky L. Ashe \\ and \\ Allan T. Scholz \\ Upper Columbia United Tribes Fisheries Center \\ Department of Biology \\ Eastern Washington University \\ Cheney, Washington 99004
}

\author{
Prepared for: \\ Fred Holm \\ Project Manager \\ U.S. Department of Energy \\ Bonneville Power Administration \\ Division of Fish and Wildlife \\ Project Number 88-66 \\ Agreement DE-I 79-88BP39339
}

March, 1992 


\section{EXECUTIVE SUMMARY}

This report recommends resident fish substitution projects to partially replace anadromous fish losses caused by construction of Grand Coulee and Chief Joseph Dams. These recommendations involve enhancing the resident fishery in the Pend Oreille River as a substitute for anadromous fish losses. In developing these recommendations we have intentionally attempted to minimize the impact upon the hydroelectric system and anadromous fish recovery plans. In this report we are recommending that the Northwest Power Planning Council direct Bonneville Power Administration to fund the proposed enhancement measures as resident fish substitution projects under the NPPC's Columbia Basin Fish and Wildlife Program.

The Pend Oreille River, located in northeast Washington, was historically a free flowing river which supported anadromous steelhead trout and chinook salmon, and large resident cutthroat trout and bull trout. In 1939, Grand Coulee Dam eliminated the anadromous species from the river. In 1955, Box Canyon Dam was constructed, inundating resident trout habitat in the river and creating many back water and slough areas. By the late 1950's the fishery in the reservoir had changed from a quality trout fishery to a warm water fishery, supporting largemouth bass, yellow perch and rough fish (tench, suckers, squawfish).

The object of this study was to examine the existing fishery, identify fishery improvement opportunities and recommend fishery enhancement projects. Three years of baseline data were collected from the Box Canyon portion of the Pend Oreille River to assess population dynamics, growth rates, feeding habits, behavior patterns and factors limiting the fishery. Fishery improvement opportunities were identified based on the results of these data.

Relative abundance surveys in the reservoir resulted in the capture of 47,415 fish during the study. The most abundant species in the reservoir were yellow perch, composing $44 \%$ of the fish captured. The perch population in the river is stunted and therefore not popular with anglers. Pumpkinseed composed $16 \%$ of the total catch, followed by tench $(9 \%)$, largemouth bass $(8 \%)$, mountain whitefish $(6 \%)$, largescale sucker $(5 \%)$, northern squawfish $(4 \%)$ and longnose sucker (3\%). 
Largemouth bass were the largest game fish captured in the reservoir and currently the only species of sufficient size and population to provide a recreational fishery. Current biomass of largemouth bass, age $1+$ and older, in the river is $8 \mathrm{lbs} /$ acre. Production of a quality bass fishery is around 15-20 Ibs/acre, so, despite the apparent optimal habitat of the Pend Oreille River, bass production is limited. Despite limiting factors, quality sized largemouth bass (>500 $\mathrm{mm}$ ) were often captured. The three bass tournaments held on the river in 1990 resulted in the second highest CPUE (catch-per-unit-effort) $(0.19 \mathrm{fish} / \mathrm{hr})$ for bass tournaments in Washington State. The Pend Oreille River also produced the third largest tournament fish in the State during 1990. Based on habitat utilization (determined by sonic and radio telemetry), the amount of available habitat and the abundance of preferred prey species (yellow perch) in the reservoir, the Pend Oreille River could support a much larger bass population.

Of all the fish captured, trout species were the rarest; composing less than 1 percent of the total abundance. Brown trout were the most abundant trout species. Factors limiting trout production in the reservoir were identified as warm water temperatures, lack of habitat diversity and food availability.

Trout were more abundant in the tributaries to the Pend Oreille River, which supported mostly brook trout and brown trout, although cutthroat, rainbow and bull trout were also captured. Production potential of the tributaries is limited. The spawning habitat in most tributaries is of good quality, however the streams are high gradient and low order which are typically unproductive. Grazing and logging impacts present problems in several tributaries while immense beaver dams constitute migration barriers in others. Calispell Creek, the largest tributary to the river is not accessible to fish due to blockage by a hydro-project dam at the mouth.

Taking into account the available fish populations, existing habitat conditions and existing limiting factors, we developed two biological objectives for the Pend Oreille River fishery:

1) Restore tributary populations of native cutthroat and bull trout which were historically prominent in the Box Canyon reach of the Pend Oreille River; and 
2) Enhance the largemouth bass population to provide a quality sport and subsistence fishery in the reservoir.

These objectives were identified as management goals for the fishery by the Kalispel Indian Tribe. These objectives were presented to the Washington Department of Wildlife (WDW) at a meeting January 28, 1992. The WDW representatives approved these fishery management objectives for the Pend Oreille River and it's tributaries. Based on these biological objectives we are making the following recommendations to the Northwest Power Planning Council for inclusion as amendments to the Columbia River Basin Fish and Wildlife Program in NPPC's Phase IV process.

Gilbert and Evermann (1895) commented on the Pend Oreille River fishery after their survey in 1893 and 1894, "trout are abundant in this river; salmon trout [bull trout (Gilbert and Evermann 1895)] are also quite abundant, and both bite readily. We know of no stream which offers finer opportunities for sport with the rod than the lower Pend Oreille." Based on results of this baseline study, the native cutthroat and bull trout that historically supported an excellent fishery currently exist only as remnant populations in a few of the tributaries. Westslope cutthroat trout are a species of special concern in Montana, Idaho and Washington (Johnson 1983). Bull trout are currently listed as a sensitive species in Washington State and have the potential to be listed as endangered. The decline of these native trout species is a cause of great concern to the Kalispel Indian Tribe, who historically subsisted upon these species.

in order to successfully accomplish our biological objective for native trout species, three major goals were identified:

1) Protect existing stocks of native trout species in the Pend Oreille River and its tributaries;

2) Expand populations of native trout species to levels above endangerment of extinction; and

3) Reestablish self-sustaining populations of native trout species in the tributaries to the Pend Oreille River.

The following recommendations will address the three goals listed above. Presentation of the recommendations will be as follows: 1) Detailed recommendation, 2) Brief synopsis of 
scientific rationale upon which each recommendation is based; and 3) Description of what has been accomplished to date on each recommendation and further actions necessary by various entities involved.

In order to protect the existing stocks of native trout species in the Pend Oreille River and its tributaries we recommend:

\section{1 - 1 Consideration be given to petition the U.S. Fish and Wildlife Service to list bull trout in the Box Canyon Reach of the Pend Oreille River under the Endangered Species Act of 1973.}

- Scientific basis:

Gilbert and Evermann (1895) reported that, 'bull trout are abundant in the Pend Oreille River" during their explorations in 1894. In 1957, large numbers of Dolly Varden (bull trout) were reportedly captured in a Field and Stream Tournament on the Pend Oreille River (Metaline Falls Gazette, April 3, 1957). In contrast, during this three year survey a total of 4 adults and 1 juvenile bull trout were captured by electrofishing the 55 mile Box Canyon Reach. One juvenile was also captured in one of the tributaries to the river. No spawning activity was documented during this study. Bull trout were also rare in the creel.

- Accomplishments and further actions required:

NPPC/BPA: None, unless a petition is filed.

WDW/Kalispel Tribe: At this time we recommend only consideration of listing bull trout. With cooperation from the Department of Wildlife, NPPC, BPA and USFS we believe we can reestablish the fishery through the Columbia Basin Fish and Wildlife Program. However, this recommendation is included to express the seriousness of the situation and emphasize that the Kalispel Indian Tribe wishes to protect their native species. The Kalispel Tribe has informed us that they will pursue listing in the event that enhancement measures do not occur expeditiously (in FY 93) under the NPPC's Fish and Wildlife Program.

Pend Oreilie County Public Utilities District/Federal Energy Regulation Commission (POCPUD/FERC): None, unless a petition is filed.

U.S.Forest Service (USFS): None, unless a petition is filed.

\section{1 - 2 Complete closure of fishing season for cutthroat trout and bull trout in the reservoir and tributaries.}


- Scientific basis:

This recommendation will protect declining stocks from mortality due to angler harvest. A total of 88 cutthroat trout were reportedly harvested in 1988 . No cutthroat trout were caught or harvested in 1989. The only time bull trout were reported in the creel was during spawning season. Although no bull trout were reporte in the 1988 creel, it was estimated that 181 bull trout were harvested in 1989.

- Accomplishments and further actions required:

NPPC/BPA: None, as this is a harvest management issue.

WDW/Kalispel Tribe: The Department of Wildlife imposed a statewide closure of bull trout harvest in 1992 which we fully support. We recommend that this also be done fo cutthroat trout in the Box Canyon Reservoir drainage. The Kalispel Tribe is currently in the process of changing their hunting/fishing regulations to close bull trout and cutthroat trout harvest by both tribal members and non-Indians on waters on or adjacent to the Reservation.

POCPUD/FERC: None, as this is a harvest management issue.

USFS: None, as this is a harvest management issue.

\section{1 - 3 Discontinuation of brook trout stocking by the Department of Wildlife in tributaries to the Pend Oreille River identified for native species enhancement.}

- Scientific basis:

It is well documented that brook trout outcompete cutthroat trout for food and space (Griffith 1972). It has also been reported that brook trout will hybridize with bull trout (Hisata, pers. comm.). Each tributary surveyed during this study supported reproducing populations of brook trout, largely a result of annual stockings by the Department of Wildlife since the 1940's. Brook trout composed $79 \%$ of fish captured in LeClerc Creek, 97\% in Ruby Creek, 45\% in Cee Cee Ah Creek, 85\% in Tacoma Creek, and $77 \%$ in Skookum Creek.

- Accomplishments and further actions required:

NPPC/BPA: None

WDW/Kalispel Tribe: Discontinuation of brook trout stocking in tributaries identified for native species enhancement.

POCPUD/FERC: None

USFS: None

We also recommend: 
1 - 4 Active removal of brook trout be conducted in tributaries identified for native species reintroduction or enhancement.

- Scientific basis:

Same as recommendation 1-3 above. In order to successfully reestablish the native trout populations we believe removal of this exotic species is important. Cowley (1987) estimated that if brook trout were removed from Priest Lake tributaries, a $64 \%$ increase in adult recruit production of cutthroat trout could be expected.

- Accomplishments and further actions required:

NPPC/BPA: Approval by the Council. Funding by BPA of the labor and equipment necessary for removal of exotic trout species.

WDW/Kalispel Tribe: Kalispel Tribe should provide technical support and labor necessary to complete the project via BPA funding.

POCPUD/FERC: None

USFS: Cooperation between the Forest Service and the Kalispel Tribe would be more effective, as the Forest Service would also like to remove brook trout from the Pend Oreille River tributaries on Forest Service land. The USFS may be able to provide equipment and manpower necessary to help accomplish brook trout removal.

Even with the protection measures previously mentioned, the current population of native trout in the Pend Oreille River system will probably not be sufficient for rapid repopulation of the tributaries to carrying capacity. Consequently it will be necessary to supplement native populations, especially bull trout, to accomplish our second goal of population expansion. For this reason it is recommended that:

1 - 5 Bonneville Power Administration (BPA) fund design, construction, operation and maintenance of a low capital hatching facility for native trout species, on the Kalispel Indian Reservation (cold water section of warm/cold water hatchery). Hatchery design should incorporate ideas from BPA's compendium of low-cost production facilities (Senn et al. 1984). Eggs would be collected from fish in each tributary, hatched and reared in separate incubators and raceways, then seeded back into the tributary their parents were collected from to maintain genetic integrity of native trout populations in each tributary. Projected 


\section{production goals are 50,000 each, bull trout and cutthroat trout fry, 25,000 each, bull trout and cutthroat fingerlings and 25,000 each, bull trout and cutthroat trout juveniles.}

- Scientific basis:

Current population levels of cutthroat trout and bull trout are so low that it would likely take several decades to rebuild these populations solely by natural reproduction. Although it is not currently known if trout production is limited in the hatching or rearing stage of the life cycle, we feel seeding the tributaries with native trout is the approach best suited to determine at which life stage trout production is limited in the Box Canyon Reach of the Pend Oreille River. This approach has the advantage of increasing recruitment of these threatened fish while providing a tool to work with to determine what is limiting their natural production. Thus, this recommendation is consistent with the Adaptive Management Policy in the 1987 Fish and Wildlife Program. Production goals are based on population estimates of age 1+ and older trout conducted in tributary streams. A total production of 2,293 trout was estimated in 8.5 miles of LeClerc Creek, 4,108 in 5.6 miles of Ruby Creek, 6,702 in 9.5 miles of Cee Cee Ah Creek, 8,536 in 9.1 miles of Tacoma Creek and 18,024 trout in 4.5 miles of Skookum Creek. The majority of trout species present were brown trout, brook trout and cutthroat trout. Only one bull trout was captured in the tributaries during this study. Cutthroat trout production estimates were 131 in LeClerc Creek, 28 in Ruby Creek, 645 in Cee Cee Ah Creek, 1,383 in Tacoma Creek and 1,235 in Skookum Creek. The bull trout production goal of 22,500 fish is designed to partially replace the 24,671 non-native brook trout observed in these streams. We estimate that after taking mortality of stocked bull trout into account, about 7,000 will survive to the sub-adult stage. The cutthroat trout goal of 22,500 fish will, after taking into account mortality after stocking, produce about 7,000 juvenile cutthroat trout or about double the 3,422 wild cutthroat trout observed in the five tributaries.

- Accomplishments and further actions required:

NPPC/BPA: Approval by the Council. Funding by BPA for the design, construction, operation and maintenance of hatching facility on the Kalispel Indian Reservation. Hatchery design and environmental assessment should commence in 1993.

WDW/Kalispel Tribe: The Kalispel Tribe should operate and manage the hatchery via funding from BPA. This will partially mitigate the Kalispel Tribe for anadromous fish losses. The Department of Wildlife and Kalispel Tribe, with participation from BPA and USFS, will form a Hatchery Advisory Board to oversee production and outplanting.

POCPUD/FERC: None

USFS: Cooperation on seeding tributaries located on Colville National Forest land.

The hatching facility for native trout is only a short term plan to aid in reestablishing the native species. Our long term goal for is for the tributaries to support self-sustaining populations of native trout species. In order to accomplish this it will be necessary to 
conduct some habitat enhancement measures and some additional fisheries investigations. We recommend:

\section{1 - 6 Habitat enhancement be conducted on three} demonstration tributaries (LeClerc, Cee Cee Ah and Skookum Creeks) at necessary sites to improve and reclaim fisheries habitat. This recommendation is an essential part of increasing bull trout and cutthroat trout populations in Pend Oreille River tributaries.

Improvements on LeClerc Creek should Include: formation of pools to improve pool:riffle ratlo, installation of sediment traps, removing or laddering large beaver dams or debris jams for improved fish passage and clean up of unauthorized dumping sites along the creek.

Improvements on Cee Cee Ah Creek should include: riparian zone restoration and stream bank stabllization by planting vegetation, installation of sediment traps and removing or laddering large beaver dams or debris jams for improved flsh passage.

Improvements on Skookum Creek should Include: fencing of riparian areas to restrict cattle access to stream and planting vegetation for stream bank stabilization.

- Scientific basis:

Portions of the tributaries we surveyed were damaged and degraded by land use practices, such as grazing and logging. Buchanan et a/. (1990) reported that Cee Cee Ah Creek has been significantly affected by the cutting of timber in the drainage, especially in the upper reaches of the creek where a clear cut has devastated the riparian zone. Problems encountered were eroding stream banks, massive sediment loading, no shade canopy or overhanging cover. In some cases fish passage was blocked by beaver dams and large organic debris jams. Animal keeping practices pose problems in the Skookum Creek drainage. Coots and Willms (1991) reported fecal coliform densities in Skookum Creek exceeded Class A water quality criteria. In order for the native species to effectively utilize these tributaries for spawning and rearing we believe improvements to these problems areas are necessary. LeClerc Creek is a high gradient stream which would benefit by construction of pool habitat and cleanup of unauthorized dump sites along the creek.

- Accomplishments and further actions required:

NPPC/BPA: Approval by the Council. Funding by BPA of advanced design, construction, operation and maintenance for habitat improvements mentioned.

WDW/Kalispel Tribe: Technical design, labor, construction, operation and maintenance of habitat improvements by the Kalispel Tribe, in collaboration with the USFS, using funding from BPA. 
The Kalispel Tribe is currently coordinating with the Pend Oreille County Conservation District to educate landowners that fencing cattle from the riparian zone is essential. Upon approval of this project we expect landowner cooperation of fencing project on Skookum Creek using the BPA fund to purchase and install fences.

POCPUD/FERC: None

USFS: Collaboration with the Kalispel Tribe on habitat enhancement measures.

The above measures should be monitored to determine effectiveness as outlined in the Power Councils' Adaptive Management Strategy. Therefore, it is recommended that:

1 - 7 All fishery enhancement projects (habitat improvements and supplementation efforts) be monitored for three years after implementation to determine effectiveness. Monitoring program In demonstration streams should include
seasonal evaluation of:

Physical characteristics of stream channel and habitat types avallable (e.g., pool, riffle), stream bed (e.g., sediment load), and changes in riparian zone condition.

Habitat enhancement structures and sites in the demonstration streams to document functional status, maintenance and replacement needs.

Population estimates of both hatchery and wild cutthroat and bull trout In each enhanced tributary to determine change in population structure.

Invertebrate abundance (benthic and drifting) of preferred prey organisms to determine effect of stocking different numbers of fish on the ecosystem and how habitat improvements effect prey abundance.

Growth rates of hatchery and wild fish stocks.

Effectiveness of different release locations, size at release and time of release, along with ability of fish to return to stocking sites for egg collection.

- Scientific basis:

Monitoring of hatchery outplanting and habitat improvements will provide important knowledge upon which future management decisions can be based. It is essential that the habitat improvements are monitored, as they are envisioned as demonstration 
projects to determine if low cost habitat improvements can be successful in other Pendl Oreille River tributaries.

- Accomplishments and further actions required:

NPPC/BPA: Approval by the Council. Funding by BPA of the design, labor and equipment necessary for monitoring habitat improvements and supplementation of trou't populations.

WDW/Kalispel Tribe: Technical design and labor required to conduct monitoring study should be provided by the Kalispel Tribe, with funding from BPA.

POCPUD/FERC: None

USFS: The Forest Service is currently conducting some habitat assessment in tributaries to the Pend Oreille River. Cooperation between the Forest Service and the Kalispel Tribe on the monitoring study would be helpful.

Our investigation did not identify the limiting stage of Pend Oreille River trout lifecycles. It is suspected that the lack of adult habitat in the river is partially responsible for low production. In order for successful reestablishment of native trout species and expansion of all trout populations it is important to identify the limiting factors. In order to accomplish this we recommend that additional fisheries investigations be conducted:

1 - 8 Determine secondary productivity and trout carrying capacity of each of the tributaries, especially those identified for native species reestablishment.

\section{1 - 9 Installation of migration traps at the mouth of} tributaries to the Pend Oreille River to determine cutthroat trout, bull trout and brown trout contribution to reservoir fishery and utilization of tributaries by adults.

\section{1-10 Tracking adult cutthroat trout, bull trout (if possible) and brown trout to determine habitat preferences in the river and then evaluation of preferred habitat available.}

- Scientific basis:

Data collected during the above recommended study will provide information upon which intelligent decisions can be made about managing the trout fishery in the Pend Oreille River and its tributaries. As the native species of cutthroat trout and bull trout 
continue to decline in the Pacific Northwest, information collected from this type of study will be invaluable for the management of stocks elsewhere.

- Accomplishments and further actions required:

NPPC/BPA: Approval by the Council. Funding by BPA of fisheries investigations outlined above.

WDW/Kalispel Tribe: Kalispel Tribe should conduct these studies with funding provided by BPA.

POCPU D/FERC: None

USFS: None

The biological objective to enhance largemouth bass production stems from the existing warm water temperatures and lack of habitat diversity in the reservoir, which would make any attempts to enhance the trout populations in the reservoir difficult, unless Box Canyon Dam is removed. Largemouth bass have the most potential of all the species in the river to provide a quality sport and subsistence fishery.

Factors currently limiting bass production in the river include water elevation fluctuation, nest abandonment due to parent removal during bass tournaments which results in predation, cold water temperatures, short growing season, lack of overwinter cover, competition for food with yellow perch and dense Eurasian milfoil beds which effectively attract and hide yellow perch, reducing the predation rate of adult bass.

The goal of the following recommendations is to maintain the quality bass fishery that currently exists while expanding the population to take advantage of the available habitat and food supply. Two sets of alternate recommendations are presented in this report: 1) Natural expansion of the population: and 2) Supplementation to expand the population. Both sets of recommendations address the biological objective, however, supplementation is believed to be the best, most cost effective way to double current biomass production.

In order for enhancement of the naturally reproducing population of largemouth bass to expand, necessary changes in the current management regime of the reservoir and fisheries management are recommended: 


\section{2 - 1 Maintenance on Box Canyon Dam be restricted during critical largemouth bass spawning time (June-July) to avoid occurrences such as the drawdown of 1988.}

- Scientific basis:

The most obvious obstacle to bass production in the reservoir at this time is the negative water level fluctuations that occur during their spawning season. Due to the shallow depths of the sloughs that bass utilize for spawning, negative fluctuations of over $1 \mathrm{~m}$ during spawning season results in nest dewatering and/or nest abandonment. A reoccurrence of the drawdown in 1988, which resulted in complete dewatering of sloughs on Kalispel Indian Reservation, could cause a complete failure of an entire year class.

- Accomplishments and further actions required:

NPPC/BPA: None

WDW/Kalispel Tribe: None

POCPUD/FERC: Restriction of maintenance of Box Canyon Dam during critical largemouth bass spawning time (June-July).

USFS: None

In order to enhance the natural production of bass in the reservoir it is essential that water elevation levels be held stable or at positive fluctuation during spawning season. Because the Box Canyon Reach of the Pend Oreille River is a run-of-the-river reservoir and the water levels in the river are naturally decreasing during bass spawning season the following recommendation may be difficult, if not impossible to implement.

\section{2 - 2 Water elevation fluctuation of the Pend Oreille River between Box Canyon Dam and Albeni Falls Dam be regulated during critical largemouth bass spawning time (June-July).}

- Scientific basis:

Based on telemetry data, collected during this study, bass peak spawning period is between June 15 and July 15, at depths ranging from $0.45 \mathrm{~m}$ to $2 \mathrm{~m}$. During 1988 and 1989 negative fluctuations of over $1 \mathrm{~m}$ occurred both years during this critical period. In northern Idaho lakes it was reported that prolonged periods of declining water levels greater than $3 \mathrm{~cm}$ a day, or $38 \mathrm{~cm}$ over a 13 day period increased the probability of nest abandonment by the guarding male (Bennett and Bowles 1985). When the guarding 


male abandons the nest the embryos left in the nest are susceptible to predation by
other fish species.
NPPC/BPA: None
WDW/Kalispel Tribe: None
POCPUD/FERC: Coordination between POCPUD and the Army Corps of Engineers to
regulate water elevation of the Box Canyon reach of the Pend Oreille River at a stable
or positive fluctuation during critical largemouth bass spawning time (June-July).
USFS: None

\section{2 -3 Support of proposed regulation change by Washington State Department of Wildlife from the current daily bag limit of ten (10) bass, with not more than three (3) fish over 17" to a daily bag limit of five (5) bass, with not more than three (3) fish over 15".}

- Scientific basis:

Our data support the above proposed regulation change by the WDW. This regulation change should help to protect the quality bass fishery that currently exists in the Pend Oreille River.

- Accomplishments and further actions required:

NPPC/BPA: None, as this is a harvest management issue.

WDW/Kalispel Tribe: Change of regulation by the Department of Wildlife. Currently the Kalispel Tribe hunting and fishing regulations do not include a limit for the number or size of bass harvested by tribal members, because bass now support the tribal subsistence fishery that was historically supported by native trout species. We recommend that the tribe identify a limit between 10 and 20 fish per day per tribal member.

POCPUD/FERC: None, as this is a harvest management issue.

USFS: None, as this is a harvest management issue.

According to results collected by WDW, the Pend Oreille River is one of the most successful bodies of water to hold bass tournaments on. However, nest abandonment due to angler removal of the parent fish is considered to be one of the factors limiting bass production. Therefore it is recommended that: 


\section{2 - 4 Bass tournaments be scheduled before or after peak spawning period (June 15 to July 15) to eliminate nest abandonment due to parent removal.}

- Scientific basis:

Bass tournaments result in fish captured in various locations taken to one central location for weigh in. After weigh in all fish are released at one location, regardless of where they were captured. This results in involuntary nest abandonment by the parent fish leaving these nests open to predation or destruction. In northern Idaho lakes, high nest mortality was caused by pumpkinseeds which preyed on the unguarded bass embryos (Bennett and Bowles 1985). As pumpkinseed are the second most abundant fish species in the Pend Oreille River, serious nest mortality could occur as a result of abandonment.

- Accomplishments and further actions required:

NPPC/BPA: None

WDW/Kalispel Tribe: Change of regulation by the Department of Wildlife to restrict bass tournaments from June 15 to July 15. We recommend that the Kalispel Tribe amend their hunting and fishing regulations to include a restriction of bass tournament anglers from fishing in sloughs on the Reservation from June 15 to July 15.

POCPUD/FERC: None

USFS: None

Most of the factors currently limiting natural population recruitment of the bass population are uncontrollable and therefore the recommendations listed for natural expansion of the population are suspected to be only slightly effective, while at the same time expensive. It would place the burden on: 1) POCPUD in terms of potentially lost power revenues, 2) non-Indian anglers in terms of more restrictions on fishing in a reservoir that already receives low fishing pressure and low harvest rates, and 3) Kalispel tribal anglers who harvest bass for subsistence (their historical fisheries have already been decimated and there are very few other species in the reservoir which could provide a subsistence base). One of the best, most cost effective alternative options is to supplement the natural bass population. The following recommendations were made with current operation conditions and fishing regulations in mind and are therefore an alternative to:

1) Water elevation fluctuation control of the Box Canyon Reach: 
2) Restriction of bass tournaments during spawning season; and

3) Closure of the bass fishery during peak spawning season if non-tournament angler pressure increases.

To accomplish a successful supplementation program while maintaining genetic integrity of largemouth bass that have adapted to the environmental conditions in the Pend Oreille River it is recommended that:

\section{2 - 5 BPA should fund design, construction, operation and} maintenance of an experimental, low capital warm water hatchery on the Kalispel Indian Reservation for largemouth bass egg incubation and rearing. This facility would be built in conjunction with the recommended trout hatchery and would therefore be the warm water section of warm/cold water hatchery.

The hatchery and its water heating system should be modeled after the sturgeon hatchery on the Kootenai Indian Reservation in Bonners Ferry, ID. Gamete collection should be from bass in the Pend Oreille River to maintain the genetic stock that has adapted to such a variable environment. The production goal of this hatchery would be 100,000 bass fry and 50,000 bass fingerlings. No fewer than 20 pairs of parents should be utilized as brood stock.

- Scientific basis:

A hatchery would bypass the factors currently limiting hatching success of largemouth bass in the river; water level fluctuation causing nest abandonment and nest dewatering, predation caused by nest abandonment due to angler removal of parent. Our data supports the hypothesis that there is sufficient habitat to support a much larger largemouth bass population. Calculated biomass for fish of a harvestable size was $5.5 \mathrm{lbs} / \mathrm{acre}(6.2 \mathrm{~kg} / \mathrm{ha})$ in 1989 and $5.8 \mathrm{lbs} / \mathrm{acre}(6.5 \mathrm{~kg} / \mathrm{ha})$ in 1990 . Our biological objective is to double current biomass production in an attempt to achieve a quality bass fishery, which typically produce about 15-20 Ibs/acre (Hisata, pers. comm.). Current production (natural) of the first year class of bass is estimated to be 150,000 , so supplementing the population with an additional 150,000 fish would effectively double current production. We propose stocking 100,000 fry and 50,000 fingerlings to determine which size of fish reflects the best growth, survival and predation rates once they are stocked into the river. An increase in the bass population should decrease the number of perch and pumpkinseed, as a result of predation. A decrease in the perch population would decrease the intraspecific competition and increase the size of perch in the river. 
- Accomplishments and further actions required:

NPPC/BPA: Approval by the Council. Funding by BPA of the design, construction, operation and maintenance of hatching facility on the Kalispel Indian Reservation. Hatchery design and environmental assessment should commence in 1993.

WDW/Kalispel Tribe: The Kalispel Tribe should operate and manage hatchery via funding from BPA. This will partially mitigate the Kalispel Tribe for anadromous fish losses. The Washington Department of Wildlife and Kalispel Tribe, with participation from BPA, should form a Hatchery Advisory Board to oversee production and outplanting.

POCPUD/FERC: None

USFS: None

At the time of this publication, the Kalispel Indian Tribe, through Bonneville Power Administration, is attempting to purchase 420 acres along the river (north of the Kalispel Indian Reservation) to utilize as a wetland refuge. Historically, dikes were built on this property along the river to prevent flooding. The plan to transform this land back into a wetland is to install water control structures which would create ponds behind the dikes. If water control structures are screened, then ponds will not be accessible to fish in the reservoir. With this in mind it is recommended that:

\section{2 - 6 The wetland refuge on the Kalispel Indian Reservation} be utilized to raise the 100,000 largemouth bass fry from the hatchery. Fry would be present in the refuge from June to October, when they would be released into the reservoir as fingerlings $(100 \mathrm{~mm})$. Growth and condition of these bass should be compared to that of bass raised in a hatchery environment on hatchery food.

- Scientific basis:

Slow growth rates and low overwinter survival of young bass is caused by cold water temperatures and competition with yellow perch for food. Rearing of bass in an "offsite' pond has the advantage of warmer water temperatures earlier in the year and greater food production. Data collected from this study determined zooplankton densities were much greater in the sloughs than in the main channel. For example, cladoceran biomass (preferred prey item of bass) in the main channel during 1990, ranged from $0.65 \mu \mathrm{g} / \mathbf{l}$ (micrograms per liter) in April to $19.43 \mu \mathrm{g} / \mathrm{l}$ in September (Ashe et al. 1991). Cladoceran biomass in sloughs and littoral areas ranged from 3.76 $\mu \mathrm{g} / \mathrm{l}$ in April to $37.16 \mu \mathrm{g} / \mathrm{l}$ in July. The greater biomass in the early months is 
especially important for newly hatched fry. Water temperatures are also warmer in the sloughs earlier in the year. For example, temperatures in the sloughs ranged from 11.2 to $13.0^{\circ} \mathrm{C}$ in April, 1988 while temperature in the mainstem ranged from 10.3 to $10.9^{\circ} \mathrm{C}$ (Soltero et al. 1988).

Interspecific competition with perch could be avoided by screening water control structures so bass were the only species in the ponds. Using these methods it is believed that bass fry could attain a size that would allow them to prey on fish (yellow perch of the same age) when they were released into the reservoir. This should increase over-winter survival, therefore increasing recruitment and year-class strength. This project also has the potential of cutting hatchery operation costs, as natural food could be utilized. Also, production of a 'natural' fish has the advantage of a fish adapted to the natural environment and food source, which should increase the chances of survival once the fish are released into the river.

- Accomplishments and further actions required:

NPPC/BPA: The NPPC approved acquisition of the Pend Oreille Wetlands Wildlife Project in January 1991. The proposed project is included in the advanced design report for the wildlife refuge (Merker 1992). BPA purchased an option on this land in 1992 but still needs to acquire the title.

WDW/Kalispel Tribe: The Kalispel Tribe should operate and manage the wetland rearing ponds via funding from BPA.

POCPUD/FERC: None

USFS: None

To enhance the survival of the younger classes of bass (both natural and supplemented) during the winter it is recommended that:

\section{2 - 7 Construction and strategic placement of artificial cover structures to increase the amount of winter cover available in the reservoir.}

- Scientific basis:

Bennett et a/. (1991) estimated over-winter survival of age 0+ largemouth bass in the Pend Oreille River ranged from $\mathbf{0 . 4 - 3 . 9 \%}$ in 1989 and 1990. Although we suspect survival rates are somewhat higher than Bennett estimated, it's obvious that overwinter survival is currently a major limiting factor. It's suspected that poor over-winter survival of young bass is partially due to the lack of cover during the winter months. Aquatic macrophytes provide the majority of cover for fish in the river and sloughs. Falter et a/. (1991) estimated that $54.6 \%$ of the river (from Albeni Falls Dam to Box Canyon Dam) supported aquatic macrophyte communities. In the winter, when aquatic macrophytes die back little physical cover remains for fish species. At this time the larger bass may cannibalize smaller bass. Artificial reefs have been used in several western reservoirs where water fluctuation regime and lack 
of cover for fish posed severe problems for the management of cover-dependent centrarchid species (Brouha and von Geldern, Jr. 1979).

Accomplishments and further actions required:

NPPC/BPA: Approval by the Council. Funding by BPA of design, materials, construction, operation and maintenance of cover structures.

WDW/Kalispel Tribe: The Kalispel Tribe should construct, operate and maintain cover structures via BPA funding.

POCPUD/FERC: None

USFS: None

It is also recommended that:

2 - 8 Supplementation and habitat structure projects be monitored for three years after implementation to determine effectiveness.

Monitoring program should include seasonal evaluation of:

Effectiveness of the slough on the Pend Oreille wetland wildlife mitigation project as bass fry rearing habltat.

Use of habitat enhancement structures by bass fry, as well as, malntenance and replacement needs.

Population estimates of both hatchery and wild largemouth bass in the reservoir to determine change in population structure.

Abundance of zooplankton and yellow perch to determine effect of stocking different numbers of fish on the ecosystem.

Growth rates of hatchery and wild fish stocks.

Effectiveness of different release locations, size at release and time of release, in terms of contributing to creel harvest.

- Scientific basis:

Monitoring of these projects will provide important knowledge upon which future management decisions can be based. Evaluation of wetland rearing ponds will determine effectiveness and cost efficiency of rearing fish in a natural environment on a natural food source. Knowledge about how stocking and habitat enhancement structures effect the population dynamics and ecology of the system will be invaluable to successful management of the fishery. 
- Accomplishments and further actions required:

NPPC/BPA: Approval by the Council. Funding by BPA of the design, labor and equipment necessary for monitoring habitat improvements and supplementation of bass populations.

WDW/Kalispel Tribe: Technical design and labor required to conduct monitoring study should be provided by the Kalispel Tribe.

POCPU D/FERC: None

USFS: None

Independent of whether natural or supplemental method is utilized to expand the largemouth bass population we strongly support the following recommendations regarding management of the Eurasian milfoil and possible introduction of an exotic predator fish species in the Pend Oreille River.

Recently the exotic macrophyte Eurasian watermilfoil has established itself in the Pend Oreille River. Due to the rapid spread of this macrophyte and its potential to create damage to the fishery (by reducing rearing habitat and adult predation rates) management plans for the fishery should include macrophytes. The current management of Eurasian watermilfoil in the reservoir is to "control" it by rotovation. The success of this treatment is currently being evaluated by determining regeneration in a rotovated area. Based on data collected in this study it is recommended that:

\section{2 - 9 Utilization of the "edging" technique (rotovating rows through the weed bed) during rotovation to increase the amount of "big" fish (bass) habitat.}

- Scientific basis:

Most of the bass captured during electrofishing surveys throughout the three year study period were associated with weed beds in littoral areas. Radio and sonic tagged bass were frequently located near the edge of large, dense macrophyte beds.

According to Prince and Maughan (1979) prey that are attracted to structure become concentrated in vegetation, thereby increasing encounter rates with, and vulnerability to, foragers that also reside there. Predation rate is reduced as structural complexity increases (Savino and Stein 1982), therefore the dense beds of milfoil in the river pose serious feeding obstacles to adult largemouth bass. Open spaces or 'trails' through the dense macrophyte beds would be advantageous to predators (bass) as these spaces would provide more areas for ambushes. 
- Accomplishments and further actions required:

NPPC/BPA: None

WDW/Kalispel Tribe: None

POCPUD/FERC: None

Army Corps of Engineers/Pend Oreille County (COE/POC): Change in current rotovating program to include rotovating of 'trails' through dense milfoil beds to increase 'big' fish habitat.

USFS: None

Bennett et a/. (1991) suggested planting northern pike or tiger muskies in the Pend Oreille River to decrease the perch and pumpkinseed populations and improve the fishery. We strongly recommend:

\section{2-10 No further introductions of exotic fish species (i.e. walleye, northern pike, tiger muskies) be made into the Pend Oreille River.}

- Scientific basis:

Magnuson (1976) and Li and Moyle (1981) caution that introductions of exotic species: 1) frequently have the opposite effect of the intended impact and 2) often reduce the fish managers ability to effectively manage the system because the introduction destabilizes existing interactions. Based on the data collected during this study the introduction of another piscivorous species into the Pend Oreille River fishery is not recommended. The fish species that currently exist in the river have evolved for the past forty years to where now fairly stable populations are supporting the fishery. If the largemouth bass population was well managed it should be sufficient to decrease the perch and pumpkinseed populations. An introduction of exotic fish species into this system at this time would reduce the biological stability and decrease our ability to manage the fishery with any amount of predictability. Exotic fish introduction could also negate any benefits of the fishery enhancement projects recommended in this report, which are consistent with the management goals of the Kalispel Indian Tribe and Washington Department of Wildlife, the two entities with management jurisdiction in the Box Canyon Reach of the Pend Oreille River. Consistency with the management goals of the agencies and tribes is required by the Northwest Power Act.

It's possible that an introduction of pike may not accomplish the desired affect of reducing the perch and pumpkinseed population. Rodger (1991) reported that northern pike are indiscriminate in their feeding habits, eating large numbers of trout and bass. Inskip (1982) found pike preferred soft-rayed, cylindrical fishes which are apparently more easily swallowed as compared to the spiny and/or laterally compressed fish species. This suggests that the pike may preferentially prey on the trout and whitefish in the Pend Oreille River, which could be disastrous to the already threatened bull trout 
and cutthroat trout populations. In addition, many studies (Beyerle and Williams 1968; Coble 1973; Inskip 1982; Wahl and Stein 1988) found that northern pike are not effective predators and do not prefer spiny, laterally compressed fish (pumpkinseed and bluegill). Anderson and Schupp (1986) speculated that the reduction of yellow perch through northern pike predation allowed bluegill numbers to increase. In the case of the Pend Oreille River it is likely that the pumpkinseed population would increase. Pumpkinseed are not a sport fish, are not harvested by anglers and already compose $16 \%$ of the fish species present in the river.

Another consideration is that, although movement of these species is not well documented, studies done in lakes and small streams have shown that northern pike can display high mobility (Miller 1948, Ross and Winter 1981). Pike tracked in the Yampa River, Utah traveled $>75 \mathrm{~km}$ in one year (Tyus and Beard 1990). Based on these data pike released in the Pend Oreille River have the potential to migrate into the Columbia River which could impact resident fish enhancement efforts in Lake Roosevelt. As Lake Roosevelt lacks optimal northern pike habitat these fish could move through the reservoir, below Grand Coulee Dam, and impact anadromous fish recovery efforts. Northern pike are well known voracious predators. Their introduction to the lower Columbia reservoirs could result in a serious reduction of the salmon and steelhead smolts passing through those reservoirs during their migration to the ocean.

An additional consideration in introducing northern pike into the Pend Oreille River are diseases common to the species. Twenty percent of the feral population of northern pike are infected with lymphosarcoma, a malignant blood cancer (Sonstegard and Hnath 1978). In addition, pike are infected with the tapeworm Triaenophorus crassus which utilizes whitefish as it's intermediate host (Lawler 1965). This could effect the native mountain whitefish population in the Pend Oreille River, which currently supports a population of around 160,000 fish. Although there is currently low angler preference for whitefish, this species has the potential to support a healthy fishery.

Accomplishments and further actions required:

NPPC/BPA: None

WDW/Kalispel Tribe: Restriction of introduction of exotic fish species into the Pend Oreille River by the Department of Wildlife and the Kalispel Indian Tribe.

POCPUD/FERC: None

USFS: None 


\section{ACKNOWLEDGEMENTS}

The authors greatly appreciate the following individuals for the many hours they spent in field data collection and laboratory analysis: Michael R. Barber, Kelly Lillengreen, Roger Willms, John Vella, Loreley Clark, Dale Chess, Diana Richards, Tami Skillingstad, Steve Martin, Lori Hill and Suzy Graves, (Upper Columbia United Tribes Fisheries Center); and Glen Nenema, Jr., Lloyd Finley, George Campbell and David Nenema (Kalispel Tribal Assistants); and Kathleen O'Shields, Suzie Lam, Kiki Lam, Rich Williams, Laura Dunton, Charles Gallagher, Philip Ashe, Nate Renberg, Dave Renberg, Philip Lillengreen, Keith Underwood, George Gerainos, Zorre Dearborn, Russ Heaton and Richard LeCaire (undergraduates and family volunteers). A special thanks goes to Tami Skillingstad, who spent many hours designing and revising the bass tracking maps.

We appreciate the technical advice and assistance received from Don Brumbaugh (Sonotronics, Tucson, AZ) and Paul Anders (USFWS, Cook, WA) on surgical implantation of transmitters and tracking of the fish. A special thanks goes to Mike Barber who performed implantation surgery on half of the fish and who also provided invaluable technical advice throughout this project. We also appreciate the many hours Glen Nenema, Jr. and Dave Nenema spent tracking bass.

Thanks also go to D.r. Dave Bennett (Professor, University of Idaho) and John Hisata (Washington Dept. of Wildlife, Spokane) for their technical support and advice. Doug Fletcher (Washington Dept. of Wildlife, Olympia), Pat Buckley (Pend Oreille County Public Utilities District, Newport), Jay Hammond (BC Ministry of Environment, BC), Randy Coots (Dept. of Ecology, Olympia), James Mullan (USFWS, Leavenworth, WA), Bret Smith (USGS, Water Resources Division, Spokane) and Larry LaBolle (Washington Water Power, Spokane) were helpful in obtaining necessary data.

Funding for this project was provided by the U.S. Department of Energy, Bonneville Power Administration, Contract number DEA179-88BP39339. Special thanks go to Fred Holm (BPA Project Manager), Glen Nenema, Sr. (Chairman, Kalispel Tribal Council), Francis Cullooyah, Stan Bluff, Alice O'Conner and Vickie Pierre (Kalispel Tribal Council) and Dave Bonga (Kalispel Tribal Planner) for their assistance with this project. 


\section{TABLE OF CONTENTS}

EXECUTIVE SUMMARY

ACKNOWLEDGEMENTS

$\mathbf{x} x \mathbf{i}$

1.0 INTRODUCTION

1.1 FISHERIES MANAGEMENT HISTORY OF THE

PEND OREILLE RIVER

1.2 STUDY OBJECTIVES ……..................................................... 7

2.0 METHODS AND MATERIAL ....................................... 8

2.1 DESCRIPTION OF THE STUDY AREA ………................... 8

2.2 SAMPLING REGIME …................................................... 12

2.3 RELATIVE ABUNDANCE ….......................................... 12

2.4 POPULATION ESTIMATES............................................... 14

2.4.1 RIVER …........................................................... 14

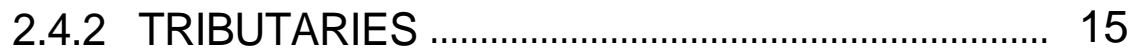

2.5 MORTALITY

2.6 AGE, GROWTH, AND CONDITION ….................................. 23

2.7 FOOD AVAILABILITY IN THE RIVER,

SLOUGHS, AND TRIBUTARIES .......................................... 25

2.7.1 BENTHIC MACROINVERTEBRATE

DENSITIES IN THE RIVER AND SLOUGHS..........25

2.7.2 BENTHIC MACROINVERTEBRATE

DENSITIES IN TRIBUTARIES AND

INVERTEBRATE ABUNDANCE IN

THE DRIFT .......................................................... 26

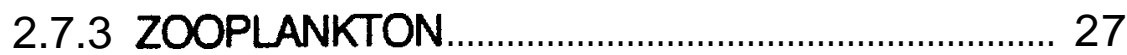

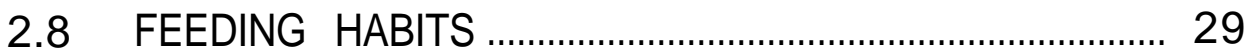

2.8.1 FIELD COUECTION METHODS …........................... 29

2.8.1.1 RIVER AND SLOUGHS ................................. 29

2.8.1.2 TRIBUTARIES ……....................................... 31

2.8.2 LABORATORY METHODS …..................................... 31

2.8.3 DATA ANALYSIS ................................................. 32

2.8.3.1 INDEX OF RELATIVE IMPORTANCE ................................................... 33

2.8.3.2 DIET OVERLAP INDEX .................................. 34

2.8.3.3 ELECTIVITY INDEX ….................................. 34

2.9 FISH MOVEMENT AND MIGRATION ................................... 35

2.9.1 FLOY TAGGING OF TARGET SPECIES

2.9.2 ULTRASONIC AND RADIO

TELEMETRY OF LARGEMOUTH BASS ..................... 36

2.9.3 LARGEMOUTH BASS SEASONAL MOVEMENT AND MIGRATION 
2.10 HABITAT UTILIZATION

2.10.1 LARGEMOUTH BASS HABITAT

UTILIZATION DURING TELEMETRY ................39

2.10.2 HABITAT UTILIZATION CURVES

OF LARGEMOUTH BASS AS

DETERMINED FROM ULTRASONIC

AND RADIO TELEMETRY

2.10.3 HABITAT UTILIZATION OF

TARGET SPECIES DURING

ELECTROFISHING SURVEYS.

2.11 CREELSURVEY

3.0 SUMMARY OF FISHERIES ASSESSMENT $\ldots \ldots \ldots \ldots \ldots \ldots, \ldots$

3.1 RESERVOIR POPULATION DYNAMICS ............................. 48

3.1.1 RELATIVE ABUNDANCE AND CPUE......................50

3.1.2 POPULATION ESTIMATES...................................... 55

3.1.3 MORTALITY ............................................................. 60

3.1.3.1 TOTAL INSTANTANEOUS

MORTALTY.................................................. 60

3.1.3.2 FISHING MORTALITY .................................. 65

3.2 AGE, GROWTH AND CONDITION OF FISH

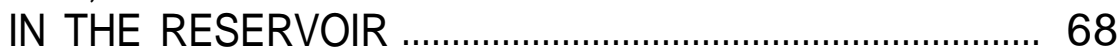

3.3 FOOD AVAILABILITY ................................................... 84

3.4 FEEDING HABITS OF FISH IN

THE RESERVOIR

92

3.5 MOVEMENT AND MIGRATION OF

FLOY TAGGED FISH

3.6 MOVEMENT AND MIGRATION OF

RADIO AND SONIC TAGGED

LARGEMOUTH BASS

118

3.6.1 TIGER SLOUGH.................................................. 118

3.6.2 GARDINER SLOUGH ........................................... . I 22

3.6.3 CAMPBELL SLOUGH............................................ 125

3.6.4 DIKE SLOUGH ……........................................... 127

3.6.5 POW WOW SLOUGH .............................................. 130

3.6.6 INDIAN ISLAND SLOUGH ...................................... 133

3.6.7 ASHENFELDER BAY ............................................. 136

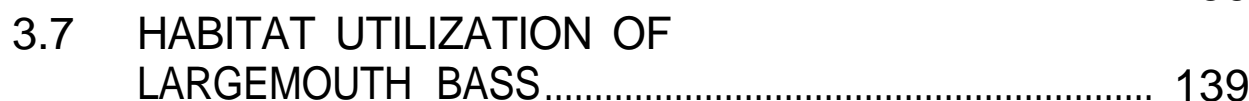

3.8 TRIBUTARIES …........................................................... 147

3.8.1 POPULATION ESTIMATES ...................................... 147

3.9 AGE, GROWTH AND CONDTIION

OF FISH IN THE TRIBUTARIES 
3.10 FOOD AVAILABILITY IN THE

TRIBUTARIES

3.10.1 BENTHIC MACROINVERTEBRATE

DENSITIES IN THE TRIBUTARIES.

3.10.2 ABUNDANCE OF DRIFTING

INVERTEBRATES IN THE

TRIBUTARIES

3.11 FEEDING HABITS OF FISH IN THE

TRIBUTARIES

3.11.1 LECLERCCREEK

172

3.11.2 RUBYCREEK

177

3.11.3 CEECEEAHCREEK.

181

3.11.4 TACOMA CREEK 186

3.11.5 SKOOKUM CREEK 191

\subsection{DISCUSSION}

4.1 FISHERY STATUS 198

4.1.1 TROUT FISHERY IN THE RESERVOIR. 198

4.1.2 TROUT FISHERY IN THE TRIBUTARIES. .206

4.1.3 MOUNTAIN WHITEFISH FISHERY.. 222

4.1.4 LARGEMOUTH BASS FISHERY. 227

4.1.5 PERCH FISHERY... 241

4.1.6 CRAPPIE FISHERY 245

4.1.7 POTENTIAL FOR

INTRODUCED SPECIES FISHERY 248

4.1 .8 NON-TARGET SPECIES FISHERY......................... 50

4.2 EURASIAN MILFOIL................................................... 252

4.3 RECOMMENDATIONS FOR ENHANCEMENT....................25

4.3.1 OBJECTIVE 1:

NATIVE TROUT SPECIES 255

4.3.2 RECOMMENDATIONSTO ENHANCE

THE NATIVE TROUT SPECIES 256

4.3.2.1 PROTECT EXISTING NATIVE TROUT STOCKS 258

4.3.2.2 NATIVE TROUT POPULATION EXPANSION 259

4.3.2.3 REESTABLISH SELFSUSTAINING NATIVE TROUT POPULATIONS 260

4.3.3 OBJECTIVE 2:

LARGEMOUTH BASS 265

4.3.4 RECOMMENDATIONS TO ENHANCE

THE LARGEMOUTH BASS FISHERY.

4.3.4.1 NATURAL POPULATION 266 


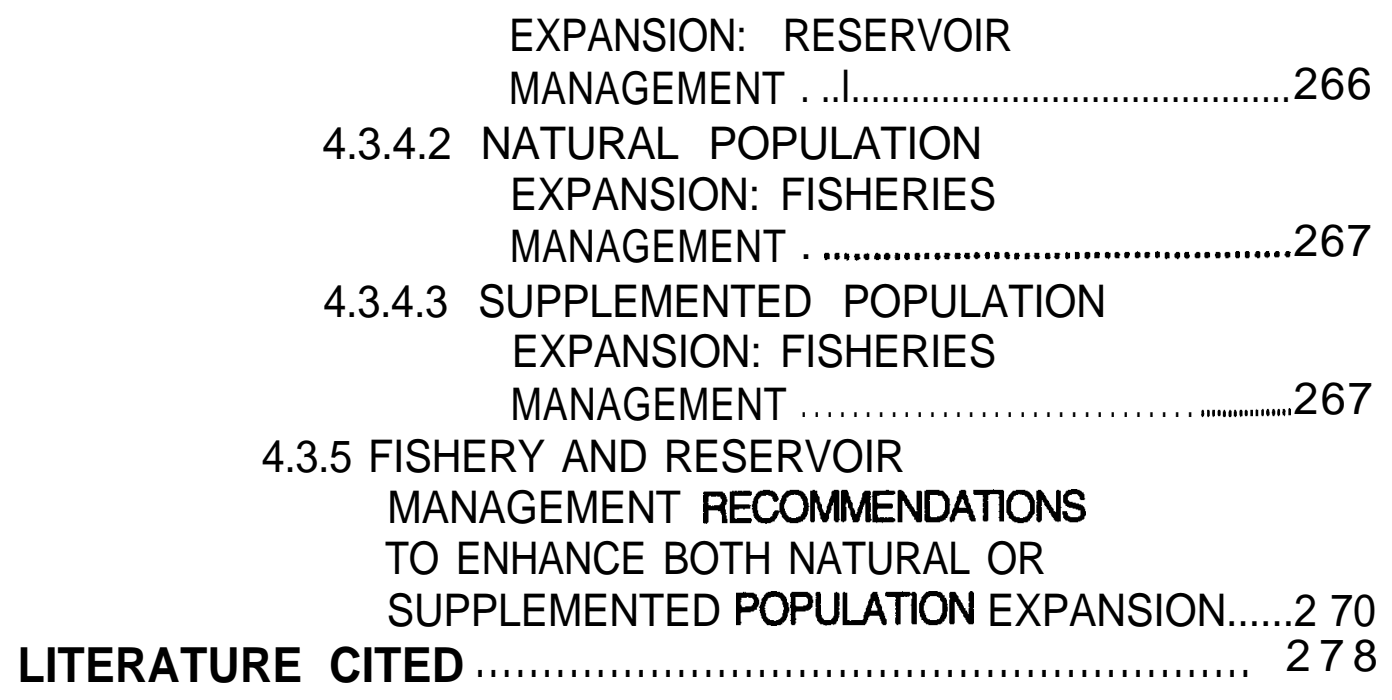




\section{1 .O INTRODUCTION}

In 1987, the Northwest Power Planning Council amended its Columbia River Basin Fish and Wildlife Program to include a resident fish substitution policy. This policy called for substitution of resident fish in place of anadromous salmonids as partial mitigation for losses in the blocked area above Chief Joseph and Grand Coulee Dams. One of the resident fish substitution projects adopted by the Council was: "An assessment of fishery improvement opportunities in the Pend Oreille River within the boundaries of the Kalispel tndian Reservation. This survey will provide: i) Baseline information about existing fish populations and habitat and ii) information on possible means of improving fisheries. When the assessments are completed, recommendations for projects will be submitted to the Council" [Section 903(g)(I)(G)]. The Council's Five Year Action Plan stated that Bonneville Power Administration (BPA) should commence funding of a three year assessment of the fishery improvement opportunities on the Pend Oreille River adjacent to the Kalispel Reservation starting in Fiscal Year 1988 [Section 1400(7.7)]. This report contains a summary of the findings of the three year survey of the Pend Oreille River fishery and recommendations for fishery enhancement as partial mitigation for the permanent blocks of anadromous fish caused by construction of Grand Coulee and Chief Joseph Dams. These recommendations are proposed as a resident fish substitution under the Power Council's 1987 Resident Fish Substitution Policy.

\subsection{FISHERIES MANAGEMENT HISTORY OF PEND OREILLE RIVER}

Historically, both chinook salmon (Oncorhynchus tshawytscha [Walbaum]) and steelhead (Oncorhynchus mykiss [Richardson]) formerly spawned in the Pend Oreille River (Gilbert and Evermann 1895; Bryant and Parkhurst 1950; Fulton 1968, 1970; and Fulton and Laird, unpublished report, reviewed by Scholz et al. 1985). Gilbert and Evermann (1895) reported that "steelhead were abundant in the Pend Oreille River in 1894." Salmon and steelhead continued to be present in the lower segment of the river until Grand Coulee Dam was built (Bryant and Parkhurst 1950).

A report by McDonald (1894) to the United States Senate contained a map entitled "The natural limits of the distribution of salmon in the Columbia Basin", which showed salmon as being present in the Pend Oreille system. McDonald's map was based upon 
information obtained by Livingston Stone (1885) who was sent by the U.S. Fish Commission to survey the Clark Fork and Pend Oreille Rivers for the purpose of selecting a hatchery site at a point along the Northern Pacific Railway Line. Stone reported, "Very few salmon reach Lake Pend Oreille or the Clark fork above the Lake. The testimony of all persons consulted on the subject at Deer Lodge, Missoula, Sandpoint and at various smaller stations on the railroad was unanimous to the effect that no salmon were ever caught in Clark Fork or above. The cause of the absence of salmon on Lake Pend Oreille or above is the falls of Senniacwateen [i.e., Albeni Falls] 15 miles below the outlet of the Lake."

In an article published in Transactions of the American Fisheries Society in 1883, Stone wrote, "I heard of salmon being caught all the way up to the falls of the Senniacwateen [i.e., Albeni Falls]--so the salmon are obviously not all stopped at the falls of the Pend Oreille [i.e., Metaline Falls], though probably not a very large proportion get by them. The falls of the Senniacwateen . . . mark the highest point of the upward migration of salmon on [the Pend Oreille River]. "

Gilbert and Evermann (1895) were the only investigators to explore the entire length of the Pend Oreille River. Their description was, "The Pend d'Oreille River is one of the most beautiful and picturesque in America. It is a magnificent river, probably averaging over 1,000 feet in width and being very deep throughout most of its course. In most places there is a good, strong current, becoming dangerous rapids in the narrower places. The water is clear and pure and co/d-an ideal trout stream." They described Albeni Falls, Box Canyon, and Metaline Falls as the most serious obstacles to salmon. Gilbert and Evermann wrote, "All agree that Metaline Falls is the most serious obstruction found anywhere in the Pend d'Oreille. The falls [Metaline] are over a ledge of limestone, through which the river has cut, and are the largest and most important of any found in this river. The total fall is perhaps as much as 30 feet, but it is in a series of rapids, there being no vertical drop at all-- Salmon could probably ascend these falls without much difficulty.

Downstream from Metaline Falls, Big Eddy Cascade was also identified as an obstacle, but not a barrier. Gilbert and Evermann wrote, "The river rushes through this canon [Big Eddy] with great 
fury, but there are no falls, and we do not believe that the ascent of salmon would be seriously interfered with. "

Native resident fish in the Box Canyon reach included cutthroat trout (Oncorhynchus clarki [Richardson]) and bull trout (Salvelinus confluentus [Suckley]). Gilbert and Evermann (1894) reported that bull trout "are abundant in the Pend Oreille River. We saw in the possession of an Indian several fine specimens, the largest of which was 26 inches long, 11 inches in greatest circumference, and weighted 5 pounds and 1 ounce."

The Kalispel Tribe historically depended heavily on fish for subsistence and used a variety of means to catch both anadromous salmonids and resident fishes such as char (bull trout), trout, chub, whitefish, suckers, and squawfish (Bonga 1978, Scholz et al. 1985). Ray (1937) reported that the Kalispels maintained a permanent village at the mouth of the Calispel River near Cusick, WA. During the early summer up to one thousand persons often gathered for the communal distribution of fish caught in the fish trap maintained at the site (Ray 1937).

While the construction of Grand Coulee Dam eliminated salmon and steelhead from the Pend Oreille River, the construction of Box Canyon Dam in 1955 resulted in a decline in the population of resident salmonids. Evidence to support this contention can be found in correspondence and creel information on file at the Washington Department of Wildlife (WDW, formerly Washington Department of Game [WDG]) Regional office in Spokane, WA.

In a letter dated May 15, 1949 from Don Earnest (WDG, Spokane) to Clarence Patuzke (WDG, Seattle) was the following information on the Pend Oreille River: "Rainbow in large numbers are being caught in the Pend Oreille River from fingerlings planted in 1946 and 1947. Most of these fish are now 17 to 18 inches in length. Many large fish are being taken. One rainbow had a dressed weight of 13 lbs 9 oz, length of 31 inches and girth of 20 inches. Such stream survivals have not been found elsewhere."

In a letter dated October 1, 1952 from Don Earnest (WDG, Spokane) to Robert C. Meigs (WDG, Seattle) concern was expressed about the potential impacts of Box Canyon Dam. "From damsite upstream for approximately 25 miles is found the majority of the riffle and fishable pool area of the entire Pend Oreille River. The elevation at Box Canyon is $1195 \mathrm{ft}$ at low water (7943) and at Ruby 
2023.5 -- a difference of $28.5 \mathrm{ft}$. The pool elevation of 2025 will inundate all the good riffle and pool area in the 25 miles of Box Canyon. Fish populations of the Pend Oreille River are relatively heavy. Good populations of large rainbow, cutthroat and brown trout inhabit the riffle and pool areas principally. Whitefish are found in countless thousands throughout all riffle and pool areas... When Box Canyon Dam is built at least $75 \%$ of the best water in the Pend Oreille will be destroyed as trout and whitefish habitat. The results of such impoundments are well illustrated in Roosevelt Lake. Prior to construction of Coulee Dam whitefish were very abundant. They are still below Coulee but only small remnants are found in Lake Roosevelt. Rainbow trout were found in all the faster water. At present the rainbow and cutthroat trout are restricted to the extreme upper portion of Roosevelt Lake where the river is still in relatively natural condition and good fishing is enjoyed only in this area."

A newspaper article in the April 3, 1957 issue of the Metaline Falls Gazette reported that a $15 \mathrm{lb} 8 \mathrm{oz}$ rainbow was caught in Pend Oreille during a 1957 Field and Stream tournament. Also caught in the tournament were a $13 \mathrm{lb} 9 \mathrm{oz}$ rainbow, $9 \mathrm{lb} 8 \mathrm{oz}$ rainbow, $6 \mathrm{lb} 8$ oz rainbow, and many large Dolly Varden [i.e., bull trout].

In 1958, Don Earnest (WDG, Spokane) stated that the river was "a lost cause for trout and will be full of squawfish in a few years." In August, 1968 a squawfish derby was held and during an 18 day period 3,350 squawfish and 27 game fish were caught.

In a letter dated July 17, 1972 to the United States Department of the Interior (Portland), L.G. Perry (USFWS Bureau of Sport Fish and Wildlife) made the following statement concerning the Box Canyon Reservoir: "Formerly as the free-flowing Pend Oreille River it provided a salmon fishery of moderate to high value. Presently the reservoir supports primarily a spiny ray fishery that is largely unused."

In a letter dated April 19, 1973 to Mr. Bob Bayless, R.R. Simmons (WDG) remarked that "Good fishing on the Pend Oreille River cannot be expected."

A letter dated May 9, 1978 from Ray Duff (WDG, Spokane) to Dave Gufler (WDF, Olympia) contained the following: "Box Canyon Dam was completed in 1955. Prior to impoundment, the freeflowing Pend Oreille River offered some fair trout angling, which 
according to our records, diminished shortly after completion of the dam. Most recently, the bass fishery has received considerable interest (from Spokane Bass Clubs). A primary concern to many has been the water fluctuations during June, which is the peak spawning period for the Pend Oreille River bass population. Shallow flooded areas are essential for reproduction. Stable water levels would be helpful. To my knowledge no efforts were made by the department to mitigate lost resources as a result of Box Canyon Dam construction. I believe Box Canyon Dam was built by the Pend Oreille County PUD and Albeni Falls by U.S. Army Corps of Engineers. I further believe that neither impoundment has been used for flood control, only power generation."

Creel census data collected by the WDW from 1946 to 1985 demonstrates the decline in the trout fishery in the Pend Oreille River. Prior to 1958, the river was primarily a cold water fishery with cutthroat trout, rainbow trout (Oncorhynchus mykiss [Richardson]), brown trout (Salmon trutta [Linnaeus]), and whitefish making up most of the creel. The dam construction resulted in the river being converted from a free flowing system to slow moving reservoir. The flooding resulted in the formation of shallow sloughs that provide spawning areas for warm water species such as largemouth bass, pumpkinseeds, and black crappie. The proliferation of aquatic macrophytes provided yellow perch with ample spawning habitat and cover from predators and led to increased numbers of herbivorous (i.e., tench) and detritivorous fishes (i.e., suckers). The substrate in the reservoir is dominated by mud and silt and a few areas having sand, gravel or cobble. The physical changes in the habitat, resulting from dam construction, has led to a change in the creel to warm water species since 1958 (WDW files).

Trout species are now more abundant in tributaries than in the reservoir. The WDW, in 1978, set gill nets in Sand and Sweet Creeks, catching brown trout to 21 inches, rainbow trout in the 6 to 7 inch range, cutthroat trout to 12.5 inches and whitefish 8 to 14 inches long. Anderson et al. (1985) conducted a population estimate for Cee Cee Ah Creek, on the Kalispel Indian Reservation. The population estimate ( \pm 95 percent confidence interval) for a 700 yard section from the mouth upstream was 1,417 \pm 213 brown trout, $123 \pm 36$ brook trout and 1,578 \pm 851 sculpins.

This report focuses on recommendations for resident fish substitution projects to partially replace anadromous fish losses 
caused by the permanent blocks to migration caused by the construction of Grand Coulee and Chief Joseph Dams. These recommendations involve enhancing the resident fishery in the Pend Oreille River as a substitute for anadromous fish losses. These recommendations do not include mitigation for fish losses caused by the Box Canyon Dam. Various changes in Box Canyon Dam reservoir management could benefit native species but have not been addressed in this report. The reason for this is benefits to fish would be at the expense of power production because it would require operating the reservoir at a lower pool. Even if operating conditions were altered, at this point we are unsure about the benefits to the native trout species but there would be negative impacts to the largemouth bass population.

Additionally, these recommendations directly address biological concerns only and do not address compensation or mitigation owed to the Kalispel Indian Tribe for the destruction of both their salmon fishery (caused, in part, by construction of Grand Coulee Dam) and resident trout fishery (owing to construction of Box Canyon Dam). In developing these recommendations we have intentionally attempted to minimize the impact upon the hydroelectric system and anadromous fish recovery plans. In this report we are recommending that the Northwest Power Planning Council direct Bonneville Power Administration to fund the proposed enhancement measures as resident fish substitution projects under the Northwest Power Planning Council's Columbia Basin Fish and Wildlife Program. 


\subsection{STUDY OBJECTIVES}

The purpose of this three year study was to identify -fishery improvement opportunities for the Box Canyon Reservoir of the Pend Oreille River and its tributaries. Species targeted in this study included all trout, mountain whitefish, largemouth bass, yellow perch and black crappie. The objectives of the study were to collect information on:

1. Population dynamics (including relative abundance, population levels, natural and fishing mortality, and recruitment);

2. Growth rates;

3. Feeding habits;

4. Behavior patterns; and

5. Factors limiting fish production (e.g., food availability, competition, habitat availability, environmental fluctuations).

Details of this work were presented in annual reports; Barber et al. (1989), Barber et al. (1990) and Ashe et al. (1991).

This report:

1. Summarizes the three year baseline information on fishery population dynamics, growth rates, feeding habits, behavior patterns and limiting factors; and

2. Provides recommendations for fishery enhancement in the Pend Oreille River based on the three year survey. 


\subsection{METHODS AND MATERIALS}

\subsection{DESCRIPTION OF THE STUDY AREA}

The Pend Oreille River begins at the outlet from Pend Oreille Lake, ID, and flows in a westerly direction. The river changes direction near Dalkena, WA, and flows approximately $67 \mathrm{~km}$ north to British Columbia, Canada, where it enters the Columbia River. The approximate drainage area of the river at the international border is $65,300 \mathrm{~km}$ ? Fig. 2.1 shows the 38 year mean (1953-1990) monthly flows as measured at the Newport, WA gage. The normal high flow month is June with a mean discharge of 61,858 cubic feet per second (cfs). Normal low flow month for the Pend Oreille River is August with a mean discharge 11,897 cfs.

The study area covers the 90 kilometer section of the river from Box Canyon Dam at river kilometer (RK) 55.5 to Albeni Falls Dam at RK 145 (Fig. 2.2). Within this reach, eleven river, four slough and five tributary study sites were established (Table 2.1). The tributaries studied were LeClerc Creek, Ruby Creek, Cee Cee Ah Creek, Tacoma Creek and Skookum Creek.

Fish species reported to occur in the Box Canyon Reservoir of the Pend Oreille River include: brown trout, cutthroat trout, rainbow trout, brook trout (Salvelinus fontinalis [Mitchill]), bull trout, mountain whitefish, largemouth bass, black crappie, pumpkinseed (Lepomis gibbosus [Linnaeus]), yellow perch, tench, redside shiner, northern squawfish, peamouth, lake chub, longnose sucker, largescale sucker, brown bullhead and sculpin (Barber et al. 1989; Barber et al. 1990; Ashe et al. 1991). Kokanee have been reported in the Box Canyon Reservoir, but these presumably originated from Lake Pend Oreille and were flushed over Albeni Falls Dam (Ashe et al. 1991; Bennett et al. 1991). Sturgeon have also been reported in the reservoir, however, attempts to catch one by setting 19, 18 gangion sturgeon set lines for 243 hours during May, June and July of 1988 met with no success. A total of 753,000 walleye (Stizostedion vitreum vitreum [Mitchill]) fry were planted in the reservoir in 1983 and 1984; and 148 adult tagged walleye were planted in 1987 (WDW, Spokane). Several anglers reported catching walleye during this study, however, no confirmed siting was made, and none were caught in fisheries studies conducted by Barber et al. 1989, 1990, Ashe et al. 1991 or Bennett et al. 1991. 


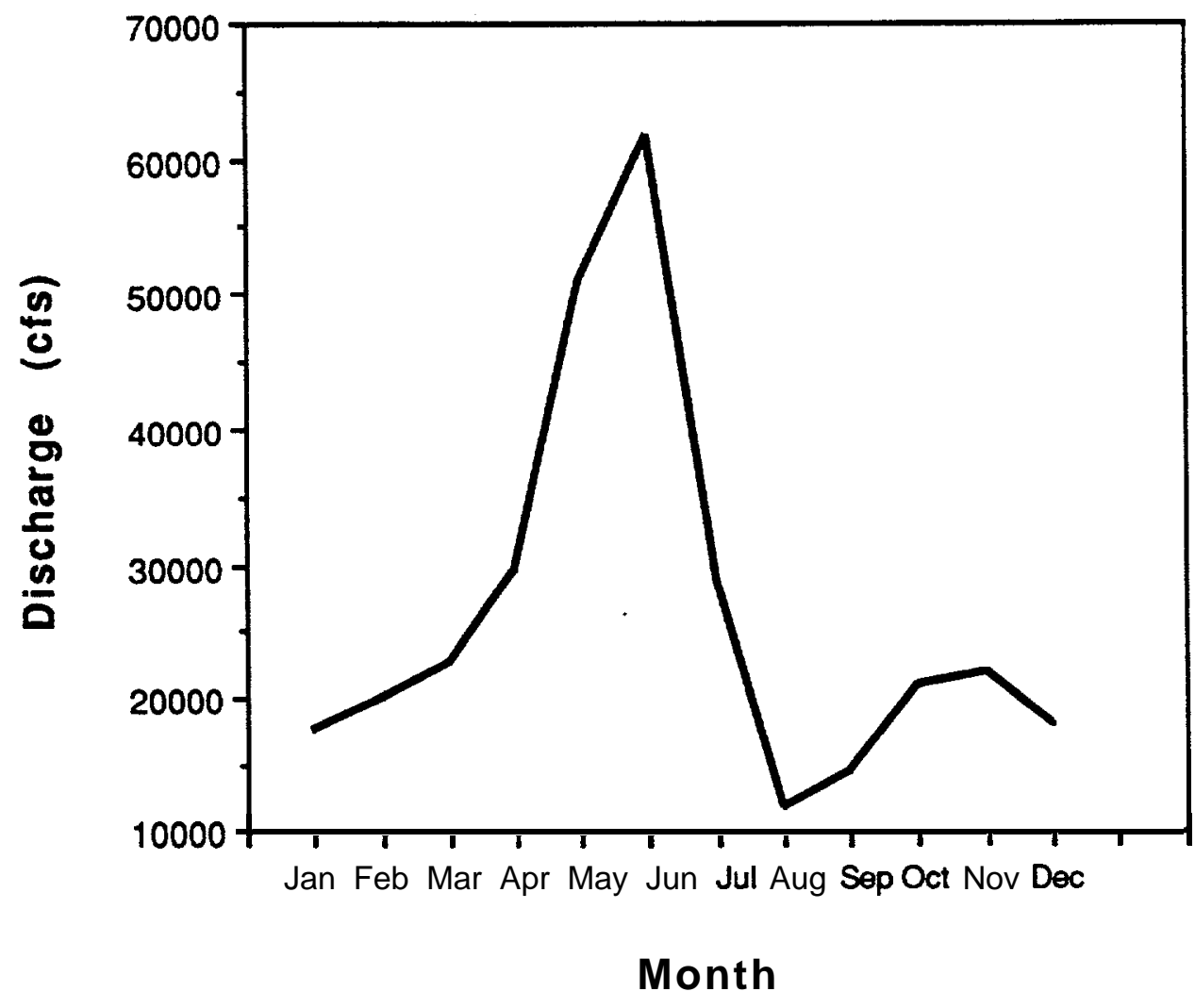

Figure 2.1. Thirty-eight year mean (19534990) monthly flows of the Pend Oreille River as measured at Newport, WA (USGS gage 12395500). 


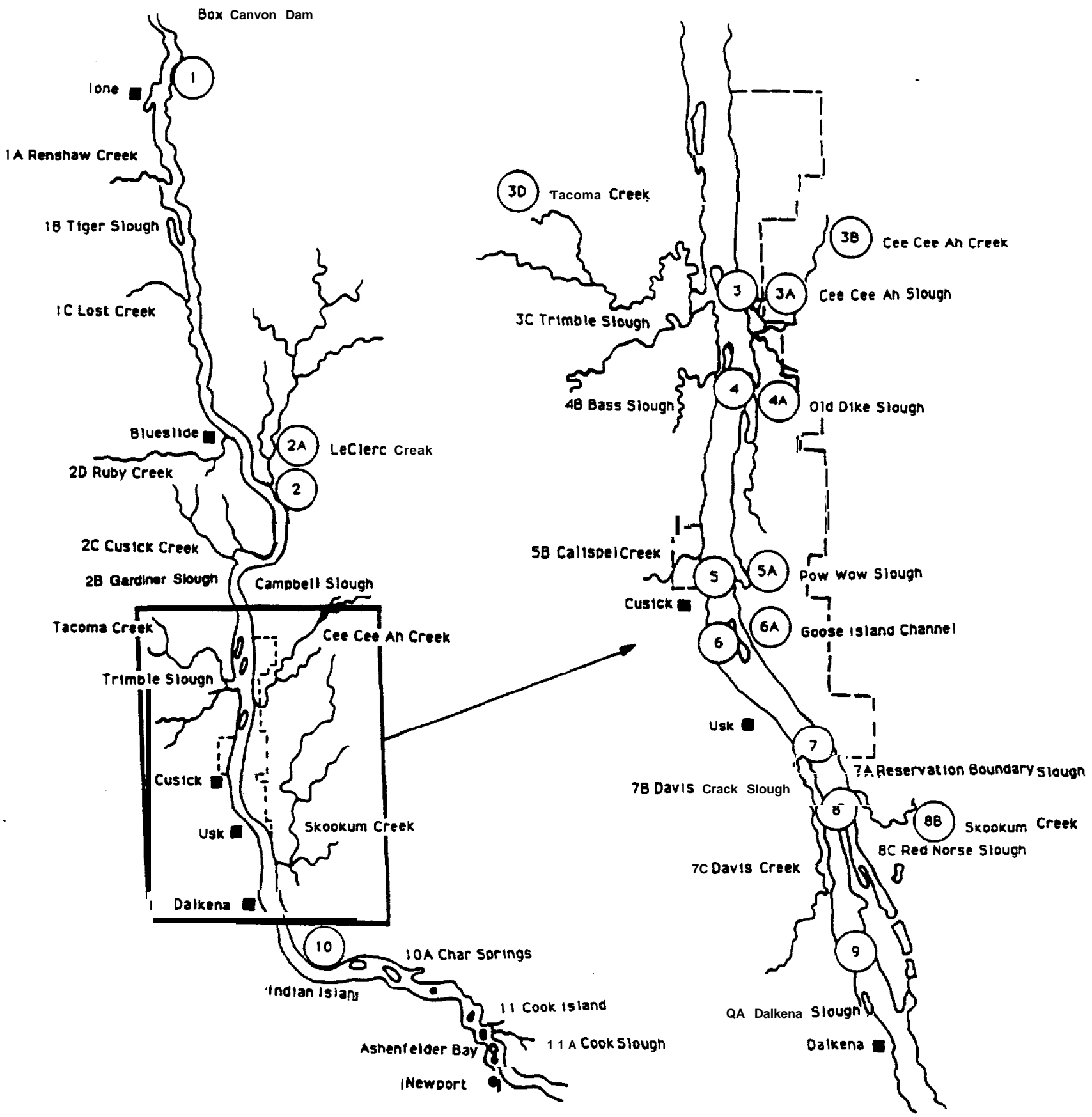

Figure 2.2. Map of the Pend Oreille River showing the location of study sites. 
Table 2.1. Locations of study sites. Sites shown on Fig.

2.1 but not described here are not normal study sites but were sampled when time and budget allowed.

\begin{tabular}{|c|c|}
\hline STUDY SITE & LOCATION \\
\hline 1 & At RK 59.5 , just north of lone, WA \\
\hline 2 & $\begin{array}{l}\text { At RK 90.4, near the confluence with LeClerc } \\
\text { Creek }\end{array}$ \\
\hline $2 \mathrm{~A}$ & $\begin{array}{l}\text { LeClerc Creek; confluence with the Pend Oreille } \\
\text { River at RK } 90.4\end{array}$ \\
\hline $2 \mathrm{D}$ & $\begin{array}{l}\text { Ruby Creek: confluence with the Pend Oreille } \\
\text { River at RK } 83.7\end{array}$ \\
\hline 3 & $\begin{array}{l}\text { At about RK 107, near the mouth of Cee Cee Ah } \\
\text { Slough }\end{array}$ \\
\hline $3 A$ & $\begin{array}{l}\text { Cee Cee Ah Slough; located at RK } 107 \text { on east } \\
\text { bank }\end{array}$ \\
\hline $3 B$ & Cee Cee Ah Creek: enters Cee Cee Ah Slough \\
\hline $3 \mathrm{D}$ & $\begin{array}{l}\text { Tacoma Creek: enters Trimble Slough located on } \\
\text { west bank at RK } 107\end{array}$ \\
\hline 4 & At RK 108.6 \\
\hline $4 \mathrm{~A}$ & Dike Slough: east bank at RK 108.6 \\
\hline 5 & At RK 113 , adjacent to Cusick, WA \\
\hline $5 \mathrm{~A}$ & Pow Wow Slough; east bank at RK 112 \\
\hline 6 & At RK 114 , adjacent to Goose Island \\
\hline $6 \mathrm{~A}$ & Goose Island Slough, at RK 114 \\
\hline 7 & At $\mathrm{RK} 116.5$ \\
\hline 8 & At RK 119, near mouth of Skookum Creek \\
\hline $8 B$ & $\begin{array}{l}\text { Skookum Creek; enters river on east bank at RK } \\
118\end{array}$ \\
\hline 9 & At RK 121.5 \\
\hline 10 & At RK 130 , adjacent to Indian Island \\
\hline 11 & At RK 139.2, adjacent to Cook island \\
\hline
\end{tabular}




\subsection{SAMPLING REGIME}

The information contained in this report is based on data collected from March 1988 through October 1990, with the exception of creel survey data which were collected from March 1988 through December 1989 and bass movement, migration and habitat utilization data which were collected from June 1990 to June 1991.

Between 4 to 10 days were spent in the field each month. Fish in the river and sloughs were marked monthly for estimating population size; relative abundance, age, growth, and condition information were also collected at that time. Tributary populations were estimated during September of 1988, 1989 and 1990. In order to obtain seasonal information on fish feeding habits and food availability in the river, sloughs, and tributaries, samples were collected in March, April, June, July, September and October during 1988 and 1989. In 1990 these samples were collected in April, July and September. Creel data was collected during 18 days (12 weekday and 6 weekend days) each month.

\subsection{RELATIVE ABUNDANCE}

Fish relative abundance was determined by electrofishing using a Smith-Root SR-18 boom electrofishing boat with the voltage adjusted to produce a current of about 8 amps. River stations were sampled monthly from March 1988 through October 1990, with the exception of February 1989 and January 1990 when the reservoir was iced over. Sloughs were sampled every month that they were accessible. During some months some sloughs were not accessible due to heavy macrophyte growth, low water levels or both. During the winter months (December-March) most of the sloughs were iced over. Generally a minimum three ten-minute electrofishing transects were made at each study site. This included one along each bank, or along weed beds, and one across the river.

During electrofishing, selective netting was sometimes used to catch target species found in low numbers in the relative abundance samples. By targeting these species in areas where they were more common, it was possible to collect more information on them. These fish were not included in the relative abundance data.

Fish collected by electrofishing, gill nets and beach seining were identified to species, measured to the nearest millimeter, and given a specific. mark. In 1988 larger fish were given a Floy FD-686 
numbered anchor tag and smaller fish, and non-target species were given a Floy FD-67F anchor tag with the paddle removed. Tag types and colors used at each study site can be found in Appendix B. Fish considered to small to tag were not marked. Beginning in June of 1989, smaller fish and non-target species were given a right pectoral fin clip instead of a Floy FD-67F anchor tag. This was necessary to distinguish fish tagged in 1989 from those tagged in 1988 for population estimation. Starting January of 1990, smaller fish and non-target species were given a left ventral (or pelvic) fin clip in order to distinguish fish tagged in 1990 from those tagged in 1988 and 1989.

Additional relative abundance information was collected using gill nets following the methods of Hubert (1983). Monofilament research nets were set at various depths in the river to sample the entire water column. Typically, the nets used at study sites 2 through 11 were $6,8,10$ or, on occasion, 20 feet deep and 200 feet long with 4 graded panels of various square mesh sizes ranging from 0.5 to 4 inches. On occasion at study site 1 a 50 foot deep $\times 150$ foot long net with 3 graded panels was used. Two nets were usually set at a study site perpendicular or parallel to the shore. During some months nets were not set at all study sites to allow nets to set longer in one location.

Since gill nets proved to be ineffective at catching fish in the mid-channel of the river in 1988 and 1989, less effort was expended setting nets in 1990.

A $6.8 \times 1.1$ meter bag seine was used to collect young-of-theyear fish from July through October (all three years) in the sloughs. Seine hauls were made parallel to the shore. A fiberglass tape was stretched along the shore to measure the distance of each haul. Generally, three 30.5 meter hauls were made at study sites $4 \mathrm{~A}, 5 \mathrm{~A}$, 8C and 9A each month. Exceptions to this occurred in 1989 and 1990 when due to dense macrophyte growths, beach seining was not conducted at sites 8C and 9A in August 1989 and 1990, September 1989; no seining was conducted in September 1990 and October 1989 and 1990. 


\subsection{POPULATION ESTIMATES}

\subsubsection{RIVER}

Fish populations were estimated in the river and sloughs using the Schnabel multiple census as described by Ricker (1975). The tagging period for the estimate ran from March through October in 1988, June through December in 1989 and February through October in 1990. Using this method populations can be estimated by conducting the fish marking and recapturing at the same time using the following formula:

$$
N=\frac{\sum_{i=1}^{n}\left(C_{t} M_{t}\right)}{R},
$$

where: $\quad \mathrm{N}=$ estimated population size;

$\mathrm{C}_{\mathrm{t}}=$ total number of fish caught at time $\mathrm{t}$;

$\mathbf{M}_{\mathbf{t}}=$ total number of marked fish at large at the start of sampling at time $t$;

$\mathrm{R}=$ total number of recaptures during all sampling periods; and

$\mathrm{n}=$ number of sampling periods

The 95 percent confidence range was placed around the estimate by treating $R$ as a Poisson variable and using the table found in Appendix A of Ricker (1975) to get the upper and lower confidence limits for $R$. The values from the table were then substituted for $R$ in the above equation to get the upper and lower confidence limits for the population estimate.

Fish populations were estimated for all species for which there was at least one recapture during the sampling periods (March 1988-May 1989, June-December 1989, January-October 1990). Only fish one year and older (as determined from back-calculated lengths) were included in the estimate to exclude fish hatched during the census. Marked fish that died during recapture and tagged fish 
harvested by anglers were subtracted from the number of marked fish at large for the next sample period. The number of fish caught and the number of recaptures from all transects were combined to make population estimates for the river. Population estimates and confidence limits were then expanded for the river by multiplying the approximate distance sampled at each study site $(0.4 \mathrm{~km})$ times the number of river sites (11) and expanded for the entire $90 \mathrm{~km}$ of the river. If a species was typically caught only in a few locations (e.g., brown trout) then the population was only estimated for those individual locations.

During some months the same study site was sampled more than once. If a fish was recaptured in the same month it was tagged, it was not included as a recapture for estimating the population of the river. In doing this, each month was treated as a sample period. Largemouth bass, mountain whitefish, and brown trout populations were estimated at some select locations where they were frequently caught and recaptured. For these estimates each sample time was used as a separate sample whether they occurred in the same month or not.

\subsubsection{TRIBUTARIES}

Trout populations were estimated in LeClerc, Ruby, Cee Cee Ah, Tacoma, and Skookum in September, 1990. Four reaches (Figs. 2.3 through 2.7) ranging in size from 200 to 360 feet in length were blocked off with nets to prevent immigration and emigration during the estimate. From two to four electrofishing passes were then made depending upon the proportion of fish caught in a pass. The goal was to catch less than 50 percent of the number of fish caught in the previous pass or to make at least four passes.

For each reach in which two passes were made, the population was estimated using the following equation of Seber and LeCren (1967):

$$
N=\frac{\left(U_{1}\right)^{2}}{\left(U_{1}-U_{2}\right)},
$$

where: $\quad \mathrm{N}=$ estimated population size:

$U_{1}=$ number of fish collected in the first pass: 


$$
\mathrm{U}_{2}=\text { number of fish collected in the second pass }
$$

The standard error of the estimate was calculated by:

$$
\text { S.E. }(N)=\sqrt{\frac{\left(U_{1}\right)^{2}(}{\left(U_{1}-U_{2}\right)^{4}}},
$$

where: $\quad$ S.E. $(\mathrm{N})=$ standard error of the population

$$
\text { estimates; and }
$$

$$
\mathrm{T}=\text { total number of fish collected }\left(U_{1}+U_{2}\right) \text {. }
$$

Ninety-five percent confidence intervals were placed around the estimate by multiplying the standard error by 1.96 .

When three or more passes were made in a section, the population was estimated using the methodology of Zippen (1958). The first number needed to use this method was:

$$
T=\sum_{i=1}^{n} U_{i}
$$

where: $\quad T=$ total number of fish collected;

$U_{i}=$ number of fish collected in the ith removal; and

$\mathrm{n}=$ the number of removals.

The ratio $(R)$ was then calculated using the equation:

$$
R=\frac{\sum_{i=1}^{n}(i-1) u_{i}}{T} .
$$




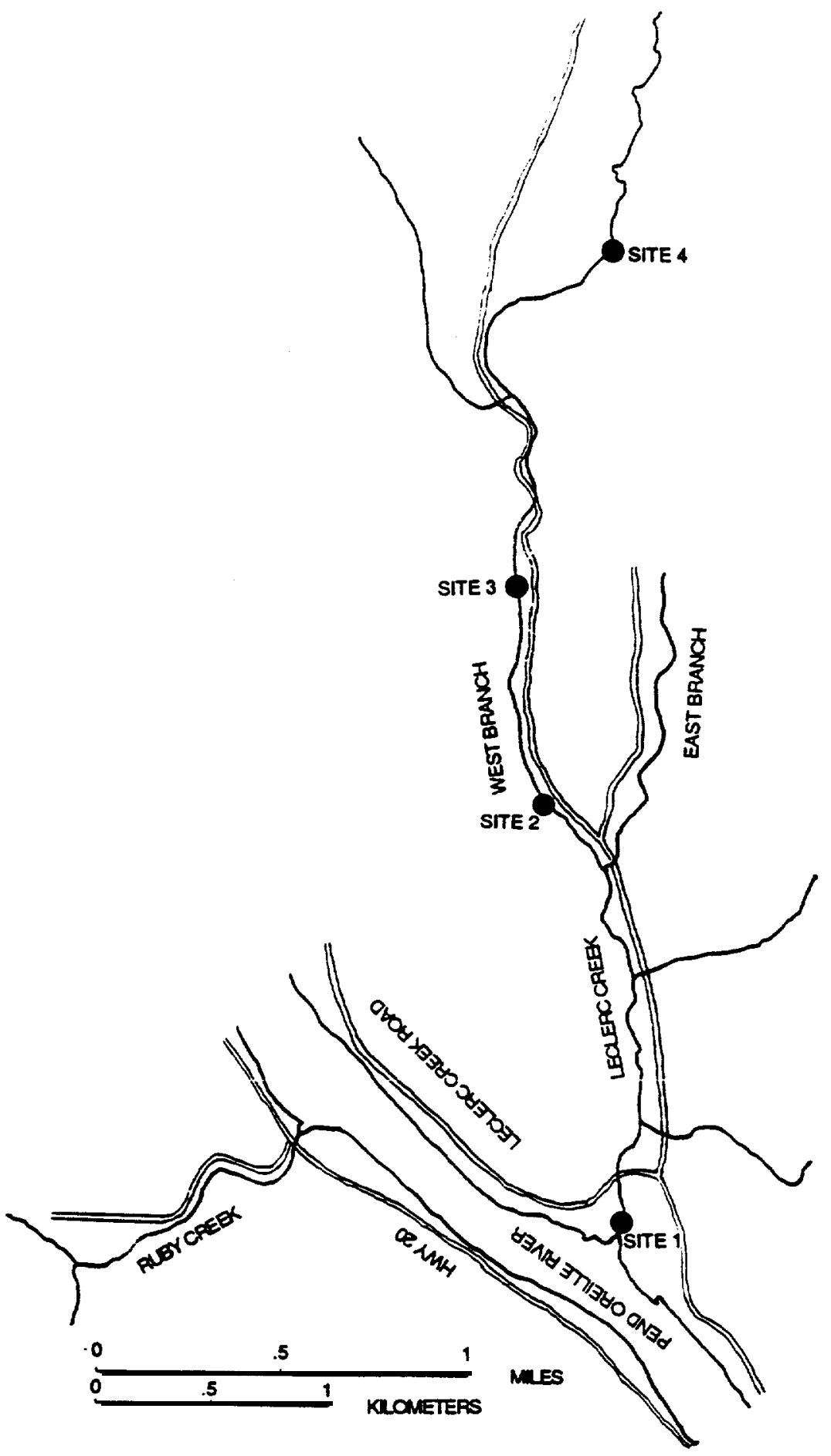

Figure 2.3. Map of LeClerc Creek showing the locations of population study sites. 


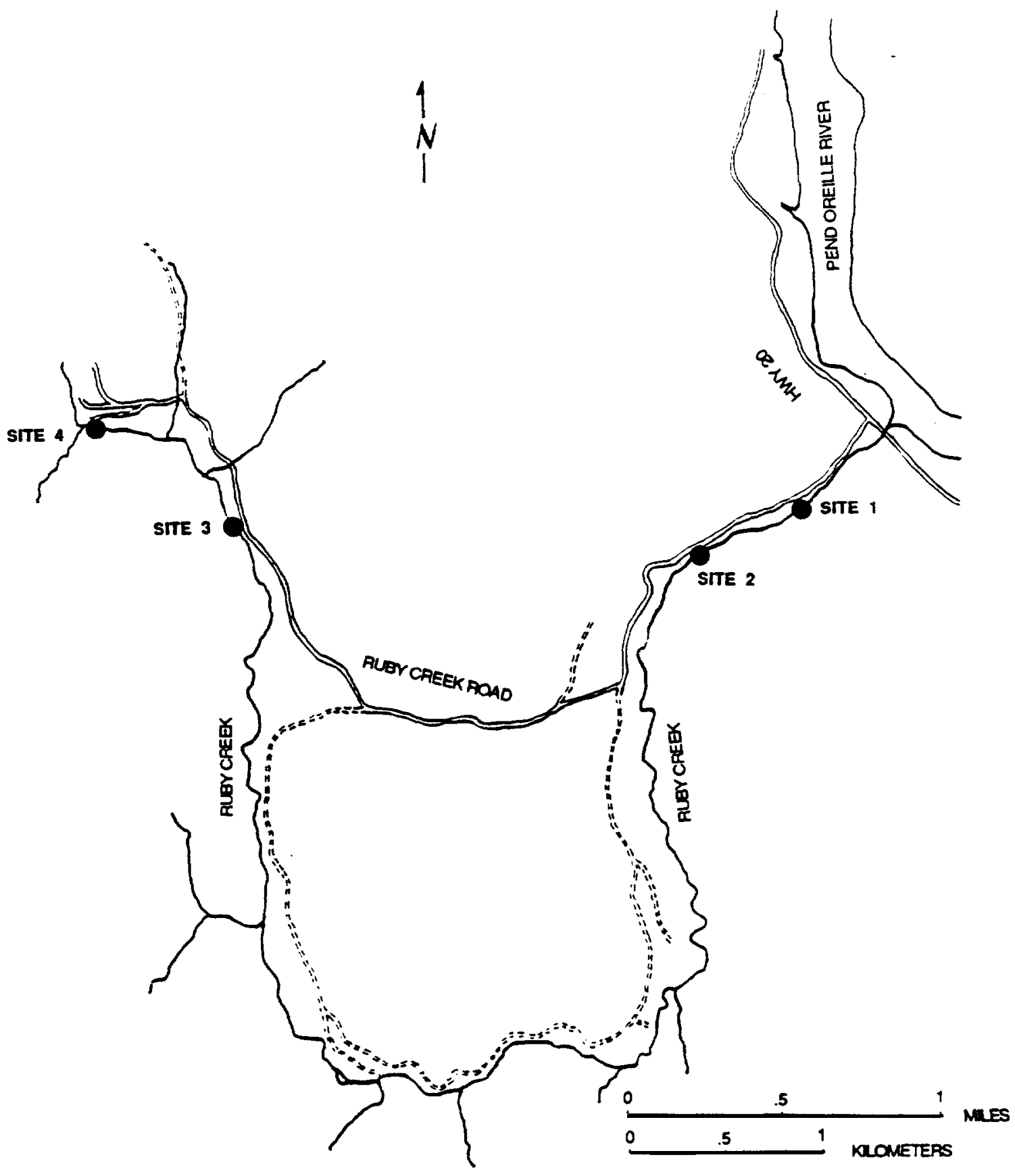

Figure 2.4. Map of Ruby Creek showing the locations of population study sites. 


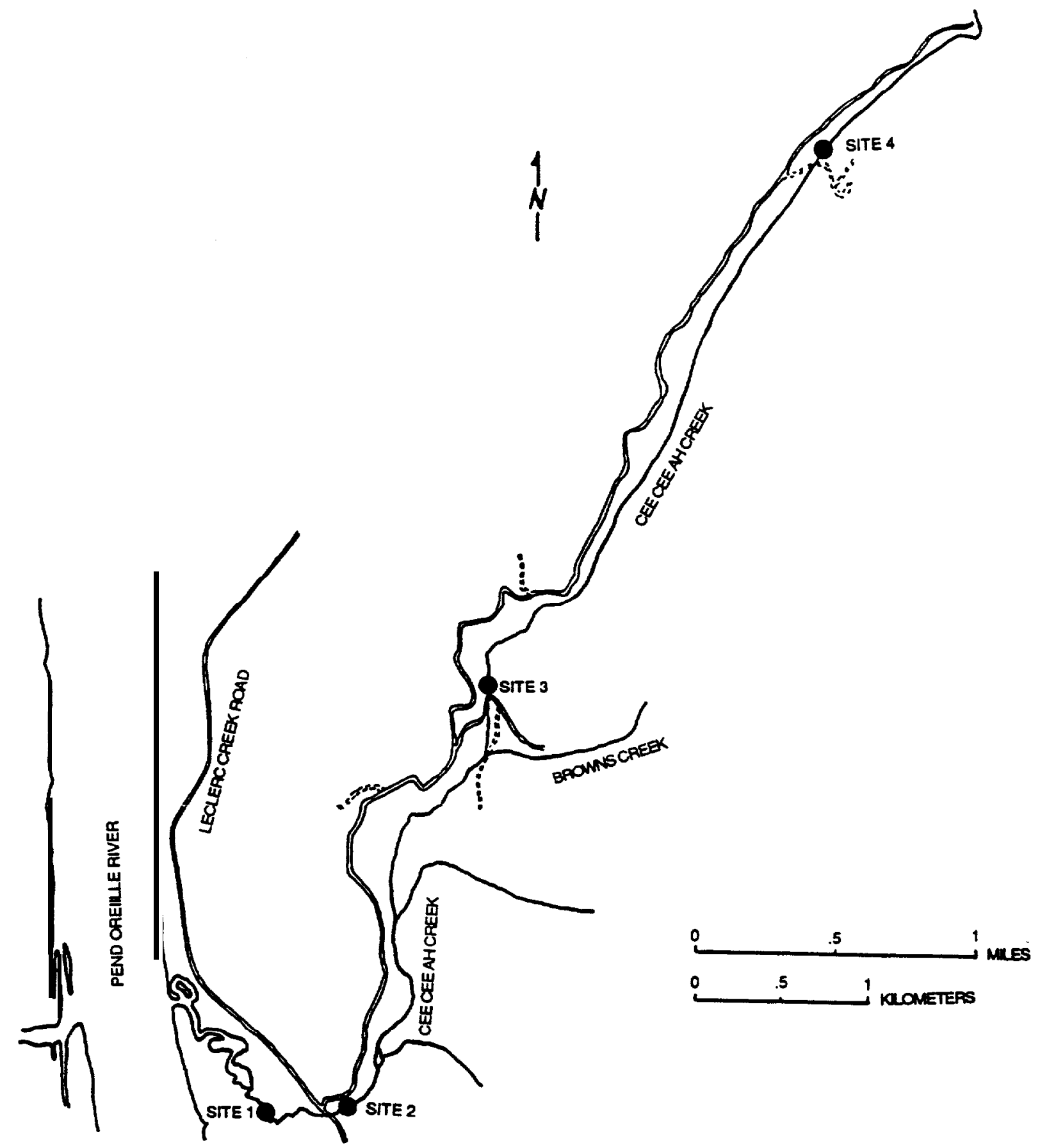

Figure 2.5. Map of Cee Cee Ah Creek showing the locations of population study sites. 


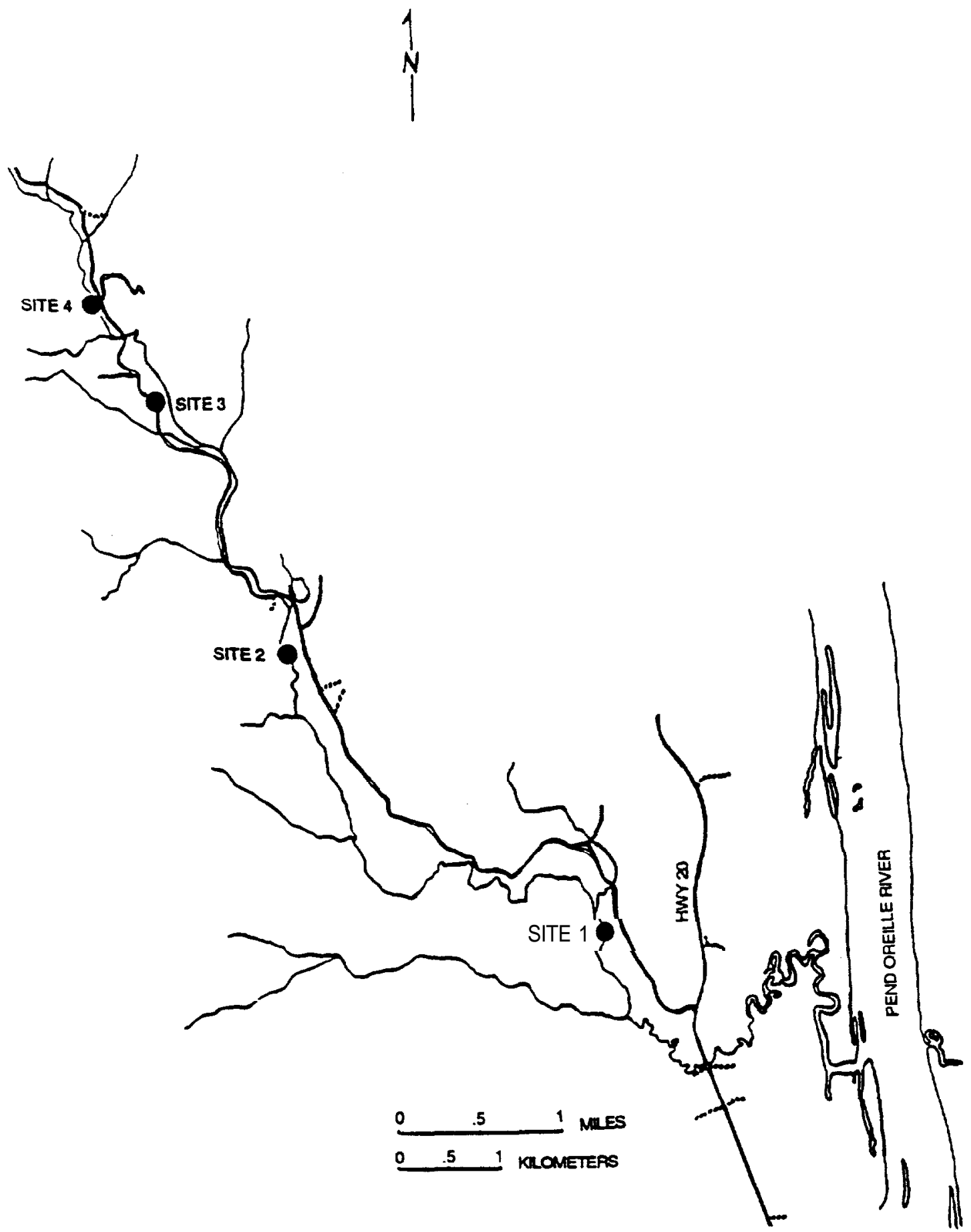

Figure 2.6. Map of Tacoma Creek showing the locations of population study sites. 


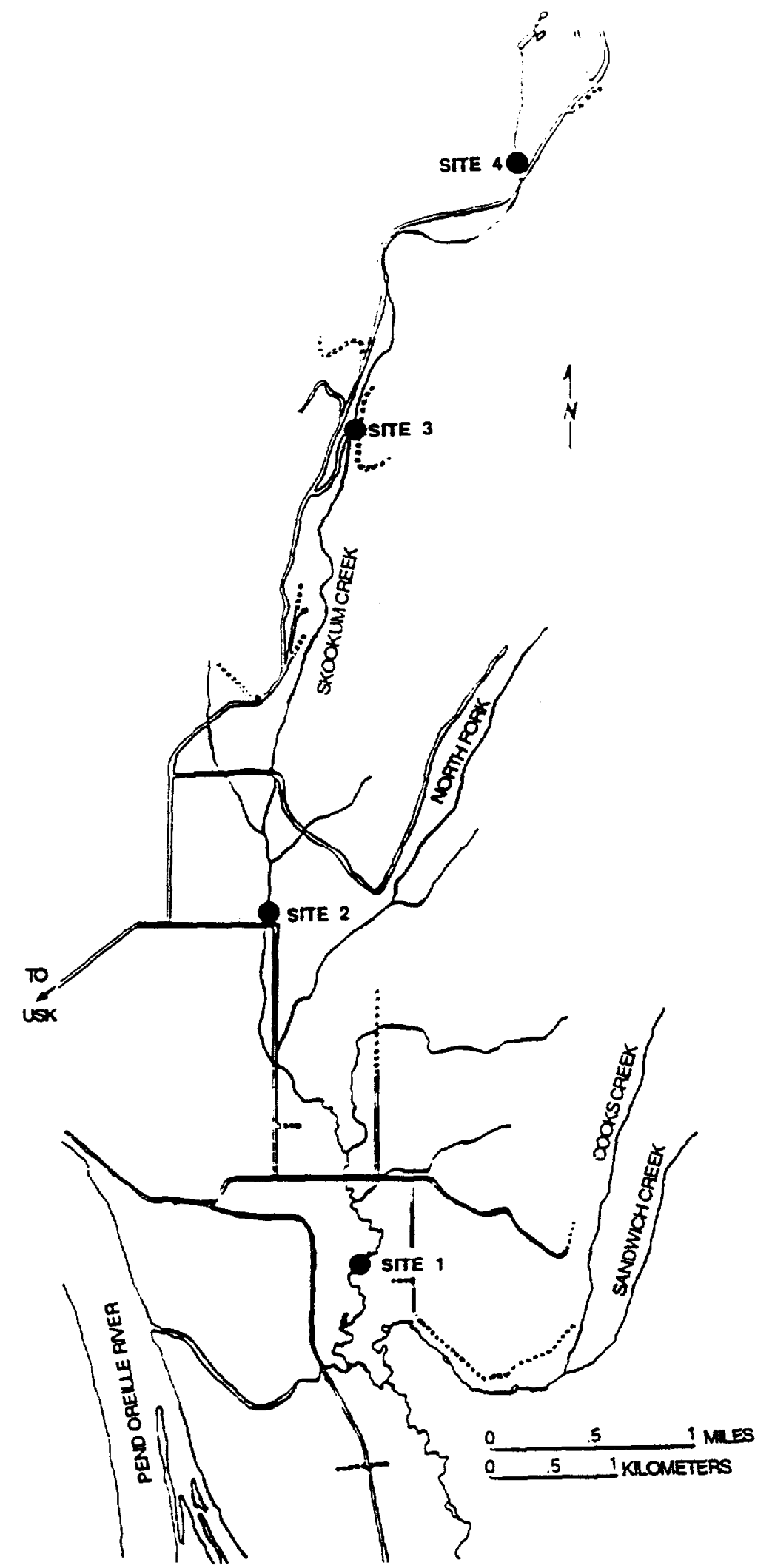

Figure 2.7. Map of Skookum Creek showing the locations of the population study sites. 
The population estimate $(\mathrm{N})$ was then calculated using the equation:

$$
N=\frac{T}{Q},
$$

where: $\quad Q=$ the proportion of fish captured during all passes. $Q$ was located by using the ratio $(R)$ on the curve found in Fig. 22 of Platts et $a /$. (1983).

The standard error of the estimate was calculated by:

$$
\text { S.E. }(N)=\sqrt{\frac{N(N-T) T}{T^{2}-N(N-) \frac{(k P)^{2}}{1-P}}},
$$

where: $\quad P=$ the estimated probability of capture during a single recapture as found using the ratio $(R)$ on the curve found in Fig. 23 of Platts et al. (1983).

Ninety-five percent confidence intervals were placed around the estimate by multiplying the standard error by 1.96 .

Width measurements were made at a distance equal to 10 percent of the length of the section. Mean width was then calculated and multiplied by the length to yield the area of the section. Fish density in each section was then calculated.

\subsection{MORTALITY}

Mortality estimates were calculated for yellow perch, largemouth bass, mountain whitefish and black crappie using catch curves (Ricker 1975). The number of each species in each age class captured during eiectrofishing, gillnetting and beach seining were combined and converted to natural logarithms. The natural log of each species abundance was then plotted against fish age in a simple linear regression. Total instantaneous mortality ( $Z$ ) was estimated as the absolute value of the slope of the descending limb (Everhart and Youngs 1981). The annual mortality rate was then determined by: 


$$
A=1-e^{-z}
$$

where:

$$
\begin{aligned}
& A=\text { annual mortality rate } \\
& Z=\text { total instantaneous mortality }
\end{aligned}
$$

\subsection{AGE, GROWTH, AND CONDITION}

Scale samples were collected by following the methods of Jearld (1983). In the laboratory, several scales were mounted between two glass microscope slides and viewed using a Realist, Inc., Vantage 5 microfiche reader. The age was determined by counting the number of annuli (Lux 1971, Jearid 1983).

Simultaneous to age determination measurements were made from the center of the focus to the furthest edge of the scale. Along this line, measurements were made to each annulus. The measurements were made to the nearest millimeter under a constant magnification. Annual growth was then back-calculated using the Lee method as described by Carlander (1977). This method involved the use of the formula:

$$
L_{i}=a+\left(\frac{L_{c}-a}{S_{e}}\right) s_{i}
$$

where: $\quad \mathrm{L}_{\mathrm{i}}=$ length of fish (in $\mathrm{mm}$ ) at each annulus;

$a=$ intercept of the body-scale regression line:

$L_{c}=$ length of fish (in $\mathrm{mm}$ ) at time of capture;

$\mathrm{S}_{\mathrm{c}}=$ distance (in $\mathrm{mm}$ ) from the focus to the edge of the scale; and

$S_{i}=$ scale measurement to each annulus

The intercept (a) was obtained from the regression analysis of body length -v.- scale length at time of capture. This was accomplished using StatView 512+ (Brainpower 1986) on a Macintosh SE computer.

The only difference in methodology during the three year study was that in 1988 ail scale samples were used for regression 
analysis while in 1989 and 1990 the number of fish in each age class was equalized before the regression analysis of the body length-scale length was conducted. This was accomplished by randomly selecting an equal number of fish from each age class. If an age class was represented by only a few fish then all were used. It was felt that this method yielded a more reliable intercept value since the regression line was not biased by strong age classes.

The proportional method of back-calculation was used for some species when small sample sizes led to poor regressions. The following equation was used:

$$
L_{i}=\frac{S_{i}}{S_{c}} L_{c}
$$

where: $\quad L_{i}=$ length of fish (in $\mathrm{mm}$ ) at each annulus;

$$
\begin{aligned}
& S_{i}=\text { scale measurement to each annulus } \\
& S_{c}=\text { distance (in } \mathrm{mm} \text { ) from the focus to the edge } \\
& \text { of the scale; and } \\
& \mathrm{L}_{c}=\text { length of fish (in } \mathrm{mm} \text { ) at time of capture; }
\end{aligned}
$$

This method, unlike the Lee method, does not take into account the size of fish at scale formation.

Condition factors were computed as an indicator of the fishes growth pattern and, therefore, an indication of its general condition (Tesch 1971, Everhart and Youngs 1981, Anderson and Gutreuter 1983). The formula to calculate the condition factor was:

$$
\mathrm{K}_{\mathrm{TL}}=\left(\frac{\mathrm{W}}{\mathrm{L}^{3}}\right) 10^{5}
$$

where: $\quad K_{T L}=$ condition factor

$$
\begin{aligned}
& W=\text { weight of fish in grams; and } \\
& \mathrm{L}=\text { total length of fish in millimeters. }
\end{aligned}
$$

Comparisons were made to condition factors in other bodies of water in the Pacific Northwest. 


\subsection{FOOD AVAILABILITY IN THE RIVER, SLOUGHS, AND TRIBUTARIES}

\subsubsection{BENTHIC MACROINVERTEBRATE DENSITIES IN THE RIVER AND SLOUGHS}

Quantitative samples of benthic macroinvertebrates were collected using a Ponar dredge with an opening of $0.053 \mathrm{~m}$. Grabs were made at three locations along each river transect. In 1988 benthic grabs were made at one quarter, half and three quarters of the way across the river. In 1989 and 1990 sampling was modified so that samples were collected at mid-channel and near both the east and west banks. This change was made to better quantify benthic macroinvertebrate densities in the littoral areas where most fish were found. Three grabs were made in each slough; just inside the mouth, about halfway in and near the end of the slough. Grabs were collected during the same sampling period as fish stomachs. The grabs generally were made up of a sand or silt/mud substrate. The excess water was poured off and a subsample of 10 percent by weight was taken after thoroughly mixing the sample. In 1988 organisms were separated from the sand substrate by sugar floatation (Anderson 1959). Samples were floated two or three times depending upon the size of the sample. The sediment portion was retained and manually sorted to remove organisms retained in the sediment. The sugar fioatation method was not followed in 1989 and 1990. Silt/mud grabs were washed through a U.S. Standard No. 30 sieve to remove the sediment. All samples were preserved in 10 percent formalin and later transferred to 70 percent alcohol.

Organisms were sorted and identified to family with the taxonomic keying sources of Borror and White (1970), Borror et al. (1976), Baumann et al. (1977), Wiggins (1977), Pennak (1978), and Merrit and Cummins (1984). Organisms obtained from the dredge samples were converted to number per square meter.

Densities and diversities found in the Pend Oreilie River were compared with other rivers and reservoirs in the region. 


\subsubsection{BENTHIC MACROINVERTEBRATE DENSITIES IN THE TRIBUTARIES AND INVERTEBRATE ABUNDANCE IN THE DRIFT}

Benthic macroinvertebrates were collected using a modified Hess-Waters sampler (Hess 1941, Waters and Knapp 1961) with an area of $0.1 \mathrm{~m}^{2}$ and a net aperature of $390 \mathrm{pm}$. Samples were collected by pushing the sampler $10 \mathrm{~cm}$ into the substrate. The area within the sampler was disturbed to a depth of $8-10 \mathrm{~cm}$ to adequately sample the hyporeic community (Hynes 1970, Williams and Hynes 1974). Large rocks were removed from the sampler and organisms removed with a brush. Samples were collected in the riffles since they contain higher invertebrate densities and diversities than pools and runs (Eggiishaw and Mackay 1967, Armitage et al. 1958, Scuilian et al. 1982, O'Laughlin et al. 1988). In April, June and July of 1988 three samples were collected from each tributary at one location. In September and October of 1988 and every month sampled in 1989 and 1990, two samples were collected at an upstream and downstream site in each tributary, except Tacoma Creek, where two samples were taken only at one site.

Organisms were preserved in 10 percent formalin and later transferred to 70 percent alcohol. In 1988 organisms were separted from the substrate by sugar floatation (Anderson 1959). The sediment portion was saved and manually sorted to remove any organisms left after floating. In 1989 and 1990 ail organisms in the benthic samples were manually sorted instead of using the sugar fioatation method. Organisms were sorted and identified to family with the taxonomic keys listed in 2.7.1.

Two drift samples were collected immediately above the location that Hess samples were taken from. Water depth passing through the sampler was measured using a wading rod. Mean column velocity of the water passing through the sampler was measured directly in front of the sampler at 0.6 of the water depth using a Price pygmy meter (Buchanan and Somers 1980). This made it possible to determine the volume of water passing through the sampler and calculate densities for organisms found in the drift. Samples were preserved in 10 percent formaiin and later transferred to 70 percent isopropyl alcohol. Organisms were sorted and keyed to family using the sources listed in 2.7.1. 
The Shannon-Weiner diversity index was used as a measure of the eveness and richness of the invertebrate communities in the tributaries. This indices takes into account not only the number of species, but the number of individuals within each species (Krebs 1985). The equation for the indices is:

$$
H=-\sum_{i=1}^{n}\left(p_{i}\right)\left(\log ^{2} p i\right),
$$

where: $\quad H=$ index of species diversity

$$
\begin{aligned}
& \mathbf{s}=\text { number of species; and } \\
& \mathbf{p}_{\mathrm{i}}=\text { proportion of total sample belonging to the } \\
& \mathbf{i} \text { th species. }
\end{aligned}
$$

A high diversity value (i.e., above 3.0) indicates a healthy stable community while low values may indicate unhealthy conditions.

To determine if there was a significant difference in densities of the top five prey items (as determined from feeding analysis) between tributaries, the Kruskal-Wallis test (Zar 1984) was performed. The tests were run on a Macintosh SE using StatView $512+$ (Brainpower 1986).

Densities and diversities were compared with those reported for other streams in the Pacific Northwest.

\subsubsection{ZOOPLANKTON}

Zooplankton samples were collected by making a vertical tow from the bottom to the surface using a Wisconsin plankton net with an $80 \mu \mathrm{m}$ silk net and bucket. In 1988 two samples were collected from mid-channel at each river transect during the same period as fish stomach collection. In 1989 and 1990 sampling was modified to one mid-channel sample and one littoral sample at each transect. This change was made to better quantify zooplankton densities in the littoral areas where most fish were found. One tow was also taken at each of the slough study sites during all three years.

Upon collection organisms were washed into a $253 \mathrm{ml}$ bottle containing $10 \mathrm{ml}$ of 37 percent formaldehyde. Organisms were 
stained with $1.0 \mathrm{ml}$ of five percent Lugol's solution and $1.0 \mathrm{ml}$ of saturated eosin-y ethanol stain.

In the laboratory zooplankton were identified to genus and species when possible, using the keys of Brooks (1957). Emondson (1959), Brandiova et al. (1972), Ruttner-Kolisko (1974), Pennak (1978), Steinberger (1979) and Pennak (1989). A Nikon SMZ-10 dissecting microscope with a ring illuminator system and Nikon phase contrast microscope were used for making identifications. A minimum of three subsamples was counted using a modified counting chamber (Ward 1955) until 100 organisms or $25 \mathrm{ml}$ of the sample had been counted (Edmondson and Windberg 1971, Downing and Rigler 1984).

The counts for each species in each subsample were recorded in Microsoft Excell on a Macintosh SE computer. Densities (number of organisms per liter) was calculated in this program utilizing three equations. First, the volume of the sample was calculated by the following equation:

$$
V=\pi r^{2} h
$$

where: $\quad v=$ volume:

$$
\begin{aligned}
& \mathbf{r}^{2}=\text { radius of sampler: and } \\
& \mathrm{h}=\text { depth of sample. }
\end{aligned}
$$

Second, the multiplication factor for each set of samples was calculated using the number of subsamples taken, the volume of the subsample, the volume of the entire sample, and the dilution used. The following equation was used:

$$
M F=\frac{\left(\frac{1}{S n} \times \frac{S V}{S S V}\right)}{V} D F,
$$

where: $\quad \mathbf{M F}=$ multiplication factor;

$\mathrm{Sn}=$ number of subsamples;

$\mathrm{SV}=$ sample volume;

SSV = subsample volume; and 


$$
\text { DF = dilution factor. }
$$

Finally, the density (number of organisms per liter) for each sample was calculated by the following equation:

$$
D=(M F)\left(T_{n}\right) \text {, }
$$

where: $\quad D=$ density (number of organisms per liter): and

$$
T_{n}=\text { total number of each group of organisms. }
$$

Cladoceran biomass was estimated using the length-weight relationships summarized by Downing and Rigier (1984). The lengthweight regression equation, the values used for each species, and sources of the equations are listed in Table 2.2. The length-weight relationship for some ciadoceran species found in this study has not been described, so their biomass was not estimated.

After the mean weight of an organism was calculated with the appropriate equation, the total weight of the organisms in the sample was calculated by multiplying the mean weight of the organisms in the sample.

\subsection{FEEDING HABITS}

\subsubsection{FIELD COLLECTION METHODS}

Stomach samples were collected at each study site, from target fish species in April, June, July, September and October 1988; March, April, June, July, September and October 1989; and April, July and September, 1990. Upon capture each fish was identified, measured to the nearest millimeter and weighed to the nearest gram. A scale sample was removed for age determination and backcalculation of growth. The body cavity was opened and sex was noted, when distinguishable. The stomach was removed by cutting posterior to the pyioric sphincter and at the anterior portion of the esophagus and preserved in 10 percent formalin.

\subsubsection{RIVER AND SLOUGHS}

Fish were collected at each study site using a Smith-Root SR18 boom electrofisher, gill nets and beach seines. Ten stomachs were collected from the predominant species at each river study site in 1988 and 1989. in July and September of 1990 collection 


\section{Table 2.2. Length-weight relationships for crustacean zooplankton (Cladocera) collected from the literature as summarized by Downing and Rigier (1984).}

\begin{tabular}{|l|c|c|c|}
\hline Species & In a & $\mathrm{b}$ & Range \\
\hline Bosmina longirostris & 2.7116 & 2.5294 & $0-28-0.54$ \\
\hline Ceriodaphnia quadrangula & 2.5623 & 3.3380 & $0.30-0.71$ \\
\hline Ceriodaphnia reticulata & 3.0727 & 3.29 & $\ldots$ \\
\hline Chydorus sphaericus & 4.5430 & 3.636 & $0.20-0.40$ \\
\hline Daphnia ambigua & 1.54 & 2.29 & $\ldots$ \\
\hline Daphnia galeata mendotae & 1.51 & 2.56 & $\ldots$ \\
\hline Daphnia parvula & 1.08 & 2.16 & $0.44-1.22$ \\
\hline Daphnia pulicaria & 2.30 & 3.10 & $1.00-2.50$ \\
\hline Daphnia schødleri & 2.30 & 3.10 & $1.00-2.50$ \\
\hline Daphnia retrocurva & 1.4322 & 3.129 & $0.50-2.00$ \\
\hline Daphnia thorata & 2.64 & 2.54 & $0.60-2.20$ \\
\hline Diaphanosoma birgei & 1.6242 & 3.0468 & $0.44-10.44$ \\
\hline Diaphanosoma brachyurum & 1.6242 & 3.0468 & $0.44-10.44$ \\
\hline Leptodora kindti & -0.8220 & 2.670 & $1.00-5.00$ \\
\hline Megafenestra aurita & 2.8713 & 3.079 & $0.30-0.80$ \\
\hline Sida crys ta llina & 2.0539 & 2.189 & $0.80-2.30$ \\
\hline
\end{tabular}


was decreased to five stomachs. Stomachs collected from rough fish and non-target species were reduced to one per species in April, 1990. No stomachs were collected from non-target species during July and September, 1990.

Largemouth bass and all species of trout, in excess of approximately $200 \mathrm{~mm}$, were anesthetized with TMS and their stomach contents removed by lavaging or injecting water into their stomach using a garden sprayer with a hose attachment (Light et al. 1983). Stomach contents were collected on a No. 45 sieve $(355 \mu \mathrm{m})$ and placed in 10 percent formalin. Fish that sometimes remained in the stomach were removed by using forceps or fingers. Fish that had stomach contents removed by lavaging were allowed to recover and subsequently released.

\subsubsection{TRIBUTARIES}

Tributary stomach samples were collected using a Smith-Root Type VII pulsed DC backpack electrofisher. Stomachs were collected from each tributary at one location in April, June and July of 1988. in these early samples brown trout were found to be predominant in the lower reaches and brook trout predominant in the upper reaches. To eliminate sample bias, collections were made at two locations (an upper and lower reach) on LeClerc, Ruby, Cee Cee Ah and Skookum Creeks in September and October 1988 and during 1989 and 1990. Only one site was sampled on Tacoma Creek during all three years since the predominant species was brook trout wherever the stream was accessible. Ten stomachs were collected from various sizes of the predominant species in each location. Stomachs were also collected from any incidental species captured at each location. In 1989 stomachs collected from fish in the tributaries was increased to twenty per species. In 1990 this number was again decreased to 10 per species.

\subsubsection{LABORATORY METHODS}

In the laboratory the stomachs were transferred to 70 percent isopropyl alcohol and the stomach contents were identified to family using a Bausch and Lomb Stereozoom 5 or Nikon SMZ-1B dissecting microscope with fiber optic illiminator and keys of Borror and White (1970), Borror et al. (1976), Baumann et al. (1977), Wiggins (1977), Pennak (1978) and Merrit and Cummins (1984). Once the prey items were grouped to family, they were counted and dry weights obtained by drying in an oven for 24 hours at $105^{\circ} \mathrm{C}$ and 
weighed to the nearest $0.1 \mathrm{mg}$ on a Sartorious model H51 balance (Weber 1973).

Stomachs containing large numbers of zooplankton were subsampled following the methodology described by Weber (1973). Minor food items were removed and counted leaving the dominant food group. Ciadocerans were identified to family and copepods to suborder. The dominant food group was then placed into a beaker and the volume brought up to $100 \mathrm{ml}$. The beaker was stirred to completely randomize the sample. Three $2 \mathrm{ml}$ aliquotes were then taken and counted. The total number of zooplankton in the group was calculated by using the formula:

$$
\text { Total No. }=\frac{\sum_{i=1}^{3}\left(\frac{D V}{S V} \times T n\right)}{3} .
$$

where: $\quad \mathrm{DV}=$ total diluted volume $(100 \mathrm{ml})$;

$S V=$ total subsample volume $(2 \mathrm{ml}) ;$ and

$\mathrm{Tn}=$ total number of the particular species of zooplankton in the sample.

\subsubsection{DATA ANALYSIS}

The number and weight of each prey group found in the stomach of each fish was placed into a computer file using Microsoft Excel on a Macintosh SE. River and slough stomachs were combined and each tributary was analyzed individually. Mean number, mean weight, and frequency occurrence (i.e., presence/absence) were computed for each age class of each species for each month. In 1988 when stomachs were collected once in the spring (April), twice in the summer (June and July) and twice in the fall (September and October), the summer and fall samples were averaged to yield seasonal means. The April, summer and fail values were then averaged to describe the annual feeding habits. By taking the mean of the seasonal means, biases introduced due to unequal sample sizes were eliminated. in 1989 samples were collected twice during each season (March and April, June and July and September and October). Monthly values were averaged to yield seasonal means and seasonal means were averaged to yield annual values. During 
1990 samples were collected only once during each season (April, July and September). These three months were averaged to describe annual feeding habits.

\subsubsection{INDEX OF RELATIVE IMPORTANCE}

Frequency of occurrence, mean number and mean weight of prey items in the stomach contents are biased if used individually to assess the bioenergetic contribution of a particular prey item to fishes metabolic requirements (Windell 1971, Bowen 1983). For example, frequency of occurrence is the proportion of stomachs that contained a particular prey item. It does not take into account the number of biomass of each prey item. The prey item may be frequently found in fish stomachs, thus yielding a high frequency of ocurrence, yet they may be few in number or small in size, therefore not contributing significantly to the dietary needs of the fish. Numerical proportions overemphasize the importance of small prey items that may be present in large numbers but may have a lower nutritional value than large prey items that are present in lower numbers. Since nutritional value is approximately proportional to weight, percent by weight is used to determine a prey items improtance in the fish diet. Percent by weight may overemphasize the relative importance of large prey items that are harder to find and capture (Bowen 1983).

The Index of Relative Importance (George and Hadley 1979) combines the frequency of occurrence, percent by number and percent by weight into an index intended to compensate for the biases of each alone. The IRI was calculated by:

$$
R I_{a}=\frac{100 A I_{a}}{\sum_{a=1}^{n} A I_{a}},
$$

where: $\quad \mathrm{Rl}_{\mathrm{a}}=$ relative importance of food item a;

$\mathrm{Al}_{\mathrm{a}}=$ absolute importance of food item a (i.e., frequency of occurrence + numbercal frequency + weight frequency of food item a): and

$\mathrm{n}=$ number of different food types. 
The relative importance values range from 0 to 100 percent with prey groups near zero being relatively less important than prey groups near 100 .

\subsubsection{DIET OVERLAP INDEX} (1966):

Diet overlap indices were calculated using the equation of Horn

$$
C x=\frac{2 \sum_{i=1}^{n}(P x i \times P y i)}{\sum_{i=1}^{n} P x i^{2}+\sum_{i=1}^{n} P y i^{2}}
$$

where: $\quad c x=$ the overlap coefficient;

$\mathrm{Pxi}=$ the proportion of food category $\mathrm{i}$ in the diet of species $\mathrm{x}$;

Pyi $=$ the proportion of food category $\mathrm{i}$ in the diet of species $y$; and

$\mathrm{n}=$ the number of food categories.

The overlap coefficients were computed by using the IRI values in the equation for the variable Pxi and Pyi. The overlap coefficients range from 0 (no overlap) to 1 (complete overlap). Values of less than 0.3 are considered low and values greater than 0.7 indicate high overlap (Peterson and Martin-Robichaud 1982). High diet overlap values may indicate competition if the food items utilized by the species are limited (MacArthur 1968). High diet overlap values may also indicate that there is an abundant food supply and competiton does not exist.

\subsubsection{ELECTIVITY INDEX}

Eiectivity indices were computed to compare the abundance of food items in the diet to the abundance of those food items in the environment. Densities of invertebrates in the benthos and drift and zooplankton densities in the environment were converted to proportions, and used along with the numerical proportion of the prey items in the stomach to calculate a linear index of Strauss (1979). Some advantages of this index are; (1) while the use of any 
indices requires adequate sample sizes, this indix is not biased by unequal sample sizes, (2) extreme values are obtained only when a prey item is rare in the environment and very abundant in the diet, (3) it is distributed approximate1 normally, and (4) statistical comparisons can be made between calculated values (Strauss 1979). The equation for the linear food selection index was:

$$
L=r_{i}-p_{i},
$$

where: $L=$ the measure of food selection:

$$
\begin{aligned}
& \mathbf{r}_{i}=\text { the relative abundance of prey } i \text { in the gut; } \\
& \mathbf{p}_{i}=\text { the relative abundance of same prey } i \text { in the } \\
& \text { environment. }
\end{aligned}
$$

Food selection values ranged from +1 to -1 . Values near zero indicate that the fish is either feeding on that prey group in relation to its abundance or feeding on the group randomly. Positive values indicate that the fish are selecting those prey groups. Negative values indicate that either the prey are not accessible, protectively camouflaged or hard to catch or that the fish are avoiding those prey groups.

\subsection{FISH MOVEMENT AND MIGRATION}

\subsubsection{FLOY TAGGING OF TARGET SPECIES}

Fish were tagged during collection of relative abundance and population data (see sections 2.3 and 2.4) during all three years of the study. In 1988 smaller individuals were tagged with site specific tags and larger individuals were given numbered floy tags. In 1989 and 1990 only the larger fish were tagged with numbered floy tags. Tagged fish captured in subsequent sampling trips or caught by anglers provided information about fish movements. In addition to getting information on fish movement from fish recaptured with numbered Fioy tags, information was obtained about changes in length. Fish were grouped according to age at tagging. Upon recapture the difference in length (growth) was determined from the time of tagging to the time of recapture. The monthly growth increment was calculated by dividing the length difference by the number of months between tagging and recapture. The mean monthly growth increment was calculated for ail fish tagged within a particular age class. The mean annual growth increment was then 
calculated by multiplying the mean monthly growth increment by 12 . Fish with very large (positive or negative) growth increments were assumed to have been incorrectly measured and not used in the mean growth increment.

\subsubsection{ULTRASONIC AND RADIO TELEMETRY OF LARGEMOUTH BASS}

Sonic and radio telemetry of largemouth bass in the Pend Oreiile River was designed to determine (1) seasonal movement and migration of bass in the Pend Oreille River and (2) types of habitat utilized by bass.

The river was divided into four reaches, each of which provides a slightly different type of habitat (Figure 2.8). The first reach was 11 miles long extending from just north of lone, WA at river mile (RM) 34 to $R M 45$. This section is primarily lacustrine with deep water, an abundance of macrophytes and marshy sloughs. The second reach was 15 miles long extending from RM 45 to RM 60, near Riverbend. This reach represents a slightly more riverene section of the river with a narrower deeper channel and fewer macrophytes. Reach 3 encompassed 20 miles if river from RM 60 to RM 80. Within this section the river is shallow and slow moving with an abundance of macrophytes. There are also numerous sloughs and backwater areas in this section. The fourth reach was 8 miles long extending from RM 80 to RM 88 at Albeni Fails. The section represents the most riverine habitat of the reservoir. The channel is narrow, with a detectable current and fewer macrophytes.

Tracking devices consisted of twenty ultrasonic transmitters (Sonotronics Inc. Model CT-82) with a frequency of $75 \mathrm{kHz}$ and ten radio transmitters (Advanced Telemetry Systems Model 5) with a frequency of $48 \mathrm{MHz}$. Each of the sonic transmitters were coded with a three or four digit identification number for individual identification of fish. These transmitters measured 16 millimeters in diameter, 60 millimeters long, weighed 20 grams in the air and 8 grams in the water. Life expectancy was in excess of one year at one pulse per second. Each radio transmitter had a different frequency on the $48 \mathrm{MHz}$ band, Individual transmitters were spaced $10 \mathrm{KHz}$ apart for individual identification. The radio transmitters measured $12 \mathrm{~mm}$ in diameter and $53 \mathrm{~mm}$ in length, weighed 21 grams in the air and 8 grams in the water. These transmitters were lithium battery powered and had a life expectancy of 190 days. Both 


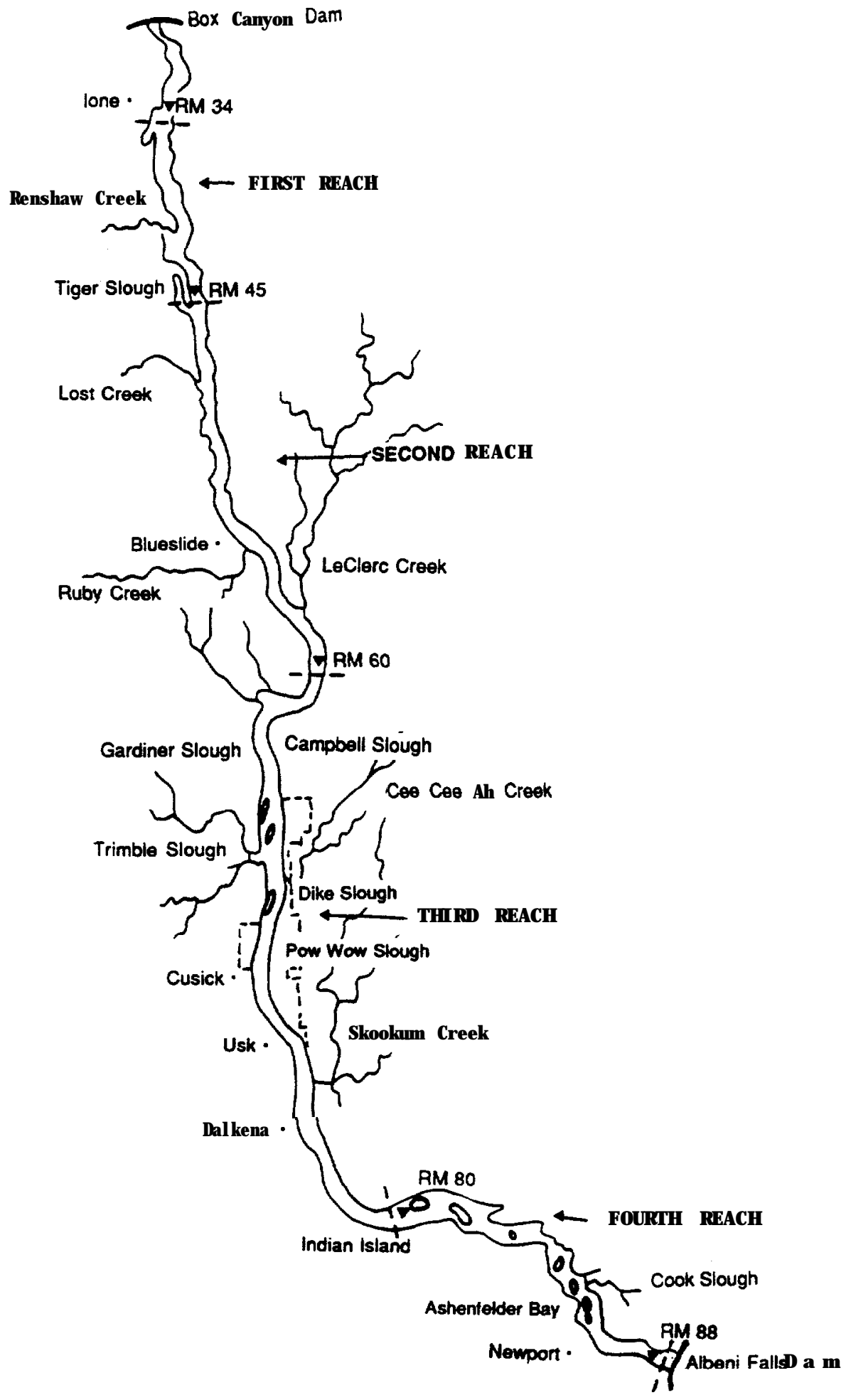

Figure 2.8. The four reaches of different habitat types in the Box Canyon Reach of the Pend Oreille River. 
types of transmitters were designed for internal implantation in fish.

Based on transmitter weight and physical size, large -bass are less affected by bouyancy problems or negative transmitter implant interferences (Knopf 1982). Advanced Telemetry Systems, Inc. (1989) advised that transmitter weight in air should be $2 \%$ of the fish weight. Therefore, fish chosen for implant weighed 1000 grams or more. Transmitters were surgically implanted into the abdominal cavity of the bass by procedures outlined by Hart and Summer-felt (1975). A $35 \mathrm{~mm}$ incision was made midventral along the linea alba between the vent and pelvic fins, directly into the abdominal cavity. A transmitter sterilized in 95\% ethyl alcohol was then inserted into the fish with the battery (heaviest portion) forward. The wound was closed by suturing approximately every $5 \mathrm{~mm}$ with non-dissolving cotton surgical thread. The fish was then placed in a live well for recovery and transmitter function was checked.

Before this type of surgery was done on largemouth bass from the Pend Oreille River, dummy transmitters were implanted into ten largemouth bass in the laboratory. This was done to assure that ultrasonic transmitters could be surgically implanted into the bass with little or no lasting changes in behavior (i.e., swimming, bouyancy, feeding) and that surgical procedures could be accomplished smoothly and efficiently in a field setting.

A directional hydrophone (Sonotronics $\mathrm{DH}-2$ ) connected to a sonic receiver (Sonotronics UR 5) was used to track fish containing sonic transmitters. Fish carrying radio transmitters were tracked using a directional loop antenna connected to either a Fieldmaster 16 Channel Receiver (Advanced Telemetry Systems) or a Smith-Root SR-40 Search Receiver. To precisely locate radio tagged fish once their general location was known a 10 foot long coaxial cable mounted on a long pole was used as the antenna. Tracking was done from a 17 foot Boston Whaler.

Seasonal movements and migration of bass were determined by attempting to locate each fish at least twice a week during the months of June-October 1990, and at least once a week during the months of November, 1990-June, 1991, unless ice conditions on the river prohibited boat access and operation.

Exact locations of bass containing sonic transmitters were determined using signal intensity: the clearest and loudest signal 
represents the position of closest proximity to the tagged fish (Winters 1983). Radio locations were determined by triangulation using compass bearings from known locations or line of sight to shore markers. Upon the location of tagged fish the time of monitoring and weather conditions were recorded. The location of the fish was then plotted on USGS 7.5 minute topographic maps by taking compass bearings and referencing shoreline locations. The location of the fish, time of monitoring, water depth, weather conditions, and habitat information was recorded.

\subsubsection{LARGEMOUTH BASS SEASONAL MOVEMENT AND MIGRATION}

A map was created to track the movement of each fish implanted with a transmitter. Upon each location of a marked fish, its location and date located was recorded with a mark on the respective individual map. These locations and movements were combined with habitat data collected to determine if changes in season prompted changes in movement to similar or different habitat.

\subsection{HABITAT UTILIZATION}

\subsubsection{LARGEMOUTH BASS HABITAT UTILIZATION DURING TELEMETRY}

Habitat utilization information of ultrasonic and radio tagged bass was collected from June 1990 to June 1991. When a bass carrying a transmitter was located, observations on depth, temperature,cover and water velocity were made.

Depth of the fish was determined by a weighted line marked off in 1 foot intervals. Temperature was recorded at 0.5 meters under the surface as temperature profiles conducted of the Pend Oreille River (Soltero et al. 1988) determined that temperatures in the river and sloughs were uniform from top to bottom. Cover where a fish was located was categorized as small object (i.e., small bush), large object (i.e., large log), overhead (overhanging brush), or combination and aquatic macrophytes (Table 2.3 and 2.4). If aquatic macrophytes were present they were identified to species (e.g. Ceratophyllum) and determinations made on whether they were submergent or emergent, sparse or dense and what the dominant and subdominant macrophyte were. 
Table 2.3. Cover codes used to categorize cover in the Pend Oreille River.

\begin{tabular}{|c|c|}
\hline COVER CODES & DESCRIPTION \\
\hline 0 & No cover \\
\hline 1 & Small object \\
\hline 2 & $\begin{aligned} \text { Large object } & >60 \mathrm{~cm} \text { in length and } \\
& >15 \mathrm{~cm} \text { in diameter or } \\
& >30 \mathrm{~cm} \text { in diameter }\end{aligned}$ \\
\hline 3 & $\begin{array}{c}\text { Overhead cover }<45 \mathrm{~cm} \text { from the water } \\
\text { surface }\end{array}$ \\
\hline 4 & Combination of object and overhead \\
\hline 5 & Macrophytes (see Table 2.4) \\
\hline
\end{tabular}

Table 2.4. Codes used to categorize macrophytes in the Pend Oreille River.

\begin{tabular}{|c|c|}
\hline MACROPHYTE CODE & DESCRIPTION \\
\hline 1 & Macrophytes restricted to bottom \\
\hline $2 \ldots$ & $\begin{array}{l}\text { Macrophytes extending from bottom to } \\
\text { mid-water }\end{array}$ \\
\hline 3 & Macrophytes extending above mid-water \\
\hline-1. & Macrophytes sparse \\
\hline$-5 \cdot-$ & Macrophytes moderate \\
\hline _9._- & Macrophytes dense \\
\hline-.1 & Elodea dominant \\
\hline$---_{-}$ & Potamogeton dominant \\
\hline.- .3 & Ceratophyllum dominant \\
\hline$--_{-}^{-4}$ & Myriophyllum dominant \\
\hline$-\ldots \cdot-0$ & No subdominant \\
\hline---1 & Elodea subdominant \\
\hline---2 & Potamogeton subdominant \\
\hline---3 & Ceratophyllum subdominant \\
\hline.- .4 & Myriophyllum subdominant \\
\hline
\end{tabular}


Due to the close proximity of fish to massive dense weedbeds it was impossible to collect velocity measurements with a Price current meter for most of the year. Although actual measurements were impossible visual observations of flow was usually zero.

\subsubsection{HABITAT UTILIZATION CURVES OF LARGEMOUTH BASS AS DETERMINED FROM ULTRASONIC AND RADIO TELEMETRY}

Habitat information was collected on each fish during the growing season (May-October) and the winter season (NovemberApril). This information was combined to create habitat utilization curves of adult largemouth bass for each of the four reaches (Figure 2.7) and for the entire reach of the Box Canyon Reservoir during both seasons.

Habitat utilization indices were developed based on water depth, temperature and cover. Utilization data was arranged from the lowest to the highest measured value at equal increments for depth and temperature. A tally was then made of the total number of times a bass was observed at each increment. The number of observations at each increment were normalized by dividing each one by the highest number observed. In this manner an index from 0 to 1 was achieved. This sometimes resulted in an irregular curve that was smoothed by connecting the highest points (Raleigh et al. 1986, Barber 1988). Cover utilization criteria were used to construct histogram analysis since there were five cover types, making the curve fitting methods impractical. Preference histograms were constructed by enumerating the number of observations at each cover type and normalized by dividing by the largest number observed. Preference curves were not constructed for water velocity due to the lack of data points.

\subsubsection{HABITAT UTILIZATION OF TARGET SPECIES DURING ELECTROFISHING SURVEYS}

Two types of habitat information was collected during electrofishing surveys conducted in 1988. The first type consisted of recording information about the habitat electrofished during the collection of relative abundance/population information. General observations were made about depth, substrate, water velocity and cover. The second type of habitat utilization information was collected in June and July of 1988. Wherever a fish was captured by electrofishing, physical measurements were made of the habitat. 
Depth and velocity measurement were made with a boat mounted boom with an attached sounding reel, Price AA current meter, and 50 lb sounding weight. Depth was measured by first lowering-the sounding weight to the water surface and zeroing the depth indicator on the reel. The weight was then lowered to the bottom and the depth recorded to the nearest $0.1 \mathrm{ft}$ off the indicator. No adjustments were necessary to correct for weight drift since the currents were not sufficient to cause drift downstream. Mean column velocity was measured using the two point method $(0.2$ and 0.8 of the total depth) when depths were greater than $2.5 \mathrm{ft}$ and the one point method (0.6 of the total depth) when depths were less than $2.5 \mathrm{ft}$ (Buchanan and Somers 1980). When using the two point method, both velocities were averaged to get a mean column velocity.

Cover was categorized according to Table 2.3. Cover was broken down into no cover, small and large object, overhead, combination and aquatic macrophytes. If aquatic macrophytes were present Table 2.4 was used for their categorization. This system made it possible to account for the density of the macrophytes as well as the type of macrophytes composing the weed bed. Substrate was categorized according to Table 2.5; a mixture of two substrate types was categorized according to the relative percentage of each type.

The intent was to construct habitat suitability and preference curves from habitat data collected. Due to time constraints the amount of data collected was minimal therefore making utilization and preference curves impractical. Information collected is reported in Appendix I.

\subsection{CREEL SURVEY}

The Pend Oreille River creel survey was designed to:

(1) estimate total angler effort along the Box Canyon portion of the Pend Oreille River from Albeni Falls dam to Box Canyon dam;

(2) determine catch per unit effort (CPUE) for boat and shore anglers:

(3) estimate the annual harvest for each fish species; 
Table 2.5. Cover codes used to categorize substrate in the Pend Oreille River.

\begin{tabular}{cll}
\hline COVER CODES & DESCRIPTION & SIZE $(\mathrm{MM})$ \\
\hline 1 & Silt/mud & $\mathrm{c} 0.062$ \\
2 & Sand & $0.062-2.0$ \\
3 & Gravel & $2.0-64.0$ \\
4 & Small cobble & $64.0-128.0$ \\
5 & Large cobble & $128.0-256.0$ \\
6 & Boulder & $>256.0$ \\
\hline
\end{tabular}


(4) obtain information on fish migration patterns in the Pend Oreille River:

(5) collect length and weight data on fish checked during creel surveys; and

(6) obtain information on angler use patterns (i.e., time of day most heavily fished, seasonal variations in angler preferences, etc.).

The river was divided into three sections (Fig. 2.8). Section 1 extended from Albeni Falls Dam to the Usk bridge $(29.6 \mathrm{~km})$ Section 2 ran from the Usk bridge to Panhandle Park $(23.7 \mathrm{~km})$. Section 3 went from Panhandle Park to Box Canyon Dam $(36.2 \mathrm{~km})$. Each section was further divided into subsections to determine areas of high angler usage and to obtain information about fish movements by identifying the location of tagged fish recovered by anglers.

The days in the month were divided into weekdays and weekend days (included holidays). Holidays included all officially declared federal holidays. The day was then divided into two time periods. The AM time period went from sunrise to 1 PM. The PM time period went from noon to sunset. The times of sunrise and sunset were obtained from sunrise/sunset tables compiled for Spokane, WA (Nautical Almanac Office, U.S. Naval Observatory, Washington, D.C.).

During each $\mathrm{AM}$ and $\mathrm{PM}$ creel period tow randomly timed progressive angler pressure counts were conducted. These pressure counts were made by automobile with the direction of travel randomly selected. Virtually all of the river can be observed from points along the road. The number of boats and shore anglers within the section was recorded. Automobile pressure counts were checked for accuracy by conducting four simultaneous pressure counts by automobile and fixed-wing aircraft.

Angler interviews were conducted to obtain information about the number of anglers per boat, the total number of hours fished, the species of preference, the type of angler (boat or shore), the number of each species caught and kept or released, the river zones fished, and whether any tagged fish were caught. Anglers were encouraged to submit information on fish they caught that were captured.

Information requested included: tag number and color; species; date 


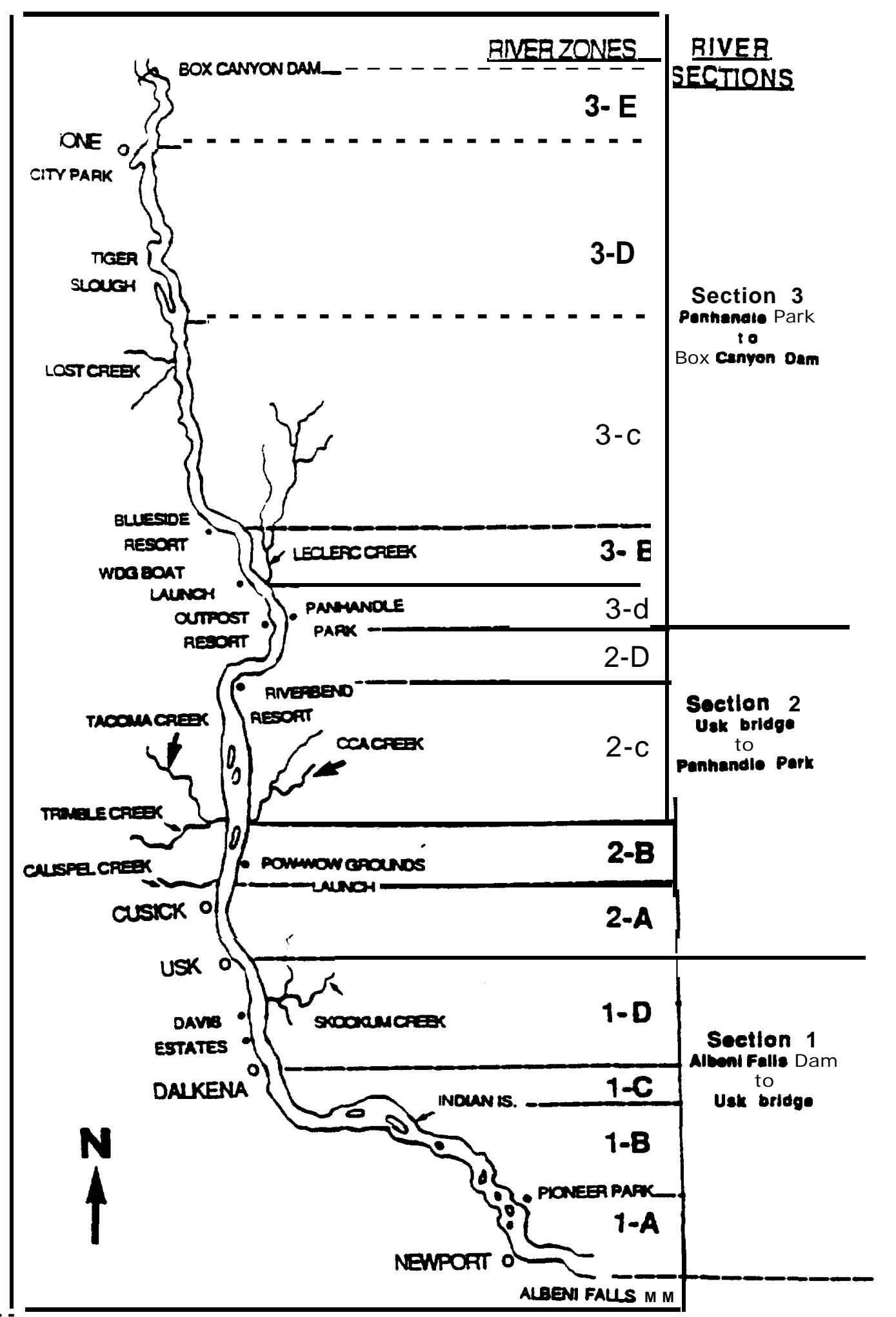

F́igure 2.9 Map of Pend Oreille River study area showing major river sections and river zone designations utilized in creel surveys. 
of capture; location of capture; fish length; and weight (if possible). If a tagged fish was kept the angler was requested to return the tag along with the above information. Posters were put up at resorts, boat launches, and campgrounds to inform the public of the study and where to send information on tagged fish. Two presentations were made to local bass clubs to inform them of the study and to coordinate bass tagging with their tournaments.

Creel clerks requested that each angler allow them to examine any fish (if possible ) they had caught to obtain the species, length, weight, sex and to remove a scale sample for age determination. Creel clerks also inspected the fish for fin clips or tags.

Pressure was estimated monthly for each river section, day type, angler type and time period by the formula:

$$
P E_{s}=N_{s} X_{s}
$$

where: $\quad \mathrm{PE}_{\mathbf{s}}=$ pressure estimate for stratum;

$$
\begin{aligned}
& \mathbf{N}_{\mathbf{s}}=\text { number of hours in stratum: and } \\
& \mathbf{X}_{\mathbf{s}}=\text { mean number of anglers in stratum. }
\end{aligned}
$$

Total pressure for a given month was estimated for each river section by:

$$
P E_{m}=\sum_{i=1}^{n} P E_{s i}
$$

where: $\quad \mathrm{PE}_{\mathrm{m}}=$ pressure estimate for the month;

$$
\mathrm{n}=\text { number of strata. }
$$

The variance of the pressure estimate for each stratum was calculated by:

$$
V_{P E s}=\frac{N_{s}}{n} S_{s}^{2}
$$

where: $\quad \mathrm{VPE}_{\mathbf{s}}=$ variance of the pressure estimate for each stratum;

$\mathrm{N}_{\mathbf{s}}=$ number of hours in the stratum; 


$$
\begin{aligned}
& \mathrm{n}=\begin{array}{l}
\text { number of hours sampled in the } \\
\text { stratum: and }
\end{array} \\
& \mathrm{S}_{\mathbf{s}}=\begin{array}{l}
\text { standard deviation of the mean number } \\
\text { of anglers in the the stratum. }
\end{array}
\end{aligned}
$$

The monthly variance of the pressure estimate for each river section was calculated by:

$$
\text { VPEm }=\sum_{i=1}^{n} V_{P E s}
$$

where: $\quad \mathrm{VPEm}_{\mathrm{m}} \quad=\quad$ monthly variance of the pressure estimate: and

$$
\mathrm{n} \quad=\quad \text { number of strata. }
$$

The monthly pressure estimate and variance for the river was completed by summing the pressure estimates and variances for each river section. Similarly, the annual (March through December 1988 and January through December 1989) pressure estimates and variances were calculated by summing the monthly pressure estimates and variances.

The 95 percent confidence interval for the pressure estimate was calculated by:

$$
\text { C.I. }=P E \pm \sqrt{V P E \times 1.96}
$$

Catch per unit effort (CPUE) was calculated for each species of fish caught, whether the fish was kept or released. CPUE was calculated by dividing the number of fish caught by the number of hours spent fishing by interviewed anglers.

Harvest was estimated by multiplying the CPUE times the pressure estimate. By multiplying the CPUE times the upper and lower confidence interval for the pressure estimate the confidence interval for the harvest estimate was obtained.

Information was obtained from the Washington Department of Wildlife and the Inland Empire Bass Club pertaining to past bass tournaments. This information was analyzed to determine trends in CPUE and mean size of catch. 


\subsection{SUMMARY OF FISHERIES ASSESSMENT}

The first year of this study (1988) was atypical in that the river had abnormally low flows. The amount of precipitation observed in 1988 was 7.27 inches less than normal (50 year average) which greatly affected the river levels. In addition, on May 19, 1988 a crane used to operate the gates at Box Canyon Dam malfunctioned resulting in the gates at the dam being left open. Water levels in the reservoir dropped more than 20 feet near lone and 6 to 8 feet near Cusick before the crane was repaired and gates closed on June 2. Fortunately, no other malfunctions occurred during the course of the study and 1989 was much closer to an average year with respect to flow and reservoir elevations (Figure 3.1). The amount of precipitation received in 1989 was only 1.30 inches less than normal. The final year of the study (1990) precipitation received was 3.07 inches above normal and as a result the river had flows above average.

During January and February of 1989 , extremely cold weather may have effected the fish populations in the river. The average air temperature for the month of February was $-5.4^{\circ} \mathrm{C}$.

\subsection{RESERVOIR POPULATION DYNAMICS}

During the first year of the study (March through October 1988) a total of 23,602 fish were captured; 19,931 by electrofishing, 264 by gillnetting and 3,407 by beach seining. During the second year of the study (November 1988 through December 1989) electrofishing resulted in the capture of 18,434 fish; 17,554 during electrofishing, 75 by gillnetting and 805 by beach seining. The third year of the study (February through December 1990) a total of 10,517 fish were captured; 9,933 by electrofishing, 67 by gillnetting and 517 by beach seining. Fish species captured during the study included:

Brown trout

Cutthroat trout

Rainbow trout

Brook trout
Salmo trutta [Linnaeus]

Oncorhynchus clarki [Richardson]

Oncorhynchus mykiss [Richardson]

Salvelinus fontinalis [M itch ill] 


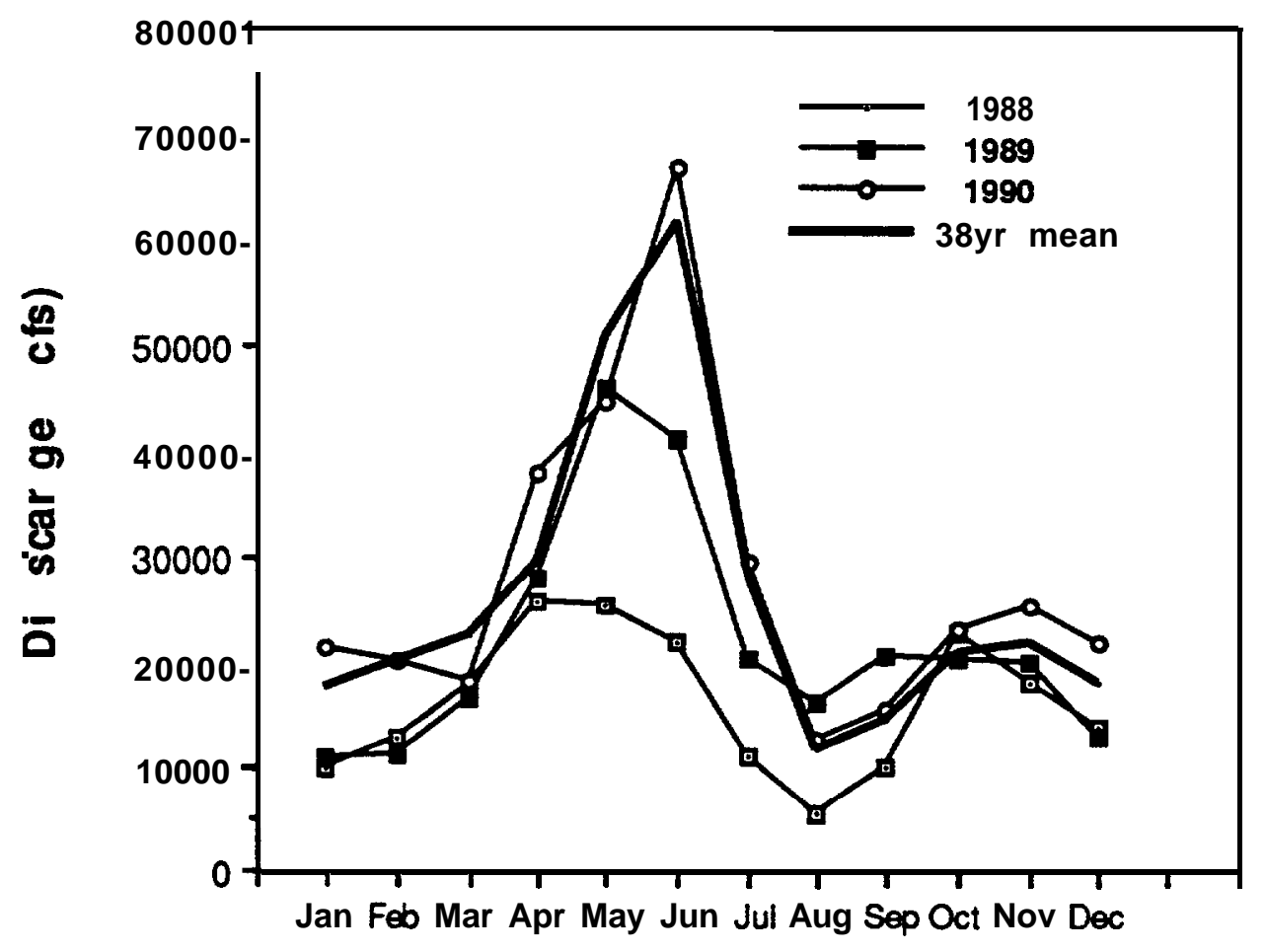

Month

Figure 3.1 Comparison of 38 year (19534990) mean monthly flows with the mean monthly flows during 1988, 1989 and 1990 at Newport, WA (USGS gauge 12395500). The 19534987 data was compiled by Soltero et al. (1988) and the 1988,. 1989 and 1990 provisional data was obtained from the USGS, Sandpoint, ID. 


$\begin{array}{ll}\text { Bull trout } & \begin{array}{l}\text { Salvelinus confluentus [Suckley] } \\ \text { Kokanee }\end{array} \\ \text { Oncorhynchus nerka [Walbaum] } \\ \text { Largemouth bass } & \text { Prosopium williamsoni [G i ra rd] } \\ \text { Black crappie } & \text { Pomoxis nigromaculatus [Lesueur] } \\ \text { Pumpkinseed } & \text { Lepomis gibbosus [Linnaeus] } \\ \text { Yellow perch } & \text { Perca flavescens [Mitchill] } \\ \text { Tench } & \text { Tinca tinca [ Linnaeus] } \\ \text { Redside shiner } & \text { Richardsonius balteatus [Richardson] } \\ \text { Northern squawfish } & \text { Ptychocheilus oregonensis [Richardson] } \\ \text { Peamouth } & \text { Mylocheilus caurinus [Richardson] } \\ \text { Lake chub } & \text { Couesius plumbeus [Agassiz] } \\ \text { Longnose sucker } & \text { Catostomus catostomus [Forster] } \\ \text { Largescale sucker } & \text { Catostomus macrocheilus [Girard] } \\ \text { Brown bullhead } & \text { Ictalurus nebulosus [ Lesueur] } \\ \text { Sculpin } & \text { Cottus spp. }\end{array}$

\subsubsection{RELATIVE ABUNDANCE AND CATCH-PER-UNIT- EFFORT (CPUE)}

A total of 12,973 minutes were spent electrofishing in the Pend Oreille River during the three year study period to determine relative abundance of fish species. The relative abundance of fish species in the river was very similar during each year of the survey (Table 3.1). Yellow perch were the most abundant species during all three years of the study ranging from 42 to 45 percent. In general, pumpkinseed were the next most abundant species followed by tench, largemouth bass, mountain whitefish, suckers and northern squawfish. Black crappie represented less than two percent of the 
relative abundance during all three years of the study. Trout were rarely captured during the survey. Of the trout species, brown trout were the most abundant. The relative abundance of kokanee and lake trout increased in 1989 and again in 1990. This was probably due to the higher flows during those years which probably flushed these fish from Lake Pend Oreille over Albeni Falls Dam. Relative abundance of fish species captured at each study site during the study can be found in Appendix A, Table A.I-A.6.

The catch-per-unit-effort (CPUE) was $6.12 \mathrm{fish} / \mathrm{min}$ of electrofishing in 1988, $3.23 \mathrm{fish} / \mathrm{min}$ of electrofishing in 1989, and $2.32 \mathrm{fish} / \mathrm{min}$ of electrofishing in 1990. CPUE for individual fish species during electrofishing surveys was greater in 1988 than in both 1989 and 1990 (Table 3.1). In most cases in 1988, the CPUE was double of that for the latter two years. It's believed this was due to the lower than normal flow of the river in 1988 (Figure 3.1). Generally in months with high water levels fewer fish were caught than in months with low water levels. The increased flows (discharge) observed during the latter two years of the study were probably responsible for the reduced-catch-per-unit-effort (CPUE). Increased flows and water levels decrease the efficiency of the sampling gear. It is suspected, however, that the drawdown in 1988 may have been partly responsible for the reduced CPUE during the latter two years of the study. Flows and water levels were lower than normal in 1988 reducing the amount of fish habitat available in the sloughs and in the shallow littoral areas. As a result there were probably a greater number of fish in the main channel of the river. When the drawdown occurred it's possible that a number of fish were flushed from the reservoir which may have contributed to the lower CPUE during the latter two years of the study.

Gillnets were set for a total of 761 hours during the study. Northern squawfish were the most abundant species caught in the nets followed by peamouth and pumpkinseed (Table 3.2). Trout species, bass and crappie were rarely caught in gill nets. Relative abundance of fish species captured by gill net at each study site can be found in Appendix A, Table A.7-A.9.

A total of 2526 meters were beach seined in slough study sites resulting in a catch of predominantly pumpkinseed (Table 3.3). Largemouth bass was the next most prevalent species but at only one quarter of the abundance of pumpkinseed. Yellow perch were rarely caught in beach seines relative to their abundance in the 


\section{Table 3.1. Comparison of total numbers of fish (and relative abundance) of fish captured by electrofishing in 1988 (Barber et al.1989), 1989 (Barber et a/. 1990) and 1990 (Ashe et a/. 1991).}

\begin{tabular}{|c|c|c|c|c|}
\hline $\begin{array}{l}\text { Year } \\
\text { Shock ti ne (mi n) }\end{array}$ & $\begin{array}{c}1988 \\
3,258 \\
\end{array}$ & $\begin{array}{c}1989 \\
5,432 \\
\end{array}$ & $\begin{array}{r}1990 \\
4,285 \\
\end{array}$ & $\begin{array}{c}\text { Total } \\
\text { 1988-90 } \\
12.973 \\
\end{array}$ \\
\hline Yel I ow perch & $8,390 \quad(42.1)$ & 7, 917 (45. 1) & $4,453 \quad(44.8)$ & $20,780 \quad(43.8)$ \\
\hline Pumpki nseed & 3, $791 \quad(19.0)$ & $2,897 \quad(16.5)$ & 1. $026(10.3)$ & $7,714 \quad(16.3)$ \\
\hline Tench & $1,920 \quad(9.6)$ & $1,465 \quad(8.3)$ & $1,045 \quad(10.5)$ & $4,430 \quad(9.3)$ \\
\hline Largenouth bass & $1,434 \quad(7.2)$ & $1,589 \quad(9.1)$ & $842(8.5)$ & $3,865 \quad(8.2)$ \\
\hline Northern squauf i sh & $1,057 \quad(5.3)$ & $620(3.5)$ & $284(2.9)$ & $1,961 \quad(4.1)$ \\
\hline Largescal e sucker & 949 (4. 8) & 789 (4.5) & $590(5.9)$ & $2,328 \quad(4.9)$ \\
\hline Mbuntai $n$ whi tefi sh & 860 (4.3) & $1,054 \quad(6.0)$ & 709 (7. 1) & $2,623 \quad(5.5)$ \\
\hline Longnose sucker & $723(3.6)$ & $530(3.0)$ & $362(3.6)$ & $1,615 \quad(3.4)$ \\
\hline Brown bul I head & $268(1.3)$ & $219(1.2)$ & $185(1.9)$ & $672(1.4)$ \\
\hline Black crappi e & $262(1.3)$ & $233(1.3)$ & $155(1.6)$ & $650(1.4)$ \\
\hline Peamouth & $127(0.6)$ & $62(0.4)$ & $118(1.2)$ & $307(0.6)$ \\
\hline Brown trout & $114(0.6)$ & $117(0.7)$ & $104(1.0)$ & $335(0.7)$ \\
\hline Cutthroat trout & $11(0.05)$ & $15(0.1)$ & $8(0.1)$ & $34(0.1)$ \\
\hline Redside shi ner & $11(0.05)$ & $2(0.01)$ & $2(0.01)$ & $15(<0.1)$ \\
\hline Rai nbow trout & $6(0.03)$ & $13(0.01)$ & $10(0.1)$ & $29(0.1)$ \\
\hline Rai nbow $x$ cutthroat trout & t $0(0.0)$ & $3(0.1)$ & $0(0.0)$ & $3(<0.1)$ \\
\hline Scul pi n & $6(0.03)$ & $11(0.1)$ & $1(0.01)$ & $16(<0.1)$ \\
\hline Brook trout & $1(0.01)$ & $2(0.01)$ & $3(0.03)$ & $6(<0.1)$ \\
\hline Bull trout & $1(0.01)$ & $2(0.01)$ & $1(0.01)$ & $4(<0.1)$ \\
\hline Kokanee & $0(0.0)$ & $12(0.1)$ & $32(0.3)$ & $44(0.1)$ \\
\hline Lake trout & $0(0.0)$ & $2(0.01)$ & $3(0.03)$ & $5(<0.1)$ \\
\hline TOTAL & 19,931 & 17,554 & 9,933 & 47.418 \\
\hline
\end{tabular}


Table 3.1. (cont.) Catch-per-unit-effort (\#fish/minute) of each fish species captured by electrofishing during the three year study period.

\begin{tabular}{|c|c|c|c|c|}
\hline $\begin{array}{l}\text { Year } \\
\text { Shock ti ne (min) }\end{array}$ & $\begin{array}{l}1988 \\
3,256\end{array}$ & $\begin{array}{l}1989 \\
5,432\end{array}$ & $\begin{array}{c}1990 \\
4,285\end{array}$ & $\begin{array}{c}\text { Total } \\
1988-90 \\
12,973\end{array}$ \\
\hline Yel I ow perch & 2.57 & 1. 46 & 1.04 & 1. 60 \\
\hline Pumpki nseed & 1. 16 & 0.53 & 0.24 & 0.59 \\
\hline Tench & 0.59 & 0.27 & 0.24 & 0.34 \\
\hline Largenouth bass & 0.44 & 0.29 & 0.20 & 0.30 \\
\hline Northern squauf i sh & 0.32 & 0.11 & 0.07 & 0.15 \\
\hline Largescal e sucker & 0.29 & 0.15 & 0.14 & 0.18 \\
\hline Mbuntai $n$ whi tefi sh & 0.26 & 0.19 & 0.17 & 0.20 \\
\hline Longnose sucker & 0.22 & 0.10 & 0.08 & 0.12 \\
\hline Brown bul I head & 0.08 & 0.04 & 0.04 & 0.05 \\
\hline Bl ack crappi e & 0.08 & 0.04 & 0.04 & 0.05 \\
\hline Peamouth & 0.04 & 0.01 & 0.03 & 0.02 \\
\hline Brown trout & 0.04 & 0.02 & 0.02 & 0.03 \\
\hline Cutthroat trout & 0.003 & 0.003 & 0.002 & 0.003 \\
\hline Redside shi ner & 0.003 & $<0.001$ & $<0.001$ & 0.001 \\
\hline Rai nbow trout & 0.002 & 0.002 & 0.002 & 0.002 \\
\hline Rai nbow $x$ cutt hroat trout & 0 & $<0.001$ & 0 & $<0.001$ \\
\hline Scul pi n & 0.002 & 0.002 & co. 001 & 0.001 \\
\hline Brook trout & $<0.001$ & $<0.001$ & $<0.001$ & $<0.001$ \\
\hline Bull I trout & $<0.001$ & $<0.001$ & $<0.001$ & $<0.001$ \\
\hline Kokanee & 0 & 0.002 & 0.007 & 0.003 \\
\hline Lake trout & 0 & $<0.001$ & $<0.001$ & $<0.001$ \\
\hline TOTAL & 6.21 & 3.23 & 2.32 & 3.65 \\
\hline
\end{tabular}


Table 3.2. Comparison of total numbers of fish (and relative abundance) of fish captured in gillnets during 1988 (Barber et a/. 1989), 1989 (Barber et al. 1990) and 1990 (Ashe et al. 1991).

\begin{tabular}{|c|c|c|c|c|}
\hline Year & 1988 & 1989 & 1990 & $\begin{array}{c}\text { Total } \\
\text { 1988-90 }\end{array}$ \\
\hline Soak ti me & 393 hours & 314 hours & 54 hours & 761 hours \\
\hline Cutthroat trout & $1(0.4)$ & $1(1.3)$ & & $2(0.5)$ \\
\hline Brown trout & $5(1.9)$ & $1(1.3)$ & $1(1.5)$ & $7(1.7)$ \\
\hline Mbuntai $n$ whi tefi sh & $12(4.5)$ & $5(6.7)$ & & $17(4.2)$ \\
\hline Largenouth bass & & $1(1.3)$ & $2(3.0)$ & $3(0.7)$ \\
\hline Bl ack crappi e & & $1(1.3)$ & & $1(0.2)$ \\
\hline Pumpki nseed & 48 (18. 2) & $24(32.0)$ & $11(16.4)$ & $83(20.4)$ \\
\hline Yel I ow perch & $14(5.3)$ & $5(6.7)$ & $13(19.4)$ & $32(7.9)$ \\
\hline Longnose sucker & $18(6.8)$ & $2(2.7)$ & & $20(4.9)$ \\
\hline Largescal e sucker & $27(10.2)$ & $6(8.0)$ & $2(3.0)$ & $35(8.6)$ \\
\hline Tench & $14(5.3)$ & $4(5.3)$ & $1(1.5)$ & $19(4.7)$ \\
\hline Northern squaufi sh & 72 (27. 3) & 11 (14.7) & $18(26.9)$ & 101 (24.9) \\
\hline Peamouth & $51(19.3)$ & $14(18.7)$ & $19(28.4)$ & $84(20.7)$ \\
\hline Brown bul I head & $2(0.8)$ & & & $2(0.5)$ \\
\hline TOTAL & 264 & 75 & 67 & 406 \\
\hline
\end{tabular}

Table 3.3. Comparison of total numbers of fish (and relative abundance) of fish captured by beach seining in 1988 (Barber et al. 1989), 1989 (Barber et al. 1990) and 1990 (Ashe et al. 1991).

\begin{tabular}{lcccc}
\hline & & & & \multicolumn{1}{c}{ Total } \\
Year & 1988 & 1989 & 1990 & $1988-90$ \\
Di stance sei ned & $1321 \mathrm{~m}$ & $656 \mathrm{~m}$ & $\mathbf{5 4 9} \mathbf{~ m}$ & $\mathbf{2 5 2 6} \mathbf{~ m}$ \\
\hline Largenouth bass & $327(9.6)$ & $187(23.2)$ & $68(13.4)$ & $582(12.3)$ \\
Bl ack crappi e & $2(0.1)$ & $13(1.6)$ & $1(0.2)$ & $16(0.3)$ \\
Pumpki nseed & $2982(87.5)$ & $480(59.6)$ & $423(82.1)$ & $3885(82.2)$ \\
Yel I ow perch & $80(2.3)$ & $61(7.6)$ & $15(3.0)$ & $156(3.3)$ \\
Tench & $15(0.4)$ & $63(7.8)$ & $6(1.2)$ & $84(1.8)$ \\
Brown bul I head & $1(0.03)$ & $1(0.1)$ & $1(0.2)$ & $2(<0.1)$ \\
Longnose sucker & & & 507 & $1(<0.1)$ \\
TOTAL & 3407 & 805 & & 4726 \\
\hline
\end{tabular}


reservoir. This may indicate that either young-of-the-year perch were not rearing in the sloughs or that our sampling equipment was ineffective in their capture. Relative abundance of fish species captured by beach seine at each study site can be found in Appendix A, Table A.1 O-A.1 5.

\subsubsection{POPULATION ESTIMATES}

The minimum number of recaptures required to estimate a population using the Schnabel multiple census method is four (Ricker 1975). For some species this requirement was not met. The species for which this occurred are denoted by asterisks in Table 3.4. Recruitment and mortality should be "approximately" zero during the period of the estimate (Ricker 1975). Mortality was not determined and the degree it influenced the estimates is unknown. Recruitment of the young-of-the-year fish was eliminated by estimating the population for one year and older fish. There was no movement of tagged fish between sites during the estimate. The number of each species captured, marked and recaptured during the study period can be found in Appendix B, Table B.I -B. 12.

Most species in the reservoir showed a similar trend in population fluctuation during the three year investigation (Figures 3.2 and 3.3). In general, the population estimates in 1989 and 1990 were very similar; typically lower than those in 1988 (Table 3.4). The yellow perch estimate fluctuated from 41.7 million in 1988, to 6.1 million in 1989, to 8.8 million in 1990 . The pumpkinseed estimate went from 16.8 million in 1988 , to 3.9 million in 1989 , to 4.4 million in 1990. The tench estimate decreased from 4.2 million in 1988 to 1.1 million in 1989 and to 1.0 million in 1990. The largescale sucker, longnose sucker and northern squawfish populations fluctuated in the same manner during the investigation (Figure 3.3). The largescale sucker population was estimated at 821,863 in 1988; 186,693 in 1989; and 194,551 in 1990. Estimates for longnose sucker were 781,166 in 1988; 183,457 in 1989; and 218,743 in 1990. Northern squawfish estimates fluctuated from 580,565 in 1988 to 248,988 in 1989 to 280,663 in 1990 .

Largemouth bass were the only species that exhibited a continual decline in population size during the study, although the declines were only slight. Their population decreased from 657,549 in 1988 to 590,906 in 1989 to 570,098 in 1990 . 


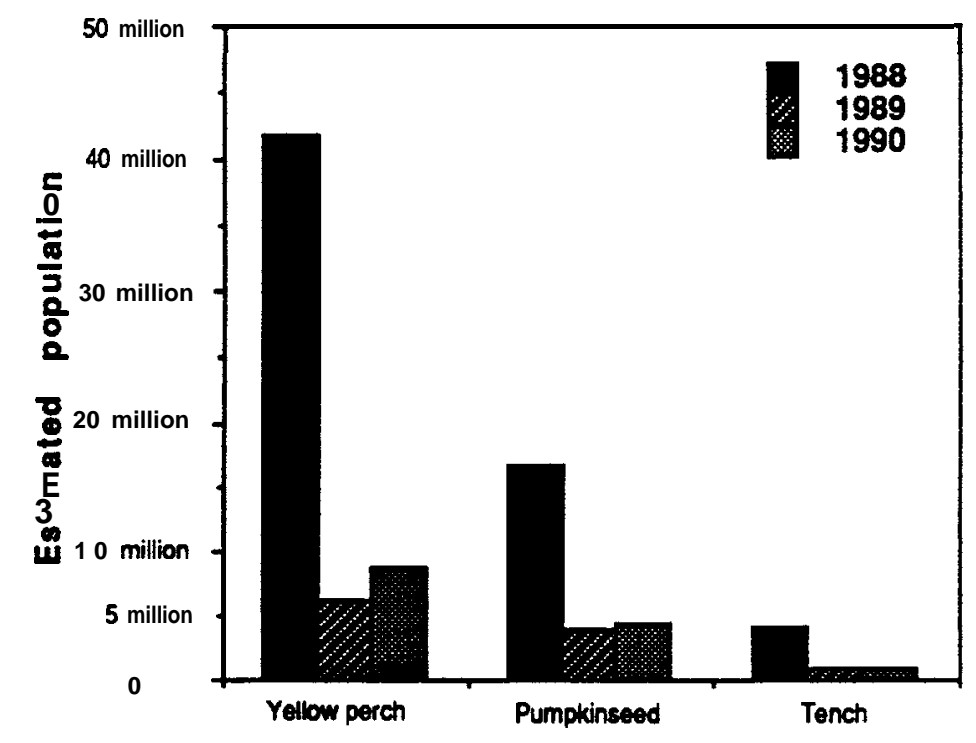

Figure 3.2. Estimated population of yellow perch, pumpkinseed and tench in the Pend Oreille River during 1988, 1989 and 1990.

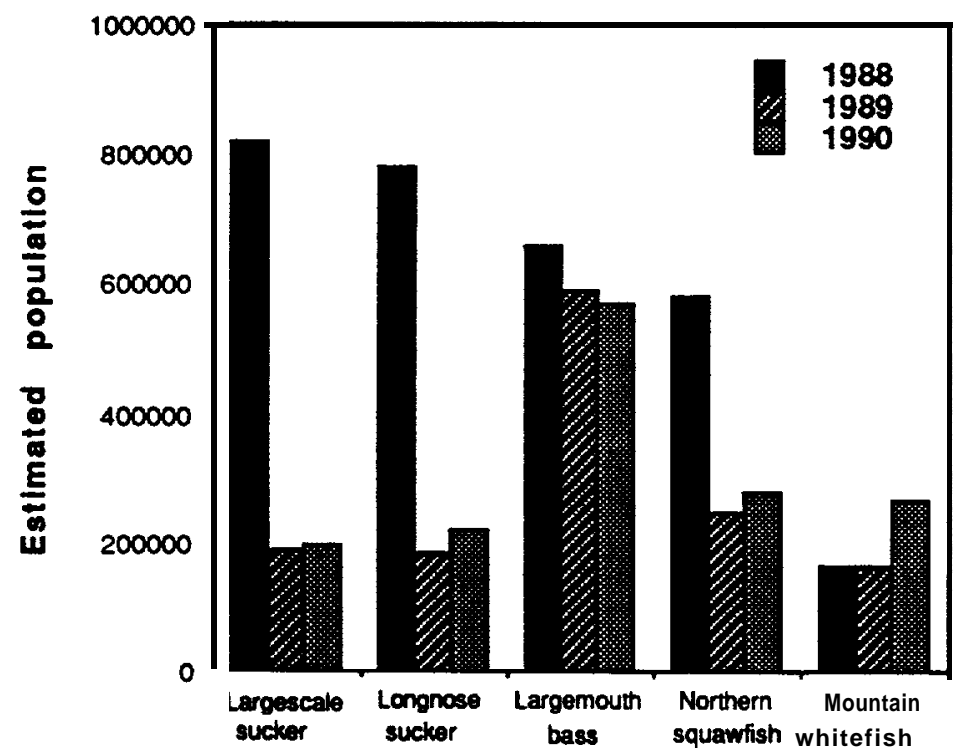

Figure 3.3. Estimated population of largescale sucker, longnose sucker, largemouth bass, northern squawfish and mountain whitefish in the Pend Oreille River during 1988, 1989 and 1990. 
Table 3.4. Comparison of river population estimates and $95 \%$ confidence limits from 1988 (Barber et a/. 1989), 1989 (Barber et al. 1990) and 1990 (Ashe et a/. 1991).

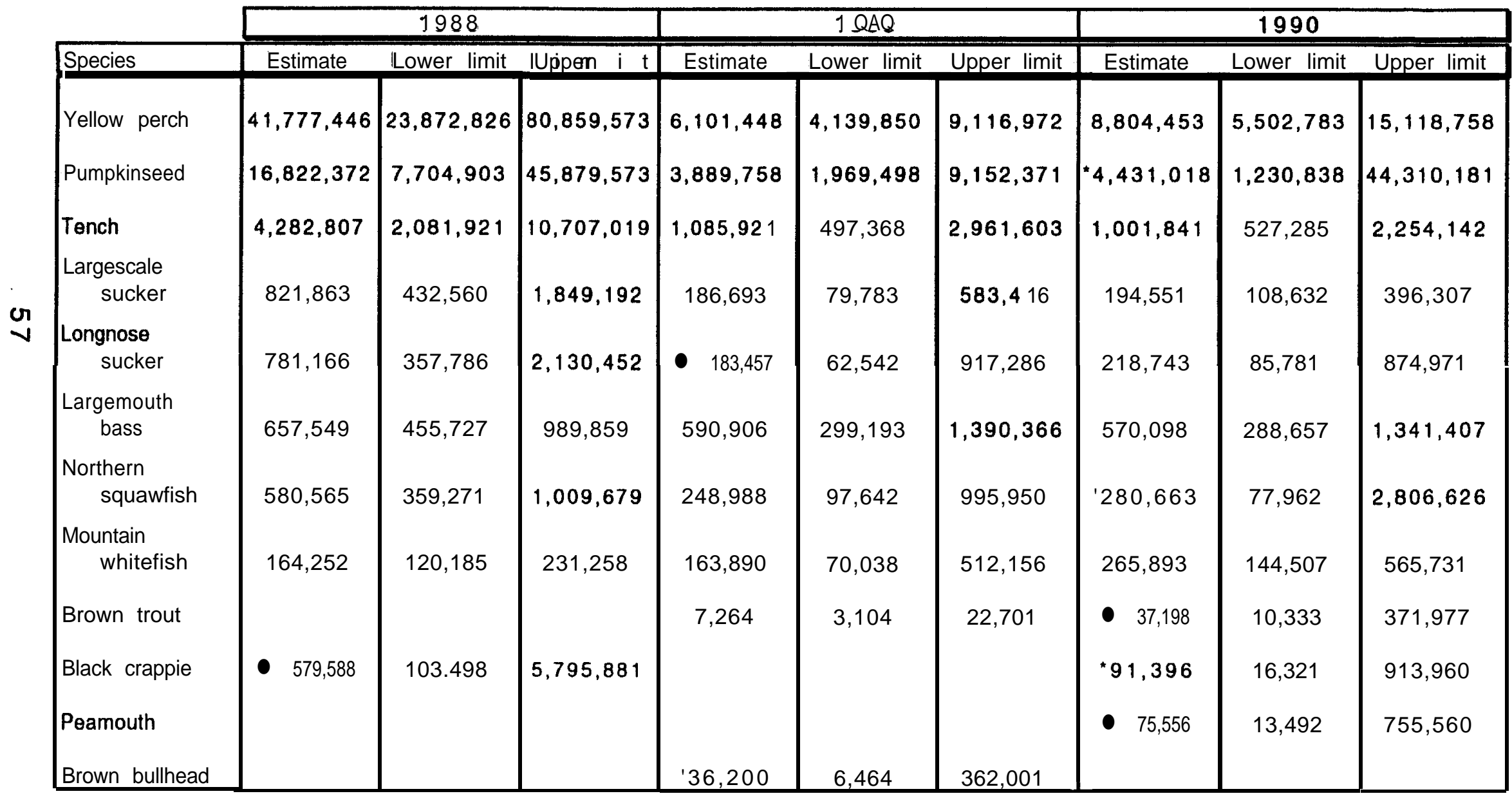

- Estimates based on less than four recaptures. 
Mountain whitefish and brown trout were the only species that didn't show a decrease in population from 1988 to 1989 . The mountain whitefish population was estimated at 164,252 in 1988 and 163,890 in 1989. This increased to 265,893 in 1990. The brown trout population for the river was not estimated in 1988 but in 1989 the estimate was 7,264 . This increased to 37,198 in 1990.

Black crappie estimates were calculated in 1988 and 1990. The estimate for 1988 was 579,588 and for 1990 was 91,396 . The brown bullhead population was estimated at 36,200 in 1989 and 75,556 in 1990. The estimates for both of these species were based on only one recaptured fish so the reliability of the estimates are questionable.

In order to better evaluate the estimates, the percent composition from the population estimates was compared to the electrofishing relative abundance (Table 3.5). During all three years of the study yellow perch and pumpkinseed were more abundant in the population data than the relative abundance data, suggesting that the population estimates, especially those of 1988 , were high. In contrast, tench, largemouth bass, northern squawfish, mountain whitefish, longnose and largescale sucker, and brown trout were represented by higher numbers in the relative abundance data than in the population data, suggesting their populations may be higher than we estimated.

The 95 percent confidence intervals were also evaluated for the three years to determine validity of the population estimates. There was a high degree of overlap of the 95 percent confidence intervals for the estimates in 1989 and 1990 while the confidence intervals for estimates in 1988 have a lesser degree of overlap or no overlap at all (Table 3.4). This leads to the conclusion that the 1988 estimates were inflated or that there was a tremendous reduction in certain species of the fish population during that year.

There was some evidence that populations of certain species of fish were overestimated in 1988 due to differential mortality owing to size. In 1988, captured fish were given a Floy FD-67F anchor tag with the paddle removed. It is possible that this marking method resulted in a high mortality of the smaller fish, or at least a poor tag retention since the anchor was positioned near the surface. There were more recaptures in 1989 and 1990, whether it was due to a change in the marking technique or fewer fish in the reservoir. The increase in recaptures resulted in much narrower confidence 
Table 3.5. Comparison of the percent composition for each species from population estimates and electrofishing relative abundance for 1988 (Barber et a/. 1989), 1989 (Barber et al. 1990) and 1990 (Ashe et al. 1991).

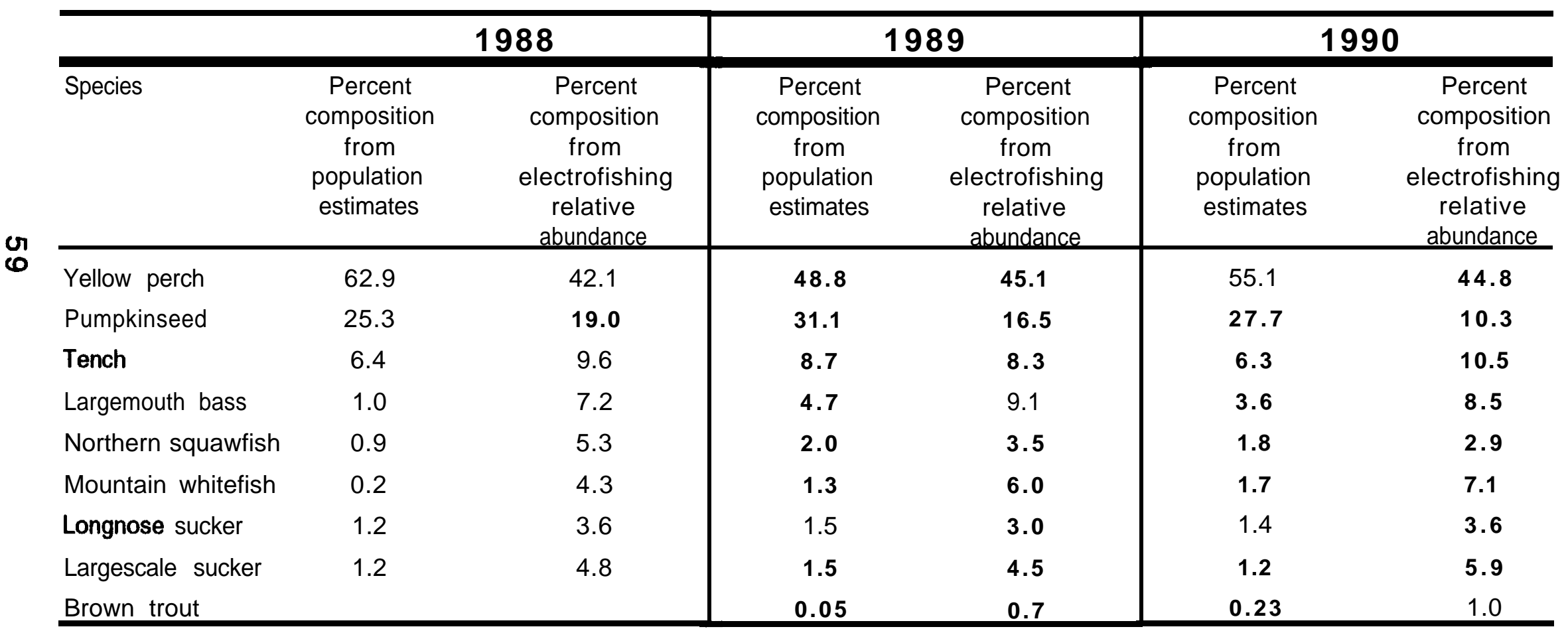


intervals, so it is believed that the population estimates from the latter two years are more reliable.

However, the fact that nearly all species demonstrated a population reduction in 1989 indicates the possibility of a reservoir wide impact in 1988. It's possible these declines were due to the extreme drawdown of the reservoir in 1988. The drawdown may have resulted in a density independent mortality of all species, causing a population decline in 1989. In addition to the drawdown the flow and reservoir elevation of the river in 1988 were lower than normal (Figure 3.1). Either of these factors or a combination of the two may have been responsible for density independent mortality during that year since they impacted the entire reservoir.

It appears that the drawdown in 1988 impacted fish populations in the reservoir. Species of fish that spawned in the late spring-early summer appear to have been impacted most by the drawdown. All spring reservoir spawners except largemouth bass and yellow perch decreased in relative abundance in 1989 over 1988. It's possible that the drawdown dewatered nests along with concentrating these fish. The newly hatched fry may have been forced out of the sloughs into the river and eventually flushed from the reservoir. It is also possible that the concentration of these fish caused some density dependent mortality due to competition and increased predation.

\subsubsection{MORTALITY}

\subsubsection{TOTAL INSTANTANEOUS MORTALITY}

Using catch curves to estimate total instantaneous mortality involves the following conditions: (1) The survival rate is uniform with age, over the range of age-groups in question; (2) Since survival rate is the complement of mortality rate, and the latter is compounded of fishing and natural mortality, this will usually mean that each of these, individually is uniform; (3) There has been no change in mortality rate with time; (4) The sample is taken randomly from the age-groups involved; and (5) The age-groups in question were equal in numbers at the time each was being recruited to the fishery (Ricker 1975).

The above conditions were assumed to be true for calculation of mortality rates of target species in the river. Regression equations determined from the descending limb of catch curves 
indicated varying levels of mortality rates for the target species of yellow perch, largemouth bass, mountain whitefish and black crappie. The descending limb of each catch curve was used- to calculate mortality because of the incomplete recruitment to fishing gear of the younger age classes.

Total instantaneous mortality for yellow perch between age 4+ and $7+$ in 1988 was 0.76 for an annual mortality of $53 \%$ (Figure 3.4 ). In 1989 total instantaneous mortality for yellow perch between age $4+$ and $7+$ was 0.84 for an annual mortality of $57 \%$ (Figure 3.4 ). Total instantaneous mortality for yellow perch between age $5+$ and $8+$ in 1990 was 0.82 for an annual mortality rate of $56 \%$ (Figure 3.4). Information used to determine yellow perch mortality can be found in Appendix C, Table C.I.

Total instantaneous mortality for largemouth bass between age $2+$ and $10+$ in 1988 was 0.17 which resulted in an annual mortality rate of $16 \%$ (Figure 3.5). In 1989 total instantaneous mortality for largemouth bass between age $0+$ and 9+ was 0.16 for an annual mortality rate of $15 \%$ (Figure 3.5 ). Total instantaneous mortality for largemouth bass between age 1+ and 7+ in 1990 was 0.28 which resulted in an annual mortality rate of $24 \%$ (Figure 3.5 ). Information used to determine largemouth bass mortality can be found in Appendix C, Table C.2.

It was assumed that overwinter survival of largemouth bass was low, especially for the younger age classes. Instantaneous mortality rates for largemouth bass age $2+$ to $4+$ were calculated to determine annual mortality of the younger age classes. In 1988 the instantaneous mortality rate was 0.43 for an annual mortality rate of $24 \%$ (Figure 3.5). In 1989 the instantaneous mortality rate was 0.29 for an annual mortality rate for $35 \%$ (Figure 3.5). The instantaneous mortality rate in 1990 was 0.14 for an annual mortality rate of $13 \%$ (Figure 3.5 ).

Total instantaneous mortality was calculated for mountain whitefish between ages 3+ and 5+ during all three years. In 1988 the total instantaneous mortality was 0.98 for an annual mortality rate of $62 \%$ (Figure 3.6). In 1989 total instantaneous mortality was 1.02 which resulted in an annual mortality rate of $64 \%$ (Figure 3.6). Total instantaneous mortality in 1990 was 0.25 for an annual mortality rate of $22 \%$ (Figure 3.6). Information used to determine mountain whitefish mortality can be found in Appendix C, Table C.3. 

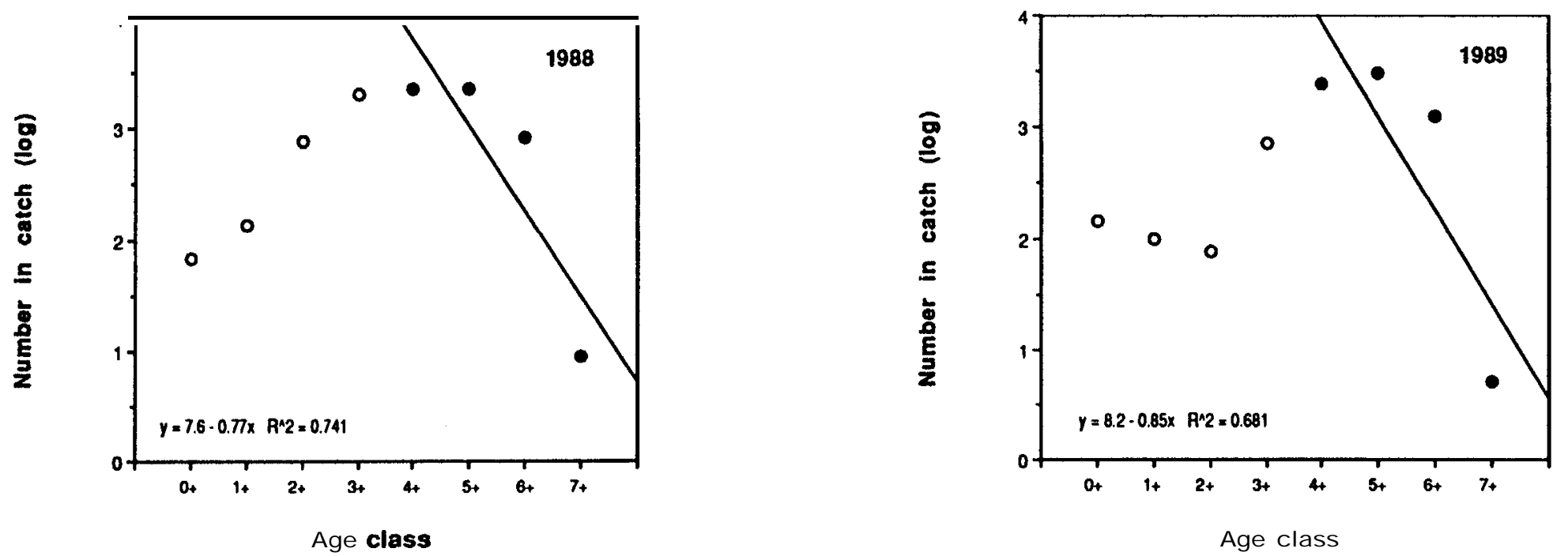

O

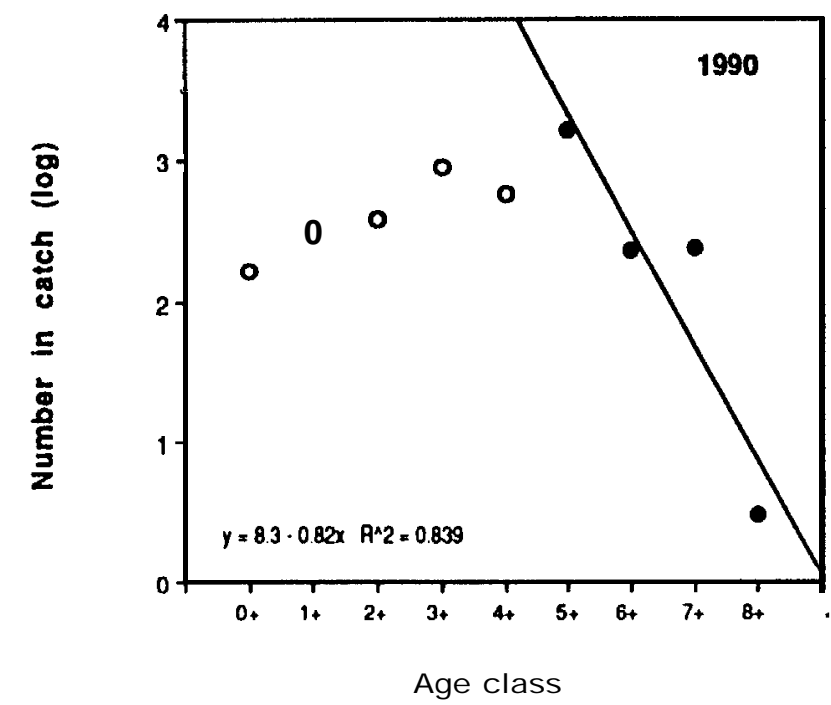

Figure 3.4. Total instantaneous mortality rates for yellow perch in the Pend Oreille River during 1988, 1989 and 1990. 


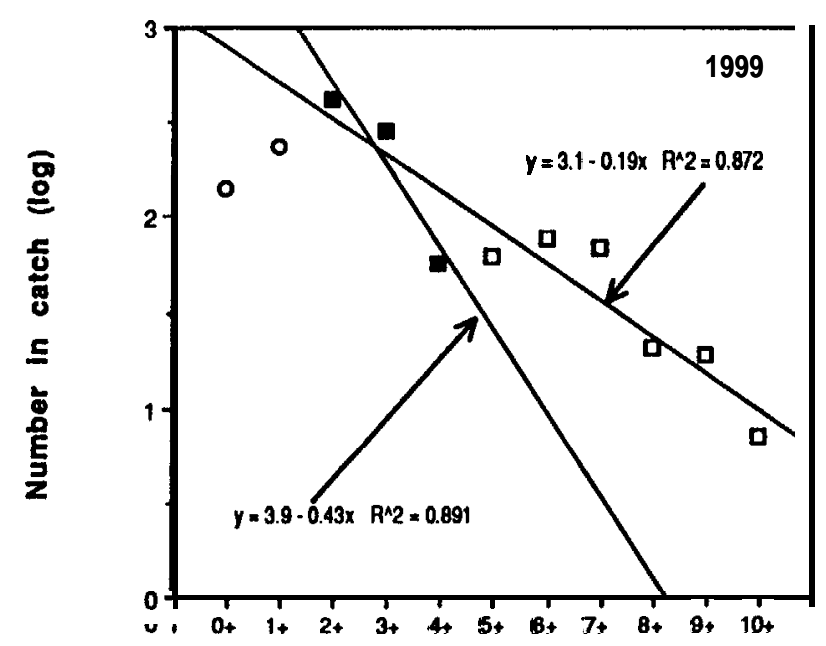

Age class

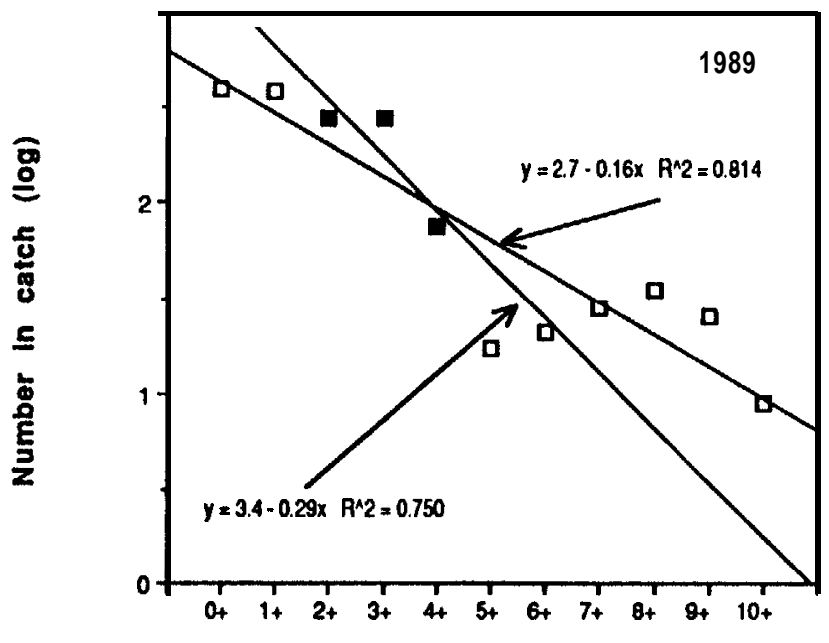

Age class

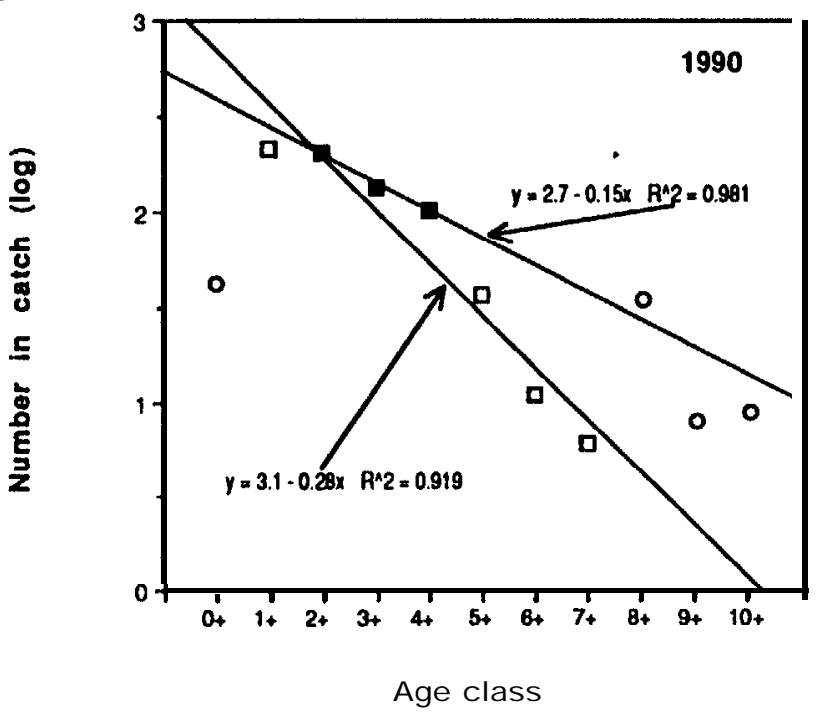

Figure 3.5. Total instantaneous mortality rates for largemouth bass in the Pend Oreille River during 1988, 1989 and 1990. 

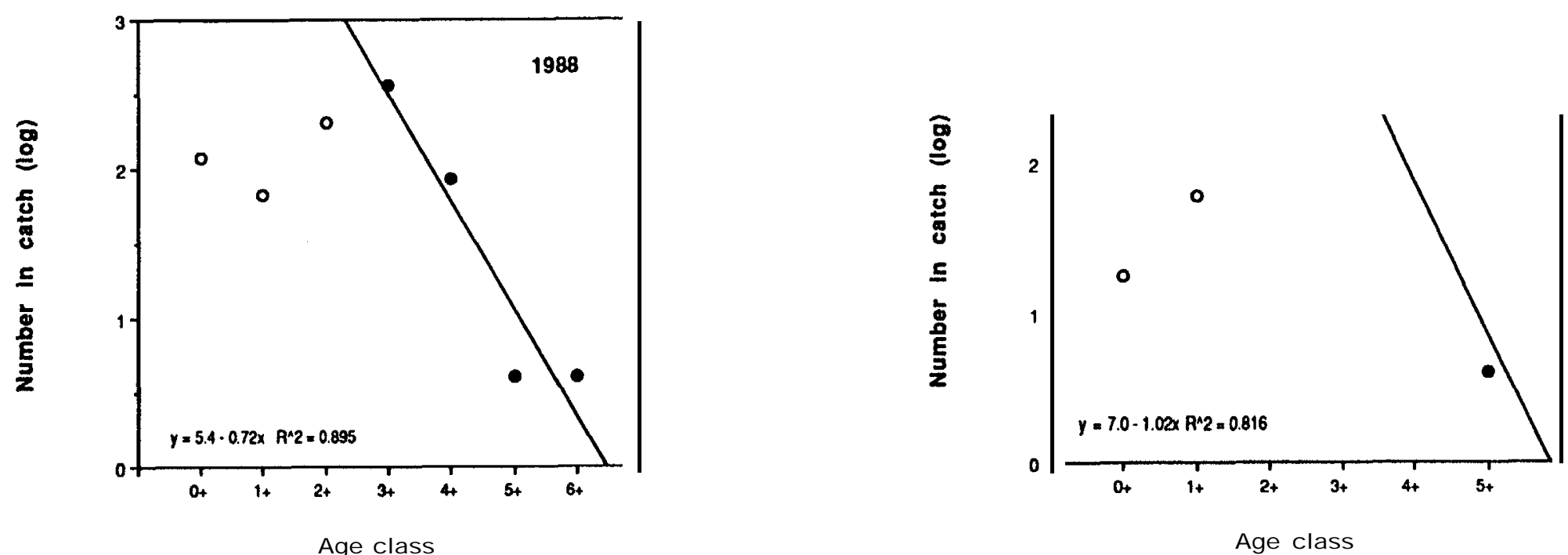

$\stackrel{\boldsymbol{D}}{\boldsymbol{1}}$

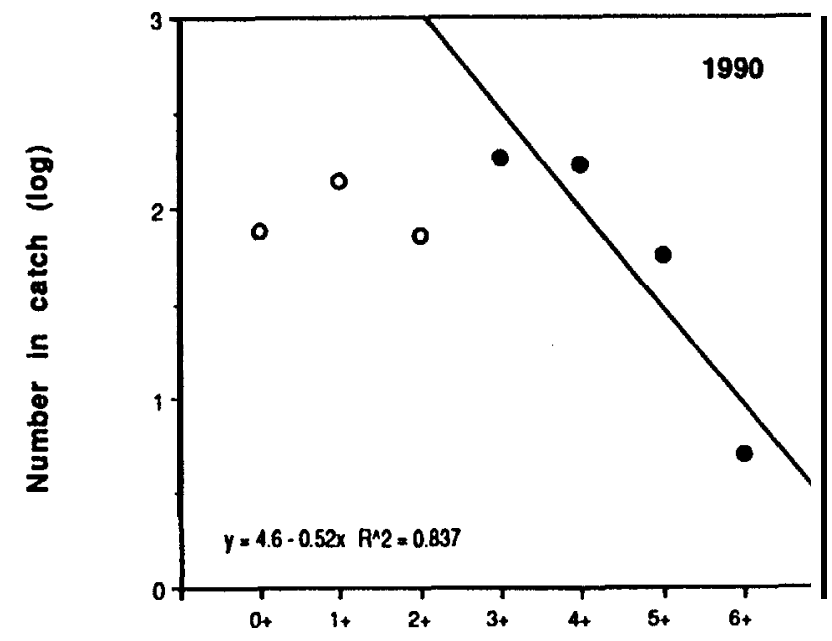

Age class

Figure 3.6. Total instantaneous mortality rates for mountain whitefish in the Pend Orellle River during 1988, 1989 and 1990. 
Total instantaneous mortality for black crappie between age $2+$ and $7+$ in 1988 was 0.26 for an annual mortality of 23\% (Figure 3.7). In 1989 total instantaneous mortality for black crappie between age $3+$ and $8+$ was 0.27 for an annual mortality of $23 \%$ (Figure 3.7). Total instantaneous mortality for black crappie between age $0+$ and $4+$ in 1990 was 0.35 for an annual mortality rate of $29 \%$ (Figure 3.7). Information used to determine black crappie mortality can be found in Appendix C, Table C.4.

\subsubsection{FISHING MORTALITY}

From March through December of 1988 angler effort on the Pend Oreille River was estimated at 4,139 \pm 467 hours. Boat anglers were estimated to apply $55 \%$ of this pressure and shore anglers $45 \%$. In 1989, estimated pressure decreased to 3,029 \pm 374 hours. Of this boat anglers applied $62 \%$ and shore anglers $38 \%$. Creel census data for each year of the study can be found in Appendix C, Tables C.5C.10.

The catch-per-unit-effort (CPUE) in 1989 for total catch (5.89 fish/hour), was more than twice the CPUE for total catch in 1988 (2.44 fish/hour)(Table 3.6). The success of bass anglers during catch and release bass tournaments was not included in the CPUE calculation for either year.

The estimated total catch (including fish released) was 10,082 fish in 1988. Yellow perch was the species of fish with the highest number caught in 1988, estimated at 4,519 \pm 588 (Table 3.6). Largemouth bass were next at $3434 \pm 320$, followed by pumpkinseed $(757 \pm 94)$ and brown bullhead $(549 \pm 77)$. In 1989, the estimated total catch almost doubled to 18,171 fish. This increase in catch over 1988 was owing, in part, to the fact that the 1988 drawdown of the reservoir occurred during the peak of the fishing season. The fish species with the highest number caught in 1989 was largemouth bass at 9,402 \pm 1169 . Yellow perch were next at 6,120 \pm 754 , followed by northern squawfish $(826 \pm 101)$, black crappie (719 \pm $89)$ and pumpkinseed (718 \pm 88$)$.

The number of fish harvested by anglers in 1988 was 2,505 \pm 312. Yellow perch composed $51 \%$ of the fish species harvested followed by largemouth bass (16\%) and pumpkinseed (11\%) (Table 3.6). Total fish harvested decreased in 1989 to $1,331 \pm 164$. Yellow perch again composed $51 \%$ of the fish species harvested followed by 

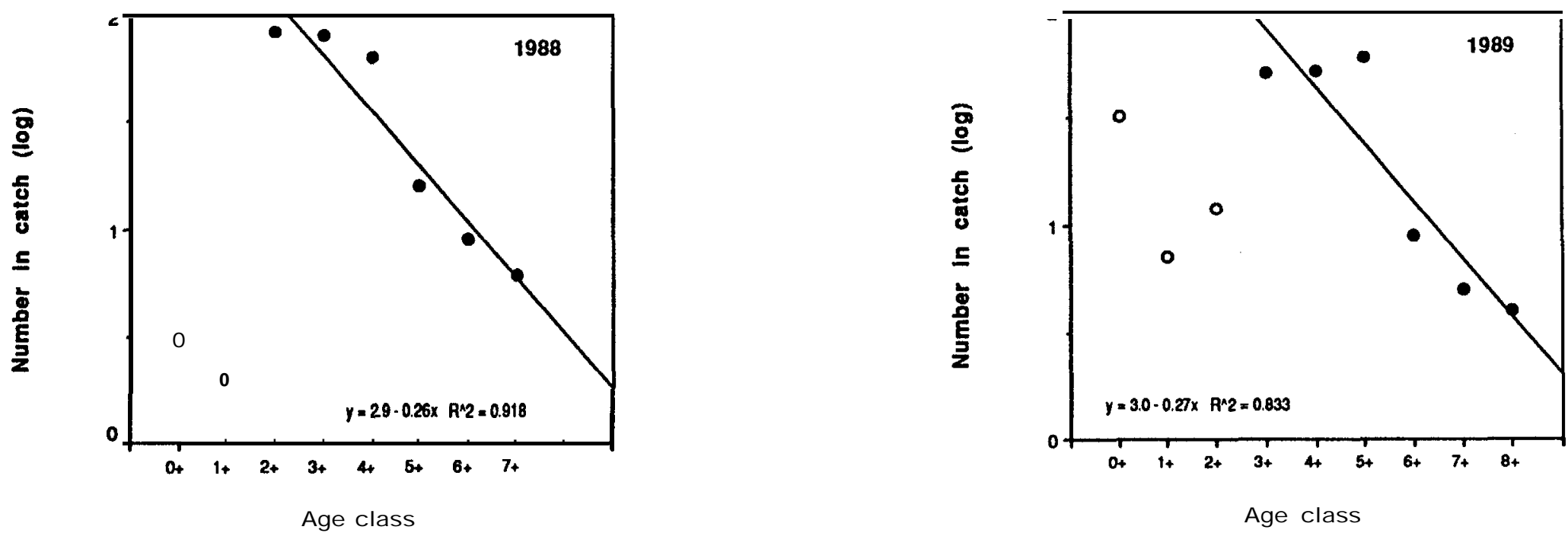

\%

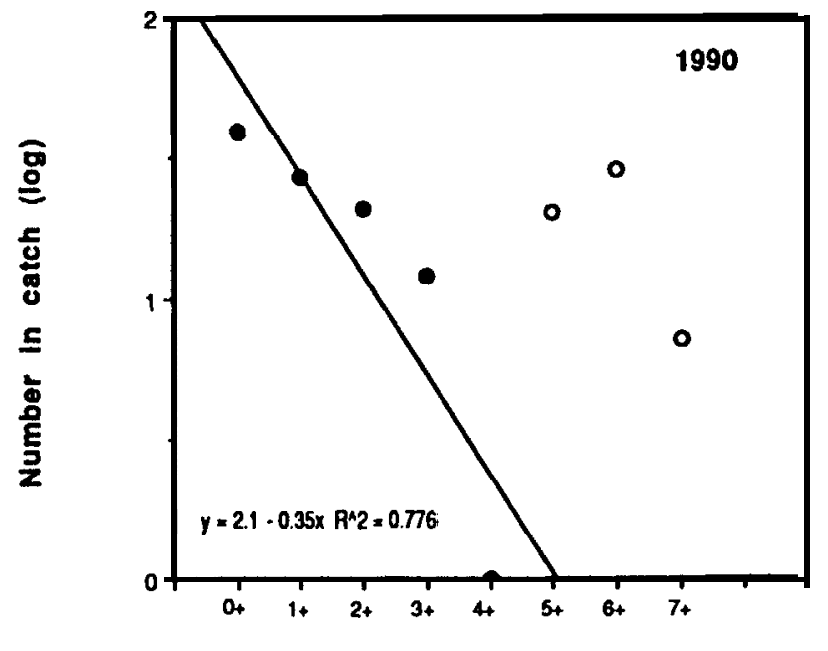

Age class

Figure 3.7. Total instantaneous mortality rates for black crappie in the Pend Oreille River during 1988, 1989 and 1990. 
Table 3.6. Comparison of annual estimates of catch $\pm 95 \%$ C.I. (including fish released), total harvest ( \pm 95\% Cl) and CPUE for the Pend Oreille River, WA in 1988 (Barber et al. 1989) and 1989 (Barber et al. 1990).

\begin{tabular}{|c|c|c|c|c|}
\hline & \multicolumn{2}{|c|}{ TOTAL CATCH } & \multicolumn{2}{|c|}{ HAR'VEST } \\
\hline & 1988 & 1989 & 1988 & 1989 \\
\hline CPUE (Fish/Hour) & 2.44 & 5.89 & 0.61 & 0.41 \\
\hline Largemouth bass & $3,434 \pm 320$ & $9,402 \pm 1169$ & $389 \pm 40$ & $103 \pm 12$ \\
\hline Yellow perch & $4,519 \pm 588$ & $6,120 \pm 754$ & $1,268 \pm 157$ & $684 \pm 84$ \\
\hline Black crappie & $69 \pm 8$ & $719 \pm 89$ & $41 \pm 4$ & \\
\hline Brown trout & $36 \pm 4$ & $91 \pm 11$ & $36 \pm 4$ & $68 \pm 9$ \\
\hline Bull trout & & $181 \pm 23$ & & $181 \pm 23$ \\
\hline Cutthroat trout & $91 \pm 12$ & & $86 \pm 11$ & \\
\hline Rainbow trout & $20 \pm 3$ & & $20 \pm 2$ & \\
\hline Mountain whitefish & $146 \pm 21$ & $34 \pm 4$ & $75 \pm 11$ & $11 \pm 2$ \\
\hline Pumpkinseed & $757 \pm 94$ & $718 \pm 88$ & $278 \pm 39$ & $182 \pm 22$ \\
\hline Northern squawfish & $411 \pm 47$ & $826 \pm 101$ & & $102 \pm 12$ \\
\hline Peamouth & $15 \pm 2$ & $46 \pm 5$ & & \\
\hline Tench & $7 \pm 1$ & $34 \pm 4$ & & \\
\hline Brown bullhead & $549 \pm 77$ & & $312 \pm 44$ & \\
\hline Sucker & $26 \pm 4$ & & & \\
\hline TOTAL & $10.082 \pm 1181$ & $18,171 \pm 2248$ & $2,505 \pm 312$ & $1,331 \pm 164$ \\
\hline
\end{tabular}


pumpkinseed (14\%) and bull trout (14\%). Largemouth bass composed $8 \%$ of the species harvested in 1989.

Based on population estimates and creel survey results the percent of each species population harvested was calculated to determine what role fishing mortality played on each species. The percent population harvested was highest for brown trout $(0.94 \%)$ in 1989 (Table 3.7). According to these data fishing mortality is only a small part of the annual mortality rate.

\subsection{AGE, GROWTH AND CONDITION OF FISH IN THE RESERVOIR}

A total of 2,242 scale samples were collected from largemouth bass during the three year study period: 1,076 in 1988, 876 in 1989 and 290 in 1990. Growth rates for largemouth bass were very similar in 1988 and 1990 (Table 3.8). Growth rates in 1989 tended to be higher for the younger age classes of fish and lower for the older age classes of fish. It is thought the increased growth seen in the younger age classes of fish in 1989 may have been due to reduced competition owing to the density independent mortality caused by the reservoir drawdown in 1988. The lower values for the first three age classes of bass were lower in 1988 than the following years owing, in part, to the use of a different intercept value in the back-calculation equation used in 1988 (See section 2.5). The mean condition factor for all age classes of largemouth bass decreased only slightly from 1.30 in 1988 and 1989 to 1.28 in 1990. Growth rates and condition factors for each age class of largemouth bass during each year of the study can be found in Appendix D, Tables D.I-D.6.

Mean lengths and weights for each age class of bass were very similar for all three years of the study (Figure 3.8) During the course of investigation, largemouth bass seemed to display a marked weight gain after they reached 6 years of age. At this age and larger size, the dietary preference of largemouth bass changes to include sizable perch and pumpkinseed, which would account for the marked increase in weight.

A total of 2,555 scale samples were collected from yellow perch during the three year study period; 1,002 in 1988, 1,134 in 1989 and 419 in 1990. Back-calculated growth for yellow perch was very similar for all three years of the study (Table 3.9) Ashe et al. (1991) determined that a check mark found on the perch scales 
Table 3.7. Comparison of percent of fish population harvested based on population estimates and creel survey results in 1988 (Barber et al. 1989) and 1989 (Barber et a/. 1990).

\begin{tabular}{|c|c|c|c|c|c|c|}
\hline & $\begin{array}{l}\text { Estimated } \\
\text { population }\end{array}$ & $\begin{array}{c}1988 \\
\text { Estimated } \\
\text { harvest } \\
\end{array}$ & $\begin{array}{c}\text { Percent } \\
\text { larvested }\end{array}$ & $\begin{array}{l}\text { Estimated } \\
\text { opulation }\end{array}$ & $\begin{array}{c}1989 \\
\text { Estimated } \\
\text { harvest }\end{array}$ & $\begin{array}{c}\text { Percent } \\
\text { Iarvested }\end{array}$ \\
\hline Yellow perch & $11,777,446$ & 1,268 & $c 0.011$ & $6,101,448$ & 684 & 0.01 \\
\hline Largemouth bass & 657,549 & 389 & 0.06 & $590,906 i$ & 103 & 0.02 \\
\hline Black crappie & 579,588 & 41 & Co.01 & • & 0 & 0 \\
\hline Brown trout & • & 36 & tht & 7,264 & 68 & 0.94 \\
\hline Mountain whitefish & 164,252 & 75 & 0.04 & 163,890 & 11 & co.0 1 \\
\hline Pumpkinseed & $16,822,372$ & 278 & co.011 & $3,889,758$ & 182 & co.01 \\
\hline Northern squawfish & 580,565 & 0 & 0 & 248,988 & 102 & 0.04 \\
\hline Tench & 4.282 .807 & & $\underline{0}$ & 1.085 .921 & & 0 \\
\hline
\end{tabular}

- Insufficient recaptures for population estimate. 
Table 3.8. Comparison of mean back-calculated lengths at annulus formation and mean annual condition factors for largemouth bass In the Pend Oreille River, WA.

\begin{tabular}{|c|c|c|c|c|c|c|c|c|c|c|c|c|c|c|c|}
\hline & \multicolumn{15}{|c|}{ LENGTH AT ANNULUS FORMATION } \\
\hline & 1 & 2 & 3 & 4 & 5 & 6 & 7 & 8 & 9 & 10 & 11 & 12 & 13 & 14 & 15 \\
\hline $\begin{array}{c}\text { Box Canyon Reservoir, WA } \\
1988\end{array}$ & 66 & 102 & 142 & 198 & 241 & 280 & 317 & 355 & 387 & 412 & 427 & 461 & 467 & 473 & -- \\
\hline $\begin{array}{l}\text { (Barber ot al. 1989) } \\
1989\end{array}$ & 80 & 120 & 159 & 203 & 143 & 179 & 313 & 343 & 369 & 392 & 414 & 437 & 463 & 482 & 512 \\
\hline $\begin{array}{l}\text { (Barber et al. 1990) } \\
\mathbf{1 9 9 0} \\
\text { (Ashe et a/. 1991) }\end{array}$ & 65 & 112 & 150 & 192 & 235 & 281 & 323 & 339 & 395 & 424 & 452 & 469 & 485 & 486 & 488 \\
\hline Average & 70 & 111 & 150 & 196 & 206 & 247 & 318 & 346 & 384 & 409 & 431 & 456 & 472 & 480 & 500 \\
\hline
\end{tabular}

6

\begin{tabular}{|c|c|c|c|c|}
\hline Location & Age class & Mean & Condition factor & Range \\
\hline \multicolumn{5}{|l|}{ Box Canyon Reservoir, WA } \\
\hline 1988 & & & & \\
\hline (Barber et al. 1989) & I-XIV & KTL & 1.30 & $1.14-1.82$ \\
\hline (Barber et al. 1989) & VII-XIV & $\mathrm{K}_{\mathrm{TL}}$ & 1.61 & $1.61-1.82$ \\
\hline $\begin{array}{l}1989 \\
\text { (Barber et al. 1990) }\end{array}$ & $\mathrm{I}-\mathrm{XV}$ & KTL & 1.30 & $1.16-1.83$ \\
\hline $\begin{array}{l}1990 \\
\text { (Ashe et al. 1991) }\end{array}$ & $\mathrm{I}-\mathrm{XV}$ & $\mathrm{KTL}$ & 1.28 & $1.05-2.08$ \\
\hline
\end{tabular}




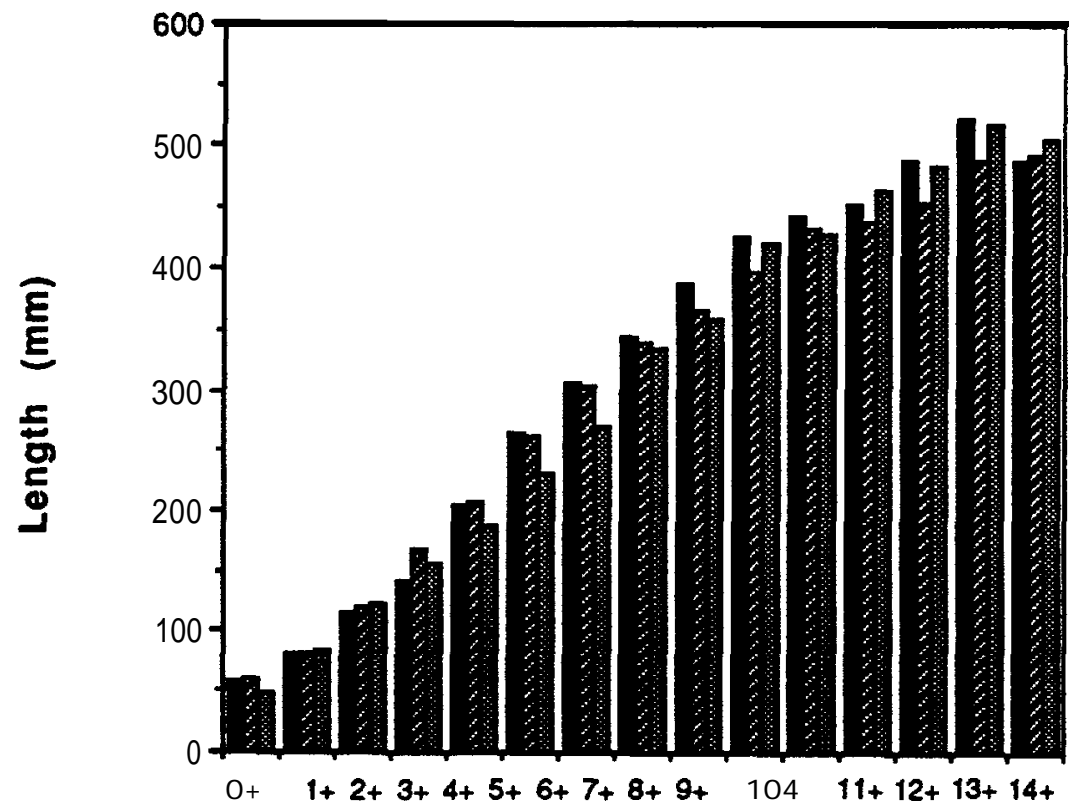

Age class

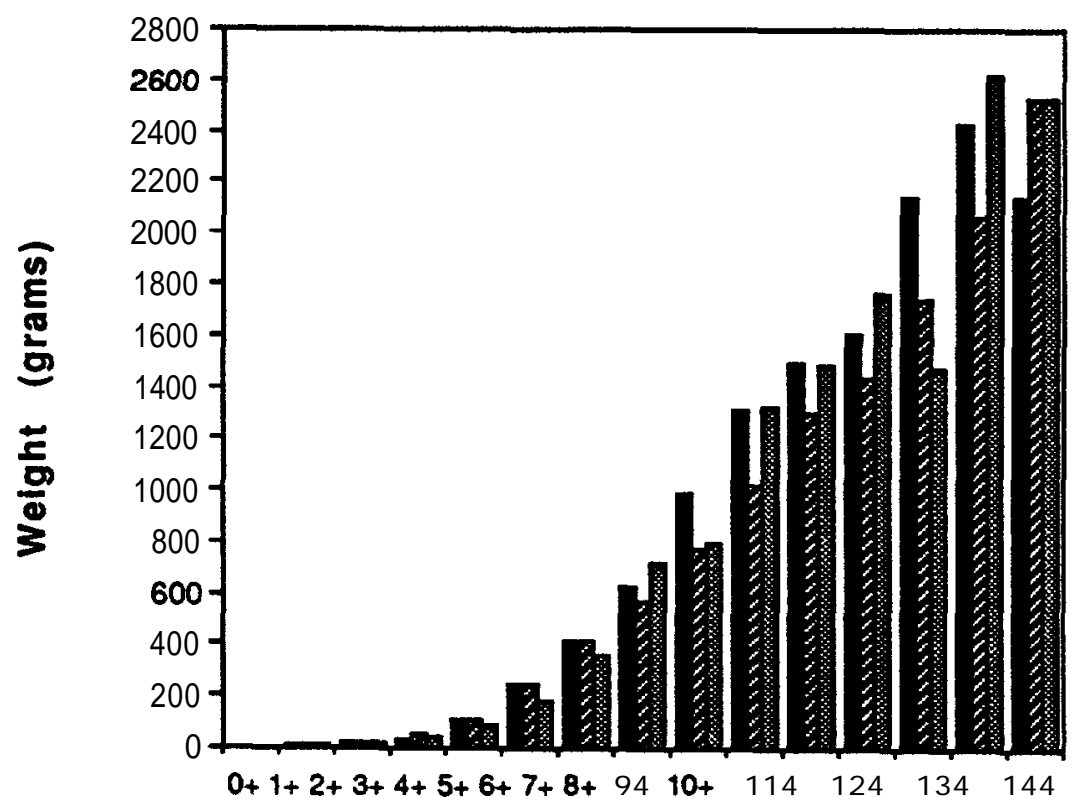

Age class

Figure 3.8 Mean lengths $(\mathrm{mm})$ and weights (grams) for each age class of largemouth bass captured in the Pend Oreille River during 1988, 1989 and 1990. 
between the actual first and second annuli was being counted as an extra year during 1988 and 1989, therefore the back-calculated growth increments reported by Barber et a/. (1989) and Barber et al. (1990) are different than those cited in this report. The mean condition factor for yellow perch was greater in 1990 than both 1988 and 1989. Growth rates and condition factors for each age class of yellow perch during each year of the study can be found in Appendix D, Tables D.7-D. 12.

Mean lengths and weights for each age class of yellow perch were very similar during all three years of the study (Figure 3.9). In 1990, both mean lengths and weights tended to be lower than those reported for 1988 and 1989 but this may have been due to the smaller sample size during the third year of the study.

A total of 1,540 scale samples were collected from mountain whitefish during the three year study period: 546 in 1988, 659 in 1989 and 335 in 1990. Back-calculated growth of mountain whitefish was also very similar during all three years of the study (Table 3.10). The mean lengths from 1988 were slightly higher than both the latter two years, but as with largemouth bass, this difference was mainly due to the different intercept used in the regression equation. The mean condition factor was highest in 1990. This could be attributed to a small sample size in 1990 or it may have resulted from reduced intra and interspecific competition that would have resulted from density independent mortality during the reservoir drawdown of 1988. Growth rates and condition factors for each age class of mountain whitefish during each year of the study can be found in Appendix D, Tables D.13-D.18.

The mean lengths and weights of each age class of mountain whitefish were similar for all three years of the study (Figure 3.10). Mean annual growth increments calculated for recaptured, tagged fish were smaller than the increments from the back-calculations. It is possible that the tags interfered with fish behavior in this case (mountain whitefish are small streamlined fish) resulting in reduced growth.

A total of 428 scale samples were collected from black crappie during the three year study period; 174 in 1988, 188 in 1989 and 66 in 1990. Back calculated growth of black crappie was very similar in 1988 and 1989 (Table 3.11). Back-calculated growth in 1990 was slightly lower at every annulus. The smaller sample size in 1990 may have responsible for the lower values. The mean 
Table 3.9. Comparison of mean back-calculated lengths at annulus formation and mean . annual condition factors for yellow perch in the Pend Oreille River, WA.

\begin{tabular}{|c|c|c|c|c|c|c|c|c|}
\hline & \multicolumn{8}{|c|}{ LENGTH AT ANNULUS FORMATION } \\
\hline & 1 & 2 & 3 & 4 & 5 & 6 & 7 & 8 \\
\hline $\begin{array}{l}\text { Box Canyon Reservoir, WA } \\
1988\end{array}$ & 77 & 114 & 134 & 150 & 166 & 206 & $\ldots$ & $\cdots$ \\
\hline $\begin{array}{l}\text { (Barber ot a/. 1989) } \\
\mathbf{1 9 8 9}\end{array}$ & 70 & 114 & 133 & 150 & 166 & 200 & 211 & . \\
\hline $\begin{array}{l}\text { (Barber et al. 1990) } \\
1990\end{array}$ & 78 & 113 & 137 & 152 & 159 & 177 & 182 & 211 \\
\hline $\begin{array}{l}\text { (Ashe et a/. 1991) } \\
\text { Average }\end{array}$ & 75 & 114 & 135 & 151 & 164 & 194 & 197 & \\
\hline
\end{tabular}

$\omega$

CONDITION FACTORS

\begin{tabular}{|c|c|c|c|c|}
\hline Location & Age class & Mean & Condition factor & Range \\
\hline $\begin{array}{l}\text { Box Canyon Reservoir, WA } \\
1988 \\
\text { (Barber et a/. 1989) }\end{array}$ & $\mathrm{I}-\mathrm{VII}$ & $\mathrm{K}_{\mathrm{TL}}$ & 1.04 & $0.97-1.12$ \\
\hline $\begin{array}{l}1989 \\
\text { (Barber et al. 1990) } \\
1990 \\
\text { (Ashe et a/. 1991) }\end{array}$ & I-VIII & $\begin{array}{l}\mathrm{KTL} \\
\mathrm{KTL}\end{array}$ & 1.08 & $1.05-1.16$ \\
\hline
\end{tabular}



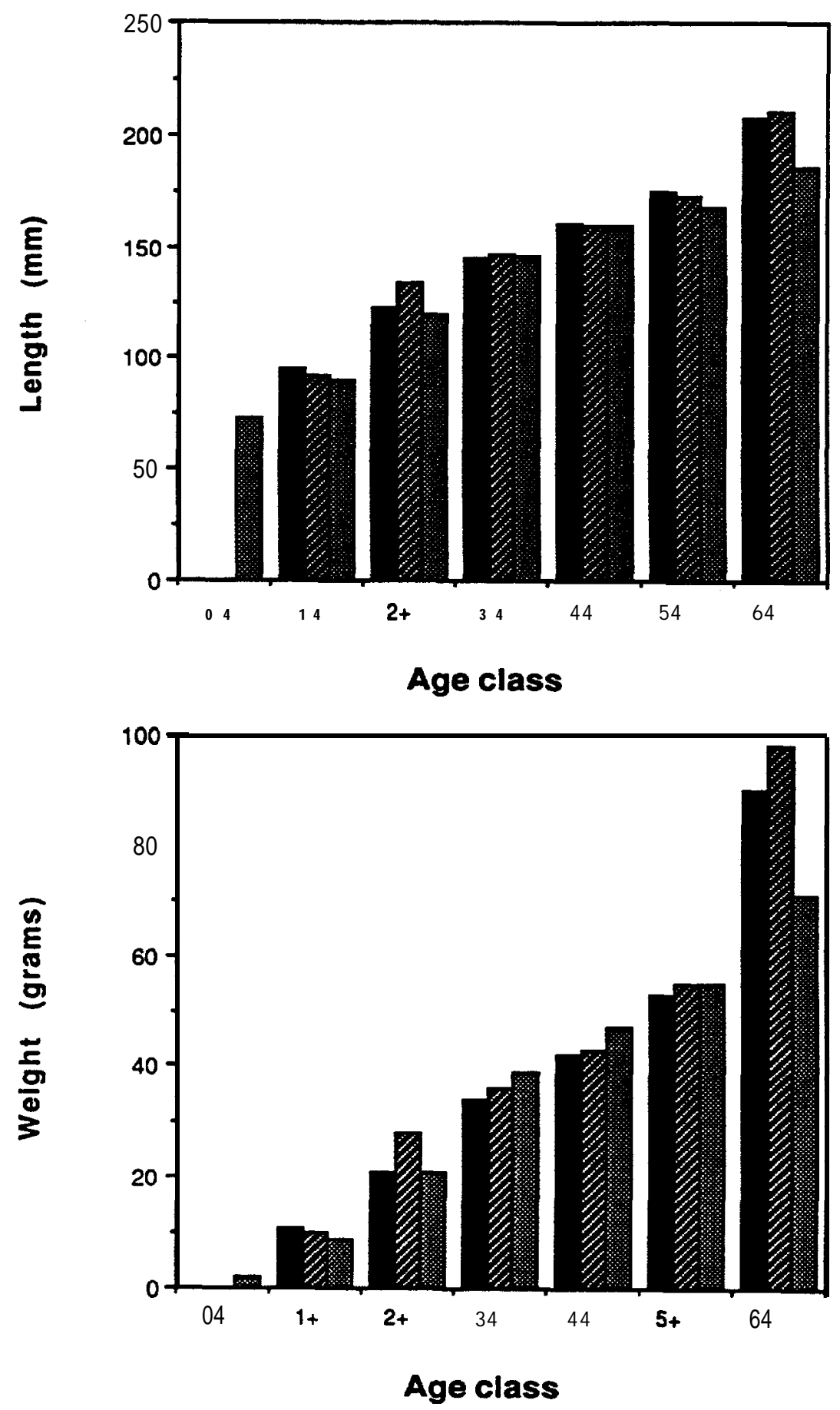

Figure 3.9 Mean lengths $(\mathrm{mm})$ and weights (grams) for each age class of yellow perch captured in the Pend Oreille River during 1988, 1989 and 1990. 
Table 3.10. Comparison of mean back-calculated lengths at annulus formation and mean annual condition factors for mountain whitefish in the Pend Oreille River, WA.

\begin{tabular}{|c|c|c|c|c|c|c|c|c|}
\hline & \multicolumn{8}{|c|}{ LENGTH AT ANNULUS FORMATION } \\
\hline & 1 & 2 & 3 & 4 & 5 & 6 & 7 & 8 \\
\hline Box Canyon Reservoir, WA & & & & & & & & \\
\hline $\begin{array}{l}1988 \\
\text { (Barber et al. 1989) }\end{array}$ & 174 & 219 & 259 & 299 & 360 & 390 & 413 & 435 \\
\hline $\begin{array}{l}1989 \\
\text { (Barber of al. 1990) }\end{array}$ & 138 & 199 & 244 & 279 & 355 & $\ldots$ & $\ldots$ & - \\
\hline $\begin{array}{l}1990 \\
\text { (Ashe et a/. 1991) }\end{array}$ & 135 & 201 & 247 & 278 & 308 & 371 & - & $\ldots$ \\
\hline Average & 149 & 208 & 250 & 285 & 341 & 381 & & \\
\hline
\end{tabular}

cr

CONDITION FACTORS

\begin{tabular}{|c|c|c|c|c|}
\hline \multirow{2}{*}{\multicolumn{5}{|c|}{$\begin{array}{l}\text { Location } \\
\text { Box Canyon Reservoir, WA } \\
1988\end{array}$}} \\
\hline & & & & $\begin{array}{l}0.69-0.81 \\
1.10-1.26\end{array}$ \\
\hline $\begin{array}{l}1989 \\
\text { (Barber ef al. 1990) }\end{array}$ & I-V & $\begin{array}{l}K_{T L} \\
K_{S L}\end{array}$ & $\begin{array}{l}0.74 \\
1.19\end{array}$ & $\begin{array}{l}0.69-0.81 \\
1.12-1.31\end{array}$ \\
\hline $\begin{array}{l}1990 \\
\text { (Ashe et a/. 1991) }\end{array}$ & I-VI & $\begin{array}{l}K_{T L} \\
K_{S L}\end{array}$ & $\begin{array}{l}0.87 \\
1.40\end{array}$ & $\begin{array}{l}0.73-0.92 \\
1.18-1.48\end{array}$ \\
\hline
\end{tabular}




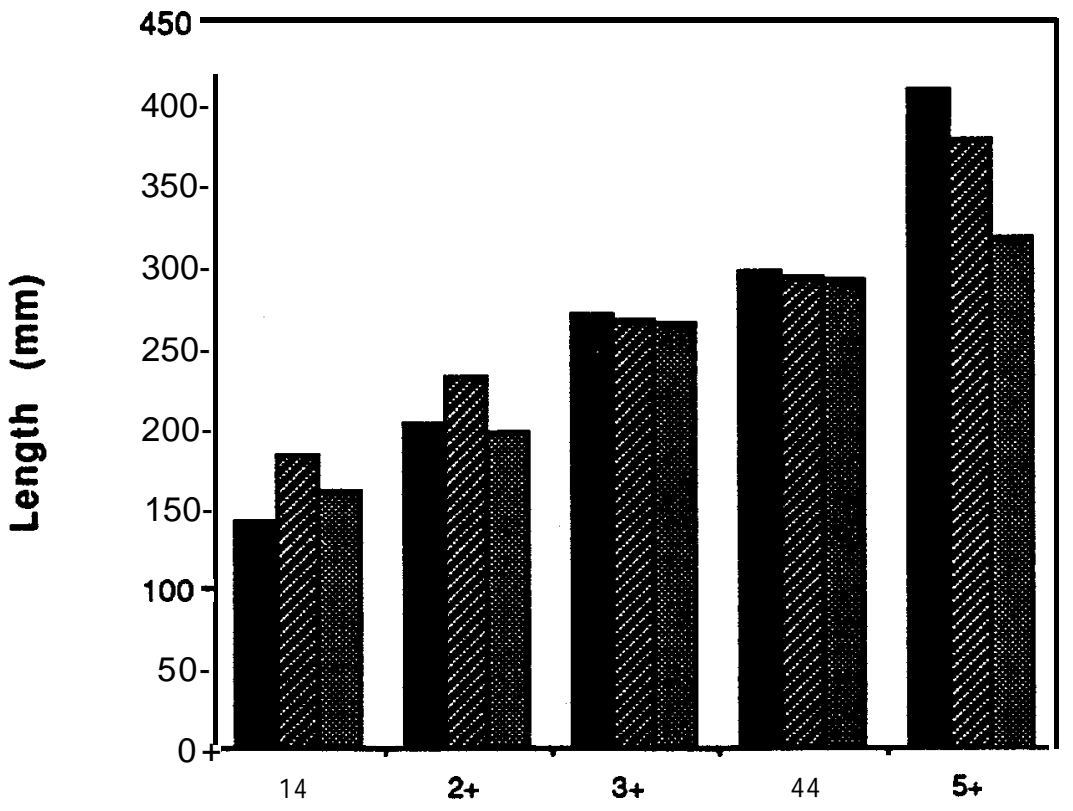

Age class

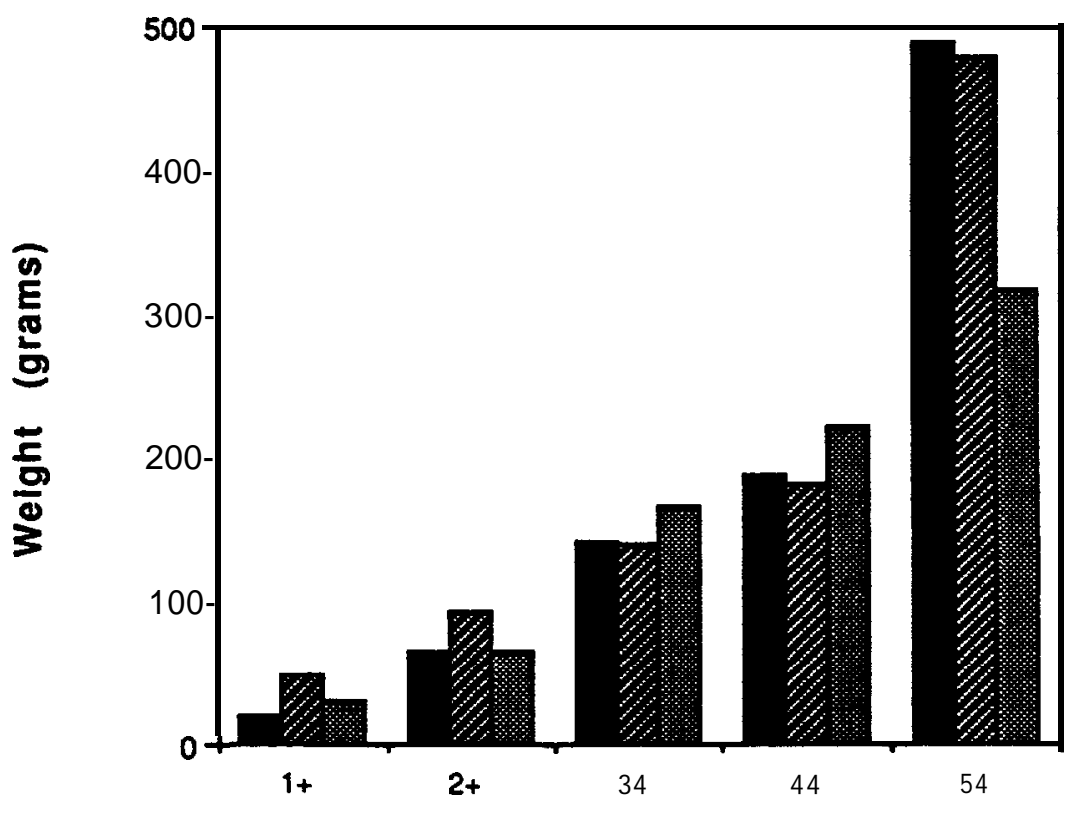

Age class

Figure 3.10. Mean lengths $(\mathrm{mm})$ and weights (grams) for each age class of mountain whitefish captured in the Pend Oreille River during 1988, 1989 and 1990. 
condition factor was the highest in 1990 but very similar to the two preceding years. Growth rates and condition factors for each age class of black crappie during each year of the study can be found in Appendix D, Tables D.19-D.24.

The mean lengths and weights of each class of black crappie were similar for all three years of the study (Figure 3.11).

Two hundred and eighty-two scale samples were collected from brown trout during the three year study: 115 in 1988, 121 in 1989 and 46 in 1990. The mean lengths of brown trout at annulus formation were lower in 1990 than both 1988 and 1989 (Table 3.12). This difference was more than likely due to the smaller sample size. The mean condition factor for brown trout in 1990 was similar to those recorded in 1988 and 1989. Growth rates and condition factors for each age class of brown trout during each year of the study can be found in Appendix D, Tables D.25-D.30.

Mean lengths and weights for each age class of brown trout captured in 1990 were more similar to those of 1988 and 1989 (Figure 3.12).

A total of 39 scale samples were collected from cutthroat trout captured in the reservoir during the three year study; 17 in 1988, 15 in 1989 and 7 in 1990. The mean back-calculated lengths for cutthroat trout from the Pend Oreille River in 1990 were lower at every annulus when compared to 1988 and 1989 (Table 3.13). The condition factor for cutthroat trout in 1990 was also lower than in the two previous years of the study. As with the brown trout, this is probably due to sample size. Growth rates and condition factors for each age class of cutthroat trout during each year of the study can be found in Appendix D, Tables D.31-D.36.

Twenty-nine scale samples were collected from rainbow trout captured in the reservoir during the three year study; 5 in 1988, 15 in 1989 and 9 in 1990. Back-calculated lengths at each annulus were fairly similar for all three years (Table 3.14). Condition factors were similar during all three years, but highest in 1990 . Growth rates and condition factors for each age class of rainbow trout during each year of the study can be found in Appendix D, Tables D.39-D.44. 
Table 3.11. Comparison of mean back-calculated lengths at annulus formation and mean annual condition factors for black crappie in the Pend Oreille River, WA.

\begin{tabular}{|c|c|c|c|c|c|c|c|c|}
\hline & \multicolumn{8}{|c|}{ LENGTH AT ANNULUS FORMATION } \\
\hline & 1 & 2 & 3 & 4 & 5 & 6 & 7 & 6 \\
\hline Box Canyon Reservoir, WA & & & & & & & & \\
\hline $\begin{array}{l}1966 \\
\text { (Barber et al. 1989) }\end{array}$ & 72 & 104 & 136 & 170 & 209 & 228 & 241 & -- \\
\hline $\begin{array}{l}1969 \\
\text { (Barber et al. 1990) }\end{array}$ & 74 & 109 & 142 & 168 & 180 & 207 & 226 & 237 \\
\hline $\begin{array}{l}1990 \\
\text { (Ashe et al. 1991) }\end{array}$ & 62 & 93 & 130 & 156 & 173 & 183 & 178 & 188 \\
\hline Average & 69 & 102 & 136 & 166 & 167 & 206 & 216 & \\
\hline
\end{tabular}

$\infty$

CONDITION FACTORS

\begin{tabular}{|c|c|c|c|c|}
\hline Location & Age class & Mean & Condition factor & Range \\
\hline $\begin{array}{l}\text { Box Canyon Reservoir, WA } \\
1966\end{array}$ & & & & \\
\hline (Barber et al. 1989) & $\cdots$ & $\mathrm{KTL}$ & 1.39 & $1.34-1.68$ \\
\hline $\begin{array}{l}1969 \\
\text { (Barber et a/. 1990) } \\
1990\end{array}$ & I-VIII & KTL & 1.36 & $1.21-1.42$ \\
\hline (Ashe et al. 1991) & I-VIII & $\mathrm{K}_{\mathrm{TL}}$ & 1.40 & $1.27-1.55$ \\
\hline
\end{tabular}




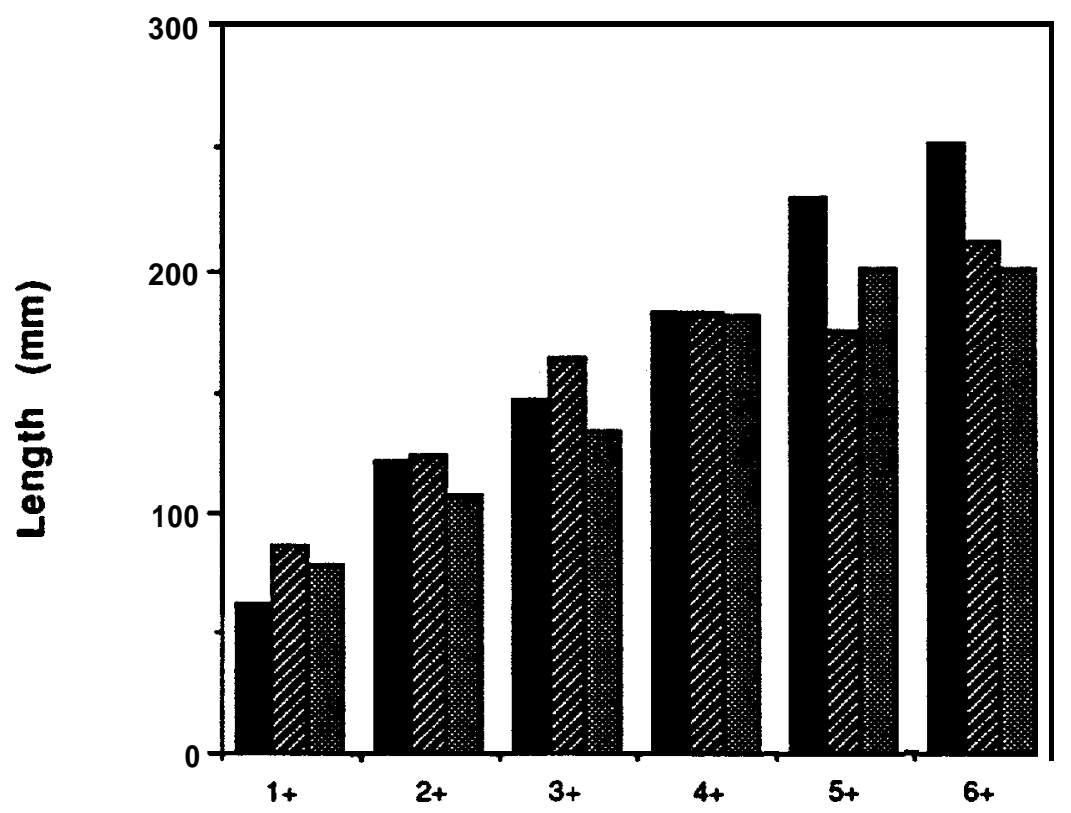

Age class

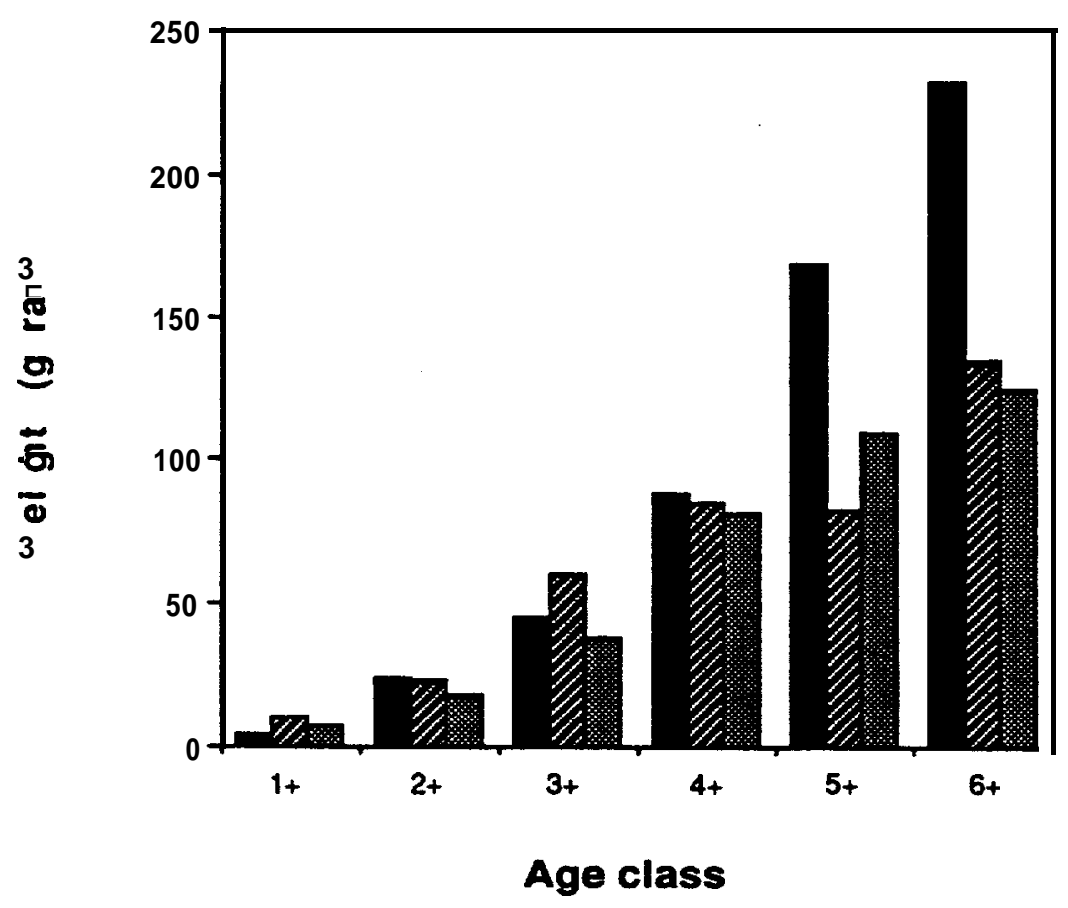

Figure 3.11. Mean lengths $(\mathrm{mm})$ and weights (grams) for each age class of black crappie captured in the Pend Oreille River during 1988, 1989 and 1990. 
Table 3.12. Comparison of mean back-calculated lengths at annulus formation and mean annual condition factors for brown trout in the Pend Oreille River, WA.

\begin{tabular}{|c|c|c|c|c|c|c|c|c|c|}
\hline & \multicolumn{9}{|c|}{ LENGTH AT ANNULUS FORMATION } \\
\hline & 1 & 2 & 3 & 4 & 5 & 6 & 7 & 6 & 9 \\
\hline $\begin{array}{l}\text { Box Canyon Reservoir, WA } \\
1966\end{array}$ & 98 & 167 & 249 & 341 & 411 & 468 & 507 & -- & - - \\
\hline $\begin{array}{l}\text { (Barber ol al. 1989) } \\
1969\end{array}$ & 101 & 170 & 240 & 311 & 375 & 423 & 472 & 519 & 517 \\
\hline $\begin{array}{l}\text { (Barber et al. 1990) } \\
\mathbf{1 9 9 0}\end{array}$ & 67 & 129 & 198 & 249 & 310 & 300 & 383 & 436 & - \\
\hline $\begin{array}{l}\text { (Ashe et a/. 1991) } \\
\text { Average }\end{array}$ & 69 & 155 & 229 & 300 & 366 & 397 & 454 & 476 & \\
\hline
\end{tabular}

$\stackrel{\infty}{0}$

CONDITION FACTORS

\begin{tabular}{|c|c|c|c|c|}
\hline Location & Age class & Mean & Condition factor & Range \\
\hline $\begin{array}{l}\text { Box Canyon Reservoir, WA } \\
1966\end{array}$ & I-VII & $K_{T I}$ & 095 & $078-109$ \\
\hline $\begin{array}{l}1969 \\
\text { (Barber et al. 1990) } \\
1990 \\
\text { (Ashe et a/. 1991) }\end{array}$ & I-VIII & KTL & 0.90 & $\begin{array}{l}0.87-1.04 \\
0.73-1.04 \\
\end{array}$ \\
\hline
\end{tabular}




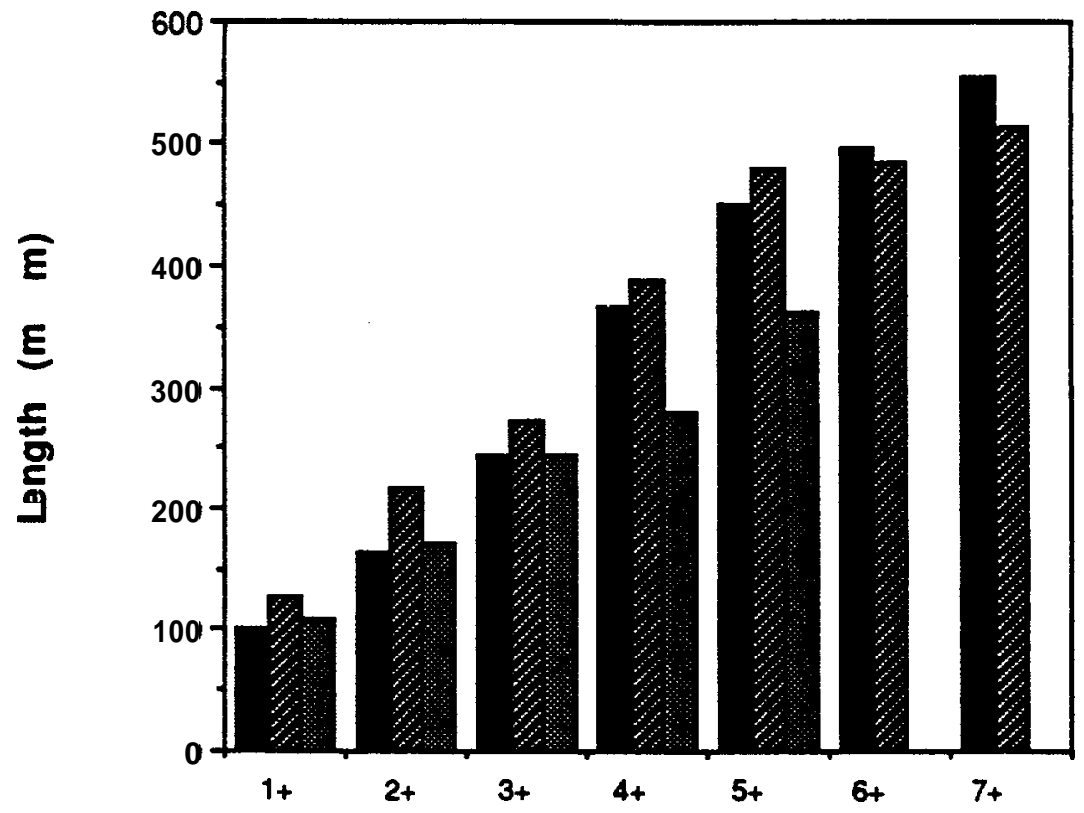

Age class

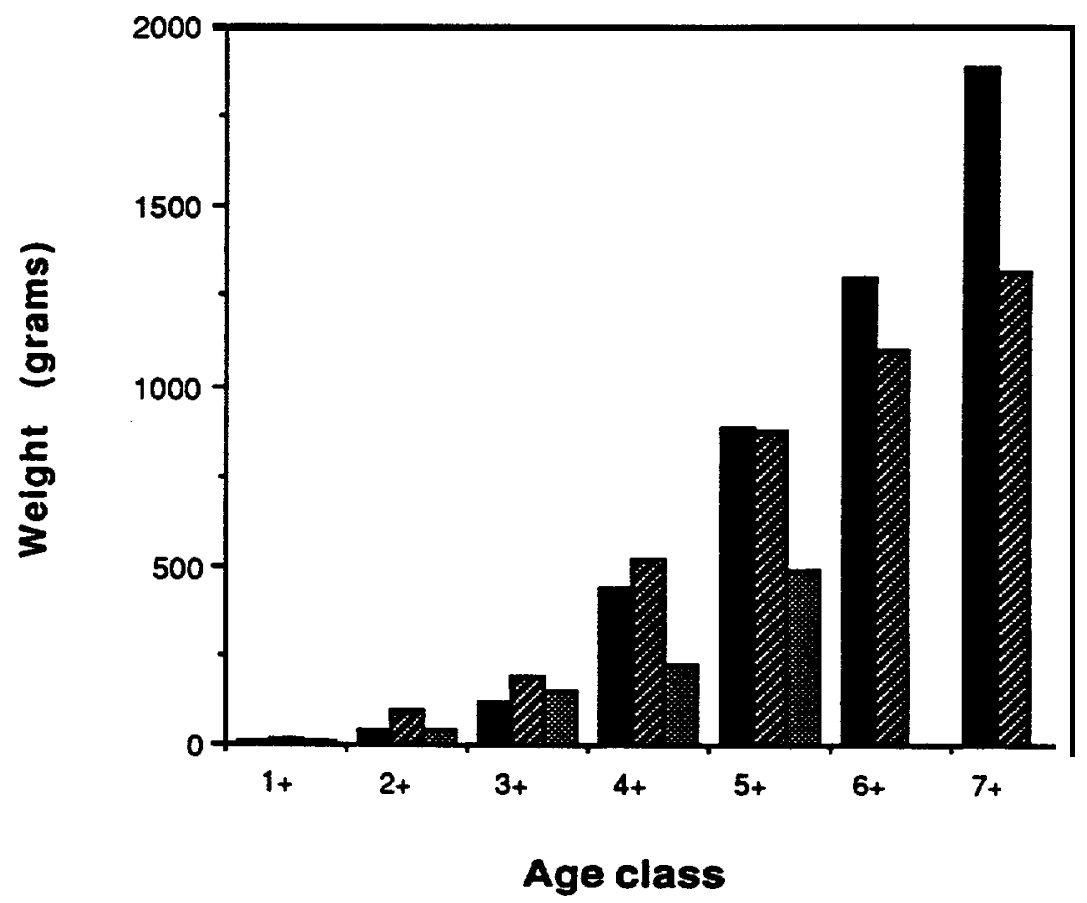

Figure 3.12. Mean lengths $(\mathrm{mm})$ and weights (grams) for each age class of brown trout captured in the Pend Oreille River during 1988, 1989 and 1990. 
Table 3.13. Comparison of mean back-calculated lengths at annulus formation and mean annual condition factors for cutthroat trout in the Pend Oreille River, WA.

\begin{tabular}{|c|c|c|c|c|c|}
\hline \multicolumn{6}{|c|}{ LENGTH AT ANNULUS FORMATION } \\
\hline & 1 & 2 & 3 & 4 & 5 \\
\hline $\begin{array}{c}\text { Box Canyon Reservoir, WA } \\
1966\end{array}$ & 102 & 176 & 239 & 287 & - \\
\hline $\begin{array}{l}\text { (Barber et al. 1989) } \\
1969\end{array}$ & 87 & 141 & 222 & 290 & 324 \\
\hline $\begin{array}{l}\text { (Barber et a/. 1990) } \\
\mathbf{1 9 9 0}\end{array}$ & 65 & 117 & 204 & 278 & 318 \\
\hline $\begin{array}{l}\text { (Ashe et al. 1990) } \\
\text { Average }\end{array}$ & 65 & 145 & 222 & 266 & 321 \\
\hline
\end{tabular}

$\infty$

\begin{tabular}{|c|c|c|c|c|}
\hline \multicolumn{5}{|c|}{ CONDITION FACTORS } \\
\hline Location & Age class & Mean & Condition factor & Range \\
\hline \multicolumn{5}{|l|}{$\begin{array}{c}\text { Box Canyon Reservoir, WA } \\
1966\end{array}$} \\
\hline (Barber ot a/. 1989) & II-V & $\mathrm{KTL}$ & 0.91 & 0.89 .05 \\
\hline & & $\mathrm{KF}$ & 1.10 & $1.03-1.21$ \\
\hline $\begin{array}{l}1969 \\
\text { (Barber et a/. 1990) } \\
1990\end{array}$ & $\mathrm{I}-\mathrm{V}$ & $\mathrm{KTL}$ & 0.90 & $0.83-0.95$ \\
\hline (Ashe eta/. 1991) & III-V & $\mathrm{KTL}$ & 0.74 & $0.77-1.04$ \\
\hline
\end{tabular}


Table 3.14. Comparison of mean back-calculated lengths at annulus formation and mean annual condition factors for rainbow trout in the Pend Oreille River, WA.

LENGTH AT ANNULUS FORMATION

\begin{tabular}{|c|c|c|c|c|c|c|}
\hline $\begin{array}{l}\text { Box Canyon Reservoir, WA } \\
1966\end{array}$ & 105 & 154 & 233 & 321 & 387 & $\ldots$ \\
\hline $\begin{array}{l}\text { (Barber et a/. 1989) } \\
\mathbf{1 9 6 9}\end{array}$ & 99 & 156 & 252 & 434 & 641 & 817 \\
\hline $\begin{array}{l}\text { (Barber et al. 1990) } \\
1990\end{array}$ & 83 & 159 & 282 & 351 & 585 & -. \\
\hline $\begin{array}{l}\text { (Ashe et a/. 1990) } \\
\text { Average }\end{array}$ & 96 & 156 & 256 & 369 & 536 & \\
\hline
\end{tabular}

$\infty$

$\omega$

\begin{tabular}{|c|c|c|c|c|}
\hline \multirow{2}{*}{\multicolumn{5}{|c|}{$\begin{array}{l}\text { Location } \\
\text { Box Canyon Reservoir, WA } \\
1966\end{array}$}} \\
\hline & & & & \\
\hline (Barber et a/. 1989) & II, v & $\mathrm{K}_{\mathrm{TL}}$ & 0.90 & $0.86-1.03$ \\
\hline $\begin{array}{l}1969 \\
\text { (Barber et a/. 1990) }\end{array}$ & $\mathrm{I}-\mathrm{VI}$ & KTL & 0.91 & $0.84-0.99$ \\
\hline $\begin{array}{l}1990 \\
\text { (Ashe eta/. 1991) }\end{array}$ & II-V & KTL & 0.99 & $0.90-1.36$ \\
\hline
\end{tabular}




\subsection{FOOD AVAILABILITY}

A total of 437 benthic samples were collected from the 11 study sites in the river during the three year investigation;- 140 in 1988, 198 in 1989 and 97 in 1990. Mean annual invertebrate densities were greatest in 1989 and least in 1990 (Table 3.15). The mean density for all sites combined was 8,343 organisms $/ \mathrm{m}^{2}$ in 1988, 13,758 organisms/m² in 1989 and 6,677 organisms/m2 in 1990. It is believed that the greater macroinvertebrate densities in 1989 over 1988 were partly due to changes in the sampling scheme. Two of the three benthic samples were collected from the littoral zone in 1989, instead of the limnetic zone, as in 1988. This change was made since fish were predominantly found in the littoral areas. It is also possible that the drawdown of the reservoir in May of 1988, resulted in reduced populations of invertebrates as several sloughs and most of the littoral areas were dewatered. Also during this time the reservoir was more riverine and the higher water velocities may have caused increased drifting of benthic macroinvertebrates. The sampling scheme in 1990 was the same as that used in 1989, however, half the amount of samples were collected during the latter year. It's possible that the lower densities in 1990 were due to a smaller sample size. In addition, the abnormally high flows and water levels in 1990 flooded land that was not submerged in 1988 and 1989. Possibly, samples that were collected in July and September when water levels were higher than normal were taken in areas that had not yet been colonized. Chironomidae larvae was the most abundant organism collected in benthic samples during all three years of the study. Oligochaeta, Talitridae, and Sphaeriidae were also prominent organisms in the benthos during the study. Densities of benthic organisms collected from each river study site during the study can be found in Appendix E, Table E.I-E.3.

One hundred thirty seven benthic samples were collected from the 4 study slough sites during the three year investigation: 51 in 1988, 60 in 1989 and 26 in 1990. The highest density in 1988 was 13,354 organisms/m2 at site $5 \mathrm{~A}$ (Table 3.16 ). The highest density was found at site $6 \mathrm{~A}$ during 1989 and 1990, at 38,629 and 9,985 organisms/m? respectively. The low densities observed in 1990, again may be due to the smaller sample size and the differences in water levels during the year. Also, macrophyte abundance was so great during September 1990, that samples were not collected from study site 5A and 6A. Invertebrate densities are typically greater in 
Table 3.15. Mean annual benthic macroinvertebrate denslties $\left(\# / \mathrm{m}^{2}\right)$ and percent abundance in the Pend Oreille River (study sites 1 through 11) during 1988, $1989,1990$.

\begin{tabular}{|c|c|c|c|c|c|c|c|c|}
\hline ORGANISMS & $\begin{array}{c}1988 \\
\text { Mean } \\
N=140\end{array}$ & $\begin{array}{c}1988 \\
\% \text { Abundance }\end{array}$ & $\begin{array}{c}1969 \\
\text { Mean } \\
N=198\end{array}$ & $\begin{array}{cc}1989 \\
\% \quad \text { Abundance }\end{array}$ & $\begin{array}{c}1990 \\
\text { Mean } \\
\mathrm{N}=97\end{array}$ & $\begin{array}{c}1990 \\
\text { \%Abundance }\end{array}$ & $\begin{array}{c}\text { Three year } \\
\text { Mean } \\
\mathrm{N}=437\end{array}$ & $\begin{array}{l}\text { Three year } \\
\% \text { Abundance }\end{array}$ \\
\hline \multicolumn{9}{|l|}{ TRICHOPTERA } \\
\hline Srachycentridae & 55 & 07 & & & & & 16 & $\overline{0.2}$ \\
\hline Hydroptilidae & 91 & 11 & 160 & 12 & 4 & $<0.1$ & 65 & 0.9 \\
\hline Lepidoslomatidae & & & & & 2 & $\mathrm{C} 0.1$ & $<1$ & $<0.1$ \\
\hline Leploceridae & 141 & 17 & 153 & 1.1 & 13 & 0.2 & 102 & 1.1 \\
\hline Limnephilidae & 56 & 07 & 1 & $<0.1$ & 2 & 0.1 & 20 & 0.2 \\
\hline Phryganeidae & & & 3 & $<0.1$ & & & 1 & $<0.1$ \\
\hline Polycenlropodidae & 9 & 01 & 13 & 0.1 & 13 & 0.2 & 12 & 0.1 \\
\hline Rhyacophilidae & & & 1 & $<0.1$ & 2 & $\begin{array}{c}c 0.1 \\
\end{array}$ & 1 & $<0.1$ \\
\hline \multicolumn{9}{|l|}{ EPHEMEROPTERA } \\
\hline Baetidae & 62 & 07 & 64 & 0.6 & 43 & 0.6 & 63 & 0.7 \\
\hline Ephemerellidae & 9 & 0.1 & 2 & $<0.1$ & 13 & $\overline{0.2}$ & 6 & 0.1 \\
\hline Ephemeridae & & & 2 & $<0.1$ & & & $<1$ & $<0.1$ \\
\hline Heptageniidae & & & 2 & $<0.1$ & & & $<1$ & $<0.1$ \\
\hline Leptophlebiidae & 5 & 0.1 & 1 & $<0.1$ & 4 & C0.1 & 3 & $<0.1$ \\
\hline Tricorylhidae & 72 & 0.9 & 1510 & 11.0 & 113 & 1.7 & 565 & 5.9 \\
\hline \multicolumn{9}{|l|}{ COLEOPTERA } \\
\hline Elmidae larvae & 356 & 4.3 & 429 & 3.1 & 63 & 0.9 & 283 & 2.9 \\
\hline Elmidae adult & & & 24 & 0.2 & 2 & $<0.1$ & 9 & 0.1 \\
\hline Haliplidae & & & & & 6 & 0.1 & $\overline{2}$ & $<0.1$ \\
\hline Hydrophilidae & & & 1 & CQ.I & & & $<1$ & $<0.1$ \\
\hline Chrysomelidae & 1 & $<0.1$ & & & & & $<1$ & $<0.1$ \\
\hline \multicolumn{9}{|l|}{ PLECOPTERA } \\
\hline Chloroperlidae & 7 & 0.1 & & & & & 2 & $<0.1$ \\
\hline \multicolumn{9}{|l|}{ DIPTERA } \\
\hline Ceratopogonidae & 103 & 1.2 & 297 & 2.2 & $\overline{4}$ & 0.1 & 135 & 1.4 \\
\hline Chironomidae larvae & 2695 & 32.3 & 3217 & 23.4 & 2616 & 39.2 & 2643 & 29.5 \\
\hline Chironomidae pupae & 159 & 1.9 & 97 & 0.7 & 199 & 3.0 & 152 & .1 .6 \\
\hline Dolichopodidae & 1 & $<0.1$ & & & & & $<1$ & $<0.1$ \\
\hline Empididae & 20 & 0.2 & 70 & 0.5 & 4 & 0.1 & 31 & $\overline{0.3}$ \\
\hline Psychodidae & & & 4 & $<0.1$ & & & 1 & $<0.1$ \\
\hline Simuliidae & 1 & co.1 & 122 & 0.9 & 12 & 0.2 & 45 & 0.5 \\
\hline Tabanidae & 2 & $<0.1$ & & & & & $<1$ & $<0.1$ \\
\hline Tipulidae & 72 & 0.9 & 16 & 0.1 & 8 & 0.1 & 32 & 0.3 \\
\hline
\end{tabular}


Table 3.15. (cont.)

\begin{tabular}{|c|c|c|c|c|c|c|c|c|}
\hline ORGANISMS & $\begin{array}{l}1988 \\
\text { Mean }\end{array}$ & $\begin{array}{c}1988 \\
\% \text { Abundance }\end{array}$ & $\begin{array}{l}989 \\
\text { Mean }\end{array}$ & $\begin{array}{c}1989 \\
\% \text { Abundance }\end{array}$ & $\begin{array}{l}1990 \\
\text { Mean }\end{array}$ & $\begin{array}{c}1990 \\
\text { \%Abundance }\end{array}$ & $\begin{array}{l}\text { Three year } \\
\text { Mean }\end{array}$ & $\begin{array}{l}\text { Three year } \\
\% \text { Abundance }\end{array}$ \\
\hline \multicolumn{9}{|l|}{ ODONATA } \\
\hline Aeshneidae & & & & & 4 & 0.1 & 1 & $<0.1$ \\
\hline Coenagrionidae & & & 158 & 1.2 & 42 & 0.6 & 70 & 0.7 \\
\hline Libellulidae & & & & & 4 & 0.1 & 1 & $<0.1$ \\
\hline Macromilidae & & & 6 & $<0.1$ & & & 2 & $<0.1$ \\
\hline \multicolumn{9}{|l|}{ LEPIDOPTEAA } \\
\hline Pyralidae & & & 1 & $<0.1$ & & & $\leq 1$ & $<0.1$ \\
\hline HYDRACARINA & 112 & 1.3 & 660 & 4.8 & 211 & 3.2 & 328 & 3.4 \\
\hline \multicolumn{9}{|l|}{ CLADOCERA } \\
\hline Daphnidae & 37 & 0.4 & & & & & 12 & 0.1 \\
\hline Cydoridae & 2 & $<0.1$ & & & & & $<1$ & $<0.1$ \\
\hline \multicolumn{9}{|l|}{ COPEPODA } \\
\hline Calanoida & 1 & $<0.1$ & & & & & $<1$ & $<0.1$ \\
\hline Cyclopoida & 18 & 0.2 & & & & & 6 & 0.1 \\
\hline Harpacticoida & 15 & 0.2 & & & & & 5 & 0.1 \\
\hline \multicolumn{9}{|l|}{ AMPHIPODA } \\
\hline Talitridae & 203 & 2.4 & 2005 & 14.6 & 1705 & 25.6 & 1304 & 13.5 \\
\hline OSTRACODA & 2 & 1.3 & & & & & 35 & 0.4 \\
\hline \multicolumn{9}{|l|}{ OUGOCHAETA } \\
\hline Lumbriculidae & 2593 & 31.1 & 1671 & 12.1 & 662 & 9.9 & 1642 & 17.0 \\
\hline NEMATODA & 207 & 2.5 & 421 & 3.1 & & & 209 & 2.2 \\
\hline \multicolumn{9}{|l|}{ TURBELLARIA } \\
\hline Planariidae & 79 & 0.9 & 156 & 1.1 & 29 & 0.4 & 66 & 1.0 \\
\hline HIRUDINEA $^{-}$ & 19 & 0.2 & 37 & 0.3 & & & 19 & 0.2 \\
\hline \multicolumn{9}{|l|}{ MOLLUSCA } \\
\hline Lymnaeidae & 36 & $\overline{0.4}$ & 146 & 1.1 & 57 & 0.9 & 60 & 0.6 \\
\hline Physidae & & & & & 6 & 0.1 & 2 & $<0.1$ \\
\hline Planorbidae & 254 & 3.0 & 1075 & 7.0 & 424 & 6.4 & 564 & 6.1 \\
\hline \multicolumn{9}{|l|}{ BIVALVIA } \\
\hline Sphaerifdae & 652 & 7.6 & 1766 & 6.5 & 359 & 5.4 & 726 & 7.5 \\
\hline TERRESTRIAL & 80 & 1.0 & 50 & 0.4 & 50 & 0.7 & 120 & 1.2 \\
\hline TOTAL & 8,343 & & 13,758 & & 6,677 & & 9,647 & \\
\hline
\end{tabular}


Table 3.16. Mean annual benthic macroinvertebrate densities $\left(\# / \mathrm{m}^{2}\right)$ in Pend Oreille River sloughs (sites 3A, 4A, 5A and 6A) during 1988, 1989, 1990.

\begin{tabular}{|c|c|c|c|c|c|c|c|c|c|c|c|c|}
\hline Jrganisms & $\begin{array}{c}\text { Ce日 } \\
1988 \\
N=14\end{array}$ & $\begin{array}{c}\text { Cee Ah Sl } \\
1989 \\
N=15\end{array}$ & $\begin{array}{l}\text { Jgh } \\
1990 \\
N=8\end{array}$ & $\begin{array}{l}\text { Ol } \\
1988 \\
N=\quad 1\end{array}$ & $\begin{array}{c}\text { Dike Slor } \\
1989 \\
N=15\end{array}$ & $\begin{array}{l}1990 \\
\mathbf{N}=\mathbf{8}\end{array}$ & $\begin{array}{r}P 0 \\
1968 \\
N=15\end{array}$ & $\begin{array}{c}\text { wow Slc } \\
1989 \\
N=15\end{array}$ & $\begin{array}{l}\text { gh } \\
1990 \\
N=5\end{array}$ & $\begin{array}{c}\text { Goo! } \\
1988 \\
N=11\end{array}$ & $\begin{array}{c}\text { Island } \mathrm{Ch} \\
1989 \\
\mathrm{~N}=15\end{array}$ & $\begin{array}{l}\text { nnel } \\
1990 \\
\mathbf{N}=\mathbf{5}\end{array}$ \\
\hline $\begin{array}{l}\text { RICHOPTERA } \\
\text { Hydroptilidae } \\
\text { Leptoceridae } \\
\text { Limnephilidae } \\
\text { Phryganeidae } \\
\text { Polycentropodidae } \\
\text { Glossosomatidae } \\
\text { Psychomyiidae } \\
\text { :PHEMEROPTERA } \\
\text { Baetidae } \\
\text { Heptageniidae } \\
\text { Tricorythidae } \\
\text { Leptophlebiidae } \\
\text { OLEOPTERA } \\
\text { Elmidae larvae } \\
\text { Elmidae adult } \\
\text { Dytiscidae } \\
\text { IPTERA } \\
\text { Chironomidae larva } \\
\text { Chironomidae pupae } \\
\text { Ceratopogonidae } \\
\text { Tipulidae } \\
\text { Empididae } \\
\text { Chaoboridae } \\
\text { Simuliidae } \\
\text { JDONATA } \\
\text { Coenagrionidae } \\
\text { Corduliidae } \\
\text { IYDRACARINA }\end{array}$ & $\begin{array}{c}792 \\
52 \\
355\end{array}$ & $\begin{array}{c}2,502 \\
81 \\
332 \\
\\
13\end{array}$ & $\begin{array}{l}21 \\
105 \\
21\end{array}$ & $\begin{array}{c}1,966 \\
315\end{array}$ & $\begin{array}{c}453 \\
893 \\
\\
63 \\
38 \\
\\
6,214 \\
302 \\
742 \\
25 \\
38 \\
25\end{array}$ & $\begin{array}{c}2,495 \\
84 \\
126 \\
\\
63 \\
\\
63 \\
734\end{array}$ & $\begin{array}{c}2,908 \\
90 \\
1,093 \\
20 \\
25 \\
8 \\
\\
35 \\
76\end{array}$ & $\begin{array}{c}25 \\
289 \\
\\
63 \\
13 \\
\\
8,013 \\
126 \\
440 \\
\\
25 \\
25 \\
13 \\
\\
642 \\
38 \\
1,195\end{array}$ & $\begin{array}{c}1,070 \\
63 \\
95\end{array}$ & $\begin{array}{c}1,611 \\
350 \\
392 \\
52\end{array}$ & $\begin{array}{c}5,572 \\
3,660 \\
1,107 \\
38 \\
\\
13 \\
554 \\
1,497\end{array}$ & $\begin{array}{r}95 \\
1,079 \\
35\end{array}$ \\
\hline
\end{tabular}


Table 3.16. (cont.)

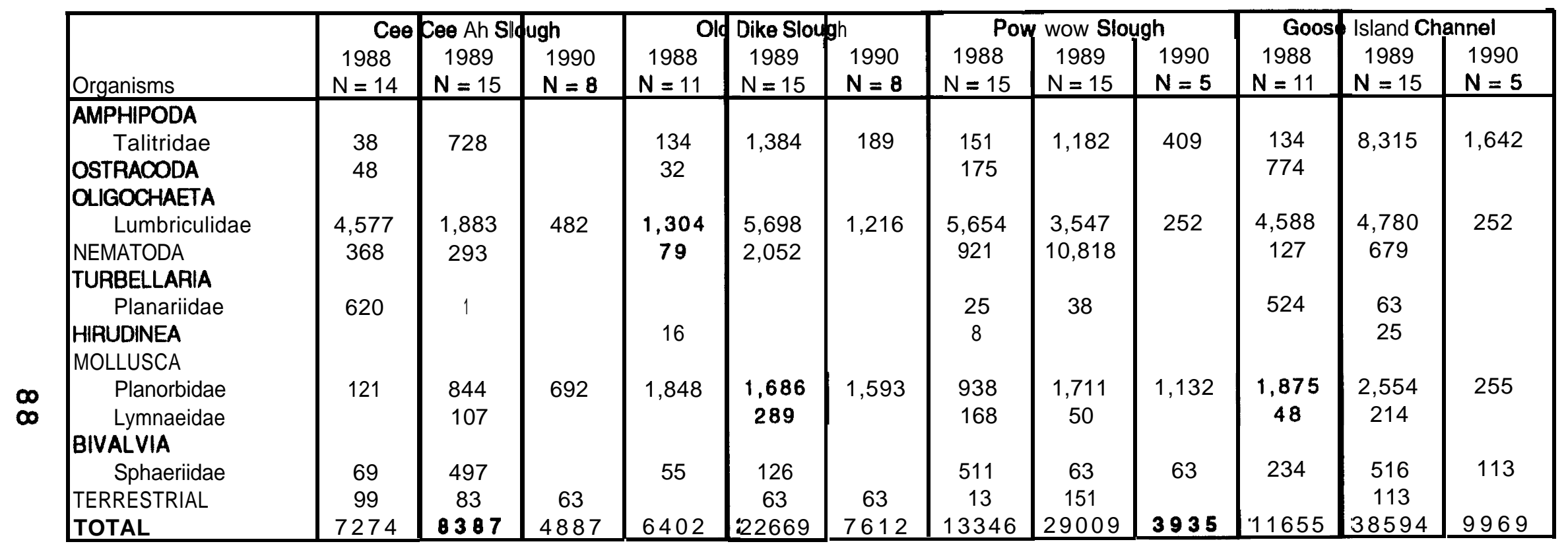


the fall than any other time during the year: an exclusion of these samples may have decreased the annual mean densities.

Chironomidae larvae, Oligochaeta and Planorbidae composed a major percent of the invertebrates collected from the sloughs at every site during all three years. Densities of benthic organisms collected from each slough study site during the study can be found in Appendix E, Table E.4-E.6.

A total of 368 zooplankton samples were collected from the river and sloughs during the three year study period; 156 in 1988, 112 in 1989 and 76 in 1990. Samples collected in 1988 were both collected from the mid-channel zone, while in 1989 and 1990 one sample was collected from the mid-channel zone and one from the littoral zone. This change was made since fish were predominantly found in the littoral areas. A synoptic list of cladoceran and copepod species identified in both types of samples throughout the course of the study can be found in Table 3.17.

The mean annual cladocera and copepoda density from the midchannel was 35.6 organisms/liter in 1988, 19.8 organisms/liter in 1989 and 12.8 organisms/liter in 1990 (Table 3.18). Reasons for the lower zooplankton density in the mid-channel during 1990 may be attributed to the fewer number of samples taken and also the higher than average flow observed in the river in 1990 (Figure 3.1). These increased flows may have flushed the zooplankton in the midchannel of the reservoir through the system. Zooplankton densities for each mid-channel study site during the study can be found in Appendix E, Table E.7-E.9.

Densities of cladocerans and copepods in littoral samples taken in 1989 and 1990 were almost identical (Table 3.19). Again fewer samples were collected from the littoral zone in 1990, which adds weight to the theory that the mid-channel zooplankton densities were affected by the increased flow of the reservoir. Zooplankton densities for each littoral study site during the study can be found in Appendix E, Table E.10-E.11.

Densities of cladocerans in the mid-channel zooplankton samples decreased from a high in 1988 of 8.38 cladoceralliter to a low in 1990 of 3.42 cladocera/liter (Table 3.20). Copepods decreased in the same manner, from a high of 27.05 copepods/liter in 1988 to a low of 9.33 copepods/liter in 1990. Rotifers increased slightly from 1988 to 1989 , from 85.11 organisms/liter to 89.95 


\section{Table 3.17. Ciadocera and copepoda species observed in the Pend Oreiiie River, 1988, 1989 and 1990.}
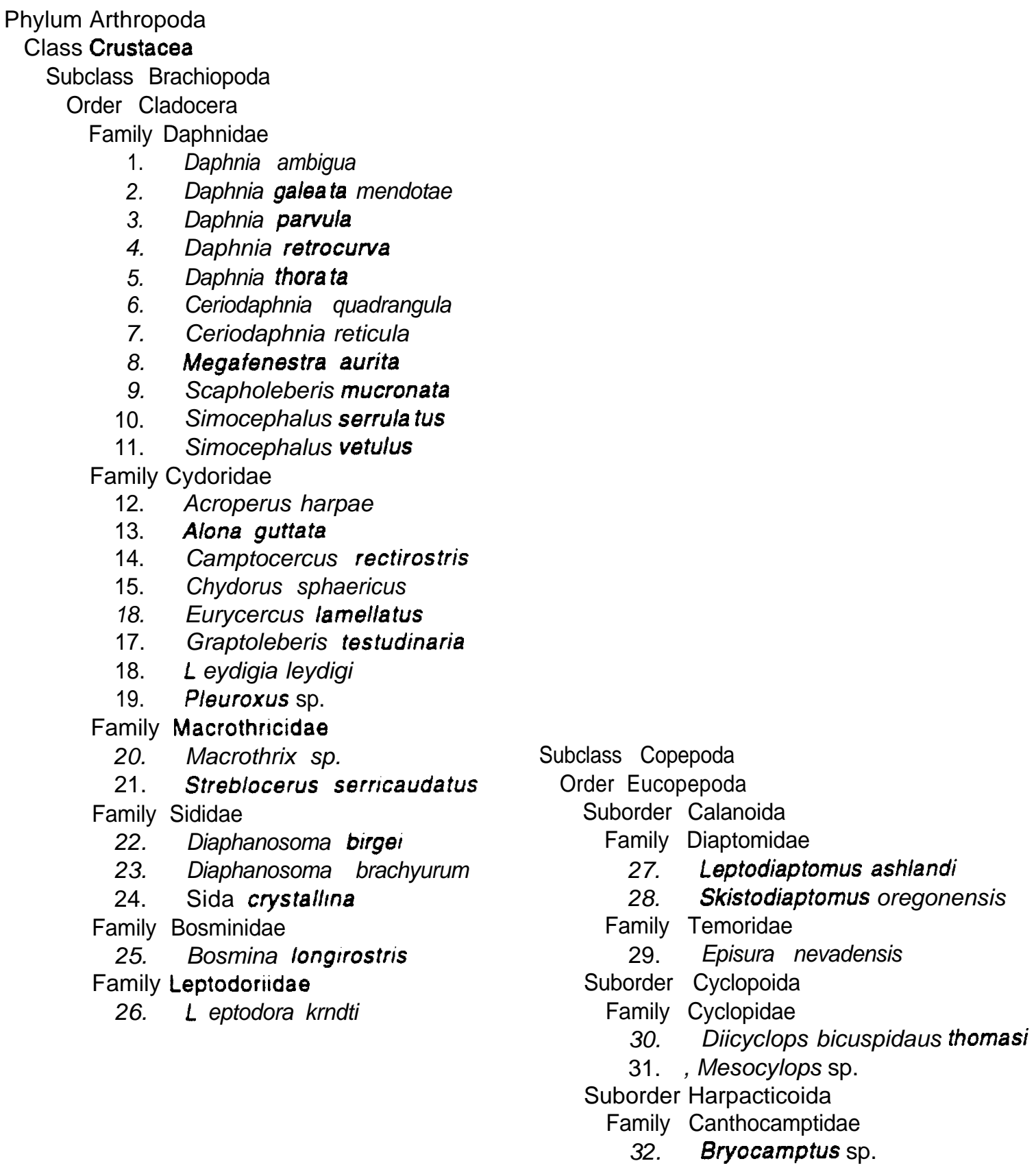
Table 3.18. Cladocera and copepoda density (organisms/liter) in samples collected from mid-channel locations (study sites 1 through 11) of the Pend Oreille River in 1988, -1989, and 1990.

\begin{tabular}{|c|c|c|c|}
\hline & $\begin{array}{c}1988 \\
\text { Mid-channel }\end{array}$ & $\begin{array}{c}1989 \\
\text { Mid-channel }\end{array}$ & $\begin{array}{c}1990 \\
\text { Mid-channel }\end{array}$ \\
\hline TVARCH & $\because$ & 8 & $\ldots$ \\
\hline $\begin{array}{l}\text { APRIL } \\
\text { JUNE }\end{array}$ & $\begin{array}{l}27 \\
48\end{array}$ & $\begin{array}{l}27 \\
33\end{array}$ & 5 \\
\hline $\begin{array}{l}\text { JULY } \\
\text { SEPTEMBER } \\
\text { OCTOBER }\end{array}$ & $\begin{array}{l}50 \\
31 \\
22\end{array}$ & $\begin{array}{c}33 \\
9 \\
9\end{array}$ & $\begin{array}{l}20 \\
12 \\
--\end{array}$ \\
\hline ANNUAL MEAN & 35.6 & 19.8 & 12.8 \\
\hline
\end{tabular}

Table 3.19. Cladocera and copepoda density (organisms/liter) in samples collected from littoral locations (study sites 1 through 11 and sloughs sites $3 A, 4 A, 5 A$ and $6 A$ ) of the Pend Oreille River in 1988, 1989, and 1990.

\begin{tabular}{|c|c|c|c|}
\hline & $\begin{array}{c}1988 \\
\text { Littoral }\end{array}$ & $\begin{array}{c}1989 \\
\text { Littoral }\end{array}$ & $\begin{array}{c}1990 \\
\text { Littoral }\end{array}$ \\
\hline MARCH & & 16 & $\bar{\cdots}$ \\
\hline $\begin{array}{l}\text { APRIL } \\
\text { JUNE }\end{array}$ & $\begin{array}{l}\text { No samples } \\
\text { collected from }\end{array}$ & $\begin{array}{l}39 \\
55\end{array}$ & $\begin{array}{l}22 \\
--\end{array}$ \\
\hline JULY & the littoral & 95 & 69 \\
\hline SEPTEMBER & area in 1988 & 47 & 52 \\
\hline OCTOBER & & 32 & $\cdots$ \\
\hline ANNUAL MEAN & & 47.3 & 47.7 \\
\hline
\end{tabular}


organisms/liter, respectively. Rotifers were not enumerated in 1990.

Zooplankton densities from littoral areas showed a decrease in cladocerans from 20.34 organisms/liter in 1989 to 15.64 organisms/liter in 1990 (Table 3.21). The copepod densities increased, however, from 27.20 organisms/liter in 1989 to 32.01 organisms/liter in 1990. Rotifer density in 1989 was 72.94 organisms/liter. Rotifers were not enumerated in 1990.

Total biomass for cladocerans in the mid-channel of the Pend Oreille River was $22.9 \mu \mathrm{g} / \mathrm{l}$ in 1988, $11.3 \mu \mathrm{g} / \mathrm{l}$ in 1989 and $10.4 \mu \mathrm{g} / \mathrm{l}$ in 1990 (Table 3.22). Biomass of cladocerans in the littoral samples was also lower in 1990, at $25.1 \mu \mathrm{g} / \mathrm{l}$, compare to $35.8 \mu \mathrm{g} / \mathrm{l}$ in 1989 (Table 3.23). It's possible that these lower cladoceran biomass values were also due to the increased flow regime of the river in 1990. At higher flows, zooplankton densities in the river would reflect the density and biomass of zooplankton in Lake Pend Oreille, which was very low (Bowles et al. 1989).

Biomass was calculated for each of seven major cladoceran species: Daphnia galeata mendotae, Daphnia retrocurva, Ceriodaphnia reticulata, Bosmina longirostris, Chydorus sphaericus, Sida crystallina, Diaphanosoma leuchtenbergianum and Leptodora kindtii. In samples taken from the mid-channel, Daphnia galeata mendotae had the highest average biomass value $(5.04 \mu \mathrm{g} / \mathrm{l})$ during the three year study period followed by Bosmina longirostris (3.78 $\mu \mathrm{g} / \mathrm{l})$ and Leptodora kindti (2.17 $\mu \mathrm{g} / \mathrm{l})$ (Table 3.24).

In samples taken from the littoral area, Ceriodaphnia spp. had the highest average biomass value $(7.50 \mu \mathrm{g} / \mathrm{l})$ during 1989 and 1990, followed by Bosmina longirostris $(5.86 \mu \mathrm{g} / \mathrm{l})$ and Sida crystallina (4.95 $\mu \mathrm{g} / \mathrm{l})$ (Table 3.25).

\subsection{FEEDING HABITS OF FISH IN THE RESERVOIR}

A total of 1,332 yellow perch stomachs were collected from fish age $0+$ to $7+$ during the three year study: 565 in 1988, 609 in 1989 and 158 in 1990. There was little variation of prey organisms found in yellow perch stomachs during the study, although perch tended to be more omnivorous in 1988 and 1989 and more planktivorous in 1990. Generally yellow perch of all ages were primarily planktivorous, with the highest mean index of relative importance values during the study for Chydoridae and Daphnidae at 
Table 3.20. Densities of major zooplankton taxa (organisms/liter) in samples collected from mid-channel locations (study sites 1 through 11) of the Pend Oreille River in 1988, -1989, and 1990.

\begin{tabular}{l|c|c|c}
\hline & $\begin{array}{c}\mathbf{1 9 8 8} \\
\text { Mid-channel }\end{array}$ & $\begin{array}{c}\mathbf{1 9 8 9} \\
\text { Mid-channel }\end{array}$ & $\begin{array}{c}\mathbf{1 9 9 0} \\
\text { Mld-channel }\end{array}$ \\
\hline CLADOCERA & 0.38 & 4.58 & 3.42 \\
OOPEPOAA & 27.05 & 16.93 & 9.33 \\
ROIFEAA & 85.11 & 89.95 & $\cdot$ \\
\hline TOTAL & 120.54 & 112.23 & 12.75 \\
\hline
\end{tabular}

Table 3.21. Densities of major zooplankton taxa (organisms/liter) in samples collected from mid-channel locations (study sites 1 through 11 and slough sites $3 A, 4 A, 5 A$ and $6 A$ ) of the Pend Oreille River in 1988, 1989, and 1990.

\begin{tabular}{|c|c|c|c|}
\hline & $\begin{array}{c}1988 \\
\text { Littoral }\end{array}$ & $\begin{array}{c}1989 \\
\text { Littoral }\end{array}$ & $\begin{array}{c}1990 \\
\text { Littoral }\end{array}$ \\
\hline $\begin{array}{l}\text { CLADOCERA } \\
\text { OOPEPOOAA } \\
\text { ROTIFERA }\end{array}$ & $\begin{array}{c}\text { No samples } \\
\text { collected } \\
\text { in } 1988\end{array}$ & $\begin{array}{l}20.34 \\
27.20 \\
72.94\end{array}$ & $\begin{array}{l}15.64 \\
32.01\end{array}$ \\
\hline TOTAL & & 120.48 & $47.65^{\prime}$ \\
\hline
\end{tabular}

- Rotifers were not enumerated in 1990 
Table 3.22. Comparison of total cladoceran biomass $(\mu \mathrm{g} / \mathrm{l})$ in samples collected from mid-channel locations (study sites 1 through 11) of the Pend Oreille River, in 1988, 1989 and 1990.

\begin{tabular}{c|c|c|c}
\hline & $\begin{array}{c}\mathbf{1 9 8 8} \\
\text { Mid-channel }\end{array}$ & $\begin{array}{c}\mathbf{1 8 8 9} \\
\text { Mid-channel }\end{array}$ & $\begin{array}{c}\mathbf{1 9 9 0} \\
\text { Mid-channel }\end{array}$ \\
\hline April & 5.6 & 2.6 & 0.7 \\
June & 20.7 & 13.7 & - \\
July & 53.3 & 22.7 & 11.2 \\
September & 12.7 & 11.6 & 19.4 \\
October & 22.1 & 5.9 & $\cdots$ \\
\hline Mean & 22.9 & 11.3 & 10.4 \\
\hline
\end{tabular}

Table 3.23. Comparison of total cladoceran biomass $(\mu \mathrm{g} / \mathrm{l})$ in samples collected from littoral locations (study sites 1 through 11 and slough sites 3A, 4A, 5A and 6A) of the Pend Oreille River, in 1988, 1989 and 1990.

\begin{tabular}{c|c|c|c}
\hline & $\begin{array}{c}\mathbf{1 9 8 8} \\
\text { Littoral }\end{array}$ & $\begin{array}{c}\mathbf{1 9 8 9} \\
\text { Littoral }\end{array}$ & $\begin{array}{c}\mathbf{1 9 9 0} \\
\text { Littoral }\end{array}$ \\
\hline April & No samples & 2.5 & 3.8 \\
June & collected from & 110.2 & - \\
July & the littoral area & 24.4 & 37.2 \\
September & in 1988 & 7.5 & 34.4 \\
October & & 35.6 & -- \\
\hline Mean & & 25.1 \\
\hline
\end{tabular}


Table 3.24 Biomass of selected cladocerans found in samples collected from mid-channel locations (study sites 1 through 11) of the Pend Oreille river during 1988, 1989, and 1990.

\begin{tabular}{|l|c|c|c|c|}
\hline & 1988 & 1989 & 1990 & Mean \\
\hline Ceriodaphnia spp. & 0.93 & 0.25 & 0.18 & 0.45 \\
\hline Daphnia ambigua & & 0.13 & & 0.13 \\
\hline Daphnia galeata mendotae & 11.09 & 0.96 & 3.07 & 5.04 \\
\hline Daphnia parvula & & 0.04 & 0.01 & 0.03 \\
\hline Daphnia pulicaria & & 0.09 & & 0.09 \\
\hline Daphnia retrocurva & 3.73 & 0.67 & 0.01 & 1.47 \\
\hline Daphnia schodleri & & 0.01 & & 0.01 \\
\hline Daphnia thorata & & 1.89 & 2.27 & 2.08 \\
\hline Megafenestra aurita & & 0.02 & & 0.02 \\
\hline Chydorus sphaericus & 1.45 & 0.31 & 0.18 & 0.65 \\
\hline Bosmina longirostris & 4.70 & 4.22 & 2.41 & 3.78 \\
\hline Diaphanosoma spp. & 1.25 & 0.32 & 0.59 & 0.72 \\
\hline Sida crystallina & & 0.55 & 1.24 & 0.90 \\
\hline Leptodora kindti & 0.09 & 0.10 & 0.46 & 2.17 \\
\hline TOTAL & 23.24 & 9.56 & 10.42 & 17.54 \\
\hline
\end{tabular}

Table 3.25. Biomass of selected cladocerans found in samples collected from littoral locations (study sites 1 through 11 and slough sites $3 A$, $4 A, 5 A$ and $6 A$ ) of the Pend Oreille river during 1988, 1989, and 1990.

\begin{tabular}{|l|c|c|c|}
\hline & 1989 & 1990 & Mean \\
\hline Ceriodaphnia spp. & 8.94 & 6.05 & 7.50 \\
\hline Daphnia galoata mendotae & 1.08 & 3.32 & 2.20 \\
\hline Dahpnia parvula & 0.01 & 0.03 & 0.02 \\
\hline Daphnia pulicaria & 0.02 & & 0.02 \\
\hline Daphnia retrocurva & 0.28 & 0.007 & 0.14 \\
\hline Daphnia schodleri & 0 & & 0.00 \\
\hline Daphnia thorata & 4.00 & 0.85 & 2.40 \\
\hline Megafenestra aurita & 0.06 & & 0.06 \\
\hline Chydorus sphaericus & 2.67 & 3.65 & 3.16 \\
\hline Bosmina longirostris & 7.99 & 3.72 & 5.86 \\
\hline Diaphanosoma spp. & 1.01 & 0.65 & 0.83 \\
\hline Sida crystallina & 3.91 & 5.99 & 4.95 \\
\hline Leptodora kindti & 0.08 & 0.82 & 0.45 \\
\hline TOTAL & 30.05 & 25.09 & 27.59 \\
\hline
\end{tabular}


$13.2 \%$ and $9.2 \%$, respectively (Table 3.26 ). Chironomidae larvae (12.1\%), Baetidae (9.4\%) and Chironomidae pupae (7.6\%) were also important prey items for perch. IRI values for each prey item consumed by yellow perch during the study can be found in 'Appendix F, Table F.1-F.3.

Seven hundred and fifty-six largemouth bass stomachs from age 0+ to 14+ were analyzed during the three year study; 321 in 1988, 336 in 1989 and 99 in 1990. There was little variation of prey organisms found in largemouth bass stomachs from year to year. In general, young largemouth bass were highly planktivorous, with a diet consisting of zooplankton and other small invertebrates, predominantly mayflies (Baetidae). For age $0+$ to $3+$ Daphnidae and Chydoridae had mean index of relative importance values of $13.1 \%$ and $10.7 \%$, respectively (Table 3.27 ). At age $4+$ fish became the major prey item for bass and remained the major food source throughout the rest of the age classes. Yellow perch were by far the most important fish species found in largemouth bass diets (Table 3.28). IRI values for each prey item consumed by largemouth bass during the study can be found in Appendix F, Table F.4-F.6.

A total of 667 mountain whitefish stomachs were collected from age $0+$ to $7+$ fish during the three year study; 288 in 1988, 279 in 1989 and 100 in 1990. Mountain whitefish of all age classes fed primarily on benthic invertebrates, mainly Chironomidae larvae (36.3\%) and Chironomidae pupae (11.5\%) (Table 3.29). Age 0+ and 1+ mountain whitefish also relied on Chydoridae and Daphnidae as a major prey item. Other important items were Hydroptilidae (7.3\%) Simuliidae larvae (5.0\%) and Coenagrionidae (3.6\%). IRI values for each prey item consumed by mountain whitefish during the study can be found in Appendix F, Table F.7-F.9.

Black crappie diet analysis was performed on age $0+$ to $6+$ fish during the study. One hundred and three stomachs were collected in 1988, eighty-two in 1989 and thirty-six in 1990. The most important prey items for black crappie were Daphnidae $(22.6 \%)$, Chironomidae larvae (12.3\%) Cylopoida (10.6\%) Chironomidae pupae $(8.0 \%)$ and Chydoridae (7.9\%) (Table 3.30). Age $0+$ to $3+$ fish were primarily planktivorous and age 4+ and older fed mainly on benthic invertebrates. IRI values for each prey item consumed by black crappie during the study can be found in Appendix F, Table F.10-F.12.

A total of 59 stomachs were collected from age $0+$ to $7+$ brown trout in the Pend Oreille River during the study; 28 in 1988, 
Table 3.26. Mean annual index of relative importance values for prey items consumed by yellow perch in Pend Oreille River, WA during 1988, 1989 and 1990.

\begin{tabular}{|c|c|c|c|c|}
\hline Prey Organisms & $\begin{array}{c}1988 \\
\text { All ages } \\
n=565\end{array}$ & $\begin{array}{c}1989 \\
\text { All ages } \\
n=609\end{array}$ & $\begin{array}{c}1990 \\
\text { All ages } \\
n=158\end{array}$ & $\begin{array}{c}\text { Average } \\
1988-90 \\
\text { All ages } \\
n=1332\end{array}$ \\
\hline \multicolumn{5}{|l|}{ AQUATIC ORGANISMS } \\
\hline \multicolumn{5}{|l|}{ TRICHOPTERA } \\
\hline Hydroptilidae & 5.1 & 2.4 & 4.6 & 4.0 \\
\hline Limnephilidae & 0.2 & 2.4 & 0.6 & 3.2 \\
\hline Lepidostomatidae & 0.1 & & & $<0.1$ \\
\hline Leptoceridae & 1.2 & 1.4 & 0.5 & 3.1 \\
\hline Phryganeidae & 0.2 & 0.2 & 0.4 & 0.3 \\
\hline Hydropsychidae & $<0.1$ & $<0.1$ & & 0.1 \\
\hline Brachycentridae & $<0.1$ & $<0.1$ & & 0.1 \\
\hline Psychomyiidae & & $<0.1$ & & $<0.1$ \\
\hline Polycentropodidae & & & 1.4 & 0.5 \\
\hline \multicolumn{5}{|l|}{ EPHEMEROPTERA } \\
\hline Baetidae & 8.0 & 14.2 & 6.0 & 9.4 \\
\hline Ephemerellidae & 0.4 & $<0.1$ & $<0.1$ & 0.2 \\
\hline Leptophlebiidae & & $<0.1$ & & $<0.1$ \\
\hline Tricorythidae & $<0.1$ & 0.3 & 1.1 & 0.5 \\
\hline \multicolumn{5}{|l|}{ PLECOPTERA } \\
\hline Nemouridae & & $<0.1$ & & $<0.1$ \\
\hline \multicolumn{5}{|l|}{ ODONATA } \\
\hline Coenagrionidae & 4.3 & 7.1 & 6.7 & 6.0 \\
\hline Lestidae & 2.3 & & & 0.8 \\
\hline Libellulidae & 1.4 & $<0.1$ & & 0.5 \\
\hline Aeshnidae & & 0.4 & & 0.1 \\
\hline \multicolumn{5}{|l|}{ COLEOPTERA } \\
\hline Elmidae larvae & 0.8 & 0.1 & & 0.3 \\
\hline Elmidae adult & & $<0.1$ & & $<0.1$ \\
\hline Chrysomelidae & 0.7 & & & 0.2 \\
\hline Dytiscidae & & & 0.2 & 0.1 \\
\hline LEPIDOPTERA & $<0.1$ & & & $<0.1$ \\
\hline \multicolumn{5}{|l|}{ DIPTERA } \\
\hline Chironomidae larvae & 8.4 & 16.5 & 11.5 & 12.1 \\
\hline Chironomidae pupae & 5.5 & 8.4 & 8.9 & 7.6 \\
\hline Tipulidae & 0.3 & $<0.1$ & & 0.1 \\
\hline Chaoboridae & & 0.5 & & 0.2 \\
\hline Ceratopogonidae larvae & 0.6 & 1.1 & 1.1 & 0.9 \\
\hline Ceratopogonidae pupae & & 0.1 & 0.1 & 0.1 \\
\hline Simuliidae larvae & $<0.1$ & 0.2 & 0.3 & 0.2 \\
\hline Simuliidae pupae & & 0.3 & 0.1 & 0.1 \\
\hline Muscidae & co.1 & & & $\mathrm{co.1}$ \\
\hline Sciomyzidae & & 0.1 & & $<0.1$ \\
\hline
\end{tabular}


Table 3.26. (cont.)

\begin{tabular}{|c|c|c|c|c|}
\hline Prey Organisms & $\begin{array}{c}1988 \\
\text { All ages } \\
n=565\end{array}$ & $\begin{array}{c}1989 \\
\text { All ages } \\
n=609\end{array}$ & $\begin{array}{c}1990 \\
\text { All ages } \\
n=158\end{array}$ & $\begin{array}{c}\text { Average } \\
1988-90 \\
\text { All ages } \\
n=1332\end{array}$ \\
\hline \multicolumn{5}{|l|}{ HEMIPTERA } \\
\hline Corixidae & & & 0.1 & $<0.1$ \\
\hline HYDRACARINA & 6.6 & 3.6 & 2.1 & 4.1 \\
\hline \multicolumn{5}{|l|}{ COPEPODA } \\
\hline Cyclopoida & 6.6 & 5.0 & 2.4 & 4.7 \\
\hline Calanoida & 0.7 & 0.1 & 1.8 & 0.9 \\
\hline \multicolumn{5}{|l|}{ CLADOCERA } \\
\hline Daphnidae & 9.3 & 9.5 & 20.9 & 13.2 \\
\hline Chydoridae & 9.9 & 6.7 & 11.0 & 9.2 \\
\hline Ceriodaphnia & & 0.1 & & $<0.1$ \\
\hline Bosminidae & & $<0.1$ & & $<0.1$ \\
\hline MYSIDACEA & & 0.3 & 1.1 & 0.5 \\
\hline \multicolumn{5}{|l|}{ AMPHIPODA } \\
\hline Talitridae & 3.3 & 5.7 & 8.2 & 5.7 \\
\hline Gammaridae & 3.6 & & & 1.2 \\
\hline OSTRACODA & 5.1 & 3.5 & 2.2 & 3.6 \\
\hline \multicolumn{5}{|l|}{ GASTROPODA } \\
\hline Planorbidae & 6.7 & 3.1 & 3.5 & 4.4 \\
\hline Lymnaeidae & 1.2 & 1.3 & 1.3 & 1.3 \\
\hline Physidae & 0.3 & 0.4 & 0.8 & 0.5 \\
\hline \multicolumn{5}{|l|}{ BIVALVIA } \\
\hline Sphaeriidae & 1.2 & 0.1 & & 0.4 \\
\hline \multicolumn{5}{|l|}{ OLIGOCHAETA } \\
\hline Lumbriculidae & 0.2 & 3.6 & 0.1 & 1.3 \\
\hline Naididae & & 0.1 & 0.1 & 0.1 \\
\hline NEMATODA & $<0.1$ & $\mathrm{co.1}$ & & 0.1 \\
\hline TOTAL OSTEICHTHYES & 2.9 & 0.4 & 0.6 & 1.3 \\
\hline Yellow perch & 1.2 & 0.1 & & 0.4 \\
\hline FSH EGGS & 0.5 & & & 0.2 \\
\hline UNIDENTIFIED & 1.7 & 0.3 & & 0.7 \\
\hline TERRESTRIALS & 1.5 & 0.6 & & 0.7 \\
\hline
\end{tabular}


Table 3.27.

\begin{abstract}
Mean annual index of relative importance values for prey items consumed by age $0+$ to $3+$ largemouth bass in Pend Oreille River, WA -during 1988, 1989 and 1990.
\end{abstract}

\begin{tabular}{|c|c|c|c|c|}
\hline Prey Organisms & $\begin{array}{c}1986 \\
\text { Age } 0+-3+ \\
n=263\end{array}$ & $\begin{array}{c}1969 \\
\text { Age } 0+-3+ \\
n=296\end{array}$ & $\begin{array}{c}1990 \\
\text { Age } 0+-3+ \\
n=68\end{array}$ & $\begin{array}{c}\text { Average } \\
1988-90 \\
\text { Age } 0+-3+ \\
n=627\end{array}$ \\
\hline \multicolumn{5}{|l|}{ AQUATIC ORGANISMS } \\
\hline \multicolumn{5}{|l|}{ TRICHOPTERA } \\
\hline Hydroptilidae & 0.2 & & & 0.1 \\
\hline Leptoceridae & & & 0.4 & 0.1 \\
\hline Psychomyiidae & & 0.2 & & 0.1 \\
\hline \multicolumn{5}{|l|}{ EPHEMEROPTERA } \\
\hline Baetidae & 22.9 & 27.1 & 12.3 & 20.8 \\
\hline Ephemerellidae & 0.1 & & & 0.0 \\
\hline Tricorythidae & 0.6 & 0.2 & 0.9 & 0.4 \\
\hline \multicolumn{5}{|l|}{ ODONATA } \\
\hline Coenagrionidae & 5.3 & 6.5 & 8.3 & 6.7 \\
\hline Libellulidae & 2.2 & & & 0.7 \\
\hline Aeshnidae & & 0.3 & 2.8 & 1.0 \\
\hline \multicolumn{5}{|l|}{ COLEOPTERA } \\
\hline Hydrophilidae & & 0.1 & & $<0.1$ \\
\hline \multicolumn{5}{|l|}{ DIPTERA } \\
\hline Chironomidae larvae & 6.3 & 11.2 & 7.9 & 8.5 \\
\hline Chironomidae pupae & 4.4 & 9.9 & 5.6 & 6.6 \\
\hline Ceratopogonidae larvae & 0.2 & 3.2 & 0.7 & 1.4 \\
\hline Simuliidae larvae & $<0.1$ & & & $<0.1$ \\
\hline Muscidae & $<0.1$ & & & $<0.1$ \\
\hline HYDRACARINA & 1.6 & 0.6 & 0.2 & 0.8 \\
\hline \multicolumn{5}{|l|}{ COPEPODA } \\
\hline Cyclopoida & 2.5 & 1.6 & 0.7 & 1.6 \\
\hline Calanoida & 0.4 & 0.1 & 1.0 & 0.5 \\
\hline \multicolumn{5}{|l|}{ CLADOCERA } \\
\hline Daphnidae & 12.9 & 7.7 & 18.9 & 13.2 \\
\hline Chydoridae & 18.0 & 10.0 & 4.1 & 10.7 \\
\hline Leptidoridae & & $<0.1$ & & $<0.1$ \\
\hline \multicolumn{5}{|l|}{ AMPHIPODA } \\
\hline Talitridae & 4.9 & 4.3 & 6.7 & 5.3 \\
\hline Gammaridae & 1.6 & & & \\
\hline OSTRACODA & 0.8 & 0.1 & & 0.3 \\
\hline \multicolumn{5}{|l|}{ BIVALVIA } \\
\hline Sphaeriidae & & $<0.1$ & & $<0.1$ \\
\hline \multicolumn{5}{|l|}{ OLIGOCHAETA } \\
\hline Lumbriculidae & & 0.5 & & 0.2 \\
\hline Naididae & & 0.1 & & $<0.1$ \\
\hline
\end{tabular}


Table 3.27. (cont.)

\begin{tabular}{|c|c|c|c|c|}
\hline Prey Organisms & $\begin{array}{c}1988 \\
\text { Age } 0+-3+ \\
n=263\end{array}$ & $\begin{array}{c}1989 \\
\text { Age } 0+-3+ \\
n=296\end{array}$ & $\begin{array}{c}1990 \\
\text { Age } 0+-3+ \\
n=68\end{array}$ & $\begin{array}{c}\text { Average } \\
1988-90 \\
\text { Age } 0+-3+ \\
n=627\end{array}$ \\
\hline TOTAL OSTEICHTHYES & 9.8 & 7.8 & 26.0 & 14.5 \\
\hline Pumpkinseed & & 1.4 & & 0.5 \\
\hline Largemouth bass & & 1.8 & & 0.6 \\
\hline \multicolumn{5}{|l|}{ DECAPODA } \\
\hline Astacidae & & 0.1 & & $<0.1$ \\
\hline FSHEGGS & 0.1 & & & $<0.1$ \\
\hline UNIDENTIFIED & & 4.6 & & 1.5 \\
\hline TERRESTRIALS & 4.7 & 3.1 & 3.9 & 3.9 \\
\hline \multicolumn{5}{|l|}{ HEMIPTERA } \\
\hline Corixidae & 0.3 & & & 0.1 \\
\hline Gerridae & 0.2 & & & 0.1 \\
\hline \multicolumn{5}{|l|}{ DIPTERA } \\
\hline Simuliidae & & $<0.1$ & & $<0.1$ \\
\hline \multicolumn{5}{|l|}{ ODONATA } \\
\hline Coenagrionidae & & 2.0 & & 1.5 \\
\hline \multicolumn{5}{|l|}{ HYMENOPTERA } \\
\hline Formicidae & & $<0.1$ & & $<0.1$ \\
\hline ARACHNIDA & & 0.2 & & 0.1 \\
\hline
\end{tabular}


Table 3.28.
Mean annual index of relative importance values for prey items consumed by age 4+ to 14+ largemouth bass in Pend Oreille River, WA during 1988, 1989 and 1990.

\begin{tabular}{|c|c|c|c|c|}
\hline Prey Organisms & $\begin{array}{c}1988 \\
\text { Age } \begin{array}{c}4+-14+ \\
n=58\end{array}\end{array}$ & $\begin{array}{c}1989 \\
\text { Age } 4+-14+ \\
n=40\end{array}$ & $\begin{array}{c}1990 \\
\text { Age } 4+-14+ \\
n=31\end{array}$ & $\begin{array}{c}\text { Average } \\
1988-90 \\
\text { Age 4+-14+ } \\
n=129\end{array}$ \\
\hline \multicolumn{5}{|l|}{ AQUATIC ORGANISMS } \\
\hline \multicolumn{5}{|l|}{ TRICHOPTERA } \\
\hline Hydroptilidae & $<0.1$ & & & $<0.1$ \\
\hline \multicolumn{5}{|l|}{ EPHEMEROPTERA } \\
\hline Baetidae & 1.7 & 4.7 & 1.3 & 2.6 \\
\hline \multicolumn{5}{|l|}{ ODONATA } \\
\hline Coenagrionidae & 1.2 & 2.1 & 0.6 & 1.3 \\
\hline Libellulidae & 0.2 & & & 0.1 \\
\hline \multicolumn{5}{|l|}{ DIPTERA } \\
\hline Chironomidae larvae & 1.6 & 0.5 & 1.4 & 1.2 \\
\hline Chironomidae pupae & 3.5 & & 0.5 & 1.3 \\
\hline Ceratopogonidae larvae & 0.3 & & & 0.1 \\
\hline HYDRACARINA & 1.0 & & & 0.3 \\
\hline \multicolumn{5}{|l|}{ COPEPODA } \\
\hline Calanoida & & & 0.8 & 0.3 \\
\hline \multicolumn{5}{|l|}{ CLADOCERA } \\
\hline Daphnidae & & & 2.1 & 0.7 \\
\hline Chydoridae & 0.8 & 1.0 & & 0.6 \\
\hline \multicolumn{5}{|l|}{ AMPHIPODA } \\
\hline Talitridae & $<0.1$ & 0.7 & 0.3 & 0.3 \\
\hline \multicolumn{5}{|l|}{ GASTROPODA } \\
\hline Planorbidae & 0.6 & 0.6 & & 0.4 \\
\hline Lymnaeidae & 0.3 & & & 0.1 \\
\hline \multicolumn{5}{|l|}{ BIVALVIA } \\
\hline Sphaeriidae & 0.9 & & & 0.3 \\
\hline \multicolumn{5}{|l|}{ OLIGOCHAETA } \\
\hline Lumbriculidae & & 0.4 & 0.4 & 0.3 \\
\hline TOTAL OSTEICHTHYES & 40.0 & 50.5 & 59.5 & 50.0 \\
\hline Yellow perch & 22.6 & 31.9 & & 33.2 \\
\hline Pumpkinseed & 3.6 & 1.4 & & 1.7 \\
\hline FOG & 1.2 & & & 0.4 \\
\hline FSHEGGS & $<0.1$ & & & $<0.1$ \\
\hline CESTODA (Tapeworms) & 0.2 & & & 0.1 \\
\hline UNIDENTIFIED & & 18.7 & & 6.2 \\
\hline TERRESTRIALS & 1.9 & 1.5 & & 0.3 \\
\hline \multicolumn{5}{|l|}{ HEMIPTERA } \\
\hline Corixidae & 0.1 & 0.3 & & 0.1 \\
\hline
\end{tabular}


Table 3.29. Mean annual index of relative importance values for prey items consumed by mountain whitefish in Pend Oreille River, WA during 1988, 1989 and 1990.

\begin{tabular}{|c|c|c|c|c|}
\hline Prey Organisms & $\begin{array}{c}1988 \\
\text { All ages } \\
n=208\end{array}$ & $\begin{array}{c}1989 \\
\text { All ages } \\
n=279\end{array}$ & $\begin{array}{c}1990 \\
\text { All ages } \\
n=100\end{array}$ & $\begin{array}{c}\text { Average } \\
1988-90 \\
\text { All ages } \\
n=587\end{array}$ \\
\hline \multicolumn{5}{|l|}{ AQUATIC ORGANISMS } \\
\hline \multicolumn{5}{|l|}{ TRICHOPTERA } \\
\hline Hydroptilidae & 4.1 & 11.1 & 6.7 & 7.3 \\
\hline Limnephilidae & 0.3 & 0.6 & 1.3 & 0.7 \\
\hline Phyrganeidae & 0.5 & 0.1 & 0.3 & 0.3 \\
\hline Leptoceridae & 2.8 & 4.1 & 0.8 & 2.6 \\
\hline Hydropsychidae & & $<0.1$ & 0.1 & $<0.1$ \\
\hline Brachycentridae & 0.6 & 0.4 & 2.0 & 1.0 \\
\hline Rhyacophilidae & 0.2 & & 0.1 & 0.1 \\
\hline Glossosomatidae & & 0.2 & & 0.1 \\
\hline Psychomyiidae & & $<0.1$ & & $<0.1$ \\
\hline Polycentropidae & & & 0.5 & 0.2 \\
\hline Lepidostomatidae & & & $<0.1$ & $<0.1$ \\
\hline \multicolumn{5}{|l|}{ EPHEMEROPTERA } \\
\hline Baetidae & 1.4 & 2.6 & 2.1 & 2.0 \\
\hline Ephemerellidae & 0.4 & $<0.1$ & 1.0 & 0.5 \\
\hline Heptageniidae & $<0.1$ & $<0.1$ & 0.1 & 0.1 \\
\hline Tricorythidae & & & 1.8 & 0.6 \\
\hline Leptophlebiidae & & & 0.3 & 0.1 \\
\hline \multicolumn{5}{|l|}{ PLECOPTERA } \\
\hline Nemouridae & & $<0.1$ & 0.4 & 0.2 \\
\hline Perlodidae & & $<0.1$ & 0.2 & 0.1 \\
\hline Capniidae & $<0.1$ & & & $<0.1$ \\
\hline Chloroperlidae & & & 0.1 & $<0.1$ \\
\hline \multicolumn{5}{|l|}{ ODONATA } \\
\hline Coenagrionidae & 6.1 & 1.9 & 2.8 & 3.6 \\
\hline Libellulidae & $<0.1$ & $<0.1$ & & $<0.1$ \\
\hline \multicolumn{5}{|l|}{ COLEOPTERA } \\
\hline Elmidae & 0.5 & & & 0.2 \\
\hline Elmidae larvae & & 0.8 & 0.4 & 0.4 \\
\hline \multicolumn{5}{|l|}{ DIPTERA } \\
\hline Chironomidae larvae & 42.5 & 37.8 & 28.6 & 36.3 \\
\hline Chironomidae pupae & 13.0 & 6.8 & 14.7 & 11.5 \\
\hline Tipulidae & 0.6 & $<0.1$ & 0.1 & 0.3 \\
\hline Bibionidae & & $<0.1$ & & $<0.1$ \\
\hline Ceratopogonidae larvae & 0.2 & 0.2 & 0.3 & 0.3 \\
\hline Simuliidae larvae & 0.8 & 5.8 & 8.4 & 5.0 \\
\hline Simuliidae pupae & & 2.0 & 1.8 & 1.3 \\
\hline Empididae & 0.3 & & 0.3 & 0.2 \\
\hline Amphizoidae & $<0.1$ & & & $<0.1$ \\
\hline
\end{tabular}


Table 3.29. (cont.)

\begin{tabular}{|c|c|c|c|c|}
\hline Prey Organisms & $\begin{array}{c}1988 \\
\text { All ages } \\
n=208\end{array}$ & $\begin{array}{c}1989 \\
\text { All ages } \\
n=279\end{array}$ & $\begin{array}{c}1990 \\
\text { All ages } \\
n=100\end{array}$ & $\begin{array}{c}\text { Average } \\
1988-90 \\
\text { All ages } \\
n=587\end{array}$ \\
\hline Chaoboridae & & & 0.4 & 0.1 \\
\hline Muscidae & & $<0.1$ & & $<0.1$ \\
\hline \multicolumn{5}{|l|}{ MEGALOPTERA } \\
\hline Sialidae & & 0.8 & & 0.3 \\
\hline HYDRACARINA & 4.8 & 3.6 & 2.4 & 3.6 \\
\hline LEPIDOPTERA & 0.2 & & & 0.1 \\
\hline \multicolumn{5}{|l|}{ OOPEPODA } \\
\hline Cyclopoida & 0.6 & 0.4 & & 0.3 \\
\hline \multicolumn{5}{|l|}{ CLADOCERA } \\
\hline Daphnidae & 2.7 & 0.8 & 13.2 & 5.6 \\
\hline Chydoridae & 3.2 & 5.0 & 0.3 & 2.8 \\
\hline \multicolumn{5}{|l|}{ Leptodoridae } \\
\hline MYSIDACEA & & 0.4 & & 0.1 \\
\hline \multicolumn{5}{|l|}{ AMPHIPODA } \\
\hline Talitridae & 0.3 & 4.6 & 5.5 & 3.5 \\
\hline Gammaridae & 2.1 & 0.2 & & 0.8 \\
\hline OSTRACODA & 0.5 & 0.3 & 0.1 & 0.3 \\
\hline \multicolumn{5}{|l|}{ GASTROPODA } \\
\hline Planorbidae & 3.6 & 1.4 & 1.1 & 2.0 \\
\hline Lymnaeidae & 1.2 & 2.1 & 0.5 & 1.3 \\
\hline \multicolumn{5}{|l|}{ BIVALVIA } \\
\hline Sphaeriidae & 1.0 & 1.0 & & 0.7 \\
\hline \multicolumn{5}{|l|}{ OLIGOCHAETA } \\
\hline Lumbriculida $\theta$ & 0.6 & 0.9 & 0.1 & 0.5 \\
\hline ANNELIDA & 0.2 & & & 0.1 \\
\hline NEMATODA & 0.4 & $<0.1$ & 0.4 & 0.3 \\
\hline Naididae & & 0.6 & & 0.2 \\
\hline FSHEGGS & 0.7 & & & 0.2 \\
\hline TERRESTRIALS & 4.2 & & 1.4 & 1.9 \\
\hline Aphididae & & 0.3 & & 0.1 \\
\hline
\end{tabular}


Table 3.30. Mean annual index of relative importance values for prey items consumed by black crappie in Pend Oreille River, WA during 1988, 1989 and 1990.

\begin{tabular}{|c|c|c|c|c|}
\hline Prey Organisms & $\begin{array}{c}1988 \\
\text { All ages } \\
n=103\end{array}$ & $\begin{array}{c}1989 \\
\text { All ages } \\
n=82\end{array}$ & $\begin{array}{c}1990 \\
\text { All ages } \\
n=36\end{array}$ & $\begin{array}{c}\text { Average } \\
1988-90 \\
\text { All ages } \\
n=221\end{array}$ \\
\hline \multicolumn{5}{|l|}{ AQUATIC ORGANISMS } \\
\hline \multicolumn{5}{|l|}{ TRICHOPTERA } \\
\hline Hydroptilidae & 0.5 & 0.2 & & 0.2 \\
\hline Phyrganeidae & 1.8 & & & 0.6 \\
\hline Leptoceridae & 0.1 & & & $<0.1$ \\
\hline \multicolumn{5}{|l|}{ EPHEMEROPTERA } \\
\hline Baetidae & 5.8 & 3.2 & 4.0 & 4.3 \\
\hline Ephemerellidae & 0.3 & & & 0.1 \\
\hline Tricorythidae & 5.6 & 1.7 & 2.8 & 3.4 \\
\hline Leptophlebiidae & & & 0.7 & 0.2 \\
\hline \multicolumn{5}{|l|}{ PLECOPTERA } \\
\hline Nemouridae & & 0.2 & & 0.1 \\
\hline \multicolumn{5}{|l|}{ ODONATA } \\
\hline Coenagrionidae & 6.4 & 2.2 & 2.5 & 3.7 \\
\hline \multicolumn{5}{|l|}{ DIPTERA } \\
\hline Chironomidae larvae & 7.7 & 16.3 & 12.9 & 12.3 \\
\hline Chironomidae pupae & 7.5 & 11.4 & 5.1 & 8.0 \\
\hline Ceratopogonidae lanae & 0.1 & 13.0 & 4.2 & 5.8 \\
\hline Simuliidae larvae & & 0.1 & & $<0.1$ \\
\hline Muscidae & $<0.1$ & & & $<0.1$ \\
\hline Culicidae & 0.2 & & & 0.1 \\
\hline Chaoboridae & & & 0.7 & 0.2 \\
\hline HYDRACARINA & 0.5 & 1.4 & 0.6 & 0.8 \\
\hline LEPIDOPTERA & & 0.1 & & $<0.1$ \\
\hline \multicolumn{5}{|l|}{ OOPEPODA } \\
\hline Cyclopoida & 8.7 & 14.0 & 9.1 & 10.6 \\
\hline Calanoida & 5.0 & & 5.6 & 3.5 \\
\hline \multicolumn{5}{|l|}{ CLADOCERA } \\
\hline Daphnidae & 28.8 & 6.7 & 32.3 & 22.6 \\
\hline Chydoridae & 8.9 & 10.7 & 4.2 & 7.9 \\
\hline Ceriodaphnia & & 8.5 & & 2.8 \\
\hline Leptodoridae & $<0.2$ & & & $<0.1$ \\
\hline Sididae & $<0.1$ & & & $<0.1$ \\
\hline \multicolumn{5}{|l|}{ AMPHIPODA } \\
\hline Talitridae & 1.0 & 6.6 & 6.0 & 4.5 \\
\hline Gammaridae & 3.7 & & & 1.2 \\
\hline OSTRACODA & 4.4 & 2.6 & 7.1 & 4.7 \\
\hline TOTAL OSTEICHTHYES & 1.0 & & 1.6 & 0.9 \\
\hline TERRESTRIALS & 1.3 & 0.7 & 0.7 & 0.9 \\
\hline
\end{tabular}


18 in 1989 and 13 in 1990. Brown trout fed mainly on benthic macroinvertebrates. The highest IRI value was for Chironomidae pupae $(21.8 \%)$ followed by Baetidae $(15.8 \%)$, Coenagrionidae $(11.3 \%)$ and Chironomidae larvae (11.1\%) (Table 3.31). The younger age classes of brown trout preyed mostly on mayflies (Baetidae) and damselflies (Coenagrionidae) while the older trout were omnivorous, feeding on invertebrates as well as other fish. IRI values for each prey item consumed by brown trout during the study can be found in Appendix F, Table F.13-15.

Cutthroat trout diet analysis was performed only in 1989 on 3 stomachs from fish age $3+$ and $4+$. The highest IRI value was for Chironomidae pupae (34.2\%) followed by Osteichthyes $(20.2 \%)$ and Plecoptera (13.0\%) (Table 3.32). IRI values for each prey item consumed by cutthroat trout during the study can be found in Appendix F, Table F.16-F.18.

Rainbow trout diet analysis was performed in 1990 on three stomachs from fish age 2+,4+ and 5+. All items found in the stomachs were benthic invertebrates. The highest IRI value was for Chironomidae larvae $(69.7 \%)$ followed by Coenagrionidae $(11.1 \%)$ and Libellulidae (10.1\%) (Table 3.33). IRI values for each prey item consumed by rainbow trout during the study can be found in Appendix F, Table F.19-F.21.

Nine kokanee stomachs were analyzed during the survey; 3 in 1989 and 6 in 1990. The highest IRI value was for Daphnidae (41.9\%) followed by Chironomidae pupae (11.9\%) (Table 3.34). IRI values for each prey item consumed by kokanee during the study can be found in Appendix F, Table F.22-F.24.

Based on index of relative importance values calculated for each species with all age classes combined, most of the diet overlaps observed between species were low. Moderate diet overlaps were observed between several different species (Table 3.35). Yellow perch and black crappie had high diet overlaps each year of the study, mainly due to their common reliance upon zooplankton and chironomids. Target species that exhibited high diet overlaps were mountain whitefish and yellow perch, and black crappie and kokanee (Table 3.36).

Changes in diet overlaps occurred between several species of fish found in the Pend Oreille River. Most of the overlap changes were from moderate overlaps in 1988 to high in 1989. In general the 
Table 3.31. Mean annual index of relative importance values for prey items consumed by brown trout in Pend Oreille River, WA during 1988, 1989 and 1990.

\begin{tabular}{|c|c|c|c|c|}
\hline Prey Organisms & $\begin{array}{c}1988 \\
\text { All ages } \\
n=28\end{array}$ & $\begin{array}{c}1989 \\
\text { All ages } \\
n=18\end{array}$ & $\begin{array}{c}1990 \\
\text { All ages } \\
n=13\end{array}$ & $\begin{array}{c}\text { Average } \\
1988-90 \\
\text { All ages } \\
n=59\end{array}$ \\
\hline \multicolumn{5}{|l|}{ AQUATIC ORGANISMS } \\
\hline \multicolumn{5}{|l|}{ TRICHOPTERA } \\
\hline Hydroptilidae & 0.1 & & & $<0.1$ \\
\hline Limnephilidae & & & 0.8 & 0.3 \\
\hline Phyrganeidae & & & 1.0 & 0.3 \\
\hline Leptoceridae & 1.5 & 0.9 & & 0.8 \\
\hline Brachycentridae & & & 0.7 & 0.2 \\
\hline \multicolumn{5}{|l|}{ EPHEMEROPTERA } \\
\hline Baetidae & 18.9 & 10.8 & 17.6 & 15.8 \\
\hline Ephemerellidae & & 20.0 & & 6.7 \\
\hline \multicolumn{5}{|l|}{ PLECOPTERA } \\
\hline Nemouridae & & & 0.7 & 0.2 \\
\hline \multicolumn{5}{|l|}{ ODONATA } \\
\hline Coenagrionidae & 8.9 & 21.3 & 3.8 & 11.3 \\
\hline Libellulidae & 1.4 & & 3.0 & 1.5 \\
\hline Aeshnidae & & 3.2 & & 1.1 \\
\hline Lestidae & & 0.4 & & 0.1 \\
\hline \multicolumn{5}{|l|}{ COLEOPTERA } \\
\hline Elmidae & 14.7 & 1.2 & & 5.3 \\
\hline Dytiscidae & & 0.5 & & 0.2 \\
\hline \multicolumn{5}{|l|}{ DIPTERA } \\
\hline Chironomidae larvae & 11.9 & 0.4 & 21.1 & 11.1 \\
\hline Chironomidae pupae & 8.4 & 20.1 & 36.9 & 21.8 \\
\hline Ceratopogonidae larvae & & 1.7 & & 0.6 \\
\hline Simuliidae larvae & & & 1.1 & 0.4 \\
\hline Simuliidae pupae & & & 1.8 & 0.6 \\
\hline LEPIDOPTERA & & 0.6 & & 0.2 \\
\hline \multicolumn{5}{|l|}{ COPEPODA } \\
\hline Cyclopoida. & 3.3 & & & 1.1 \\
\hline \multicolumn{5}{|l|}{ CLADOCERA } \\
\hline Chydoridae & 3.9 & & & 1.3 \\
\hline \multicolumn{5}{|l|}{ AMPHIPODA } \\
\hline Talitridae & & 2.7 & 4.7 & 2.5 \\
\hline Gammaridae & & 0.4 & & 0.1 \\
\hline \multicolumn{5}{|l|}{ GASTROPODA } \\
\hline Planorbidae & 2.4 & 2.8 & 0.7 & 2.0 \\
\hline Lymnaeidae & & 0.5 & 0.9 & 0.5 \\
\hline Physidae & & 0.7 & & 0.2 \\
\hline \multicolumn{5}{|l|}{ OLIGOCHAETA } \\
\hline Naididae & & 7.6 & & 2.5 \\
\hline
\end{tabular}


Table 3.31. (cont.)

\begin{tabular}{|l|c|c|c|c|}
\hline & $\begin{array}{c}1988 \\
\text { All ages } \\
n=28\end{array}$ & $\begin{array}{c}1989 \\
\text { All ages } \\
n=18\end{array}$ & $\begin{array}{c}1990 \\
\text { All ages } \\
n=13\end{array}$ & $\begin{array}{c}\text { Average } \\
1988-90 \\
\text { All ages } \\
n=59\end{array}$ \\
\hline Prey Organisms & 3.3 & 4.2 & 5.4 & 4.3 \\
\hline TETAL OSTEICHTHYES & 9.6 & & & 3.2 \\
\hline Chironomidae Adult & 0.2 & & & 0.1 \\
\hline COLEOPTERA & 0.2 & & & 0.1 \\
\hline Cerambycidae & & & & 1.8 \\
\hline HEMIPTERA & 5.4 & & & 0.3 \\
\hline Corixidae & 0.8 & & & 0.1 \\
\hline Lygaeidae & 0.2 & & & 0.1 \\
\hline Pentatomidae & & & & 0.4 \\
\hline HOMOPTERA & 0.4 & & & 0.5 \\
\hline Aphididae & 0.8 & & & \\
\hline Cicadellidae & & & & \\
\hline HYMENOPTERA & 1.2 & & & \\
\hline Orussidae & 1.4 & & & \\
\hline Formicidae &
\end{tabular}


Table 3.32. Mean annual index of relative importance values for prey items consumed by -cutthroat trout in Pend Oreille River, WA during 1989.

\begin{tabular}{|c|c|}
\hline Prey Organisms & $\begin{array}{c}1989 \\
\text { All ages } \\
n=3\end{array}$ \\
\hline \multicolumn{2}{|l|}{ AQUATIC ORGANISMS } \\
\hline PLECOPTERA & 13.0 \\
\hline \multicolumn{2}{|l|}{ ODONATA } \\
\hline Coenagrionidae & 4.1 \\
\hline OOLEOPTERA & 4.1 \\
\hline \multicolumn{2}{|l|}{ DIPTERA } \\
\hline Chironomidae larvae & 8.2 \\
\hline Chironomidae pupae & 34.2 \\
\hline \multicolumn{2}{|l|}{ CLADOCEPA } \\
\hline Daphnidae & 9.8 \\
\hline \multicolumn{2}{|l|}{ GASTROPODA } \\
\hline Planorbidae & 6.2 \\
\hline TOTAL OSTEICHTHYES & 20.2 \\
\hline
\end{tabular}

Table 3.33. Mean annual index of relative importance values for prey items consumed by rainbow trout in Pend Oreille River, WA during 1990.

\begin{tabular}{|c|c|}
\hline Prey Organisms & $\begin{array}{c}1990 \\
\text { All ages } \\
n=\mathbf{3}\end{array}$ \\
\hline \multicolumn{2}{|l|}{ AQUATIC ORGANISMS } \\
\hline \multicolumn{2}{|l|}{ TRICHOPTERA } \\
\hline Phyrganeidae & 3.3 \\
\hline \multicolumn{2}{|l|}{ EPHEMEROPTERA } \\
\hline Baetidae & 2.9 \\
\hline \multicolumn{2}{|l|}{ ODONATA } \\
\hline Coenagrionidae & 11.1 \\
\hline Libellulidae & 10.1 \\
\hline \multicolumn{2}{|l|}{ DIPTERA } \\
\hline Chironomidae larvae & 69.7 \\
\hline Chironomidae pupae & 3.0 \\
\hline
\end{tabular}




\section{Table 3.34. Mean annual index of relative importance}

values for prey items consumed by kokanee trout in Pend Oreille River, WA during 1989 and 1990.

\begin{tabular}{|l|c|c|c|}
\hline & $\begin{array}{c}1989 \\
\text { All ages } \\
\mathbf{n = 3}\end{array}$ & $\begin{array}{c}1990 \\
\text { All ages } \\
\mathbf{n = 6}\end{array}$ & $\begin{array}{c}\text { Average } \\
1989-90 \\
\text { All ages } \\
\mathbf{n}=9\end{array}$ \\
\hline Pray Organisms \\
\hline AQUATIC QRGANISMS \\
\hline DIPTERA \\
\hline Chironomidae larvae & 5.8 & 3.2 & 4.4 \\
\hline Chironomidae pupae & 5.6 & 30.0 & 17.8 \\
\hline Simuliidae larvae & & 2.3 & 1.2 \\
\hline COPEPODA & \multicolumn{3}{|l}{} \\
\hline Cyclopoida & 18.8 & 3.4 & 11.1 \\
\hline CLADOCERA & 64.4 & 61.3 & 62.9 \\
\hline Daphnidae & 5.6 & & 2.8 \\
\hline Chydoridae &
\end{tabular}




\section{Table 3.35. Fish species that exhibited moderate diet overlaps (0.5-0.7) based on index of relative importance (IRI) values in the Pend Oreille River during 1988, 1989 and 1990.}

\author{
Yellow perch-Tenth \\ Brown bullhead-Tenth \\ Mountain whitefish-Northern squawfish \\ Brown bullhead-Largescale sucker \\ Mountain whitefish-Longnose sucker \\ Brown bullhead-Longnose sucker \\ Yellow perch-Mountain whitefish \\ Yellow perch-Tenth \\ Black crappie-Pumpkinseed \\ Black crappie-Brown bullhead \\ Black crappie-Tenth \\ Black crappie-Longnose sucker \\ Northern squawfish-Longnose sucker \\ Mountain whitefish-Black crappie \\ Mountain whitefish-Rainbow trout
}

1988

1989

Mountain whitefish-Black crappie

Mountain whitefish-Tenth

Brown trout-Cutthroat trout

Tench-Peamouth

Pumpkinseed-Peamouth

Brown bullhead-Longnose sucker

1990
Yellow perch-Kokanee
Mountain whitefish-Brown trout

\section{Table 3.36. Fish species that exhibited high diet overlaps (20.7) based on index of relative importance (IRI) values in the Pend Oreille River during 1988, 1989 and 1990.}

\footnotetext{
Yellow perch-Black crappie

Pumpkinseed-Brown bullhead

Yellow perch-Black crappie

Yellow perch-Pumpkinseed

Yellow perch-Brown bullhead

Brown bullhead-Tenth

Yellow perch-Black crappie Yellow perch-Mountain whitefish
}

1988

Mountain whitefish-Pumpkinseed

Mountain whitefish-Brown bullhead

1989
Mountain whitefish-Pumpkinseed
Pumpkinseed-Brown bullhead
Pumpkinseed-Tenth

1990 
high diet overlaps were the result of many species of fish utilizing, to a high degree, chironomid larvae, Daphnidae, and Chydoridae. Diet analysis was not done on non-target species in 1990, therefore diet overlaps listed for 1990 in Table 3.35 were only between target species.

Due to the difference in diet of each age class of largemouth bass, diet overlaps were calculated between the separate age classes of bass and fish species that exhibited geographic overlap with them (Table 3.37). High overlaps were observed most often between perch and bass age $0+$ to $2+$. Overlaps with other species were generally low. Diet overlaps were calculated between

different age classes of perch and bass to determine where overlaps were most extensive (Table 3.38). Age $0+$ largemouth bass had mostly moderate overlaps with all age classes of perch, age 1+ largemouth bass had mostly high overlaps with all age classes of perch, age 2+ largemouth bass had moderate to high overlaps with all age classes of perch and bass that were age $3+$ had mostly low overlaps with all age classes of perch. 
Table 3.37. Annual diet overlaps between largemouth bass year classes and other fish species based on index of relative importance values during 1988, 1989 and 1990.

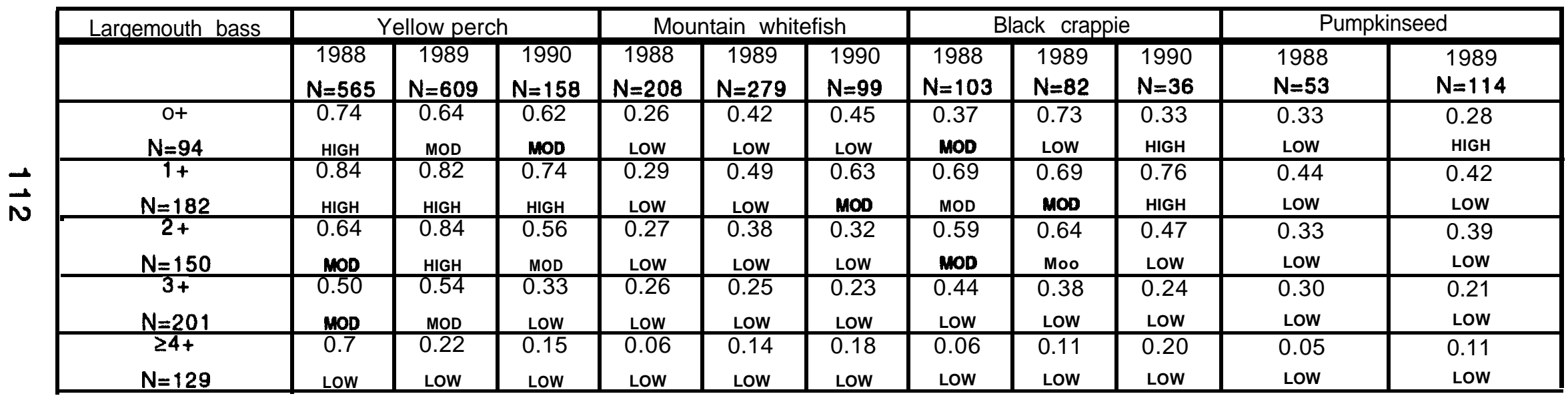


Table 3.38. Annual diet overlaps between largemouth bass year classes and yellow perch year classes based on index of relative importance values during 1989 and 1990.

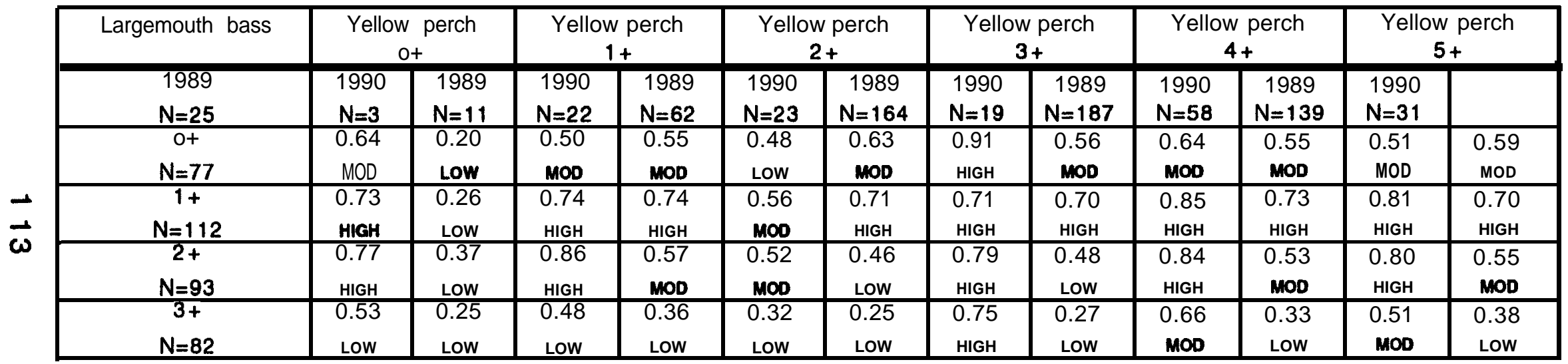




\subsection{MOVEMENT AND MIGRATION OF FLOY TAGGED FISH}

Movement or migration of fish marked with site specific floy tags was determined by recaptures during electrofishing surveys and from angler returns. A total of 366 marked fish were recaptured during electrofishing surveys over the course of the study; 30 in 1988, 254 in 1989 and 82 in 1990. One rainbow trout was recaptured during the study between 5 and $10 \mathrm{~km}$ from the tagging site. Eighty percent of the brown trout and $89 \%$ of the mountain whitefish exhibited no movement from their original tagging location (Table 3.39). Largemouth bass exhibited the most movement of all fish species in the river: $59 \%$ were recaptured at the same location they were tagged, $15 \%$ moved from 1 to 5 kilometers, $10 \%$ moved from 5 to 10 kilometers and $15 \%$ moved over 10 kilometers.

Of the tagged yellow perch that were recaptured $71 \%$ exhibited no movement and $24 \%$ moved from 1 to 5 kilometers. Only two tagged black crappie were recaptured during the survey. One displayed no movement and the other had moved less than 5 kilometers. Of the six pumpkinseed captured $50 \%$ exhibited no movement, 33\% moved between 1 and 5 kilometers and $17 \%$ moved between 5 and 10 kilometers.

Recapture of tagged non-target species determined that $74 \%$ of largescale suckers, $67 \%$ of longnose suckers, $76 \%$ of northern squawfish and $65 \%$ of tench displayed no movement from the location of original tagging (Table 3.39).

A total of 102 marked fish were recaptured by anglers over the course of the study: 14 in 1988, 52 in 1989 and 36 in 1990. One brown trout and one cutthroat trout were both reportedly caught over $10 \mathrm{~km}$ from their original tagging location (Table 3.40). The two brook trout that were recaptured displayed no movement.

Seventy five percent of the mountain whitefish recaptured exhibited no movement and the other twenty five percent moved over $10 \mathrm{~km}$ from the tagging site.

Of the largemouth bass recaptured by anglers $61 \%$ displayed no movement, $3 \%$ moved from 1 to 5 kilometers, $17 \%$ moved from 5 to 10 kilometers and $18 \%$ moved over 10 kilometers. The single black crappie recaptured by an angler moved a distance of over 10 kilometers from the original tagging location. 
Table 3.39. Migration or movement of fish species

captured during electrofishing surveys in the

Pend Oreille River during 1988, 1989 and 1990.

Distance traveled $(\mathrm{km})$ was determined from

location of tagging to location of recapture.

No movement was determined if a fish was recaptured in the same location it was tagged.

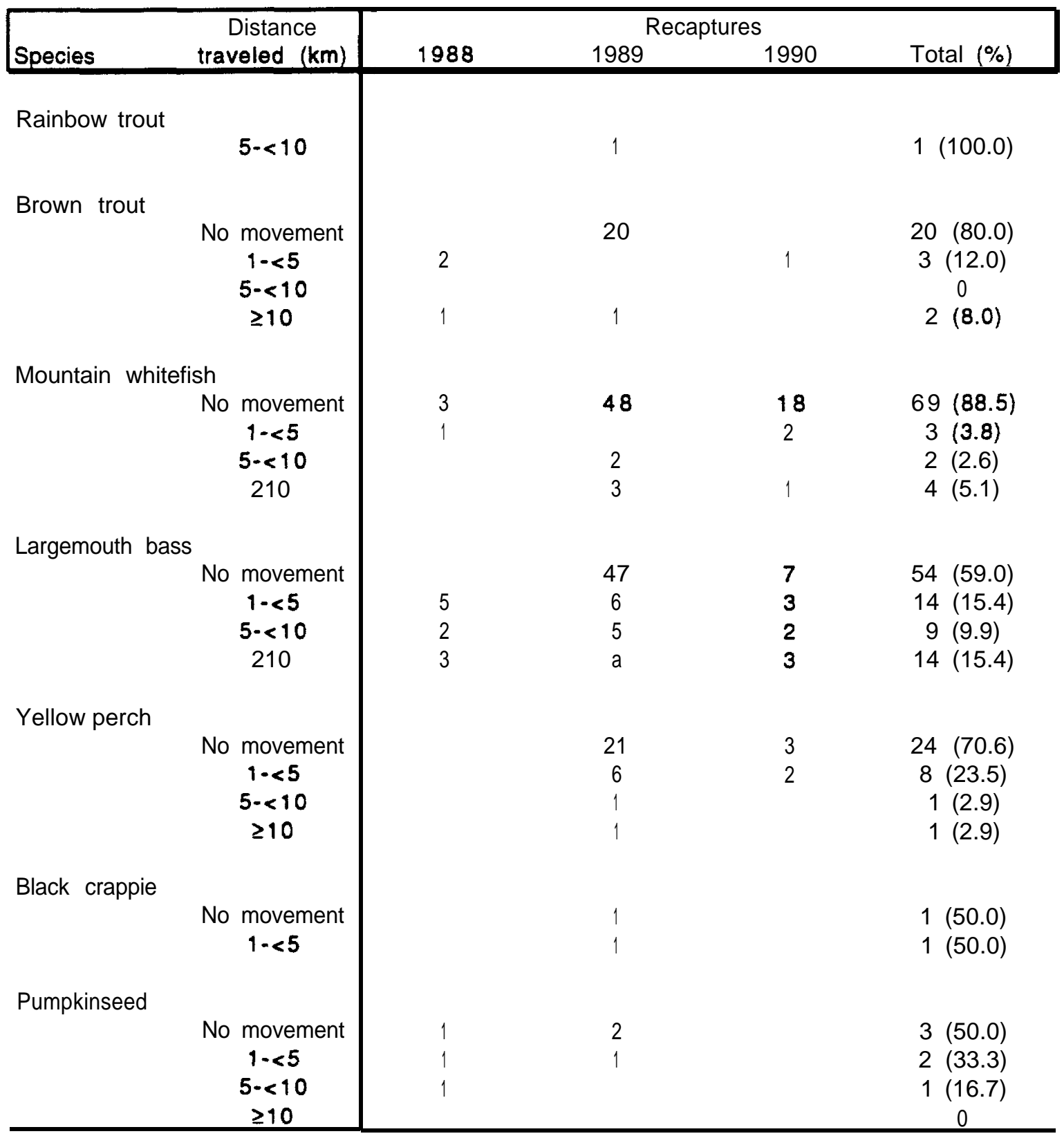




\section{Table 3.39 (cont.)}

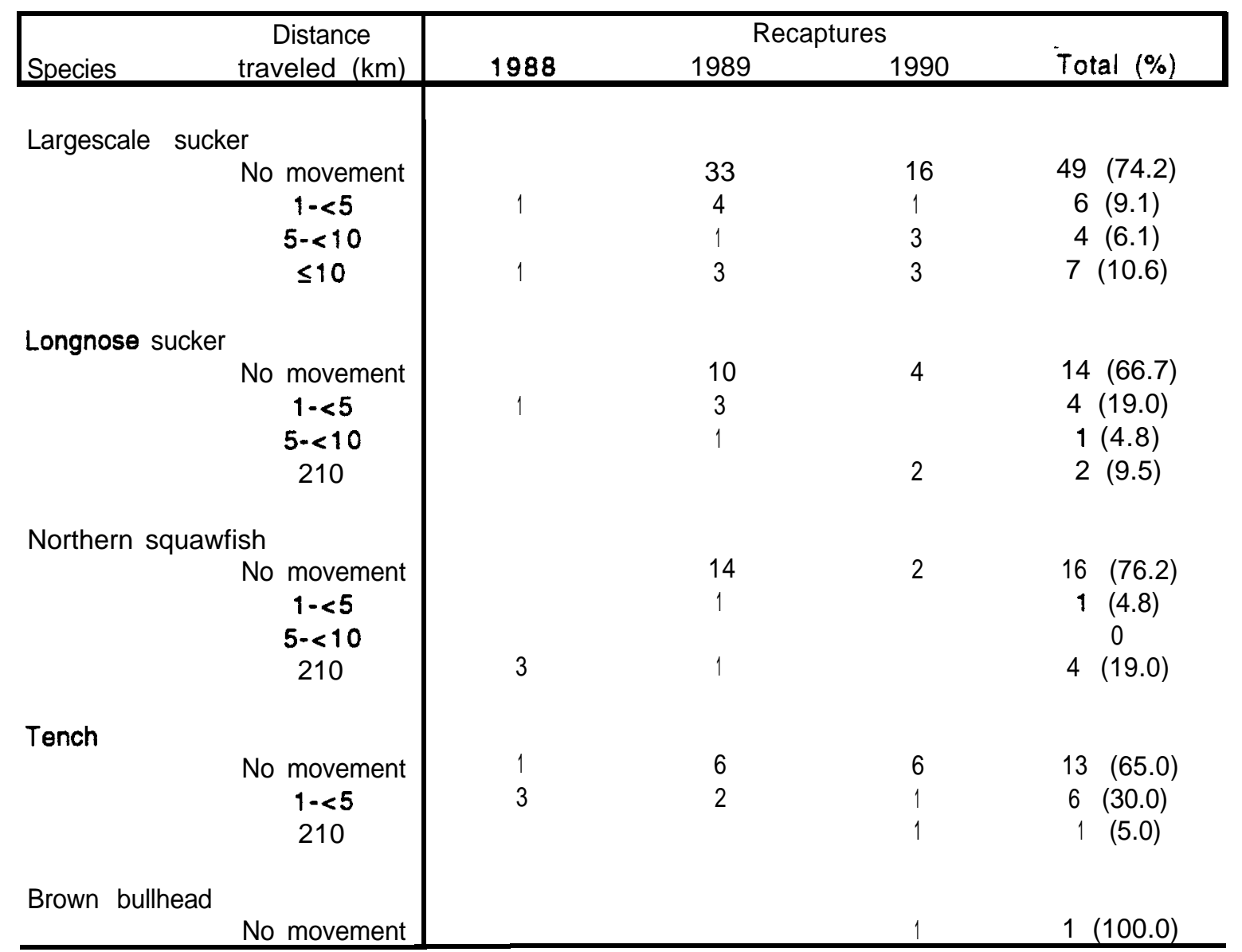


Table 3.40. Migration or movement of fish speciesdetermined from angler tag returns from the Pend Oreille River during 1988, 1989 and 1990. Distance traveled $(\mathrm{km})$ was determined from location of tagging to the reported location of recapture. No movement was determined if the reported catch location was the same as the tagging location.

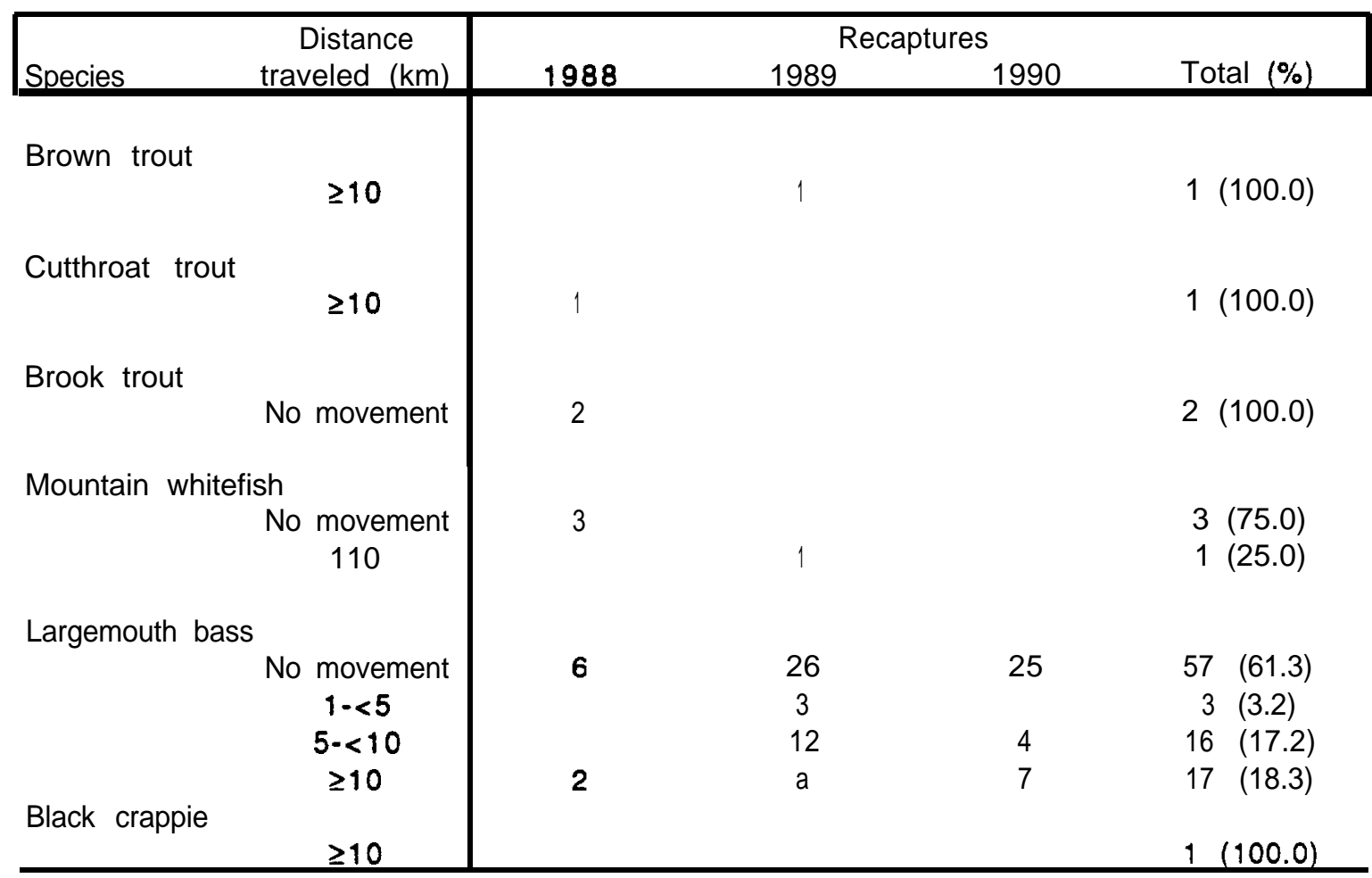


Largemouth bass tended to exhibit the most movement within the reservoir. It's possible that some of this movement was due to relocating of bass during tournaments. Largemouth bass that were tagged at bass tournaments and later caught by electrofishing, gill netting or by anglers were often recaptured in locations other than their release (Table 3.41). During the study 39\% of bass released after a bass tournament were captured in different locations. Two of these traveled as far as 42 kilometers.

\subsection{MOVEMENT AND MIGRATION OF RADIO AND SONIC TAGGED LARGEMOUTH BASS}

A total of 67 days from June of 1990 to May of 1991 were spent in the field tracking largemouth bass equipped with sonic and radio transmitters. During the tracking period we found that it was easier to determine an exact location of fish equipped with sonic transmitters than radio transmitters. However, in August,

September and October, the range of signals from sonic transmitters were limited due to heavy macrophyte growths and low water levels. During this time the radio transmitters were much easier to find.

From December 1990 to March 1991 the sloughs were inaccessible due to ice cover. It's possible that some of the bass were in the sloughs during this time because in March, when the ice melted, several bass that hadn't been located for months were found in the sloughs.

\subsubsection{TIGER SLOUGH}

Tiger Slough is located at approximately river mile (RM) 45 in reach 1 of the river (Figure 2.8). Reach 1 was 11 miles long extending from just north of lone, WA at river mile (RM) 34 to RM 45. This section is primarily lacustrine with deep water, an abundance of macrophytes and marshy sloughs. Two radio transmitters and three sonic transmitters were implanted in largemouth bass from Tiger Slough on June 20, 1990. These fish were captured, surgically implanted with transmitters and released in the back of the slough.

Largemouth bass equipped with sonic transmitter 258 was a female of $518 \mathrm{~mm}$ in total length and 2509 grams in weight. After release this fish was not located until almost a year later, on April 2, 1991, at the mouth of Tiger Slough (Figure 3.12). 
Table 3.41. Recapture information on largemouth bass tagged at bass tournaments and recaptured by anglers or during electrofishing and gill netting surveys in 1988, 1989 and 1999. The location BT-2B or BT-9A indicates the fish was captured at an unknown location during a bass tournament and was released at site $2 \mathrm{~B}$ or 9 A.

\begin{tabular}{|c|c|c|c|c|c|c|c|}
\hline SPECIES & $\begin{array}{l}\text { LOCATION } \\
\text { TAGGED }\end{array}$ & $\begin{array}{l}\text { DATE } \\
\text { TAGEED }\end{array}$ & $\begin{array}{c}\text { LENGTHAT } \\
\text { TAGGING }(\mathrm{mm})\end{array}$ & TAG */COLOR & $\begin{array}{l}\text { LOCATION } \\
\text { PECAPTUPED }\end{array}$ & $\begin{array}{c}\text { DATE } \\
\text { PECAPTUFED }\end{array}$ & $\begin{array}{c}\text { LENGTHAT } \\
\text { RECAPTURE }(\mathrm{mm})\end{array}$ \\
\hline Largemouth bass & BT.2B & Jun-89 & 364 & BA 21515 & 2B & Jun-89 & 364 \\
\hline Largemouth bass & $\mathrm{BT}-2 \mathrm{~B}$ & Jun-89 & 353 & BA 21516 & 28 & Jun-89 & 352 \\
\hline Largemouth bass & $B T-2 B$ & Jun-89 & 382 & BA 21562 & Campbell SI. & Jun-89 & 382 \\
\hline Largemouth bass & BT-2B & Jun-89 & 389 & BA 21588 & 28 & Jun-89 & 387 \\
\hline Largemouth bass & BT-2B & Jun-89 & 376 & BA 21628 & Campbell Sl. & Jun-89 & 376 \\
\hline Largemouth bass & BT-28 & Jun-89 & 388 & BA 21640 & Campbell SI. & Jun-89 & 384 \\
\hline Largemouth bass & BT-2Q & Jun-B9 & 388 & BR 21640 & Campbell SI. & Jun-89 & 383 \\
\hline Largemouth bass & BT-2B & Jun-88 & 320 & BA 21658 & Campbell SI. & Jun-89 & 330 \\
\hline Largemouth bass & $B T-2 B$ & Jun-89 & 356 & Rh 39666 & Campbell SI. & Jun-89 & 356 \\
\hline Largemouth bass & BT-28 & Jun-89 & 366 & BA 21678 & $3 \mathrm{~A}$ & Jun.89 & 370 \\
\hline Largemouth base & BT-2B & Jun-8g & 294 & $8 A 21691$ & $2 B$ & Jun-89 & 296 \\
\hline Largemouth bass & $\overline{\mathrm{BT}-2 \mathrm{~B}}$ & Jun-89 & 346 & BA 21694 & $2 B$ & Jun.89 & 346 \\
\hline Largemouth bass & BT-2B & Jun-89 & 364 & BA 21697 & $2 B$ & Jun-39 & 353 \\
\hline Largemouth bass & BT-2B & Jun.89 & 302 & BR 21698 & $2 B$ & Jun-89 & 305 \\
\hline Largemounh bass & BT-2B & Jun-89 & 366 & BA 21715 & Campbell SI. & Jun-69 & 365 \\
\hline Largemouth bass & $B T-2 B$ & Jun-89 & 374 & $B A 21776$ & $2 B$ & Jun-89̣ & 375 \\
\hline Largemouth base & BT-2B & Jun-89 & 412 & BA 21792 & Campbell S1. & Jun-89 & 407 \\
\hline Largemoun bass & BT-2B & Jun-89 & 320 & BA 21815 & $2 B$ & Jun-69 & 317 \\
\hline Largemouth bass & BT.2B & Jun-89 & 337 & BA 21819 & 2B & Jun-89 & 334 \\
\hline Largemouth bass & $B T-2 B$ & Jun+B9 & 436 & OR 21717 & 6 & Aug-89 & 432 \\
\hline Largemouth bass & $B T-2 B$ & May-88 & 382 & YL 18027 & $2 B$ & Jun-89 & 382 \\
\hline Largemouth bass & BT-2B & May-89 & 313 & YL 18049 & 2B & Jun-89 & 308 \\
\hline Largemouth bass & BT.2B & Mav.69 & 356 & $Y L 18056$ & $2 \mathrm{~B}$ & Jun-89 & 444 \\
\hline Largemouth bass & BT-28 & Mav-68 & 408 & $Y L 18063$ & $2 B$ & Jun-B9 & 409 \\
\hline Largemouth bass & BT.2B & Mar.69 & 330 & YL 18376 & $4 A$ & May-89 & 334 \\
\hline Largemouth bass & $\mathrm{BT}-2 \mathrm{~B}$ & Mav. 89 & 309 & YL 18388 & $4 A$ & Jun-89 & 304 \\
\hline Largemouth bass & $\mathrm{BT} \cdot 2 \mathrm{~B}$ & Mav.89 & 378 & YL 18388 & $4 A$ & May.89 & 382 \\
\hline Largemouth bass & $\mathrm{BT}-2 \mathrm{~B}$ & Mav. 89 & 395 & $Y L 18404$ & $2 \mathrm{~B}$ & Jun-89 & 401 \\
\hline Largemouth bass & $\mathrm{BT} \cdot 2 \mathrm{~B}$ & Mer.89 & 420 & $Y L 18414$ & 18 & May-89 & 426 \\
\hline Largemouth bass & $\mathrm{BT} \cdot 2 \mathrm{~B}$ & Mar. 69 & 381 & $Y ! 18445$ & AA & May-89 & 390 \\
\hline Largemoun bass & $B T \cdot 9 A$ & Aug. & 324 & $Y L 12535$ & 84 & May.69 & $3 x$ \\
\hline Largemouth bass & QT-2B & Jun.80 & 376 & BA 21796 & 3 & May-00 & 394 \\
\hline Largemouth bass & BT.2B & 500.60 & 376 & BA 21632 & 3 & Jun-90 & 401 \\
\hline Largemouth base & BT-2B & $\operatorname{sun} \cdot 10$ & 475 & BA 12510 & 11 & Jun-90 & 485 \\
\hline Largemouth bass & $\mathrm{BT}-2 \mathrm{~B}$ & Mav. 89 & 465 & $Y L 18031$ & $2 B$ & Jun-90 & $47 \xi$ \\
\hline Largemouth bass & $8 T-2 B$ & Jun-69 & 325 & BA 21757 & 6 & May-00 & 342 \\
\hline Beysemesh, basa & $B T-2 B$ & Mar.90 & 455 & $Y L=19340$ & 7 & Jun-90 & 445 \\
\hline Largemouth bass & $B T \cdot 2 B$ & $=0$ & 355 & YL 36090 & $2 B$ & surt.90 & 355 \\
\hline Largemouth Das & BT.2B & dun.89 & $2 \sqrt{2}$ & IJ R 21602 & Campbell s I o u & h) Jun-89 & 361 \\
\hline Largemouth bass & $\mathrm{BT}-2 \mathrm{~B}$ & Mar.69 & 370 & $\begin{array}{ll}\text { YL } & 18168 \\
\end{array}$ & near Cusick & May-69 & 419 \\
\hline Largemouth bass & BT-28 & sun. 89 & 316 & \begin{tabular}{|ll} 
8A & 21704 \\
\end{tabular} & $2 B$ & M.3y-90 & 305 \\
\hline Largemouth bass 1 & BT.2B & $\sin \ln 9$ & 364 & $B P=21739$ & 28 & $J 41-90$ & \\
\hline Largemouth bass & BT.2B & Jun. 08 & 465 & 21740 & 5 & May-90 & 495 \\
\hline Largemouth bass & BT.2B & Jun. 69 & 407 & BA 21809 & 1 & Aug-90 & 431 \\
\hline Largemouth bess & BT.2日 & Mar.Bo & 339 & YL 18441 & 5 & May-90 & 366 \\
\hline Largemouth bass & ET-28 & May.90 & 410 & YL 36066 & 11 & Jun-80 & 432 \\
\hline Largemouth bass & ET-20 & May-90 & 370 & YL 36323 & 6 & Sep-90 & 413 \\
\hline Largemouth uaso & $B T-2 B$ & Jun-69 & 365 & & 4 & Jun-90 & \\
\hline Largemouth bass & $\mathrm{BT}-2 \mathrm{~B}$ & Jun.69 & 466 & & 4 & Jun.90 & 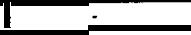 \\
\hline
\end{tabular}


Largemouth bass equipped with sonic transmitter 447 was a female of $460 \mathrm{~mm}$ in total length and 1878 grams in weight. This fish was located only once after its release on June 27, 1990 a few meters farther back into Tiger Slough (Figure 3.12). During the rest of the study this fish was never located again. This was either due to a faulty transmitter, the escapement of the fish from the system over Box Canyon Dam, or capture and harvest of the fish by an angler who didn't report it.

Largemouth bass equipped with sonic transmitter 465 was a female of $515 \mathrm{~mm}$ in total length and 2588 grams in weight. It was located seven days later a few meters from its release location (Figure 3.12). On July 7 it was located in the river approximately 2 miles downstream from Tiger Slough. The next location was made on July 18 five miles downstream from the previous location (RM 39.5). On July 23 it was located slightly downstream from the previous location. On August 2 it was located around RM 38 on its way back upstream. This fish was not located again until December. It's suspected that the loss of signal from August to December was due to a combination of low river elevations and dense macrophyte growth cutting down the signal range of the sonic transmitters; water elevations are lowest and macrophyte growth is heaviest in August. When it was located on December 7 it had moved upstream approximately 24 miles from the last noted location to the islands just outside Campbell Slough at RM 62.

Largemouth bass equipped with radio transmitter $3 \mathrm{~A}$ was a female of $484 \mathrm{~mm}$ in total length and 2325 grams in weight. On June 27 this fish was located a few meters from the original tagging location (Figure 3.12). On July 7 this fish was located downstream from Tiger Slough at RM 41. The next location was July 12, downstream at RM 39.5. On July 23 this fish was located approximately one mile south of Tiger Slough; seven miles upstream from the previous location. On August 2 it was located five mile further upstream near RM 50. The last location was September 27 back downstream near Tiger Slough and RM 45.

Largemouth bass equipped with radio transmitter $2 \mathrm{~B}$ was a female of $501 \mathrm{~mm}$ in total length and 2313 grams in weight. This fish was a recapture that had been tagged in June of 1988 in Tiger Slough when it was $493 \mathrm{~mm}$ long. It's first location after release was on July 7, 1990 seven miles downstream in a bay southeast of lone (Figure 3.12). This fish was located in the same area on July 

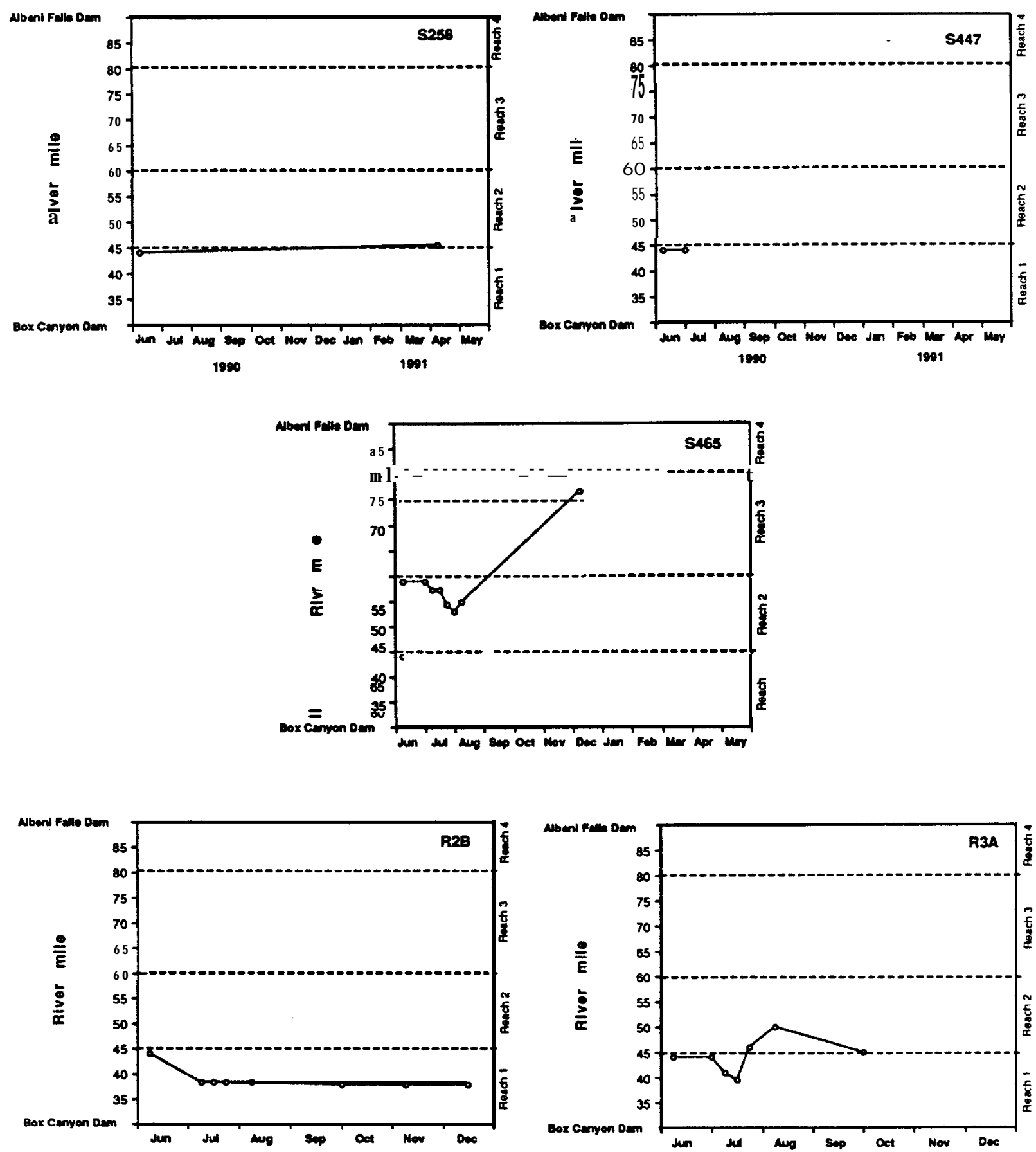

Figure 3.12. Recorded locations (river mile) and movements of sonic and radio tagged largemouth bass tracked in the Pend Oreille River from June 1990 to June 1991. These fish were tagged and released in Tiger Slough. 
18, July 23 and August 2. On September 27 and November 5 it was located approximately half a mile downstream from the previous location. The last location was on December 15 in the same area.

Three of the five bass tagged in Reach 1 were recorded at each location within Reach 1 (Figure 3.12). Two of the tagged bass moved upstream into the second reach which represented a slightly more riverene section of the river with a narrower deeper channel and fewer macrophytes. One of these fish eventually returned to the release location.

Maps detailing movement and location of each fish tagged in Tiger Slough can be found in Appendix H, Figures H.1-H.5. Habitat utilization of these fish at each location is also recorded in Appendix H, Tables H.1-H.5.

\subsubsection{GARDINER SLOUGH}

Gardiner Slough is located along the west bank of the river at approximately river mile 62 in reach 3 (Figure 2.8). Reach 3 encompassed 20 miles of river from RM 60 to RM 80 . Within this section the river is shallow and slow moving with an abundance of macrophytes. There are also numerous sloughs and backwater areas in this section. One radio transmitter and three sonic transmitters were implanted in largemouth bass from Gardiner Slough. Fish captured in Gardiner Slough were tagged and released on June 20, 1990.

Largemouth bass equipped with sonic transmitter 348 was a male of $428 \mathrm{~mm}$ in total length and 1116 grams in weight, The day after its release this fish was located in the same area it was released (Figure 3.13). On June 30 it was still in the slough. On July 7 it had moved out into the river and was located outside the mouth of Campbell Slough across the river. On this siting the signal (beep) from the transmitter was inconsistent. The fish was never located again after this siting and its suspected this was due to a faulty transmitter.

Largemouth bass equipped with sonic transmitter 456 was a female of $476 \mathrm{~mm}$ in total length and 1828 grams in weight. This fish was a recapture that had been tagged at a bass tournament in May of 1989 at a length of $465 \mathrm{~mm}$. It was reportedly released in the Riverbend area after the tournament. After its release this fish was located directly across the river in Campbell Slough on July 6 
and 7 (Figure 3.13). The third location was downstream at river mile (RM) 58.5 on July 17 . On July 23 , this fish was located a half mile further downstream. The fifth location was at RM 52 on August 1. This fish was not located again until March of 1991. Again, it's believed this was due to low river elevations and dense macrophyte growth cutting down the range and intensity of the sonic signal. On March 6, 1991 this fish was located back upstream at RM 63. On March 21 and 29 it was located in the same area.

Largemouth bass equipped with sonic transmitter 2228 was a male of $408 \mathrm{~mm}$ in total length and 1134 grams in weight. At two different times on June 30 this fish was located in Gardiner Slough (Figure 3.13). It was not located again until October 17 when it was located in the same area but on the opposite side of the river from the release location (RM 63). The next location wasn't until May 26, 1991. On this date it was located back in Gardiner Slough in the same location it was tagged and released.

Largemouth bass equipped with radio transmitter $6 \mathrm{~B}$ was a male of $455 \mathrm{~mm}$ in total length and 1762 grams in weight. This fish was a recapture that had been tagged in August of 1988 at approximately river mile (RM) 57 . At the time of the first tagging this fish was $431 \mathrm{~mm}$ long. Ten days after release this fish was still in the slough (Figure 3.13). By July 7 it had moved out into the river and traveled downstream to RM 58. During an aerial survey on July 12 the signal from this fish was not picked up. On July 17 a location was made near RM 57. This fish was located in the same area on July 23 and August 1 . The next location was on September 27 across from the mouth of Cee Cee Ah Slough: upstream approximately nine miles from the previous location. The next location was back downstream at RM 63 on October 17. This fish was recorded in the same area the last time it was located on December 6.

Generally, bass tagged and released in Gardiner Slough remained within habitat reach 3 throughout the study (Figure 3.13). During the winter months it was difficult or impossible to locate fish due to ice cover on the river so it is not known if these fish migrated out of the area or not. However, in the spring of 1991 two of the tagged bass from Gardiner Slough were located in the area they were released.

Maps detailing movement and location of each fish tagged in Gardiner Slough can be found in Appendix H, Figures H.6-H.9. Habitat 

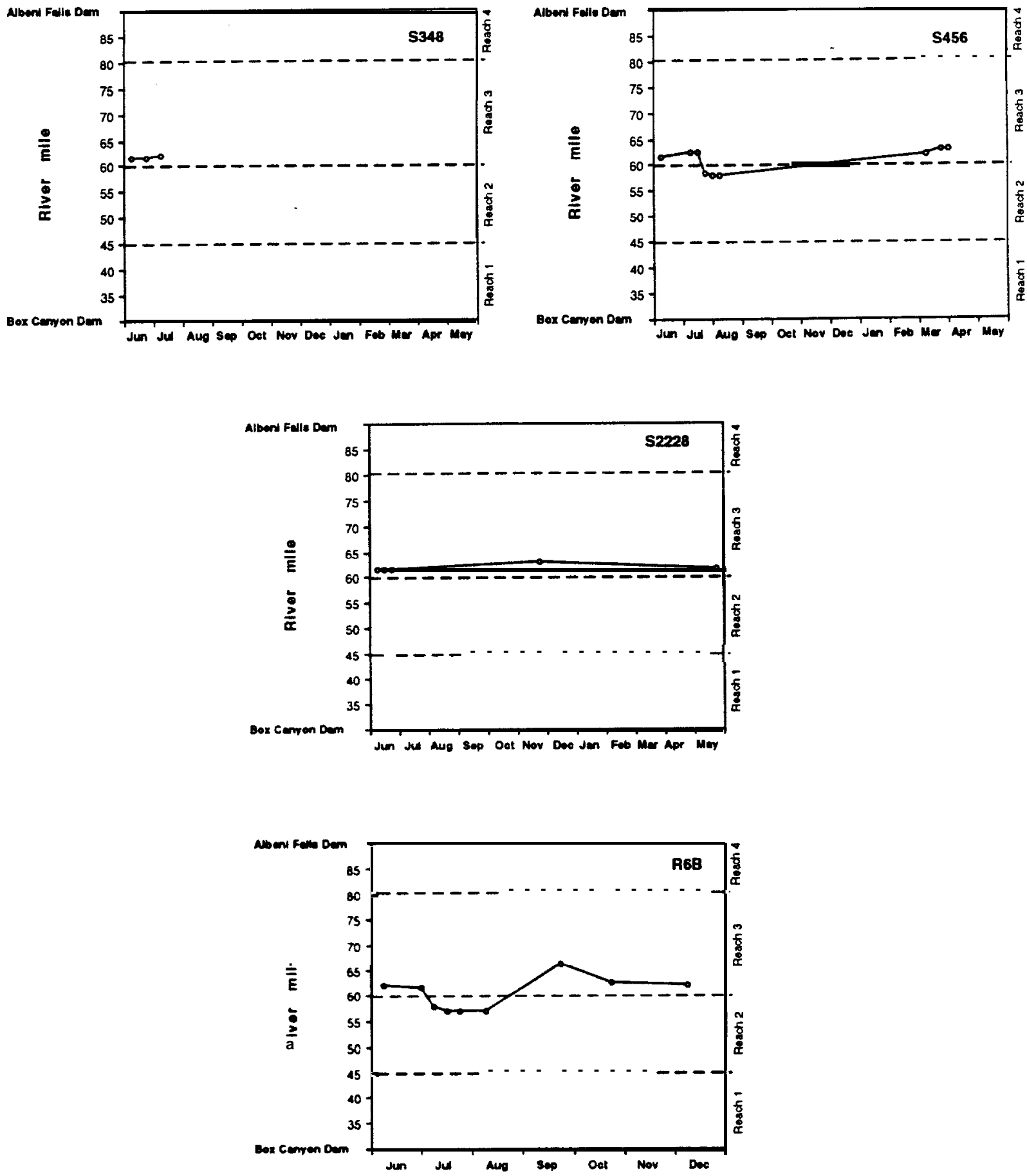

Figure 3.13. Recorded locations (river mile) and movements of sonic and radio tagged largemouth bass tracked in the Pend Oreille River from June 1990 to June 1991 . These fish were tagged and released in Gardiner Slough. 
utilization of these fish at each location is also recorded in Appendix H, Tables H.6-H.9.

\subsubsection{CAMPBELL SLOUGH}

Campbell Slough is located in reach 3 (Figure 2.8) on the east bank of the Pend Oreille River across from Gardiner Slough at approximately river mile 62.5. One radio transmitter and two sonic transmitters were implanted in largemouth bass from Campbell Slough. These fish were captured, tagged and released on June 20, 1990.

Largemouth bass equipped with sonic transmitter 88 was a female of $460 \mathrm{~mm}$ in total length and 1873 grams in weight. On the first two locations of this fish it was still in Campbell Slough (Figure 3.14). By July 25 it was no longer in the slough and during the summer this fish was not located. On October 17 it was located in the river (RM 64) outside Campbell Slough. This fish was not located during the winter; the next location was May 26, 1991. On this date it was found near the islands in the river adjacent to Campbell Slough. In order to check the accuracy of the tracking equipment, examine the condition of the surgery wound and determine overall condition of the fish, it was removed from the water using an electroshocking boat. We found the tracking equipment was very accurate in determining the exact location of the fish. The wound on the ventral surface of the fish had healed nicely except where there were stitches still intact. It appeared that the stitches had caused small ulcerations of the skin. The length of the fish upon recovery was $476 \mathrm{~mm}$ and it weighed 2202 grams. In the year it carried the transmitter around it grew $17 \mathrm{~mm}$ in length and gained 329 grams, despite the surgery wound.

Largemouth bass equipped with sonic transmitter 375 was a female of $463 \mathrm{~mm}$ in total length and 1524 grams in weight. Ten days after release this fish was still in the slough (Figure 3.14). It was located July 6 in the same area. This fish was not located again until October 11, when it was found in the river, downstream from Campbell Slough, at approximately river mile 58.5. The next and last location. of this fish was on May 26, 1991. It was located near the islands adjacent to Campbell Slough at approximately river mile 63.5. This fish was also removed from the water on this date. Again the tracking equipment was very effective in determining the location of the fish. The surgery wound on S375 was completely healed as all of the stitches had fallen out. Upon recovery this fish 

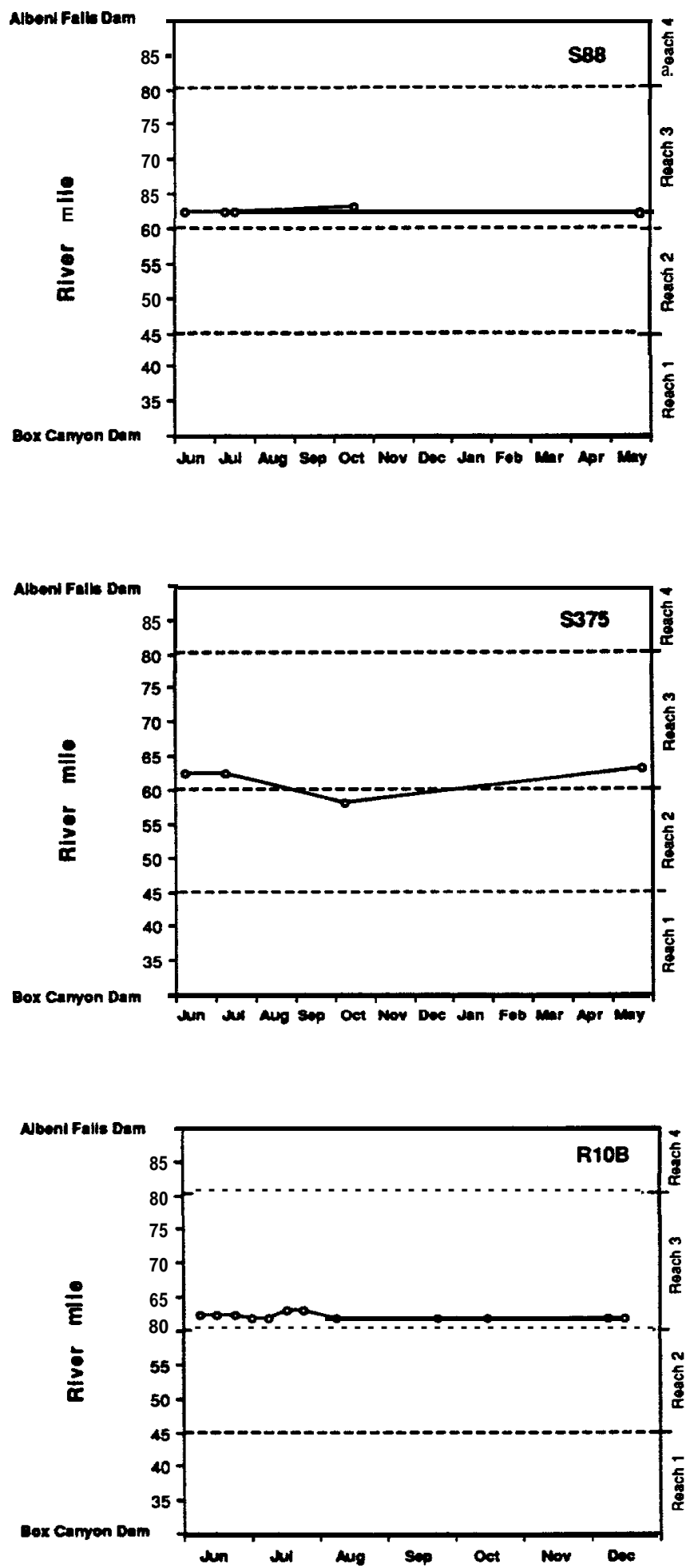

Figure 3.14. Recorded locations (river mile) and movements of sonic and radio tagged largemouth bass tracked in the Pend Oreille River from June 1990 to June 1991. These fish were tagged and released in Campbell Slough. 
was $470 \mathrm{~mm}$ long and 1775 grams. In its year of carrying the transmitter it grew $7 \mathrm{~mm}$ in length and gained 251 grams.

Largemouth bass equipped with radio transmitter $10 \mathrm{~B}$ was a female of $448 \mathrm{~mm}$ in total length and 1801 grams in weight. This fish was located on June 21, 27 and 30 in the slough not far from the release point (Figure 3.14). On July 6 and 7 it was located in the river at the mouth of Campbell Slough. The next two locations on July 15 and 17 were slightly upstream from the previous locations. On August 1 this fish was located in the same general area but downstream. September 27 it was located along the west bank of the river in the same area. The next locations were made October 17, December 6 and December 7 all near the islands adjacent to Campbell Slough.

Generally, all observations of largemouth bass tagged in Campbell Slough were made within habitat reach 3 (Figure 3.14). The only exception was S375 who migrated downstream into reach 2 .

Maps detailing movement and location of each fish tagged in Campbell Slough can be found in Appendix H, Figures H.10-H.12. Habitat utilization of these fish at each location is also recorded in Appendix H, Tables H.10-H.12.

\subsubsection{DIKE SLOUGH}

Dike Slough is located at approximately RM 67.5 along the east bank of the river in reach '3 (Figure 2.8). One radio and three sonic transmitters were implanted in largemouth bass from Dike Slough. These fish were captured, tagged and released on June 18, 1990.

Largemouth bass equipped with sonic transmitter 267 was a female of $480 \mathrm{~mm}$ in total length and 2164 grams in weight. On June 21 and 30 this fish was located in the slough it was released in (Figure 3.15). The next location was on July 6 when the fish was located in Cee Cee Ah Slough which is approximately one mile downstream from Dike Slough. On July 23 this fish was in the river between Cee Cee Ah Slough and Dike Slough. The next three locations, made on August 1, October 11 and October 17 were in the same area. This fish was not located during the winter but on March 21 it was found in Dike Slough. On March 29 it was at the same location. 
Largemouth bass equipped with sonic transmitter 285 was a female of $460 \mathrm{~mm}$ in total length and 2023 grams in weight. It was located on June 30 near the mouth to Campbell Slough: approximately five and a half miles downstream from where it was released (Figure 3.15). On July 6, 15, 17, 23 and August 1 and 2 it was located in the same area. It was located again September 27 along the east bank in the same area. The next location was on October 17 bank slightly downstream from the previous locations. It wasn't located again until May 25, 1991 when it was found in Dike Slough (the release location). At this time the fish was removed from the water using an electrofishing boat so that the accuracy of the tracking equipment could be checked, the surgery wound could be examined and overall condition of the fish could be determined. We found the tracking equipment was very accurate in determining the exact location of the fish. The wound on the ventral surface of the fish had healed very nicely; except for a few stitches that still remained intact it was hard to detect any evidence of surgery. The length of the fish upon recovery was $469 \mathrm{~mm}$ in length and it weighed 2023 grams. So, in the year it carried the transmitter around it grew $9 \mathrm{~mm}$ and lost no weight.

Largemouth bass equipped with sonic transmitter 357 was a female of $505 \mathrm{~mm}$ in total length and 2438 grams in weight. This fish was tagged previously with a floy tag in December 1988 at approximately RM 69 when it was $490 \mathrm{~mm}$ long. It was recaptured in April 1989 at a length of $490 \mathrm{~mm}$ in Campbell Slough. Three days after release this fish still in the slough near the release location (Figure 3.15). The next week, on June 30, this bass had moved five miles downstream from Dike Slough and was located near the islands adjacent to Campbell Slough. On July 17 it was located 17 miles upstream from the previous location at RM 77 near Dalkena. On July 23 and August 1 it was located near RM 75. This fish was not located again until December 7 when it was found near the mouth of Pow Wow Slough (RM 70). The last location was made on March 21, 1991 when this fish was located in Pow Wow Slough.

Largemouth bass equipped with radio transmitter $5 \mathrm{~B}$ was a female of $515 \mathrm{~mm}$ in total length and 2266 grams in weight. On June 21 and 27 this fish was still in Dike Slough (Figure 3.15). June 31 this fish was located in the river near the mouth of Dike Slough. The next location was made July 12 eight miles upstream from the previous location. On July 15 it was located at approximately RM 73 

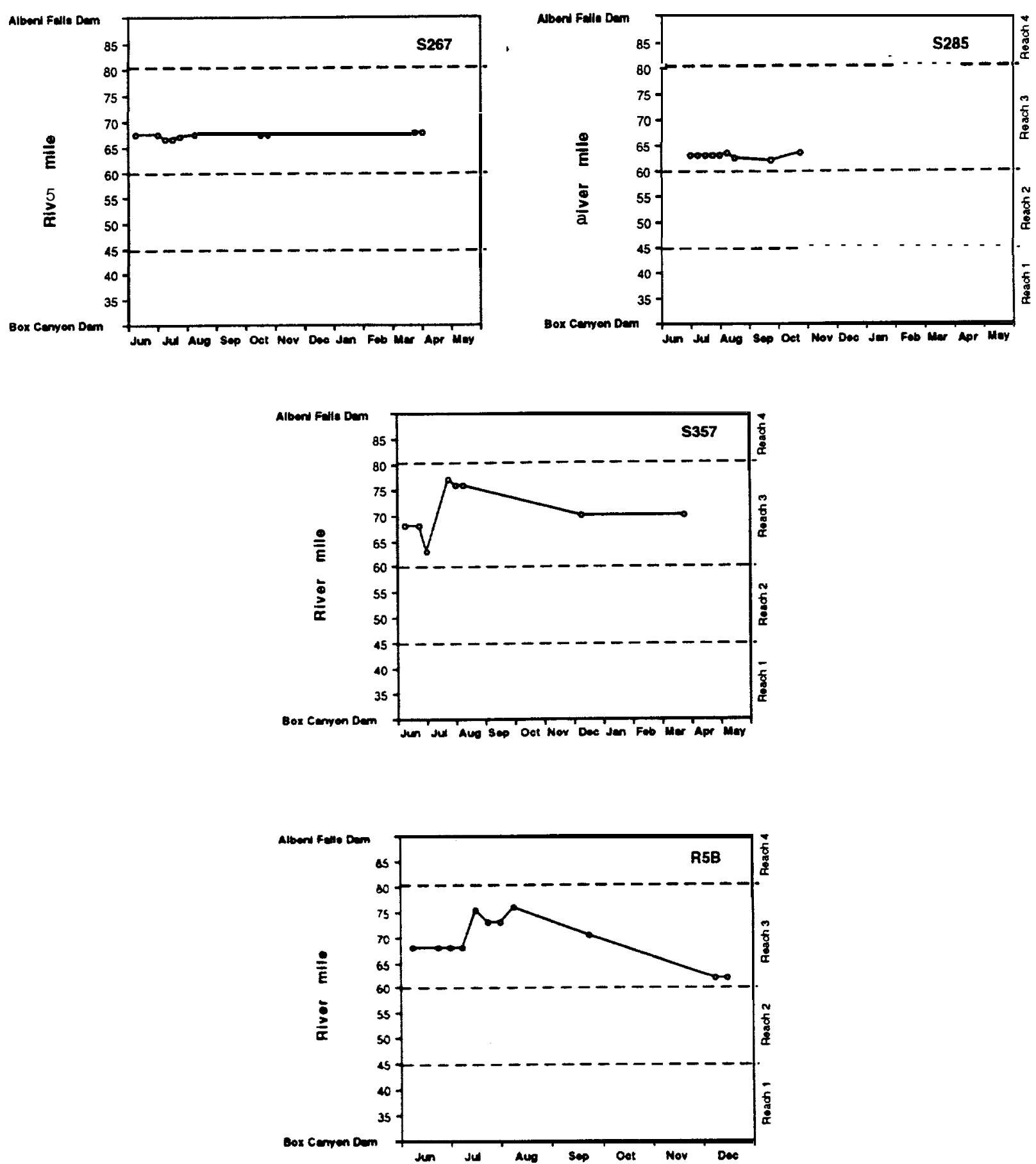

Figure 3.15. Recorded locations (river mile) and movements of sonic and radio tagged largemouth bass tracked in the Pend Oreille River from June 1990 to June 1991. These fish were tagged and released in Dike Slough. 
along the west bank. July 23 it was still in the same area but along the east bank. The next location was back upstream at RM 76 on August 1. September 27 this fish was located near RM 70 along the west bank. The last two locations were made December 6 and 7 at the north tip of the islands adjacent to Campbell Slough (RM 63).

Without exception, all observations of largemouth bass tagged in Dike Slough were made within habitat reach 3 (Figure 3.15).

Maps detailing movement and location of each fish tagged in Campbell Slough can be found in Appendix H, Figures H.13-H.16. Habitat utilization of these fish at each location is also recorded in Appendix H, Tables H.13-H.16.

\subsubsection{POW WOW SLOUGH}

Pow Wow Slough is located along the east bank of the Pend Oreille River at approximately RM 69.5 in the third reach (Figure 2.8) of the study area. Two radio transmitters and three sonic transmitters were implanted in largemouth bass from Pow Wow Slough. These fish were captured, tagged and released on June 18, 1990.

Largemouth bass equipped with sonic transmitter 249 was a female of $494 \mathrm{~mm}$ in total length and 2439 grams in weight. On June 21 and 29 this fish was still located in the slough (Figure 3.16). On June 30 it had moved to near the mouth and the following day was not found in the slough. After this fish left the slough it was not located again until October 11, when it was found in the middle of the river at approximately RM 69. This fish was not located during the winter months. On March 21 and 29 it was found in Cusick Slough, on the west side of the river opposite of Pow Wow Slough. May 5 this fish was back in Pow Wow Slough. The last location for this fish was on May 25 in Pow Wow Slough. On this date the fish was removed from the water using an electrofishing boat so that the accuracy of the tracking equipment could be checked, the surgery wound could be examined and overall condition of the fish could be determined. We found the tracking equipment was very accurate in determining the exact location of the fish. The surgery wound on the ventral surface of the fish had healed completely except where there were still stitches present. The condition of the fish was excellent. It was $503 \mathrm{~mm}$ long and weighed 2452 grams. In the year it carried the transmitter it grew $9 \mathrm{~mm}$ in length and gained 13 grams. 
Largemouth bass equipped with sonic transmitter 276 was a female of $480 \mathrm{~mm}$ in total length and 1985 grams in weight. After its release on June 18, this fish was found only once; six months later on December 15 (Figure 3.16). On this date it was approximately three miles upstream from the slough it was released in. This fish was not located again during the study. It is not known where this fish was from July to December or from December to May. Evidently this fish was either out of range of the receiving equipment during tracking or the transmitter wasn't working continuously.

Largemouth bass equipped with sonic transmitter 294 was a female of $440 \mathrm{~mm}$ in total length and 1365 grams in weight. It was located June 19, 21 and 27 still in Pow Wow Slough (Figure 3.16). This fish was not found again until February of 1991. February 13 and 27 it was located in the river at the mouth of Pow Wow Slough. At this time the slough was frozen over. On March 21 this fish was in the same area but had moved downstream about half a mile. March 29 it was found slightly upstream and along the west bank of the river. On May 10 this fish was captured and harvested by an angler in Cusick Slough.

Largemouth bass equipped with radio transmitter $5 \mathrm{~A}$ was a female of $425 \mathrm{~mm}$ in total length and 1288 grams in weight. June 19 and 21 it was still located in Pow Wow Slough (Figure 3.16). The next location was made across the river in Cusick Slough on June 27. During an aerial survey on July 12 the signal from $5 \mathrm{~A}$ was not received. July 15 and 17 this fish was found approximately three miles downstream along the east bank near Cee Cee Ah Slough (RM 65). July 23 and August 1 it was located about half a mile upstream from the previous location, outside the mouth of Dike Slough. The last location was September 27 when this fish was in the same area, but on the opposite side of the river near the mouth of Trimble Slough. This fish was not found again during the study. Either the transmitter quit emitting signals in September or this fish was harvested by an angler who didn't report it.

Largemouth bass equipped with radio transmitter $6 \mathrm{~A}$ was a female of $470 \mathrm{~mm}$ in total length and 1810 grams in weight. June 19 and 21 this fish was still located in Pow Wow Slough (Figure 3.16). On June 27 it was located about 2 miles downstream at the south end of Dike Slough (RM 68). By June 30 it had moved into the river and was located along the west bank across from Cee Cee Ah 

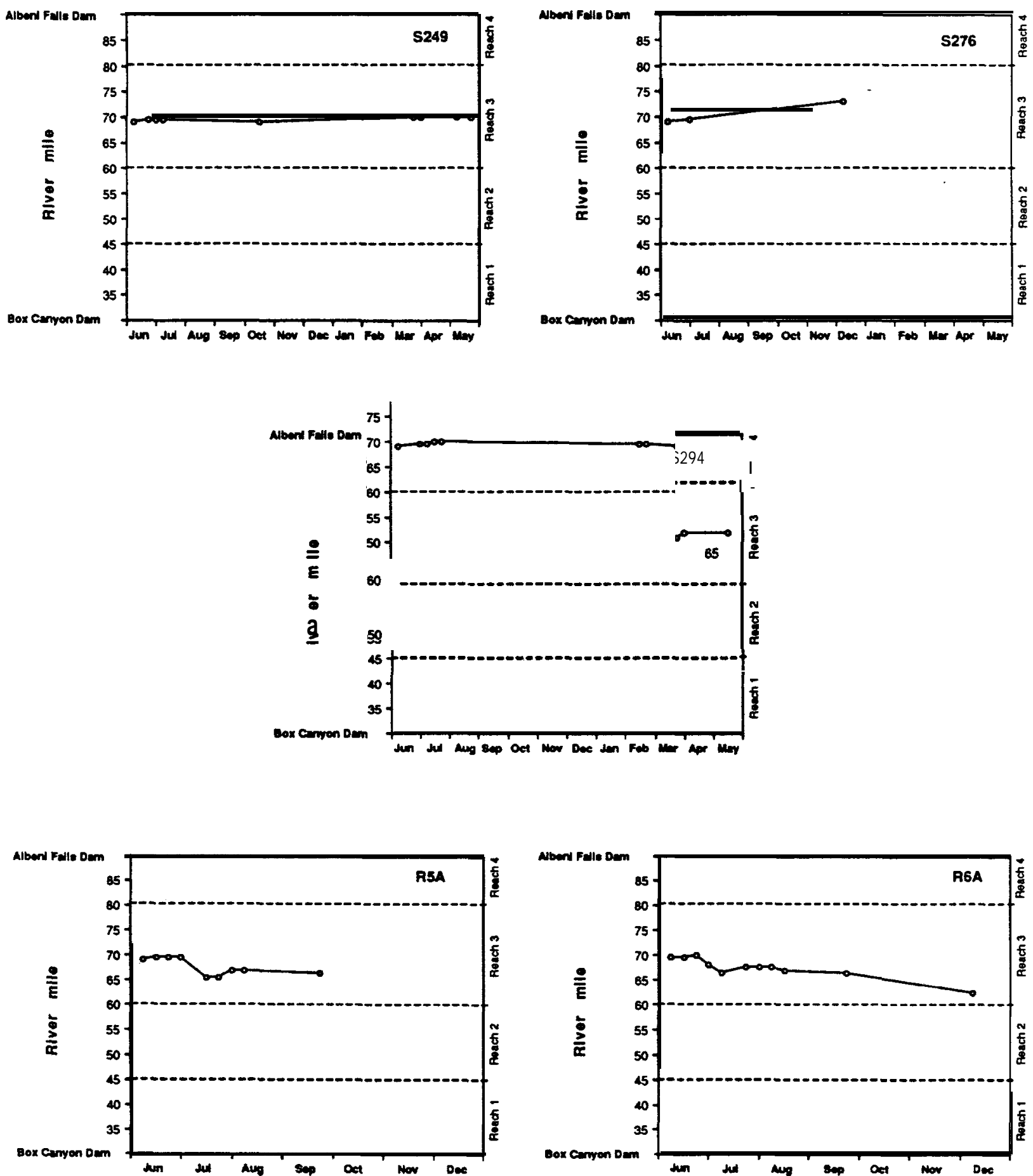

Figure 3.16. Recorded locations (river mile) and movements of sonic and radio tagged largemouth bass tracked in the Pend Oreille River from June 1990 to June 1991. These fish were tagged and released in Pow Wow Slough. 
Slough at approximately RM 67. During an aerial survey on July 12 the signal from 6A was not received. On July 15 this fish was located back upstream at the mouth of Dike Slough (RM 68). It was located in the same area on July 17, 23, August 1 and September 27. This fish was not located again until December 7 when it was found approximately four miles downstream near the island outside of Campbell Slough.

Without exception, all observations of largemouth bass tagged in Pow Wow Slough were made within habitat reach 3 (Figure 3.16).

Maps detailing movement and location of each fish tagged in Pow Wow Slough can be found in Appendix H, Figures H.17-H.21. Habitat utilization of these fish at each location is also recorded in Appendix H, Tables H.17-H.21.

\subsubsection{INDIAN ISLAND SLOUGH}

Indian Island is located approximately at RM 80.5 just on the border of habitat reach 4 (Figure 2.8). Reach 4 was 8 miles long extending from RM 80 to RM 88 at Albeni Falls. This section of the river represents the most riverine habitat of the reservoir. The channel is narrow, with a detectable current and fewer macrophytes. The center of Indian Island is submerged, creating a slough from March to July of each year. Two radio transmitters and two sonic transmitters were implanted in largemouth bass from Indian Island Slough. These fish were captured, tagged and released on June 19, 1990.

Largemouth bass equipped with sonic transmitter 555 was a female of $475 \mathrm{~mm}$ in total length and 1772 grams in weight. Three days after release this fish was still in Indian Island Slough (Figure 3.17). On July 1 and 6 it was still in the slough but had moved to the mouth. This fish was not located again until December 15 when it was found approximately 6 miles downstream, outside the mouth of Red Norse Slough.

Largemouth bass equipped with sonic transmitter 2237 was a female of $466 \mathrm{~mm}$ in total length and 1617 grams in weight. On June 21,27 and July 6 this fish was still located in the slough (Figure 3.17). By July 17 it had moved out of the slough into the river and was located approximately 2 miles downstream from Indian Island. The next location was July 23, when this fish was located back upstream along the east bank of Indian Island at RM 81. On August 1 
it was located back downstream at RM 77.5. This fish was not located again until December 15 when it was found in the river along the west side of Indian Island (RM 80). On January 23 it was located in the same area.

Largemouth bass equipped with radio transmitter $2 \mathrm{~A}$ was a female of $40 \mathrm{~mm}$ in total length and 1031 grams in weight. June 21 and 27 this fish was still in Indian Island Slough (Figure 3.17). On July 1 , this fish had moved into the river and was located about a mile and a half downstream along the west bank in McCloud Slough. On July 6 it was located back in Indian Island Slough. During an aerial survey conducted on July 12 this fish was not picked up. The next location was approximately five miles downstream from Indian Island on July 15 at RM 75. On July 23 it was located about a mile further downstream (RM 74). On August 1 it had moved back upstream to RM 77. The next location was on August 20. This fish was recorded between RM 72 and 73 . On September 27 and October 10 it was located at about RM 74. The last location was on December 12 when in was found back upstream near RM 76.

Largemouth bass equipped with radio transmitter $8 \mathrm{~B}$ was a female of $424 \mathrm{~mm}$ in total length and 1314 grams in weight. On June 21 , three days after release it was still located in the slough. By June 27, this fish had moved to the mouth of the slough. It was located in the same area on July 1 and 6 . During an aerial survey on July 12, it was still in Indian Island Slough. Three days later it had moved into the river and was located along the east bank across from Indian Island. By July 23 it was located approximately four miles downstream (RM 76). On August 1 and September 27 it was located in the same area. On October 10 it was found further downstream, at the mouth of Red Norse Slough (RM 74). The last location was downstream from the previous location, at approximately RM 73.5.

Generally, the bass tagged in Indian Island Slough either migrated a few miles downstream from the island or remained in the vicinity of the island. Most of the habitat utilization observed occurred in reach 3 (Figure 3.17).

Maps detailing movement and location of each fish tagged in Indian Island Slough can be found in Appendix I-I, Figures I-I.22H.25. Habitat utilization of these fish at each location is also recorded in Appendix H, Tables H.22-H.25. 

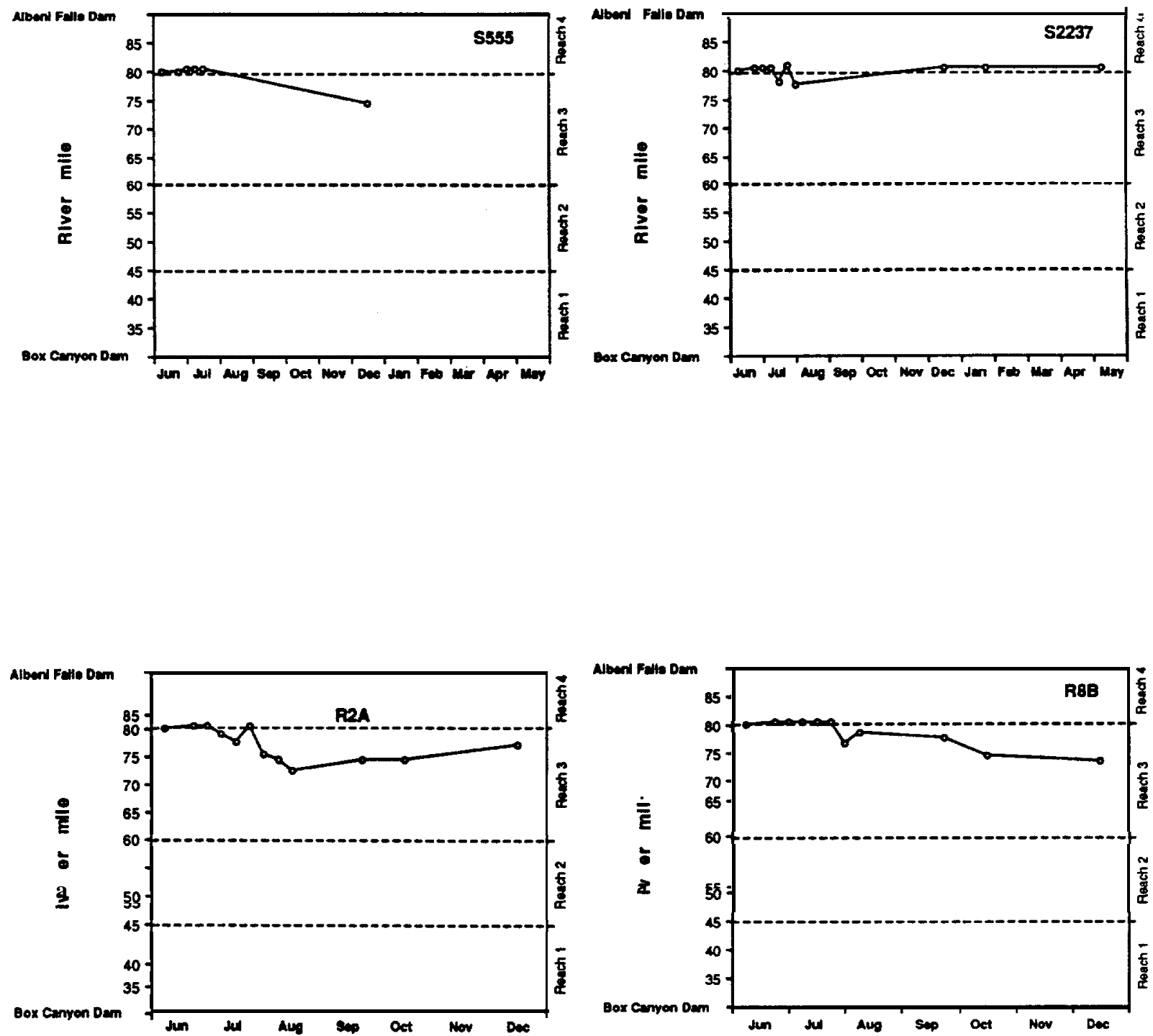

Figure 3.17. Recorded locations (river mile) and movements of sonic and radio tagged largemouth bass tracked in the Pend Oreille River from June 1990 to June 1991. These fish were tagged and released in Indian Island Slough. 


\subsubsection{ASHENFELDER BAY}

Ashenfelder Bay is located on the west *bank of the Pend Oreille River at approximately RM 88 in the reach 4 (Figure-2.8). Two radio transmitters and three sonic transmitters were implanted in largemouth bass from Ashenfelder Bay. These fish were captured, tagged and released on June 19, 1990.

Largemouth bass equipped with sonic transmitter 97 was a female of $446 \mathrm{~mm}$ in total length and 1706 grams in weight. After its release this fish was located in the bay on June 21,27 , July 1, 6, 7 and 16 (Figure 3.18). By July 17 it moved out of the bay into the river and was found on the southeast side of Kelly Island, which is adjacent to Ashenfelder Bay. July 23 it was still in the river but had moved back near the mouth of the bay. This fish was not located again until October 10. At this date it was found in the same location as recorded three months earlier. December 15 it was in the same location. This fish was not located again until March of 1991 when it was found approximately a mile downstream from Ashenfelder Bay. From January through March Ashenfelder Bay was covered with ice making boat access impossible. During this time we searched for tagged bass in the river near the bay but none were located. It's possible that the fish were in the bay under the ice at this time but it's thought unlikely as the bay is only about 3 feet deep in the winter. Two weeks later, on March 30, it had moved back upstream about two miles. The last location of this fish was made April 24; the fish was back inside Ashenfelder Bay.

Largemouth bass equipped with sonic transmitter 339 was a male of $485 \mathrm{~mm}$ in total length and 1810 grams in weight. This fish was previously tagged with a floy tag after it was caught during a bass tournament in June 1989. At the time of this tagging the fish was $475 \mathrm{~mm}$ long. According to bass tournament officials all tournament bass were released near Riverbend (approximately RM 62 ). If that was the case this fish moved 26 miles upstream to where it was captured in Ashenfelder Bay. After it was tagged and released on June 19, 1990 it was located on June 21, 27 and July 1 inside the bay. This fish was not located again until December 15, 1990. It is suspected that during this time the fish was in the river but we were unable to pick up its signal due to dense macrophyte growths and low water levels. In December it was located approximately 10 miles north of Ashenfelder Bay along the west shore of the river near the Dalkena boat launch. This fish was 
caught and harvested by an angler in Ashenfelder Bay, in June of 1991.

Largemouth bass equipped with sonic transmitter 366 was a female of $495 \mathrm{~mm}$ in total length and 2505 grams in weight. Three days after release this fish was no longer in the bay. It was not located until July 17, when it was found seven miles downstream from the release location, at RM 80 just north of Indian Island (Figure 3.18). On July 23 it was located in the same area; approximately a half a mile downstream. This fish was also lost during the late summer and fall months: again probably due to the heavy macrophyte growth and low water level. On December 15 it was located at RM 80 across from Indian Island. It was located in the same area on January 23, 1991. Exact location was difficult to determine due to ice cover on the water during that date.

Largemouth bass equipped with sonic transmitter 284 was a male of $466 \mathrm{~mm}$ in total length and 1736 grams in weight. On June $21,27,30$, July $1,6,7$ and 15 this fish was located at various points inside Ashenfelder Bay (Figure 3.18). By July 23 it had moved outside the bay into the river channel. By August 1 this fish had moved upstream to approximately RM 89, where it was located about half a mile below Albeni Falls Dam among some pilings. On

September 27 it was located at RM 75 (about 14 miles downstream from the previous location). This fish was not found again until December 15 when it was located at the mouth of Red Norse Slough (RM 74).

Largemouth bass equipped with radio transmitter 3B was a female of $460 \mathrm{~mm}$ in total length and 1576 grams in weight. This fish was located inside Ashenfelder Bay on June 21, 27, and July 1 and 6 . On July 12 it was recorded in the same location during an aerial survey. By July 15 this fish had moved out of the bay and 6 miles downstream (RM 81) to the Indian Island area. On July 23 it was located along the east bank of the river around RM 76. The next location was made on August 1, approximately one mile upstream from the previous location, also along the east bank. On September 27 and October 10 it was located in the same area.

Three of the bass tagged in Ashenfelder Bay migrated several miles downstream after they left the bay in July. To the best of our knowledge only one of these fish returned to the bay in the spring. The other two bass tagged in the bay were only located in the 

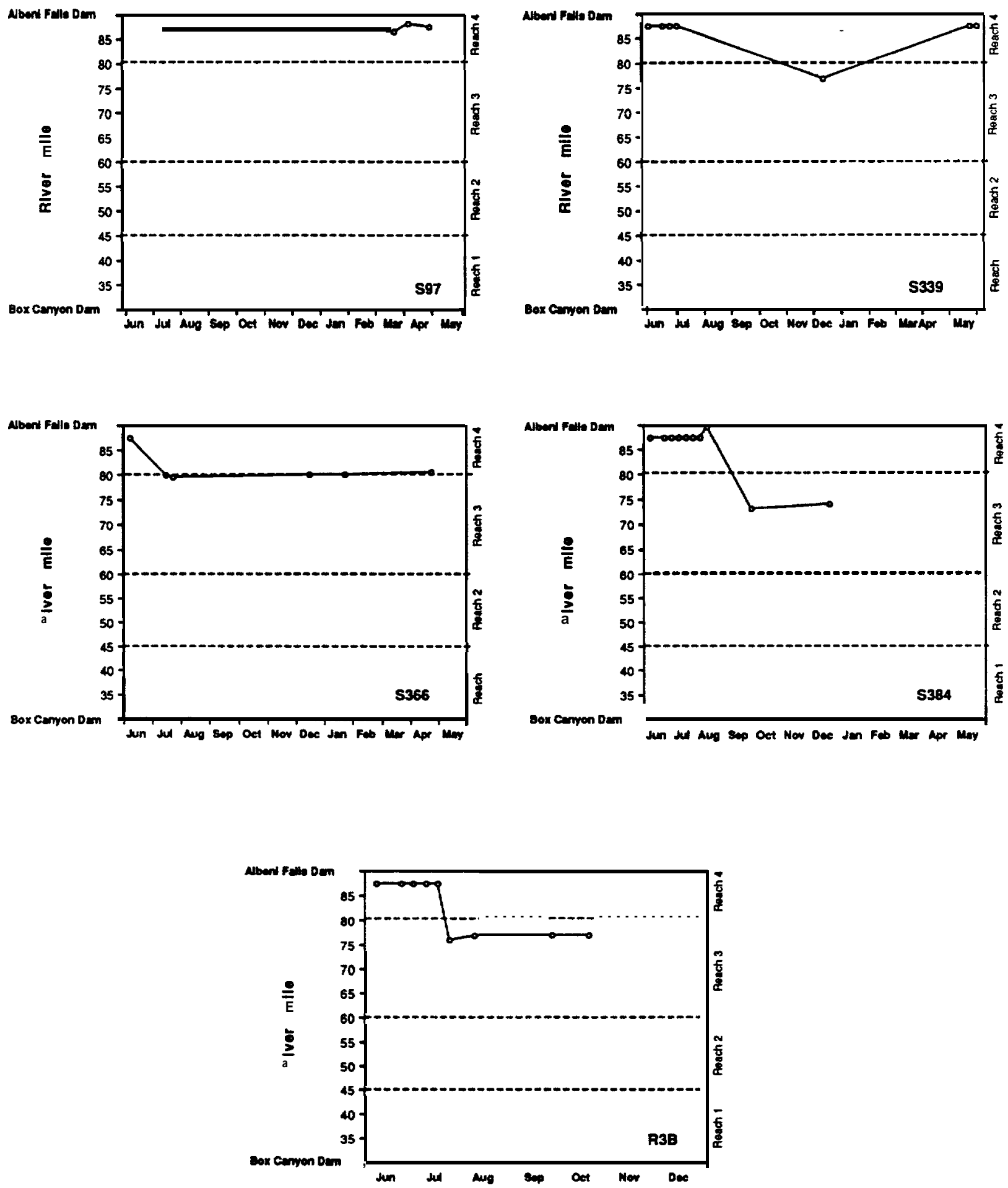

Figure 3.18. Recorded locations (river mile) and movements of sonic and radio tagged largemouth bass tracked in the Pend Oreille River from June 1990 to June 1991. These fish were tagged and released in Ashenfelder Bay. 
surrounding area. None of these fish migrated into habitat reach 1 or 2 , but utilized the habitat in reach 3 and 4 (Figure 3.18).

Maps detailing movement and location of each fish tagged in Ashenfelder Bay can be found in Appendix H, Figures H.26-H.30.

Habitat utilization of these fish at each location is also recorded in Appendix H, Tables H.26-H.30.

\subsection{HABITAT UTILIZATION OF LARGEMOUTH BASS}

One hundred and fifty four habitat utilization observations were made of radio and sonic tagged largemouth bass during the growing season (May-October) in the entire reach of the Box Canyon Reservoir. Figure 3.19 graphically presents the utilization of depth, temperature and cover. Utilized depths during the growing season ranged from $2 \mathrm{ft}$. to $43 \mathrm{ft}$. with an optimum of $10 \mathrm{ft}$. Temperatures of $9^{\circ} \mathrm{C}$ to $24^{\circ} \mathrm{C}$ were utilized during the growing season, with an optimum of $20^{\circ} \mathrm{C}$. The optimum cover during the growing season was macrophytes, although large objects were also widely utilized.

During the winter season (November-April) 36 habitat utilization observations were made of sonic and radio tagged largemouth bass in the entire reach of the reservoir. Utilization of depth, temperature and cover during the winter season are graphically presented in Figure 3.20. Utilized depths during the winter season ranged from $3 \mathrm{ft}$. to $25 \mathrm{ft}$. with and optimum of $10 \mathrm{ft}$. Temperatures of $1^{\circ} \mathrm{C}$ to $12^{\circ} \mathrm{C}$ were utilized during the winter season, with an optimum of $7^{\circ} \mathrm{C}$. The cover utilized most during the winter season was macrophytes, although the second most observations were made in areas where there was no cover.

Habitat utilization observations were made in each of the four reaches (Figure 2.7) to determine if there was differences in utilization as each reach provides a different type of habitat. In reach 1 during the growing season 15 observations were made (Figure 3.21). Depth utilized ranged from $7 \mathrm{ft}$. to $43 \mathrm{ft}$. with an optimum at $12 \mathrm{ft}$. Temperatures ranging from $15^{\circ} \mathrm{C}$ to $20^{\circ} \mathrm{C}$ were utilized, with the optimum at $20^{\circ} \mathrm{C}$. The optimum cover during the growing season in reach 1 was macrophytes. There was an insufficient number of observations (2) made during the winter season to create a utilization indices.

In reach 2 during the growing season, eight observations were made (Figure 3.22). Utilized depths ranged from $4 \mathrm{ft}$. to $20 \mathrm{ft}$. with 

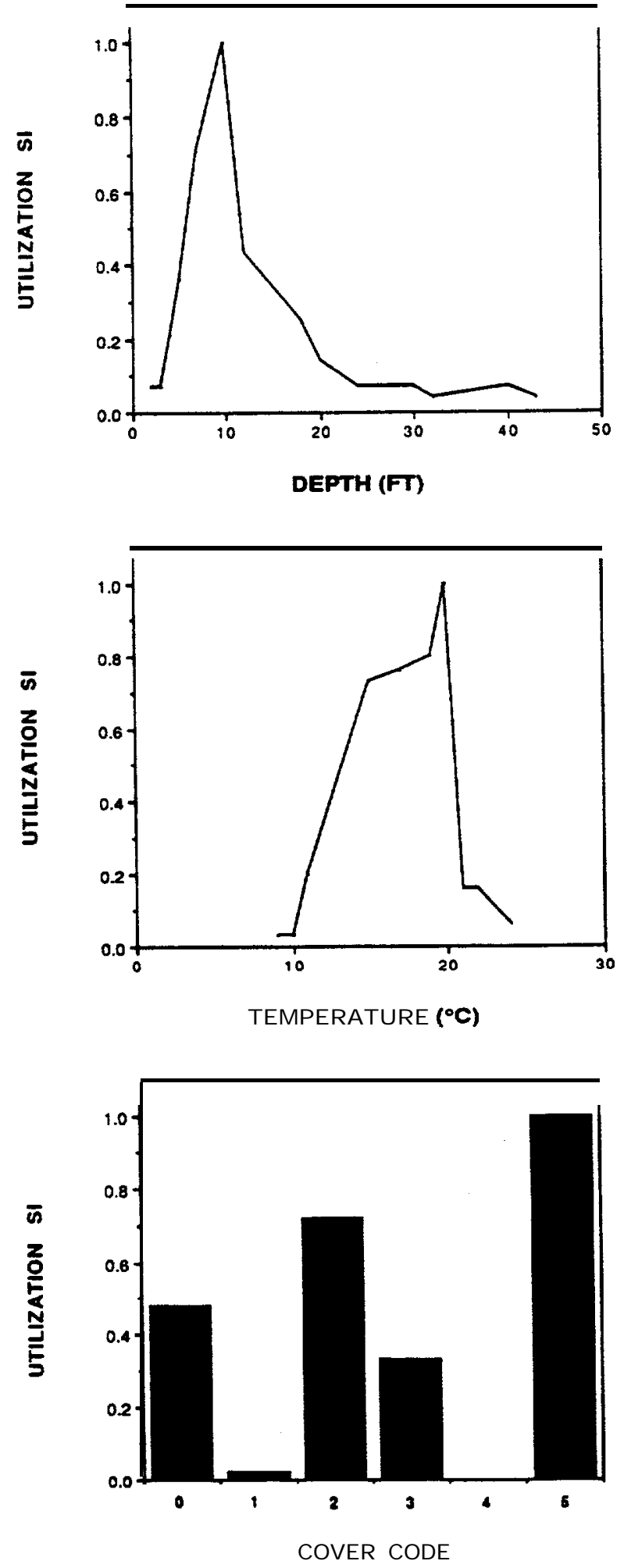

Figure 3.19. Utllization suitability indices for largemouth bass in the entire reach of the Box Canyon Reservoir during the growing season (MayOctober). Cover codes 0 through 5 represent no cover, small object, large object, overhead cover, combination of object and overhead and macrophytes. 

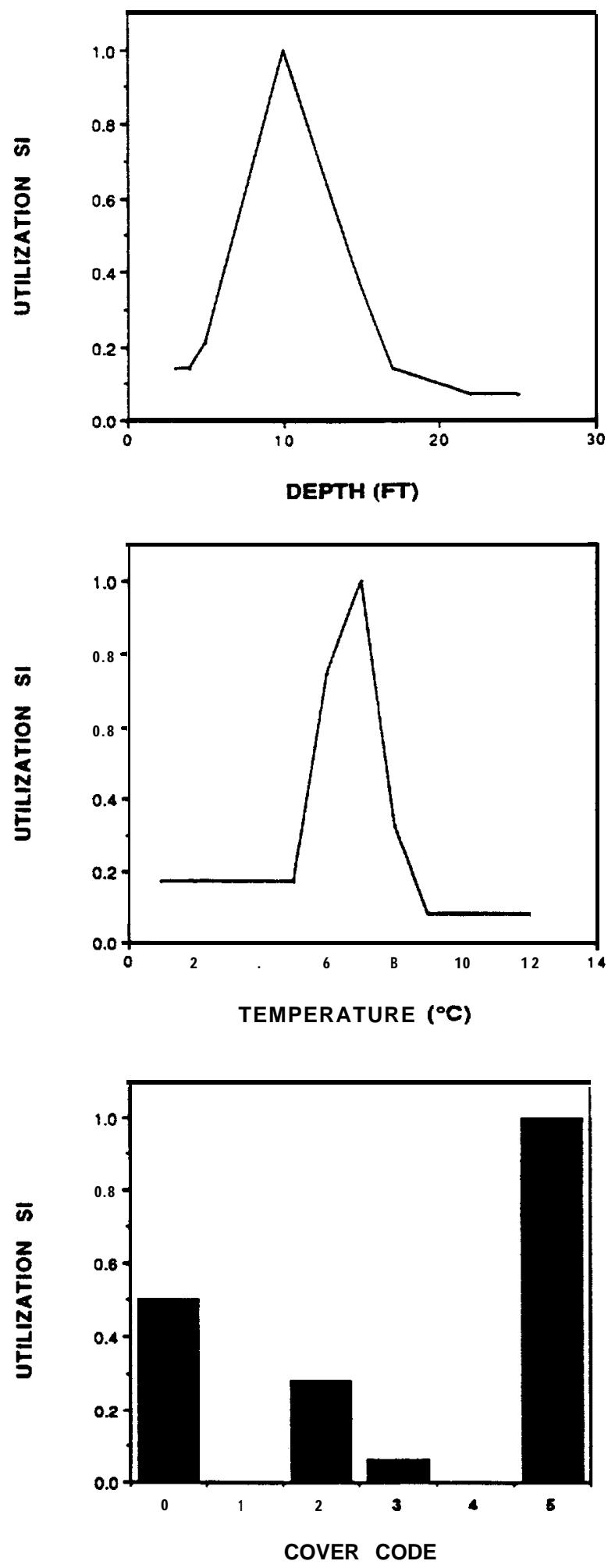

Figure 3.20. Utilization suitability indices for largemouth bass in the entire reach of the Box Canyon Reservoir during the winter season (NovemberApril). Cover codes 0 through 5 represent no cover, small object, large object, overhead cover, combination of object and overhead and macrophytes. , 41 

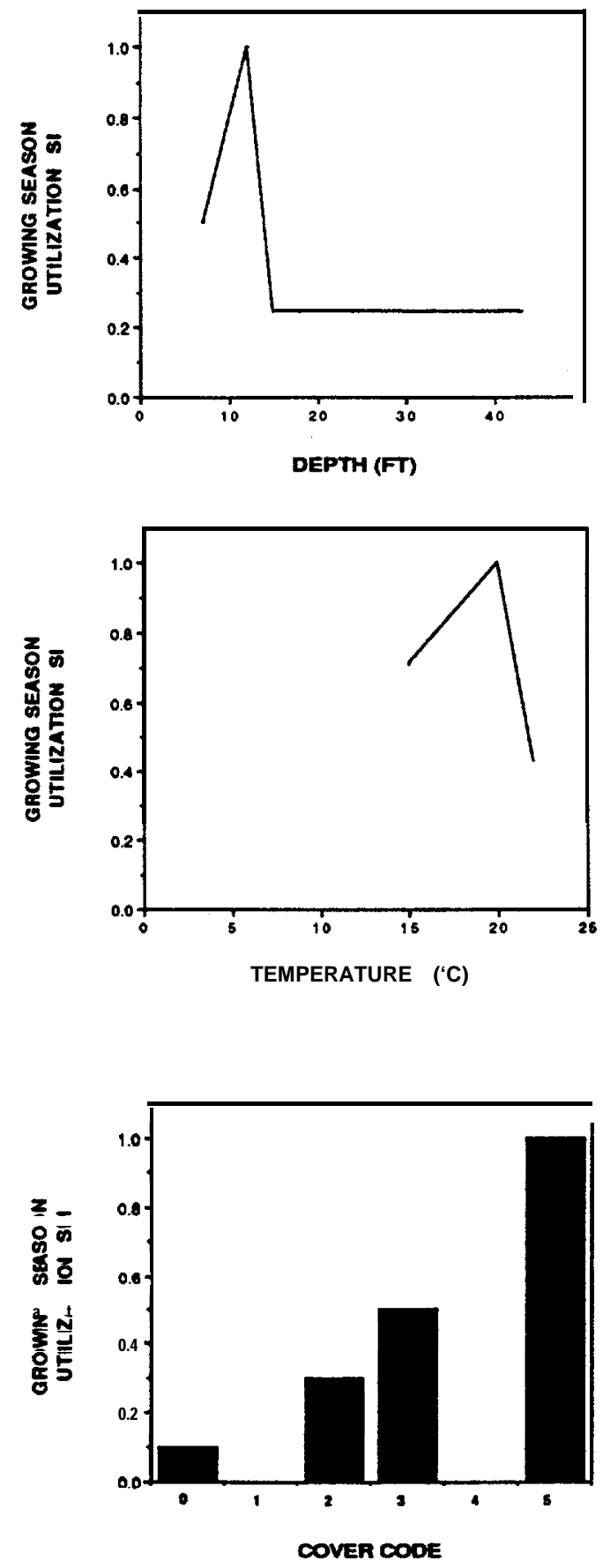

Figure 3.21. Utilization suitability indices for largemouth bass in reach 1 (Figure 2.8) of the Box Canyon Reservoir during the growing season (MayOctober). Cover codes 0 through 5 represent no cover, small object, large object, overhead cover, combination of object and overhead and macrophytes. 
an optimum of $18 \mathrm{ft}$. The optimum temperature for bass in reach 2 was $20^{\circ} \mathrm{C}$ with a range from $11^{\circ} \mathrm{C}$ to $20^{\circ} \mathrm{C}$. Large objects were considered optimum cover in reach 2 , although no cover received the same indices rating as the same number of observations were made of fish utilizing objects and no cover. There were an insufficient number of observations (2) in reach 2 during the winter season to create a utilization indices.

Habitat utilization in reach 3 during the growing season was determined from 75 observations, while utilization during the winter season was determined from 22 observations (Figure 3.23). Depths utilized during the growing season ranged from $2 \mathrm{ft}$. to $30 \mathrm{ft}$. with an optimum at $10 \mathrm{ft}$., while depths utilized during the winter season ranged from $3 \mathrm{ft}$. to $15 \mathrm{ft}$. also with an optimum of $10 \mathrm{ft}$. Temperature utilization ranged from $9^{\circ} \mathrm{C}$ to $24^{\circ} \mathrm{C}$ during the growing season and from $1^{\circ} \mathrm{C}$ to $8^{\circ} \mathrm{C}$ during the winter season. The optimum temperature was $17^{\circ} \mathrm{C}$ during the growing season and $7^{\circ} \mathrm{C}$ during the winter season. Optimum cover in reach 3 during both the growing and winter season was macrophytes.

Forty-one observations were made in reach 4 during the growing season and 4 observations were made in the winter season to determine habitat utilization (Figure 3.24). Depths utilized during the growing season ranged from $3 \mathrm{ft}$. to $26 \mathrm{ft}$. and from $4 \mathrm{ft}$. to $25 \mathrm{ft}$. during the winter season. The optimum depth in reach 4 was $10 \mathrm{ft}$. during the growing season and $15 \mathrm{ft}$. during the winter season. Utilization of temperatures in reach 4 during the growing season ranged from $13^{\circ} \mathrm{C}$ to $21^{\circ} \mathrm{C}$ and from $1^{\circ} \mathrm{C}$ to $12^{\circ} \mathrm{C}$ during the winter season. Growing season optimum temperature was $18^{\circ} \mathrm{C}$, while winter season optimum was $7^{\circ} \mathrm{C}$. Bass in reach 4 were observed utilizing areas where no cover was located during the growing season while during the winter season macrophytes were the optimum cover. 

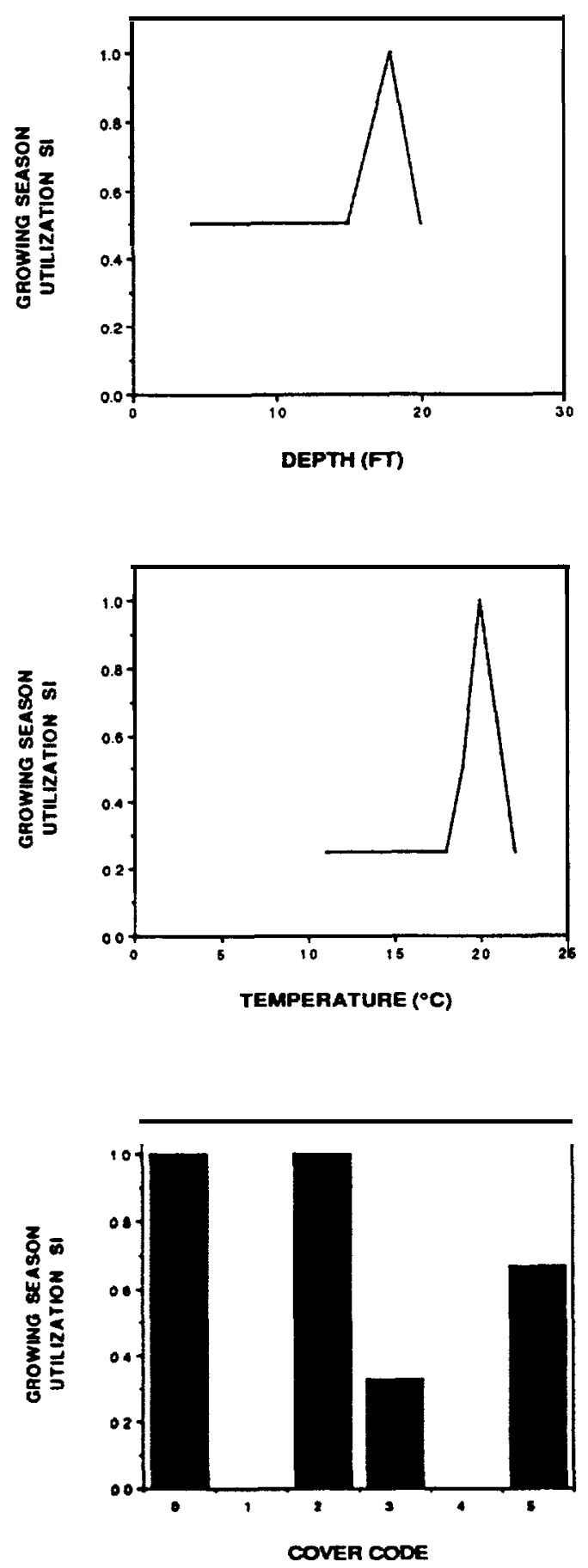

Figure 3.22. Utilization suitability indices for largemouth bass in reach 2 (Figure 2.8) of the Box Canyon Reservoir during the growing season (MayOctober). Cover codes 0 through 5 represent no cover, small object, large object, overhead cover, combination of object and overhead and macrophytes. 

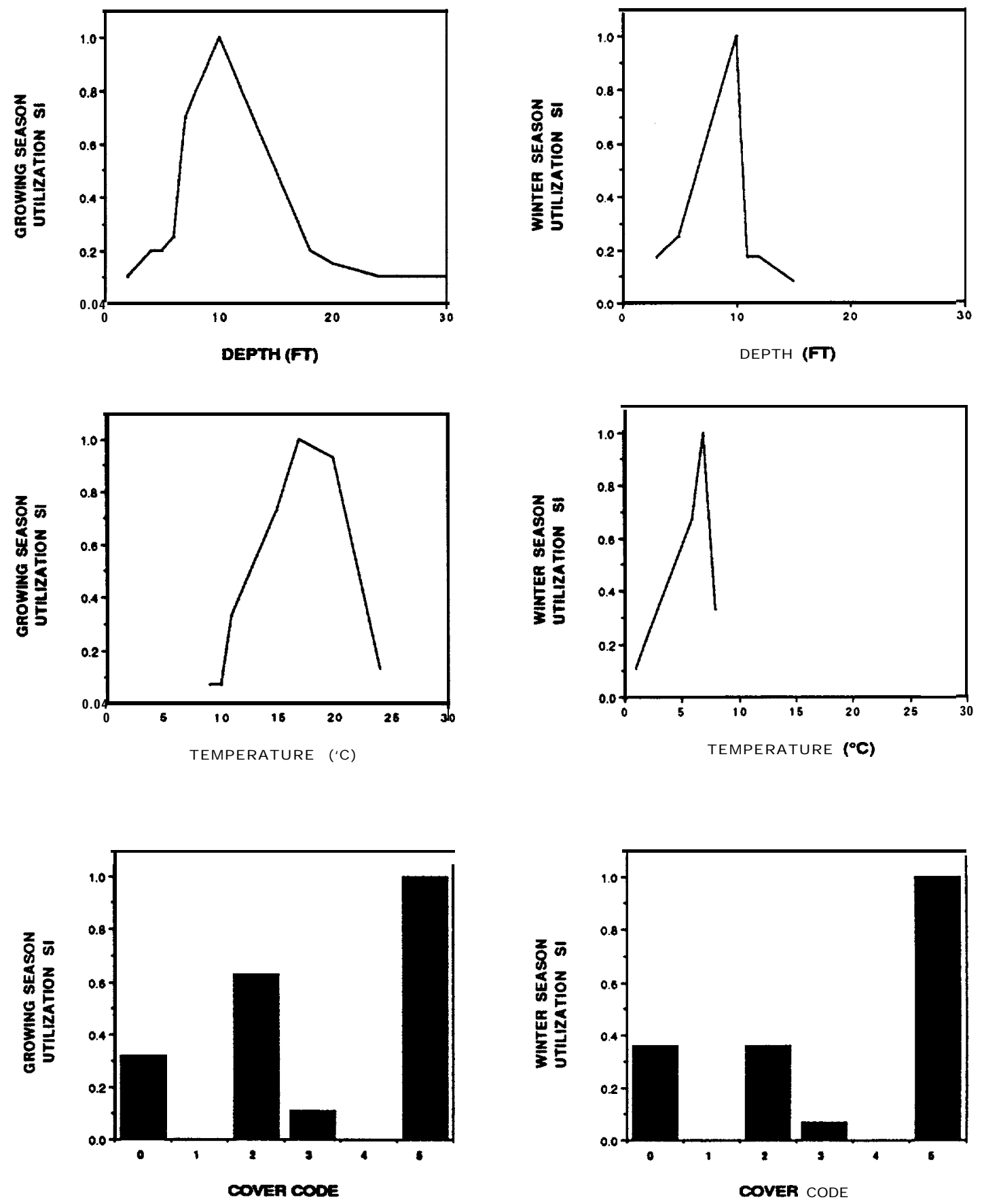

Figure 3.23. Utilization suitability indices for largemouth bass in reach 3 (Figure 2.8) of the Box Canyon Reservoir during the growing season (MayOctober) and the winter season (NovemberApril). Cover codes 0 through 5 represent no cover, small object, large object, overhead cover, combination of object and overhead and macrophytes. 

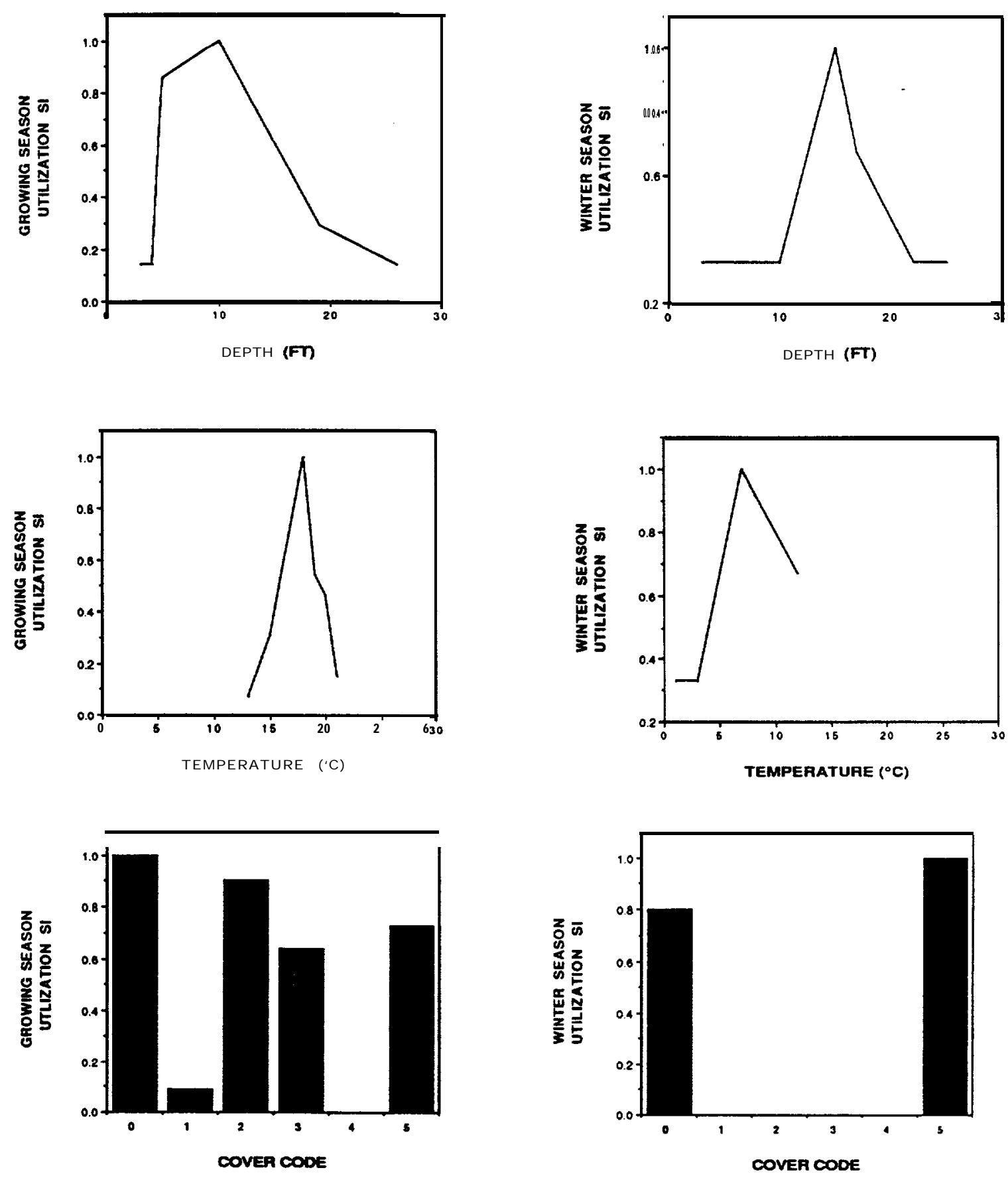

Figure 3.24. Utilization suitability indices for largemouth bass in reach 4 (Figure 2.8) of the Box Canyon Reservoir during the growing season (MayOctober) and the winter season (NovemberApril). Cover codes 0 through 5 represent no cover, small object, large object, overhead cover, combination of object and overhead and macrophytes. 


\subsection{TRIBUTARIES}

\subsubsection{POPULATION ESTIMATES}

Population estimates were made for five tributaries using either the Petersen or removal-depletion method in 1988. Data from the 1988 estimates is not included here as it is not comparable with 1989 and 1990 due to difference in methods and techniques.

In 1989 and 1990 densities of fish (\#/100 m²) were determined for each of the five tributaries using the removaldepletion method. Three assumptions should be met for a removal depletion estimate: (1) no fish can move in or out of the sample area; (2) each fish has an equal chance of being captured; and (3) the probability of capture is constant over all removal occasions. These assumptions were met by: (1) placing blocknets at the upstream and downstream ends of the study reach; (2) keeping the shocking time as close as possible on each pass; and (3) keeping the same crew for each pass to insure consistency in effort between passes.

The average density of brown trout in LeClerc Creek was 2.05 fish/l $00 \mathrm{~m}^{2}$ in 1989 and $0.58 \mathrm{fish} / 100 \mathrm{~m}^{2}$ in 1990 (For location of sites sampled see Figure 2.2). The average density of brook trout in LeClerc Creek was $13.15 \mathrm{fish} / 100 \mathrm{~m}^{2}$ in 1989 and $3.25 \mathrm{fish} / 100 \mathrm{~m}^{2}$ in 1990. The average cutthroat trout densities in LeClerc Creek were $0.45 \mathrm{fish} / 100 \mathrm{~m}^{2}$ in 1989 and $0.10 \mathrm{fish} / 100 \mathrm{~m}^{2}$ in 1990. Rainbow trout were captured in LeClerc Creek during both years but never in sufficient numbers to allow a population estimate. Densities for each species, at each study site, for both years can be found in Figures 3.25 and 3.26. Specific information regarding trout captured in LeClerc Creek is recorded in Appendix J, Tables J.I, J.2, J.Il and J.12.

No brown trout were captured in Ruby Creek in 1989. In 1990 the average density of brown trout was $0.05 \mathrm{fish} / 100 \mathrm{~m}^{2}$ (For location of sites sampled see Figure 2.3). The average density of brook trout in Ruby Creek was 38.33 fish $/ 100 \mathrm{~m}^{2}$ in 1989 and 15.18 fish $/ 100 \mathrm{~m}^{2}$ in 1990. Average cutthroat trout densities in Ruby Creek were 0.18 fish $/ \mathbf{0 0 \mathrm { m } ^ { 2 }}$ in 1989 and $0.03 \mathrm{fish} / 100 \mathrm{~m}^{2}$ in 1990 . Rainbow trout were captured in Ruby Creek during 1990 for an average density of $0.05 \mathrm{fish} / 100 \mathrm{~m}^{2}$. Densities for each species, at each study site, for both years can be found in Figures 3.27 and 3.28. Specific information regarding trout captured in Ruby Creek is recorded in Appendix J, Tables J.3, J.4, J.13 and J.14. 


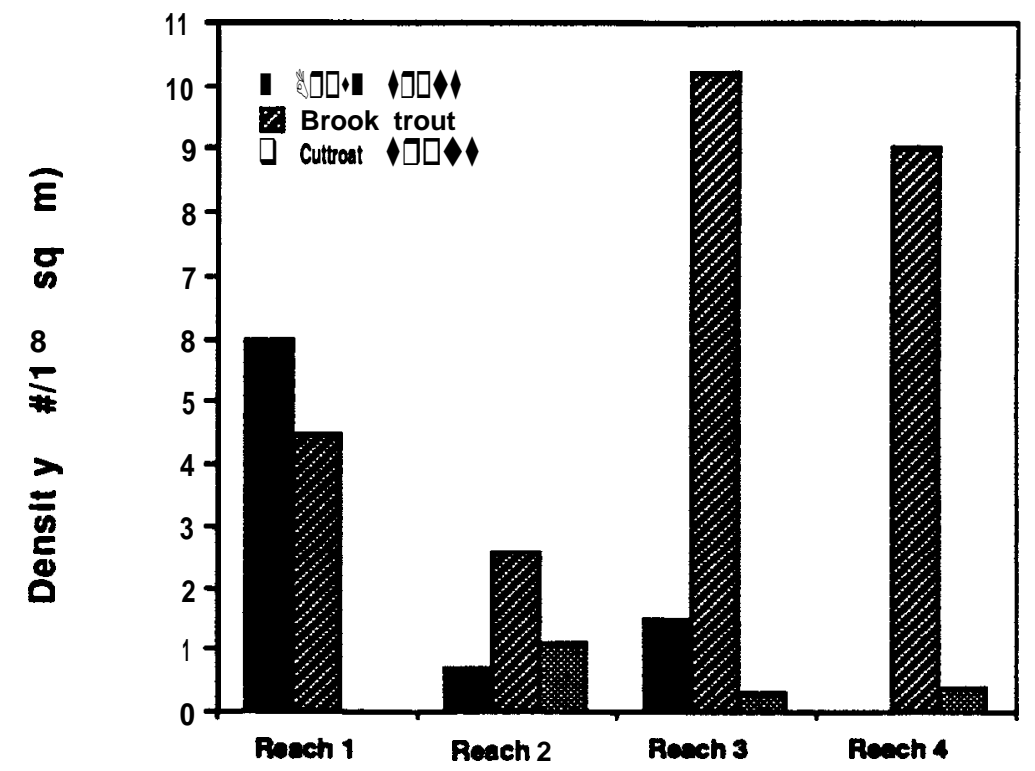

Figure 3.25. Estimated densities of brown trout, brook trout and cutthroat trout at each study site in LeClerc Creek, WA during 1989.

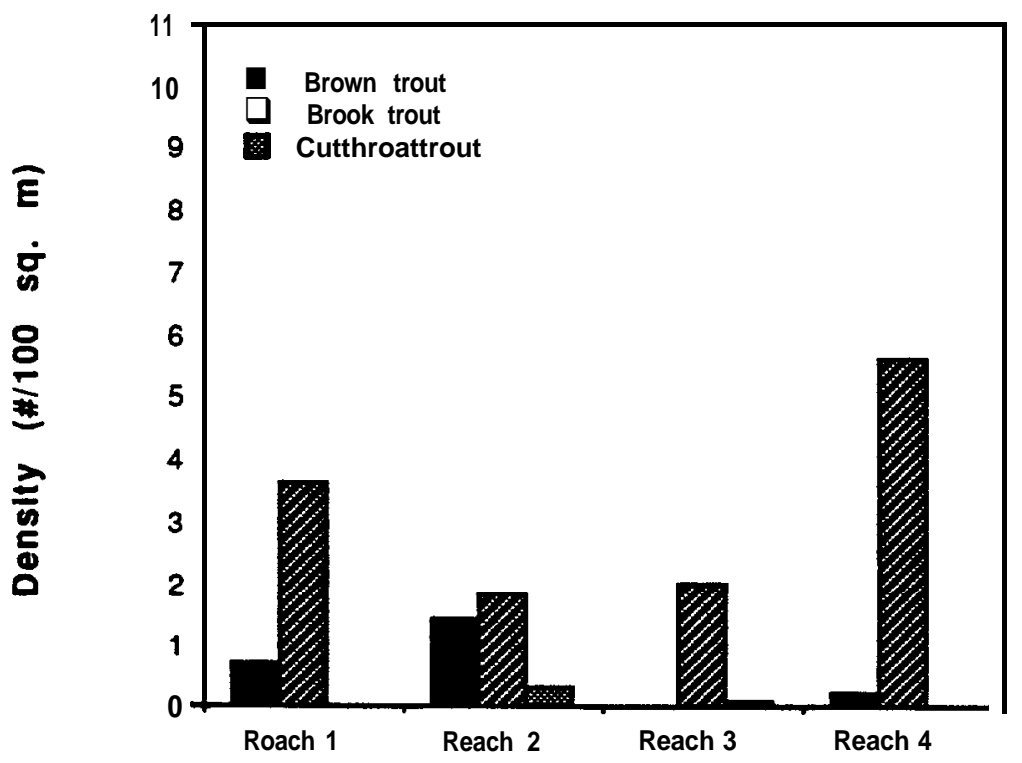

Figure 3.26. Estimated densities of brown trout, brook trout and cutthroat trout at each study site in LeClerc Creek, WA during 1990. 


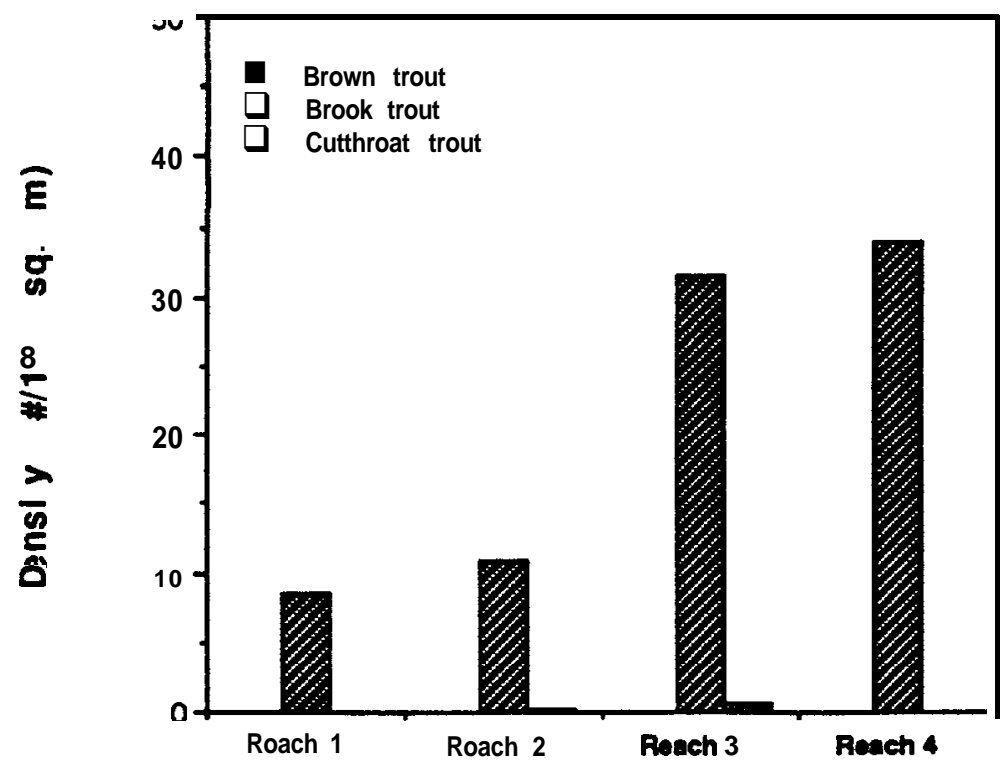

Figure 3.27. Estimated densities of brown trout brook trout and cutthroat trout at each $s$ udy site in Ruby Creek, WA during 1989.

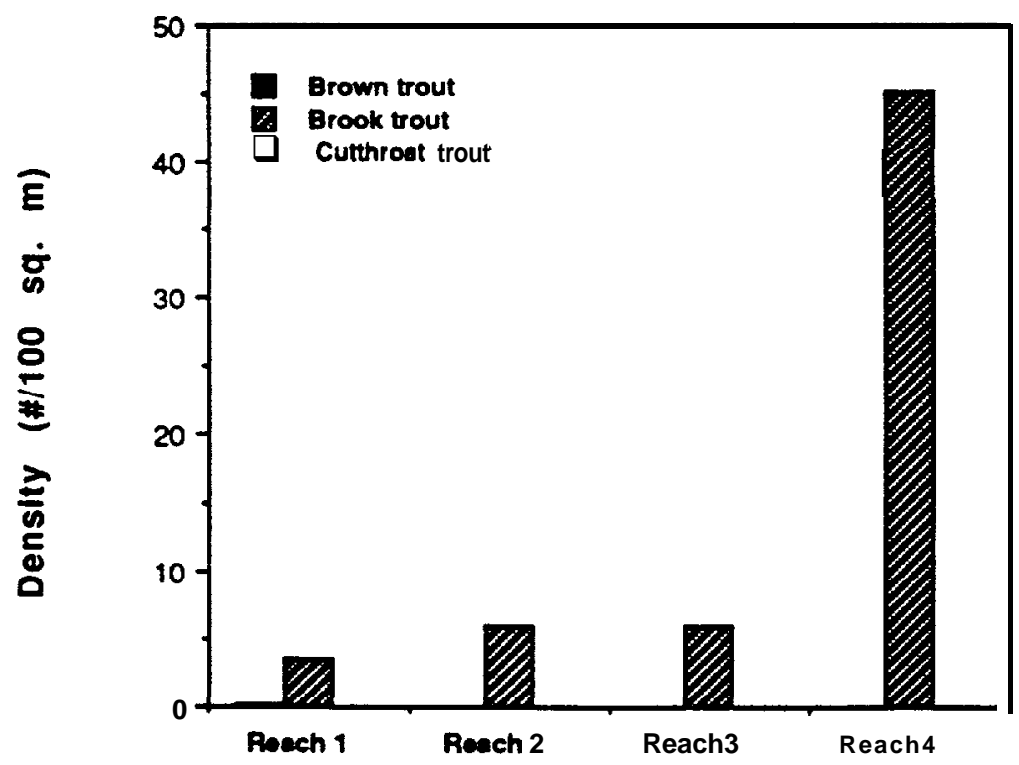

Figure 3.28. Estimated densities of brown trout, brook trout and cutthroat trout at each study site in Ruby Creek, WA during 1990. 
The average density for brown trout in Cee Cee Ah Creek was $16.35 \mathrm{fish} / 100 \mathrm{~m}^{2}$ in 1989 and $4.93 \mathrm{fish} / \mathrm{l} 00 \mathrm{~m}^{2}$ in 1990 (For location of sample sites see Figure 2.4). Average brook trout densities in Cee Cee Ah Creek were 11.5 fish/l 00m² in 1989 and $7.63 \mathrm{fish} / \mathrm{l} 00 \mathrm{~m}^{2}$ in 1990 . Average cutthroat trout densities were $3.30 \mathrm{fish} / \mathrm{l} 00 \mathrm{~m}^{2}$ in 1989 and $1.53 \mathrm{fish} / 100 \mathrm{~m}^{2}$ in 1990 . No rainbow trout were captured in Cee Cee Ah Creek during electroshocking surveys either year. Densities for each species, at each study site, for both years can be found in Figures 3.29 and 3.30. Specific information regarding trout captured in Cee Cee Ah Creek is recorded in Appendix J, Tables J.5, J.6, J.15 and J.16.

No brown trout were captured in Tacoma Creek in 1989. In 1990 one brown trout was captured for a average density of 0.05 fish/100 $\mathrm{m}^{2}$ (For location of sample sites see Figure 2.5). The average density of brook trout in Tacoma Creek was 38.90 $\mathrm{fish} / \mathrm{l} 00 \mathrm{~m}^{2}$ in 1989 and $9.15 \mathrm{fish} / 100 \mathrm{~m}^{2}$ in 1990. Average cutthroat trout densities in Tacoma Creek were $3.93 \mathrm{fish} / 100 \mathrm{~m}^{2}$ in 1989 and $1.63 \mathrm{fish} / \mathrm{l} \mathbf{0 0 \mathrm { m } ^ { 2 }}$ in 1990 . No rainbow trout were captured in Tacoma Creek during electroshocking surveys either year.

Densities for each species, at each study site, for both years can be found in Figures 3.31 and 3.32. Specific information regarding trout captured in Tacoma Creek is recorded in Appendix J, Tables J.7, J.8, J.17 and J.18.

The average density of brown trout in Skookum Creek was $21.68 \mathrm{fish} / \mathrm{l} 00 \mathrm{~m}^{2}$ in 1989 and $3.90 \mathrm{fish} / \mathrm{l} 00 \mathrm{~m}^{2}$ in 1990 (For location of sample sites see Figure 2.6). The average density of brook trout in Skookum Creek was 18.1 fish/l 00m² in 1989 and 9.05 fish $/ 100 \mathrm{~m}^{2}$ in 1990. Average cutthroat trout densities in Skookum Creek were $0.63 \mathrm{fish} / 100 \mathrm{~m}^{2}$ in 1989 and $0.05 \mathrm{fish} / 100 \mathrm{~m}^{2}$ in 1990. Rainbow trout were not captured in Skookum Creek during either year. Densities for each species, at each study site, for both years can be found in Figures 3.33 and 3.34. Specific information regarding trout captured in Skookum Creek is recorded in Appendix $\mathrm{J}$, Tables J.9, J.10, J.19 and J.20.

In general, brown trout densities were observed to be highest in the downstream reaches, while brook trout densities were highest in the upstream reaches of the study tributaries during both years. Skookum and Cee Cee Ah Creeks had the highest densities of brown trout. The highest brook trout densities were found in Ruby and Skookum Creeks. The highest cutthroat density was observed in 


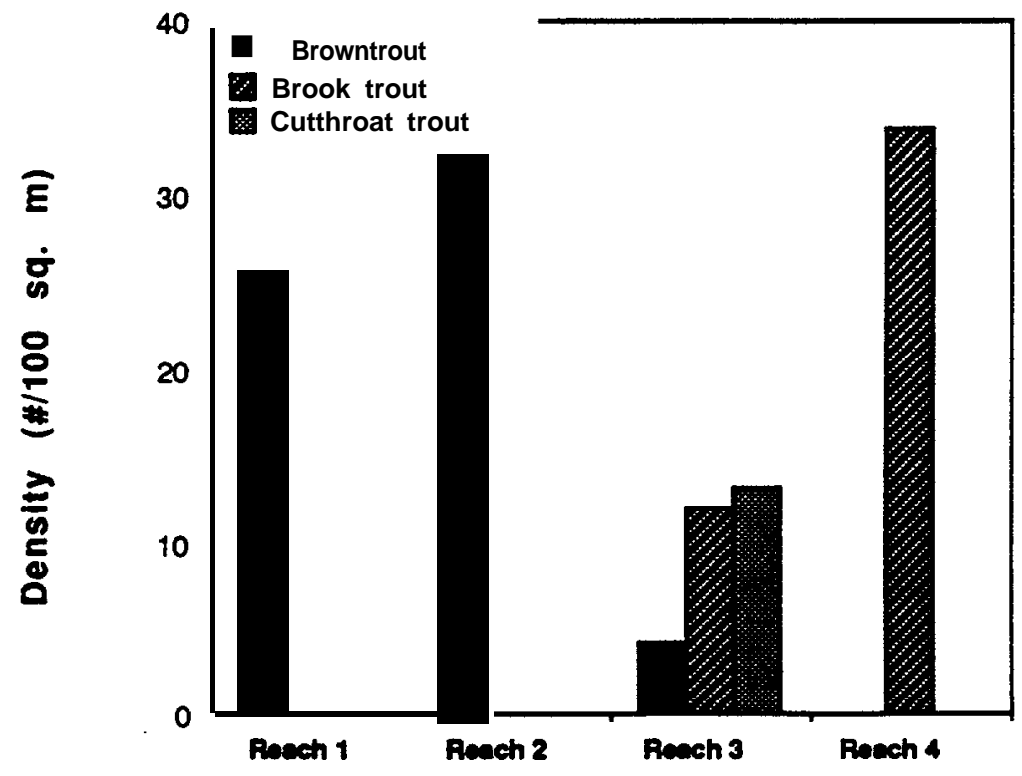

Figure 3.29. Estimated densities of brown trout, brook trout and cutthroat trout at each study site in Cee Cee Ah Creek, WA during 1989.

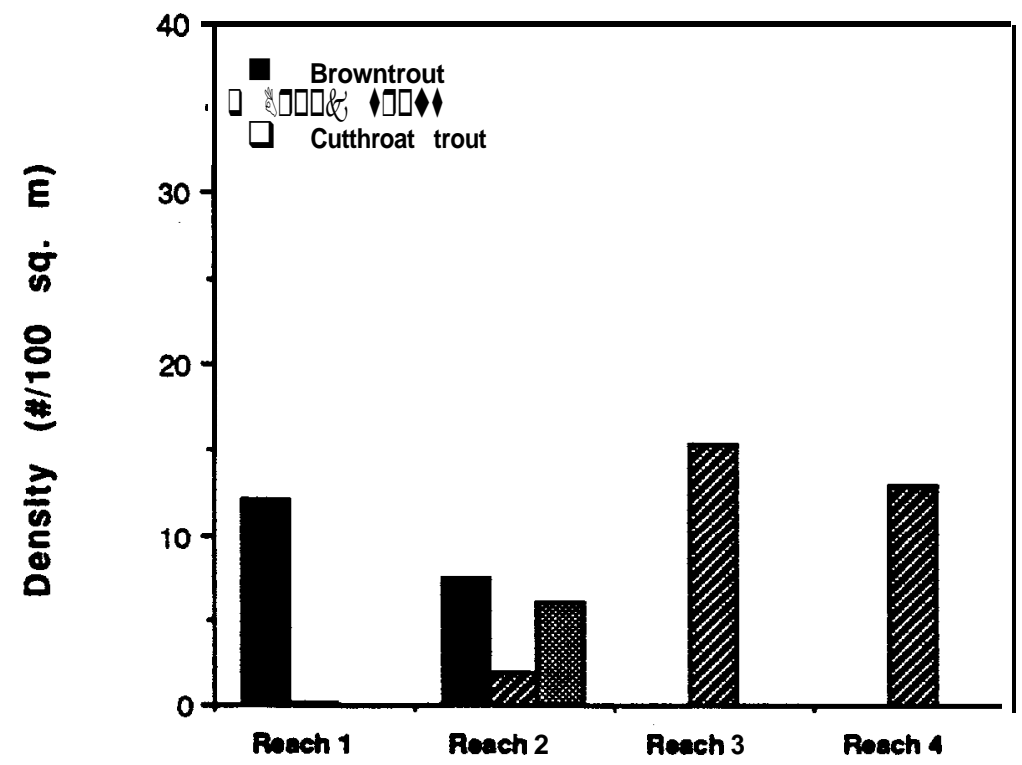

Figure 3.30. Estimated densities of brown trout, brook trout and cutthroat trout at each study site in Cee Cee Ah Creek, WA during 1990. 


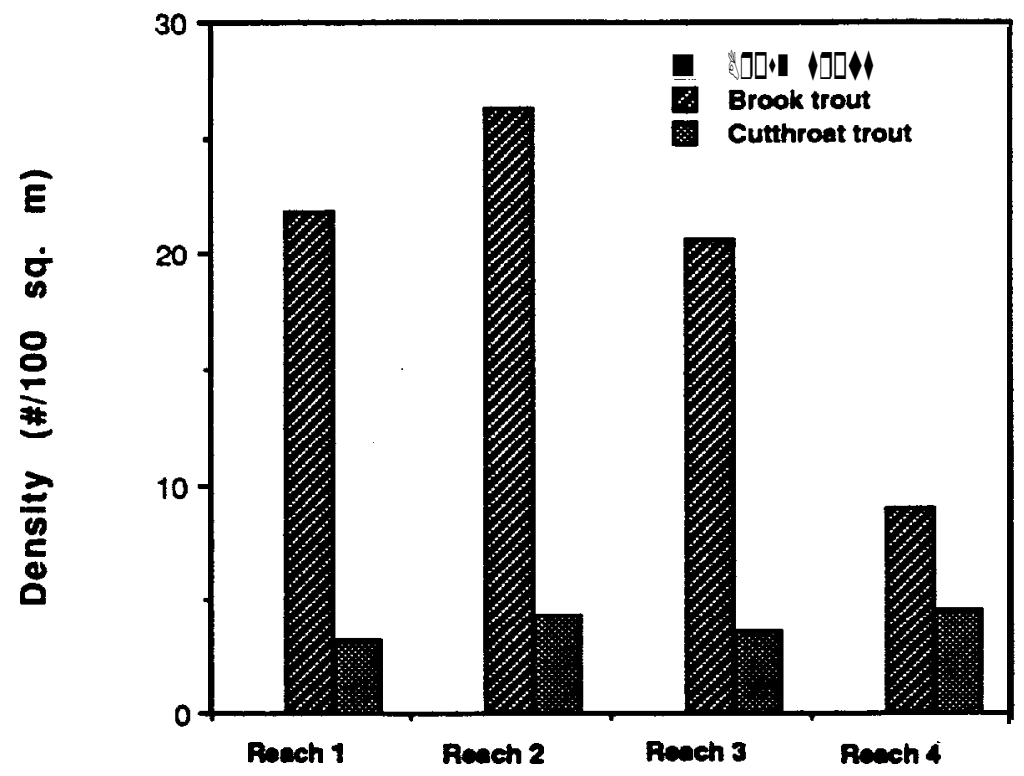

Figure 3.31. Estimated densities of brown trout, brook trout and cutthroat trout at each study site in Tacoma Creek, WA during 1989.

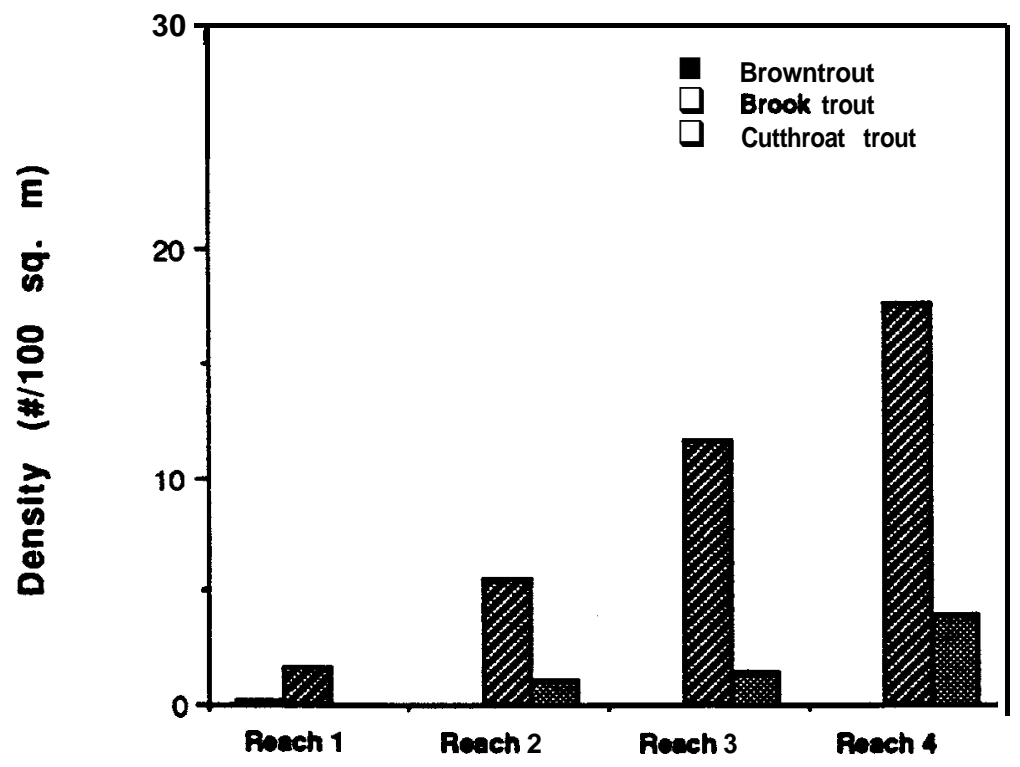

Figure 3.32. Estimated densities of brown trout, brook trout and cutthroat trout at each study site in Tacoma Creek, WA during 1990. 


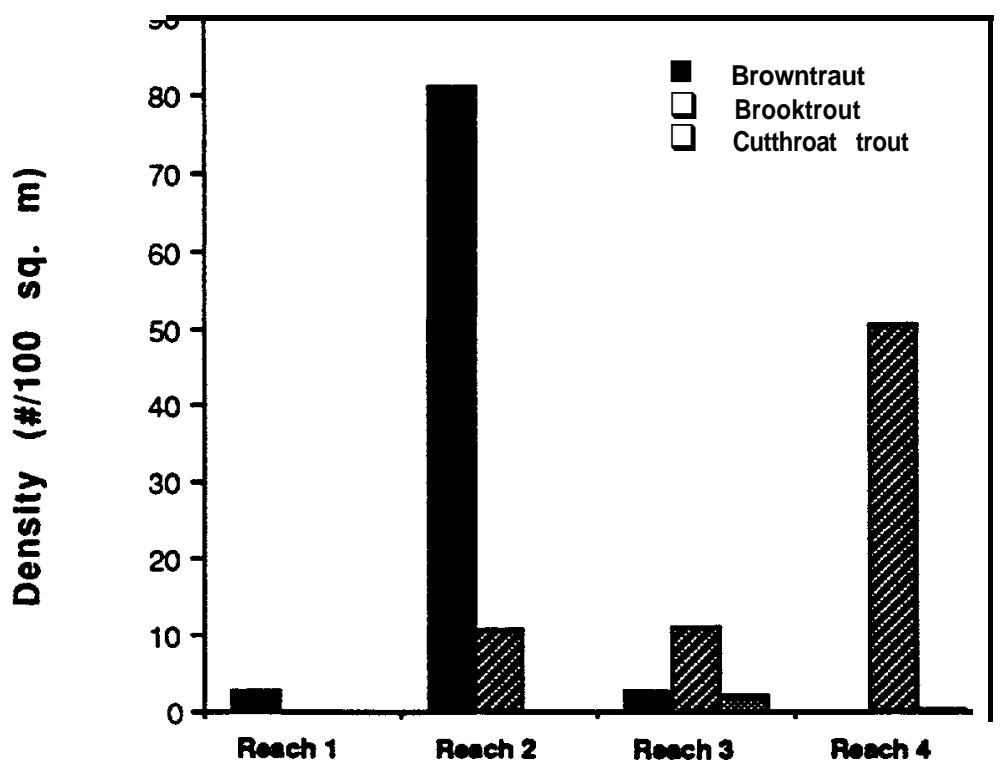

Figure 3.33. Estimated densities of brown trout, brook trout and cutthroat trout at each study site in Skookum Creek, WA during 1989.

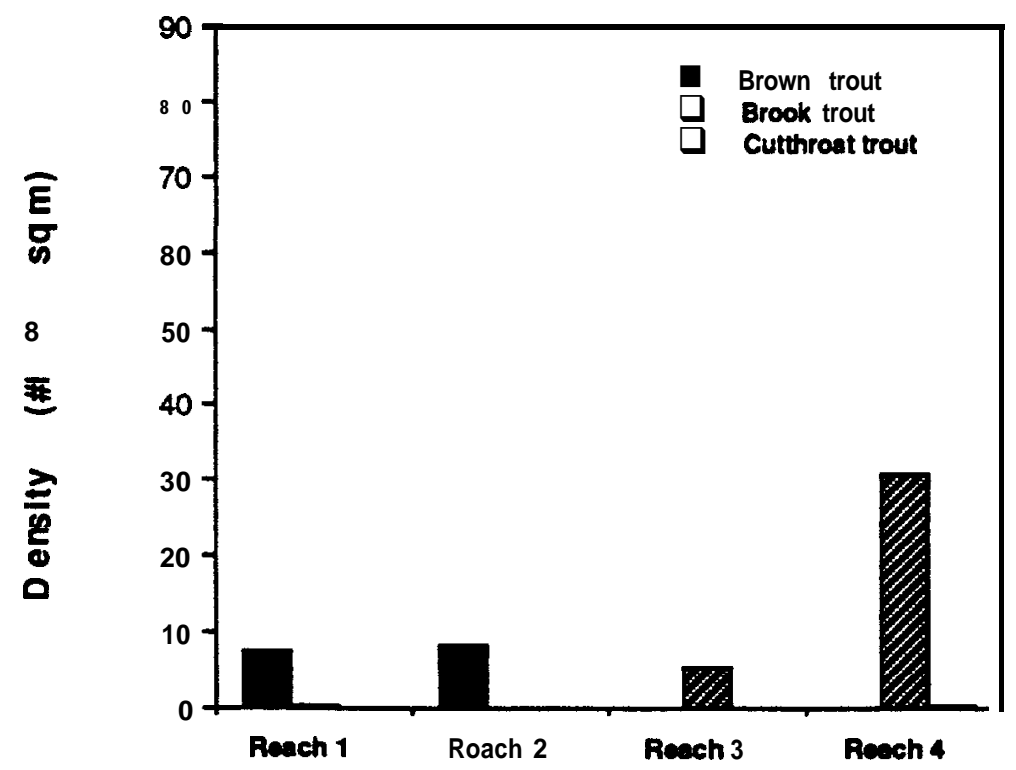

Figure 3.34. Estimated densities of brown trout, brook trout and cutthroat trout at each study site in Skookum Creek, WA during 1990. 
Tacoma Creek in 1988 and in Cee Cee Ah in 1989. Trout densities estimated in 1990 were much lower than the estimates of 1989. An extended rainy period during August of 1990 caused high runoff conditions during the time of population estimate which decreased the efficiency of the sampling equipment a great deal and was thought to be responsible for the lower estimates.

\subsection{AGE, GROWTH AND CONDITION OF FISH IN THE TRIBUTARIES}

A total of 821 scale samples were collected from brown trout in the tributaries during the three year study period; 241 in 1988, 383 in 1989 and 197 in 1990. Back-calculated growth was very similar between tributaries and similar in each tributary over the three year study period (Table 3.42). Tacoma Creek appears to have the best growth rates of brown trout. However, brown trout were only captured in Tacoma Creek on one occasion and the results were from a sample size of only 6 fish. Based on a three year average for all tributaries, brown trout ranged in length from $76 \mathrm{~mm}$ to $93 \mathrm{~mm}$ after the first years growth. After the second year of growth they ranged in size from $126 \mathrm{~mm}$ to $164 \mathrm{~mm}$. After the third year of growth they ranged in size from $182 \mathrm{~mm}$ to $212 \mathrm{~mm}$. After the fourth year of growth they ranged in size from $228 \mathrm{~mm}$ to $256 \mathrm{~mm}$ and after the fifth year of growth the range was from $219 \mathrm{~mm}$ to $345 \mathrm{~mm}$. The mean condition factors for brown trout collected from the tributaries was 1.04 (three year average) in LeClerc Creek, 1.07 in Ruby Creek, 0.97 (three year average) in Cee Cee Ah Creek and 0.98 (three year average) in Skookum Creek (Table 3.42). Back calculated growth and condition factors of brown trout in each tributary is recorded in Appendix K, Tables K.1-6.

A total of 1,287 scale samples were collected from brook trout in the tributaries during the three year study period; 345 in 1988, 543 in 1989 and 399 in 1990. Back-calculated growth was very similar between tributaries and similar in each tributary over the three year study period (Table 3.43). No one tributary stood out as having the best growth rates. Based on a three year average for all tributaries, brook trout ranged in length from $78 \mathrm{~mm}$ to $87 \mathrm{~mm}$ after the first years growth. After the second year of growth they ranged in size from $123 \mathrm{~mm}$ to $134 \mathrm{~mm}$ and after the third year of growth they ranged in size from $169 \mathrm{~mm}$ to 198. The mean condition factors (three year average) for brook trout collected from the tributaries was 0.99 in LeClerc Creek, 0.96 in Ruby Creek, 0.99 in 


\section{Table 3.42. Average back-calculated length (at annulus formation) and condition factors of brown trout in Pend Oreille River tributaries- during 1988, 1989 and 1990.}

\section{LENGTH AT ANNULUS FORMATION}

\begin{tabular}{|c|c|c|c|c|c|c|}
\hline & & 1 & 2 & 3 & 4 & 5 \\
\hline $\begin{array}{l}\text { LoClerc Creek } \\
\text { (Barber et a/. 1989) }\end{array}$ & 1988 & 78 & 141 & 208 & 271 & $\cdots$ \\
\hline $\begin{array}{l}\text { (Barber et al.1990) } \\
\text { (Ashe et a/. 1991) }\end{array}$ & $\begin{array}{l}1989 \\
1990\end{array}$ & $\begin{array}{l}72 \\
77\end{array}$ & $\begin{array}{l}132 \\
134\end{array}$ & $\begin{array}{l}225 \\
180\end{array}$ & $\begin{array}{l}300 \\
193\end{array}$ & $\begin{array}{l}392 \\
298\end{array}$ \\
\hline Average & & 78 & 138 & 204 & 256 & 345 \\
\hline $\begin{array}{l}\text { Rubv Creek } \\
\text { (Ashe et al. 1991) }\end{array}$ & 1990 & 78 & 125 & 163 & $\cdots$ & $\cdots$ \\
\hline $\begin{array}{l}\text { Cee Cee Ah Creek } \\
\text { (Barber et al. 1989) }\end{array}$ & 1988 & 81 & 135 & 198 & 251 & $\cdots$ \\
\hline (Barber ot a/. 1990) & 1989 & 68 & 121 & 177 & 240 & $\ldots$ \\
\hline (Ashe et al. 1991) & 1990 & 82 & 122 & 171 & $\ldots$ & .. \\
\hline Average & & 77 & 126 & 162 & 246 & \\
\hline $\begin{array}{l}\text { Tacoma Creek } \\
\text { (Barber ef al.1989) }\end{array}$ & 1988 & 93 & 164 & 212 & $\cdots$ & $\cdots$ \\
\hline $\begin{array}{l}\text { Skookum Creek } \\
\text { (Barber et al. 1989) }\end{array}$ & 1986 & 80 & 132 & 192 & 264 & $\cdots$ \\
\hline $\begin{array}{l}\text { (Barber et a/. 1990) } \\
\text { (Ashe of a/. 1991) }\end{array}$ & $\begin{array}{l}1989 \\
1990\end{array}$ & $\begin{array}{l}77 \\
81\end{array}$ & $\begin{array}{l}134 \\
133\end{array}$ & $\begin{array}{l}179 \\
182\end{array}$ & $\begin{array}{l}205 \\
215\end{array}$ & $\begin{array}{r}219 \\
\ldots\end{array}$ \\
\hline Average & & 79 & 133 & 184 & 226 & 219 \\
\hline
\end{tabular}

CONDITION FACTORS

\begin{tabular}{|c|c|c|c|c|c|}
\hline Locati on & & Age $\mathrm{C}$ ass & Mean & Condition Factor & Range \\
\hline \multicolumn{6}{|l|}{ LeCerc Creek } \\
\hline Barber et a/. & 1968 & O-IV & $K_{\pi}$ & 1.05 & $0.99-1.17$ \\
\hline Barber et al. & 1989 & $0-v$ & $K_{\pi}$ & 0.99 & $0.96-1.09$ \\
\hline Asthe ef al. & 1990 & $I-V$ & $K_{\pi}$ & 1.09 & $0.79-1.40$ \\
\hline \multicolumn{6}{|l|}{ Ruby Creek } \\
\hline Barber era/. & 1989 & 0.111 & $\mathrm{~K}_{\pi}$ & 1.07 & $0.94-1.25$ \\
\hline \multicolumn{6}{|l|}{ Cee Cee Ah } \\
\hline Barber et a/. & 1988 & O-IV & $K_{\pi}$ & 1.00 & $0.90-1.13$ \\
\hline Barber et a/. & 1989 & $0-v$ & $K_{\pi}$ & 0.96 & $0.94-1.01$ \\
\hline Ashe et al. & 1990 & $0-111$ & $\mathrm{~K}_{\pi}$ & 0.96 & $0.71-1.30$ \\
\hline \multicolumn{6}{|l|}{ Skockum Creek } \\
\hline Barber et al. & 1988 & O-IV & $K_{\pi}$ & 0.92 & $0.87 \cdot 1.13$ \\
\hline Barber ot al. & 1989 & O-IV & $K_{\pi}$ & 0.96 & $0.91-0.98$ \\
\hline Ashe et al. & 1990 & O-IV & $\mathrm{K}_{\mathrm{R}}$ & 1.07 & $0.87-1.21$ \\
\hline
\end{tabular}


Table 3.43. Average back-calculated length (at annulus formation) and condition factors of brook trout in Pend Oreille River tributaries . during 1988, 1989 and 1990.

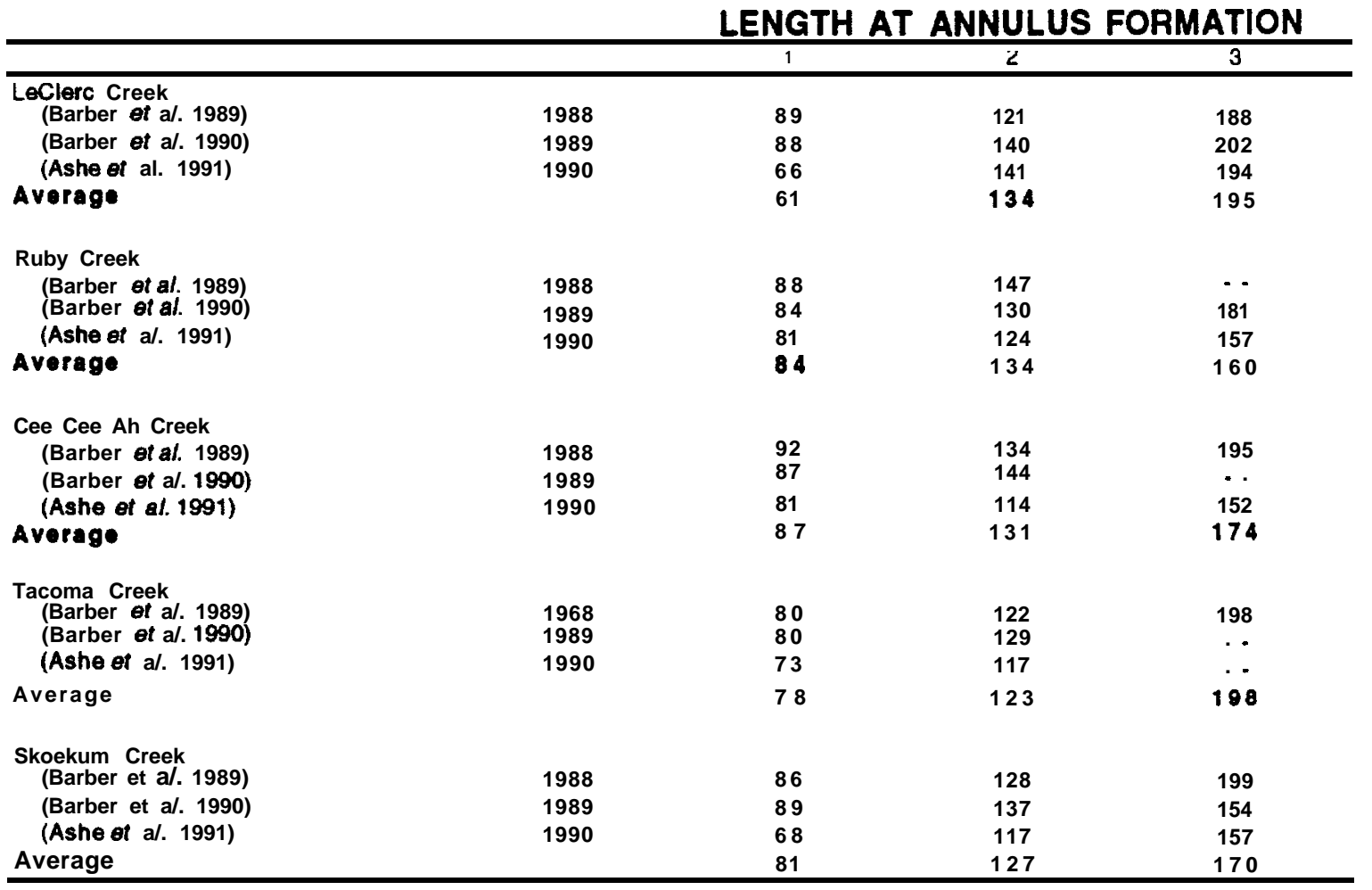

\section{CONDITON FACTORS}

\begin{tabular}{|c|c|c|c|c|c|}
\hline \multicolumn{2}{|l|}{ Location } & Age Class & Mean & Condition Factor & Range \\
\hline \multicolumn{6}{|l|}{ LeCelerc Creek } \\
\hline Barber et a/. & 1988 & 0.111 & $\mathrm{~K} \pi$ & 0.99 & $0.94-1 \quad 18$ \\
\hline Barber of a/. & 1989 & O-ill & $K_{\pi}$ & 0.97 & $0.91-I \quad 10$ \\
\hline Ashe et a/. & 1990 & 0.111 & $\mathrm{~K}_{\mathrm{T}}$ & 1.02 & 0.91-I 46 \\
\hline \multicolumn{6}{|l|}{ Ruby Creek } \\
\hline Barber et a/. & 1988 & 0-II & $K_{\pi}$ & 0.94 & $0.93-0.97$ \\
\hline Barber et $a /$. & 1989 & O-ill & $k_{n}$ & 1.00 & $0.97-1.03$ \\
\hline Ashe et al. & 1990 & O-III & $k_{\pi}$ & 0.94 & $0.94-0.99$ \\
\hline \multicolumn{6}{|c|}{ Cee Cee Ah Creek } \\
\hline Barber et $a /$. & 1988 & O-III & $\mathrm{K}_{\mathbf{T}}$ & 0.95 & $0.93-1.14$ \\
\hline Barber $e t$ a/. & 1989 & O-II & $\mathrm{K} \pi$ & 0.98 & 0.95. I-0. \\
\hline Ashe et $\mathrm{a} /$. & 1990 & O-III & $\mathrm{K}_{\mathrm{T}}$ & 1.03 & $0.92-1.12$ \\
\hline \multicolumn{6}{|l|}{ Tacoma Creek } \\
\hline Barber et $\boldsymbol{a}$. & 1988 & O-III & $\mathrm{K}_{\pi}$ & 0.96 & $0.90-1.19$ \\
\hline Barber et $\mathrm{a} /$. & 1989 & 0.11 & $\mathrm{~K}_{\pi}$ & 0.97 & $0.92-1.00$ \\
\hline Ashe et al. & 1990 & O-II & $K_{T L}$ & 1.12 & $1.12-1.13$ \\
\hline \multicolumn{6}{|l|}{ Skoekum Creek } \\
\hline Barber et $\mathrm{a} /$. & 1988 & O-III & $\mathrm{K}_{\mathrm{n}}$ & 1.07 & $0.99-1.25$ \\
\hline Barber et al. & 1989 & $0-I I I$ & $K_{n}$ & 0.97 & $0.95-1.01$ \\
\hline Ashe et al. & 1990 & $0-111$ & $K_{\pi}$ & 1.01 & $0.97-1.24$ \\
\hline
\end{tabular}


Cee Cee Ah Creek, 1.02 in Tacoma Creek and 1.02 in Skookum Creek (Table 3.43). Back calculated growth and condition factors of brook trout in each tributary is recorded in Appendix K, Tables K.7-12.

One hundred and twenty-six scale samples were collected from cutthroat trout in the tributaries during the three year study period: 16 in 1988, 72 in 1989 and 38 in 1990. Back-calculated growth was very similar between tributaries and similar in each tributary over the three year study period (Table 3.44). No cutthroat trout older than age 2+ were captured in Cee Cee Ah and Skookum Creeks. Based on a three year average for all tributaries, cutthroat trout ranged in length from $92 \mathrm{~mm}$ to $106 \mathrm{~mm}$ after the first years growth. After the second year of growth they ranged in size from $130 \mathrm{~mm}$ to 158 $\mathrm{mm}$ and after the third year of growth they ranged in size from 194 $\mathrm{mm}$ to 223. The mean condition factors for cutthroat trout collected from the tributaries was 1.03 (two year average) in LeClerc Creek, 0.93 (two year average) in Ruby Creek, (three year average) in Cee Cee Ah Creek, 0.90 (three year average) in Tacoma Creek and 1.12 (two year average) in Skookum Creek (Table 3.44). Back calculated growth and condition factors of cutthroat trout in each tributary is recorded in Appendix K, Tables K.13-18.

\subsection{FOOD AVAILABILITY IN TRIBUTARIES}

\subsubsection{BENTHIC MACROINVERTEBRATE DENSITIES IN THE TRIBUTARIES}

A total of 203 Hess samples were collected from the tributaries during the three year study period. The mean density of benthic macroinvertebrates collected in samples from LeClerc Creek was 3,589 organisms $/ \mathrm{m}^{*}$ (Table 3.45). The average density in Ruby Creek was 1,298 organisms $/ \mathrm{m}^{*}$ (Table 3.46 ), 3,819 organisms $/ \mathrm{m}^{*}$ in Cee Cee Ah Creek (Table 3.47), 3,278 organisms/m* in Tacoma Creek (Table 3.48) and 3,766 organisms/ $\mathrm{m}^{*}$ in Skookum Creek (Table 3.49). Mean density and percent abundance of each family of invertebrate collected by Hess sampler in the tributaries during the three year investigation is recorded in Append'ix K, Table K.1-K.5.

Benthic macroinvertebrate densities were lower in 1990 than in 1988 and 1989 for all five of the tributaries sampled (Table 3.50). These lower densities may be due to the smaller sample sizes, and to the extreme runoff condition of the tributaries during the spring and fall sampling periods. Due to high runoff conditions it was difficult, and in some cases, impossible, to obtain benthic 


\section{Table 3.44, Average back-calculated length (at annulus formation) and condition factors of cutthroat trout in Pend Oreille River tributaries- during 1988, 1989 and 1990.}

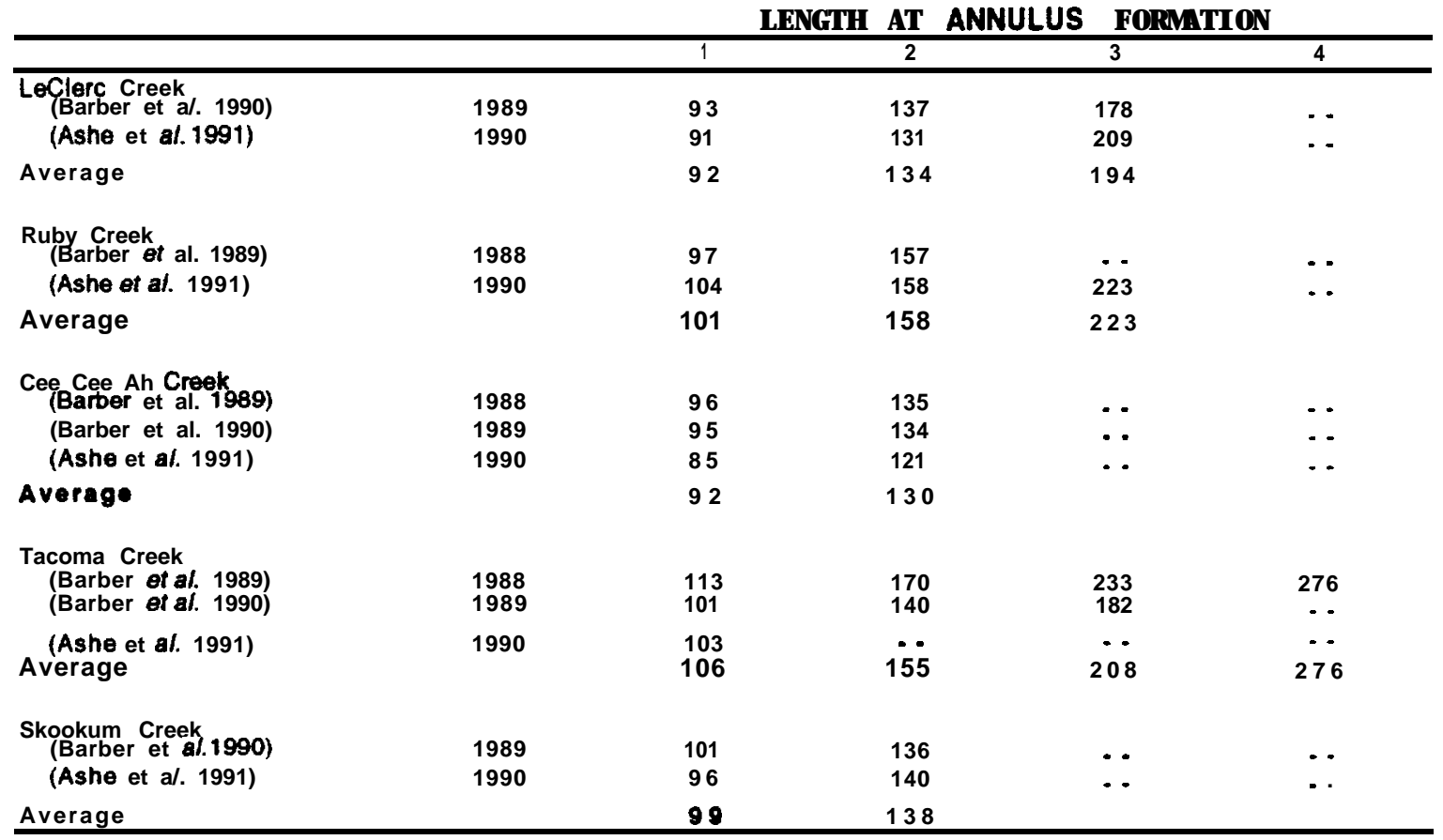

\begin{tabular}{|c|c|c|c|c|c|}
\hline \multicolumn{6}{|c|}{ CONDITION FACTORS } \\
\hline LOCATI ON & & Age $\mathrm{d}$ ass & Mean & Conditi on Fact or & Range \\
\hline \multicolumn{6}{|l|}{ LeClerc Creek } \\
\hline Barber et al. & 1989 & $|-| I \mid$ & $\mathrm{K}_{\pi}$ & 0.93 & 0.93- . . \\
\hline Ashe et al. & 1990 & I-III & $K_{\pi}$ & 1.12 & $0.83-1.82$ \\
\hline \multicolumn{6}{|l|}{ Ruby Creek } \\
\hline Barber ot a/. & 1988 & $0-11$ & $K_{\pi}$ & 0.96 & $0.95-0.99$ \\
\hline Barber et al. & 1989 & I-III & $k_{\pi}$ & 0.89 & $0.80-1.12$ \\
\hline \multicolumn{6}{|c|}{ Cee Cee Ah Creek } \\
\hline Barber et a/. & 1988 & 0-I & $K_{\pi}$ & 0.91 & $0.86-0.99$ \\
\hline Barber et a/. & 1989 & $0-11$ & $K_{T L}$ & 0.89 & $0.84-0.94$ \\
\hline Ashe et al. & 1990 & $I-I I$ & $K_{\pi}$ & 0.44 & $0.4-0.44$ \\
\hline \multicolumn{6}{|l|}{ Tacoma Creek } \\
\hline Barber et al. & 1988 & O-II & $K_{\pi}$ & 0.91 & $0.86-0.99$ \\
\hline Barber et al. & 1989 & O-III & $K_{\pi}$ & 0.84 & $0.80-05$ \\
\hline Ashe et $a l$. & 1990 & 1 & $\mathrm{~K}_{\mathrm{T}}$ & 0.95 & . \\
\hline \multicolumn{6}{|l|}{ Skookum Creek } \\
\hline Barber ot al. & 1989 & O-II & $K_{\pi}$ & 1.02 & $0.99-1.03$ \\
\hline Ashe et al. & 1990 & $|-1|$ & $K_{\pi}$ & 1.21 & $0.99-1.43$ \\
\hline
\end{tabular}


Table 3.45. Mean annual benthic macroinvertebrate densities $\left(\# / \mathrm{m}^{2}\right)$ and percent abundance in samples collected from LeClerc Creek, WA during 1988, 1989 and 1990.

\begin{tabular}{|c|c|c|c|c|c|c|c|c|}
\hline ORGANISMS & $\begin{array}{c}19 \\
\text { Mean } \\
\mathbf{N}=\end{array}$ & $\%$ & $\begin{array}{r}\mathbf{1} \\
\text { Mean } \\
\mathbf{N}\end{array}$ & $0^{\%}$ & $\begin{array}{r}1 \\
\text { Mean } \\
\text { N }\end{array}$ & $\%$ & $\begin{array}{r}\text { Thre } \\
\text { Mean } \\
\mathbb{N}\end{array}$ & $\begin{array}{l}\text { y } \\
\%\end{array}$ \\
\hline AQUATIC & & & & & & & & \\
\hline $\begin{array}{l}\text { TRICHOPTERA } \\
\text { EPHEMEROPTERA } \\
\text { COLEOPIERA } \\
\text { PLECOPTERA } \\
\text { DIPTERA } \\
\text { ODONATA } \\
\text { HYORACARINA } \\
\text { OSTRACODA } \\
\text { OLGOCHAETA } \\
\text { NEMATODA } \\
\text { TURBEULARIA } \\
\text { MOUUSCA } \\
\text { BIVALVIA } \\
\end{array}$ & $\begin{array}{c}708 \\
1537 \\
438 \\
253 \\
1013 \\
\\
21 \\
1 \\
745 \\
25 \\
54 \\
1 \\
1 \\
\end{array}$ & $\begin{array}{c}14.6 \\
31.9 \\
9.1 \\
5.3 \\
21.2 \\
\\
0.4 \\
<0.1 \\
15.4 \\
0.5 \\
1.1 \\
<0.1 \\
<0.1 \\
\end{array}$ & $\begin{array}{c}448 \\
1859 \\
230 \\
167 \\
1527 \\
1 \\
13 \\
\\
163 \\
4 \\
29 \\
3 \\
1 \\
\end{array}$ & $\begin{array}{l}10.0 \\
41.7 \\
5.1 \\
3.8 \\
34.1 \\
\text { co. } 5 \\
0.3 \\
\\
3.7 \\
0.1 \\
0.7 \\
0.1 \\
\text { co. } \\
\end{array}$ & $\begin{array}{c}115 \\
222 \\
146 \\
60 \\
897 \\
5 \\
6\end{array}$ & $\begin{array}{l}7.7 \\
14.9 \\
9.8 \\
4.0 \\
60.2 \\
0.3 \\
0.4\end{array}$ & $\begin{array}{c}423 \\
1206 \\
272 \\
161 \\
1142 \\
\text { cl } \\
13 \\
c l \\
305 \\
10 \\
28 \\
5 \\
2 \\
\end{array}$ & $\begin{array}{l}10.9 \\
33.6 \\
7.5 \\
4.4 \\
31.8 \\
\text { Co. } 1 \\
0.4 \\
<0.1 \\
8.5 \\
0.3 \\
0.8 \\
0.1 \\
0.1 \\
\end{array}$ \\
\hline FERRESTRIAL & & & & & & & & \\
\hline $\begin{array}{l}\text { EPHEMEROPTERA } \\
\text { DIPTERA } \\
\text { HEMIPTERA } \\
\text { HOMOPTERA } \\
\text { PSOCOPTERA } \\
\text { THYSANOPTERA } \\
\text { COUEMBOLA } \\
\text { ARANEIDA } \\
\text { UNKNOWN } \\
\text { TOTAL } \\
\end{array}$ & $\begin{array}{c}4 \\
2 \\
3 \\
6 \\
\\
10 \\
4,822 \\
\end{array}$ & $\begin{array}{c}0.1 \\
<0.1 \\
1.0 \\
0.1 \\
<0.1\end{array}$ & $\begin{array}{c}2 \\
4 \\
3 \\
2 \\
1 \\
4,457\end{array}$ & $\begin{array}{c}\text { Co. } 1 \\
0.1 \\
0.1 \\
<0.1 \\
<0.1\end{array}$ & $\begin{array}{l}12 \\
13 \\
1\end{array}$ & $\begin{array}{l}0.8 \\
0.8 \\
0.1\end{array}$ & $\begin{array}{l}\mathbf{4} \\
\mathbf{2} \\
\mathbf{4} \\
\mathbf{2} \\
1 \\
1 \\
\mathbf{3} \\
\mathbf{0} \\
\mathbf{3} \\
\mathbf{3 ,} \mathbf{5 8 9}\end{array}$ & $\begin{array}{l}0.1 \\
<0.1 \\
0.1 \\
0.1 \\
<0.1 \\
<0.1 \\
0.1 \\
<0.1 \\
0.1\end{array}$ \\
\hline
\end{tabular}


Table 3.46. Mean annual benthic macroinvertebrate densities $\left(\# / \mathrm{m}^{2}\right)$ and percent abundance in samples collected from Ruby Creek, WA during 1989 and 1990.

\begin{tabular}{|c|c|c|c|c|c|c|}
\hline ORGANISMS & Mean & $\%$ & Mean & $\%$ & Mean & $\%$ \\
\hline IQUATIC & & & & & & \\
\hline $\begin{array}{l}\text { TRICHOPTERA } \\
\text { EPHEMEROPTERA } \\
\text { COLEOPIERA } \\
\text { PLECOPTERA } \\
\text { DIPTERA } \\
\text { ODONATA } \\
\text { HYDRACARINA } \\
\text { OUGOCHAETA } \\
\text { NEMATODA } \\
\text { TURBEUARIA } \\
\text { HIRUDINEA } \\
\text { MOUUSCA } \\
\text { BIVALVIA }\end{array}$ & $\begin{array}{c}198 \\
399 \\
253 \\
168 \\
506 \\
1 \\
15 \\
99 \\
1 \\
7 \\
1 \\
2 \\
70 \\
\end{array}$ & $\begin{array}{l}11.4 \\
23.0 \\
14.5 \\
9.6 \\
29.3 \\
\text { co. } 1 \\
0.9 \\
5.7 \\
<0.1 \\
0.4 \\
\text { co. } \\
0.1 \\
4.5 \\
\end{array}$ & $\begin{array}{c}52 \\
126 \\
111 \\
43 \\
206 \\
\\
8 \\
18 \\
3 \\
3 \\
5 \\
281 \\
\end{array}$ & $\begin{array}{l}6.0 \\
14.8 \\
13.0 \\
5.1 \\
24.1 \\
\\
0.9 \\
2.1 \\
0.4 \\
0.4 \\
\\
0.6 \\
32.8\end{array}$ & $\begin{array}{c}128 \\
264 \\
183 \\
107 \\
356 \\
1 \\
12 \\
59 \\
2 \\
5 \\
1 \\
6 \\
180 \\
\end{array}$ & $\begin{array}{l}9.8 \\
20.1 \\
14.0 \\
8.1 \\
27.2 \\
0.1 \\
0.9 \\
4.5 \\
0.2 \\
0.4 \\
0.1 \\
0.5 \\
13.7\end{array}$ \\
\hline IERAESTRIAL & & & & & & \\
\hline $\begin{array}{l}\text { DIPTERA } \\
\text { HOMOPTERA } \\
\text { HYMENOPTERA } \\
\text { COUIEMBOLA } \\
\text { ARANEIDA } \\
\text { UNKAOWN } \\
\text { POTAL }\end{array}$ & $\begin{array}{c}1 \\
4 \\
3 \\
4 \\
2 \\
1,739 \\
\end{array}$ & $\begin{array}{c}<0.1 \\
0.2 \\
0.1 \\
<0.1 \\
0.1\end{array}$ & $\begin{array}{c}1 \\
857 \\
\end{array}$ & 0.1 & $\begin{array}{c}1 \\
2 \\
2 \\
<1 \\
1 \\
1 \\
1,298 \\
\end{array}$ & $\begin{array}{l}0.1 \\
0.2 \\
0.2 \\
<0.1 \\
0.1 \\
0.1\end{array}$ \\
\hline
\end{tabular}


Table 3.47. Mean annual benthic macroinvertebrate densities $\left(\# / \mathrm{m}^{2}\right)$ and percent abundance in samples collected from Cee Cee Ah Creek, WA during 1988, 1989 and 1990.

\begin{tabular}{|c|c|c|c|c|c|c|c|c|}
\hline ORGANISMS & $\begin{array}{c}10 \\
\text { Mean } \\
\mathbf{N}\end{array}$ & $\%$ & $\begin{array}{r}\mathbf{1} \\
\text { Mean } \\
\mathbf{N}\end{array}$ & $\%$ & $\begin{array}{r}1 \\
\text { Mean } \\
N\end{array}$ & $\%$ & $\begin{array}{r}\text { Thre } \\
\text { Mean } \\
\mathbf{N}\end{array}$ & $\begin{array}{l}\text { ear } \\
\% \\
\end{array}$ \\
\hline IQUATIC & & & & & & & & \\
\hline $\begin{array}{l}\text { TRICHOPTERA } \\
\text { EPHEMEROPTERA } \\
\text { COLEOPIERA } \\
\text { PLECOPTERA } \\
\text { DIPTERA } \\
\text { HYDRACARINA } \\
\text { COPEPODA } \\
\text { AMPHIPODA } \\
\text { OSTRACODA } \\
\text { OLGOCHAETA } \\
\text { NEMATODA } \\
\text { TURBELLARIA } \\
\text { HIRUDINEA } \\
\text { MOUUSCA } \\
\text { BIVALVIA }\end{array}$ & $\begin{array}{c}736 \\
1868 \\
1287 \\
345 \\
1197 \\
97 \\
6 \\
3 \\
22 \\
176 \\
14 \\
79 \\
\\
23 \\
50\end{array}$ & $\begin{array}{c}12.5 \\
31.5 \\
21.4 \\
5.8 \\
20.2 \\
1.6 \\
0.1 \\
<0.1 \\
0.4 \\
3.0 \\
0.2 \\
1.3 \\
\\
0.4 \\
0.8\end{array}$ & $\begin{array}{c}203 \\
936 \\
405 \\
349 \\
1067 \\
33\end{array}$ & $\begin{array}{c}6.1 \\
28.0 \\
12.1 \\
10.5 \\
31.9 \\
1.0\end{array}$ & $\begin{array}{c}60 \\
532 \\
239 \\
148 \\
559 \\
3\end{array}$ & $\begin{array}{c}2.8 \\
24.3 \\
10.9 \\
6.6 \\
25.4 \\
0.2\end{array}$ & $\begin{array}{c}332 \\
1112 \\
637 \\
281 \\
941 \\
44 \\
2 \\
1 \\
7 \\
162 \\
13 \\
36 \\
17 \\
10 \\
205\end{array}$ & $\begin{array}{c}6.5 \\
29.1 \\
16.6 \\
7.3 \\
24.7 \\
1.2 \\
0.1 \\
0.1 \\
0.2 \\
5.2 \\
0.3 \\
0.9 \\
0.4 \\
0.2 \\
5.4\end{array}$ \\
\hline \multicolumn{9}{|l|}{ 'ERRESTRIAL } \\
\hline $\begin{array}{l}\text { TRICHOPTERA } \\
\text { EPHEMEROPTERA } \\
\text { COLEOPTERA } \\
\text { DIPTERA } \\
\text { HEMIPTERA } \\
\text { HOMOPTERA } \\
\text { HYMENOPTERA } \\
\text { PSOCOPTERA } \\
\text { THYSANOPTERA } \\
\text { COUEMBOLA } \\
\text { ARANEIDA } \\
\text { UNWOWN } \\
\text { 'OTAL }\end{array}$ & $\begin{array}{l}1 \\
3 \\
1 \\
5 \\
1 \\
1\end{array}$ & $\begin{array}{c}<0.1 \\
<0.1 \\
<0.1 \\
0.1 \\
c 0.1 \\
1\end{array}$ & $\begin{array}{c}3 \\
<1 \\
2 \\
1 \\
2 \\
2 \\
3,342\end{array}$ & $\begin{array}{l}0.1 \\
<0.1 \\
0.1 \\
\text { co. } 1 \\
0.1 \\
0.1\end{array}$ & $\begin{aligned} & 8 \\
& 2,198\end{aligned}$ & $<0.1$ & $\begin{array}{c}<1 \\
<1 \\
<1 \\
1 \\
<1 \\
2 \\
<1 \\
<1 \\
1 \\
<1 \\
1 \\
12 \\
3,819\end{array}$ & $\begin{array}{l}\text { co. } 1 \\
<0.1 \\
<0.1 \\
<0.1 \\
c 0.1 \\
0.1 \\
<0.1 \\
<0.1 \\
c 0.1 \\
<0.1 \\
c 0.1 \\
0.3\end{array}$ \\
\hline
\end{tabular}


Table 3.48. Mean annual benthic macroinvertebrate densities $\left(\# / \mathrm{m}^{2}\right)$ and percent abundance in samples collected from Tacoma Creek, WA during 1988, 1989 and 1990.

\begin{tabular}{|c|c|c|c|c|c|c|c|c|}
\hline ORGANISMS & $\begin{array}{c}19 \\
\text { Mean } \\
\mathrm{N}=\end{array}$ & $\%$ & $\begin{array}{r}1 \\
\text { Mean } \\
\mathbf{N}\end{array}$ & $\%$ & $\begin{array}{c}10 \\
\text { Mean } \\
N\end{array}$ & $\%$ & $\begin{array}{c}\text { Three } \\
\text { Mean } \\
\mathbf{N}\end{array}$ & $\begin{array}{l}\text { ear } \\
\% \\
6\end{array}$ \\
\hline QUATIC & & & & & & & & \\
\hline $\begin{array}{l}\text { TRICHOPTERA } \\
\text { EPHEMEROPIERA } \\
\text { COLEOPTERA } \\
\text { PLECOPTERA } \\
\text { DIPTERA } \\
\text { LEPIDOPTERA } \\
\text { HYDRACARINA } \\
\text { COPEOODA } \\
\text { AMPHIPODA } \\
\text { OLIGOCHAETA } \\
\text { NEMATODA } \\
\text { TURBELARIA } \\
\text { MOLLUSCA } \\
\text { BIVALVIA }\end{array}$ & $\begin{array}{c}619 \\
1182 \\
988 \\
116 \\
1819 \\
\\
32 \\
7 \\
7 \\
64 \\
2 \\
21 \\
9 \\
27 \\
\end{array}$ & $\begin{array}{c}12.6 \\
24.0 \\
20.1 \\
2.3 \\
37.0 \\
\\
0.7 \\
0.1 \\
0.1 \\
1.3 \\
0.1 \\
0.4 \\
0.2 \\
0.6 \\
\end{array}$ & $\begin{array}{c}515 \\
1305 \\
963 \\
160 \\
476 \\
25 \\
60\end{array}$ & $\begin{array}{c}14.3 \\
36.2 \\
26.7 \\
4.3 \\
13.1 \\
0.7 \\
1.7\end{array}$ & $\begin{array}{c}272 \\
500 \\
355 \\
36 \\
141 \\
\\
5\end{array}$ & $\begin{array}{c}20.5 \\
37.6 \\
26.9 \\
2.9 \\
10.7 \\
\\
0.4\end{array}$ & $\begin{array}{c}427 \\
996 \\
769 \\
105 \\
811 \\
6 \\
32 \\
2 \\
2 \\
36 \\
2 \\
14 \\
3 \\
11 \\
\end{array}$ & $\begin{array}{l}14.3 \\
30.4 \\
23.5 \\
3.2 \\
24.9 \\
0.2 \\
1.0 \\
0.1 \\
0.1 \\
1.2 \\
0.1 \\
0.4 \\
0.1 \\
0.3\end{array}$ \\
\hline ERRESTRIAL & & & & & & & & \\
\hline $\begin{array}{l}\text { EPHEMEROPTERA } \\
\text { DIPTERA } \\
\text { HEMIPTERA } \\
\text { HOMOPTERA } \\
\text { PSOCOPTERA } \\
\text { THYSANOPTERA } \\
\text { COUEMBOLA } \\
\text { ARANEIDA } \\
\text { UNNOWN } \\
\text { DTAL }\end{array}$ & $\begin{array}{l}1 \\
8 \\
1 \\
8 \\
2\end{array}$ & $\begin{array}{l}<0.1 \\
3.8 \\
<0.1 \\
0.2 \\
0.8\end{array}$ & $\begin{array}{c}2 \\
4 \\
3 \\
1 \\
1 \\
3,608\end{array}$ & $\begin{array}{l}\text { co. } 1 \\
0.1 \\
0.1 \\
\text { co. } 1 \\
\text { co. } 1\end{array}$ & $\begin{array}{c}3 \\
1,325\end{array}$ & $\begin{array}{l}0.2 \\
0.2\end{array}$ & $\begin{array}{c}\text { cl } \\
3 \\
1 \\
5 \\
<1 \\
1 \\
<1 \\
1 \\
2 \\
3,278\end{array}$ & $\begin{array}{c}c 0.1 \\
0.1 \\
\text { co. } 1 \\
0.1 \\
\text { co. } 1 \\
\text { co. } 1 \\
<0.1 \\
<0.1 \\
0.1\end{array}$ \\
\hline
\end{tabular}


Table 5. 4^? Mean annual'oetitinc macroinvertebrate densities $\left(\# / \mathrm{m}^{2}\right)$ and percent abundance in samples collected from Skookum Creek,. WA during 1988, 1989 and 1990.

\begin{tabular}{|c|c|c|c|c|c|c|c|c|}
\hline ORGAN SMS & $\begin{array}{c}19 \\
\text { Mean } \\
\mathrm{N}\end{array}$ & $\%$ & $\begin{array}{c}10 \\
\text { Mean } \\
\mathbf{N}\end{array}$ & $\%$ & $\begin{array}{c}19 \\
\text { Mean } \\
N\end{array}$ & $\%$ & $\begin{array}{c}\text { Thre } \\
\text { Mean } \\
\mathrm{N}\end{array}$ & $\begin{array}{l}\text { ear } \\
\% \\
\end{array}$ \\
\hline \multicolumn{9}{|l|}{ AOUATIC } \\
\hline $\begin{array}{l}\text { TRICHOPTERA } \\
\text { EPHEMEROPTERA } \\
\text { COLEOPTERA } \\
\text { PLECOPTERA } \\
\text { DIPTERA } \\
\text { HYDRACARINA } \\
\text { CLADOCERA } \\
\text { COPEPODA } \\
\text { AMPHIPODA } \\
\text { OUGOCHAETA } \\
\text { NEMATODA } \\
\text { TURBELLARIA } \\
\text { MOUUSCA } \\
\text { BIVALVIA }\end{array}$ & $\begin{array}{c}566 \\
1169 \\
282 \\
424 \\
1404 \\
49 \\
16 \\
1 \\
198 \\
729 \\
58 \\
104 \\
10 \\
\end{array}$ & $\begin{array}{l}11.4 \\
23.5 \\
5.7 \\
8.5 \\
28.3 \\
1.0 \\
0.3 \\
<0.1 \\
4.0 \\
14.7 \\
1.2 \\
2.1 \\
\\
0.2\end{array}$ & $\begin{array}{c}393 \\
1732 \\
618 \\
566 \\
791 \\
25\end{array}$ & $\begin{array}{c}8.4 \\
37.2 \\
13.2 \\
12.6 \\
16.6 \\
0.5\end{array}$ & $\begin{array}{c}137 \\
625 \\
144 \\
125 \\
162 \\
8\end{array}$ & $\begin{array}{c}8.1 \\
49.0 \\
8.5 \\
7.3 \\
9.6 \\
0.5\end{array}$ & $\begin{array}{c}366 \\
1049 \\
348 \\
352 \\
786 \\
27 \\
5 \\
0 \\
66 \\
417 \\
39 \\
65 \\
7 \\
55 \\
\end{array}$ & $\begin{array}{c}10.2 \\
21.0 \\
9.8 \\
9.6 \\
22.1 \\
0.8 \\
0.1 \\
<0.1 \\
1.9 \\
11.7 \\
1.1 \\
1.8 \\
0.1 \\
1.5\end{array}$ \\
\hline \multicolumn{9}{|l|}{ TERRESTRIAL } \\
\hline $\begin{array}{l}\text { TRICHOPTERA } \\
\text { PLECOPTERA } \\
\text { DIPTERA } \\
\text { HOMOPTERA } \\
\text { HYMENOPTERA } \\
\text { NEUROPTERA } \\
\text { PSOCOPTERA } \\
\text { THYSANOPTERA } \\
\text { COUEMBOLA } \\
\text { MPLOPODA } \\
\text { ARANEIDA } \\
\text { UNONOWN } \\
\text { IOTAL }\end{array}$ & $\begin{array}{c}1 \\
1 \\
2 \\
4,969\end{array}$ & $\begin{array}{l}<0.1 \\
<0.1 \\
<0.1\end{array}$ & $\begin{array}{c}3 \\
<1 \\
1 \\
3 \\
<1\end{array}$ & $\begin{array}{l}0.1 \\
<0.1 \\
<0.1 \\
<0.1 \\
<0.1\end{array}$ & $\begin{array}{l}3 \\
1\end{array}$ & $\begin{array}{c}0.1 \\
\text { co. } 1\end{array}$ & $\begin{array}{l}2 \\
c l \\
3 \\
1 \\
<1 \\
<1 \\
1 \\
<1 \\
c 1 \\
<1 \\
<1 \\
1 \\
3,766\end{array}$ & $\begin{array}{l}0.1 \\
c 0.1 \\
0.1 \\
c 0.1 \\
c 0.1 \\
<0.1 \\
<0.1 \\
<0.1 \\
<0.1 \\
c 0.1 \\
c 0.1 \\
<0.1\end{array}$ \\
\hline
\end{tabular}


samples from the creeks. Despite the differences in densities, the percent abundance of the most prevalent invertebrates was very similar for all three years (Table 3.51). Organisms in the orders Diptera and Ephemeroptera were the most prevalent in every tributary we studied.

\subsubsection{ABUNDANCE OF DRIFTING INVERTEBRATES IN THE TRIBUTARIES}

A total of 180 drift samples were collected from the tributaries over the three year study period. The average density of drifting macroinvertebrates in LeClerc Creek was 91 organisms $/ 100 \mathrm{~m}^{3}$ (Table 3.52). The average density in Ruby Creek was 235 organisms $/ / 00 \mathrm{~m}^{3}$ (Table 3.53), 78 organisms $/ 100 \mathrm{~m}^{3}$ in Cee Cee Ah Creek (Table 3.54), 93 organisms $/ 100 \mathrm{~m}^{3}$ in Tacoma Creek (Table 3.55) and 137 organisms $/ 100 \mathrm{~m}^{3}$ in Skookum Creek (Table 3.56). Mean density and percent abundance of each family of invertebrate collected by drift sampler in the tributaries during the three year investigation is recorded in Appendix K, Table K.6-K.10.

Densities of macroinvertebrates collected in drift samples in the Pend Oreille tributaries in 1988 and 1989 were similar. Densities from 1990 samples, however, were substantially lower than the previous two years (Table 3.57). The only tributary comparable in respect to drift densities throughout the three years of the study was Cee Cee Ah Creek. These lower densities again may be a result of the smaller sample size and the high flows observed during fall sampling. When samples were collected in September, it was often hard to keep the samplers in place against the force of the current. At some sites, water depth and current strength made it impossible to collect samples from the main channel of the tributary. Drift nets were set along side the stream as far into the current as possible, however, in some cases these areas were backwater areas. Percent composition of major invertebrate families in the drift of LeClerc, Cee Cee Ah and Skookum Creeks was generally the same for all three years (Table 3.58). Percent composition of drifting invertebrates collected from Ruby and Tacoma Creeks was different during each year of the study (Table 3.59). 


\section{Table 3.50. Comparison of mean annual densities of bent hic macroinvertebrates $\left(\# / \mathrm{m}^{2}\right)$ collected from tributaries of the Pend Oreille River during 1988, 1989 and $1990 . \quad$ Number of samples enclosed in parentheses.}

\begin{tabular}{l|cc|cc|cc}
\hline STUDY SITE & \multicolumn{2}{|c|}{1988} & \multicolumn{2}{c|}{$\mathbf{1 9 8 9}$} & \multicolumn{2}{c}{$\mathbf{1 9 9 0}$} \\
\hline LeClerc Creek & 4,822 & $\mathbf{( 1 7 )}$ & $\mathbf{4 , 4 5 7}$ & $(20)$ & 1,493 & $(\mathbf{8})$ \\
Ruby Creek & -- & - & 1,739 & $(20)$ & $\mathbf{8 5 7}$ & $(10)$ \\
Cee Cee Ah Creek & 5,922 & $\mathbf{( 1 7 )}$ & $\mathbf{3 , 3 4 2}$ & $\mathbf{( 2 3 )}$ & 2,198 & $(12)$ \\
Tacoma Creek & $\mathbf{4}, 91 \mathrm{a}$ & $\mathbf{( 1 3 )}$ & 3,608 & $(\mathbf{9})$ & 1,325 & $(4)$ \\
Skookum Creek & 4,969 & $\mathbf{( 1 4 )}$ & $\mathbf{4 , 6 5 6}$ & $\mathbf{( 2 4 )}$ & 1,673 & $(12)$ \\
\hline
\end{tabular}

Table 3.51. Comparison of the top benthic macroinvertebrates, by percent abundance, from samples collected from the Pend Oreille River during 1988, 1989 and 1990.

\begin{tabular}{|c|c|c|c|c|c|}
\hline \multicolumn{2}{|l|}{1988} & \multicolumn{2}{|l|}{1989} & \multicolumn{2}{|l|}{1990} \\
\hline \multicolumn{6}{|c|}{ LECERC CREEK } \\
\hline Chironomidae larvae & 15.9 & Chironomidae larvae & 31.4 & Chironomidae larvae & 52.2 \\
\hline Baetidae & 15.3 & Baetidae & 27.3 & Elmidae larvae & 9.4 \\
\hline Naididae & 14.8 & Ephemerellidae & 7.2 & Beatidae & 7.8 \\
\hline \multicolumn{6}{|c|}{ RUBYCREEK } \\
\hline \multirow{3}{*}{\multicolumn{2}{|c|}{ No samples collected }} & Chironomidae larvae & 18.9 & Sphaeriidae & 32.8 \\
\hline & & Elmidae larvae & 12.8 & Chironomidae larvae & 13. 8 \\
\hline & & Baetidae & 12.1 & Elmidae larvae & 11.6 \\
\hline \multicolumn{6}{|c|}{ CEE CEE AH CREEK } \\
\hline Elmidae larvae & 20.2 & Chironomidae larvae & 30.3 & Chironomidae larvae & 22.9 \\
\hline Chironomidae larvae & 15.8 & Baetidae & 17.6 & Sphaeriidae & 21.1 \\
\hline Heptageniidae & 14.6 & Elmidae & 11.8 & Baetidae & 11.2 \\
\hline Baetidae & 11.5 & Heptageniidae & 7.2 & Elmidae larvae & 10.7 \\
\hline \multicolumn{6}{|c|}{ TACOMA CREEK } \\
\hline Chironomidae larvae & 26.7 & Elmidae larvae & 25.0 & Elmidae larvae & 25.8 \\
\hline Elmidae larvae & 18.6 & Baetidae & 21.9 & Baetidae & 22.7 \\
\hline Baetidae & 9.7 & Brachycentridae & a.3 & Brachycentridae & 10.8 \\
\hline \multicolumn{6}{|c|}{ SKOOKUM CREEK } \\
\hline Chironomidae larvae & 25.1 & Baetidae & 14.9 & Baetidae & 29.9 \\
\hline Baetidae & 9.8 & Heptageniidae & 12.7 & Ephemerellidae & 13.0 \\
\hline Heptageniidae & a.9 & Chironomidae larvae & 12.2 & Lumbriculidae & 11.2 \\
\hline
\end{tabular}


Table 3.52. Mean annual invertebrate densities $\left(\# / 100 \mathrm{~m}^{3}\right)$ and percent abundance in samples collected by drift sampler from LeClerc Creek, WA during 1988, 1989 and 1990.

\begin{tabular}{|c|c|c|c|c|c|c|c|c|}
\hline \multirow[b]{2}{*}{ ORGANI SMS } & \multicolumn{2}{|c|}{1988} & \multicolumn{2}{|c|}{1989} & \multicolumn{2}{|c|}{1990} & \multicolumn{2}{|c|}{ Three year } \\
\hline & \multicolumn{2}{|c|}{$N=12$} & \multicolumn{2}{|c|}{$N=12$} & \multicolumn{2}{|c|}{$N=8$} & \multicolumn{2}{|c|}{$N=32$} \\
\hline IQUATIC & & & & & & & & \\
\hline $\begin{array}{l}\text { TAICHOPTERA } \\
\text { EPHEMEAOPTERA } \\
\text { PLECOPTERA } \\
\text { COLEOPIERA } \\
\text { PLECOPTERA } \\
\text { DIPTERA } \\
\text { LEPIDOPTERA } \\
\text { HYDRACARINA } \\
\text { OLGOCHAETA } \\
\text { NEMATODA } \\
\text { TURBEULARIA } \\
\text { HIRUDINEA } \\
\text { MOLLUSCA } \\
\text { BIVALVIA }\end{array}$ & $\begin{array}{l}21.2 \\
24.0 \\
22.5 \\
22.5 \\
28.5 \\
2.8 \\
1.4 \\
0.3 \\
0.6 \\
0.3 \\
0.2\end{array}$ & $\begin{array}{l}18.7 \\
19.0 \\
17.6 \\
17.6 \\
22.5 \\
\\
2.2 \\
1.1 \\
0.2 \\
0.5 \\
0.2 \\
0.2 \\
\end{array}$ & $\begin{array}{c}6.7 \\
38.5 \\
3.8 \\
12.4 \\
3.8 \\
47.5 \\
\\
2.5 \\
0.7\end{array}$ & $\begin{array}{c}5.4 \\
29.2 \\
3.0 \\
9.9 \\
3.0 \\
37.8 \\
\\
2.0 \\
0.5\end{array}$ & $\begin{array}{l}0.8 \\
3.0 \\
0.3 \\
4.4 \\
0.3 \\
8.1 \\
0.2 \\
0.2 \\
0.2\end{array}$ & $\begin{array}{c}4.4 \\
16.1 \\
1.5 \\
23.3 \\
1.5 \\
43.7 \\
0.9 \\
0.9 \\
0.9\end{array}$ & $\begin{array}{l}9.49 \\
21.17 \\
8.85 \\
5.59 \\
8.85 \\
28.04 \\
0.05 \\
1.82 \\
0.75 \\
0.10 \\
0.20 \\
0.07 \\
0.13 \\
0.1\end{array}$ & $\begin{array}{r}10.40 \\
23.26 \\
9.73 \\
6.14 \\
9.73 \\
30.81 \\
0.05 \\
2.00 \\
0.82 \\
0.11 \\
0.22 \\
0.08 \\
0.14 \\
0.11\end{array}$ \\
\hline PERRESTRIAL & & & & & & & & \\
\hline $\begin{array}{l}\text { DIPTERA } \\
\text { EPHEMEAOPTERA } \\
\text { COLEOPIERA } \\
\text { HEMIPTERA } \\
\text { HOMOPTERA } \\
\text { HMMENOPTERA } \\
\text { N E - } \\
\text { PSOCOPTERA } \\
\text { TRICHOPTERA } \\
\text { COUEMBOLA } \\
\text { ARANEIDA } \\
\text { UNAOWN } \\
\text { IOTAL }\end{array}$ & $\begin{array}{l}9.6 \\
3.8 \\
0.1 \\
0.4 \\
6.0 \\
0.5 \\
1.2 \\
0.1\end{array}$ & $\begin{array}{l}7.5 \\
3.0 \\
0.1 \\
0.3 \\
4.7 \\
0.6 \\
1.0 \\
0.1\end{array}$ & $\begin{array}{r}3.9 \\
3.2 \\
0.8 \\
0.1 \\
3.4 \\
1.0 \\
0.1 \\
0.5 \\
0.7 \\
0.3 \\
0.4 \\
0.7 \\
126.00\end{array}$ & $\begin{array}{r}3.0 \\
2.5 \\
0.4 \\
\text { Co. } 1 \\
2.7 \\
0.8 \\
0.1 \\
0.4 \\
0.6 \\
0.3 \\
0.3 \\
0.5\end{array}$ & $\begin{array}{c}0.4 \\
0.1 \\
0.2 \\
19.00\end{array}$ & $\begin{array}{l}2.1 \\
0.5 \\
1.1\end{array}$ & $\begin{array}{l}4.66 \\
2.4 \\
0.28 \\
0.16 \\
3.19 \\
0.63 \\
0.03 \\
0.12 \\
0.40 \\
0.10 \\
0.17 \\
0.30 \\
91.00\end{array}$ & $\begin{array}{l}5.06 \\
2.62 \\
0.31 \\
0.18 \\
3.51 \\
0.69 \\
0.03 \\
0.13 \\
0.44 \\
0.10 \\
0.19 \\
0.33\end{array}$ \\
\hline
\end{tabular}


Table 3.53. Mean annual invertebrate densities $\left(\# / 100 \mathrm{~m}^{3}\right)$ and percent abundance in samples collected by drift sampler from Ruby Creek, WA during 1989 and 1990.

\begin{tabular}{|c|c|c|c|c|c|c|}
\hline \multirow[b]{2}{*}{ ORGANI SMS } & \multicolumn{2}{|c|}{1989} & \multicolumn{2}{|c|}{1990} & \multicolumn{2}{|c|}{ Two year } \\
\hline & $\begin{array}{l}\text { MEAN } \\
\mathbf{N}\end{array}$ & $\%$ & MEAN & $\%$ & $\begin{array}{r}\text { MEAN }_{N} \\
\end{array}$ & $2^{\%}$ \\
\hline \multicolumn{7}{|l|}{ AQUATIC } \\
\hline $\begin{array}{l}\text { TRICHOPTERA } \\
\text { EPHEMEROPTERA } \\
\text { PLECOPTERA } \\
\text { COLEOPTERA } \\
\text { DI PTERA } \\
\text { HYDRACARINA } \\
\text { OLGOCHAETA } \\
\text { NEMATODA } \\
\text { TURBEUARIA } \\
\text { MOLUUSCA } \\
\text { BIVALVIA }\end{array}$ & $\begin{array}{c}38.9 \\
127.4 \\
125.7 \\
25.7 \\
72.3 \\
6.2 \\
8.5 \\
0.4 \\
2.4 \\
0.2 \\
4.5\end{array}$ & $\begin{array}{c}9.3 \\
30.3 \\
29.9 \\
6.0 \\
17.4 \\
1.5 \\
2.1 \\
0.1 \\
0.6 \\
\text { co. } 1 \\
1.1\end{array}$ & $\begin{array}{l}0.6 \\
2.4 \\
1.3 \\
3.4 \\
28.2 \\
1.3 \\
0.9 \\
0.5 \\
0.4 \\
0.1 \\
9.1 \\
\end{array}$ & $\begin{array}{l}1.1 \\
4.8 \\
2.5 \\
6.9 \\
57.5 \\
2.7 \\
1.8 \\
0.9 \\
0.8 \\
0.3 \\
18.1\end{array}$ & $\begin{array}{l}19.75 \\
64.91 \\
63.50 \\
14.57 \\
51.03 \\
3.77 \\
4.71 \\
0.44 \\
1.41 \\
0.17 \\
6.79 \\
\end{array}$ & $\begin{array}{r}8.39 \\
27.57 \\
26.97 \\
6.18 \\
21.67 \\
1.60 \\
2.00 \\
0.18 \\
0.60 \\
0.07 \\
2.88\end{array}$ \\
\hline \multicolumn{7}{|l|}{ TERRESTRIAL } \\
\hline $\begin{array}{l}\text { EPHEMEROPTERA } \\
\text { PLECOPTERA } \\
\text { COLEOPTERA } \\
\text { DIPTERA } \\
\text { HOMOPTERA } \\
\text { HYMENOPTERA } \\
\text { NEUAOPIERA } \\
\text { COULEMBOLA } \\
\text { ARANEIDA } \\
\text { UNMONN } \\
\text { TOTAL }\end{array}$ & $\begin{array}{c}0.7 \\
0.2 \\
0.1 \\
1.6 \\
1.2 \\
0.7 \\
0.1 \\
2.3 \\
0.4 \\
0.6 \\
420.00\end{array}$ & $\begin{array}{c}0.2 \\
c 0.1 \\
c 0.1 \\
0.3 \\
0.3 \\
0.1 \\
<0.1 \\
0.5 \\
0.1 \\
0.1\end{array}$ & $\begin{array}{c}0.4 \\
0.6 \\
0.4 \\
0.4 \\
50.00\end{array}$ & $\begin{array}{l}0.7 \\
1.1 \\
0.8 \\
0.8\end{array}$ & $\begin{array}{c}0.35 \\
0.1 \\
0.05 \\
0.8 \\
0.79 \\
0.54 \\
0.05 \\
1.36 \\
0.2 \\
0.50 \\
235.44\end{array}$ & $\begin{array}{l}0.15 \\
0.04 \\
0.02 \\
0.34 \\
0.33 \\
0.23 \\
0.02 \\
0.57 \\
0.08 \\
0.21\end{array}$ \\
\hline
\end{tabular}


Table 3.54. Mean annual invertebrate densities $\left(\# / 100 \mathrm{~m}^{3}\right)$ and percent abundance in samples collected by drift sampler from Cee Cee Ah Creek, WA during 1988, 1989 and 1990.

\begin{tabular}{|c|c|c|c|c|c|c|c|c|}
\hline ORGANISMS & $\begin{array}{r}19 \\
\text { MEAN } \\
\mathbf{N}\end{array}$ & $12^{88}$ & $\begin{array}{r}10 \\
\text { MEAN } \\
\mathrm{N}\end{array}$ & & $\begin{array}{r}10 \\
\text { MEAN } \\
\mathrm{N}\end{array}$ & & \multicolumn{2}{|c|}{$\begin{array}{c}\text { Three year } \\
\text { MEAN } \% \\
\quad \mathrm{~N}=48\end{array}$} \\
\hline IQUATIC & & & & & & & & \\
\hline $\begin{array}{l}\text { TRICHOPTERA } \\
\text { EPHEMEROPTERA } \\
\text { PLECOPTERA } \\
\text { COLEOPTEAA } \\
\text { ODONATA } \\
\text { LEPIDOPTERA } \\
\text { DIPTERA } \\
\text { HYDRACARINA } \\
\text { OSTRACODA } \\
\text { OLIGOCHAETA } \\
\text { NEMATODA } \\
\text { TURBEULARIA } \\
\text { MOLUUSCA } \\
\text { BIVALVIA }\end{array}$ & $\begin{array}{l}12.1 \\
11.3 \\
4.7 \\
7.3\end{array}$ & $\begin{array}{r}19.2 \\
3.6 \\
2.4 \\
1.0\end{array}$ & $\begin{array}{c}2.5 \\
14.8 \\
1.9 \\
7.3 \\
0.5 \\
29.8 \\
4.3 \\
5.2 \\
11.2 \\
0.7 \\
1.9 \\
10.6\end{array}$ & $\begin{array}{l}2.2 \\
14.4 \\
1.5 \\
7.1 \\
0.5 \\
28.9 \\
4.2 \\
4.9 \\
10.9 \\
0.6 \\
1.8 \\
10.3\end{array}$ & $\begin{array}{l}1.1 \\
3.9 \\
0.6 \\
1.0 \\
0.1 \\
50.9 \\
0.4\end{array}$ & $\begin{array}{c}1.8 \\
6.2 \\
0.9 \\
1.7 \\
0.2 \\
81.8 \\
0.7\end{array}$ & $\begin{array}{l}6.12 \\
10.00 \\
2.40 \\
5.21 \\
0.17 \\
0.05 \\
48.97 \\
2.44 \\
0.53 \\
1.97 \\
3.73 \\
0.23 \\
0.89 \\
5.94\end{array}$ & $\begin{array}{c}7.85 \\
12.81 \\
3.08 \\
6.68 \\
0.22 \\
0.06 \\
62.78 \\
3.13 \\
0.68 \\
2.52 \\
4.78 \\
0.29 \\
1.14 \\
7.62\end{array}$ \\
\hline 'ERRESTRIAL & & & & & & & & \\
\hline $\begin{array}{l}\text { EPHEMEROPTERA } \\
\text { COLEOPTERA } \\
\text { DIPTERA } \\
\text { HEMIPTERA } \\
\text { HOMOPTERA } \\
\text { HYMENOPTERA } \\
\text { PSOCOPTERA } \\
\text { THYSANOPTERA } \\
\text { CHILOPODA } \\
\text { DIPLOPODA } \\
\text { COUEMBOLA } \\
\text { ARANEIDA } \\
\text { UNKNOWN } \\
\text { TOTAL }\end{array}$ & $\begin{array}{l}1.2 \\
0.2 \\
2.1 \\
2.7 \\
0.7 \\
0.4\end{array}$ & $\begin{array}{l}1.8 \\
0.3 \\
3.0 \\
4.0 \\
1.0 \\
0.6\end{array}$ & $\begin{array}{c}0.7 \\
1.5 \\
0.4 \\
0.1 \\
0.1 \\
0.3 \\
0.2 \\
4.7 \\
4.4 \\
0.6 \\
103.00\end{array}$ & $\begin{array}{l}0.4 \\
1.5 \\
0.4 \\
0.1 \\
0.1 \\
0.3 \\
0.2 \\
4.5 \\
4.3 \\
0.6\end{array}$ & $\begin{array}{l}0.1 \\
0.04 \\
0.3 \\
0.1\end{array}$ & $\begin{array}{l}0.2 \\
0.1 \\
0.5 \\
0.2\end{array}$ & $\begin{array}{l}0.40 \\
0.07 \\
1.65 \\
0.01 \\
1.49 \\
0.4 \\
0.17 \\
0.03 \\
0.10 \\
0.07 \\
1.57 \\
1.50 \\
1.02 \\
78.00\end{array}$ & $\begin{array}{l}0.51 \\
0.09 \\
2.12 \\
0.01 \\
1.91 \\
0.51 \\
0.22 \\
0.03 \\
0.13 \\
0.09 \\
2.01 \\
1.92 \\
1.31\end{array}$ \\
\hline
\end{tabular}


Table 3.55. Mean annual invertebrate densities (\#/100m $\left.{ }^{3}\right)$ and percent abundance in samples collected by drift sampler from Tacoma Creek, WA during 1988, 1989 and 1990.

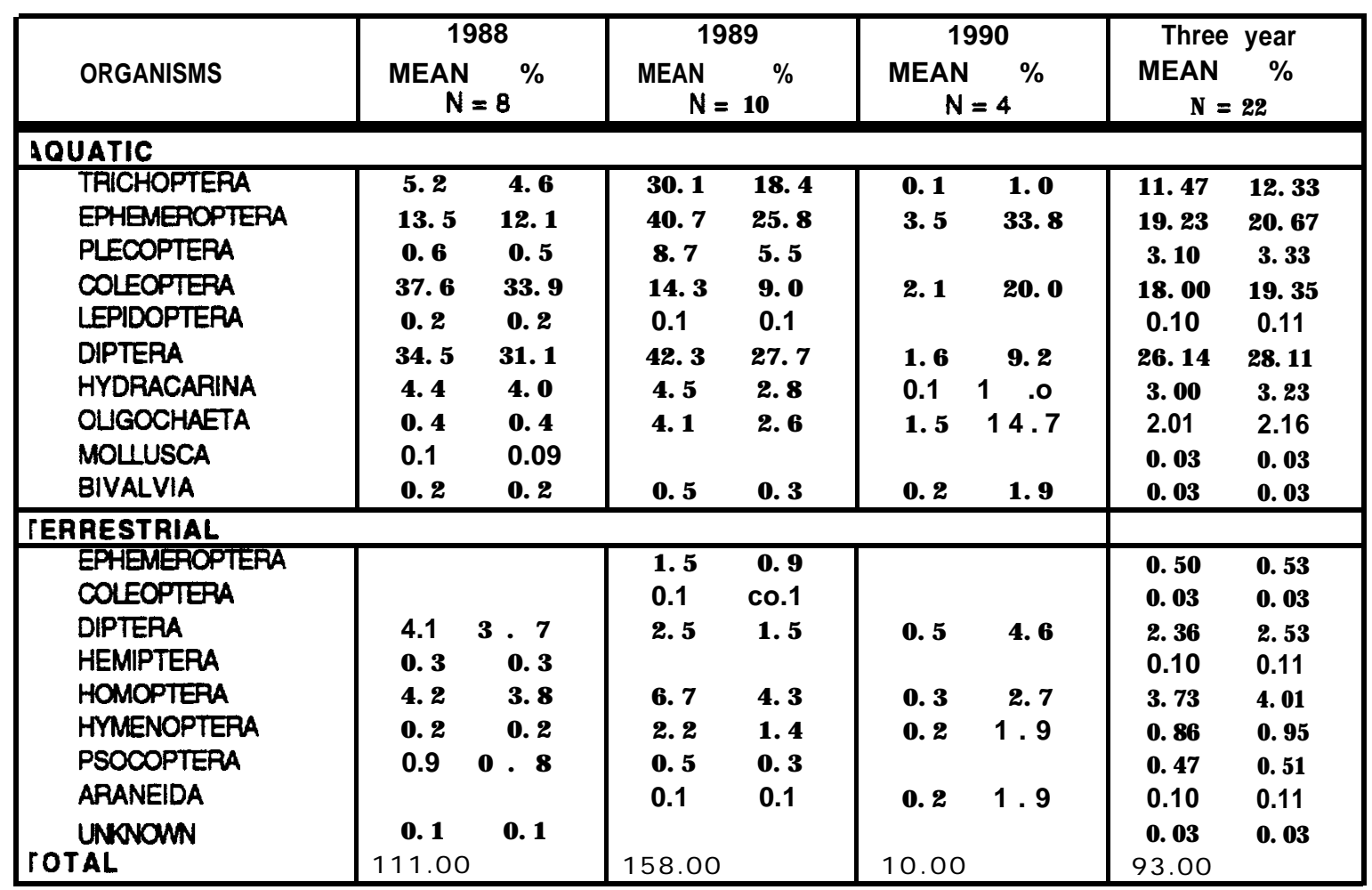


Table 3.56. Mean annual invertebrate densities (\#/100m $\left.{ }^{3}\right)$ and percent abundance in samples collected by drift sampler from Skookum Creek, WA -during 1988, 1989 and 1990.

\begin{tabular}{|c|c|c|c|c|c|c|c|c|}
\hline ORGANISMS & $\begin{array}{r}19 \\
\text { MEAN } \\
\mathrm{N}=\end{array}$ & $8 \%$ & $\begin{array}{r}1 \\
\text { MEAN } \\
\mathbf{N}\end{array}$ & $\begin{array}{l}9 \\
24\end{array}$ & $\begin{array}{r}1 \\
\text { MEAN } \\
\mathrm{N}\end{array}$ & 0 & \multicolumn{2}{|c|}{$\begin{array}{c}\text { Three year } \\
\text { MEAN } \% \\
\text { N }=46\end{array}$} \\
\hline \multicolumn{9}{|l|}{ IOUATIC } \\
\hline $\begin{array}{l}\text { TRICHOPTERA } \\
\text { EPHEMEROPTERA } \\
\text { PLECOPTERA } \\
\text { COLEOPTEAA } \\
\text { LEPIDOPTERA } \\
\text { DIPTERA } \\
\text { HYDRACARINA } \\
\text { OSTRACODA } \\
\text { OUGOCHAETA } \\
\text { NEMATODA } \\
\text { TURBELLARIA } \\
\text { MOUUSCA } \\
\text { BIVALVIA }\end{array}$ & $\begin{array}{c}7.6 \\
34.5 \\
4.0 \\
13.4 \\
200.2 \\
2.5 \\
0.2 \\
1.1 \\
0.2 \\
0.6 \\
6.5\end{array}$ & $\begin{array}{l}2.7 \\
12.1 \\
1.5 \\
4.7 \\
70.6 \\
0.9 \\
0.1 \\
0.4 \\
0.1 \\
\\
0.2 \\
2.3\end{array}$ & $\begin{array}{c}6.1 \\
38.1 \\
2.4 \\
6.7 \\
30.3 \\
2.4 \\
1.0\end{array}$ & $\begin{array}{l}6.2 \\
37.2 \\
3.5 \\
6.9 \\
31.4 \\
2.5 \\
1.0\end{array}$ & $\begin{array}{l}2.1 \\
13.7 \\
1.2 \\
2.2 \\
0.14 \\
10.3 \\
0.5 \\
\\
0.3 \\
0.09 \\
0.4 \\
0.07 \\
0.95\end{array}$ & $\begin{array}{l}4.0 \\
42.4 \\
3.8 \\
6.8 \\
0.40 \\
31.8 \\
1.6 \\
\\
0.9 \\
0.3 \\
1.3 \\
0.2 \\
2.9\end{array}$ & $\begin{array}{c}5.1 \\
28.11 \\
2.8 \\
7.42 \\
0.05 \\
80.17 \\
1.80 \\
0.07 \\
0.80 \\
0.10 \\
0.14 \\
0.22 \\
3.65 \\
\end{array}$ & $\begin{array}{c}3.72 \\
20.48 \\
2.04 \\
5.41 \\
0.04 \\
58.40 \\
1.31 \\
0.05 \\
0.60 \\
0.07 \\
0.10 \\
0.16 \\
2.66\end{array}$ \\
\hline \multicolumn{9}{|l|}{ 'ERRESTRIAL } \\
\hline $\begin{array}{l}\text { EPHEMEROPTERA } \\
\text { COLEOPTERA } \\
\text { DIPTERA } \\
\text { HOMOPTERA } \\
\text { HYMENOPIERA } \\
\text { PSOOOPTERA } \\
\text { THYSANOPTERA } \\
\text { TAICHOPTERA } \\
\text { COUEMBOLA } \\
\text { ARANEIDA } \\
\text { UNONOWN } \\
\text { OTAL }\end{array}$ & $\begin{array}{l}0.4 \\
0.2 \\
2.7 \\
7.3 \\
0.9 \\
0.7\end{array}$ & $\begin{array}{l}0.1 \\
0.1 \\
1.0 \\
2.6 \\
0.3 \\
0.2\end{array}$ & $\begin{array}{l}0.4 \\
0.4 \\
0.6 \\
2.2 \\
0.3 \\
0.1 \\
0.3 \\
0.1 \\
2.9 \\
0.1 \\
97.00\end{array}$ & $\begin{array}{l}0.4 \\
0.4 \\
0.6 \\
2.3 \\
0.3 \\
0.1 \\
0.3 \\
0.1 \\
3.0 \\
0.1\end{array}$ & $\begin{array}{c}0.3 \\
0.4 \\
0.2 \\
32.00\end{array}$ & $\begin{array}{l}1.1 \\
1.1 \\
0.7\end{array}$ & $\begin{array}{c}0.27 \\
0.20 \\
1.11 \\
3.26 \\
0.4 \\
0.27 \\
0.10 \\
0.03 \\
1.08 \\
0.15 \\
0.08 \\
137.27\end{array}$ & $\begin{array}{l}0.20 \\
0.15 \\
0.81 \\
2.37 \\
0.29 \\
0.20 \\
0.07 \\
0.03 \\
0.79 \\
0.11 \\
0.06\end{array}$ \\
\hline
\end{tabular}


Table 3.57. Comparison of mean annual densities of macroinvertebrates $\left(\# / 100 \mathrm{~m}^{3}\right)$ collected from drift samples in tributaries of the Pend Oreille River during 1988, 1989 and 1990. Number of samples enclosed in parentheses.

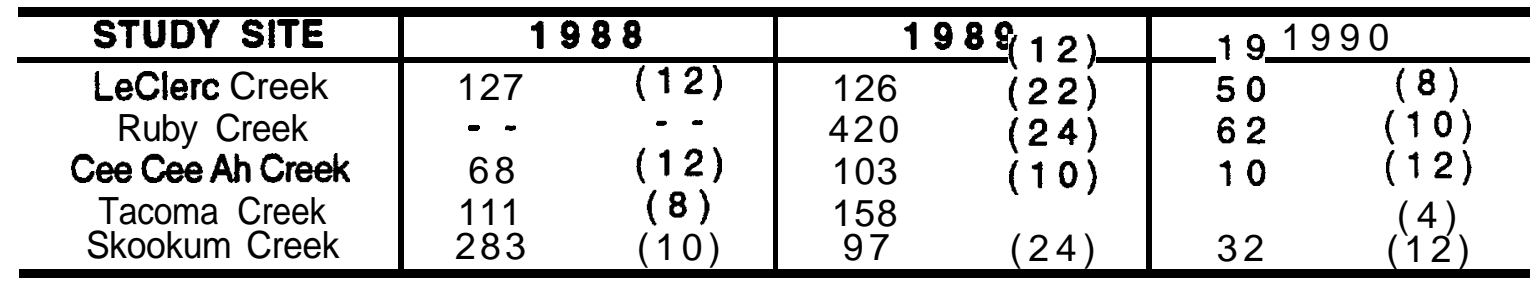

Table 3.58. Comparison of the top invertebrates, by percent composition, in drift samples collected in tributaries of the Pend Oreille River during 1988, 1989 and 1990.

\begin{tabular}{|c|c|c|c|c|c|}
\hline 1988 & & 1989 & & 1990 & \\
\hline \multicolumn{6}{|c|}{ LECERCCREEK } \\
\hline Chironomidae larvae & 16.7 & Baetidae & $\overline{23.7}$ & Chironomidae pupae & 16.9 \\
\hline Baetidae & a. 0 & Chironomidae larvae & 15.7 & Chironomidae larvae & 16.3 \\
\hline Nemouridae & 0.0 & Chironomidae pupae & 13.5 & Elmidae larvae & 15.9 \\
\hline \multicolumn{6}{|c|}{ RUBYCREEK } \\
\hline \multirow{3}{*}{ No samples collected } & & Nemouridae & 29.9 & Chironomidae larvae & 29.9 \\
\hline & & Baetidae & 23.0 & Sphaeriidae & 16.1 \\
\hline & & Simuliidae pupae & 9.2 & Chironomidae pupae & 10.3 \\
\hline \multicolumn{6}{|c|}{ CEE CEE AH CREEK } \\
\hline Chironomidae larvae & 10.0 & Chironomidae larvae & 16.2 & Chironomidae larvae & 74.2 \\
\hline Brachycentridae & 9.6 & Nematoda & 10.9 & Chironomidae pupae & 4.5 \\
\hline Elmidae larvae & 9.1 & Baetidae & 9.3 & Sphaeriidae & 4.5 \\
\hline \multicolumn{6}{|c|}{ TACOMA CREEK } \\
\hline Elmidae adult & 24.7 & Chironomidae larvae & 18.6 & Baetidae & 31.1 \\
\hline Chironomidae pupae & 17.6 & Brachycentridae & 10.2 & Elmidae larvae & 15.4 \\
\hline Elmidae larvae & 9.2 & Ephemerellidae & 10.8 & Lumbriculidae & 14.7 \\
\hline \multicolumn{6}{|c|}{ SKOOKUMCREEK } \\
\hline Chironomidae larvae & 63.0 & Baetidae & 25.4 & Baetidae & 37.6 \\
\hline Baetidae & 10.2 & Chironomidae larvae & 15.1 & Chironomidae larvae & 17.3 \\
\hline Chronomidae pupae & 5.7 & Chironomidae pupae & 11.3 & Chironomidae pupae & 9.5 \\
\hline
\end{tabular}




\subsection{FEEDING HABITS OF FISH IN THE TRIBUTARIES}

\subsubsection{LECLERC CREEK}

A total of 98 stomachs were collected from brown trout in LeClerc Creek during the study; 32 in 1988, 54 in 1989 and 12 in 1990. Prey items with the highest index of relative importance (IRI) values were from the orders Trichoptera, Ephemeroptera, and Diptera (Table 3.59). Based on a three year average, Limnephilidae (18.1\%), Brachycentridae (12.2\%) and Baetidae (8.1\%) were the most important items in LeClerc Creek brown trout diets (Appendix L, Table L. 1).

Stomach samples were collected from 131 brook trout in LeClerc Creek during the study; 35 in 1988, 74 in 1989 and 22 in 1990. Orders Trichoptera, Diptera and Coleoptera contained the prey items with the highest IRI values (Table 3.60). Based on a three year average, Brachycentridae (12.0\%), Limnephilidae (11.1\%) and Chironomidae larvae (8.3\%) were the most important items in the diet of LeClerc Creek brook trout (Appendix L, Table L.2).

Thirty-six stomach samples were collected from cutthroat trout in LeClerc Creek during the study; 1 in 1988, 9 in 1989 and 26 in 1990. Unidentifiable terrestrial insects, Trichoptera, Ephemeroptera and Diptera were the prey items with the highest IRI values (Table 3.61). Three year averages determined that unidentified terrestrials (18.9\%) Baetidae (11.8\%) and Brachycentridae (8.2\%) were the most important organisms for cutthroat trout in LeClerc Creek (Appendix L, Table L.3).

Mountain whitefish stomachs were collected from 4 fish in LeClerc Creek in 1988 (Table 3.62). The highest IRI values were for Limnephilidae (26.5\%), Baetidae (13.5\%), Rhyacophilidae (13.3\%) and Simuliidae larvae (13.3\%) (Appendix L, Table L.4).

Based on index of relative importance values interspecific and intraspecific diet overlaps between trout species were calculated. Moderate to high overlaps were observed between brown trout and brook trout in LeClerc Creek during the study (Table 3.63). Diet overlaps between brown trout and cutthroat trout and brook trout and cutthroat trout were low to moderate.

High diet overlaps between different age classes of brown trout were observed between age $1+$ and $2+$, age $1+$ and $3+$ and age 2+ 
Table 3.59.

Mean annual index of relative importance (IRI) values for prey items consumed by brown trout in Leclerc Creek during 1988, 1989 and 1990.

\begin{tabular}{|c|c|c|c|c|}
\hline Prey Organisms & $\begin{array}{l}1988 \\
n=32\end{array}$ & $\begin{array}{l}1989 \\
n=54\end{array}$ & $\begin{array}{l}1990 \\
n=12\end{array}$ & $\begin{array}{c}\text { Average } \\
1988-90 \\
n=98\end{array}$ \\
\hline \multicolumn{5}{|c|}{ AQUATIC ORGANISMS } \\
\hline TRICHOPTERA & 27.9 & 53.6 & 44.7 & 41.0 \\
\hline EPHEMEROPTERA & 18.0 & 16.4 & 12.8 & 15.7 \\
\hline DIPTERA & 9.0 & 7.5 & 12.9 & 9.7 \\
\hline PLECOPTERA & 1.0 & 1.0 & 1.5 & 1.1 \\
\hline COLEOPTEAA & 2.3 & 1.1 & 5.8 & 2.9 \\
\hline HYDRACARINA & & 0.3 & & 0.1 \\
\hline OLGOCHAETA & 1.3 & 1.9 & & 1.0 \\
\hline LEPIDOPTERA & & & 3.3 & 1.1 \\
\hline NEMATODA & & & 3.6 & 1.2 \\
\hline OSTEICHTHYES & 12.2 & 1.1 & 4.5 & 5.9 \\
\hline UN DENTI FI ED & 17.5 & & & 5.8 \\
\hline \multicolumn{5}{|l|}{ TERRESTRIALS } \\
\hline TRICHOPTERA & 1.2 & 2.0 & & 1.1 \\
\hline DIPTERA & & 1.2 & & 0.3 \\
\hline PLECOPTERA & & 0.4 & & 0.1 \\
\hline C O L E - & 0.8 & 0.6 & 1.2 & 0.9 \\
\hline HEMIPTERA & 1.6 & & & 0.5 \\
\hline HOMOPTERA & 1.8 & 1.5 & 1.0 & 1.5 \\
\hline HYMENOPTERA & 4.8 & 6.4 & 2.0 & 4.4 \\
\hline ARANEIDA & 1.0 & 1.1 & 2.1 & 1.4 \\
\hline CHILIPODA & & & 1.2 & 0.4 \\
\hline COLEMBOLA & & & 2.1 & 0.7 \\
\hline LEPIDOPIERA & 4.6 & 1.9 & & 2.2 \\
\hline OATHOPTERA & & 0.7 & & 0.2 \\
\hline UNIDENTIFIED & 3.9 & 4.3 & & 2.7 \\
\hline
\end{tabular}


Table 3.60.

Mean annual index of relative importance (IRI) values for prey items consumed by brook trout in LeClerc Creek during 1988, 1989 and 1990.

\begin{tabular}{|c|c|c|c|c|}
\hline Prey Organi sms & $\begin{array}{l}1988 \\
n=35\end{array}$ & $\begin{array}{l}1989 \\
n=74\end{array}$ & $\begin{array}{l}1990 \\
n=22\end{array}$ & $\begin{array}{c}\text { Aver age } \\
1988-90 \\
n=131\end{array}$ \\
\hline \multicolumn{5}{|l|}{ AQUATI C ORGANI SMS } \\
\hline TRICHOPTERA & 34.6 & 26.0 & 25.3 & 28.5 \\
\hline EPHEMEAOPTERA & 5.9 & 10.1 & 7. 0 & 7.5 \\
\hline DIPTERA & 24. 7 & 11. 0 & 13.8 & 16. 5 \\
\hline PLECOPTERA & & 0.9 & 1.4 & 0.7 \\
\hline COLEOPTERA & 4. 0 & 4.5 & 26. 3 & 11.5 \\
\hline GASTROPODA & 0.3 & & & 0.1 \\
\hline OLGOCHAETA & 0.7 & 1.1 & 1.3 & 1.0 \\
\hline LEPIDOPTERA & & 2.9 & 7. 6 & 3.5 \\
\hline OSTEICHTHYES & 0.2 & 4.1 & & 1.4 \\
\hline UN DENTI FI ED & 2.9 & 2.0 & & 1.6 \\
\hline \multicolumn{5}{|l|}{ TERRESTRI ALS } \\
\hline TRICHOPTERA & 2.5 & 0.6 & 4.2 & 2.4 \\
\hline DIPTERA & 2.1 & 4. 7 & 1.9 & 3.0 \\
\hline PLECOPTERA & & 0.8 & & 0.3 \\
\hline COLEOPIERA & 0.9 & 2.4 & 1. 4 & 1. 7 \\
\hline HEMIPTERA & 0.4 & & & 0.1 \\
\hline HOMOPTERA & 3. 0 & 5.9 & 3. 3 & 4.1 \\
\hline HYMENOPTERA & 1.9 & 10.2 & 6. 0 & 6.0 \\
\hline ARANEIDA & 1. 3 & 0.0 & 0.6 & 0.9 \\
\hline COUEMMBOLA & & 0.2 & & 0.1 \\
\hline DIPLOPODA & & 0.5 & & 0.2 \\
\hline LEPIDOPTERA & 5.2 & 3. 3 & & 2.8 \\
\hline NEUROPTERA & & 0.1 & & $<0.1$ \\
\hline ODONATA & & 0.8 & & 0.3 \\
\hline ORTHOPIERA & & 0.4 & & 0.1 \\
\hline UN DENTI FI ED & 9.7 & 7.3 & & 5.7 \\
\hline
\end{tabular}


Table 3.61. Mean annual index of relative importance (IRI) values for prey items consumed by cutthroat trout in LeClerc Creek during 1988, 1989 and 1990.

\begin{tabular}{|c|c|c|c|c|}
\hline Prey Organisms & $\begin{array}{c}1988 \\
n=1\end{array}$ & $\begin{array}{c}1989 \\
n=9\end{array}$ & $\begin{array}{l}1990 \\
n=26\end{array}$ & $\begin{array}{c}\text { Average } \\
1988-90 \\
n=36\end{array}$ \\
\hline \multicolumn{5}{|l|}{ AQUATIC ORGANISMS } \\
\hline TRICHOPTERA & & 22.7 & 29.5 & 17.4 \\
\hline EPHEMEROPTERA & 6.4 & 29.1 & 14.6 & 16.7 \\
\hline DIPTERA & & 9.3 & 30.7 & 13.0 \\
\hline PLECOPTERA & & 1.4 & 1.1 & 0.9 \\
\hline ODONATA & & & 2.0 & 0.7 \\
\hline COLEOPTERA & 6.2 & 8.5 & 1.1 & 5.2 \\
\hline OUGOCHAETA & & 1.8 & 1.2 & 1.0 \\
\hline LEPIDOPTERA & & 2.7 & & 0.9 \\
\hline OSTEICHTHYES & & 2.2 & & 0.7 \\
\hline UNIDENTIFED & 6.1 & & & 2.0 \\
\hline \multicolumn{5}{|l|}{ TERRESTRIALS } \\
\hline TRICHOPTERA & 6.0 & & 1.6 & 2.5 \\
\hline DIPTERA & 7.4 & 8.3 & 1.1 & 5.7 \\
\hline PLECOPTERA & & 4.6 & & 1.5 \\
\hline HOMOPTERA & 6.3 & & & 2.1 \\
\hline HYMENOPTERA & 7.1 & 2.5 & 1.2 & 3.6 \\
\hline ARANEIDA & 6.0 & 1.4 & 1.1 & 2.8 \\
\hline COUEMBOLA & & 2.0 & 1.1 & 1.0 \\
\hline GASTROPODA & & & 1.1 & 0.4 \\
\hline LEPIDOPTERA & & 3.5 & & 1.2 \\
\hline UNIDENTIFED & 48.3 & 5.2 & 3.3 & 18.9 \\
\hline
\end{tabular}

Table 3.62.

Mean annual index of relative importance (IRI) values for prey items consumed by mountain whitefish in LeClerc Creek during 1988.

\begin{tabular}{|l|c|}
\hline Prey Organi sns & $\begin{array}{c}1988 \\
n=4\end{array}$ \\
\hline AQUATIC ORGANISMS & \\
\hline TRICHOPTERA & 44.1 \\
\hline EPHEMEROPTERA & 33.1 \\
\hline DIPTERA & 20.5 \\
\hline PLECOPTERA & 1.4 \\
\hline TERRESTRIALS & \\
\hline LEPIDOPTERA & 1.3 \\
\hline
\end{tabular}


Table 3.63. Annual diet overlaps between trout species captured in LeClerc Creek during 1988, 1989 and 1990.

\begin{tabular}{|l|c|c|c|}
\cline { 2 - 4 } \multicolumn{1}{c|}{} & 1988 & 1990 \\
\hline LeClerc Creek & 0.68 & 0.73 & 0.55 \\
\hline Brown trout $\times$ brook trout & 0.20 & 0.44 & 0.50 \\
\hline Brown trout $\times$ cutthroat trout & 0.27 & 0.51 & 0.50 \\
\hline Brook trout $\times$ cutthroat trout & & 1989 \\
\hline
\end{tabular}

Table 3.64. Annual diet overlaps between age classes of trout species captured in LeClerc Creek during 1988, 1989 and 1990.

\begin{tabular}{|c|c|c|c|}
\hline & \multirow{2}{*}{\multicolumn{2}{|c|}{1989}} & \multirow[b]{2}{*}{1990} \\
\hline & & & \\
\hline \multicolumn{4}{|l|}{ Brown trout } \\
\hline $0+\times 1+$ & 0.37 & 0.63 & 0.21 \\
\hline $0+\times 2+$ & 0.40 & 0.51 & 0.39 \\
\hline $0+\times 3+$ & 0.08 & 0.25 & 0.00 \\
\hline $0+\times 4+$ & 0.16 & 0.15 & 0.07 \\
\hline $1+\times 2+$ & 0.54 & 0.84 & 0.11 \\
\hline $1+\times 3+$ & 0.48 & 0.81 & 0.05 \\
\hline $1+\times 4+$ & 0.57 & 0.55 & 0.01 \\
\hline $2+\times 3+$ & 0.51 & 0.63 & 0.45 \\
\hline $2+\times 4+$ & 0.72 & 0.31 & 0.04 \\
\hline $3+\times 4+$ & 0.68 & 0.68 & 0.30 \\
\hline \multicolumn{4}{|l|}{ Brook trout } \\
\hline $0+\times 1+$ & 0.45 & 0.54 & -- \\
\hline $0+\times 2+$ & 0.36 & 0.50 & $\cdots$ \\
\hline $0+\times 3+$ & -- & 0.51 & $\because$ \\
\hline $1+\times 2+$ & 0.16 & 0.47 & 0.42 \\
\hline $1+\times 3+$ & -- & 0.38 & 0.32 \\
\hline $2+\times 3+$ & $\cdots$ & 0.75 & 0.06 \\
\hline \multicolumn{4}{|l|}{ Cutthroat trout } \\
\hline $1+\times 2+$ & $\cdots$ & 0.33 & 0.44 \\
\hline $1+\times 3+$ & $\cdots$ & $\ldots$ & 0.33 \\
\hline $2+\times 3+$ & $\ldots$ & $\cdots$ & 0.30 \\
\hline $3+\times 4+$ & 0.53 & $\cdots$ & $\cdots$ \\
\hline
\end{tabular}


and 4+ during the study (Table 3.64). The only high diet overlap observed between different age classes of brook trout was for age $2+$ and 3+. Diet overlaps between different age classes of cutthroat trout were all low to moderate.

\subsubsection{RUBY CREEK}

Brown trout were captured in Ruby Creek only during 1989. Nine stomach samples were collected (Table 3.65). The highest index of relative importance (IRI) values were for Limnephilidae (14.9\%) Baetidae (13.1\%), Perlodidae (10.4\%) and Rhyacophilidae (10.3\%) (Appendix L, Table L.5).

A total of 146 stomach samples were collected from brook trout in Ruby Creek during the study; 122 in 1989 and 24 in 1990. Diet analysis revealed that brook trout in Ruby Creek ate a wide variety of benthic and terrestrial invertebrates during both years. Orders Trichoptera, Ephemeroptera and Plecoptera contained prey items with the highest IRI values (Table 3.66). Based on a two year average, Formicidae (12.7\%) and Chironomidae larvae $(9.4 \%)$ were the most important organisms for brook trout in Ruby Creek (Appendix L, Table L.6).

Eleven stomach samples were collected from cutthroat trout in Ruby Creek during the study; 9 in 1989 and 2 in 1990. Orders Hymenoptera, Diptera and Ephemeroptera contained the prey items with the highest IRI values (Table 3.67). Two year averages determined that Formicidae (31.6\%), Baetidae (8.2\%) and Simuliidae larvae $(6.6 \%)$ were the most important organisms for cutthroat trout in Ruby Creek (Appendix L, Table L.7).

Ten rainbow trout stomach samples were collected from Ruby Creek: 9 in 1989 and 1 in 1990. Prey items with the highest IRI values were from the orders Hymenoptera and Trichoptera (Table 3.68). Diet analysis that was performed on the single trout in 1990 revealed stomach contents of $100 \%$ Formicidae. As a result the two year average IRI value for Formicidae (54.0\%) was far higher than any other prey organisms. Heptageniidae (5.2\%) and Brachycentridae $(4.6 \%)$ were other important prey items for rainbow trout in Ruby Creek (Appendix L, Table L.8).

Stomach samples were collected from 4 mountain whitefish in Ruby Creek during the study; 1 in 1989 and 3 in 1990. The highest IRI values were for prey items in the orders Diptera, Ephemeroptera 


\section{Table 3.65 .}

\section{Mean annual index of relative importance (IRI) value for prey items consumed by brown trout in Ruby Creek during 1989.}

\begin{tabular}{|c|c|}
\hline Prey Organisms & $\begin{array}{c}1989 \\
n=9\end{array}$ \\
\hline \multicolumn{2}{|c|}{ AQUATIC ORGANISMS } \\
\hline TRICHOPTERA & 30.8 \\
\hline EPHEMEROPTERA & 18.6 \\
\hline DIPTERA & 6.9 \\
\hline PLECOPTERA & 10.4 \\
\hline COLEOPTERA & 9.0 \\
\hline \multicolumn{2}{|l|}{ TERRESTRIALS } \\
\hline EPHEMEROPTER & 0.8 \\
\hline PLECOPTEPA & 1.8 \\
\hline COLEOPIEPA & 8.2 \\
\hline \multicolumn{2}{|l|}{ HOMOPTERA } \\
\hline HYMENOPTERA & 4.1 \\
\hline ARANEIDA & 1.8 \\
\hline LEPIDOPIERA & 2.1 \\
\hline UNIDENTIFED & 2.0 \\
\hline
\end{tabular}


Table 3.66. Mean annual index of relative importance (IRI) values for prey items consumed by brook trout in Ruby Creek during 1989 and 1990.

\begin{tabular}{|c|c|c|c|}
\hline Prey Organisms & $\begin{array}{c}1969 \\
n=122\end{array}$ & $\begin{array}{c}1990 \\
n=24\end{array}$ & $\begin{array}{c}\text { Average } \\
1989.90 \\
n=146\end{array}$ \\
\hline \multicolumn{4}{|l|}{ AQUATIC ORGANISMS } \\
\hline TALCOPTERA & 20.0 & 23.6 & 15.2 \\
\hline EPHEMFROPTERA & 9.9 & 13.2 & 117 \\
\hline DIPTERA & 10.7 & 28.9 & 19.7 \\
\hline PLEOOPIERA & 19 & 3.0 & 2.5 \\
\hline ULUNA I A & 0.3 & & 02 \\
\hline COLEOPTER4 & 5.0 & 2.4 & 3.7 \\
\hline HYDRACARINA & 1.7 & Q.a & $1 / 3$ \\
\hline BIYAI \! A & $1 \_5$ & & 0.8 \\
\hline GASTROPOOA & 0.5 & & 0.3 \\
\hline LEPIDOPTERA & 22 & 0.3 & 1.3 \\
\hline OLIGOCHAETA & 5.0 & 3.0 & 4.0 \\
\hline NEMATOOA & 0.1 & 0.7 & 0.4 \\
\hline OSTECHTHES & 02 & 0.9 & 0.6 \\
\hline HEMIPTERA & 0.1 & & $<0.1$ \\
\hline \multicolumn{4}{|l|}{ TERRESTRIALS } \\
\hline TRCHOPTERA & 0.6 & 4.5 & 2.6 \\
\hline DIPTERA & 3.7 & 3.5 & 3.5 \\
\hline PLEOOPTIERA & 0.6 & & 0.4 \\
\hline COLEOPIERA & 7.5 & 2.7 & 5.4 \\
\hline HEMIPTCDA & no & ac & 41 \\
\hline HOMOPTEAA & & 0.0 & \\
\hline HMMENOPTERA & 6.1 & 21.7 & 15.1 \\
\hline ARANEIDA & 2.0 & 3.3 & 2.7 \\
\hline COLLEMBOLA & 14 & & ก7 \\
\hline DIPLOPODA & 0.2 & U.1 & 0.2 \\
\hline LEPIDOPTERA & 2.5 & & 1.3 \\
\hline NEUROPTERA & $<0.1$ & & $\mathrm{CO} .1$ \\
\hline ODONATA & 09 & & ก5 \\
\hline UNIDENTIFIED & & & 3.6 \\
\hline
\end{tabular}


Mean annual index of relative importance (IRI) values for prey items consumed by cutthroat trout in Ruby Creek during 1989 and 1990.

\begin{tabular}{|c|c|c|c|}
\hline Prey Organisms & $\begin{array}{c}1989 \\
n=9\end{array}$ & $\begin{array}{c}1990 \\
n=2\end{array}$ & $\begin{array}{c}\text { Average } \\
1989 \cdot 90 \\
n=11\end{array}$ \\
\hline \multicolumn{4}{|l|}{ AQUATIC ORGANISMS } \\
\hline TAICHOPTERA & 17.9 & 7.0 & 8.5 \\
\hline EPHEMEROPTERA & 7.5 & 11.3 & 9.4 \\
\hline DIPTERA & 15.3 & 11.3 & 13.4 \\
\hline PLECOPTERA & 15.8 & & 8.0 \\
\hline COLEOPIEAA & 3.2 & & 1.6 \\
\hline LEPIDOPTERA & 1.4 & 11.2 & 6.3 \\
\hline OLGOCHAETA & 10.0 & & 5.0 \\
\hline \multicolumn{4}{|l|}{ TERRESTRIALS } \\
\hline TRICHOPTERA & 1.6 & & 0.8 \\
\hline DIPTERA & 1.6 & & 0.8 \\
\hline COLEOPIERA & 5.7 & & 2.9 \\
\hline HEMIPTERA & 1.6 & & 0.8 \\
\hline HOMOPTERA & 3.9 & & 2.0 \\
\hline HYMENOPTERA & 7.1 & 59.3 & 33.3 \\
\hline LEPIDOPTERA & 1.7 & & 0.9 \\
\hline NEUROPTERA & 2.3 & & 1.2 \\
\hline UNIDENTIFED & 3.2 & & 1.6 \\
\hline
\end{tabular}

Table 3.68.

Mean annual index of relative importance (IRI) values for prey items consumed by rainbow trout in Ruby Creek during 1989 and 1990.

\begin{tabular}{|c|c|c|c|}
\hline Prey Organisms & $\begin{array}{c}1989 \\
n=9\end{array}$ & $\begin{array}{c}1990 \\
n=1\end{array}$ & $\begin{array}{c}\text { Average } \\
1989-90 \\
n=10\end{array}$ \\
\hline \multicolumn{4}{|l|}{ AQUATIC ORGANISMS } \\
\hline TRICHOPTERA & 25.1 & & 12.8 \\
\hline EPHEMEROPTERA & 21.0 & & 6.1 \\
\hline DIPTERA & B.8 & & 4.5 \\
\hline PLECOPTERA & 7.8 & & 3.9 \\
\hline COLEOPIERA & 7.1 & & 3.6 \\
\hline HYDRACARINA & 0.8 & & 0.4 \\
\hline LEPIDOPTERA & 3.7 & & 1.9 \\
\hline \multicolumn{4}{|l|}{ TERAESTRIALS } \\
\hline TRICHOPTERA & & & 0.7 \\
\hline DIPTERA & 1.6 & & 0.8 \\
\hline COLEO :- A & 3.1 & & 1.0 \\
\hline HOMOPTERA & 0.8 & & 0.4 \\
\hline HYMENOPTERA & 12.1 & 100.0 & 56.1 \\
\hline ARANE,IDA & 3.5 & & 1.8 \\
\hline LEPIDOPTERA & 3.1 & & 1.6 \\
\hline
\end{tabular}


and Trichoptera (Table 3.69). Based on two year averages Simuliidae larvae $(22.3 \%)$ and Baetidae (20.7\%) were the most important prey items for mountain whitefish in Ruby Creek (Appendix L, Table L.9).

Based on index of relative importance values interspecific and intraspecific diet overlaps between trout and whitefish species were calculated. Moderate overlaps were observed between brook trout and cutthroat trout in Ruby Creek during the study (Table 3.70). Brook trout and rainbow trout exhibited a high overlap in 1989 and a low overlap in 1990. High diet overlaps were observed between cutthroat trout and rainbow trout. Generally, overlaps between mountain whitefish and all trout species were low.

Diet overlaps between different age classes of brown trout were all low except for age $\mathbf{2 +}$ and $\mathbf{3 +}$, which were moderate (Table 3.71). Diet overlaps between different age classes of brook trout were low to moderate except for between age $1+$ and $2+$, which demonstrated high overlaps. In 1988, age 1+ and $2+$ cutthroat trout in Ruby Creek demonstrated high overlaps. Overiaps between all age classes of cutthroat trout the following year were low. Overlaps observed between all age classes of rainbow trout were low.

\subsubsection{CEE CEE AH CREEK}

A total of 175 brown trout stomach samples were collected from Cee Cee Ah Creek during the study; 48 in 1988, 102 in 1989 and 25 in 1990. A wide variety of prey items were identified in brown trout stomach samples (Table 3.72). Based on a three year average, Limnephilidae $(16.3 \%)$, Baetidae $(5.9 \%)$, Osteichthyes $(4.9 \%)$ and Formicidae $(4.9 \%)$ were the prey items most important to brown trout in Cee Cee Ah Creek (Appendix L, Table L.10).

One hundred and fifty-three stomach samples were collected from brook trout in Cee Cee Ah Creek during the study; 27 in 1988, 100 in 1989 and 26 in 1990. Diet analysis determined these fish consumed a wide range of benthic and terrestrial invertebrates (Table 3.73). Limnephilidae (18.4\%) Chironomidae larvae $(9.0 \%)$ and Brachycentridae $(8.9 \%)$ were the most important prey items to brook trout in Cee Cee Ah Creek based on a three year average (Appendix L, Table L.II).

Cutthroat stomach samples were collected from Cee Cee Ah Creek during 1990 (Table 3.74). Analysis of eight fish stomachs determined that Formicidae (54.4\%) and Lepidoptera (12.3\%) were 
Table 3.69.

Mean annual index of relative importance (IRI) values for prey items consumed by mountain whitefish in Ruby Creek during 1989 and 1990.

\begin{tabular}{|c|c|c|c|}
\hline Prey Organisms & $\begin{array}{c}1989 \\
n=1\end{array}$ & $\begin{array}{c}1990 \\
n=3\end{array}$ & $\begin{array}{c}\text { A ver a ge } \\
1989.90 \\
n=4\end{array}$ \\
\hline \multicolumn{4}{|l|}{ AQUATIC ORGANISMS } \\
\hline TRICHOPTERA & 38.2 & 5.1 & 21.8 \\
\hline EPHEMEROPIERA & 22.0 & 44.6 & 33.3 \\
\hline DIPTERA & 30.5 & 36.5 & 33.6 \\
\hline COLEOPTEA & 9.3 & 3.2 & 8.3 \\
\hline CLADOCERA & 7.5 & 3.8 & \\
\hline \multicolumn{4}{|l|}{ TERRESTRIALS } \\
\hline HMMENOPTERA & 3.2 & 1.6 & \\
\hline
\end{tabular}


Table 3.70. Annual diet overlaps between trout species captured in Ruby Creek during 1988, 1989 and 1990.

\begin{tabular}{|c|c|c|c|}
\hline & 1998 & 1989 & 1990 \\
\hline \multicolumn{4}{|l|}{ Ruby Creek } \\
\hline Brook trout $\mathrm{x}$ cutthroat trout & & 0.58 & 0.54 \\
\hline Brook trout $\mathrm{x}$ rainbow trout & & 0.70 & 0.37 \\
\hline Brook trout $\mathrm{x}$ mountain whitefish & & 0.41 & 0.28 \\
\hline Cutthroat trout $x$ rainbow trout & & 0.74 & 0.85 \\
\hline \multicolumn{2}{|l|}{ Cutthroat trout $\mathrm{x}$ mountain whitefish } & 0.49 & 0.29 \\
\hline Rainbow trout $\mathrm{x}$ mountain whitefis & & 0.50 & 0.05 \\
\hline
\end{tabular}

Table 3.71. Annual diet overlaps between age classes of trout species captured in Ruby Creek during 1988, 1989 and 1990.

\begin{tabular}{|c|c|c|c|}
\hline & \multirow{2}{*}{\multicolumn{2}{|c|}{1989}} & \multirow[b]{2}{*}{1990} \\
\hline & & & \\
\hline \multicolumn{4}{|l|}{ Brown trout } \\
\hline $0+\times 1+$ & $\cdots$ & 0.27 & $\cdots$ \\
\hline $0+\times 2+$ & $\cdots$ & 0.13 & $\cdots$ \\
\hline $0+\times 3+$ & $\cdots$ & 0.06 & $\cdots$ \\
\hline $1+\times 2+$ & $\cdots$ & 0.32 & -- \\
\hline $1+\times 3+$ & $\cdots$ & 0.13 & $\cdots$ \\
\hline $2+\times 3+$ & $\cdots$ & 0.69 & $\cdots$ \\
\hline \multicolumn{4}{|l|}{ Brook trout } \\
\hline $0+\times 1+$ & 0.43 & 0.66 & $\cdots$ \\
\hline $0+\times 2+$ & 0.36 & 0.58 & -- \\
\hline $0+\times 3+$ & 0.00 & 0.37 & -- \\
\hline $1+\times 2+$ & 0.65 & 0.78 & - \\
\hline $1+\times 3+$ & 0.29 & 0.48 & -- \\
\hline $2+\times 3+$ & 0.20 & 0.69 & -- \\
\hline \multicolumn{4}{|l|}{ Cutthroat trout } \\
\hline $1+\times 2+$ & 0.80 & 0.24 & -- \\
\hline $1+\times 3+$ & -- & 0.00 & -- \\
\hline $2+\times 3+$ & & 0.17 & \\
\hline \multicolumn{4}{|l|}{ Rainbow trout } \\
\hline $1+\times 2+$ & $\cdots$ & 0.36 & $\cdots$ \\
\hline
\end{tabular}


Table 3.72 .

Mean annual index of relative importance (IRI) values for prey items consumed by brown trout in Cee Cee Ah Creek during 1988, 1989 and 1990.

\begin{tabular}{|c|c|c|c|c|}
\hline Prey Organi sns & $\begin{array}{l}1988 \\
n=48\end{array}$ & $\begin{array}{c}1989 \\
n=102\end{array}$ & $\begin{array}{l}1990 \\
n=25\end{array}$ & $\begin{array}{c}\text { Average } \\
1988-90 \\
n=175\end{array}$ \\
\hline \multicolumn{5}{|l|}{$\begin{array}{l}\text { AQUATIC ORGANISMS } \\
\text { TRICHOPTERA }\end{array}$} \\
\hline TAICHOPTERA & 42.9 & '2.2.2 & 16.9 & $n \rightarrow n$ \\
\hline EPHEMEROPTERA & 9.3 & 15.3 & 11.2 & 11.9 \\
\hline DIPTERA & 7.4 & 12. 1 & 10.1 & 9.9 \\
\hline PLECOPTERA & 3.2 & 4.9 & 2.3 & 3.5 \\
\hline LEPIDOPIERA & 5.1 & 8.2. & 5.7 & 2.8 \\
\hline OSTRACODA & & & 3.5 & 1.2 \\
\hline BIVALVIA & & 1.0 & & 0.3 \\
\hline HEMIPTEROA & & 1.0 & & 0.3 \\
\hline GASTTROPOD A & 2.2 & 1.3 & 2.3 & 1.9 \\
\hline OLJGOCHAETA & 6.0 & 5.1 & 8.9 & 6.7 \\
\hline NFMATODA & & & 0.9 & 0.3 \\
\hline OSTEICIHTHYES & 1.0 & 1.8 & 12.2 & 5.0 \\
\hline UNIDENTIFIEI D & 10.8 & & & 3.6 \\
\hline \multicolumn{5}{|l|}{ TERAESTRIAI S } \\
\hline TRICHOPTERA & 0.7 & 2.3 & & .0 \\
\hline DIPTERA & 0.2 & 0.9 & 6.1 & 2.5 \\
\hline PLECOPTERA & & 1.2 & & 0.4 \\
\hline $\begin{array}{l}\text {-COLEOPTERA- } \\
\text { HEMIPTERA }\end{array}$ & 0.6 & 0 & 3.6 & 0.5 \\
\hline HOMOPTERA & 1.5 & 4.8 & 1.9 & 2.7 \\
\hline HYMENOPTERA & 5.7 & 6.7 & 3.7 & 5.4 \\
\hline ARANEIDA & 0.3 & 1.9 & & 0.7 \\
\hline DIPLOPODA & & 1.4 & & 0.5 \\
\hline LEPIDOPTERA & & 1.4 & & 0.5 \\
\hline 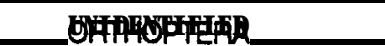 & 3.3 & 5.5 & 4.6 & A. 5 \\
\hline
\end{tabular}


Table 3.73 .

Mean annual index of relative importance (IRI) values for prey items consumed by brook trout in Cee Cee Ah Creek during 1988, 1989 and 1990.

\begin{tabular}{|c|c|c|c|c|}
\hline Prey Organisms & $\begin{array}{l}1988 \\
n=27\end{array}$ & $\begin{array}{c}1989 \\
n=100\end{array}$ & $\begin{array}{l}1990 \\
n=26\end{array}$ & $\begin{array}{c}\text { Average } \\
1988-90 \\
n=153\end{array}$ \\
\hline \multicolumn{5}{|l|}{ AQUATIC ORGANISMS } \\
\hline TRICHOPTERA & 5.3 & 20.7 & 23.4 & 32.4 \\
\hline EPHEMEAOPTERA & 7.6 & 9.6 & 6.7 & 7.9 \\
\hline DIPTERA & 5.0 & 25.6 & 24.3 & 18.0 \\
\hline PLECOPTERA & 4.8 & 9.1 & 4.8 & 6.2 \\
\hline COLEOPTEAA & 0.5 & 5.5 & 5.9 & 4.0 \\
\hline HYDRACARINA & & 1.8 & 5.6 & 2.5 \\
\hline OSTRACODA & & & 4.6 & 1.5 \\
\hline BIVALVIA & & 2.1 & 6.9 & 3.0 \\
\hline GASTROPODA & & & 5.0 & 1.7 \\
\hline LEPIDOPTERA & & 0.1 & 5.2 & 1.7 \\
\hline OLIGOCHAETA & 1.6 & 2.3 & & 1.3 \\
\hline NEMATODA & & & 1.1 & 0.4 \\
\hline UNIDENTIFED & 17.6 & 3.4 & & 7.0 \\
\hline \multicolumn{5}{|l|}{ TERRESTRIALS } \\
\hline TRICHOPTERA & 0.2 & 1.4 & & 0.5 \\
\hline EPHEMEROPTERA & & & 0.5 & 0.2 \\
\hline DIPTERA & & 2.4 & 5.2 & 2.5 \\
\hline PLECOPTERA & & 1.0 & & 0.3 \\
\hline COLEOPIEA & 3.1 & 1.1 & & 1.4 \\
\hline HEMIPTERA & 0.2 & & 0.5 & 0.3 \\
\hline HOMOPTERA & & & 0.6 & \\
\hline HYMENOPTERA & 1.6 & 3.8 & 0.4 & 1.9 \\
\hline ARANEIDA & & 0.8 & & 0.3 \\
\hline COLLEMBOLA & & 0.6 & & 0.2 \\
\hline DIPLOPODA & & 0.8 & & 0.3 \\
\hline LE:PIDOPTERA & 0.4 & 1.2 & & 0.5 \\
\hline ORTHOPTERA & & 0.2 & & 0.1 \\
\hline UNIDENTIFIED & 3.4 & 6.2 & & 3.2 \\
\hline
\end{tabular}


the organisms with the highest IRI values for cutthroat trout (Appendix L, Table L.12).

Based on index of relative importance values interspecific and intraspecific diet overlaps between trout species were calculated. Brown trout and brook trout in Cee Cee Ah Creek exhibited a high diet overlap in 1988, moderate in 1989 and low in 1990 (Table 3.75).

Diet overlaps between brown trout were low to moderate for most age classes (Table 3.76). High overlaps were observed between age 2+ and 3+ in 1989 and between age 4t and 5+ in 1988. Diet overlaps between different age classes of brook trout were low to moderate except for between age $0+$ and $1+$, which demonstrated high overlaps in 1989. Overlaps observed between all age classes of cutthroat trout were low.

\subsubsection{TACOMA CREEK}

Diet analysis of brown trout in Tacoma Creek was performed on only one fish during 1990 (Table 3.77). Polycentropodidae (20.1\%), Lepidoptera (19.2\%) and Formicidae (17.1\%) were the organisms with the highest values in the stomach (Appendix L, Table L.13).

A total of 153 stomach samples were collected from brook trout in Tacoma Creek; 51 in 1988, 76 in 1989 and 26 in 1990. Prey items with the highest IRI values during the study were from the orders Diptera, Trichoptera, Coleoptera and Hymenoptera (Table 3.78). Three year averages determined Chironomidae larvae $(11.1 \%)$ Formicidae (7.6\%) Lumbriculidae (6.5\%) and Elmidae adults (6.4\%) were the most important prey items for brook trout in Tacoma Creek (Appendix L, Table L.14).

Twenty-seven stomach samples were collected from cutthroat trout in Tacoma Creek during the study: 11 in 1988, 10 in 1989 and 6 in 1990. Prey items with the highest IRI values were represented by the orders Trichoptera, Plecoptera and Diptera (Table 3.79).

Formicidae (11.8\%) and Nemouridae (9.3\%) were the most important prey items for cutthroat trout in Tacoma Creek based on a three year average (Appendix L, Table L.15).

Based on index of relative importance values interspecific and intraspecific diet overlaps between trout species were calculated. 
Table 3.74. Mean annual index of relative importance (IRI) values for prey items consumed by cutthroat trout in Cee Cee Ah Creek during 1990.

\begin{tabular}{|c|c|}
\hline Prey Organisms & $\begin{array}{l}1990 \\
n=8\end{array}$ \\
\hline \multicolumn{2}{|l|}{ AQUATIC ORGANISMS } \\
\hline TRICHOPTERA & 9.2 \\
\hline DIPTERA & 3.2 \\
\hline PLECOPTERA & 6.3 \\
\hline COLEOPTERA & 5.5 \\
\hline OSTRACODA & 1.6 \\
\hline LEPIDOPTERA & 12.3 \\
\hline \multicolumn{2}{|l|}{ TERRESTRIALS } \\
\hline DIPTERA & 3.9 \\
\hline HYMENOPTERA & 54.4 \\
\hline PSCOPTERA & 1.6 \\
\hline COLLEMBOLA & 2.3 \\
\hline
\end{tabular}


Table 3.75. Annual diet overlaps between trout species captured in Cee Cee Ah Creek during 1988, 1989 and 1990.

\begin{tabular}{|c|c|c|c|}
\hline & 1988 & 1989 & 1990 \\
\hline \multicolumn{4}{|l|}{ Cee Cee Ah Creek } \\
\hline Brown trout $x$ brook trout & 0.91 & 0.73 & 0.31 \\
\hline
\end{tabular}

Table 3.76. Annual diet overlaps between age classes of trout species captured in Cee Cee Ah Creek during 1988, 1989 and 1990.

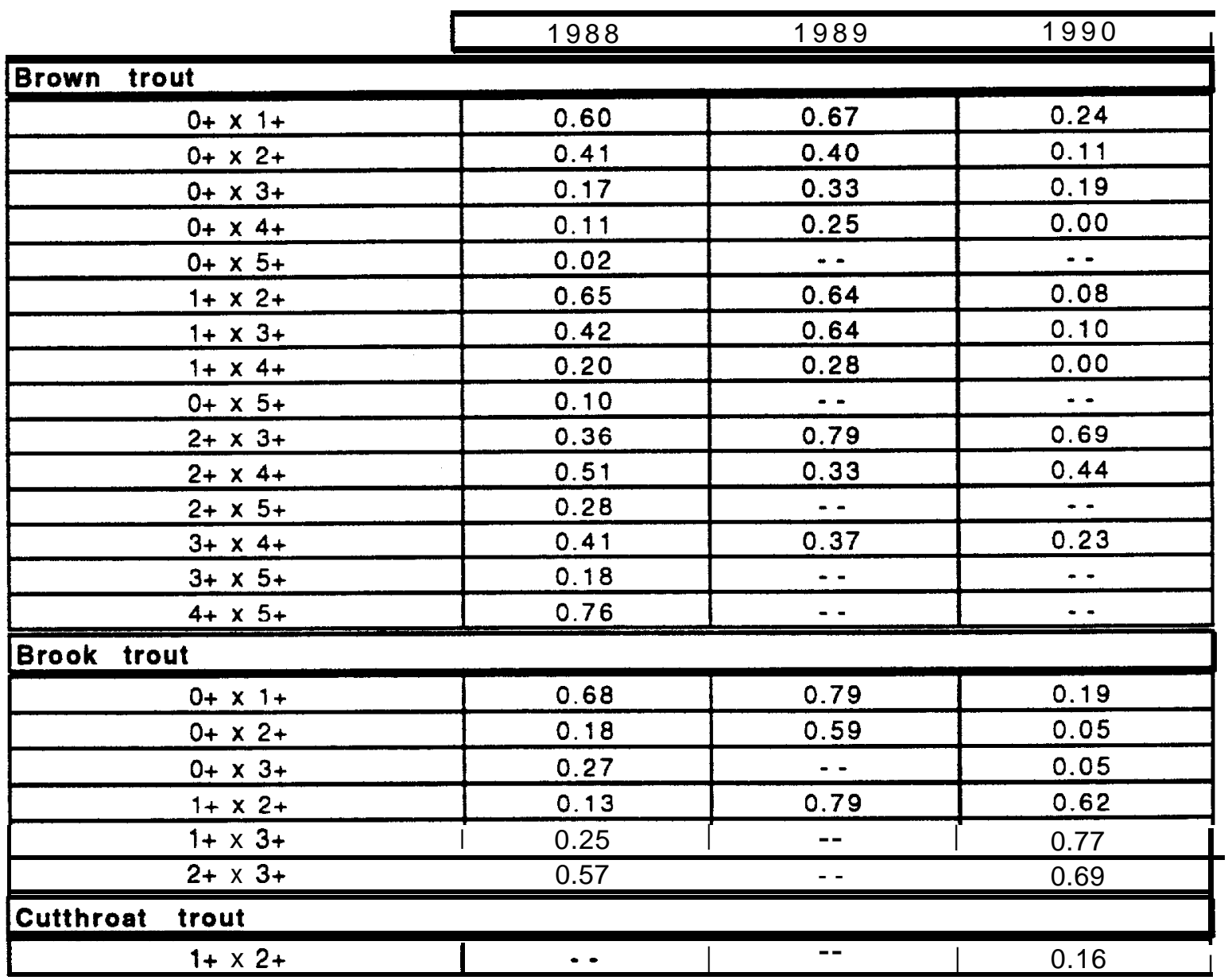


Table 3.77.

Mean annual index of relative importance (IRI) values for prey items consumed by brown trout in Tacoma Creek during 1990.

\begin{tabular}{|l|l|}
\hline Prey Organisms & $\begin{array}{c}1990 \\
\mathrm{n}=1\end{array}$ \\
\hline AQUATIC ORGANISMS & \\
\hline TRICHOPTERA & $\mathbf{3 2 . 3}$ \\
\hline LEPIDOPTERA & 19.2 \\
\hline NEMATODA & 16.2 \\
\hline TERRESTRIALS & \\
\hline HMMENOPTERA & 15.2 \\
\hline ARANEIDA & \\
\hline
\end{tabular}

Table 3.78.

Mean annual index of relative importance (IRI) values for prey items consumed by brook trout in Tacoma Creek during 1988, 1989 and 1990.

\begin{tabular}{|c|c|c|c|c|}
\hline Prey Organisms & $\begin{array}{l}1988 \\
n=51\end{array}$ & $\begin{array}{l}1989 \\
n=76\end{array}$ & $\begin{array}{l}1990 \\
n=26\end{array}$ & $\begin{array}{c}\text { Average } \\
1988-90 \\
n=153\end{array}$ \\
\hline \multicolumn{5}{|l|}{ AQUATIC ORGANISMS } \\
\hline TRICHOPTERA & 17.5 & 17.7 & 1.7 & 12.3 \\
\hline EPHEMEROPTERA & 13.0 & 8.7 & 2.4 & 8.1 \\
\hline DIPTERA & 13.0 & 20.6 & 24.9 & $1^{\prime} 9.5$ \\
\hline \multicolumn{5}{|l|}{ PLECOPTER } \\
\hline COLEOPTERA & 4.2 & 3.9 & 20.9 & 8.7 \\
\hline HYDRACARINA & & 2.0 & 0.4 & 0.6 \\
\hline BIVALVIA & & 0.9 & & 0.3 \\
\hline GASTROPODA & 0.5 & & & 0.2 \\
\hline OLGOCHAETA & 8.4 & 2.5 & 8.5 & 6.5 \\
\hline NEMATODA & & 3.0 & 0.9 & 1.3 \\
\hline LEPIDOPTERA & & 0.5 & 2.2 & 0.9 \\
\hline HEMIPTEAA & 1.2 & 0.2 & & 0.5 \\
\hline OSTEICHTHYES & & & 1.7 & 0.6 \\
\hline \multicolumn{5}{|l|}{ TERRESTRIALS } \\
\hline TPICHOPTERA & 0.4 & 0.5 & & 0.3 \\
\hline EPHEMEROPTERA & & 0.2 & & 0.1 \\
\hline DIPTERA & 0.7 & 0.7 & 1.2 & 0.8 \\
\hline PLECOPTERA & & 0.6 & & 0.2 \\
\hline COLFOPTERA & 5.7 & 4.7 & & 3.5 \\
\hline HEMIPTERA- & 07 & 0 & 31 & 12 \\
\hline HOMOPTERA & 6.8 & 4.5 & & 3.7 \\
\hline HYMENOPTERA & 1.8 & 7.4 & 18.2 & 8.6 \\
\hline ARANEIDA & 2.3 & 1.6 & & 1.3 \\
\hline COLIEMBOLA & & 0.7 & & 0.2 \\
\hline DIPLOPODA & & 0.3 & & 0.1 \\
\hline LEPIDOPTERA & 2.8 & 5.5 & 8.9 & 5.8 \\
\hline UNIDENTIFED & 14.1 & 1.7 & & 5.3 \\
\hline
\end{tabular}


Table 3.79.

Mean annual index of relative importance (IRI) values for prey items consumed by cutthroat trout in Tacoma Creek during 1988, 1989 and 1990.

\begin{tabular}{|c|c|c|c|c|}
\hline Prey Organisms & $\begin{array}{l}1988 \\
n=11\end{array}$ & $\begin{array}{l}1989 \\
n=10\end{array}$ & $\begin{array}{c}1990 \\
n=6\end{array}$ & $\begin{array}{c}\text { Average } \\
1988 \cdot 90 \\
n=27\end{array}$ \\
\hline \multicolumn{5}{|l|}{ AQUATIC ORGANISMS } \\
\hline TRICHOPTERA & 22.7 & 5.1 & 18.3 & 15.3 \\
\hline EPHEMEAOPTERA & 9.9 & 1.9 & 13.4 & 8.4 \\
\hline DIPTERA & 17.0 & 10.3 & 11.1 & 12.7 \\
\hline PLECOPTERA & 1.3 & 37.6 & 5.9 & 15.0 \\
\hline COLEOPIEPA & 18.4 & 3.3 & 1.8 & 7.9 \\
\hline HYDRACARINA & & 0.6 & & 0.2 \\
\hline LEPIDOPTERA & & & 9.2 & 3.1 \\
\hline NEMATODA & & 12.4 & 7.6 & 6.7 \\
\hline UNIDENTIFED & 1.2 & & & 0.4 \\
\hline \multicolumn{5}{|l|}{ TERAESTRIALS } \\
\hline TRICHOPTERA & 4.3 & & & 1.4 \\
\hline DIPTERA & 3.2 & & & 1.1 \\
\hline PLECOPTERA & & 0.9 & & 0.3 \\
\hline COLEOPTERA & & 3.1 & & 1.0 \\
\hline HOMOPTERA & & 0.9 & 2.8 & 1.2 \\
\hline HYMENOPTERA & 8.5 & 2.0 & 24.9 & 11.8 \\
\hline ARANEIDA & & 1.1 & 1.4 & 0.8 \\
\hline LEPIDOPTERA & & 19.9 & 1.8 & 7.2 \\
\hline UNIDENTIFIED & 10.7 & 0.9 & 1.4 & 4.3 \\
\hline
\end{tabular}


Low to moderate overlaps were observed between brook trout and cutthroat trout in Tacoma Creek during the study (Table 3.80).

Diet overlaps between different age classes of brook- trout were low to moderate (Table 3.81). In 1989, a high overlap was observed between age $1+$ and $2+$ brook trout. Diet overlaps between different age classes of cutthroat trout were mostly low. Moderate overlaps were observed between age $0+$ and 2+ in 1989 and age 1+ and $2+$ in 1990. Age $0+$ and $2+$ cutthroat trout exhibited high overlaps in 1990.

\subsubsection{SKOOKUM CREEK}

A total of 146 stomachs were collected from brown trout in Skookum Creek during the study; 24 in 1988, 96 in 1989 and 26 in 1990. Prey items with the highest index of relative importance (IRI) in the orders Trichoptera, Ephmeroptera and Diptera (Table 3.82). Based on a three year average, Baetidae (12.8\%), Limnephilidae $(7.7 \%)$ and Lumbriculidae (7.1\%) were the most important items in LeClerc Creek brown trout diets (Appendix L, Table L.16).

One hundred and eighty-two brook trout stomachs were collected from Skookum Creek; 45 in 1988, 111 in 1989 and 26 in 1990. Orders Ephemeroptera, Diptera and Trichoptera contained the prey items with the highest IRI values (Table 3.83). Based on three year averages, Chironomidae larvae $(12.5 \%)$, Baetidae $(11.6 \%)$ and Limnephilidae $(8.2 \%)$ were the most important prey items for brook trout in Skookum Creek (Appendix L, Table L.17).

Stomach samples were collected from 16 cutthroat trout in Skookum Creek during the study; 8 in 1988, 5 in 1989 and 3 in 1990. Prey items with the highest IRI values were from orders Trichoptera, Ephemeroptera and Plecoptera (Table 3.84). Based on a three year average, Plecoptera (11.3\%), Limnephilidae (10.7\%) and Brachycentridae (10.0\%) were the most important prey items for cutthroat trout in Skookum Creek (Appendix L, Table L.18).

Based on index of relative importance values interspecific and intraspecific diet overlaps between trout species were calculated. Moderate to high overlaps were observed between brown trout and brook trout in Skookum Creek during the study (Table 3.85). Brown trout and cutthroat trout exhibited low overlaps throughout the study. Low to moderate diet overlaps were observed between brook trout and cutthroat trout. 
Table 3.80. Annual diet overlaps between trout species captured in Tacoma Creek during 1988, 1989 and 1990.

1988

1989

1990

Tacoma Creok

Brook trout $x$ cutthroat trout

0.55

0.48

0.45

Table 3.81. Annual diet overlaps between age classes of trout species captured in Tacoma Creek during 1988, 1989 and 1990.

\begin{tabular}{|c|c|c|c|}
\hline & 1988 & 1989 & 1990 \\
\hline \multicolumn{4}{|l|}{ Brook trout } \\
\hline $0+\times 1+$ & 0.64 & 0.66 & 0.06 \\
\hline $0+\times 2+$ & 0.24 & 0.55 & 0.19 \\
\hline $1+\times 2+$ & 0.41 & 0.78 & 0.36 \\
\hline \multicolumn{4}{|l|}{ Cutthroat trout } \\
\hline $0+\times 1+$ & 0.42 & 0.36 & 0.44 \\
\hline $0+\times 2+$ & 0.14 & 0.57 & 0.71 \\
\hline $1+\times 2+$ & 0.31 & 0.29 & 0.61 \\
\hline
\end{tabular}


Table 3.82.

Mean annual index of relative
importance (IRI) values for prey items
consumed by brown trout in Skookum
Creek during 1988, 1989 and 1990.

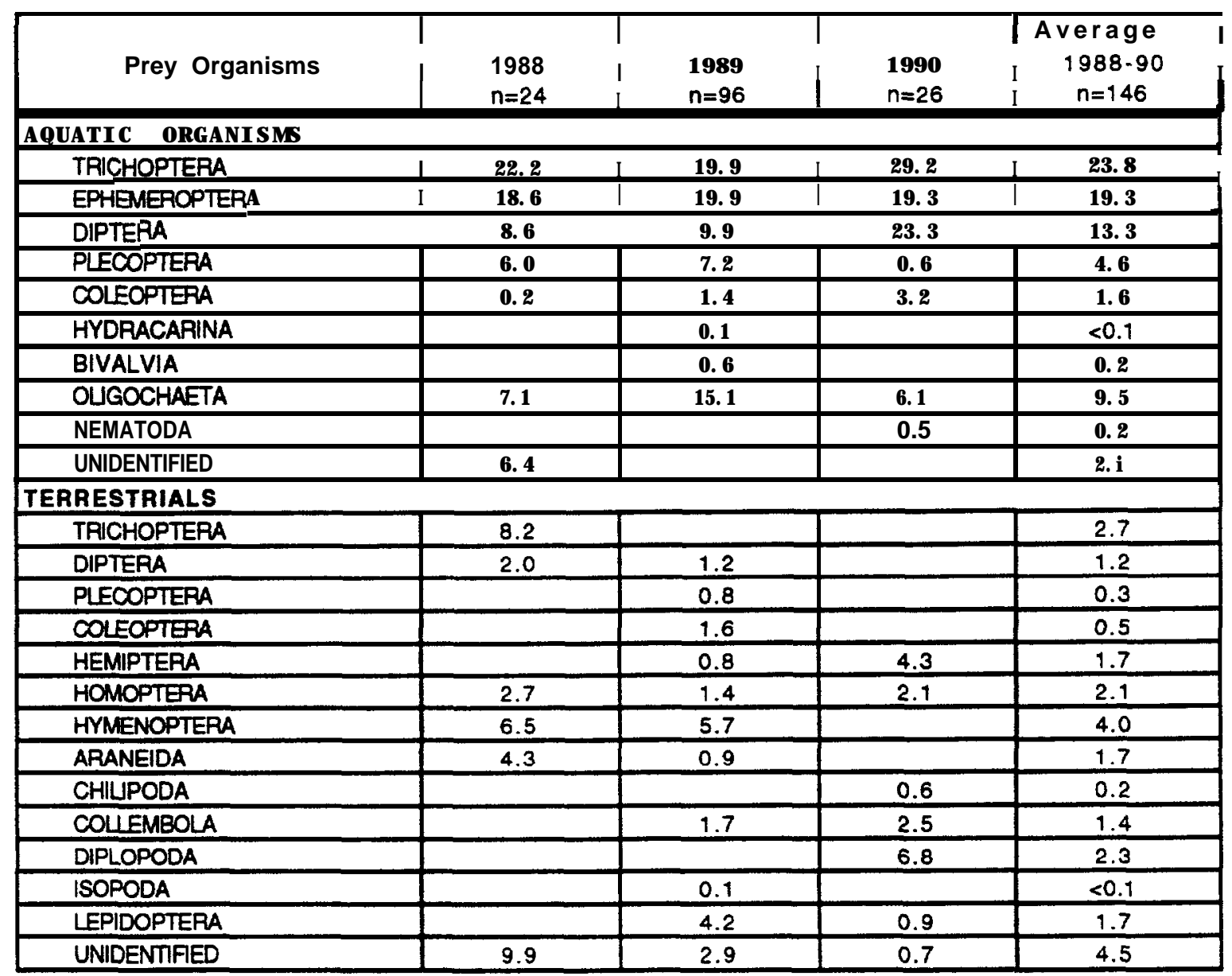


Table 3.83 .

Mean annual index of relative importance (IRI) values for prey items consumed by brook trout in Skopkum Creek during 1988, 1989 and 1990.

\begin{tabular}{|c|c|c|c|c|}
\hline Prey Organisms & $\begin{array}{l}1988 \\
n=45\end{array}$ & $\begin{array}{c}1989 \\
n=111\end{array}$ & $\begin{array}{l}1990 \\
n=26\end{array}$ & $\begin{array}{c}\text { Average } \\
1988-90 \\
n=182\end{array}$ \\
\hline \multicolumn{5}{|l|}{ AQUATIC ORGANISMS } \\
\hline TRICHOPTERA & 9.2 & 20.4 & 13.5 & 14.3 \\
\hline EPHEMEROPTERA & 15.6 & 20.7 & 22.9 & 19.7 \\
\hline DIPTERA & 12.3 & 16.6 & 27.8 & 19.0 \\
\hline PLECOPTERA & 1.6 & 3.7 & 1.9 & 2.4 \\
\hline COLEOPIEAA & 1.0 & 2.4 & 6.7 & 3.4 \\
\hline HYDRACARINA & & 1.4 & & 0.5 \\
\hline BIVALVIA & & 0.9 & 0.7 & 0.5 \\
\hline OLGOCHAETA & 0.4 & 3.9 & 1.3 & 1.9 \\
\hline NEMATODA & & & 4.5 & 1.5 \\
\hline GASTROPODA & 0.7 & 2.5 & & 1.0 \\
\hline UNIDENTIFED & 11.7 & & & 3.9 \\
\hline OSTEICHTHYES & & & 15.1 & 5.0 \\
\hline \multicolumn{5}{|l|}{ TERRESTAIALS } \\
\hline TRICHOPTERA & 2.1 & 1.3 & & 1.1 \\
\hline DIPTERA & 5.1 & 3.5 & 0.4 & 2.9 \\
\hline EPHEMEROPTERA & & 0.8 & & 0.3 \\
\hline PLECOPTERA & & 1.8 & & 0.6 \\
\hline COLFOPIERA & 0.6 & 2.8 & & 1.3 \\
\hline HEMIPTERA & 6.8 & 0.2 & & 2.4 \\
\hline HOMOPTERA & 2.0 & 1.4 & & 1.1 \\
\hline HYMENOPTERA & 5.5 & 6.3 & 0.4 & 4.1 \\
\hline ARANEIDA & 1.3 & 2.8 & 0.7 & 1.6 \\
\hline CHILOPOOA & & & 3.0 & 1.0 \\
\hline COUFMBOLA & & 1.8 & & 0.6 \\
\hline DIPLOPODA & & 0.4 & & 0.1 \\
\hline LEPIDOPIERA & 0.3 & 0.4 & 3.1 & 1.3 \\
\hline UNIDENTIFED & 25.5 & 3.9 & 0.7 & 10.0 \\
\hline
\end{tabular}


Table 3.84 .

Mean annual index of relative. importance (IRI) values for prey items consumed by cutthroat trout in Skookum Creek during 1988, 1989 and 1990.

\begin{tabular}{|c|c|c|c|c|}
\hline Prey Organisms & $\begin{array}{c}1988 \\
n=8\end{array}$ & $\begin{array}{c}1989 \\
n=5\end{array}$ & $\begin{array}{c}1990 \\
n=3\end{array}$ & $\begin{array}{c}\text { Average } \\
1988-90 \\
n=16\end{array}$ \\
\hline \multicolumn{5}{|l|}{ AQUATIC ORGANISMS } \\
\hline TRICHOPTERA & 6.1 & 48.4 & 26.8 & 27.1 \\
\hline EPHEMEROPTERA & 8.1 & 6.2 & 39.4 & 17.9 \\
\hline DIPTERA & 16.5 & 3.6 & 9.6 & 9.9 \\
\hline PLECOPTERA & & 29.0 & 4.8 & 11.3 \\
\hline COLEOPIERA & & & 19.6 & 6.5 \\
\hline OLGOCHAETA & 1.4 & & & 0.5 \\
\hline UNIDENTIFED & 4.4 & & & 1.5 \\
\hline \multicolumn{5}{|l|}{ TERRESTRIALS } \\
\hline TRICHOPTERA & 5.0 & & & 1.7 \\
\hline DIPTEFA & 11.6 & & & 3.8 \\
\hline COLEOPTERA & 2.1 & & & 0.7 \\
\hline HEMIPTERA & 0.7 & & & 0.2 \\
\hline HOMOPIERA & 4.8 & & & 1.6 \\
\hline HYMENOPTERA & 6.4 & 9.3 & & 5.2 \\
\hline ARANEIDA & 7.0 & & & 2.3 \\
\hline LEPIDOPTERA & 4.3 & & & 1.4 \\
\hline UNIDENTIFED & 21.3 & 3.6 & & 8.3 \\
\hline
\end{tabular}


Diet overlaps between different age classes of brown trout were quite variable throughout the study (Table 3.86). Generally, overlaps were low to moderate for the different age classes. However, overlaps between age $0+$ and $1+$ were moderate to high throughout the study. High overlaps were also exhibited by age 1+ and 2+, age 2+ and 3+ and age 2+ and 4+, all in 1989. Brook trout were similar to brown trout in overlap variability. Most overlaps were low to moderate. High overlaps were exhibited by age $0+$ and $1+$ and age $1+$ and $2+$ fish. Cutthroat trout diet overlaps were low to moderate between all age classes. 
Table 3.85. Annual diet overlaps between trout species captured in Skookum Creek during 1988, 1989 and 1990.

\begin{tabular}{|l|c|c|c|}
\cline { 2 - 4 } \multicolumn{1}{c|}{} & 1988 & 1989 & $\mathbf{1 9 9 0}$ \\
\hline Skookum Creek & 0.63 & 0.79 & 0.63 \\
\hline Brown trout $\times$ brook trout & 0.39 & 0.39 & 0.32 \\
\hline Brown trout $\times$ cutthroat trout & 0.63 & 0.46 & 0.24 \\
\hline Brook trout $\times$ cutthroat trout & & \\
\hline
\end{tabular}

Table 3.86. Annual diet overlaps between age classes of trout species captured in Skookum Creek during 1988, 1989 and 1990.

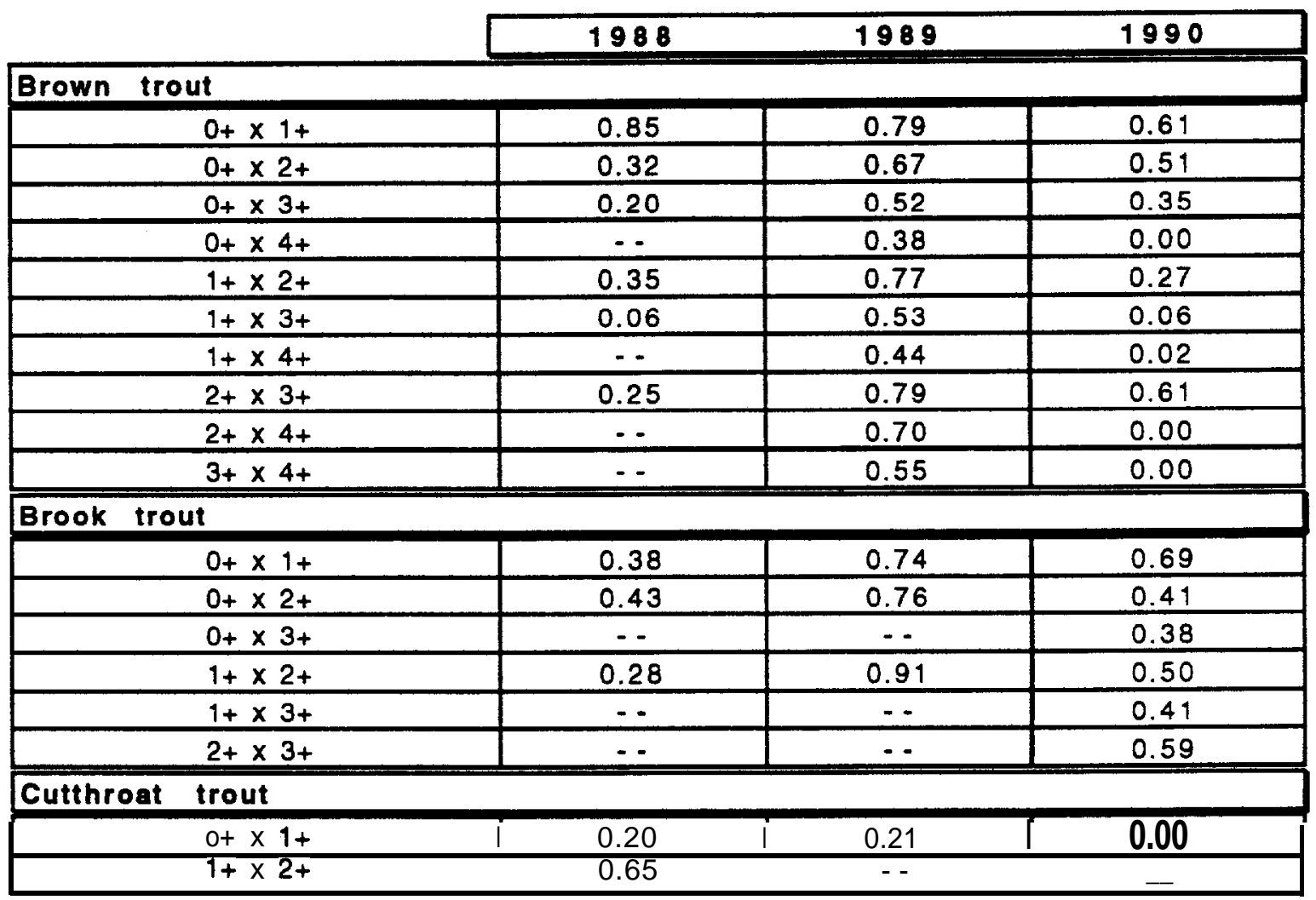




\subsection{DISCUSSION}

\subsection{FISHERY STATUS}

\subsubsection{TROUT FISHERY IN THE RESERVOIR}

It is apparent that the habitat of the Pend Oreille River is no longer suitable for the production of trout it was once known for. Bull trout, rainbow trout and cutthroat trout captures were so infrequent during the three year study period that the relative abundance of all three species added together didn't even compose a tenth of a percent of the total abundance of fish species in the reservoir (Table 4.1). Brown trout were the most abundant trout species during the survey comprising almost one percent of fish captured each year (Table 4.1). John Hisata, regional fisheries biologist for the Washington Department of Wildlife (pers. comm.) reported that the strain of brown trout in the Pend Oreille River were originally from Scotland and were planted in the late 1890's. Although brown trout are currently the most abundant trout species in the river, the current population of is not sufficient to support a healthy fishery.

The trout that were captured during electrofishing surveys were relatively large-sized fish (Table 4.2).

It appears that water temperature, lack of habitat diversity and possibly food availability are the major factors that limit trout production in the Box Canyon reach of the Pend Oreille River. Soltero et a/. (1988) recorded water temperatures in the reservoir that ranged from $7.9^{\circ} \mathrm{C}$ to $21.3^{\circ} \mathrm{C}$ during the growing season (MaySeptember). The maximum temperatures observed were several degrees higher than temperatures optimal for bull, rainbow and cutthroat trout (Table 4.3). Other water quality parameters did not appear suboptimal for trout production.

Generally there is low habitat diversity within the Pend Oreille River. Only about 8 miles (15\%) of the Box Canyon reach is even close to being considered riverine habitat preferred by trout;' described by Raleigh and Duff (1980) as clear, cold water, silt-free rocky substrate, well-vegetated stream banks, abundant instream cover and relatively stable water flow. The other 46 miles of the river represents mainly shallow slow moving water, numerous sloughs and backwater areas and an abundance of macrophytes. In 
Table 4.1. Comparison of total numbers of fish (and relative abundance) of fish captured by electrofishing in 1988 (Barber et a/. 1989), 1989 (Barber et al. 1990) and 1990 (Ashe et a/. 1991).

\begin{tabular}{|c|c|c|c|c|}
\hline $\begin{array}{l}\text { Year } \\
\text { Shock ti ne (min) }\end{array}$ & $\begin{array}{l}1988 \\
3,256\end{array}$ & $\begin{array}{r}1989 \\
5,432 \\
\end{array}$ & $\begin{array}{l}1990 \\
4,285 \\
\end{array}$ & $\begin{array}{c}\text { Total } \\
1988-90 \\
12,973\end{array}$ \\
\hline Yel I ow perch & 8. $390 \quad(42.1)$ & 7,917 (45. 1) & ' 4, 453 (44.8) & $20,760 \quad(43.8)$ \\
\hline Pumpki nseed & $3,791 \quad(19.0)$ & $2,897 \quad(16.5)$ & $1,026 \quad(10.3)$ & $7,714 \quad(16.3)$ \\
\hline Tench & $1,920 \quad(9.6)$ & $1,465 \quad(8.3)$ & $1,045 \quad(10.5)$ & $4,430 \quad(9.3)$ \\
\hline Largenouth bass & $1,434 \quad(7.2)$ & $1,589 \quad(9.1)$ & $842(8.5)$ & $3,865 \quad(8.2)$ \\
\hline Northern squauf i sh & $1,057 \quad(5.3)$ & $620(3.5)$ & $284(2.9)$ & $1,961 \quad(4.1)$ \\
\hline Largescal e sucker & 949 (4. 8) & 789 (4.5) & $590(5.9)$ & $2,328 \quad(4.9)$ \\
\hline Mbunt ai n whi tefi sh & 860 (4. 3) & $1,054 \quad(6.0)$ & 709 (7. 1) & $2,623 \quad(5.5)$ \\
\hline Longnose sucker & $723(3.6)$ & $530(3.0)$ & $362(3.6)$ & $1,615 \quad(3.4)$ \\
\hline Brown bul I head & 268 (1. 3) & 219 (1. 2) & 185 ( 1.9$)$ & $672(1.4)$ \\
\hline Bl ack crappi e & $262(1.3)$ & $233(1.3)$ & $155(1.6)$ & $650(1.4)$ \\
\hline Peamouth & $127(0.6)$ & $62(0.4)$ & $118(1.2)$ & $307(0.6)$ \\
\hline Brown trout & $114(0.6)$ & $117(0.7)$ & $104(1.0)$ & $335(0.7)$ \\
\hline Cutthroat trout & $11(0.05)$ & $15(0.1)$ & $8(0.1)$ & $34(0.1)$ \\
\hline Redside shi ner & $11(0.05)$ & $2(0.01)$ & $2(0.01)$ & $15(<0.1)$ \\
\hline Rai nbow trout & $6(0.03)$ & $13(0.01)$ & $10(0.1)$ & $29(0.1)$ \\
\hline Scul pi n & $6(0.03)$ & $11(0.1)$ & $1(0.01)$ & $18(<0.1)$ \\
\hline Brook trout & $1(0.01)$ & $2(0.01)$ & $3(0.03)$ & $6(<0.1)$ \\
\hline Bull trout & $1(0.01)$ & $2(0.01)$ & $1(0.01)$ & $4(<0.1)$ \\
\hline Kckanee & & $12(0.1)$ & $32(0.3)$ & $44(0.1)$ \\
\hline Lake trout & & $2(0.01)$ & $3(0.03)$ & $5(<0.1)$ \\
\hline TOTAL & 19. 931 & 17,551 & 9. 933 & 47. 415 \\
\hline
\end{tabular}


Table 4.2. Mean annual ranges and average lenths of trout species captured in the Pend Oreille River, WA during 1988, 1989 and 1990.

\begin{tabular}{|l|c|c|c|c|c|c|}
\cline { 2 - 7 } \multicolumn{1}{c|}{} & \multicolumn{2}{c|}{1988} & \multicolumn{2}{c|}{1989} & \multicolumn{2}{c|}{1990} \\
\hline SPECIES & $\begin{array}{l}\text { RANGE } \\
(\mathrm{m} \mathrm{m})\end{array}$ & $\begin{array}{l}\text { MEAN } \\
(\mathrm{m} \mathrm{m})\end{array}$ & $\begin{array}{c}\text { RANGE } \\
(\mathrm{m} \mathrm{m})\end{array}$ & $\begin{array}{c}\text { MEAN } \\
(\mathrm{m} \mathrm{m})\end{array}$ & $\begin{array}{l}\text { RANGE } \\
(\mathrm{m} \mathrm{m})\end{array}$ & $\begin{array}{c}\text { MEAN } \\
(\mathrm{m} \mathrm{m})\end{array}$ \\
\hline Brook trout & 165 & 165 & 175 & 175 & $175-194$ & 185 \\
Brown trout & $72-629$ & 335 & $87-640$ & 319 & $67-630$ & 290 \\
Cutthroat trout & $220-670$ & 463 & $155-355$ & 276 & $228-354$ & 317 \\
Rainbow trout & $154-245$ & 198 & $97-470$ & 249 & $135-490$ & 248 \\
\hline
\end{tabular}


Table 4.3. Optimal, tolerable and lethal water quality conditions for several trout species along with existing water quality parameters of the Pend Oreille River.

\begin{tabular}{|c|c|c|c|c|}
\hline & $\begin{array}{c}\text { Temperature } \\
\left({ }^{\circ} \mathrm{C}\right)\end{array}$ & $\begin{array}{c}\text { Dissolved } \\
\text { bxygen (mg/l) }\end{array}$ & $\mathrm{pH}$ & $\begin{array}{c}\text { Turbidity } \\
\text { (NTU) }\end{array}$ \\
\hline $\begin{array}{l}\text { Rainbow trout } \\
\text { (Raleigh 1984) }\end{array}$ & $\begin{array}{c}\text { Optimal } \\
12^{\circ}-18^{\circ} \\
\text { Lethal } \\
<0^{\circ}>25^{\circ}\end{array}$ & 3 & $\begin{array}{c}\text { Optimal } \\
6.5-8.0 \\
\text { Tolerable } \\
5.5-9.0\end{array}$ & unknown \\
\hline $\begin{array}{l}\text { Cutthroat trout } \\
\text { (Hickman and Raleigh 1982) }\end{array}$ & $\begin{array}{c}\text { Optimal } \\
11^{\circ}-15.5^{\circ} \\
\text { Lethal } \\
6^{\circ}-21^{\circ}\end{array}$ & $\begin{array}{l}7.3 \text { at } 15^{\circ} \mathrm{C} \\
9.0 \text { at }>15^{\circ} \mathrm{C}\end{array}$ & $\begin{array}{l}\text { Optimal } \\
6.5-8.0 \\
\text { Tolerable } \\
5.9-9.0 \\
\end{array}$ & 5 \\
\hline $\begin{array}{l}\text { Bull trout } \\
\text { (Fraley et al. 1989) }\end{array}$ & $\begin{array}{l}\text { Optimal } \\
9^{\circ}-15^{\circ}\end{array}$ & unknown & $\begin{array}{l}\text { assumed } \\
\text { range } \\
5.9-9-0\end{array}$ & unknown \\
\hline $\begin{array}{l}\text { Brown trout } \\
\text { (Raleigh et al. 1986) }\end{array}$ & $\begin{array}{c}\text { Optimal } \\
12^{\circ}-19^{\circ} \\
\text { Lethal } \\
>27^{\circ} \\
\end{array}$ & $\begin{array}{l}29.0 \text { at } \leq 10^{\circ} \mathrm{C} \\
212 \text { at }>10^{\circ} \mathrm{C}\end{array}$ & $\begin{array}{c}\text { Optimal } \\
6.8-7.8 \\
\text { Tolerable } \\
5.0-9.5 \\
\end{array}$ & unknown \\
\hline $\begin{array}{l}\text { Pend Oreille River } \\
\text { (Soltero et al. 1988) }\end{array}$ & $\begin{array}{c}\text { Range } \\
7.9^{\circ}-21.3^{\circ} \\
\text { Mean } \\
15.1^{\prime \prime}\end{array}$ & $\begin{array}{c}\text { Range } \\
7.3-11.6 \\
\text { Mean } \\
9.2\end{array}$ & $\begin{array}{l}\text { Range } \\
7.9-9.1\end{array}$ & 0 \\
\hline
\end{tabular}


general, there are very few deep pools within the reservoir and the substrate is mostly composed of silt and mud.

Along with habitat, food is probably limiting trout production in the river since construction of the Box Canyon Dam eliminated nearly all the food producing riffle areas. Diet analysis during the three year study period revealed that rainbow trout and cutthroat trout in the Pend Oreille River fed primarily on benthic and terrestrial organisms. Based on IRI (index of Relative Importance values) Chironomidae (midge) larvae and pupae were the most important prey items for both species. Brown trout were primarily benthic feeders and had high IRI values for Chironomidae (midge) larvae and pupae, Baetidae (mayfly larvae) and Coenagrionidae (damselfly larvae). Chironomidae larvae was the most abundant macroinvertebrate in benthic samples of the river all three years of the study. Thus, it appears that availability of the major prey item in the environment is not a problem. However, the availability of preferred prey items for trout (i.e. caddisfly larvae, stonefly larvae, and beetle larvae, which historically were assumed to be abundant) is currently limited due to the change in habitat caused by Box Canyon Dam. In addition, Chironomidae larvae and pupae are also major prey items for yellow perch, black crappie, mountain whitefish, kokanee, brown bullhead, northern squawfish, longnose sucker, largescale sucker, tench and pumpkinseed. As a result, diet overlaps were high between many of these species.

Rainbow trout growth rates in the Pend Oreille River were lower at every annulus, except age 5+, when compared to other water bodies in the region (Figure 4.1). More than likely this is due to food availability in the river and possibly diet overlap with other species of fish along with lack of habitat diversity. Warm water temperatures in the summer months, in addition to low food availability, may have been responsible for low growth rates. Cutthroat trout growth in the Pend Oreille River was average to good in comparison to other water bodies (Figure 4.2). This may be due to the cutthroats reliance on drift as a major food item. No other species in the river utilized terrestrials to a high degree. Brown trout were smaller at every annulus in comparison to the same species from other water bodies in the region (Figure 4.3). The rate of growth for brown trout appeared to be similar to growth rates in other systems, however, brown trout in the Pend Oreille River started out at a smaller size and never caught up. 


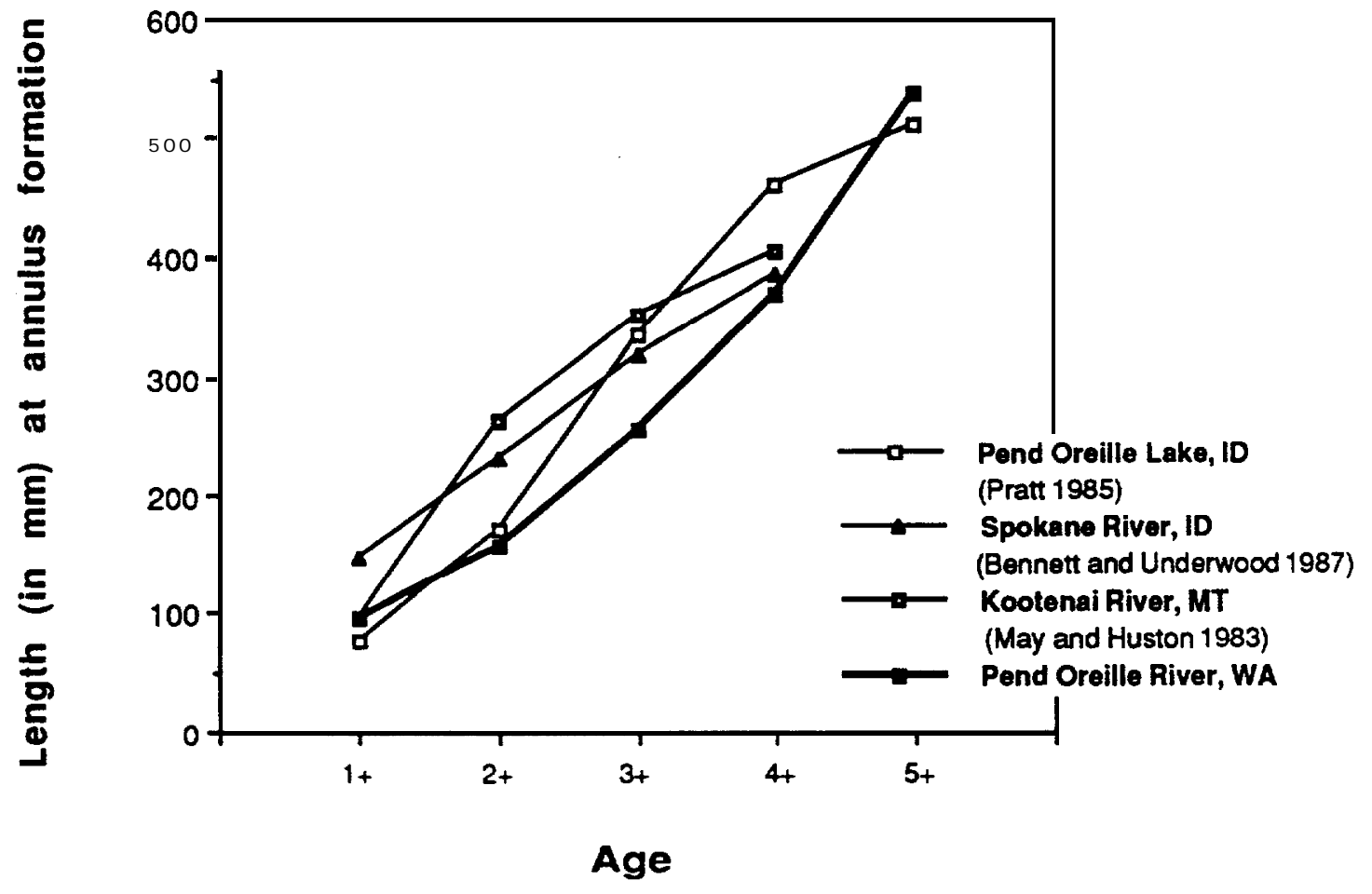

Figure 4.1. Comparison of mean back-calculated lengths at annulus formation for rainbow trout in the Pend Oreille River with other similar water bodies in the region. 


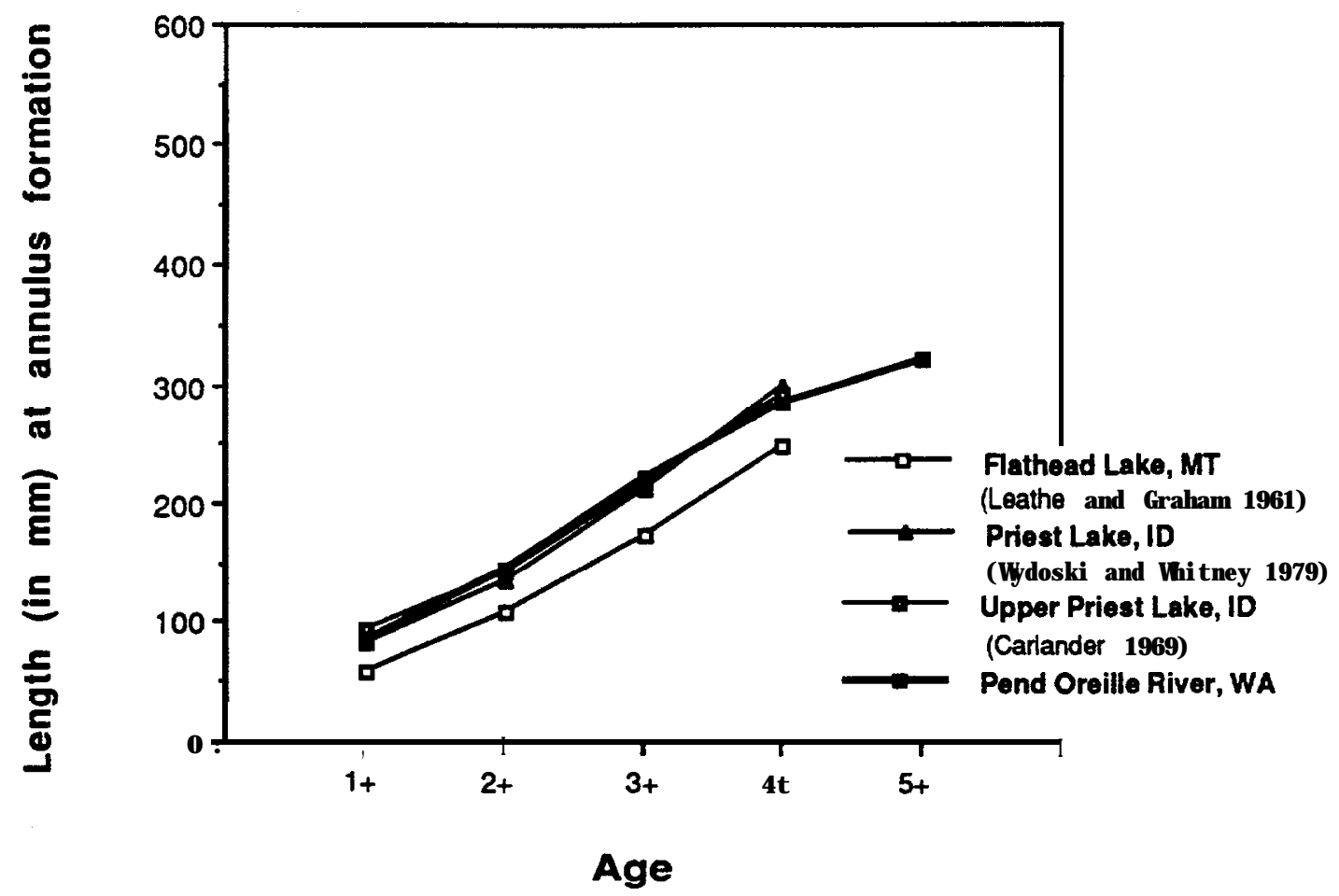

Figure 4.2. Comparison of mean back-calculated lengths at annulus formation for cutthroat trout in the Pend Oreille River with other similar water bodies in the region. 


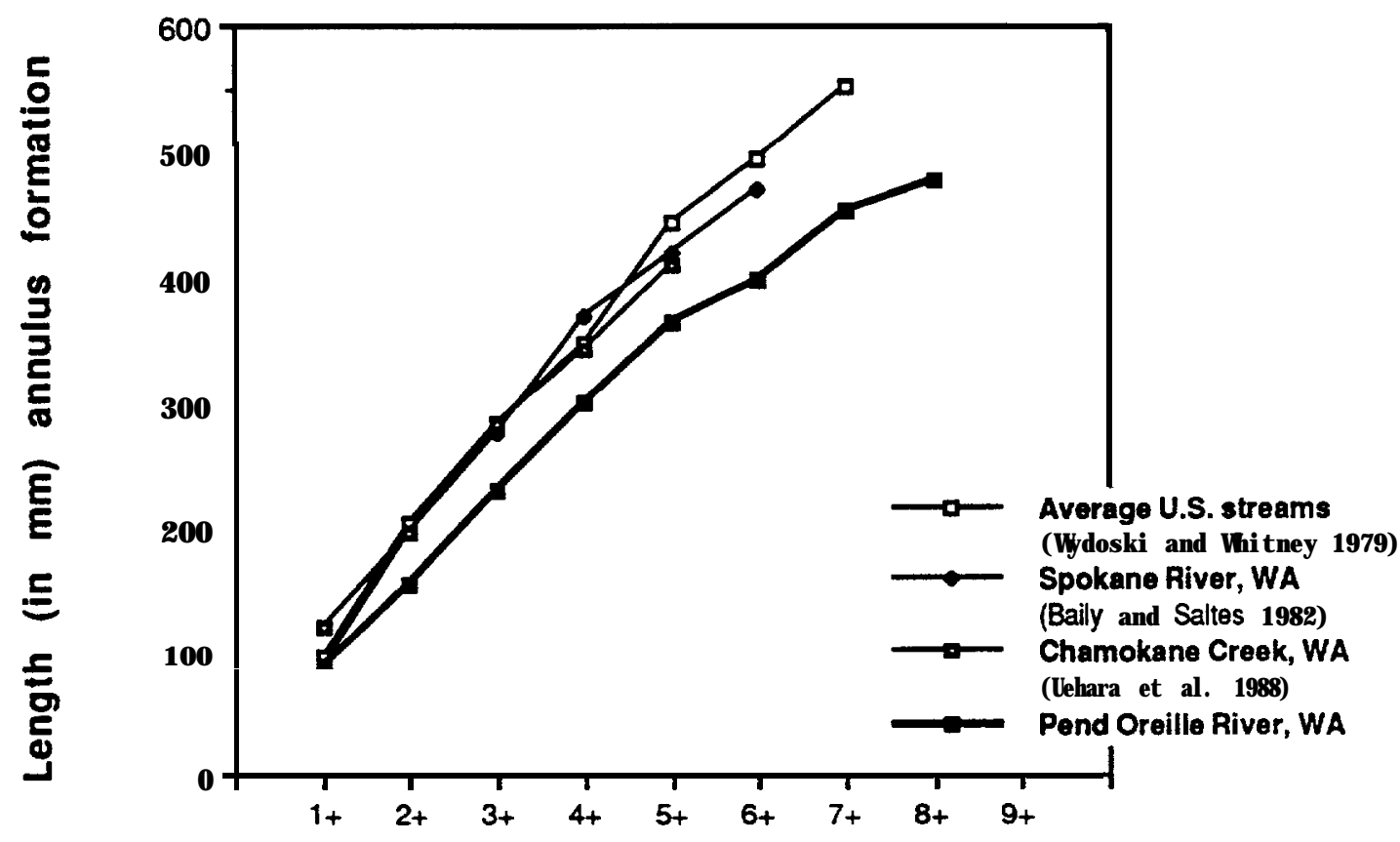

Age

Figure 4.3. Comparison of mean back-calculated lengths at annulus formation for brown trout in the Pend Oreille River with other similar water bodies in the region. 
Even though growth rates of trout in the Pend Oreille River tended to be below average for most species, a few large individuals were captured during the study. In late summer and fall, several brown trout greater than $600 \mathrm{~mm}$ were captured in Cee Cee Ah Slough, at the mouth of Cee Cee Ah Creek and at the mouth of Skookum Creek. In 1988, a rainbow trout was captured that measured $720 \mathrm{~mm}$. In 1989, a $905 \mathrm{~mm}$ rainbow trout was captured. Three bull trout were also captured in 1989, measuring from 600 to $800 \mathrm{~mm}$. One $560 \mathrm{~mm}$ lake trout was captured in 1990, along with three cutthroat trout, that were over $300 \mathrm{~mm}$. Therefore, there are some good size trout in the reservoir. They are, however, typically only captured during times when they are concentrated (spawning season) and it is suspected that some of them (e.g., the lake trout) originated from Lake Pend Oreille.

Despite low populations and slow growth rates trout are a popular sport fish in the Pend Oreille River. Angler interviews indicated that 25 percent (69 of 272) of anglers in 1988 and 30 percent (44 of 147) of anglers in 1989 had a preference for trout. Despite the popularity of trout in angler interviews, catch rates for these species were low during the study. Creel surveys estimated that $91 \pm 12$ cutthroat trout, $36 \pm 4$ brown trout and $20 \pm 3$ rainbow trout were caught in the river during 1988. Cumulatively these species had a catch-per-unit-effort (CPUE) of 0.04 fish/hour and composed $1.5 \%$ of the total catch that year. In 1989, an estimated $181 \pm 23$ bull trout and $91 \pm 11$ brown trout were caught by anglers in the Pend Oreille River. Estimated CPUE for trout species in 1989 was 0.10 fish/hour. Together, bull trout and rainbow trout composed $1.5 \%$ of the total catch in 1989.

\subsubsection{TROUT FISHERY IN THE TRIBUTARIES}

Even if the Pend Oreille River could support a healthy adult trout population it appears that the tributaries to the Box Canyon Reservoir have only limited potential to produce large numbers of trout that could be recruited into the fishery in the reservoir.

Although spawning habitat in most of the tributaries is of good quality most of the tributaries are low order, high gradient streams which are typically unproductive. As a result food availability may be limiting trout production in the tributaries. Benthic macroinvertebrate densities in samples collected from the tributaries were lower than almost all other tributaries in the region (Figure 4.4). 


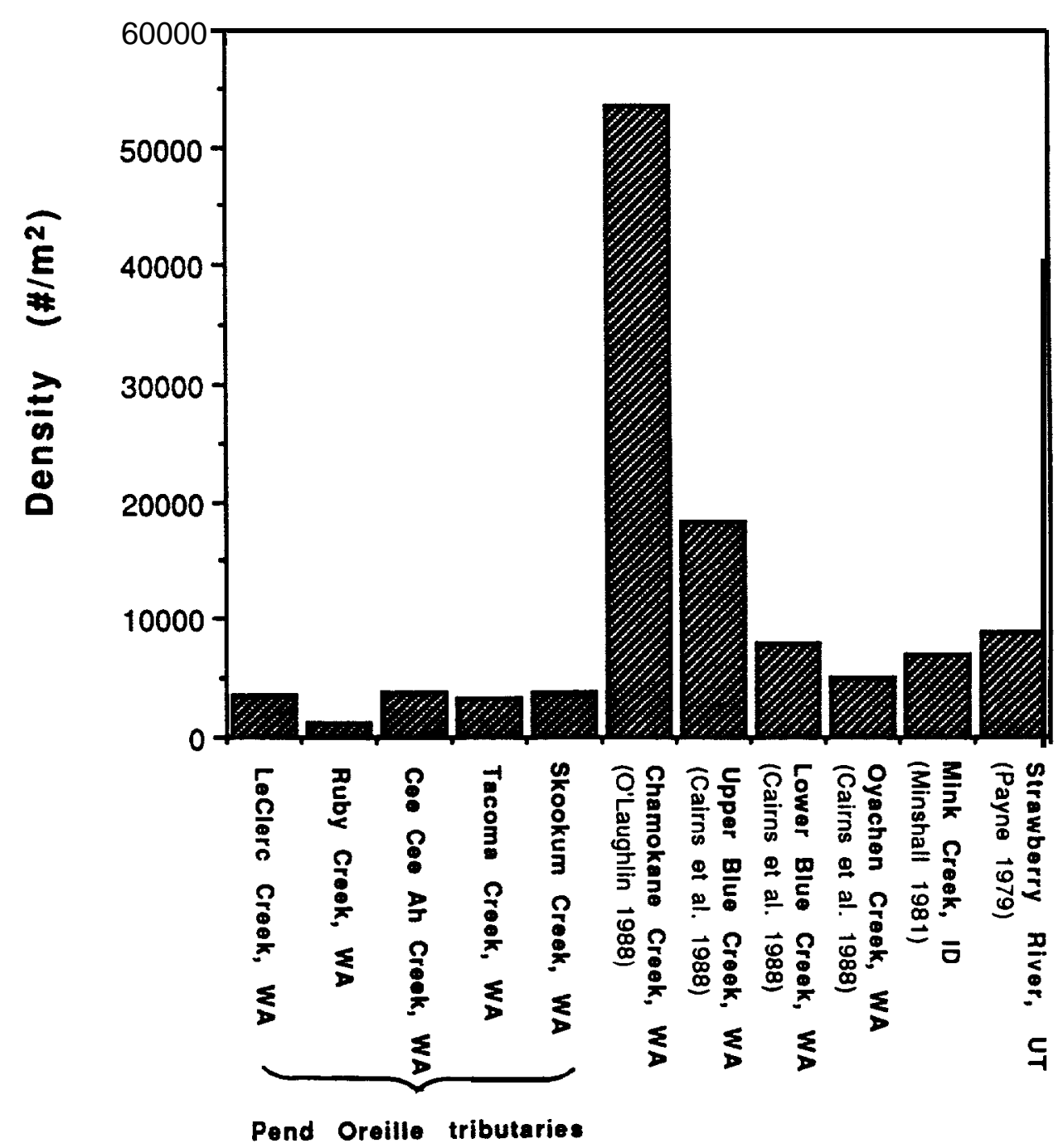

Figure 4.4. Comparison of benthic macroinvertebrate densities $\left(\# / \mathrm{m}^{2}\right)$ in tributaries to the Pend Oreille River, WA with other streams in the region. 
Some of the tributaries have been impacted by grazing and logging practices in and near the stream riparian area. As a result, sedimentation, bank erosion and habitat degradation have occurred. There are also some large beaver dams located near the mouth of some of these tributaries that pose migration barriers to spawning adults.

These limiting factors were reflected in the low populations and relatively poor growth rates of the trout residing in the tributaries. The highest cutthroat trout densities were observed in the middle reaches of Cee Cee Ah Creek. Cutthroat were also observed in every reach sampled on Tacoma Creek during both years of population estimates (Table 4.4). In comparison to other streams in the region the densities in the Pend Oreille tributaries tended to be low.

Growth rates of cutthroat trout between the tributaries were very similar but appeared best in Ruby and Tacoma Creeks (Figure 4.5). This seems odd because the results of competition between brook trout and cutthroat trout is well documented and both Ruby and Tacoma Creeks supported high densities of brook trout. In comparison to other streams in the region Pend Oreille tributaries represented the best growth for cutthroat trout (Figure 4.6). It's possible that the growth rates in Ruby Creek were due to the high macroinvertebrate densities in the drift (Figure 4.7). Despite the growth rates of cutthroat trout in Ruby Creek, there were no age $0_{+}$ fish captured in 1989 or 1990, indicating that reproduction may be limited. Cee Cee Ah Creek had the highest relative abundance for age $0+$ cutthroat trout: between $70 \%$ and $80 \%$ during all three years of the study (Figure 4.8).

Brook trout were the most abundant in Ruby and Tacoma Creeks although all five study tributaries had substantial populations throughout all of the reaches sampled (Table 4.5). The high populations of brook trout in Ruby and Tacoma Creeks are most likely the result of stocking by the Washington Department of Wildlife (Table 4.6) In comparison to other streams from the region, brook trout densities in Pend Oreille tributaries were average to high (Table 4.5). Brook trout growth rates appeared to be very similar between the tributaries, although trout in LeClerc and Tacoma Creeks were larger than trout from other creeks at age 3+ (Figure 4.9). In comparison to streams from the region brook trout from Pend Oreille tributaries demonstrated good growth (Figure 
Table 4.4. Comparison of cutthoat trout densities (fish/l $\mathrm{OOm}^{2}$ ) in Pend Oreille tributaries during 1989 (Barber et al. 1990) and 1990. Densities from other streams in the region are also listed.

\begin{tabular}{|c|c|c|}
\hline Location & 1989 Density $\left(\# / 100 m^{2}\right) 1990$ & Density $\left(\# / 100 \mathrm{~m}^{2}\right)$ \\
\hline $\begin{array}{r}\text { LeClerc Creek, WA } \\
\text { Reach } 2 \\
\text { Reach } 3 \\
\text { Reach } 4\end{array}$ & $\begin{array}{l}1.1 \\
0.3 \\
0.4\end{array}$ & $\begin{array}{l}0 \\
0.3 \\
0.1\end{array}$ \\
\hline $\begin{array}{r}\text { Ruby Creek, WA } \\
\text { Reach } 2 \\
\text { Reach } 3\end{array}$ & $\begin{array}{c}0.2 \\
\geq 0.5\end{array}$ & $\begin{array}{c}0.1 \\
0\end{array}$ \\
\hline $\begin{array}{r}\text { Cee Cee Ah Creek, WA } \\
\text { Reach } 2 \\
\text { Reach } 3\end{array}$ & $\begin{array}{c}0 \\
13.2\end{array}$ & $\begin{array}{c}6.1 \\
0\end{array}$ \\
\hline $\begin{array}{r}\text { Tacoma Creek, WA } \\
\text { Reach } 1 \\
\text { Reach } 2 \\
\text { Reach 3 } \\
\text { Reach } 4\end{array}$ & $\begin{array}{l}3.3 \\
4.3 \\
3.6 \\
4.5\end{array}$ & $\begin{array}{l}0 \\
1.1 \\
1.4 \\
4.0\end{array}$ \\
\hline $\begin{array}{r}\text { Skookum Creek, WA } \\
\text { Reach } 3 \\
\text { Reach } 4 \\
\end{array}$ & $\begin{array}{l}2.1 \\
0.4\end{array}$ & $\begin{array}{c}\text { no estimate } \\
\geq 0.2\end{array}$ \\
\hline Locati on & Density $\left(\# / 100 \mathrm{~m}^{2}\right)$ & Reference \\
\hline Honer Creek, ID & 21.6 & (Corsi and Elle 1989) \\
\hline Preuss Creek, ID & 8.0 & (Schill and Hei ner 1988) \\
\hline Badger Creek, ID & 19. 9 & (Mai ol i e and Cochnauer 1988) \\
\hline Post office Creek, ID & 5. 2 & (Mai ol i e and Cochnauer 1988) \\
\hline Wer Creek, ID & 4. 4 & (Mai ol i e and Cochnauer 1988) \\
\hline Lochsa Ri ver, I D & 3.7 & (Mai ol i e and Cochnauer 1988) \\
\hline N Fork Hayden Creek, ID & 46. 7 & (Ganbl in 1987) \\
\hline E. Fork Hayden Creek, ID & 24. 5 & (Ganbl in 1987) \\
\hline Bl ack Canyon Creek, ID & 10.3 & (Ganbl in 1987) \\
\hline Scott Creek, ID & 10. 2 & (Ganbl in 1987) \\
\hline Copper Creek, ID & 8.9 & (Ganbl in 1987) \\
\hline Onaha Creek, ID & 7.9 & (Ganbl in 1987) \\
\hline Hudl ow Creek, I D & 8.1 & (Ganbl in 1987) \\
\hline Pi cni c Creek, ID & 7.5 & (Ganbl in 1987) \\
\hline S. Fork Snake Ri ver, ID & 0.7 & (Luken 1988) \\
\hline
\end{tabular}




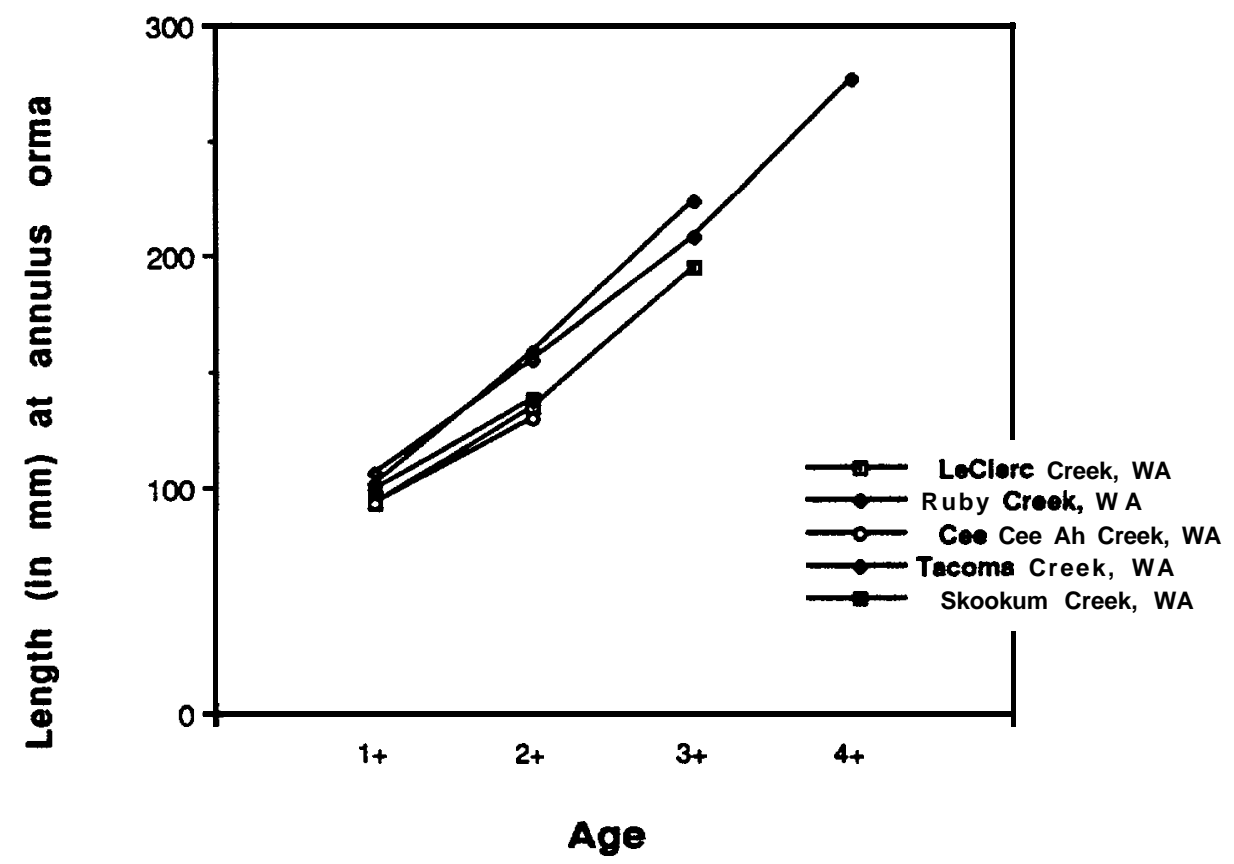

Figure 4.5. Comparison of cutthroat trout growth rates in tributaries to the Pend Oreille River, WA

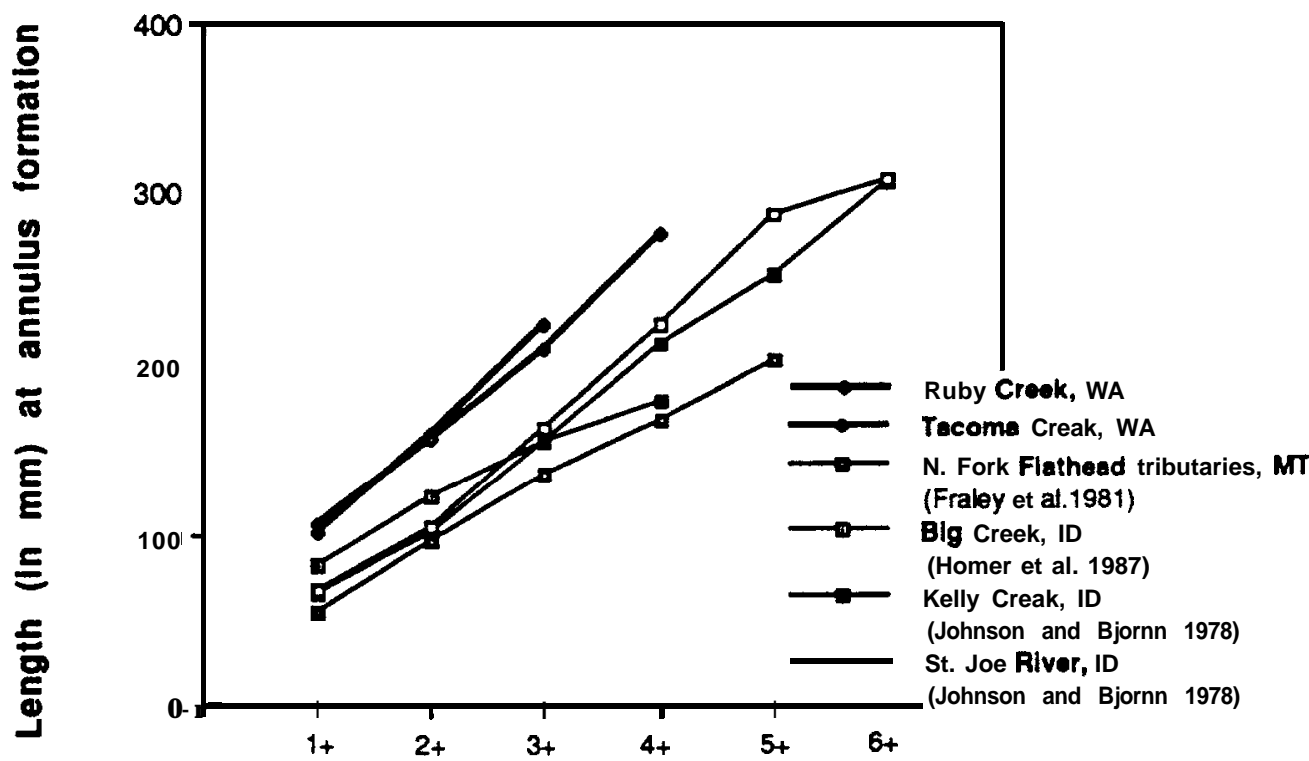

Age

Figure 4.6. Comparison of cutthroat trout growth rates in Pend Oreille tributaries with other streams in the region. 


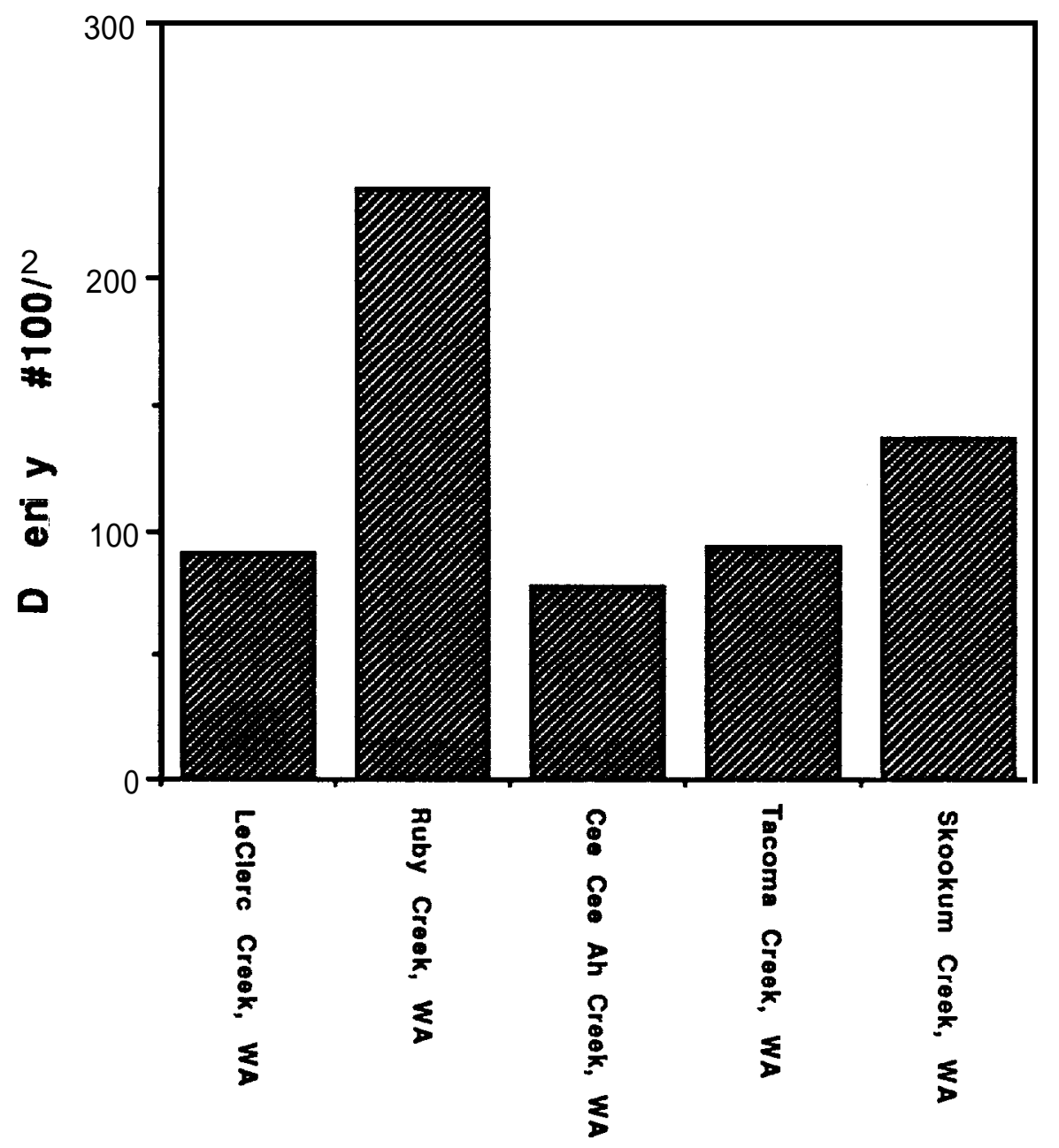

Figure 4.7. Comparison of macroinvertebrate densities $\left(\# / 100 \mathrm{~m}^{3}\right)$ in drift samples from in tributaries to the Pend Oreille River, WA 

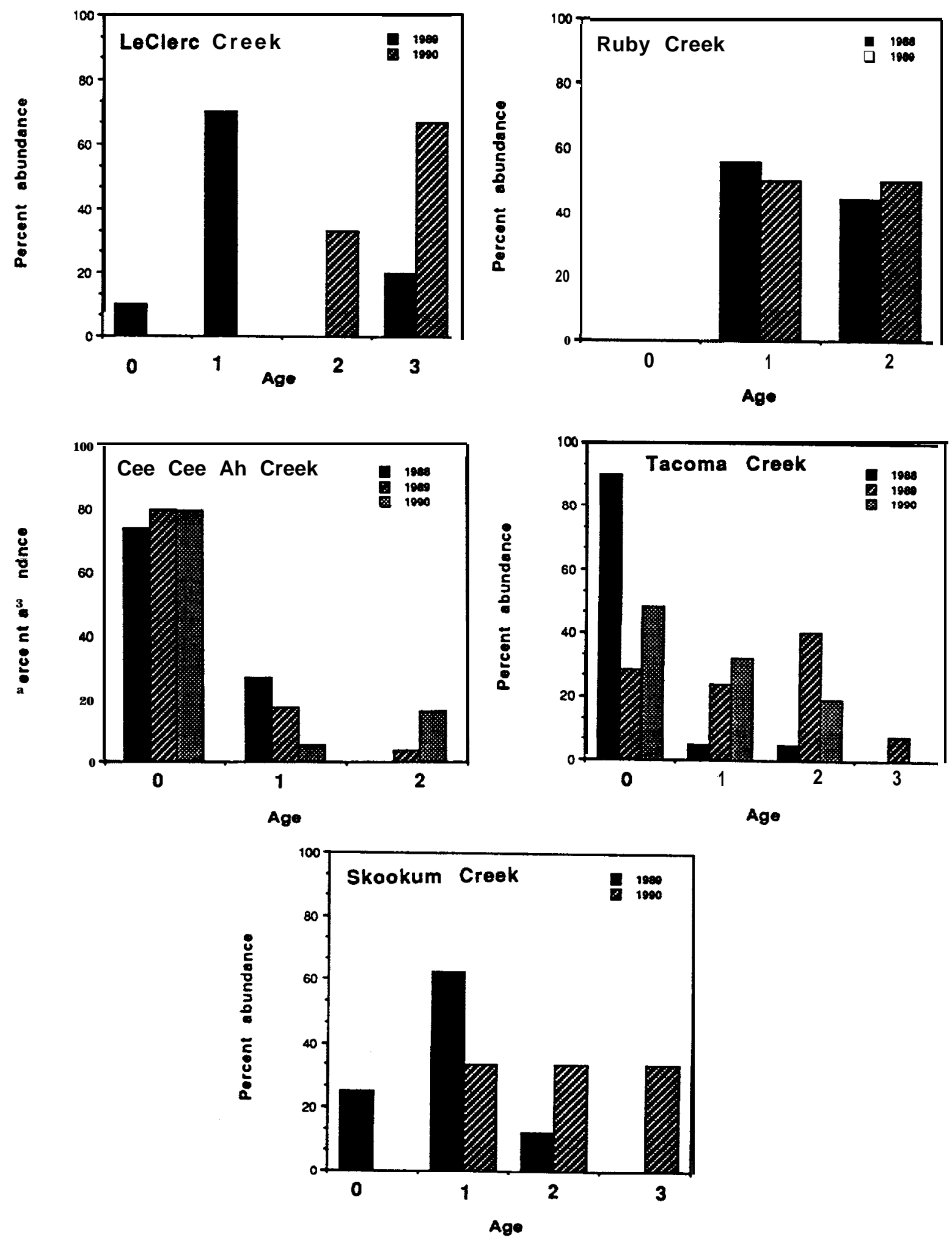

Figure 4.8. Relative abundance of cutthroat trout in each age class in LeClerc, Ruby, Cee Cee Ah, Tacoma, and Skookum Creek, during 1988, 1989 and 1990. 
Table 4.5. Comparison of brook trout densities

(fish/l $00 \mathrm{~m}^{2}$ ) in Pend Oreille tributaries during 1989 (Barber et al. 1990) and 1990. Densities from other streams in the region are also listed.

\begin{tabular}{|c|c|c|}
\hline Location & 1989 Density $\left(\# / 100 \mathrm{~m}^{2}\right)$ & 1990 Density $\left(\# / 100 \mathrm{~m}^{2}\right)$ \\
\hline $\begin{array}{c}\text { LeClerc Creek, WA } \\
\text { Reach } 1 \\
\text { Reach } 2 \\
\text { Reach } 3 \\
\text { Reach } 4\end{array}$ & $\begin{array}{l}4.5 \\
2.6 \\
10.2 \\
9.0\end{array}$ & $\begin{array}{l}3.6 \\
1.8 \\
2.0 \\
5.6\end{array}$ \\
\hline $\begin{array}{c}\text { Ruby Creek, WA } \\
\text { Reach } 1 \\
\text { Reach } 2 \\
\text { Reach } 3 \\
\text { Reach } 4\end{array}$ & $\begin{array}{c}8.6 \\
10.9 \\
31.6 \\
102.2\end{array}$ & $\begin{array}{c}3.5 \\
6.1 \\
6.0 \\
45.1\end{array}$ \\
\hline $\begin{array}{c}\text { Cee Cee Ah Creek, WA } \\
\text { Reach } 1 \\
\text { Reach } 2 \\
\text { Reach } 3 \\
\text { Reach } 4\end{array}$ & $\begin{array}{c}0 \\
\text { no estimate } \\
12.0 \\
34.0\end{array}$ & $\begin{array}{l}0.2 \\
2.0 \\
15.3 \\
13.0\end{array}$ \\
\hline $\begin{array}{c}\text { Tacoma Creek, WA } \\
\text { Reach } 1 \\
\text { Reach } 2 \\
\text { Reach } 3 \\
\text { Reach } 4\end{array}$ & $\begin{array}{c}21.8 \\
26.3 \\
20.7 \\
9.0\end{array}$ & $\begin{array}{l}1.7 \\
5.5 \\
11.7 \\
17.7\end{array}$ \\
\hline $\begin{array}{c}\text { Skookum Creek, WA } \\
\text { Reach } 1 \\
\text { Reach } 2 \\
\text { Reach } 3 \\
\text { Reach } 4 \\
\end{array}$ & $\begin{array}{c}0 \\
10.7 \\
11.0 \\
50.7\end{array}$ & $\begin{array}{c}0.3 \\
\text { no estimate } \\
5.2 \\
30.7\end{array}$ \\
\hline Location & Density $\left(\# / 100 \mathrm{~m}^{2}\right)$ & Reference \\
\hline Homer Creek, ID & 31.3 & (Corsi and Elle 1989) \\
\hline N. Fork Grouse Creek, ID & 7.7 & (Hoelscher and Bjornn 1989) \\
\hline S. Fork Grouse Creek, ID & 0.3 & (Hoelscher and Bjornn 1989) \\
\hline Twin Creek, ID & 4.8 & (Hoelscher and Bjornn 1989) \\
\hline Bear Creek, ID & 77.8 & (Cowley 1987) \\
\hline Kalispell Creek, ID & 11.6 & (Cowley 1987) \\
\hline E. Fork Hayden Creek, ID & 2.1 & (Gamblin 1987) \\
\hline Copper Creek, ID & 3.6 & (Gamblin 1987) \\
\hline Skookum Creek, ID & 0.5 & (Gamblin 1987) \\
\hline
\end{tabular}


Table 4.6. Stocking record summary of trout species planted in Ruby Creek by the Washington Department of Wildlife.

\begin{tabular}{|l|c|c|r|}
\hline Date Planted & Species & Number & Number/Ib. \\
\hline Sept 1949 & Cutthroat trout & 8,500 & 950 \\
May 1950 & Brook trout & 5,000 & 1250 \\
June 1974 & Brook trout & 1800 & 180 \\
June 1975 & Brook trout & 3,045 & 145 \\
May 1976 & Brook trout & 1,200 & 120 \\
May 1977 & Brook trout & 1,400 & 140 \\
May 1978 & Brook trout & 2,040 & 102 \\
June 1979 & Brook trout & 1,260 & 70 \\
June 1980 & Brook trout & 1,425 & 95 \\
May 1981 & Brook trout & 1,350 & 150 \\
June 1982 & Brook trout & 1,960 & 98 \\
May 1984 & Brook trout & 2,000 & 100 \\
June 1985 & Brook trout & 1,800 & 90 \\
June 1986 & Brook trout & 1,036 & 74 \\
June 1987 & Brook trout & 1,000 & 80 \\
June 1988 & Brook trout & 759 & 69 \\
\hline
\end{tabular}


4.10). Age relative abundance was similar for brook trout in all tributaries (Figure 4.11).

Cee Cee Ah Creek and Skookum Creek had the highest-brown trout densities in the lower reaches (Table 4.7). Similar density estimates for these tributaries were reported by Bennett et al. (1990). in comparison to other streams in the region these densities appeared quite high. Growth rates for brown trout between the tributaries appeared similar, although LeClerc Creek and Tacoma Creek seemed to have slightly higher rates (Figure 4.12). Brown trout in Tacoma Creek were only captured during 1989 and growth rates were based on samples from only 6 fish so these rates were assumed to be biased. In comparison to brown trout found in other locations in the region, Pend Oreille tributary brown trout had low growth rates (Figure 4.13). These low growth rates may be due to lack of benthic macroinvertebrate productivity, low water temperatures or a combination of both. Cee Cee Ah and Skookum Creeks had the highest abundance of younger age classes $(0+$ and $1+)$ of fish indicating reproduction was occurring in these creeks (Figure 4.14).

All three of these species exhibited a high degree of variation in the individual diet components. In general, Limnephilidae (caddisfly larvae), Brachycentridae (caddisfly larvae), Chironomidae (midge larvae), Baetidae (mayfly larvae), Formicidae (ants) and Elmidae (riffle beetle larvae) were primary contributors to the diet of fish in all five tributaries.

Cutthroat trout and rainbow trout had high diet overlaps in Ruby Creek, probably the result of both species utilizing Formicidae to a high degree (Table 4.8). Brook trout and cutthroat trout diet overlaps ranged from low to moderate in all tributaries during all three years of the study. There was a great deal of geographic overlap between brook trout and cutthroat trout so it's suspected these low overlaps were due to partitioning of the available food resources (Clark 1991). Brown trout and brook trout exhibited moderate to high overlaps in all tributaries but this is of little concern since these species tend to be spatially segregated within the stream. Mountain whitefish had low to moderate overlaps with all salmonid species found in the tributaries.

Based on the index of relative importance (IRI), revealed that, Baetidae and Limnephilidae were important brown trout food organisms. Trichoptera (caddisfly) pupae, Limnephilidae (caddisfly), 


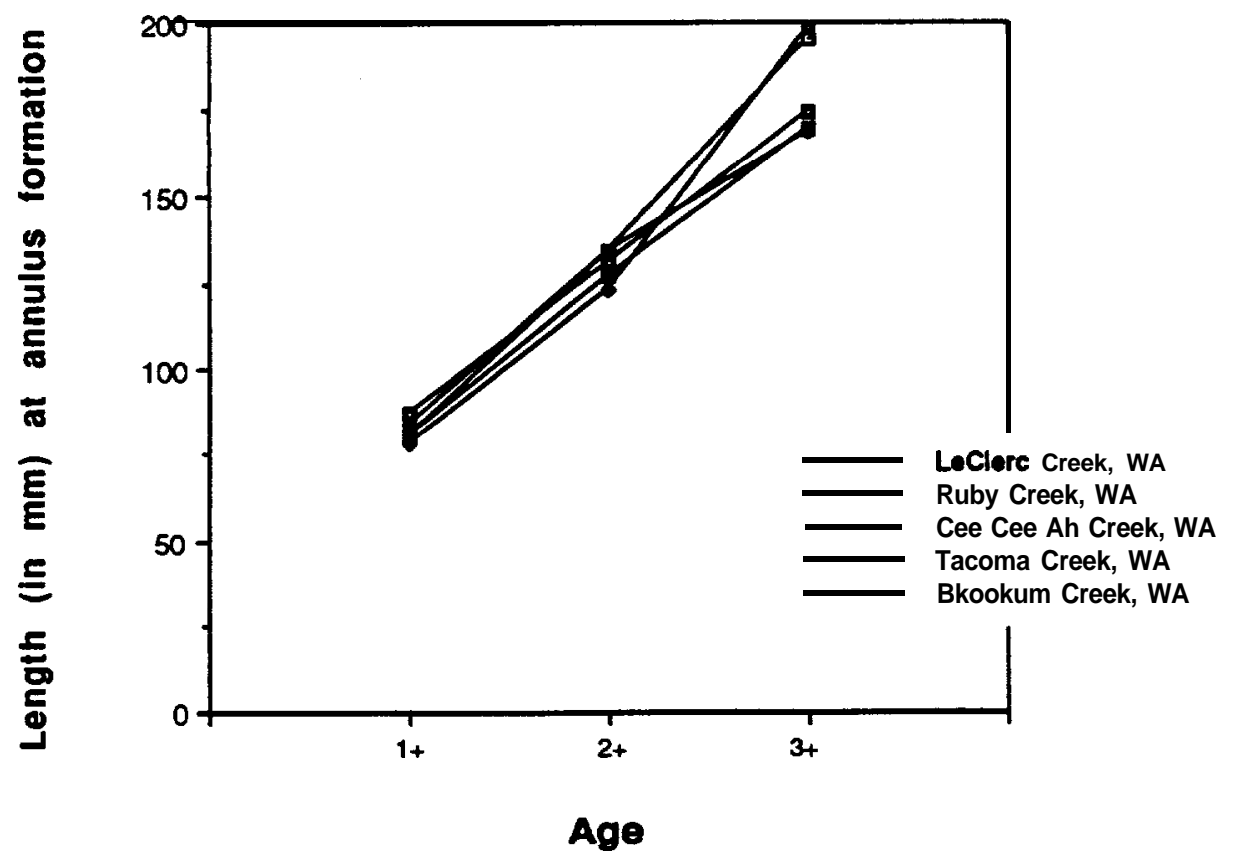

Figure 4.9. Comparison of brook trout growth rates in tributaries to the Pend Oreille River, WA

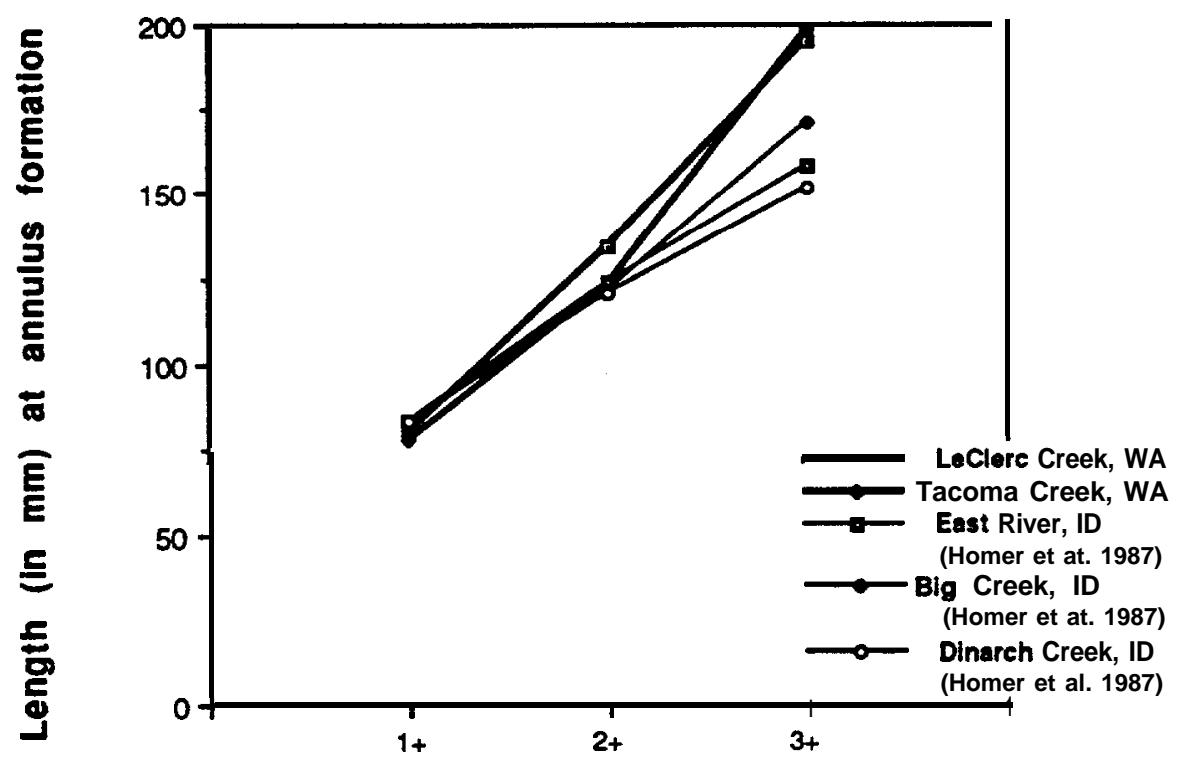

Age

Figure 4.10. Comparison of brook trout growth rates in Pend Oreille tributaries with other streams in the region. 

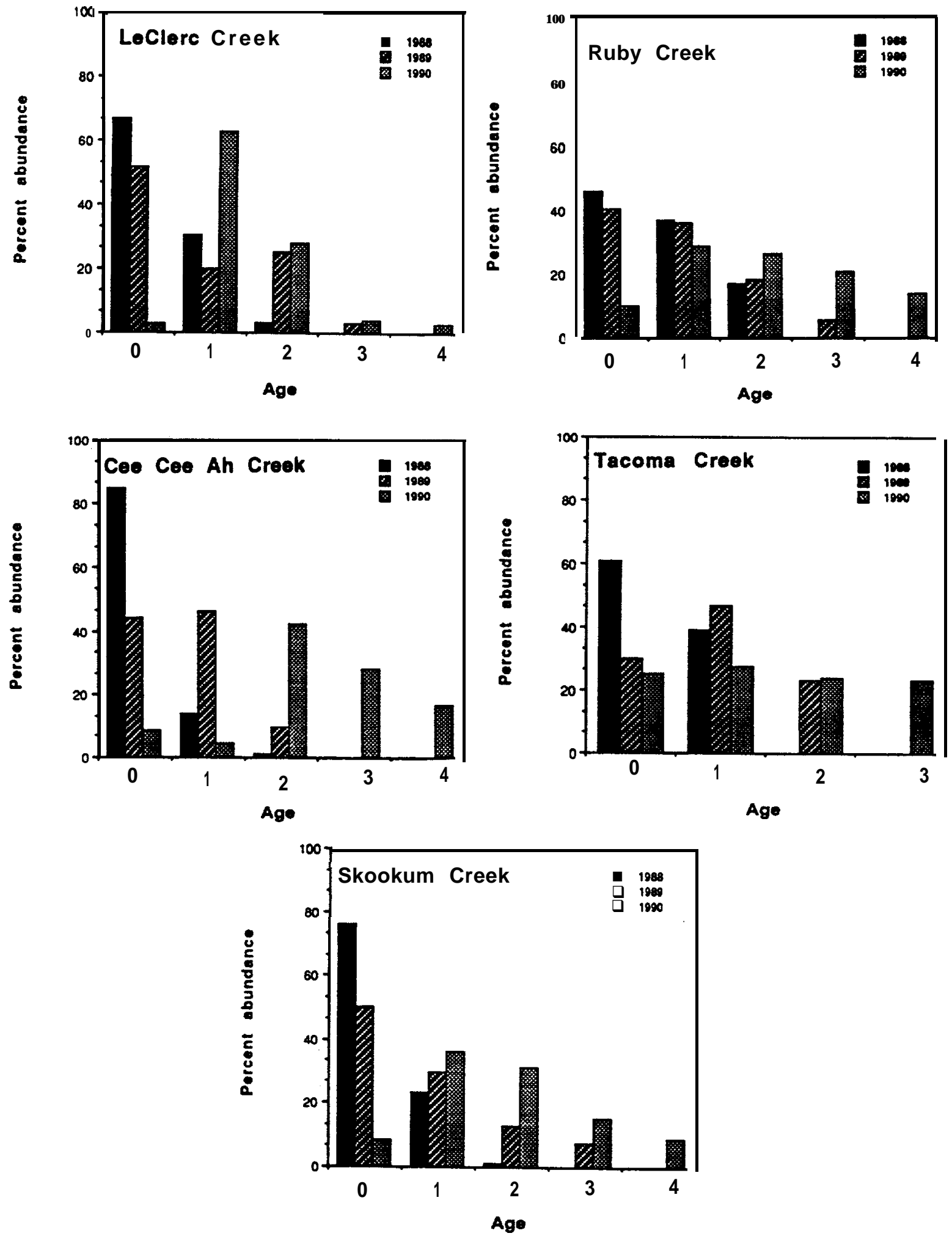

Figure 4.11. Relative abundance of brook trout in each age class in LeClerc, Ruby, Cee Cee Ah, Tacoma, and Skookum Creek, during 1988, 1989 and 1990. 
Table 4.7. Comparison of brown trout densities (fish/100m ${ }^{2}$ ) in Pend Oreille tributaries during 1989 (Barber et al. 1990) and 1990. Densities from other streams in the region are also listed.

\begin{tabular}{|c|c|c|}
\hline Location & \multicolumn{2}{|c|}{1989 Density $\left(\# / 100 \mathrm{~m}^{2}\right) 1990$ Density $\left(\# / 100 \mathrm{~m}^{2}\right)$} \\
\hline $\begin{array}{c}\text { LeClerc Creek, WA } \\
\text { Reach } 1 \\
\text { Reach } 2 \\
\text { Reach } 3 \\
\text { Reach } 4\end{array}$ & $\begin{array}{c}6.0 \\
0.7 \\
1.5 \\
0\end{array}$ & $\begin{array}{c}0.7 \\
1.4 \\
\text { no estimate } \\
0.2\end{array}$ \\
\hline $\begin{array}{c}\text { Ruby Creek, WA } \\
\text { Reach } 1\end{array}$ & no estimate & 0.2 \\
\hline $\begin{array}{c}\text { Cee Cee Ah Creek, WA } \\
\text { Reach } 1 \\
\text { Reach } 2 \\
\text { Reach } 3\end{array}$ & $\begin{array}{l}25.7 \\
35.6 \\
4.1\end{array}$ & $\begin{array}{l}12.2 \\
7.5 \\
0\end{array}$ \\
\hline $\begin{array}{c}\text { Tacoma Creek, WA } \\
\text { Reach } 1\end{array}$ & 0 & 0.2 \\
\hline $\begin{array}{c}\text { Skookum Creek, WA } \\
\text { Reach 1 } \\
\text { Reach } 2 \\
\text { Reach 3 }\end{array}$ & $\begin{array}{c}2.8 \\
80.9 \\
3.0\end{array}$ & $\begin{array}{c}7.5 \\
8.1 \\
0\end{array}$ \\
\hline Location & Density $\left(\# / 100 \mathrm{~m}^{2}\right)$ & Reference \\
\hline S. Fork Snake River, ID & 0.4 & (Luken 1988) \\
\hline Willow Creek, ID & 0.2 & (Corsi and Elle 1989) \\
\hline Henrys Fork, Snake River. ID & 0.07 & (Luken 1988) \\
\hline
\end{tabular}




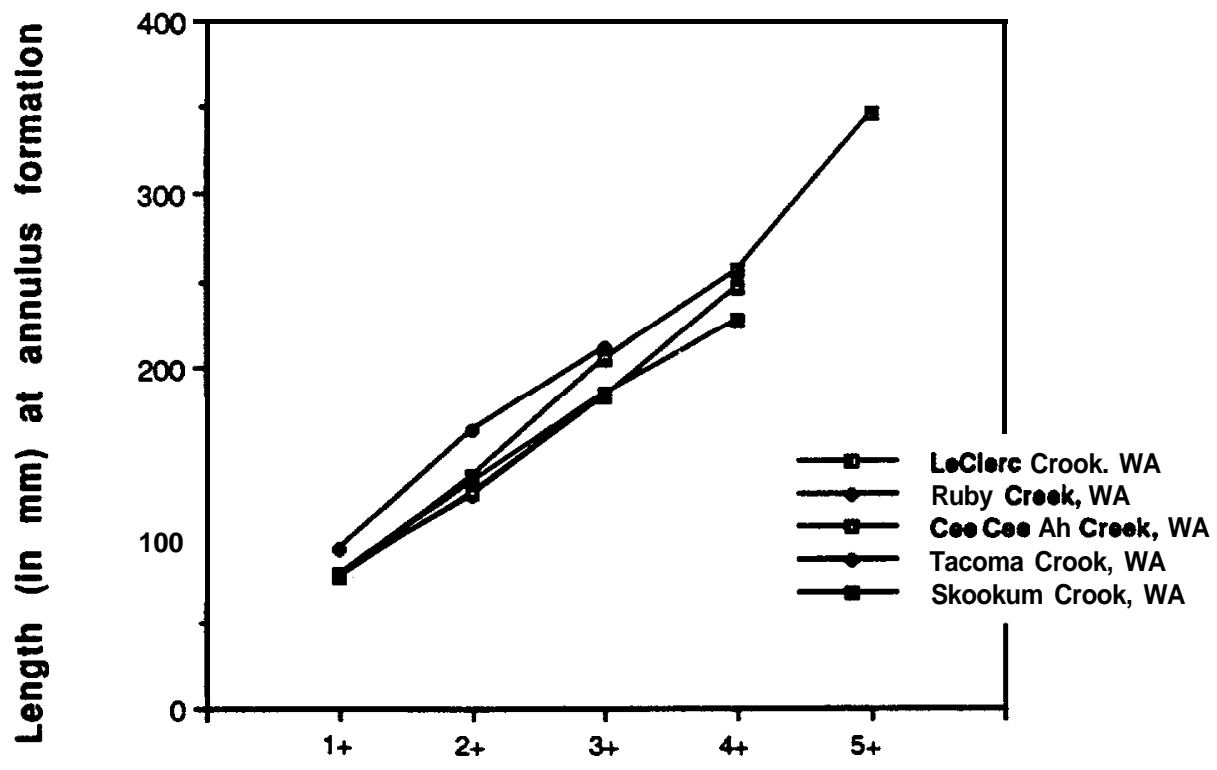

Age

Figure 4.12. Comparison of brown trout growth rates in tributaries to the Pend Oreille River, WA

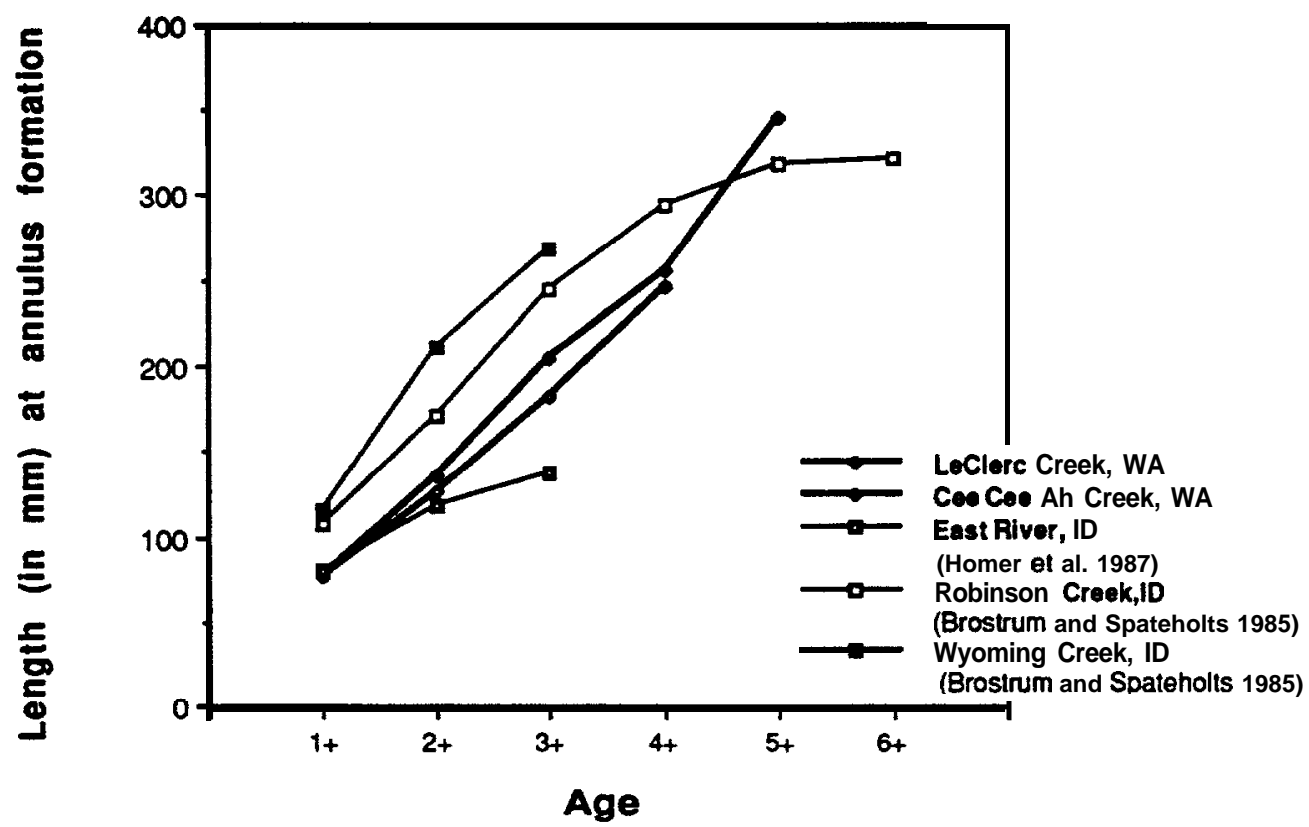

Figure 4.13. Comparison of brown trout growth rates in Pend Oreille tributaries with other streams in the region. 

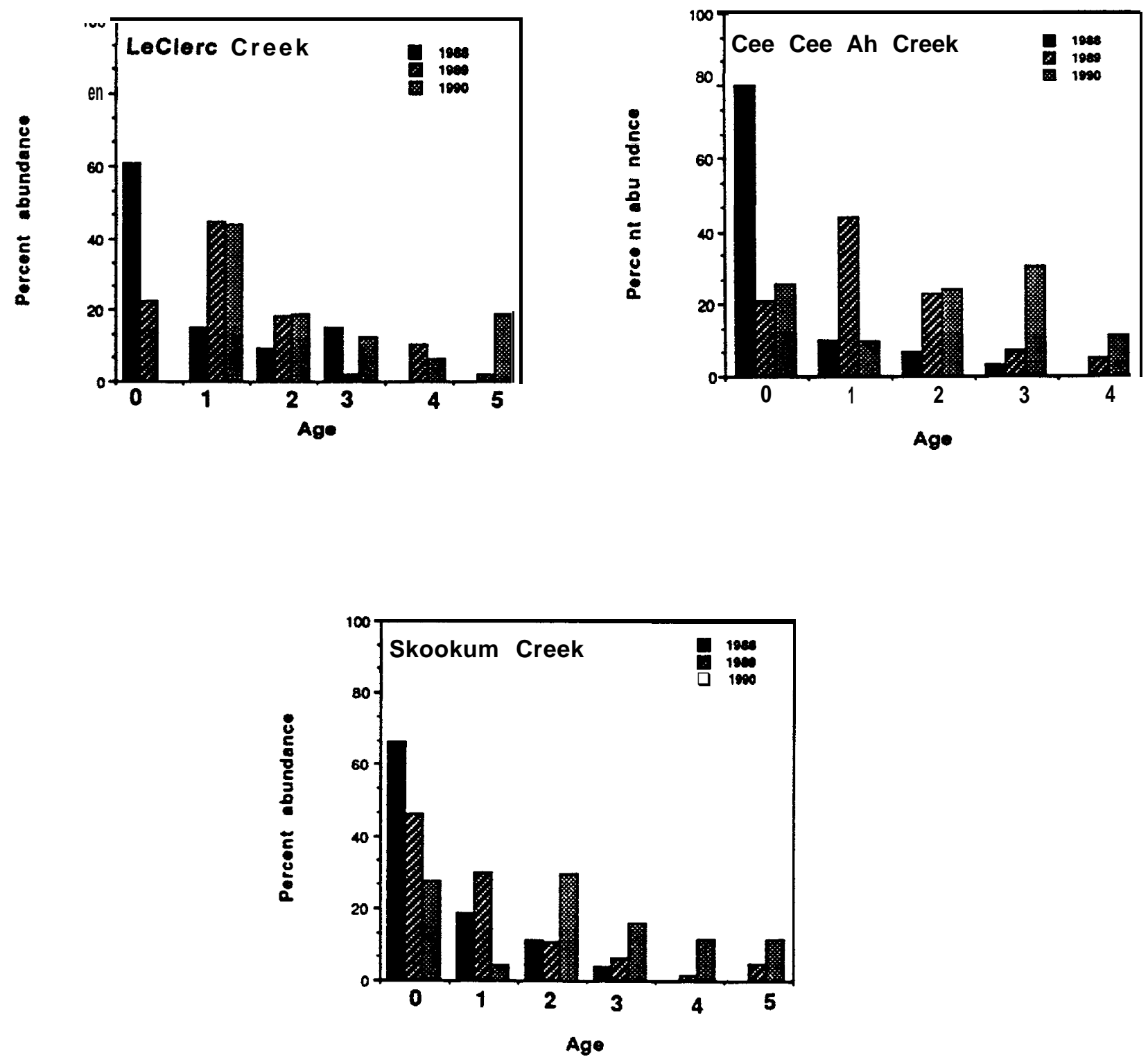

Figure 4.14. Relative abundance of brown trout in each age class in LeClerc, Ruby, Cee Cee Ah, Tacoma, and Skookum Creek, during 1988, 1989 and 1990. 
Table 4.8. Comparison of the annual diet overlaps for different species of trout from five tributaries of the Pend Oreille River, WA.

\begin{tabular}{|c|c|c|c|}
\hline & 1988 & 1989 & 1990 \\
\hline \multicolumn{4}{|l|}{ LeClerc Creek } \\
\hline Brown trout $x$ brook trout & 0.68 & 0.73 & 0.55 \\
\hline Brown trout $x$ cutthroat trout & 0.20 & 0.44 & 0.50 \\
\hline Brook trout $x$ cutthroat trout & 0.27 & 0.51 & 0.50 \\
\hline \multicolumn{4}{|l|}{ Ruby Croek } \\
\hline Brook trout $x$ cutthroat trout & & 0.58 & 0.54 \\
\hline Brook trout $x$ rainbow trout & & 0.70 & 0.37 \\
\hline Brook trout $x$ mountain whitefish & & 0.41 & 0.28 \\
\hline Cutthroat trout $x$ rainbow trout & & 0.74 & 0.85 \\
\hline \multicolumn{2}{|l|}{ Cutthroat trout $\mathrm{x}$ mountain whitefish } & 0.49 & 0.29 \\
\hline \multicolumn{2}{|l|}{ Rainbow trout $x$ mountain whitefish } & 0.50 & 0.05 \\
\hline \multicolumn{4}{|l|}{ Coe Cee Ah Creok } \\
\hline Brown trout $x$ brook trout & 0.91 & 0.73 & 0.31 \\
\hline \multicolumn{4}{|l|}{ Tacoma Creek } \\
\hline Brook trout $x$ cutthroat trout & 0.55 & 0.48 & 0.45 \\
\hline \multicolumn{4}{|l|}{ Skookum Creok } \\
\hline Brown trout $\mathrm{x}$ brook trout & 0.63 & 0.79 & 0.63 \\
\hline Brown trout $\mathrm{x}$ cutthroat trout & 0.39 & 0.39 & 0.32 \\
\hline Brook trout $\mathrm{x}$ cutthroat trout & 0.63 & 0.48 & 0.24 \\
\hline
\end{tabular}


Oligochaeta (worm), and Chironomidae (midge) pupae were important food items for brook trout. Diptera (fly) adults, Elmidae (beetle), and Hymenoptera (ants and bees) were important to cutthroat trout.

Brown trout and brook trout exhibited moderate to high overlaps in all tributaries, except in Cee Cee Ah Creek during 1990. The high overlaps between brown trout and brook trout are of little concern since they tend to be spatially segregated within the stream. Brook trout and cutthroat trout diet overlaps ranged from low to moderate in all tributaries for all three years of the study. Cutthroat trout and rainbow trout had high overlaps for 1989 and 1990 in Ruby Creek. This is probably the result of both species utilizing to a high degree Formicidae which comprised $59 \%$ of the prey items in 1990 and $100 \%$ of the prey item in 1989. Mountain whitefish had low to moderate overlaps with all salmonid species found in the tributaries.

According to Waters (1972) trout tend to feed heavier on aquatic invertebrates with higher drift tendencies such as Ephemeroptera (mayfly), Simuliidae (black fly), Trichoptera (caddisfly), and Plecoptera (stonefly). All primary aquatic prey organisms selected by trout in the tributaries fell into these groups of organisms during all three years of the study.

\subsubsection{MOUNTAIN WHITEFISH FISHERY}

The Pend Oreille River supports a fairly large unexploited mountain whitefish population. In relative abundance surveys mountain whitefish composed from 4 to 7 percent of the fish captured during the study (Table 4.1). The mountain whitefish population in the river was estimated at 164,252 in 1988, 163,890 in 1989 and 265,893 in 1990. It's possible that these estimates were conservative because mountain whitefish were more abundant in the relative abundance data than in the population estimate data during all three years.

The mountain whitefish population is probably limited to some extent by the same factors that limit trout production in the Pend Oreille River; water temperature, lack of adult habitat and food availability. Mountain whitefish generally prefer temperatures between $9^{\circ} \mathrm{C}$ and $11^{\circ} \mathrm{C}$ which is several degrees lower than the $21.3^{\circ} \mathrm{C}$ maximum temperature reported by Soltero et a/. (1988). Whitefish also prefer the same type of habitat as trout. As 
mentioned previously this type of habitat is limited in the Pend Oreille River.

Daphnidae was the main prey item for age $0+$ and $1+$ whitefish. The zooplankton densities in the Pend Oreille River are about average compared to other lakes and reservoirs but the cladoceran biomass tended to be lower. Low densities of cladocerans may limit growth and survival of young whitefish as young bass, perch and black crappie also rely heavily on Daphnidae as a prey item. Age 2+ and older fish were primarily benthic feeders relying mainly on Chironomidae larvae and pupae. Chironomidae larvae and pupae had the highest index of relative importance (IRI) values over the three year study. Chironomidae larvae and pupae were the most abundant prey items found in benthic samples indicating that prey abundance does not appear to be limiting. However, yellow perch, black crappie, rainbow trout, brown trout, kokanee, brown bullhead, northern squawfish, longnose sucker, largescale sucker, tench and pumpkinseed also relied heavily on Chironomidae larvae and pupae.

Younger age classes of mountain whitefish were observed in the reservoir during all three years of the study indicating that reproduction is occurring (Figure 4.15). From this data it appears that recruitment into the reservoir fishery occurred at age $2+$ and $3+$. Very few whitefish over age 4+ were captured during the study.

Mountain whitefish are fall to late winter, tributary spawners and therefore spawning success would be less affected by reservoir fluctuations. The increased amounts of precipitation observed during 1989 and 1990 resulted in higher flows in the tributaries and were therefore probably conducive to mountain whitefish spawning success.

Despite the possible limiting factors present in the Pend Oreille River growth of mountain whitefish was good. In comparison to other water bodies in the region growth of mountain whitefish in the Pend Oreille River was comparable and in some cases higher (Figure 4.16). Mountain whitefish captured during the study ranged from $47 \mathrm{~mm}$ to $444 \mathrm{~mm}$ with mean lengths that ranged from $238 \mathrm{~mm}$ to 263 (Table 4.9).

Even though there are sizeable mountain whitefish available for anglers, they are not a popular game fish. None of the 272 anglers interviewed in 1988 and only one of the 147 anglers interviewed in 1989 expressed a preference for catching mountain 


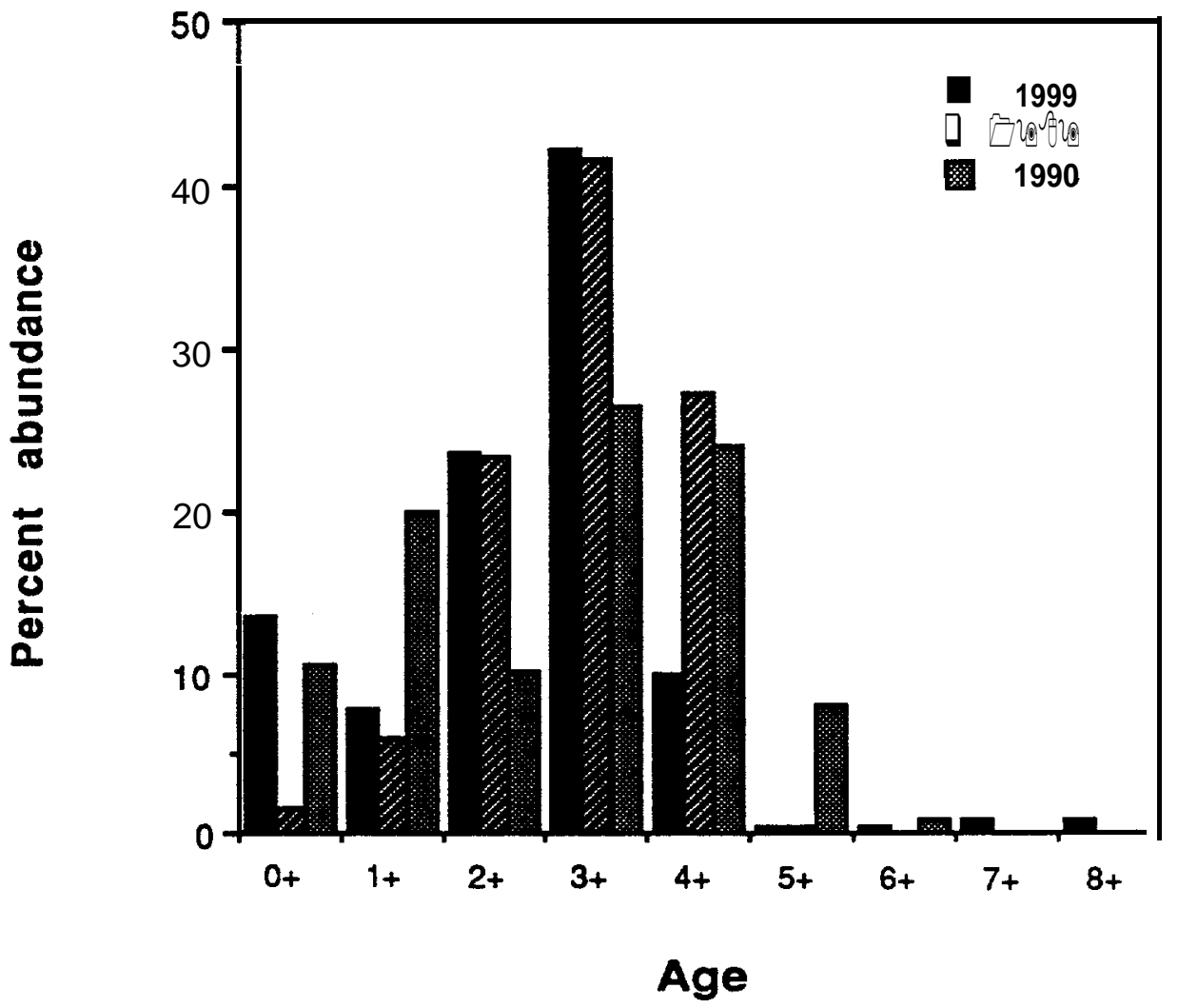

Figure 4.15. Relative abundance of mountain whitefish in each age class in the Pend Oreille River during 1988, 1989 and 1990. 


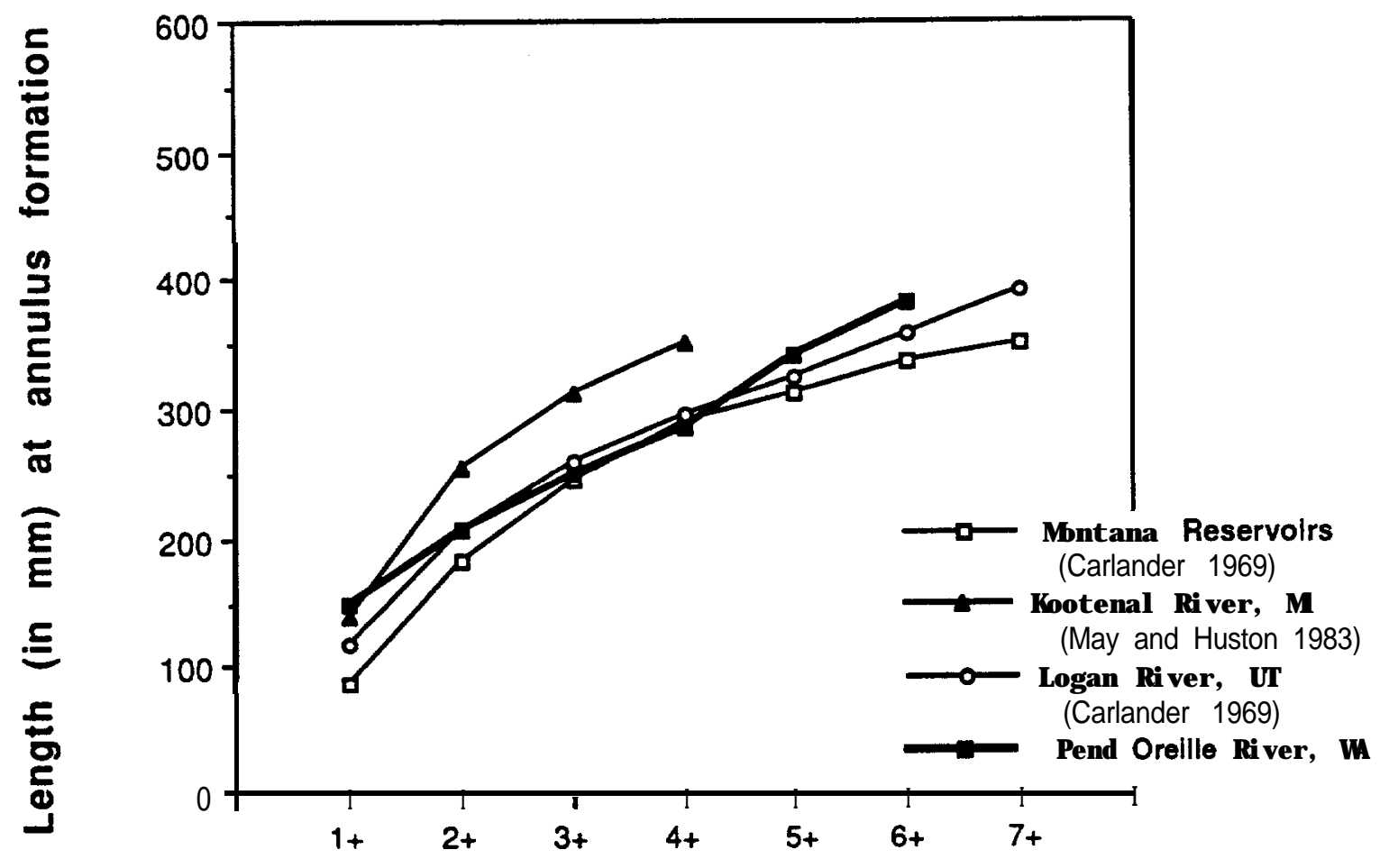

Age

Figure 4.16. Comparison of mean back-calculated lengths at annulus formation for mountain whitefish in the Pend Oreille River with other similar water bodies in the region. 

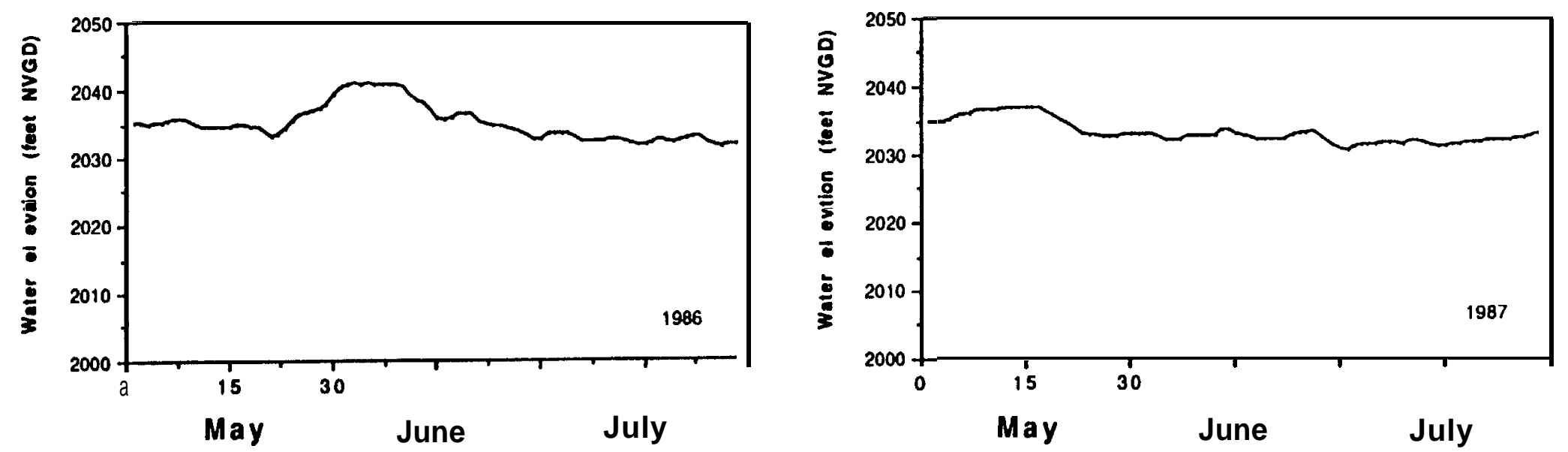

N
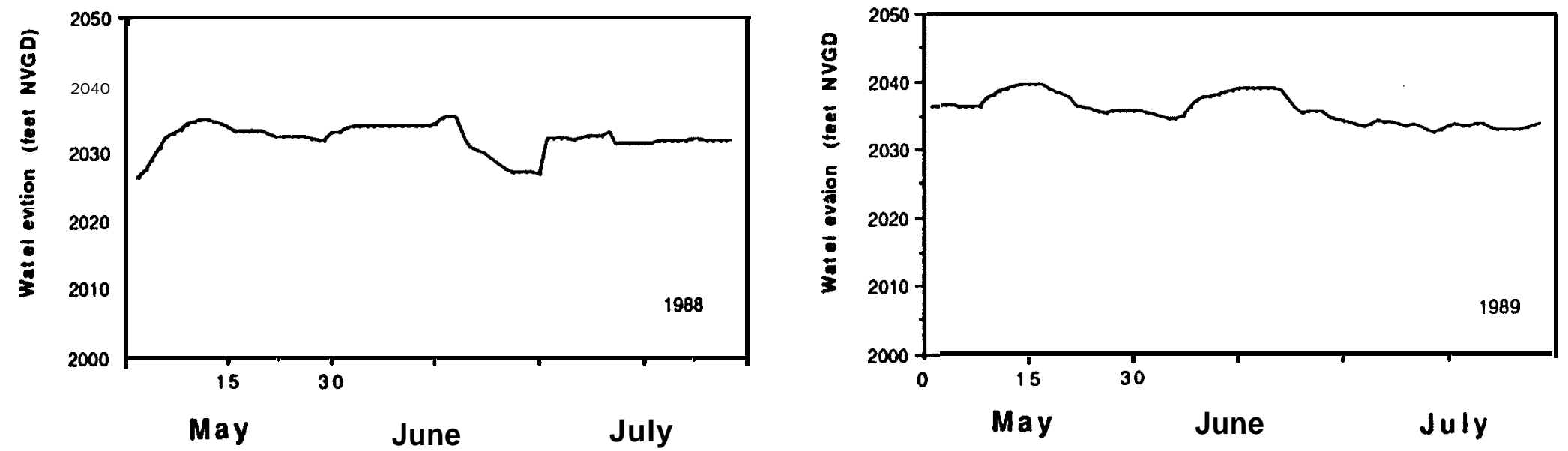

Figure 4.17. Water elevation fluctuation during largemouth bass spawning season (May-July) on the Pend Oreille River at the Cusick, WA gage during 1986-1989. 
whitefish. Creel surveys indicated that whitefish were incidentally caught but rarely harvested. In 1988, $146 \pm 21$ whitefish were caught with a catch-per-unit-effort (CPUE) of 0.04 fish/hour and composing $1.4 \%$ of the total catch. Only $51 \%$ of these fish were harvested. In 1989, $34 \pm 4$ whitefish were caught with a CPUE of 0.01 fish/hour composing $0.2 \%$ of the total catch. Only $32 \%$ of these fish were harvested.

\subsubsection{LARGEMOUTH BASS FISHERY}

Largemouth bass are currently the largest sized game fish in the Pend Oreille River with a sufficiently large population to provide a recreational fishery. In relative abundance surveys bass ranged from 7.2 to 9.1 percent of the total fish species present in the reservoir (Table 4.1). Largemouth bass populations were estimated at 657,549 in 1988, 590,906 in 1989 and 570,098 in 1990.

According to Stuber et al. (1982) optimal riverine habitat for largemouth bass is characterized by large, slow moving rivers with soft bottoms, aquatic vegetation, and relatively clear water. The Pend Oreille River appears to have optimal microhabitat for bass production. However, several factors limit the population at each life stage.

Water elevation fluctuation and bass tournaments are the two major factors that limit spawning success in the Pend Oreille River. Normal high flow in the river occurs during June (Figure 3.1) while normal low flow is only two months later. Most of the bass spawning occurs during mid June and mid July, during which time water levels in the river are steadily decreasing (Figure 4.17). According to Stuber et al. (1982) largemouth bass spawn at depths ranging from $0.15 \mathrm{~m}$ to $7.5 \mathrm{~m}$. However, the sloughs in the Pend Oreille River, where the majority of bass spawning takes place, are very shallow. During spawning season bass, presumably on spawning nests, were located at depths of $0.45 \mathrm{~m}$ to $2 \mathrm{~m}$ in the sloughs. The drawdown of 1988 caused by the mechanical malfunction at Box Canyon Dam, of 2.6 meters at Cusick, WA USGS gage, completely dewatered the shallow sloughs of the Pend Oreille River. The above data suggest that water elevation fluctuations of 0.15 to $0.45 \mathrm{~m}$ may be responsible for dewatering bass nests, resulting in nest mortality.

Based on results from telemetry data, bass peak spawning period is between June 15 and July 15. During 1988 and 1989 

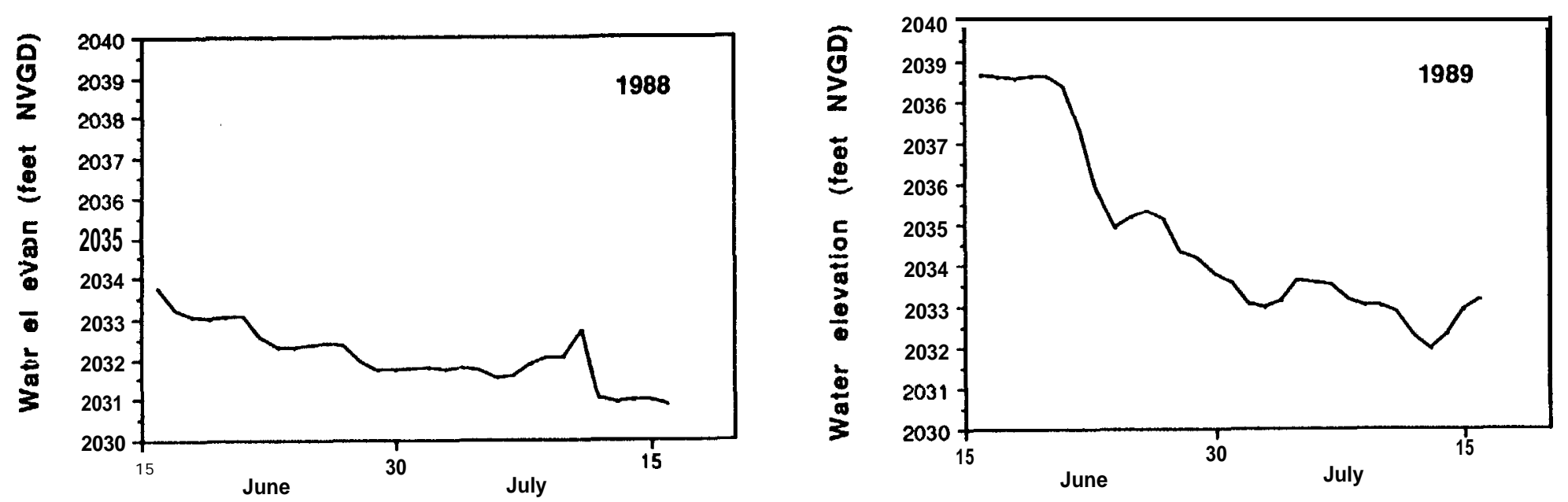

Figure 4.18. Daily water elevation fluctuation during largemouth bass peak spawning (June 15-July 15) on the Pend Oreille River at the Cusick, WA guage during 1988 and 1989. 
negative fluctuations of over $1 \mathrm{~m}$ occurred both years during this critical period (Figure 4.18). These fluctuations not only effect spawning success by dewatering nests, they also cause nest abandonment.

In northern Idaho lakes it was reported that prolonged. periods of declining water levels greater than $3 \mathrm{~cm}$ a day, or $38 \mathrm{~cm}$ over a 13 day period increased the probability of nest abandonment by the guarding male (Bennett and Bowles 1985). When the guarding male abandons the nest the embryos left in the nest are susceptible to predation by other fish species. In northern Idaho lakes, high nest mortality was caused by pumpkinseeds which preyed on the unguarded bass embryos (Bennett and Bowles 1985). As pumpkinseed are the second most abundant fish species in the Pend Oreille River serious nest mortality could occur as a result of abandonment.

Water level fluctuation is not the sole cause of nest abandonment. Several bass tournaments are conducted on the Pend Oreille River during the peak spawning season. These tournaments result in the bass being removed from their nests and transported to a central location for weigh in. The entire tournament catch is then released at one location on the river. The removal of parent fish from their nests leaves the embryos susceptible to predation and other environmental factors, reducing spawning success. It was not possible to determine if fish removed from their nests by anglers returned after release back into the river. Because the release location is up to 20 miles $(32.2 \mathrm{~km})$ from where some of the fish were captured the chance of a fish returning to its nest is thought to be slim. Fish captured by tournament anglers were marked with floy tags for later identification. Of the 31 largemouth bass that were tagged at a bass tournament in 1989, 16 (52\%) were later recaptured in different areas than they were released. In 1990, five of the seven $(71 \%)$ largemouth bass that were tagged at a bass tournament were recaptured in areas other than where they were released. By contrast, 37 largemouth bass were tagged during electrofishing surveys in 1989 and released in the immediate area. Of these only $10(27 \%)$ were recaptured in different areas than where they were released.

The major factors limiting largemouth bass during the rearing stage in the Pend Oreille River were identified as cold water temperatures, competition for food between juvenile bass and 


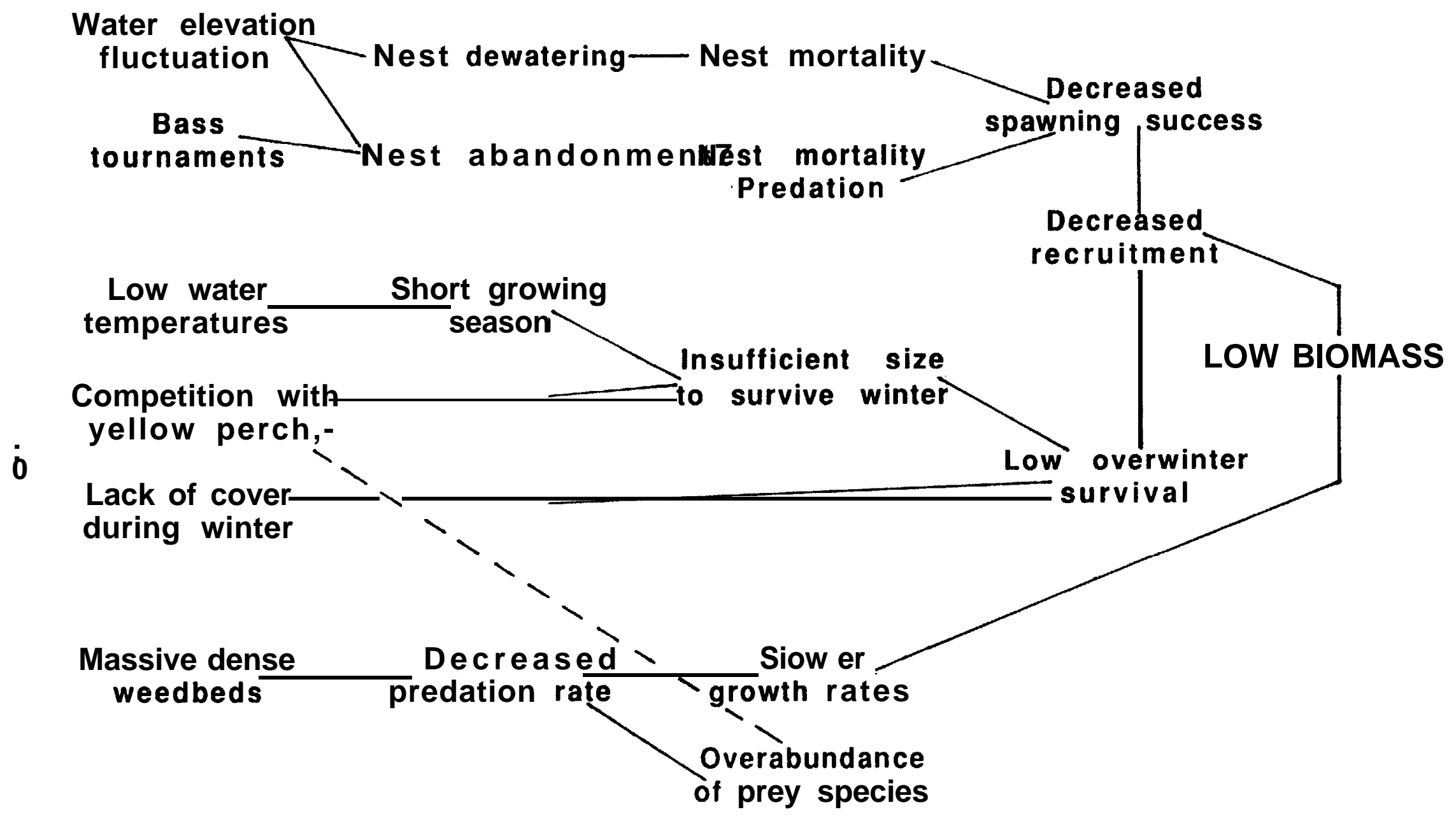

Figure 4.19. Interaction of factors limiting largemouth bass production and biomass in the Pend Oreille River, WA. 
yellow perch and lack of cover during the winter months (Figure 4.19).

Optimal temperature for growth of adult bass ranges from $24^{\circ} \mathrm{C}$ to $30^{\circ} \mathrm{C}$ and very little growth occurs below $15^{\circ} \mathrm{C}$ (Mohler 1966). Optimal temperatures for successful spawning and incubation are $20^{\circ} \mathrm{C}$ to $21^{\circ} \mathrm{C}$ with a range of $13^{\circ} \mathrm{C}$ to $26^{\circ} \mathrm{C}$ (Stuber et al. 1982). Growth of fry is inhibited below $15^{\circ} \mathrm{C}$ (Strawn 1961) and is best between $27^{\circ} \mathrm{C}$ and $30^{\circ} \mathrm{C}$. Obviously the optimal temperatures for bass growth and survival are higher than the maximum temperatures recorded in the Pend Oreille River. Temperatures in the river were above $15^{\circ} \mathrm{C}$ only from early June to late September in 1987 and 1988 (Soltero et a/. 1988); a growing season of 4 months. The short growing season is expressed by the slow growth rates of bass in the Pend Oreille River. Compared to bass from other water bodies in the region, growth rates were lower at every annulus (Figure 4.20).

It appears that bass growth and recruitment is also limited due to competition with yellow perch for zooplankton during the first few years of life. Age $0+$ to $2+$ largemouth bass utilized zooplankton (Daphnidae and Chydoridae) as their major prey item. Cladoceran densities in the Pend Oreille River tended to be average in comparison to other bodies of water, however cladoceran biomass was low. In addition, yellow perch, black crappie, and mountain whitefish also utilize Daphnidae and Chydoridae to a high degree. As a result diet overlaps between young bass and all of these species were high throughout the study. Ouedraogo (1991) reported similar results for his feeding habit study on largemouth bass in the Pend Oreille River, suggesting the slow stunted growth of young-of-theyear bass was a result of competition for food resources with sunfish (yellow perch, pumpkinseed and black crappie).

At about age $3+$ to $4+$, bass became primarily piscivorous and at this time yellow perch were the primary food item in their diet. A definite change in bass growth was seen at the same age this change in diet was observed. At about age 4+ bass gained $100 \mathrm{~g}$ a year (Figure 4.21). At age 6+ and older, bass can handle larger fish and therefore showed an increase in weight of over $200 \mathrm{~g}$ a year. Since yellow perch were the most abundant fish species in the reservoir food availability does not present a problem. In fact, it is believed that yellow perch are abundant in sufficient numbers to sustain a larger bass population. 


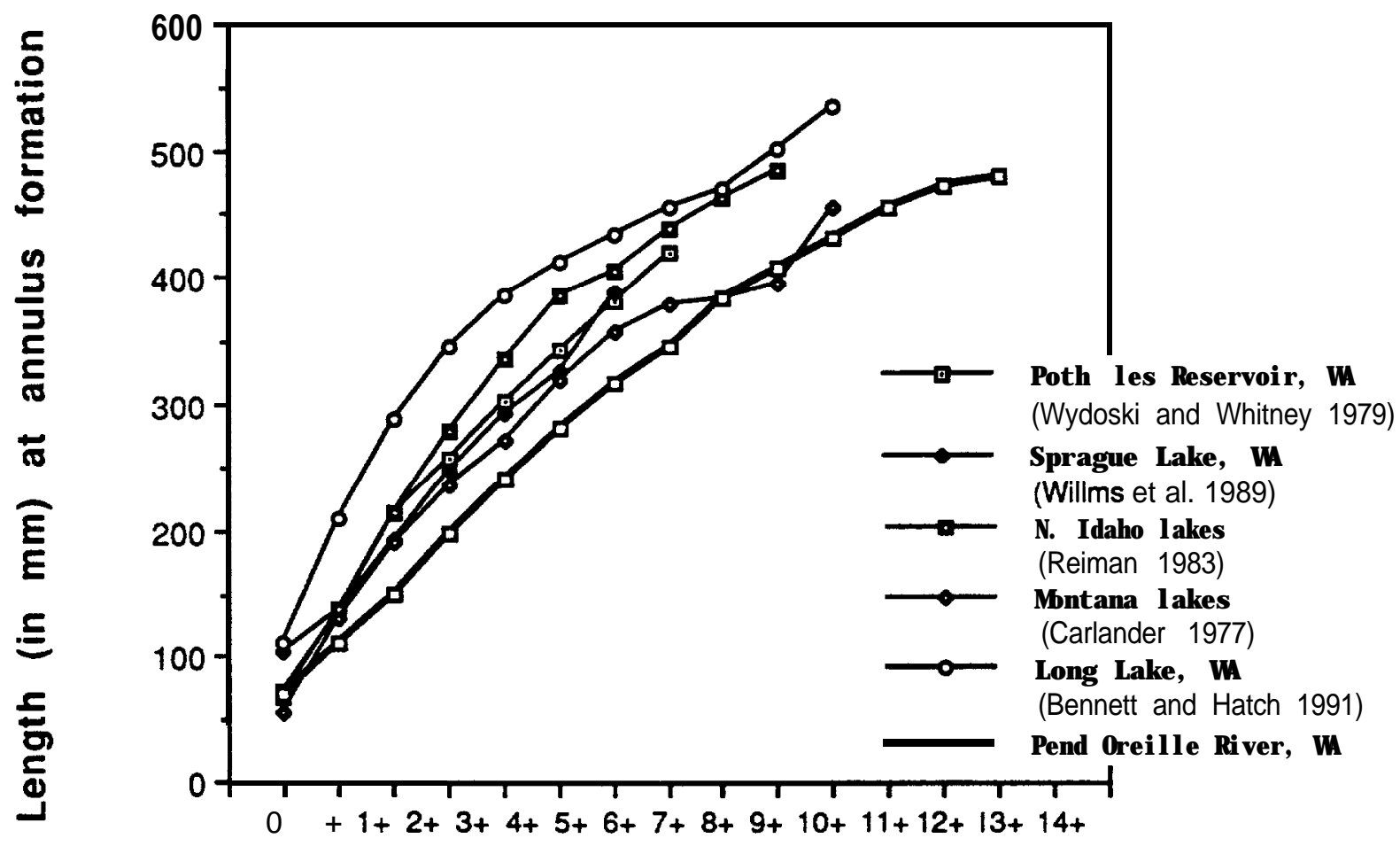

Figure 4.20. Comparison of mean back-calculated lengths at annulus formation for largemouth bass in the Pend Oreille River with other similar water bodies in the region. 


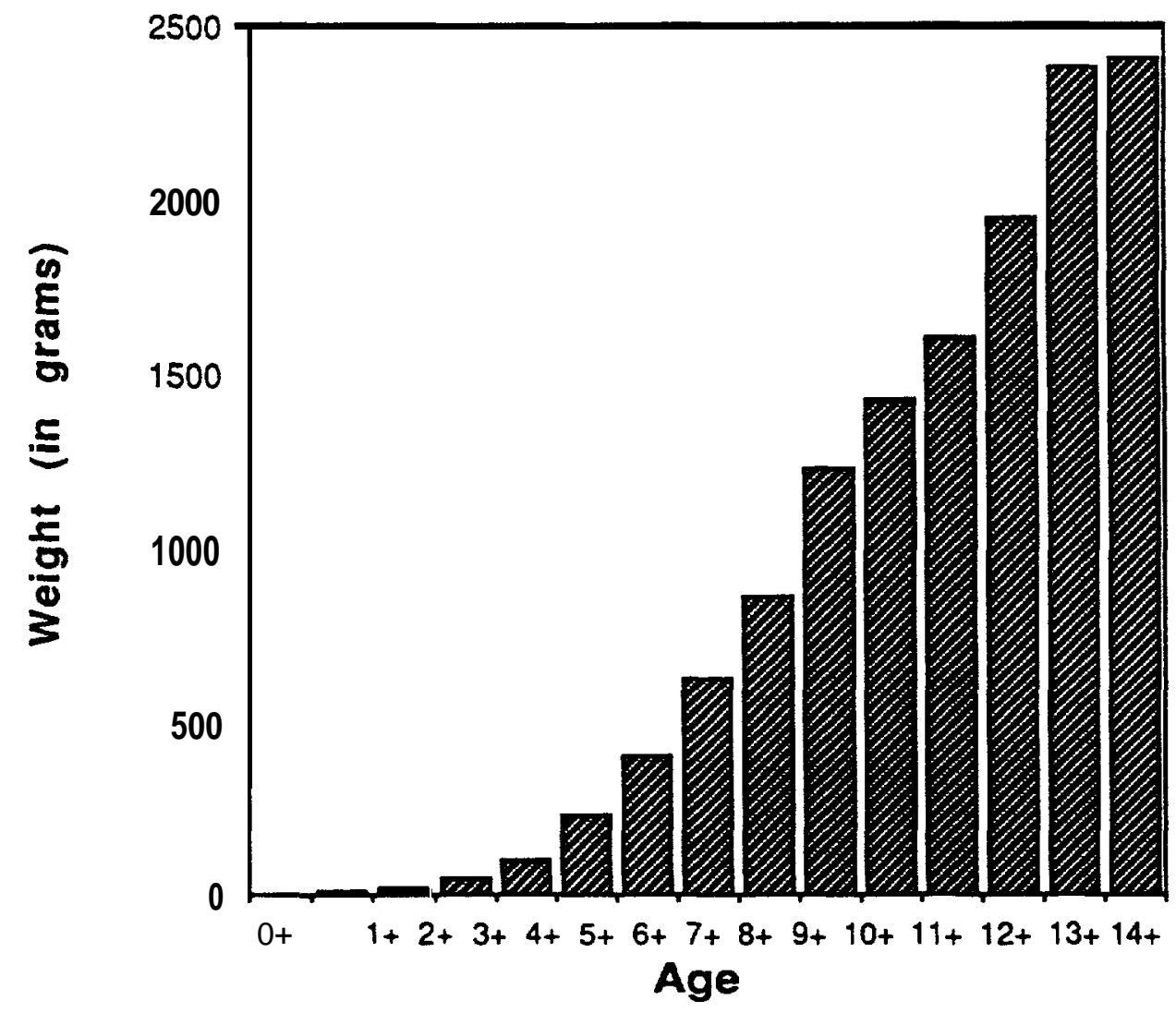

Figure 4.21. Average weight of each age class of largemouth bass collected in the Pend Oreille River during 1988, 1989 and 1990. 
It's felt that the short growing season effects the young-ofthe-year class the most, however; bass that emerge in July have a growing season of only 2-3 months. During a growing season of two months it may be hard or impossible for a young fish to attain a body size that will store up enough energy to survive the winter. Aggus and Elliot (1975) reported that larger age $0+$ bass had a significantly higher survival rate than smaller age $0+$ bass during their first winter. According to Bennett and Bowles (1985), over-winter survival was low in northern Idaho lakes for largemouth bass less than $50 \mathrm{~mm}$ long. Most of the young-of-the-year largemouth bass that were collected in October beach seine hauls and electrofishing surveys during this study were over $50 \mathrm{~mm}$ long. Bennett et al. (1991) reported similar results: the mean length of age $0+$ bass collected from the Pend Oreille River by beach seining and electrofishing in October was $64 \mathrm{~mm}$ in 1989 and $74 \mathrm{~mm}$ in 1990. It appears that even the larger young-of-the-year bass in the Pend Oreille River are not able to survive the winter. Bennett et al. (1991) estimated over-winter survival of $0+$ largemouth bass in the Pend Oreille River ranged from 0.4-3.9\% in 1989 and 1990.

It's suspected that poor over-winter survival of young bass in the Pend Oreille River is partially due to the lack of cover during the winter months. Aquatic macrophytes provide the majority of cover for fish in the river and sloughs. Falter et a/. (1991) estimated that $54.6 \%$ of the river (from Albeni Falls Dam to Box Canyon Dam) supported aquatic macrophyte communities. In the winter, when aquatic macrophytes die back little physical cover remains for fish species. At this time the larger bass may cannibalize smaller bass.

Due to the ineffectiveness of sampling gear it was difficult to collect bass that were age $0_{+}$and therefore it was difficult to determine environmental effects on the survival of that age class. Graphic representation of relative abundance of largemouth bass in each age class indicated age 1+ and 2+ bass did represent a major portion of the population during the study, which reaffirmed our belief that our equipment was unable to effectively sample the smaller, age 0+ fish (Figure 4.22).

The major limiting factor effecting the adult bass is the density of the macrophyte beds in the Pend Oreille River (Figure 4.19). Most of the fish captured during electrofishing surveys throughout the three year study period were associated with weed beds in littoral areas. Radio and sonic tagged bass were frequently 


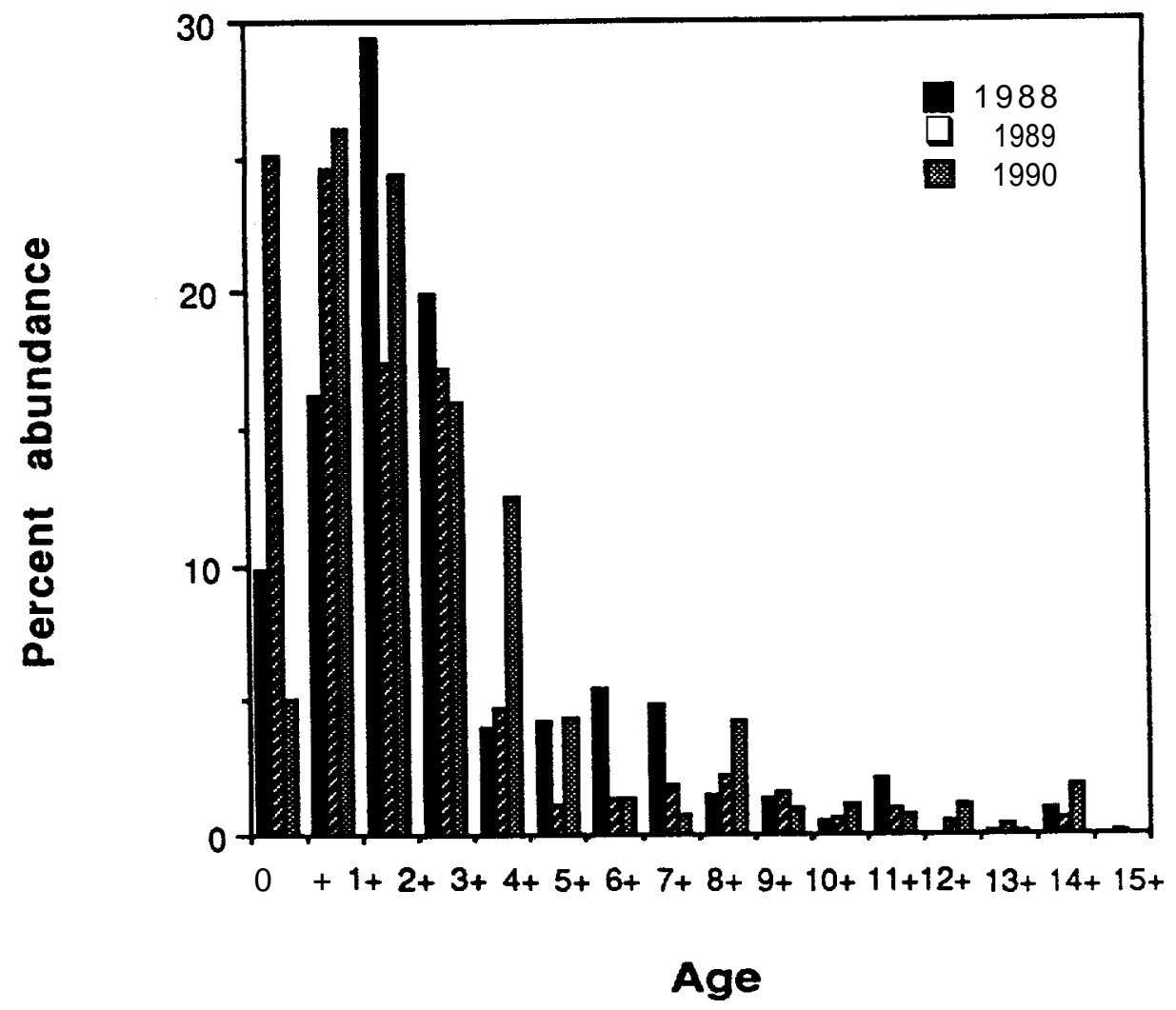

Figure 4.22. Relative abundance of largemouth bass in each age class in the Pend Oreille River during 1988, 1989 and 1990. 
located near the edge of large, dense macrophyte beds. According to Prince and Maughan (1979) prey that are attracted to structure become concentrated in vegetation thereby increasing encounter rates with, and vulnerability to, foragers that also reside there. As macrophytes compose the majority of cover and habitat available in the Pend Oreille River, perch and pumpkinseed are abundant in these dense macrophyte beds. Predation rate is reduced as structural complexity increases (Savino and Stein 1982), therefore these dense beds pose serious feeding obstacles to adult largemouth bass. A decreased predation rate results in an abundance of yellow perch increasing the number of fish that compete with the younger age classes of largemouth bass for food.

All these limiting factors acting together result in a low biomass of largemouth bass in the Pend Oreille River. Despite the limiting factors that exist in the Pend Oreille River quality sized largemouth bass were often captured. In the late spring, when bass concentrate in the sloughs, bass over $500 \mathrm{~mm}$ (20 inches) were common in electrofishing surveys. Largemouth bass captured during the study ranged from $30 \mathrm{~mm}$ to $530 \mathrm{~mm}$ with mean lengths that ranged from $130 \mathrm{~mm}$ to 182 (Table 4.10). Bass captured during tournaments held on the river during 1988, 1989 and 1990 averaged about 2 lbs. (907 g). Maximum weights of bass caught in tournaments were around $6 \mathrm{lbs}$. (2722 g). In June 1991 an $8 \mathrm{lb}$. (3629 $\mathrm{g}$ ) bass was reportedly caught by a bass club member in the Pend Oreille River (Hisata, WDW, pers. comm.)

Of the anglers interviewed (not including bass club members) $19 \%$ (51 of 272) of anglers in 1988 and 32\% (47 of 147) of anglers in 1989 indicated a preference for largemouth bass. The sport catch of largemouth bass nearly tripled in 1989 over 1988 even though the angler pressure went down. An estimated 3,434 \pm 320 bass were caught by anglers in 1988 with a catch-per-unit-effort (CPUE) of 0.83 fish/hour. In 1989, an estimated 9,402 \pm 1169 bass were caught with a CPUE of 3.10 fish/hour. It was estimated that only $11 \%$ of bass caught in 1988 and $1 \%$ of the bass caught in 1989 were harvested. Largemouth bass composed $34 \%$ of the total catch in 1988 and $52 \%$ of the total catch in 1989. The drawdown of the reservoir caused by a malfunction at Box Canyon Dam in 1988 was partly responsible for the lower total catch numbers and reduced CPUE in 1988 since it occurred during the normal peak of bass angling. Nevertheless, the bass fishery on the Pend Oreille River is increasing in popularity. 
The Department of Wildlife received only one application a year for permits to conduct bass tournaments during 1984, 1985 and 1986. Two bass tournaments were held in 1988, five in 1989 and four in 1990. Results from tournaments held on the Pend Oreille River were very good in comparison to tournaments held on other bodies of water in Washington State (Table 4.11 and 4.12). Catchper-unit-effort (CPUE) for the bass in bass tournaments on the Pend Oreille River was second only to the Potholes Reservoir during 1989 and 1990. The Pend Oreille River also had the largest weight of all the water bodies listed for both years (Table 4.11 and 4.12). It appears that the Pend Oreille River has the potential for supporting a popular bass fishery.

Concern has been expressed that bass populations may be negatively impacted by being harvested by anglers. In 1988, the estimated population for largemouth bass was 657,549 with confidence limits of 455,727 and 989,859 and estimated harvest was $389 \pm 40$ for a rate of $0.06 \%$ of the population harvested. In 1989 , the population estimate was 590,906 with confidence limits of 299,193 and 1,390,366 and estimated harvest was $103 \pm 12$ for a rate of $0.02 \%$ of the population harvested. It appears overharvest was not a problem in either year. Most of the bass anglers on the Pend Oreille River practice catch and release fishing.

Current production of largemouth bass in the river was estimated by constructing a population model from data collected during the study (Table 4.13 and 4.14). A model of the population was constructed based on population estimates, relative abundance of each class and estimated mortality rates. Models were constructed from data collected in 1989 and 1990 as a greater number of recaptures were sampled which added reliability to the estimates. The number of fish in each age class was determined both from relative abundance surveys and from calculated mortality rates. Age class size based on relative abundance was calculated by multiplying the percent abundance of an age class by the estimated population. This method more than likely overestimates the abundance of the older age classes of bass as these bigger fish tend to be selectively netted over smaller size fish during electrofishing surveys.

Age class size based on mortality rates were calculated by using the estimated size of the age 1+ fish and subsequently subtracting the fish removed from the population by natural 
Table 4.11. Comparison of results from bass tournaments held in Washington State during 1989. Number of tournaments results are based on are in parentheses. Data summarized from Washington Department of Wildlife 1989 Warmwater Fishing Contests Publication.

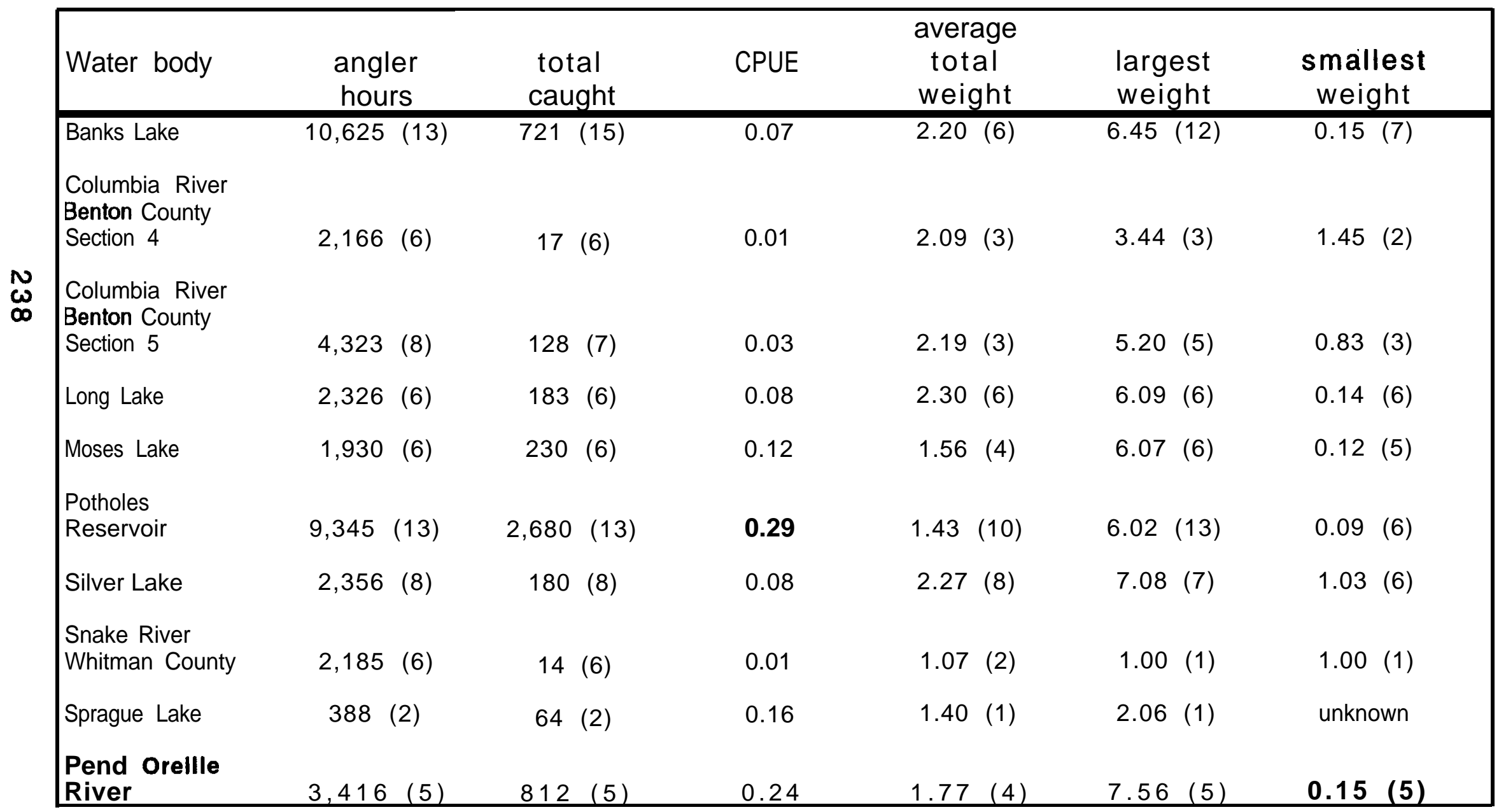


Table 4.12. Comparison of results from bass tournaments held in Washington State during 1990. Number of tournaments results are based on are in parentheses. Data summarized from Washington Department of Wildlife 1990 Warmwater Fishing Contests Publlcatlon.

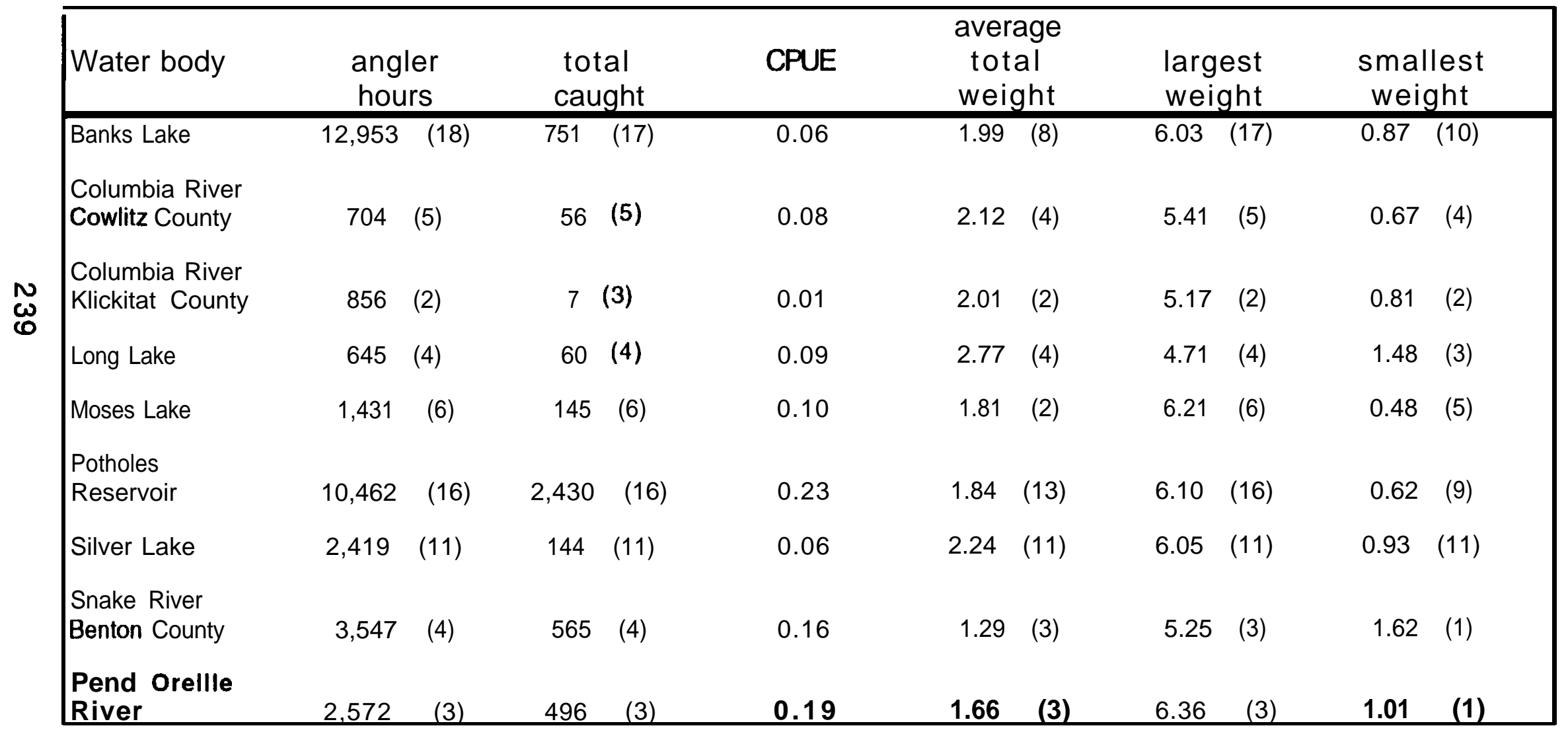


Table 4.13. Population model and estimated largemout $h$ bass biomass in the Pend Oreille River during 1989.

\begin{tabular}{|c|c|c|c|c|}
\hline $\begin{array}{c}\text { Age } \\
\text { class }\end{array}$ & $\begin{array}{c}\text { Age class size } \\
\text { based on } \\
\text { relative abundance }\end{array}$ & $\begin{array}{c}\text { Age class size } \\
\text { based on } \\
\text { mortality rates }\end{array}$ & $\begin{array}{c}\text { Average weight } \\
(\mathbf{k g})\end{array}$ & $\begin{array}{c}\text { Calculated biomass } \\
(\mathbf{k g})\end{array}$ \\
\hline $\mathbf{1 +}$ & 145,363 & 145,363 & 0.007 & 1,018 \\
$\mathbf{2 +}$ & 102,818 & 77,042 & 0.023 & 1,772 \\
$\mathbf{3 +}$ & 101,638 & 40,832 & 0.057 & 2,327 \\
$\mathbf{4 +}$ & 27,773 & 21,641 & 0.108 & 2,337 \\
$\mathbf{5 +}$ & 6,500 & 13,417 & 0.251 & 3,368 \\
$\mathbf{6 +}$ & 7,682 & 8,319 & 0.414 & 3,444 \\
$\mathbf{7 +}$ & 10,636 & 5,158 & 0.578 & 2,981 \\
$\mathbf{8 +}$ & 13,000 & 3,198 & 0.778 & 2,488 \\
$\mathbf{9 +}$ & 9,454 & 1,983 & 1.025 & 2,032 \\
$\mathbf{1 0 +}$ & 3,545 & 1,230 & 1.304 & 1,603 \\
$\mathbf{1} \mathbf{1 +}$ & 5,318 & 763 & 1.438 & 1.097 \\
$\mathbf{1 2 +}$ & 2,954 & 474 & 1.746 & 828 \\
$\mathbf{1 3 +}$ & 2,363 & 294 & 2.065 & 607 \\
\hline TOTAL & \multicolumn{3}{|l}{} \\
\hline
\end{tabular}

Table 4.14. Population model and estimated largemouth bass biomass in the Pend Oreille River during 1990.

\begin{tabular}{|c|c|c|c|c|}
\hline $\begin{array}{c}\text { Age } \\
\text { class }\end{array}$ & $\begin{array}{c}\text { Age class size } \\
\text { based on } \\
\text { elative abundance }\end{array}$ & $\begin{array}{c}\text { Age class size } \\
\text { based on } \\
\text { mortality rates }\end{array}$ & $\begin{array}{c}\text { Average weight } \\
\mathbf{( k g )}\end{array}$ & $\begin{array}{c}\text { Calculated biomass } \\
(\mathbf{k g})\end{array}$ \\
\hline $\mathbf{1 +}$ & 148,225 & 148,225 & 0.007 & 1,038 \\
$\mathbf{2 +}$ & 139,104 & 78,559 & 0.023 & 1,807 \\
$\mathbf{3 +}$ & 91,216 & 41,636 & 0.050 & 2,082 \\
$\mathbf{4 +}$ & 71,262 & 22,067 & 0.086 & 1,898 \\
$\mathbf{5 +}$ & 24,514 & 13,682 & 0.178 & 2,435 \\
$\mathbf{6 +}$ & 7,411 & 8,483 & 0.357 & 3,028 \\
$\mathbf{7 +}$ & 3,991 & 5,260 & 0.803 & 4,224 \\
$\mathbf{8 +}$ & 23,944 & 3,261 & 0.723 & 2,358 \\
$\mathbf{9 +}$ & 5,700 & 2,022 & 1.325 & 2,679 \\
$\mathbf{1 0 +}$ & 6,271 & 1,251 & 1.479 & 1,855 \\
$\mathbf{1 1 +}$ & 3,991 & 777 & 1.760 & 1,368 \\
$\mathbf{1 2 +}$ & 6,271 & 482 & 1.473 & 710 \\
$\mathbf{1 3 +}$ & 570 & 299 & 2.619 & 783 \\
\hline TOTAL & \multicolumn{4}{|l}{} \\
\hline
\end{tabular}


mortality from each age class. Mortality rates were $47 \%$ for age $1+$ to $3+$ and $38 \%$ for age $4+$ to age $13+$ (See Section 3.1.3). These mortality rates were consistent with Bennett et al. (1991) who estimated mortality of bass in the Pend Oreille River, age 5+ to age $12+$, at $37 \%$ in 1989 and $34 \%$ in 1990 . These rates were similar to other reported natural mortality rates in similar water bodies; $36 \%$ in Clear Lake, CA, 34\% in Sutherland Reservoir, CA, 49\% in Folsom Lake, CA and 56\% in Merle Collins Reservoir, CA (Carlander 1977).

Age class size based on mortality rates were used as the model population as it was less biased due to sampling methods. To obtain the biomass for each age class the estimated abundance was multiplied by the average weight for that age class. The biomass of each age class was then added for total largemouth bass biomass production in the Pend Oreille River.

Based on the 7400 acre area of the reservoir (Bennett 1990) production of age $1+$ and older fish was $7.7 \mathrm{lbs} /$ acre $(8.6 \mathrm{~kg} / \mathrm{ha})$ in 1989 and $7.8 \mathrm{lbs} . / \mathrm{acre}(8.7 \mathrm{~kg} / \mathrm{ha})$ in 1990 . Calculated biomass for fish of a harvestable size (245 $\mathrm{mm}$ or 10 inches) was $5.5 \mathrm{lbs} . / a c r e$ $(6.2 \mathrm{~kg} / \mathrm{ha})$ in 1989 and $5.8 \mathrm{lbs} . / \mathrm{acre}(6.5 \mathrm{~kg} / \mathrm{ha})$ in 1990. These values are similar to others reported in the Northwest. Average standing crop for bass > 10 inches in 19 Washington lakes was 5.3 lbs./acre in 1986 and $4.4 \mathrm{lbs} . /$ acre in 1990 (Fletcher, WDW, personal communication). Rieman (1983) reported yield of largemouth bass in Idaho's lateral lakes at $4.5 \mathrm{~kg} / \mathrm{ha}$. According to Doug Fletcher, Warmwater Fisheries Manager, WDW (personal communication) bass biomass typically ranges from 5-20 lbs./acre in Northwest lakes and reservoirs. Reported quality bass producing waters yield about 1520 lbs./acre (Hisata, personal communication).

\subsubsection{PERCH FISHERY}

Based on population estimates and relative abundance surveys yellow perch were the most abundant species in the Box Canyon Reservoir, ranging from $42 \%$ to $45 \%$ of the total fish abundance (Table 4.1). Estimates of yellow perch populations ranged from 6.1 million to 41.8 million during the study but because of technical problems encountered during the year when the perch population estimate was conducted. Due to these problems we believe that the population estimate of 41.8 million is inflated; the estimates between 6 and 8 million are more accurate. 
One of the reasons for an overabundance of yellow perch in the river is low angler interest and harvest. Three of the four hundred and nineteen (0.7\%) anglers interviewed during the study were fishing for perch. Nevertheless catch-per-unit-effort rates were higher for perch than any other species in the river. In 1988 an estimated 4,519 \pm 588 perch were caught for a catch-per-uniteffort (CPUE) of $1.09 \mathrm{fish} /$ hour; in 1989, 6,120 \pm 754 perch were caught for a CPUE of 2.02 fish/hour. Of the perch caught, $28 \%$ were harvested in 1988 and $11 \%$ in 1989.

The main reason for low popularity and harvest rates of perch is their small size. Yellow perch captured during the survey ranged from $24 \mathrm{~mm}$ to $280 \mathrm{~mm}$ with an overall average length of between $149 \mathrm{~mm}$ and $151 \mathrm{~mm}$ (Table 4.15). Although yellow perch in the Pend Oreille River start out at about the same size as perch from similar systems, growth rates of Pend Oreille perch were much lower at every annulus (Figure 4.23). It's evident that the perch population in the reservoir is stunted.

The microhabitat of the Pend Oreille River appears optimal for yellow perch. Perch are frequently associated with littoral areas where moderate amounts of vegetation are present (Krieger et al. 1983). The majority of habitat available in the Pend Oreille River fits this description. Preferred temperatures of adult perch during the growing season are between $18^{\circ} \mathrm{C}$ and $25^{\circ} \mathrm{C}$ (McCauley and Read 1973) with optimum temperatures between $19^{\circ} \mathrm{C}$ and $24^{\circ} \mathrm{C}$ (Scott and Crossman 1973). In order to ensure proper maturation of gonads yellow perch must be exposed to temperatures of $4^{\circ} \mathrm{C}$ to $10^{\circ} \mathrm{C}$ over the winter. Temperatures in the Pend Oreille River during the growing season and over-winter appear to be optimal for these requirements.

It's believed that intra and maybe interspecific competition is responsible for the stunted growth rates. Daphnidae and Chydoridae are the major prey items for all age classes of perch, although they do rely on Chironomidae larvae and pupae as well. Diet overlaps between all age classes of perch and with largemouth bass, black crappie and mountain whitefish were high. Due to the relatively small population of predatory largemouth bass in the river, the perch population is extremely large. Because the perch population is so large and the densities of zooplankton are so low, food availability is probably limited. 
Table 4.15. Mean annual ranges and average lengths of yellow perch captured in the Pend Oreille River during 1988, 1989 and 1990.

\begin{tabular}{|c|c|c|c|c|c|c|}
\cline { 2 - 7 } \multicolumn{1}{c|}{} & \multicolumn{2}{c|}{1988} & \multicolumn{2}{c|}{1989} & \multicolumn{2}{c|}{1990} \\
\hline SPECIES & $\begin{array}{c}\text { RANGE } \\
(\mathrm{mm})\end{array}$ & $\begin{array}{c}\text { MEAN } \\
(\mathrm{mm})\end{array}$ & $\begin{array}{c}\text { RANGE } \\
(\mathrm{mm})\end{array}$ & $\begin{array}{l}\text { EAN RANGE } \\
(\mathrm{mm})\end{array}$ & $\begin{array}{c}\text { MEAN } \\
(\mathrm{mm})\end{array}$ \\
\hline Yellow perch & $60-196$ & 149 & $31-280$ & 149 & $24-245$ & 151 \\
\hline
\end{tabular}




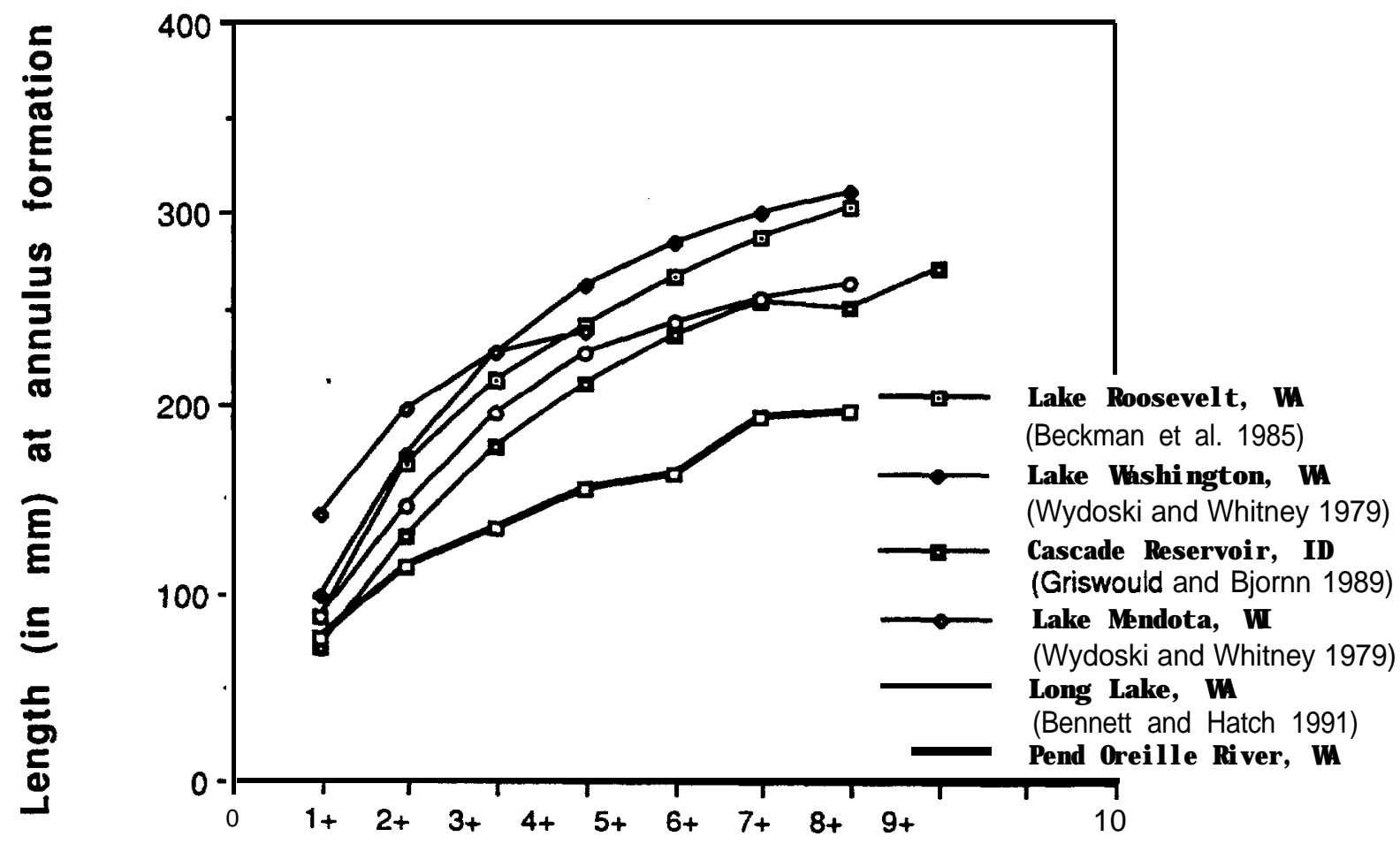

Figure 4.23. Comparison of mean back-calculated lengths at annulus formation for yellow perch in the Pend Oreille River with other similar water bodies in the region. 
Perch are so abundant in the Pend Oreille River that a perch aquaculture facility was proposed in 1986 (Geist and Scholz 1987). Geist proposed collecting adult perch from the river during- spawning season and artificially spawning these fish in an aquaculture facility. The parent stock would then be returned to the river and their offspring raised to a marketable size in the aquaculture facility. Due to the extremely high demand for aquacultured yellow perch in the United States this would be an excellent and lucrative project. This project also has the potential to enhance the perch population in the river. A reduction in perch production in the river should decrease intraspecific competition which would increase the growth rates and the quality of the perch fishery. An increase in the size of the perch produced should also increase fecundity, therefore the perch aquaculture facility would not be depleting the perch population in the river. If this project was well managed it could benefit both the local economy and the fishery.

\subsubsection{CRAPPIE FISHERY}

Black crappie were one of the least abundant species in the reservoir, ranging from $1.3 \%$ to $1.6 \%$ of the total fish abundance during the survey (Table 4.1). The estimated population of black crappie in 1988 was 579,588 . Due to low numbers of recaptures in 1989 and 1990 no other estimates were made.

Growth rates of crappie in the reservoir were low in comparison to growth rates from other bodies of water (Figure 4.24). Crappie of all ages relied mainly on Daphnidae and Chydoridae for a food source, although Chironomidae larvae and pupae and copepods were also common prey items. Since these were also common prey items for other fish species in the reservoir, diet overlaps between black crappie and other species were high. Competition for food resources, along with suboptimal water temperatures for growth, is suspected to be responsible for the low growth rates.

Black crappie captured during the survey ranged from $32 \mathrm{~mm}$ to $267 \mathrm{~mm}$ with average lengths of $169 \mathrm{~mm}$ in 1988, $142 \mathrm{~mm}$ in 1989 and $127 \mathrm{~mm}$ in 1990 (Table 4.16).

Despite their small physical size and low population, approximately $3 \%$ of the anglers interviewed during the study were fishing for black crappie. An estimated $69 \pm 8$ crappie $(0.7 \%$ of the total fish catch) were caught in 1988 and $719 \pm 89(4.0 \%$ of the total 


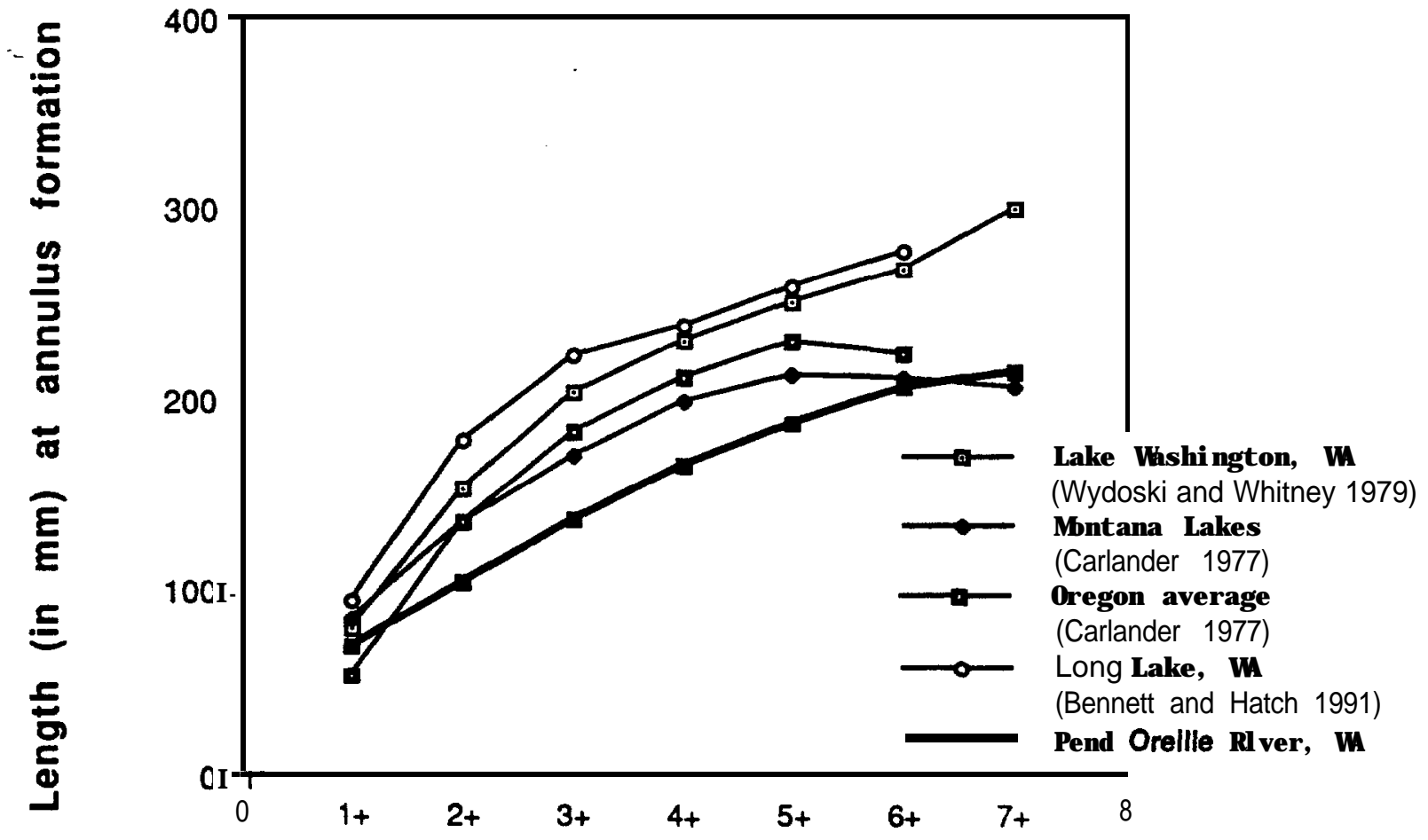

Figure 4.24. Comparison of mean back-calculated lengths at annulus formation for black crappie in the Pend Oreille River with other similar water bodies in the region. 
Table 4.16. Mean annual ranges and average lengths of black crappie captured in the Pend Oreille River during 1988, 1989 and 1990.

\begin{tabular}{|c|c|c|c|c|c|c|}
\cline { 2 - 7 } \multicolumn{1}{c|}{} & \multicolumn{2}{c|}{1988} & \multicolumn{2}{c|}{1989} & \multicolumn{2}{c|}{1990} \\
\hline SPECIES & $\begin{array}{c}\text { RANGE } \\
(\mathrm{mm})\end{array}$ & $\begin{array}{c}\text { MEAN } \\
(\mathrm{mm})\end{array}$ & $\begin{array}{c}\text { RANGE } \\
(\mathrm{mm})\end{array}$ & $\begin{array}{c}\text { MEAN } \\
(\mathrm{mm})\end{array}$ & $\begin{array}{c}\text { RANGE } \\
(\mathrm{mm})\end{array}$ & $\begin{array}{c}\text { MEAN } \\
(\mathrm{mm})\end{array}$ \\
\hline Black crappie & $47-267$ & 169 & $41-238$ & 142 & $32-223$ & 127 \\
\hline
\end{tabular}


fish catch) in 1989. It's likely that a number of these species were flushed from the reservoir during the drawdown of 1988, which may help to account for the much lower catch rate during the same year.

\subsubsection{POTENTIAL FOR INTRODUCED SPECIES FISHERY}

Due to the abundance of yellow perch in the Pend Oreille River the possibility of introducing a large predatory fish has been suggested (Bennett et al. 1991).

The Washington Department of Wildlife attempted to accomplish this in the early 1980's. They planted a total of 753,000 walleye (Stizostedion vitreum vitreum [Mitchill]) fry in the reservoir in 1983 and 1984; and 148 adult walleye (tagged with floy tags) in 1987. Several anglers reported catching walleye during this study, however, no confirmed sighting was made. Of the total 52,553 fish captured and examined during the three year investigation, not one walleye was identified. The same results were reported by Bennett et al. (1990) who found no walleye after examining 15,887 fish from the Pend Oreille River.

According to Bennett and McArthur's (1990) prediction model the variables area, maximum depth, and $\mathrm{pH}$ were found to be significantly related to walleye success in lakes. The area and $\mathrm{pH}$ for successful lakes and reservoirs are similar to values from the Pend Oreille River, however, the maximum depth for successful introductions was much greater than maximum depths in the Pend Oreille.

Walleye have a special reflecting layer in their eye called a tapetum lucidium. The tapetal layer functions to increase visual sensitivity of retinal pigments by shining most of the transmitted light back through the retina (Moyle and Cech 1988). This type of arrangement is beneficial to deep water fish as it takes advantage of all available light to increase vision. It is speculated that the tapetum lucidium is responsible for the lack of a successful introduction of walleye into the Pend Oreille River. The Pend Oreille River is a very shallow reservoir, the greatest depth being approximately 40 feet. During the night hours this is not a problem for walleye as they move to shallow waters to feed. However, during the daylight hours they seek deeper water to avoid the bright daylight (Wydoski and Whitney 1979). In the Pend Oreiile River this is not possible. It is believed that the walleye planted in the 1980's left the system soon after their release. 
Bennett et a/. (1990) recommended the introduction of a large predator species to take advantage of the extensive forage base that exists in the Pend Oreille River. Bennett suggested that northern pike or tiger muskies would be suitable introduction species as they are a cool water species which forage in and around dense vegetation. Skillingstad (1992) reported that the temperature profile, depth profile and macrophyte composition that exists in the Pend Oreille River appeared ideal for northern pike, although the reservoir elevation fluctuation that occurs during pike spawning season could limit spawning success.

Although the Box Canyon Reservoir appears to have ideal habitat for cool/warm water piscivorous fish species, proposed introduction of other exotic species (i.e. northern pike and tiger muskies) to the reservoir has met with strong opposition. The British Columbia Ministry of Environment expressed serious concern over the introduction of northern pike into the reservoir, stating, "In our opinion it is highly likely that these fish will move downstream past the Box and Boundary dams into B.C. waters. From the Seven Mile Reservoir in B.C. (which has good pike habitat) they will likely move downstream and eventually end up in the Columbia River. The Columbia River is a major sport fishery in both B.C. and Washington State. There are currently no pike in the Columbia River drainage in B.C. and we want to ensure this situation does not change." (Hammond 1990, Appendix N).

The Kalispel Indian Tribe and the Washington Department of Wildlife have also expressed strong opposition to the introduction of another exotic fish species in the Box Canyon Reservoir.

Bennett et al.'s recommendation appears to be based on the assumption that introduced exotics will not emigrate from the system. Although movement of northern pike in large rivers are not well documented, studies done in lakes and small streams have shown that pike can display high mobility (Miller 1948, Ross and Winter 1981). Pike tracked in the Yampa River, Utah traveled $>75 \mathrm{~km}$ in one year (Tyus and Beard 1990). Based on these data there is a distinct possibility that northern pike stocked in the Pend Oreille River would migrate into the Columbia River. Because pike are such voracious piscivores they could pose a serious threat to the already endangered salmon species. 
Even if the introduced pike did not migrate from the system it is possible that they may not produce the desired reduction of the yellow perch population in the Pend Oreille River. Casselman (1978) observed yellow perch to be the major prey species for northern pike in Wickett Lake, but yellow perch were the only prey species available. According to Rodger (1991) northern pike are indiscriminate in their feeding habits, eating large numbers of trout and bass. Inskip (1982) reported that food preference for pike includes the soft-rayed, cylindrical fishes which are apparently more easily swallowed as compared to the spiny and/or laterally compressed fish species. Based on this information introducing northern pike into the Box Canyon Reservoir could seriously impact the already limited trout population as well as mountain whitefish and largemouth bass.

Tiger muskies (muskellunge) have also been considered for introduction as a prelude to northern pike to determine how another piscivorous fish species in the Pend Oreille River would fare (Bennett, public meeting). Muskies are considered sterile and therefore a "safer" species for introduction into a system. Gammon and Hasler (1965) reported on a muskellunge introduction into several lakes in Wisconsin which supported small numbers of normally growing bass and large populations of stunted perch. During the five years following the introduction of muskellunge the both the perch and bass virtually disappeared.

Introductions of exotic species to the Pend Oreille River are not advisable at this time as they would add a new component to the Box Canyon ecosystem, which could potentially destabilize the fish community relationships that we observed and documented. A change in the fish community of this nature would thus reduce our understanding of the system. We emphatically recommend NO introductions of new species at this time.

\subsubsection{NON-TARGET SPECIES FISHERY}

Pumpkinseed, tench, northern squawfish, peamouth, brown bullhead, longnose sucker and largescale sucker are also present in the Pend Oreille River. Some of these non-target species represent a major portion of the fish population in the river (Table 4.1).

Relative abundance of pumpkinseed in the reservoir ranged from 10 to 19 percent during the three year study. Population 
estimates for pumpkinseed were 3.8 million, in 1989 and 4.4 million in 1990. In 1988 the population was estimated at 16.8 million, however, this estimate was felt to be inflated. Pumpkinseed were not a target species for anglers interviewed during the survey, but incidental catches were estimated at $757 \pm 94$ in 1988 and $718 \pm 88$ in 1989. Reportedly the harvest rate of fish caught was $37 \%$ and $25 \%$, respectively.

Pumpkinseed preyed mainly on Chironomidae (midge) larvae and Daphnidae. As a result they had high overlaps with yellow perch and mountain whitefish and moderate overlap with black crappie. Diet overlaps between mountain whitefish and pumpkinseed were not a concern because geographical overlap of these species was minimal. Overlap with crappie and perch, however, was probably partly responsible for the low growth rates and small sizes of all three species. The major role of pumpkinseed in the Pend Oreille River is as an important prey item for largemouth bass.

Tench composed between 8 and 11 percent of the total fish captured during the three year study. Estimated population of tench was 4.2 million in 1988, 1.1 million in 1989 and 1.0 million in 1990. The main prey items for tench during the survey -were Chironomidae (midge) larvae and Chydoridae. Tench had high overlaps with pumpkinseed and brown bullhead and moderate overlaps with yellow perch, mountain whitefish and black crappie.

Northern squawfish ranged from 3 to 5 percent of the relative abundance of fish during the three year study. The population of squawfish was estimated at 580,565 in 1988, 590,906 in 1989 and 570,098 in 1990 . During the study squawfish were omnivorous, feeding mainly on Chironomidae larvae, Nematoda, terrestrials and Osteichthyes. The fish that were identified in squawfish stomachs were mainly yellow perch, although tench were identified in several stomachs. Adult largemouth bass also rely mainly on yellow perch for a food item. Due to the overabundance of perch in the river competition for food between the two species is not a problem. Diet overlaps between northern squawfish and all other fish species in the reservoir were low.

Relative abundance of peamouth in the Pend Oreille River ranged from 0.4 to 1.2 percent. Population estimates were not possible in 1988 and 1989 due to insufficient recaptures. One peamouth was recaptured in 1990 which yielded an estimate of 91,000 fish. According to diet analysis peamouth preyed mainly on 
Talitridae (water scuds), Ceratopogonidae (midges) and Nematoda (nematodes). Overlaps were moderate with pumpkinseed and tench.

Brown bullhead composed between 1.2 and 1.9 percent of the relative abundance during the survey. Population estimates of this species were 36,200 in 1989 and 75,556 in 1990. However, these estimates were based on only one recapture during both years, so the accuracy is suspect. According to creel surveys $549 \pm 77$ bullhead were captured by anglers in 1988 of which $57 \%$ were harvested. Creel surveys indicated that no bullhead were caught by anglers in 1989.

Chironomidae (midge) larvae was one of the most important prey items in the brown bullhead diet. As a result bullhead had high diet overlaps with yellow perch and pumpkinseed and moderate overlap with black crappie.

Largescale sucker was the most abundant member of the Catostomidae family found in the Pend Oreille River ranging from 4.5 to 5.9 percent during the study. Population estimates for largescale sucker were 821,863 in 1988, 186,693 in 1989 and 194,551 in 1990. Longnose sucker composed from 3.0 to 3.6 percent of the relative abundance. Population estimates for longnose sucker were 781,166 in 1988, 183,457 in 1989 and 218,743 in 1990. Both Chironomidae (midge) larvae and Ostracoda (seed shrimp) were important prey items for both families of sucker in the Pend Oreille River. Largescale sucker had high diet overlaps with yellow perch, mountain whitefish, black crappie, pumpkinseed, brown bullhead and tench. Longnose sucker had high diet overlaps with pumpkinseed, tench, and largescale sucker.

\subsection{EURASIAN WATERMILFOIL}

The Pend Oreille River currently has a serious infestation of Eurasian watermilfoil (Myriophyllum spicatum). In 1982, Eurasian watermilfoil covered approximately 200 acres of the Pend Oreille River By 1988, it was the dominant macrophyte in 956 acres with patchier distribution in an additional 1,507 acres (Wilson 1989). The Pend Oreille River was added to the Aquatic Plant Management Program (APMP) in 1982.

The first control method applied to the watermilfoil was 2,4D (Wilson 1989). In 1986, the use of 2,4-D was banned by the US. Environmental Protection Agency (EPA) and the county decided to try 
rotovation or mechanical bottom tillage. Studies done on the effectiveness of rotovation of the watermilfoil indicate that rotovation was successful at reducing milfoil density, height and root biomass in test plots (POCPD 1990). From these reports it appears that rotovation is effective at removing milfoil from the river. However, rotovation is not very milfoil specific and it also creates plant fragments; any branch tip has the potential to regenerate roots to create a new viable plant (POCPD 1990). In 1990 the downstream boundary of the milfoil in the river was reported to be as far north as Metaline.

Milfoil beds can generate naturally through vegetative fragmentation with the help of wind and wave action as well as auto-fragmentation. However, it's possible that rotovation is accelerating the spread of milfoil in the Pend Oreille River system. Since the beginning of this study in 1987 and the completion in 1990 it was noticed that milfoil weed beds were denser and more abundant throughout the river. In some areas during late summer to mid-autumn it was impossible to operate sampling equipment (boats, beach seines, etc.) due to the dense growths.

The dense weedbeds of Eurasian watermilfoil in the reservoir have the potential to cause problems for the fishery. The general structure of an Eurasian milfoil weedbed consists of a solid mat of leafy fronds in approximately the top meter of the water column. The substrate underneath the mat is usually devoid of vegetation except for a few stems rooting the milfoil to the substrate (Falter et al. 1991). Once established, Eurasian milfoil overwhelms the native Pend Oreille River species (which utilize the entire water column) by creating a canopy and cutting off the incident light penetrating the water column. Native plant species that cannot grow to the surface of the weedbed mat are eliminated.

Fifty-five percent of the area from Albeni Falls Dam to Box Canyon Dam was estimated to support aquatic macrophyte communities (Falter et al. 1991). Eurasian milfoil accounted for $34.4 \%$ and $28.1 \%$ of the macrophyte community in the littoral area in 1989 and 1990, respectively (Falter et al. 1991). In sloughs sampled, Eurasian milfoil composed from $40.0 \%$ to $96.6 \%$ of the macrophyte community (Falter et al. 1991).

Eurasian milfoil is not only a threat to the species diversity of macrophytes in the Pend Oreille River but also to the fish habitat. Currently dense watermilfoil beds clog the sloughs and littoral 
areas of the river. If these beds become dense enough they reduce the amount of rearing habitat available by limiting access, increasing water temperatures and decreasing water quality. As macrophytes compose the majority of cover and habitat available in the Pend Oreille River, perch and pumpkinseed are abundant in these dense macrophyte beds. Predation rate is reduced as structural complexity increases (Savino and Stein 1982), therefore these dense beds also pose serious feeding obstacles to adult largemouth bass. 


\subsection{BIOLOGICAL OBJECTIVES AND RECOMMENDATIONS FOR MANAGEMENT OF PEND OREILLE RIVER FISHERY}

Based on the results from the three year study of the Pend Oreille River, there are various factors that limit the productivity of the fishery. The majority of these factors are the uncontrollable physical features of the reservoir and tributaries, climatic conditions and a poor nutrient watershed. However it is felt that proper fishery, habitat and reservoir management techniques could be used to enhance the fishery in the river and tributaries. Taking into account the available fish populations, existing habitat conditions and existing limiting factors, we developed several biological objectives for the Pend Oreille River fishery.

\subsubsection{OBJECTIVE 1: NATIVE TROUT SPECIES}

Our first biological objective is to restore the native species of cutthroat and bull trout in the Box Canyon reach of the Pend Oreille River. Very few trout of any species were captured in the river during this study and the trout species currently most abundant in the tributaries to the reservoir are brook trout and brown trout. Cutthroat trout and bull trout were historically reported to be prominent species in the system. Gilbert and Evermann (1894) commented on the Pend Oreille River fishery after their survey in 1893 and 1894, "trout are abundant in this river; salmon trout [bull trout (Gilbert and Evermann 1894)] are also quite abundant, and both bite readily. We know of no stream which offers finer opportunities for sport with the rod than the lower Pend Oreille." Even as late as 1957 the native trout species supported a fine fishery. The April 3, 1957 issue of the Metaline Falls Gazette reported that a $15 \mathrm{lb} 8 \mathrm{oz}$ rainbow was caught in Pend Oreille River during a 1957 Field and Stream tournament. Also caught in the tournament were a $13 \mathrm{lb} 9 \mathrm{oz}$ rainbow, $9 \mathrm{lb} 8 \mathrm{oz}$ rainbow, $6 \mathrm{lb} 8 \mathrm{oz}$ rainbow and many large Dolly Varden [i.e., bull trout].

Based on results of this baseline study, the native cutthroat and bull trout that historically supported a fine fishery currently exist only as remnant populations in a few of the tributaries. The existing cutthroat population is very small and the bull trout population almost non-existent. Westslope cutthroat trout are a species of special concern in Montana, Idaho and Washington (Johnson 1983). Bull trout are currently listed as a sensitive species in Washington State and have the potential to be listed as 
endangered. The decline of these native trout species is a cause of great concern to the Kalispel Indian Tribe, who historically subsisted on these species.

It may be difficult to reestablish native trout populations in the Box Canyon Reservoir due to the warm water temperatures and lack of habitat diversity, resulting from the construction of Box Canyon Dam. However, surveys of the tributaries to the Pend Oreille River indicated that existing habitat appears to be adequate to support bull trout and cutthroat trout.

Production of trout species of the five major tributaries was estimated to obtain a rough idea of production potential and stocking rates (Table 4.17). These figures were obtained from population estimates conducted in four reaches, which were expanded for segments of each stream.

Current production of trout in west branch of LeClerc Creek was estimated at 1,407 brook trout, 739 brown trout, 16 rainbow trout and 131 cutthroat trout. Native species production was approximately $5.7 \%$ of total trout production in the stream. Production in Ruby Creek was estimated to be 4,080 brook trout and 28 cutthroat trout. Production of native species was approximately $0.7 \%$. Production in Cee Cee Ah Creek was estimated at 4,196 brown trout, 1,861 brook trout and 645 cutthroat trout. Native species production was approximately $9.6 \%$ of total trout production in the stream. Production of trout in Tacoma Creek was estimated at 7,153 brook trout and 1,383 cutthroat trout. Native species production was approximately $16.2 \%$ of the total. Current production of trout species in north fork of Skookum Creek was 10,170 brook trout, 6,619 brown trout and 1,235 cutthroat trout. Native species composed approximately $6.9 \%$ of total production.

\subsubsection{RECOMMENDATIONS TO ENHANCE THE NATIVE TROUT SPECIES}

In order to successfully accomplish our biological objective we have set three major goals for the native trout species: 1) Protect the existing stocks of native trout species in the Pend Oreille River and its tributaries, 2) Expand the populations of native trout species to levels above endangerment of extinction; and 3) Reestablish self-sustaining populations of native trout species in the tributaries. The long term aim of these goals is that the native trout species will be reestablished and managed so that they will 
Table 4.17. Estimated production of trout species captured In the study tributaries to the Pend Orellle River.

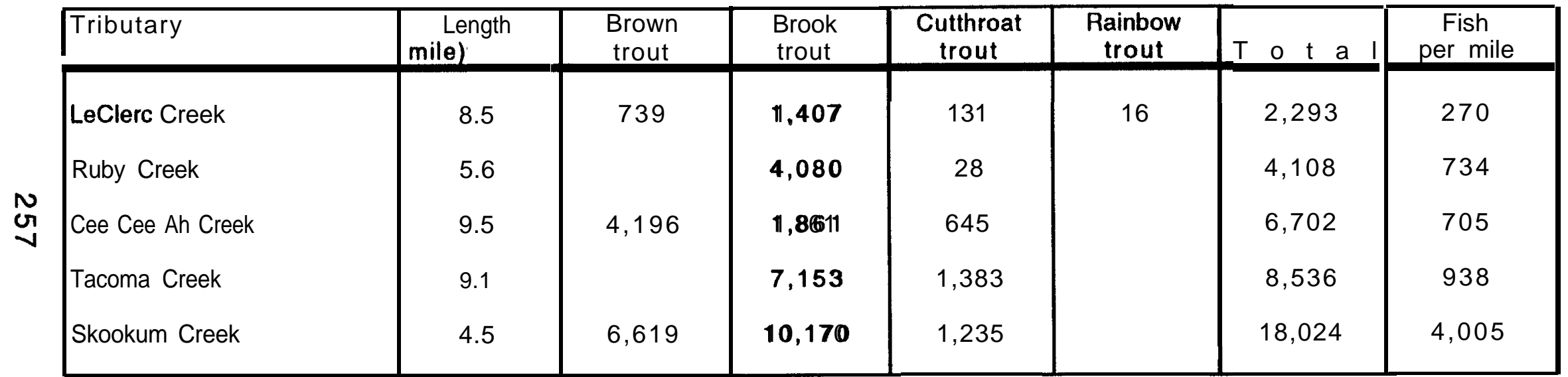

Note: Calculations were based on populations estimates conducted in 1989. For some species, such as rainbow trout, cutthroa trout and bull trout there were insufficient recaptures to allow an estimate. 
support a sport and subsistence fishery in the future. To accomplish these goals, we suggest changes in current management, several enhancement projects and additional biological investigation.

\subsubsection{PROTECT EXISTING NATIVE TROUT STOCKS}

During our three year baseline investigation only four bull trout were captured in the river and one in the tributaries. However, Barber et al. (1990) reported that anglers captured and harvested $181 \pm 23$ bull trout during the 1989 creel survey. Based on the creel information it appears that our sampling gear was ineffective at capturing bull trout in the river. It's thought that the difference between fish surveys and creel surveys is due to sampling effort. Electrofishing surveys were done on a random basis throughout the river. Most bull trout harvested by anglers were thought to be captured at or near spawning sites or during spawning migrations, and therefore were not randomly sampled. No reproducing populations were located in the reaches of the five tributaries we investigated. Based on these data it's obvious that the trout species native to this system is in serious danger of becoming extinct. For this reason it is recommended:

- Consideration be given to petition the U.S. Fish and Wildlife Service to list bull trout in the Box Canyon reach of the Pend Oreille River as a federally endangered species under the Endangered Species Act (ESA).

At the present time we do not know if the bull trout in the Pend Oreille River drainage are a genetically distinct stock, which is a criteria for the ESA. However, populations of this species throughout its range are so depleted that the entire assemblage may be listed, so proving genetic discreteness may not be necessary. Bull trout from the Box Canyon Reservoir of the Pend Oreille River drainage should be given high priority for enhancement as this river reach historically supported one of the largest populations of bull trout in the Columbia River System (Gilbert and Evermann 1894).

In order to protect the existing stocks of cutthroat trout and bull trout currently in the tributaries it is recommended that changes be made in the current management, including:

- Complete closure of fishing season for cutthroat trout and bull trout in the Pend Oreille River and tributaries. The Department of Wildlife imposed a statewide closure of bull trout harvest 
in 1992 which we fully support. We recommend that this also be done for cutthroat trout in the Box Canyon Reservoir drainage.

- Discontinuation of brook trout stocking (which compete with the native species) by the Department of Wildlife in tributaries to the Pend Oreille River identified for native species enhancement.

It is well documented that brook trout outcompete cutthroat trout for food and space (Griffith 1972). It has also been reported that brook trout will hybridize with bull trout (Hisata, pers. comm.). Each tributary that was surveyed during this study supported reproducing populations of brook trout, which is largely a result of annual stockings by the Department of Wildlife since the 1940's.

\subsubsection{NATIVE TROUT POPULATION EXPANSION}

Even with the protection measures listed above, the current population of native trout in the Pend Oreille River system will probably not be sufficient for rapid repopulation of the tributaries to carrying capacity. Current population levels of cutthroat and bull trout are so low that it would likely take several decades to rebuild these populations solely by natural reproduction. Consequently it will be necessary to supplement native populations, especially bull trout, to accomplish our second goal of population expansion. For this reason it is recommended that:

- Bonneville Power Administration (BPA) fund design, construction, operation and maintenance of a low capital hatching facility for native trout species, on the Kalispel Indian Reservation (cold water section of warm/cold water hatchery). Hatchery design should incorporate ideas from BPA's compendium of low-cost production facilities (Senn et al. 1984).

Eggs would be collected from fish in each tributary, hatched and reared in separate incubators and raceways, then seeded back into the tributary their parents were collected from to maintain genetic integrity of native trout populations in each tributary. Building a small, low capital hatching facility would be the most feasible way to accommodate these recommendations. 
Projected production goals are 20,000 each, bull trout and cutthroat fry, 2,000 each bull trout and cutthroat fingerlings and 500 each bull trout and cutthroat trout juveniles. Based on production estimates (Table 4.17) of the major tributaries to the Pend Oreille River this number of fish should be adequate to begin rebuilding populations but should not overstock the tributaries and tax food and habitat availability.

The proposed hatchery would be for native species only. Brown trout would not be included in the hatchery supplementation plan as they are an exotic species to the Pend Oreille River.

Although it is not currently known if trout production is limited in the hatching or rearing stage of the life cycle we feel seeding the tributaries with native trout is the approach best suited to determine at which life stage trout production is limited in the Box Canyon Reach of the Pend Oreille River. This approach has the advantage of increasing recruitment of these threatened fish while providing a tool to work with to determine what is limiting their natural production. Thus, this recommendation is consistent with the Adaptive Management Policy in the Northwest Power Planning Council's 1987 Fish and Wildlife Program. Ideally a study to determine limiting factors would be conducted first. However, during the time a long and expensive study was completed the already low populations of these species may continue to decline to the point of extinction.

\subsubsection{REESTABLISH SELF-SUSTAINING NATIVE TROUT POPULATIONS}

The recommended hatching facility for native trout is only a short term plan to aid in reestablishing the declining species. Our long term goal is for the tributaries to the Pend Oreille River to support self-sustaining populations of native trout species. In order to accomplish this, it will be necessary to conduct some habitat enhancement measures and some additional fisheries investigations.

Several sites on the tributaries supporting native trout species were identified during the course of the three year study as requiring habitat improvements. Portions of the tributaries we surveyed were damaged and degraded by land use practices, such as logging and grazing. Fish passage was blocked in some cases by beaver dams and large organic debris jams. In order for the native 
species to effectively utilize these tributaries for spawning and rearing we recommend the following:

- Habitat enhancement be conducted on three demonstration tributaries (LeClerc, Cee Cee Ah and Skookum Creeks) at necessary sites to improve and reclaim fisheries habitat. This recommendation is an essential part of increasing bull trout and cutthroat trout populations in Pend Oreille River tributaries. Habitat improvements should include:

1) riparian zone restoration (fencing overgrazed areas, stream bank stabilization and planting vegetation),

2) instream habitat improvements (sediment traps to increase spawning habitat by reducing sedimentation and embeddedness, and log wiers to improve riffle to pool ratio and instream cover); and

3) passage improvements (removal or laddering of large debris jams or beaver dams that totally block migration of adfluvial trout species.

Habitat enhancement measures should be performed initially on the three tributaries as demonstration projects to determine effectiveness of enhancing the native species, before further habitat improvements are accomplished on additional tributaries. Changes in the fish and benthic communities should be monitored to determine effect of the recommended improvements on the stream ecosystem. We recommend that three of the five tributaries we studied should be selected for habitat enhancment demonstration projects; LeClerc Creek, Cee Cee Ah Creek and Skookum Creek.

LeClerc Creek is one of the largest tributaries to the Pend Oreille River and the location where the majority of bull trout were captured during this study. It also appeared to be one of least impacted streams that we surveyed. The major impacts observed in the LeClerc Creek drainage were due to logging practices. Habitat improvements should include: 1) Formation of pools in the lower section of the stream to improve the pool:riffle ratio, 2) Installation of sediment traps in the upper section of the stream, 3) Fish passage improvements by removing or laddering large beaver dams; and 4) Clean up of several unauthorized dumping sites along the creek. 
Cee Cee Ah Creek is also a large tributary to the Pend Oreille River, the mouth of the creek is located on the northern end of the Kalispel Indian Reservation. The Kalispel Tribe of Indians and the Bureau of Indian Affairs contracted a hydrogeologist at Eastern Washington University to investigate and map the hydrogeology of Cee Cee Ah Creek. Buchanan et a/. (1990) reported that Cee Cee Ah Creek has been significantly affected by the cutting of timber in the drainage, especially in the upper reaches of the creek where a clear cut has devastated the riparian zone. To mitigate the affects caused by timber harvest on the main channel of Cee Cee Ah Creek Buchanan et a/. (1990) recommended that riparian zones be established/ reconstructed on all tributaries to the creek, flowing or not, to as small as first order streams. Buchanan et. a/ also recommended the riparian zone along the upper reach of the main stem be entirely reconstructed so as to limit sediment loading to the stream and also to provide shade canopy. To improve fish habitat in the main stem of the stream Buchanan et a/. (1990) recommended selective removal of large organic debris. During our surveys of this tributary large debris jams and huge beaver dams were documented as totally blocking fish passage is some areas.

We concur with recommendations suggested by Buchanan et al. (1990) believing these type of improvements would enhance the trout populations in Cee Cee Ah Creek. Specifically, habitat improvements should include: 1) Riparian zone restoration and stream bank stabilization in the upper section of the stream by planting grass, shrubs, deciduous and coniferous trees to stabilize disturbed areas and provide long term sources of woody debris and bank cover, 2) Riparian zone restoration (as described above) in the smaller tributaries to Cee Cee Ah Creek, flowing or not, to as small as first order streams, 3) Construction of sediment traps in locations immediately downstream from mass wasting sites; and 4) Improve fish passage by either removing or laddering barriers (large debris jams and beaver dams) to enhance upstream migration of adult salmonids.

Skookum Creek is the third tributary selected for demonstration habitat enhancement. The mouth of Skookum Creek is located just south of the Kalispel Indian Reservation. Animal keeping practices on the land adjacent to Skookum Creek results in the most adverse impacts on the stream. The Washington State Department of Ecology (DOE) conducted a water quality study on 
tributaries to the Pend Oreille River concurrent with our three year investigation. The results of this study determined that fecal coliform densities in Skookum, Bracket and South Fork Lost Creek exceeded Class A water quality criteria during July and August (Coots and Willms 1991). Of the tributaries tested during this study, Skookum Creek accounted for 87 percent of the fecal coliform loading to the Pend Oreille River, (Coots and Willms 1991). It appears that the source of this water quality problem is due to animal keeping practices (Coots and Willms 1991). In the interest of better water quality for fish and human use it is recommended that habitat improvements include: 1) Identification of problem areas on Skookum Creek, 2) Fencing of these areas to allow cattle only limited access to the riparian zone; and 3) Planting of grass and shrubs to increase stream bank stabilization, decrease sediment loading and provide shade canopy for the stream. The most effective way to accomplish this type of project would be to coordinate with the Pend Oreille Conservation District and the private landowners.

Another type of habitat enhancement project involves reducing the amount of competition that exists between species in low productivity tributaries. It is well documented that brook trout outcompete cutthroat trout for food and space (Griffith 1972). It has also been reported that brook trout will hybridize with bull trout (Hisata, pers. comm.). Each tributary that was surveyed during this study supported reproducing populations of brook trout. In order to successfully reestablish either species of native trout in these tributaries it will be necessary to eliminate brook trout. It is recommended that:

- Active removal of brook trout be conducted in tributaries identified for native species reintroduction or enhancement. This should initially be accomplished in one or two selected tributaries and success measured in terms of: (1) long-term reduction of brook trout population; and (2) improvement in populations and growth rates of native trout species.

All of the previously described enhancement measures directed toward the native trout species, would be meaningless to future management of the fishery unless these measures were monitored for their success or effectiveness. Therefore, it is recommended that:

- All fishery enhancement projects (habitat improvements and supplementation efforts) be monitored for three years after 
implementation to determine effectiveness. Monitoring of these projects should provide important knowledge upon which future management decisions can be based.

The monitoring program should include seasonal evaluation of:

Physical characteristics of stream channel and habitat types available (e.g., pool, riffle), stream bed (e.g., sediment load), and changes in riparian zone condition. Comparison of types of habitat available "before and after" habitat improvements in demonstration tributaries.

Habitat enhancement structures and sites in the demonstration streams to document functional status, maintenance and replacement needs

Population estimates of both hatchery raised and wild cutthroat and bull trout in each enhanced tributary to determine change in population structure.

Invertebrate abundance (benthic and drifting) of preferred prey organisms to determine effect of stocking different numbers of fish on the ecosystem and how habitat improvements effect prey abundance.

Growth rates of hatchery and wild fish stocks.

Effectiveness of different release locations, size at release and time of release, along with ability of fish to return to stocking sites for egg collection.

Our investigation did not identify the limiting stage of Pend Oreille River trout life cycles. It is suspected that the lack of adult habitat in the river is partially responsible for low production. In order for successful reestablishment of native trout species and expansion of all trout populations it is important to identify the limiting factors. In order to accomplish this we recommend that additional fisheries investigations be conducted:

- Determine secondary productivity and trout carrying capacity of each of the tributaries, especially those identified for native species reestablishment.

- Installation of migration traps at the mouth of tributaries to the Pend Oreille River to determine cutthroat trout, bull trout 
and brown trout contribution to reservoir fishery and utilization of tributaries by adults.

- Tracking adult cutthroat trout, bull trout and brown trout to determine habitat preferences in the river and then evaluate the amount of preferred habitat available.

Data collected during the above recommended study will provide information upon which intelligent decisions can be made about managing the trout fishery in the Pend Oreille River and it's tributaries. As the native species of cutthroat trout and bull trout continue to decline in the Pacific Northwest, information collected from this type of study will be invaluable for the management of stocks elsewhere.

\subsubsection{OBJECTIVE 2: LARGEMOUTH BASS}

Due to the warm water temperatures and lack of habitat diversity in the reservoir, it is felt any attempts to enhance the trout populations in the reservoir may not be successful unless Box Canyon Dam was removed. Therefore, our second biological objective is to enhance the largemouth bass fishery in the reservoir. Bass are currently the only sport species of sufficient size and population in the reservoir to support a good sport fishery. Based on the three year baseline study, the bass population in the river has room for expansion and there is adequate habitat for a larger population.

Calculated biomass production of largemouth bass in the Pend Oreille River was estimated at approximately $8 \mathrm{lbs} /$ acre for age 1+ and older fish and $6 \mathrm{lbs} /$ acre for fish of harvestable size $(>10$ inches). A quality bass fishery is considered to produce $15-20$ Ibs./acre (Hisata, WDW, personal communication). The Pend Oreille River currently produces half that. It appears that there is adequate food supply and habitat available in the Pend Oreille River to support a larger population, however recruitment remains a limiting factor to population expansion. The estimated size of the age class $1+$ in 1989 and 1990 was approximately 150,000 (Table 4.13 and 4.14). In order to enhance the bass fishery to "quality" production we estimate it will be necessary to double this number. The goal of following recommendations for enhancing the largemouth bass population are to contribute 150,000 age $1+$ fish at $150 \mathrm{~mm}$ into the population annually. This should allow for a doubling of largemouth bass biomass from $8 \mathrm{lbs} / \mathrm{acre}$ to approximately $16 \mathrm{lbs} / \mathrm{acre}$. 


\subsubsection{RECOMMENDATIONS TO ENHANCE THE LARGEMOUTH BASS FISHERY}

The following recommendations are designed to maintain the existing quality bass fishery while expanding the population to take advantage of the available habitat and food supply. Two sets of alternate recommendations are presented; 1) Natural expansion of the population; and 2) Supplementation aid to expand the population. Both sets of recommendations address the biological objective of doubling the current biomass production of bass in the Pend Oreille River, however supplementation is believed to be the most effective means to this end.

\subsubsection{NATURAL POPULATION EXPANSION: RESERVOIR MANAGEMENT}

In order for enhancement of the naturally reproducing population of largemouth bass to be successful in the Pend Oreille River it is felt necessary changes be made in the management regime of the reservoir. The most obvious obstacle to bass production in the reservoir at this time is the negative water level fluctuations that occur during their spawning season. Due to the shallow depths of the sloughs that the bass utilize for spawning, negative fluctuations of over $1 \mathrm{~m}$ during spawning season results in nest dewatering and/or nest abandonment, which, in turn, causes nest mortality. A reoccurrence of the drawdown of 1988 during peak spawning season could result in the complete failure of a year class. For this reason it is recommended that:

- Maintenance on Box Canyon Dam be restricted during critical largemouth bass spawning time (May-July) to avoid occurrences such as the drawdown of 1988.

In order to enhance the natural production of bass in the reservoir it is essential that water elevation levels be held stable or at positive fluctuation during bass spawning season. Therefore it is recommended that:

- Water elevation fluctuation of the Pend Oreille River between Box Canyon Dam and Albeni Falls Dam be regulated (i.e., held at constant elevation) during critical largemouth bass spawning time (May-July). 
Because Box Canyon Reservoir is a run-of-the-river reservoir and the water levels in the river are naturally decreasing during bass spawning season this recommendation may be difficult, if not impossible, to implement.

\subsubsection{NATURAL POPULATION EXPANSION: FISHERIES MANAGEMENT}

Several changes in the current reservoir management would be necessary to accomplish a natural expansion of the bass population.

Our data support the proposed regulation change by the Washington State Department of Wildlife from the current daily bag limit of ten bass, with not more than three fish over 17" to a daily bag limit of five bass, with not more than three fish over 15". This regulation change should help to protect the quality bass fishery that currently exists in the Pend Oreille River.

According to results collected by the Washington Department of Wildlife, the Pend Oreille River is one of the most successful bodies of water to hold bass tournaments on. However, nest abandonment due to angler removal of the parent fish is considered to be one of the factors limiting bass production and recruitment in the river. Therefore it is recommended that:

- Bass tournaments be scheduled before or after peak spawning period (June 15 to July 15) to eliminate nest abandonment due to parent removal.

An option to complete closure of bass tournaments at this time would be a "paper" tournament where the fish- would be measured, weighed and released at the same location as capture. The previous recommendation is preferred as it would reduce angler interference during spawning season.

\subsubsection{SUPPLEMENTED POPULATION EXPANSION: FISHERIES MANAGEMENT}

Most of the factors currently limiting natural population recruitment of the bass population are uncontrollable and therefore the recommendations listed for natural expansion of the population are suspected to be only slightly effective, while at the same time expensive. One of the best, most cost effective, options is to supplement the natural bass population. The following 
recommendations were made with current operating conditions and fishing regulations in mind and are therefore an alternative to:

1) Water elevation fluctuation control of Box Canyon Reservoir.

2) Restriction of bass tournaments during spawning season.

3) Closure of the bass fishery during peak spawning season if the non-tournament angler pressure increases.

To accomplish a successful supplementation program while maintaining genetic integrity of largemouth bass that have adapted to the environmental conditions in the Pend Oreille River it is recommended that:

- Bonneville Power Administration should fund design, construction, operation and maintenance of an experimental low capital facility on the Kalispel Indian Reservation for largemouth bass egg incubation and rearing. This facility would be built in conjunction with the recommended trout hatchery and would therefore be the warm water section of the warm/cold water hatchery.

This hatchery and its water heating system should be modeled after the sturgeon hatchery on the Kootenai Indian Reservation in Bonners Ferry, ID. Gamete collection should be from bass in the Pend Oreille River to maintain the genetic stock that has adapted to such a variable environment. Fecundity of female bass has been estimated between 20,000 to 40,000 eggs per year (Snow 1975, Lagler 1956). The outproduct goal of this hatchery is 150,000 bass fry, which should double the current biomass production of bass in the river. Based on these numbers very few parents would be necessary to achieve this production. However, to achieve a good genetic mix it is recommended that no fewer than 20 pairs of parents be utilized as brood stock. Using this method females would be only partially stripped of their eggs and then returned to their location of capture so that natural spawning could still occur.

At the time of this publication the Kalispel Indian Tribe, through Bonneville Power Administration, is attempting to purchase 420 acres along the river (north of the Kalispel Indian Reservation) to utilize as a wetland refuge. Historically, dikes were built on this property along the river to prevent flooding and allow the land to dry up and be cultivated. The plan to transform this land back into a 
wetland is to install water control structures in the dikes and then pump water from the river to flood the property. This flooding will create ponds behind the dikes. If the water control structures are screened, then the ponds will not be accessible to fish. With this plan in mind, it is recommended that:

- The wetland refuge on the Kalispel Indian Reservation be utilized to raise the 100,000 largemouth bass fry from the hatchery (the remaining 50,000 would be reared in the hatchery). Fry would be present in the refuge from June to October, when they would be released into the reservoir as fingerlings $(100 \mathrm{~mm})$. In this way interspecific competition could be avoided and it is believed the fry could attain a size that would allow them to prey on fish (yellow perch of the same age) when they were released into the reservoir. This should increase over-winter survival, therefore increasing recruitment and year-class strength. Growth and condition of these bass should be compared to that of bass raised in hatchery environment on hatchery food.

With an outproduct of 150,000 bass fingerlings, stocking rates would be approximately 20 fry/acre. Stocking ratios of 100 largemouth bass fingerling per acre are commonly accepted around the U.S. as indicative of approximate carrying capacity, depending on fertility of the water and forage availability (Fletcher 1988). Therefore, stocking rates recommended for the Pend Oreille River are substantially lower than common practices in other U.S. lakes and reservoirs.

To enhance the survival of the younger age classes of bass (both natural and supplemented) during the winter it is recommended that:

- Artificial cover structures be constructed for strategic placement in the reservoir. These structures would serve as cover during the winter months when the macrophytes have died back. Artificial reefs have been used in several western reservoirs where water fluctuation regime and lack of cover for fish posed severe problems for the management of coverdependent centrarchid species (Brouha and von Geldern, Jr. 1979) 
It is also recommended that:

- All fishery enhancement projects be monitored for three years after implementation to determine effectiveness. Monitoring of these projects should provide important knowledge on which future management decisions can be based.

Our data supports the hypothesis that there is sufficient habitat to support a much larger largemouth bass population. If we are successful in increasing the bass population the number of perch and pumpkinseed should be decreased. A decrease in the perch population would decrease the intraspecific competition and increase the size of perch available in the river. Larger perch have a higher fecundity and would therefore produce more young-of-theyear perch that could be utilized as a prey item for small bass. An increase in the size of perch should also provide a fish that is of sufficient size to harvest.

\subsubsection{FISHERY .AND RESERVOIR MANAGEMENT RECOMMENDATIONS TO ENHANCE BOTH NATURAL OR SUPPLEMENTED POPULATION EXPANSION}

Independent of whether natural or supplemental method is utilized to expand the largemouth bass population we strongly support the following recommendations regarding management of the Eurasian milfoil and possible introduction of an exotic predator fish species in the Pend Oreille River.

Recently the exotic macrophyte Eurasian watermilfoil has established itself in the Pend Oreille River. Due to the rapid spread of this macrophyte and its potential to create damage to the fishery (by reducing rearing habitat and adult predation rates) management plans for the fishery should include macrophytes. The current management of Eurasian watermilfoil in the reservoir is to "control" it by rotovation. The success of this treatment is currently being evaluated by determining regeneration in a rotovated area. Based on data collected in this study it is recommended that:

- Evaluation of the effectiveness of rotovation removal of Eurasion watermilfoil include total area infected or total biomass of watermilfoil in the river instead of, or along with, regeneration in the same area. 
Most of the fish captured during electrofishing surveys throughout the three year study period were associated with weed beds in littoral areas. Radio and sonic tagged bass were frequently located near the edge of large, dense macrophyte beds. According to Prince and Maughan (1979) prey that are attracted to structure become concentrated in vegetation thereby increasing encounter rates with, and vulnerability to, foragers that also reside there. Open spaces or "trails" through the dense macrophyte beds would be advantageous to predators as they would provide more areas for ambushes. For this reason it is recommended that:

- The "edging" technique (rotovating rows through the weed bed) be utilized during rotovation to increase the amount of "big" fish habitat and increase encounter rates between predator and prey.

Biological control agents of Eurasion milfoil listed by the Army Corp of Engineers included plant pathogens, herbivorous fish and herbivorous insects (EIS 1991). It seems surprising that crayfish have not been considered for aquatic plant management since their effect on aquatic plants has been known since the 1930's (Embody 1934, Langlois 1935). In Parker Lake, AZ largemouth bass, native watermilfoil (Myriophyllum exalbences) and crayfish (Orconectes causeyi) exist in sympatry (Saiki and Tash 1979). Crayfish have the potential to cause problems of an introduced species but it is felt that if grass carp are under consideration for implantation than crayfish should also be thoroughly studied and seriously considered as a control agent. If crayfish could be utilized to control the Eurasian milfoil in the Pend Oreille River it would also be beneficial to the bass population, as crayfish are a favorite prey item for largemouth bass (Willms et a/. 1989). The feasibility of using crayfish for macrophyte control should be studied.

However, at this time it is recommended that no exotic species of plants or animals be introduced into the Pend Oreille River. Introduction of a biological control agent, such as grass carp or crayfish, for the prupose of aquatic weed control, into the Pend Oreille River system would require prior approval of both managment agencies; the Washington Department of Wildlife and the Kalispel Tribe.

Several possibilities exist for reducing the macrophyte abundance as well as the perch population in the reservoir. Both of 
these involve drawing down the reservoir during different times of the year.

A winter drawdown could stunt macrophyte (Eurasian milfoil) growth by freezing the dewatered roots. This idea has merit concerning a reduction in the milfoil community but it also has the potential to seriously impact the fishery. The Box Canyon Reservoir is a shallow reservoir and therefore the milfoil plants are able to grow and thrive in a large percentage of the reservoir. In order to significantly impact the milfoil community a severe drawdown would be required. A drawdown of this nature would completely dewater the littoral areas concentrating most of the fish in the main channel of the river. As fish are not very active during the cold winter months it is likely that a good percentage of the fish would simply be flushed from the system. Also a winter drawdown could impact mountain whitefish spawning success by dewatering redds.

The second possibility which might reduce the milfoil community and also enhance the perch population is a spring drawdown. Perch spawn in late March-early April in the Pend Oreille River. If a drawdown was implemented during that time spawning success of perch would be decreased as the littoral areas they utilize for spawning during this time would be dewatered. A decrease in population would hopefully result in larger individuals in the population making them more desirable to anglers. Macrophyte growth, which is just beginning in the early spring, may also be retarded.

Certain cautions need to be considered with this last possibility. Although it is desirable to decrease the perch population, perch are the main food item of largemouth bass. If the population was decreased dramatically it could effect the bass population. At this time little is known about where young bass are rearing during the spring. If they are utilizing the littoral areas they would be forced into the reservoir where predation may cause substantial mortality. Also forced emigration is a potential result of this type of drawdown. A spring drawdown may also effect the waterfowl that utilize the marshy wetland areas along the river banks for nesting and brooding areas.

A spring drawdown may also conflict with flows required for the anadromous fish program in the lower Columbia River. Presently high flows are necessary during May and June to flush salmon smolts 
to the ocean. If the Box Canyon Reservoir was refilling at this time the water available for anadromous fish would be decreased.

Based on the reasons given previously, any drawdown suggestions should be thoroughly examined before any serious consideration is given to implementation.

Bennett et a/. (1991) suggested planting northern pike in the Pend Oreille River to decrease the perch and pumpkinseed populations and improve the fishery. Magnuson (1976) and $\mathrm{Li}$ and Moyle (1981) caution that introductions of exotic species; 1) frequently have the opposite effect of the intended impact and 2) often reduce the fish managers ability to effectively manage the system because the introduction destablilizes existing interactions. Based on the data collected during this study the introduction of , another piscivorous species into the Pend Oreille River fishery is not recommended. The fish species that currently exist in the river have evolved for the past forty years to where now fairly stable populations are supporting the fishery. If the largemouth bass population was well managed it should be sufficient to decrease the perch and pumpkinseed populations.

An introduction of exotic fish species into this system at this time would reduce the biological stability and decrease our ability to manage the fishery with any amount of predictability. Exotic fish introduction could also negate any benefits of the fishery enhancement projects recommended in this report, which are consistent with the management goals of the Kalispel Indian Tribe and Washington Department of Wildlife, the two entities with management jurisdiction in the Box Canyon Reach of the Pend Oreille River. Consistency with the management goals of the agencies and tribes is required by the Northwest Power Act.

It's possible that an introduction of pike may not accomplish the desired affect of reducing the perch and pumpkinseed population. Rodger (1991) reported that northern pike are indiscriminate in their feeding habits, eating large numbers of trout and bass. Inskip (1982) found pike preferred soft-rayed, cylindrical fishes which are apparently more easily swallowed as compared to the spiny and/or laterlly compressed fish species. This suggests that the pike may preferentially prey on the trout and whitefish in the Pend Oreille River, which could be disastrous to the already threatened bull trout and cutthroat trout populations. In addition, many studies (Beyerle and Williams 1968; Coble 1973; Inskip 1982; Wahl and Stein 1988) 
found that northern pike are not effective predators and do not prefer spiny, laterally compressed fish (pumpkinseed and bluegill). Anderson and Schupp (1986) speculated that the reduction of yellow perch through northern pike predation allowed bluegill numbers to increase. In the case of the Pend Oreille River it is likely that the pumpkinseed population would increase. Pumpkinseed are not a sport fish, are not harvested by anglers and already compose $16 \%$ of the fish species present in the river.

Another consideration is that, although movement of these species is not well documented, studies done in lakes and small streams have shown that northern pike can display high mobility (Miller 1948, Ross and Winter 1981). Northern pike introduced in the Yampa River, CO spread quickly into the Green and Colorado Rivers. Currently, they are found throughout the Yampa, Green and Upper Colorado River Basins (Tyus and Beard 1990). Pike tracked in the Yampa River, Utah traveled $>75 \mathrm{~km}$ in one year (Tyus and Beard 1990). The Colorado Division of Wildlife stocked northern pike in headwater reservoirs of the Gunnison River in 1969, 1970 and 1972. In 1974, McAda (1977) collected a northern pike that had migrated about 150 miles downstream, out of the Gunnison River into the Colorado River. Based on these data pike released in the Pend Oreille River have the potential to migrate into the Columbia River which could impact resident fish enhancement efforts in Lake Roosevelt. As Lake Roosevelt lacks optimal northern pike habitat these fish could move through the reservoir, below Grand Coulee Dam and impact anadromous fish recovery efforts. Northern pike are well known voracious predators. Their introduction to the lower Columbia reservoirs could result in a serious reduction of the salmon and steelhead smolts passing through those reservoirs during their migration to the ocean.

An additional consideration in introducing northern pike into the Pend Orielle River are diseases common to the species. Twenty percent of the feral population of northern pike are infected with lymphosarcoma, a malignant blood cancer (Sonstegard and Hnath 1978). This disease is caused by a viral enzyme. It is contagious and transmitted horizontally percutaniously during spawning. Infected fish are easily identified by skin lesions found on the posterior half of the body. This disease is not transferable to humans as the viral enzyme is inactivated at temperatures above $20^{\circ} \mathrm{C}$ and human body temperature is normally $37^{\circ} \mathrm{C}$. However, it is 
not known if this disease can be transferred to other fish species and what effect it may have on them.

Pike in Ontario waters are commonly found to have the "red sore" disease (Reed and Toner 1941). This disease is caused by an infection with Proteus hydrophilus, a bacteria shown to be responsible for the widespread "red leg" disease and thought to be responsible for "ulcer disease" in trout in a New York hatchery (Reed and Toner 1941). Fish (1934) islolated $P$. hydrophilus from "ulcer disease" in fingerling brook trout, rainbow, blackspotted and lake trout in a Cortland, New York, hatchery. Reed and Toner (1941) reported that no trout are present in regions in which the disease in pike has been studied.

In addition, pike are infected with the tapeworm Triaenophorus crassus which utilizes whitefish as it's intermediate host (Lawler 1965). This tapeworm appears as a whitish-yellow cyst in whitefish flesh, and although the parasite is harmless to humans and warm blooded animals it creates an objectionable appearance in the whitefish flesh. In Alberta and Manitoba attempts to eliminate the pike population to restore the quality of the whitefish fishery proved to be a long expensive process, which in some cases ended in futility (Lawler 1965). As discussed earlier in this report the Pend Oreille River supports a fairly large population of native mountain whitefish.

Based on the above information it is recommended that:

- No further introductions of exotic fish species (i.e. walleye, northern pike, tiger muskies) be made into the Pend Oreille River. 


\section{Table 4.18. Recommendations to accomplish biological objective \#1: Restore the native species of cutthroat trout and bull trout in the Box Canyon Reservoir system.}

\section{Changes in current fisheries management}

- Consideration be given to petition the U.S. Fish and Wildlife Service to list bull trout in the Box Canyon Reach of the Pend Oreille River under the Endangered Species Act of 1973.

- Complete closure of fishing season for cutthroat trout and bull trout in the reservoir and tributaries.

- Discontinuation of brook trout stocking by the Department of Wildlife in tributaries to the Pend Oreille River identified for native species enhancement.

Fishery enhancement projects for the tributary fishery

- Active removal of brook trout be conducted in tributaries identified for native species reintroduction or enhancement.

- Construction of a low capital hatching facility for egg collection and hatching of native trout species. Hatched fry will be seeded into respective tributaries. (Cold water section of warm/cold water hatchery).

- Habitat enhancement be conducted on three demonstration tributaries (LeClerc, Cee Cee Ah and Skookum Creeks) at necessary sites to determine effectiveness of these procedures in increasing bull trout and cutthroat trout in Pend Oreille River tributaries.

- All fishery enhancement projects (habitat improvements and supplementation efforts) be monitored for three years after implementation to determine effectiveness.

Fisheries investigations in the tributaries

- Determine secondary productivity and trout carrying capacity of each of the tributaries, especially those identified for native species reestablishment.

- Installation of migration traps at the mouth of tributaries to the Pend Oreille River to determine cutthroat trout, bull trout and brown trout contribution to reservoir fishery and utilization of tributaries by adults.

- Tracking adult cutthroat trout, bull trout (if possible) and brown trout to determine habitat preferences in the river and then evaluation of preferred habitat available. 


\section{Table 4.19. Recommendations to accomplish biological objective \#2: Enhance the largemouth bass fishery in the Box Canyon Reservoir.}

\section{Changes in current reservoir operation management:}

- Maintenance on Box Canyon Dam be restricted during critical largemouth bass spawning time (June-July) to avoid occurrences such as the drawdown of 1988.

- Water elevation fluctuation of the Pend Oreille River between Box Canyon Dam and Albeni Falls Dam be regulated during critical largemouth bass spawning time (JuneJuly).

\section{Changes in current reservoir fishery management}

- Support of proposed regulation change by Washington State Department of Wildlife from the current daily bag limit of ten (10) bass, with not more than three (3) fish over 17' to a daily bag limit of five (5) bass, with not more than three (3) fish over 15'.

- Bass tournaments be scheduled before or after peak spawning period (June 15 to July 15) to eliminate nest abandonment due to parent removal.

\section{Fishery enhancement projects for the reservoir fishery}

Construction of a low capital hatching facility for largemouth bass egg collection and hatching. (Warm water section of warm/cold water hatchery).

- Utilization of a ponds in the proposed wetland refuge on the Kalispel Indian Reservation for rearing 100,000 largemouth bass fry from the hatchery. Fry would be present in the refuge from June to October, when they would be released into the resrvoir as fingerlings $(100 \mathrm{~mm})$.

- Construction and strategic placement of artificial cover structures to increase the amount of winter cover available in the reservoir.

- Supplementation and habitat structure projects be monitored for three years after implementation to determine effectiveness.

. Utilization of the 'edging' technique (rotovating rows through the weed bed) during rotovation to increase the amount of 'big' fish habitat.

- No further introductions of exotic fish species (i.e. walleye, northern pike, tiger muskies) be made into the Pend Oreille River. 


\section{LITERATURE CITED}

Aggus, L.R. and G.J. Elliot. 1975. Effects of cover and food on yearclass strength of largemouth bass. Pp. 317-322 In: H. Clepper (ed.). Black bass biology and management. Sport Fish. Inst., Washington D.C.

Anderson, D.W. and D.H. Schupp. 1986. Fish community responses to northern pike stocking in Horseshoe Lake. Minnesota Department of Natural Resources, Section of Fisheries Investigational Report Number 307, St. Paul.

Anderson, E., J.K. Uehara and A.T. Scholz. 1985. Population estimates of trout and sculpins in Cee Cee Ah Creek on the Kalispel Indian Reservation and a fisheries inventory of the Pend Oreille River adjacent to the Kalispel Indian Reservation. Upper Columbia United Tribes Fisheries Center. Unpublished file data.

Anderson, R.O. 1959. A modified floatation technique for sorting bottom fauna samples. Limnol. Oceanogr. 4:223-225.

Anderson, R.O. and S.J. Gutreuter. 1983. Length, weight and associated structural indices. Pp. 283-300, In: Nielsen, L.A. and D.L. Johnson (ed.). Fisheries Techniques. Amer. Fish. Soc., Bethesda, MD. 468 pp.

Armitage, P.D., A.M. Machale, and D.T. Crisp. 1958. A survey of stream invertebrates in the Cow Green Basin (Upper Teesdale) before inundations. Freshwater Biology. 4:369-398.

Ashe, B.L., K.L. Lillengreen, J.J. Vella, L.O. Clark, S. Graves, M.R. Barber, G.J. Nenema Jr., and A.T. Scholz. 1991. Assessment of the fishery improvement opportunities on the Pend Oreille River. 1990 Annual Report. Upper Columbia United Tribes Fisheries Center, Dept. of Biology, EWU, Cheney, WA, prepared for U.S. Dept. of Energy, Bonneville Power Administration, Div. of Fish and Wildl. Project No. 99-66, Agreement DE-17988BP39339. 350 pp. plus 338 pp. Appendices.

Baily, G.C. and J. Salts. 1982. Fishery assessment of the upper Spokane River. Proj. Completion Report. State of Washington 
Water Research Center, Report No. 46. Wash. State Univ., Pullman, WA. 111 pp.

Barber, M.R. 1988. Predicting the effect of reduced streamflow on rainbow trout, brown trout and sculpin populations in Chamokane Creek using the instream flow incremental methodology (IFIM). MS Thesis. Eastern Washington University, Cheney, WA. 301 pp.

Barber, M.R., B.L. Renberg, J.J. Vella, A.T. Scholz, K.L. Woodward and S. Graves. 1990. Assessment of the fishery improvement opportunities on the Pend Oreille River. 1989 Annual Report. Upper Columbia United Tribes Fisheries Center, Dept. of Biology, EWU, Cheney, WA. prepared for U.S. Dept. of Energy, Bonneville Power Administration, Div. of Fish and Wildl. Project No. 99-66, Agreement DE-179-88BP39339. 184 pp.

Barber, M.R., R.A. Willms, A.T. Scholz, L.O. Clark, B.L. Renberg, K. O'Laughlin, K.L. Woodward, and R.D. Heaton. 1989. Assessment of the fishery improvement opportunities on the Pend Oreille River. 1988 Annual Report. Upper Columbia United Tribes Fisheries Center, Dept. of Biology, EWU, Cheney, WA. prepared for U.S. Dept. of Energy, Bonneville Power Administration, Div. of Fish and Wildl. Project No. 99-66, Agreement DE-17988BP39339. $391 \mathrm{pp}$.

Baumann, R.W., A.R. Gaufin and R.F. Surdick. 1977. The stoneflies (Plecoptera) of the Rocky Mountains. Memoirs of the American Entomological Society. No. 31. American Entomological Society, Academy of Natural Science, Philadelphia, PA. 208 pp.

Beattie, W., P. Clancy, J. Decker-Hess, and J. Fraley. 1985. Impacts of water level fluctuations on kokanee reproduction in Flathead Lake. Montana Dept. Fish, Wildl. and Parks. Annual Progress Report prepared for U.S. Dept. of Energy, Bonneville Power Administration. Contract No. DE-A179-83BP39641. 57 pp.

Beckman, L.G., J.F. Novotny, W.R. Persons, and T. Terrell. 1985. Assessment of the fisheries and limnology in Lake F.D. Roosevelt, 1980-83. U.S. Fish, Wildl. Serv. U.S. Bureau of Rec. Contract No. WPRS-O-07-1 0-X0216. FWS-14-06-009-904. 
Bennett, D.H. and D.R. Hatch. 1991. Factors limiting the fish community with emphasis on largemouth bass in Long Lake, Spokane County, Washington. Fish and Wildlife Department, College of Forestry, Wildlife and Range Sciences, Univ. of Idaho, Moscow, ID, prepared for Washington Water Power, Project No. 4. 76 pp.

Bennett, D.H. and E.C. Bowles. 1985. Recruitment and survival of young-of-the-year largemouth bass Micropterus salmoides in the Coeur d'Alene Lake system, ID. Completion Report, Proposal Number II, Washington Water Power Company, Spokane.

Bennett, D.H. and M. Liter. 1991. Water quality, fish and wildlife characteristics of Box Canyon Reservoir, Washington, Section 3: Fish, Completion Report 1989-1990. Dept. of Fish and Wildl. Res. College of Forestry, Wildlife and Range Sciences. University of Idaho, Moscow, ID. 94 pp.

Bennett, D.H. and T.J. McArthur. 1990. Predicting success of walleye stocking programs in the United States and Canada. Fisheries. 15(4): 19-23.

Bennett, D.H., and T.J. Underwood. 1988. Population dynamics and factors affecting rainbow trout (Salmo gairdneri) in the Spokane River, ID. Completion Report No. 3. Washington Water Power Co., Spokane, WA.

Bennett, D.H., C.M. Falter, K. Reese, W. McLaughlin, W.D. Sawle, M. Liter, J.W. Carlson, J. Hall, and N. Sanyal. 1990. Fish, wildlife, and recreational characteristics of Box Canyon Reservoir. 1989 Annual Report. College of Forestry, Wildlife and Range Sciences, University of Idaho, Moscow, Idaho. 110 pp.

Beyerle, G.B., and J.E. Williams. 1968. Some observation of food selectivity by northern pike in aquaria. Transactions of the American Fisheries Society. 97:28-31.

Bishop, C.G. 1955. Age, growth and condition of trout in Prickly Pear Creek, Montana. Trans. Amer. Microscop. Soc. LXXIV(2): 134-45.

Bonga, D. 1978. Kalispel Indians: A fishing tribe. Kalispel Tribe internal report. 
Borror, D.J. and R.W. White. 1970. A field guide to the insects of America north of Mexico. Houghton Miflin Co, Boston. 404 pp.

Borror, D.J., D.M. DeLong, C.A. Triplehorn. 1976. An introduction to the study of insects. 4th Edition. Holt, Rinehart and Winstron. $852 \mathrm{pp}$.

Bowen, S.H. 1983. Quantitative description of the diet. Pp. 325336, In: Nielsen, L.A. and D.L. Johnson (ed.). Fisheries Techniques. Amer. Fish. Soc., Bethesda, MD. 468 pp.

Bowles, E.C., V.L. Ellis, and B. Hoelscher. 1989. Kokanee stock status and contribution of Cabinet Gorge Hatchery, Lake Pend Oreille, Idaho. Annual Progress Report FY 1988 prepared for U.S. Dept. of Energy, Bonneville Power Administration, Div. of Fish and Wildl. Project No. 85-339, Contract No. DE-Al79-85BP22493. $60 \mathrm{pp}$.

Brandlova, J., Z.Brandl and C.H. Fernando. 1972. The cladocera of Ontario with remarks on some species and distribution. Can. J. of Zool. 50: 1373-I 403.

Brooks, J.L. 1957. The systematics of North American Daphnia. Mem. Conn. Acad. Arts and Sci. Vol. 13. 180 pp.

Brostrom, J., and R. Spateholts. 1985. Henry's Fork fisheries investigations. Idaho Dept. of Fish and Game, Job Performance Report, Project F-73-R-6, Subproject IV, Job. 1. 51 pp.

Brouha, P. and C.E. von Geldern, Jr. 1979. Habitat manipulation for centrarchid production in western reservoirs. Pages 11-17 in D.L. Johnson and R.A. Stein, editors. Response of fish to habitat structure in standing water. North Central Division American Fisheries Society Special Publication 6.

Bryant, F.G. and Z.E. Parkhurst. 1950. Surveys of the Columbia River and its tributaries. Part IV. Area III. Washington streams from the Klickitat and Snake River to Grand Coulee Dam. U.S. Fish Wild. Serv. Spec. Sci. Rep. Fish. No. 37. 108 pp.

Buchanan, J.P., D.J. Howard and R.A. Stone. 1990. Geomorphology of Cee Cee Ah Creek, Pend Oreille County, WA. Upper Columbia United Tribes Fisheries Center, Fisheries Technical Report No. 
26. Final Report Submitted to the Bureau of Indian Affairs, Contract No. POOC14208039. 15 pp. plus maps.

Buchanan, T.H. and W.P. Somers. 1980. Discharge measurements at gaging stations. Techniques of Water-Resources Investigations of the United States Geological Survey, Book 3, Chapter A8. USDI Geological Survey. 69 pp.

Cairns, S.C., B.Z. Lang and A.T. Scholz. 1988. Further investigations on the impact of Midnite Mine effluent on the benthic macroinvertebrate community in Blue Creek: Trends in density and diversity of benthic macroinvertebrate collected in preimpact and recovery zones. Upper Columbia United Tribes Fisheries Center, Fisheries Technical Report No 22. Final Report Submitted to the Bureau of Indian Affairs. Contract No. POOC140848. 132 pp.

Catlander, K.D. 1969. Handbook of freshwater fishery biology, Vol. 1. lowa State University Press. Ames, lowa. 752 pp.

Carlander, K.D. 1977. Handbook of freshwater fishery biology: Vol. 2. Life history data on centrarchid fishes of the United States and Canada. lowa State University Press. Ames, lowa. 431 pp.

Chisolm, I. and J. Fraley. 1985. Quantification of Libby Reservoir levels needed to maintain or enhance reservoir fisheries. Annual Report, Montana Department of Fish, Wildl. and Parks. Prepared for Bonneville Power Administration. Contract No. DE-Al 79-84BP12660. 65 pp.

Coble, D.W. 1973. Influence of appearance of prey and satiation of predator on food selection by northern pike (Esox lucius). Journal of the Fisheries Research Board of Canada. 30:317320.

Coots, R. and R. Willms. 1991. Pend Oreille River primary productivity and water quality of selected tributaries. Washington State Dept. of Ecology, Watershed Assessments Section, Olympia, WA. $35 \mathrm{pp}$.

Corsi, C. 1984. Region 6 Willow Creek Drainage fishery inventory. Idaho Dept. of Fish and Game, Job Performance Report, Project F-71-R-8. 93 pp. 
Corsi, C. and S. Elle. 1989. Regional fisheries management investigations, Idaho Dept. of Fish and Game. Job Performance Report, Project F-71-R-12. 57 pp.

Cowley, P.K. 1987. Potential for increasing abundance of cutthroat trout in streams by stocking fry and removal of brook trout. Master's thesis. University of Idaho, Moscow.

Downing, J. A. and F.H. Rigler. 1984. A manual on methods for the assessment of secondary productivity in fresh waters. 2nd. Ed. IBP Handbook No. 17. 500 pp.

Edmondson, W.T. (ed.). 1959. Fresh-water biology. 2nd. Edition. John Wiley and Sons. New York. 1248 pp.

Edmondson, W.T. and G.G. Windberg. 1971. A manual for the assessment of secondary productivity in fresh waters. IBP Handbook No. 17. 358 pp.

Egglishaw, H.J. and D.W. Mackay. 1967. A survey of the bottom fauna of streams in the Scottish Highlands. Seasonal changes in the fauna of the streams. Hydropbiologia. 30:305-334.

Embody, G.C. 1934. Discussion. Trans. Am. Fish. Soc. 64:150.

Everhart, W.H. and W.D. Youngs. 1981. Principles of fisheries science. 2nd Edition. Cornell Univ. Press, Ithaca, New York. $359 \mathrm{pp}$.

Falter, C.M., C. Baines and J.W. Carlson. 1991. Water quality, fish and wildlife characteristics of Box Canyon Reservoir, Washington, Section 2: Water Quality, Completion Report 1989-1990. Dept. of Fish and Wildl. Res. College of Forestry, Wildlife and Range Sciences. University of Idaho, Moscow, ID. $223 \mathrm{pp}$.

Fish, F.F. 1934. Transactions of the American Fisheries Society. 64:252-258.

Fletcher, D. 1989 warmwater fishing contests in Washington. Wash. Dept. of Wildl. Fish. Mgt. Div. F.M. 90-9. 11 pp.

Fletcher, D. 1990 warmwater fishing contests in Washington. Wash. Dept. of Wildl. Fish. Mgt. Div. 12 pp. 
Fraley, J.J. and B.B. Shephard. 1989. Life history, ecology and population status of migratory bull trout (Salvelinus confluentus) in the Flathead Lake and River system, Montana. Northwest Science. 63: 133-I 43.

Fraley, J.J., D. Read, and R.P. Graham. 1981. Flathead River fishery study. Montana Dept. of Fish, Wildl. and Parks. Helena, Montana.

Fulton, L.A. 1968. Spawning areas and abundance of chinook salmon (Oncorhynchus tshawytscha) in the Columbia River Basin-past and present. U.S. Fish Wildl. Serv. Spec. Rep. Fish. No. 571. 22 pp and maps.

Fulton, L.A. 1970. Spawning areas and abundance of steelhead trout and coho, sockeye and chum salmon in the Columbia River Basin-past and present. U.S. Fish Wildl. Serv. Spec. Rep. Fish. No. 116. $37 \mathrm{pp}$ and maps.

Fulton, L.A. and M.C. Laird. No date. A cursory survey of tributaries to Roosevelt Lake with reference to spawning potential for salmon, 1965, 1966. NOAA. Nat. Mar. Fish. Serv. 38 pp.

Gamblin, M.S. 1987. Taft-Bell sediment and fishery monitoring project. Progress Report prepared for U.S. Dept. of Energy, Bonneville Power Administration. Contract DE-Al 79-85 BP 23203.

Geist, D. and A.T. Scholz. 1987. Feasibility report for mitigation of the Kalispel Tribal Fisheries. Upper Columbia United Tribes Fisheries Center. Unpublished internal report. 67 pp.

George, E.L. and W.F. Hadley. 1979. Food habitat partitioning between rock bass (Ambloptites rupestris) and smallmouth bass (Micropterus dolomicui) young of the year. Trans. Amer. Fish. Soc. 108:253-261.

Gilbert, C.H. and B.W. Evermann. 1894. A report upon investigations in the Columbia River Basin, with descriptions of four new species of fishes. U.S. Senate Misc. Doc. No. 200. p19-54.

Griffith, J.S. 1972. Comparative behavior and habitat utilization of brook trout (Salvelinus fontinalis) and cutthroat trout (Salmo 
clarki) in small streams in northern Idaho. Journal of

Fisheries Research Board of Canada. 29:265-273.

Griswold, R.G. and T.C. Bjomn. 1989. Development of indices of yellow perch abundance in Cascade Reservoir, Idaho. Idaho Dept. of Fish and Game. Job Completion Report. Project F-71R-12 Subproject III Job No. 6. 36 pp.

Hart L.G. and R.C. Summer-felt. 1975. Surgical procedures for implanting ultrasonic transmitters into flathead catfish (Pylodictis olovaris). . Trans. Amer. Fish. Soc. 104(1):56-59.

Hess, A.D. 1941. New limnological sampling equipment. Limnol. Soc. Am. Spec. Publ. 6:1-5.

Hickman, T. and R.F. Raleigh. 1982. Habitat suitability index models: Cutthroat trout. U.S. Fish Wildl. Serv. FWS/OBS-82/10.5. 38 pp.

Hoelscher, B. and T.C. Bjornn. 1989. Habitat densities and potential production of trout and char in Pend Oreille Lake tributaries. Idaho Dept. of Fish and Game, Job Completion Report, Project F-71-R-10. 60 pp.

Horn, H.S. 1966. Measurement of "overlap" in comparative ecological studies. Amer. Nat. 100:419-429.

Homer, N.J., L.D. LaBolle, and C.A. Robertson. 1987. Regional fisheries management investigations. Idaho Dept. of Fish and Game, Job Performance Report, Project F-71-R-1 1. 151 pp.

Hubert, W.A. 1983. Passive capture techniques. Pp. 95-122, In: Nielsen, L.A. and D.L. Johnson (ed.). Fisheries Techniques. Amer. Fish. Soc., Bethesda, MD. 468 pp.

Hynes, H.B.N. 1970. The ecology of running waters. University of Toronto Press. Toronto, Can. 555 pp.

Inskip, P.D. 1982. Habitat suitability index models: northern pike. United States Department of the Interior, Fish and Wildlife Service. FWS/OBS-82/10.17.

Jearld, A. 1983. Age determination. Pp. 301-324, In: Nielsen, L.A. and D.L. Johnson (ed.). Fisheries Techniques. Amer. Fish. Soc., Bethesda, MD. 468 pp. 
Johnson, J.E. 1987. Protected fishes of the United States and Canada. American Fisheries Society, Bethesda, MD. 42 pp.

Johnson, T.H. and T.C. Bjomn. 1978. Evaluation of angling regulations in management of cutthroat trout. Idaho Dept. of Fish and Game, Job Completion Report, Project F-59-R-7, F59-R-8. 153 pp.

Kathrein, J.W. 1951. Growth rates of four species of fish in a section of the Missouri River between Holster Dam and Cascade, Montana. Trans. Amer. Fish. Soc. 80:93-98.

Knopf, R.R. 1982. Diel activity, habitat observations and the effects of light intensity on radio tagged largemouth bass. Masters thesis, Central Michigan University. $136 \mathrm{pp}$.

Krebs, C.J. 1985. Ecology: the experimental analysis of distribution and abundance. 3rd. Edition. Harper and Row, New York. 800 pp.

Krieger, D.A., J.W. Terrell and P.C. Nelson. 1983. Habitat suitability information: Yellow perch. U.S. Fish Wildl. Serv. FWS/OBS83/10.55. $37 \mathrm{pp}$.

Langlois, T.H. 1935. Notes on the habits of the crayfish Cambarus rusticus girard in fish pond in Ohio. Trans. Am. Fish. Soc. 65: $189-193$.

Lawler, G.H. 1965. Whitefish improvement-pike control. Fisheries Research Board of Canada, London, Ontario. 7:9-15.

Leathe, S.A., and P.J. Graham. 1981. Flathead Lake fish food habits study. Montana Dept. of Fish, Wildl. and Parks. 93 pp.

Li, H.W. and P.B. Moyle. 1981. Ecological analysis of species introduction into aquatic systems. Transactions of the American Fisheries Society. 110:772-787.

Light, R.W., P.H. Adler and D.E. Arnold. 1983. Evaluation of gastric lavage for stomach analysis. N. Amer. J. Fish. Mgt. 3:81-85.

Lorz, H.W. 1974. Ecology and management of brown trout in the Little Deschutes River. Fish. Res. Rep. Oregon Wildl. Comm. Corvallis, OR. 8: I-49. 
Luken, J.R. 1988. Rivers and streams investigations, Snake River game fish populations, fishing pressure and harvest, American Falls Reservoir to South Fork, Job Completion Report; Project F-73-R-10. $44 \mathrm{pp}$.

Lux, F.E. 1971 Age determination in fishes (revised). U.S. Dept. of Commerce, NOAA Nat. Mar. Fish. Serv. Leaflet No. 367. 7 pp.

MacArthur, R.H. 1968. The theory of the niche. In: Lewontin, R.C. (ed.). Population biology and evolution. Syracuse Univ. Press, Syracuse, New York. 205 pp.

Magnuson, J.J. 1976. Managing fish with exotics: A game of chance. Transaction of the American Fisheries Society. 105:1-9.

Maiolie, M.A. and T. Cochnauer. 1988. Lochsa River literature review. Idaho Dept. of Fish and Game. 38 pp.

Mallet, J.L. 1963. The life history and seasonal movements of cutthroat trout in the Salmon River, ID. M.S. Thesis. University of Idaho, Moscow, ID. 62 pp.

May, B. and J. Huston. 1983. Kootenai River fisheries investigations final report 1972-I 982. Final Completion Report. Montana Dept. of Fish, Wildl. and Parks. 112 pp.

McAda, C.W. 1977. Aspects of the life history of three catostomids native to the Upper Colorado River Basin. M.S. Thesis, Utah State University, Logan, UT. 105 pp.

McCauley, R.W. and L.A.A. Read. 1973. Temperature selection by juvenile and adult yellow perch acclimated to $24^{\circ} \mathrm{C}$. J. Fish. Res. Board CAN. 30:1253-1255.

McDonald, M. 1894. The salmon fisheries of the Columbia River Basin. Report of the Commissioner of fish and fisheries on investigations in the Columbia River Basin in regards to the salmon fisheries. 53rd Congress, 2nd Session Misc. Doc. No. 200. $18 \mathrm{pp}$.

McMullin, S.L. 1979. The food habits and distribution of rainbow and cutthroat trout in Lake Koocanusa, Montana. Master's thesis. University of Idaho, Moscow. 
Merritt, R.W. and K.W. Cummins. 1984. An introduction to the aquatic insects of North America. Kendell-Hunt, Dubuque, lowa. 722 pp.

Miller, R.B. 1948. A note on the movement of pike, Esox lucius. Copeia. 1948:62.

Minshall, G.W. 1981. Structure and temporal variations in the benthic macroinvertebrate community inhabiting Mink Creek, Idaho, USA, a 3rd order Rocky Mountain Stream. J. Freshwater Ecol. 1:13-26.

Minter, R.F. 1971. Plankton population structure in the lower Coeur d'Alene River, Delta and Lake. M.S. Thesis. University of Idaho, Moscow, ID. 72 pp.

Mohler, S.H. 1966. Comparative seasonal growth of the largemouth, spotted and smallmouth bass. M.S. Thesis, University of Missouri, Columbia, MO. 99 pp.

Moyle, P.B. and J.J. Cech Jr. 1988. Fishes: an introduction to ichthyology. 2nd Edition. Prentice Hall, Englewood Cliffs, NJ. $559 \mathrm{pp}$.

O'Laughlin, K., M.R. Barber, A.T. Scholz, F. Gibson and M. Weinand. 1988. An instream flow (IFIM) analysis of benthic macroinvertebrates in Chamokane Creek, Spokane Indian Reservation. Upper Columbia United Tribes Fisheries Center, Fisheries Technical Report No. 14. Final Report Submitted to the Bureau of Indian Affairs, Contract No. POOC14208484 317 pp.

Ouedraogo, P.S. 1991. The food habits of largemouth bass (Micropterus salmoides) in the Pend Oreille River (Box Canyon) Pend Oreille County, Washington. MS Thesis. University of Idaho, Moscow, Idaho. 58 pp.

Payne, J.M. 1979. Interrelationships between benthic macroinvertebrates and habitat in a mountain stream. MS. Thesis, Utah State Univ., Logan, UT. 79 pp.

Pennak, R.W. 1978. Freshwater invertebrates of the United States. 2nd Edition. John Wiley and Sons, New York. 803 pp. 
Peone, T. and A.T. Scholz. 1988. Lake Roosevelt monitoring program. Monthly reports submitted to Bonneville Power Administration. Contract DE-81 79-88BP91819.

Peone, T.L., A.T. Scholz, J.R. Griffith, S. Graves and M.G. Thatcher, Jr. 1990. Lake Roosevelt fisheries monitoring program. 1989 Annual Report. Upper Columbia United Tribes Fisheries Center, Dept. of Biology, EWU, Cheney, WA. Prepared for US. Dept. of Energy, Bonneville Power Administration, Div. of Fish and Wildl. Project Number 88-63. Agreement DE-8179-88 B P91819. 234 pp.

Perry, S.A. and J. Huston. 1983. Kootenai River investigations final report 1972-1982, Section A. Mont. Dept. of Fish, Wildl. and Parks in cooperation with the U.S. Army Corps of Engineers. $236 \mathrm{pp}$.

Perry, S.A. and P.J. Grahm. 1982. The impact of Hungry Horse Dam on the aquatic invertebrates of the Flathead River. Final Report. Montana Department of Fish, Wildlife and Parks in cooperation with the Bureau of Reclamation.

Peterson, R.H. and D.J. Martin-Robichaud. 1982. Food habits of fishes in ten New Brunswick lakes. Can. Tech. Rep. Fish. Aquat. Sci. 1094:iii + 43 pp.

Platts, W.S., W.F. Megahan and G.W. Minshall. 1983. Methods for evaluating stream, riparian and biotic conditions. USDA Forest Service General Technical Report INT-138. 70 pp.

POCPUD (Pend Oreille County Public Utilities District). 1990. 1990 program report on the control of Eurasian watermilfoil in the Pend Oreille River. Pend Oreille County Planning Department, Newport, WA. 15 pp plus appendices.

Pratt, K.L. 1985. Pend Oreille trout and char life history study. Idaho Dept. of Fish and Game. 105 pp.

Prince, E.D. and O.E. Maughan. 1979. Attraction of fishes to artificial tire reefs in Smith Mountain Lake, Virginia. Pages 19-25 in D.L. Johnson and R.A. Stein, editors. Response of fish to habitat structure in standing water. North Central Division American Fisheries Society Special Publication 6. 
Purkett, CA., Jr. 1951. Growth rate of trout in relation to elevation and temperature. Trans. Amer. Fish. Soc. 80:251-9.

Raleigh R.F. and D.A. Duff. 1980. Trout stream habitat improvement: ecology and management. Pages 67-77 in W. King, ed. Proc. of Wild Trout Symp. II. Yellowstone Park, WY.

Raleigh, R.F., L.D. Zuckerman and P.C. Nelson. 1986. Habitat suitability index models and instream flow suitability curves: brown trout. U.S. Fish and Wildlife Service Biological Report 82(10.124). $51 \mathrm{pp}$.

Raleigh, R.F., T. Hickman, R.C. Solomon and P.C. Nelson. 1984. Habitat suitability information: Rainbow trout. U.S. Fish Wildl. Serv. FWS/OBS-82/10.60. 64 pp.

Ray, V.F. 1937. Native village and groupings of the Columbia Basin. Pacific Northwest Quarterly. 27:99-1 52.

Reed, G.B. and G.C. Toner. 1941. Red sore disease of pike. Canadian Journal of Research. 19:139-143.

Reiman, B.E. 1976. Limnology of Pend Oreille Lake, Idaho, with emphasis on the macro-zooplankton community. MS. Thesis. University of Idaho, Moscow, ID. 117 pp.

Reiman, B.E. 1983. Largemouth bass investigations. Idaho Dept. of Fish and Game, Job Completion Report, Project F-3-R-5. 77 pp.

Reiman, B.E. and B. Bowler. 1980. Kokanee trophic ecology and limnology in Pend Oreille Lake. Idaho Dept. of Fish and Game. No. 1. 27 pp.

Ricker, W.E. 1975. Computation and interpretation of biological statistics of fish populations. Bull. Fish. Res. Bd. Can. 191:382 pp.

Rodger, R.W. 1991. Fish facts, an illustrated guide to commercial species. Van Nostrand Reinhold, New York.

Ross, M.J. and J. D. Winter. 1981. Winter movements of four fish species near a thermal plume in northern Minnesota. Trans. Amer. Fish. Soc. 10:14-18. 
Ruttner-Kolisko, A. 1974. Plankton rotifers biology and taxonomy. Die Binnengewasser. 26/1. Stutgart. 146 pp.

Saiki, M.K. and J.C. Tash. 1979. Use of cover and dispersal by crayfish to reduce predation by largemouth bass. Pp. 44-48 In: D.L. Johnson and R.A. Stein (ed.). Response of fish to habitat structure in standing water. N. Central Div. Am. Fish. Soc. Spec. Publ. 6.

Savino J.F. and R.A. Stein. 1982. Predator-prey interaction between largemouth bass and bluegills as influenced by simulated, submersed vegetation. Transactions of the Amercian Fisheries Society. 111:255-266.

Schaefer, W.F. 1977. Growth patterns, food habits and seasonal distributions of yellow perch in south western Lake Michigan. Trans. Wis. Acad. Sci., Arts, Lett. 65:204-216.

Schill, D.J. and J.T. Heimer. 1988. Regional fisheries management investigations, Idaho Department of Fish and Game. Job Performance Report, Project F-71-R-12. 105 pp.

Schneider, J.C. and W.R. Crowe. 1980. Effect of sucker removal on fish and fishing at Big Bear Lake, Fisheries Research Report No. 1887. Michigan Dept. of Natural Resources, Fisheries Division. $19 \mathrm{pp}$.

Scholz, A., K. O'Laughlin, D.Geist, D. Peone, J. Uehara, L. Fields, T. Kleist, I. Zozaya, T. Peone and K. Teesatuskie. 1985. Compilation of information on salmon and steelhead total run size, catch and hydropower related losses in the Upper Columbia River Basin, above Grand Coulee Dam. Fisheries technical report No. 2. Upper Columbia United Tribes Fisheries Center, Dept. of Biology, EWU, Cheney, WA. 165 pp.

Scholz, A.T., K. O'Laughlin, T. Peone, J. Uehara, T. Kleist, and J. Hisata. 1988. Environmental factors affecting kokanee salmon, Oncorhynchus nerka (Walbaum) in Deer and Loon Lakes, Stevens County, Washington. Final report submitted to Deer Lake Property Owners Association, Loon Lake Property Owners Association and Washington State Department of Wildlife. June 1988. $167 \mathrm{pp}$. 
Scholz, A.T., T. Peone, M.R. Barber, J.K. Uehara, and D.R. Geist. 1988. Rainbow trout, brown trout, brook trout, mountain whitefish, piute sculpin, and torrent sculpin population and production estimates for Chamokane Creek, Spokane Indian Reservation, in 1986 and 1987. Upper Columbia United Tribes Fisheries Center, Fisheries Technical Report No. 11. Final Report Submitted to the Bureau of Indian Affairs, Contract No. POOC14208484. 78 pp.

Scott, W.B. and E.J. Crossman. 1973. Freshwater fishes of Canada. Fish. Res. Board Can. Bull. 184. 966 pp.

Scullian, J., CA. Parish, N. Morgan, and R.W. Edwards. 1982. Comparison of benthic macroinvertebrate fauna and substratum composition in riffles and pools in the impounded River Elan and unregulated River Wye, mid-Wales. Freshwater Biology. 12:579-595.

Seber, G.A. F. and E.D. LeCren. 1967. Estimating population parameters from catches large relative to the population. J. Anim. Ecol. 36:631-643.

Senn, H., J. Mack and L. Rothfus. 1984. Compendium of low-cost Pacific salmon and steelhead trout production facilities and practices in the Pacific Northwest. Fish Management Consultants, Olympia, WA prepared for U.S. Dept. of Energy, Bonneville Power Administration, Div. of Fish and Wildl. Project No. 83-353, Agreement DE-AC79-83BP12745. 487 pp.

Skillingstad, T. 1992. The ecology of northern pike: the possiblity of a successful introduction into the Box Canyon reach of the Pend Oreille River. Upper Columbia United Tribes Fisheries Center. Unpublished internal report.

Soltero, R.A., L.A. Campbell, R.W. Plotnikoff, and L.M. Sexton. 1988.

A baseline investigation of selected water quality characteristics for a reach of the Pend Oreille River, WA, before the introduction of thermomechanical pulp mill effluent. Dept. of Biology, Eastern Washington University, Cheney, WA. $71 \mathrm{pp}$. 
Sonstegard and Hnath. 1978. Lymphosarcoma in muskellunge and northern pike: guidelines for disease control. American Fisheries Society Special Publication. 11:235-237.

Steinberger, R.S. 1979. A guide to rotifers of the Laurentian Great Lakes. Environmental Monitoring and Support Laboratory, Office of Research and Development, US. Environmental Protection Agency, Cincinnati, Ohio. EPA-600/4-79-02 1. $1985 \mathrm{pp}$.

Stone, Livingston. 1885. Explorations on the Columbia River from the head of Clarke's Ford to the Pacific Ocean made in the summer of 1883, with reference to the selection of a suitable place for establishing a salmon breeding station. Extracted from the annual report of the Commissioner of Fish and Fisheries for 1883. Washington Government Printing Off ice. 22 pp.

Strauss, R.E. 1979. Reliability of Ivlev's electivity index, the forage ratio, and a proposed linear index of food selection. Trans. Amer. Fish. Soc. 108:334-352.

Strawn, K. 1961. Growth of largemouth bass fry at various temperatures. Trans. Am. Fish. Soc. 90:334-335.

Stuber, R.J., G. Gebhart, O.E. Maughan. 1982. Habitat suitability index models: Largemouth bass. U.S. Dept. Int. Fish Wild. Serv. FWS/OBS-82110.16. 32 pp.

Tesch, F.W. 1971. Age and growth. In: Ricker, W.E. (ed.). Methods for assessment of fish production in freshwaters. IBP Handbook No. 3. Blackwell Scientific, Oxford, England. 313 pp.

Tyus, H.M. and J.M. Beard. 1990. Esox lucius (Esocidae) and Stizostedion vitreum (Percidae) in the Green River Basin, Colorado and Utah. Great' Basin Naturalist. 50(1):33-39.

U.S. Army- Corps. of Engineers. 1991. State of Washington aquatic plant management program: Final Environmental Impact Statement Supplement.

Uehara, J., T. Peone, A. Scholz, M. Barber. 1988. Growth rates of brown trout and rainbow trout in Chamokane Creek in comparison to other trout streams in the Pacific Northwest. 
Upper Columbia United Tribes Fishery Center, Fisheries Technical Report No. 16. Final Report Submitted to the Bureau of Indian Affairs, Contract No. POOC14208484. 32 pp.

Wahl, D.H. and R.A. Stein. 1988. Selective predation by three esocids: the role of prey behavior and morphology.

Transactions of the American Fisheries Society. 117:142-I 51.

Ward, J. 1955. A description of a new zooplankton counter. Quart. J. Microscop. Scien. 96:371-373.

Waters, T.F. 1972. The drift of stream insects. Annu. Rev. Entomol. 17:253-272.

Waters, T.F. and R.J. Knapp. 1961 An improved stream bottom fauna sampler. Trans. Amer. Fish. Soc. 90:225-229.

Weber, C.I. (ed.). 1973. Biological field and laboratory methods for measuring the quality of surface waters and effluents. NERC/EPA, Cincinnati, Ohio. 176 pp.

Wege, G.J. and R.O. Anderson. 1979. Influence of artificial structures on largemouth bass and bluegills in small ponds. Pages 59-69 in D.L. Johnson and R.A. Stein, editors. Response of fish to habitat structure in standing water. North Central Division American Fisheries Society Special Publication 6.

Wiggins, G.G. 1977. Larvae of the North American caddisfly genera (Trichoptera). University of Toronto, Toronto, Canada.

Williams, D.D. and H.B.N. Hynes. 1974. The occurrence of benthos deep in the substratum. Freshwater. Biol. 4:233-256.

Willms, R.A., A.T. Scholz, and J. Whalen. 1989. The assessment of a developing mixed-species fishery in Sprague Lake, Adams and Lincoln Counties, Washington, following restoration with rotenone. Dept. of Biology, Eastern Washington University, Cheney, WA. 160 pp.

Windell, J.T. 1971. Food analysis and rates of digestion. In: Ricker, W.E. Methods for assessment of fish production in freshwaters. IBP Handbook No. 3. Blackwell Scientific, Oxford, England. $313 \mathrm{pp}$. 